\title{
Recent Sandy Deposits at Five Northern California Coastal Wetlands - Stratigraphy, Diatoms, and Implications for Storm and Tsunami Hazards
}

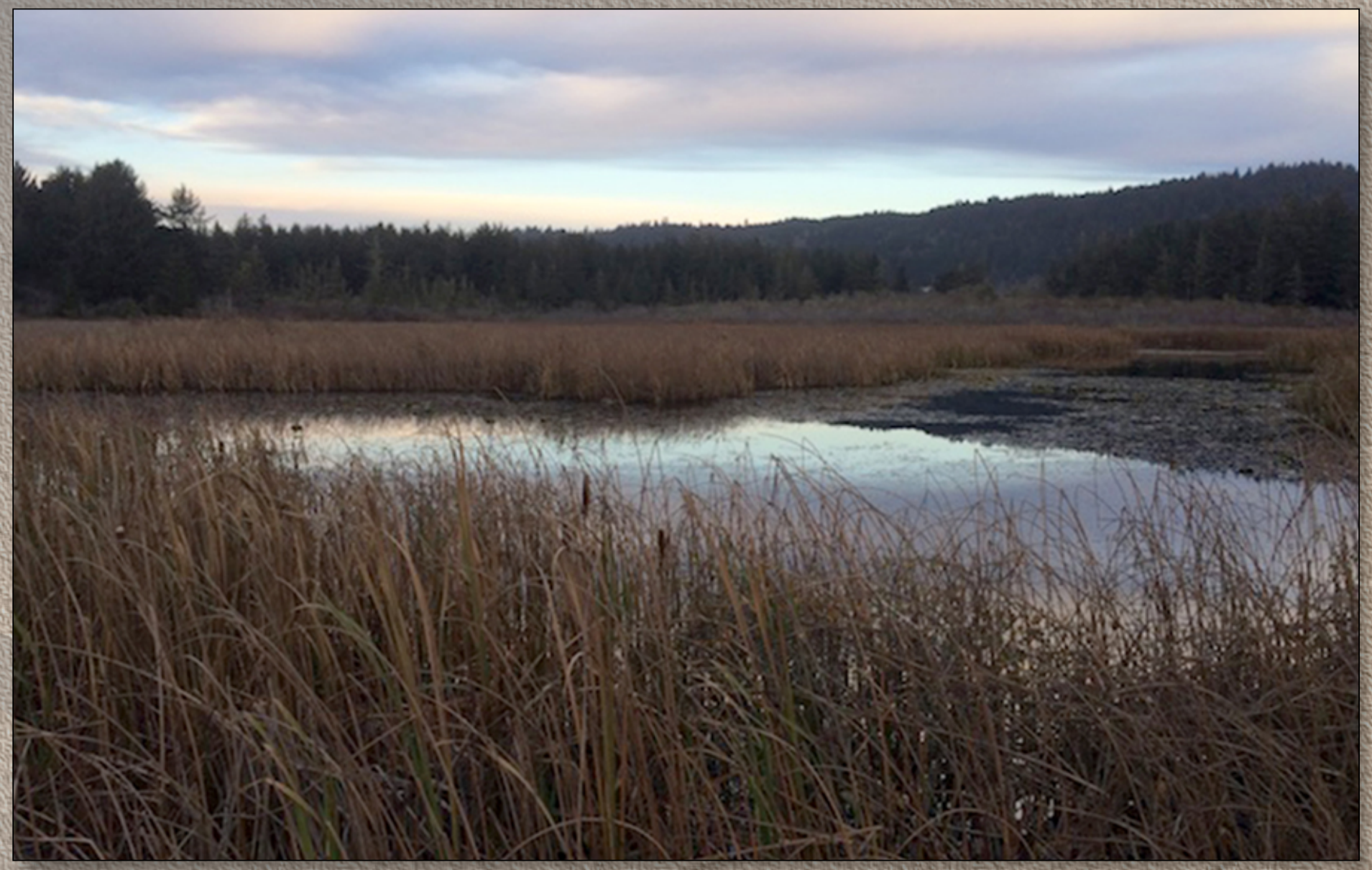

Scientific Investigations Report 2018 -5111

U.S. Department of the Interior U.S. Geological Survey 
Cover. Photograph of the Sand Mine marsh study site, a freshwater marsh, willow swamp, and residual lagoon located 2.5 kilometers south of downtown Crescent City, California. Subsurface deposits at Sand Mine marsh include evidence for inundation by far-field and near-field tsunamis, as well as large coastal storms. 


\section{Recent Sandy Deposits at Five Northern California Coastal Wetlands-Stratigraphy, Diatoms, and Implications for Storm and Tsunami Hazards}

By Eileen Hemphill-Haley, Harvey M. Kelsey, Nicholas Graehl, Michael Casso, Dylan Caldwell, Casey Loofbourrow, Michelle Robinson, Jessica Vermeer, and Edward Southwick

Scientific Investigations Report 2018-5111 


\title{
U.S. Department of the Interior DAVID BERNHARDT, Secretary
}

\author{
U.S. Geological Survey \\ James F. Reilly II, Director
}

\section{U.S. Geological Survey, Reston, Virginia: 2019}

For more information on the USGS - the Federal source for science about the Earth, its natural and living resources, natural hazards, and the environment—visit https://www.usgs.gov or call 1-888-ASK-USGS (1-888-275-8747).

For an overview of USGS information products, including maps, imagery, and publications, visit https://store.usgs.gov.

Any use of trade, firm, or product names is for descriptive purposes only and does not imply endorsement by the U.S. Government.

Although this information product, for the most part, is in the public domain, it also may contain copyrighted materials as noted in the text. Permission to reproduce copyrighted items must be secured from the copyright owner.

Suggested citation:

Hemphill-Haley, E., Kelsey, H.M., Graehl, N., Casso, M., Caldwell, D., Loofbourrow, C., Robinson, M., Vermeer, J., and Southwick, E., 2019, Recent sandy deposits at five northern California coastal wetlands-Stratigraphy, diatoms, and implications for storm and tsunami hazards: U.S. Geological Survey Scientific Investigations Report 2018-5111, 187 p., https://doi.org/10.3133/sir20185111.

ISSN 2328-0328 (online) 


\section{Acknowledgments and Author Roles}

This report represents the final project report for "Evaluating Paleotsunami Deposits along the California Coast," a study in support of the Science Applications for Risk Reduction (SAFRR) tsunami scenario and the SAFRR tsunami scenario coordination task of the Pacific Coastal and Marine Science Center project "Probabilistic Forecasting of Earthquakes and Earthquake Effects." The SAFRR tsunami scenario and the scenario coordination task were both led by Stephanie Ross of the U.S. Geological Survey.

During field operations, Mr. Terry McNamara provided access to his private property at Marhoffer Creek as well as advice and vehicle support for reaching areas in the interior marsh. Permission to collect geological field data from the O'rekw marsh locality was granted by the Yurok Tribal Council, the Yurok Tribe Cultural Committee, and Robert McConnell of the Yurok Tribe Heritage Preservation Office. Yurok tribal observer and archaeological resource specialist, Will Carlson, supervised the fieldwork. Vicki Ozaki at Redwood National and State Parks provided historical photographs of lower Redwood Creek as well as field assistance at O'rekw marsh. Bruce Jaffe, Bruce Richmond, and Steve Watt from the U.S. Geological Survey Pacific Coastal and Marine Science Center and geological consultant Robert Peters were co-participants in some field work and coring at Pillar Point marsh. Steve Watt also provided surveying data and geographic information system (GIS) support, including rectifying historical aerial photographs. At Humboldt State University, Dr. Lori Dengler provided valuable resources and first-hand knowledge about earlier tsunami studies in northern California; Steve Tillinghast, manager of the Geology Department, supplied field equipment and vehicles; Dr. Jeffrey Borgeld of the Oceanography Department allowed use of his laboratory for grain-size analyses at the Terlonicher Marine Laboratory; and Mary Dawn Enos at the Student Health Center Radiology Lab provided X-ray images of the sediment cores.

Radionuclide analyses were completed and interpreted by M. Casso at the U.S. Geological Survey Woods Hole Coastal and Marine Science Center. M. Robinson contributed particle-size analyses, and E. Hemphill-Haley completed all diatom analyses. D. Caldwell supervised the field surveys and processed and compiled location and elevation data. E. Southwick, N. Graehl, and J. Vermeer contributed core-log illustrations and maps. E. Hemphill-Haley provided the remaining figures and wrote most of the text, with initial edits by H.M. Kelsey. The manuscript was reviewed and improved by Brian Atwater, John Barron, and Carrie Garrison-Laney. Historical photographs of Crescent City, Calif., from the Wallace H. Griffin collection are reproduced by permission of the Del Norte County Historical Society. 


\section{Contents}

Abstract

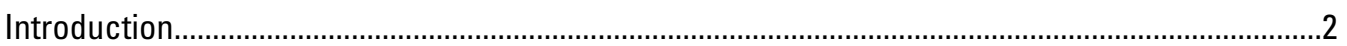

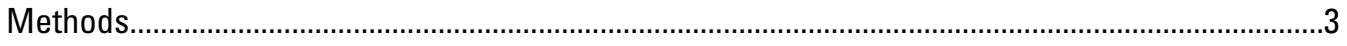

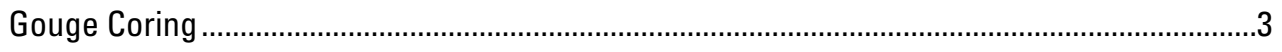

Modern-Analog Samples ..............................................................................................

GPS and Real-Time Kinematic Surveying .....................................................................

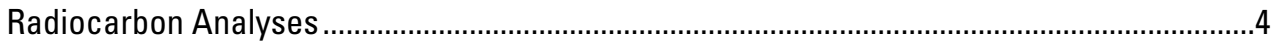

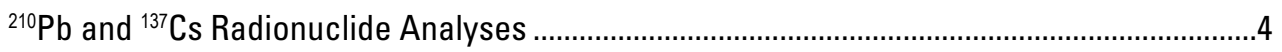

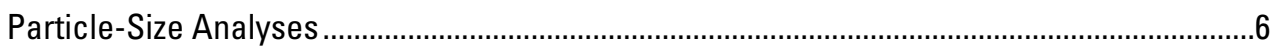

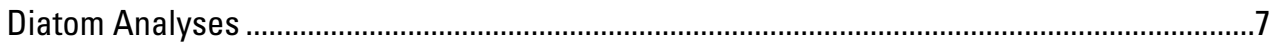

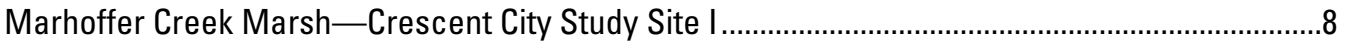

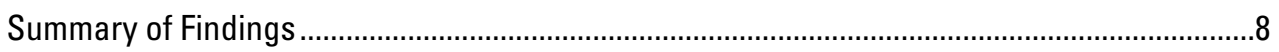

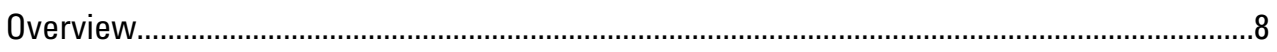

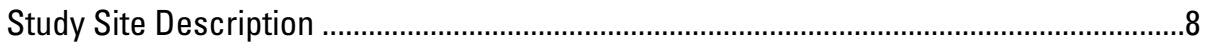

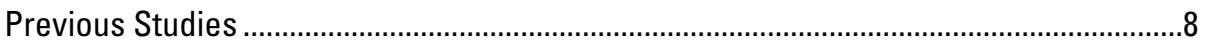

Field Data Collection Strategies ...................................................................................

Tsunami and Storm Deposit Identification.......................................................................11

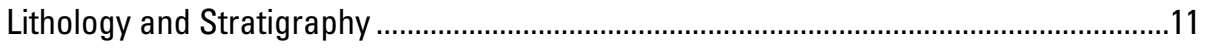

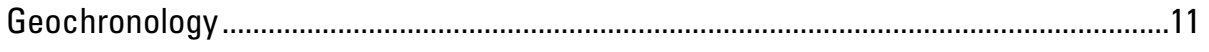

Summary of First-Order Evidence for Tsunami and Storm Deposits................................16

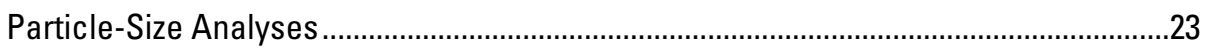

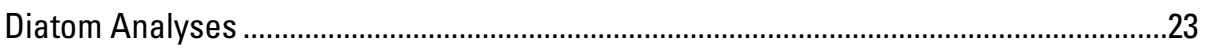

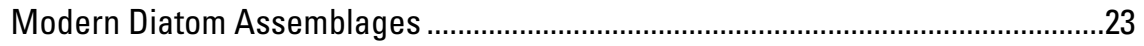

Fossil Diatom Assemblages ..................................................................................27

Comparison of Tsunami and Storm Deposits ............................................................

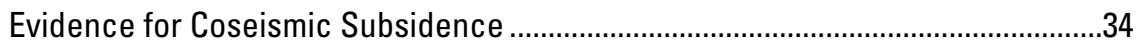

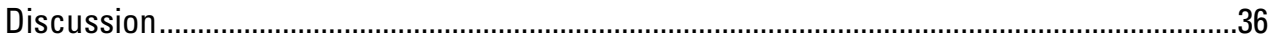

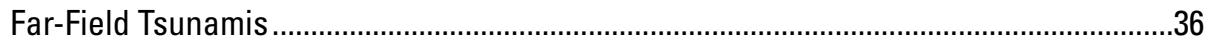

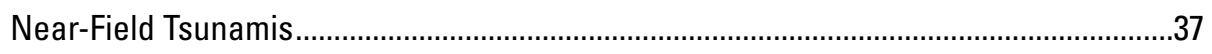

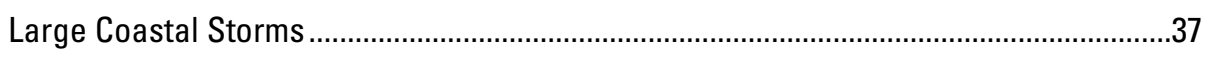

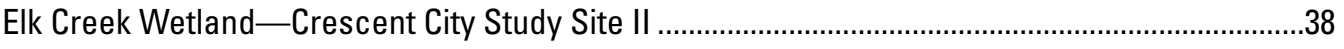

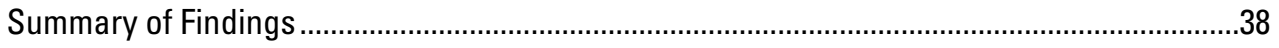

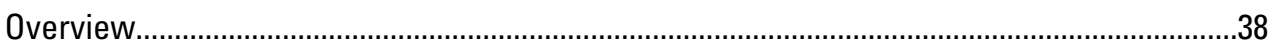

Study Site Description .........................................................................................38

Natural Morphology and Subsequent Modifications ...................................................42

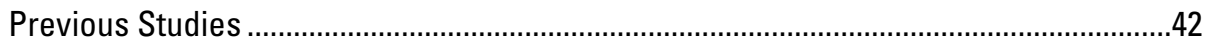

Field Data Collection Strategies ...............................................................................4

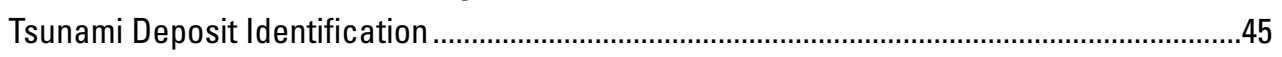

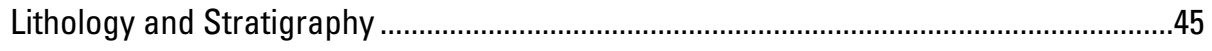

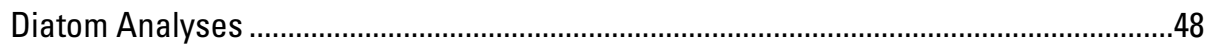

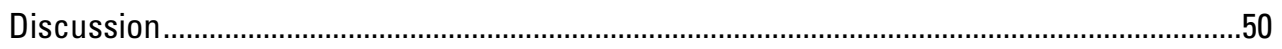

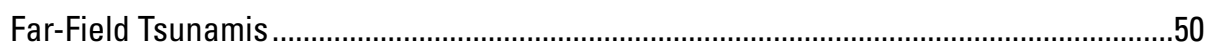

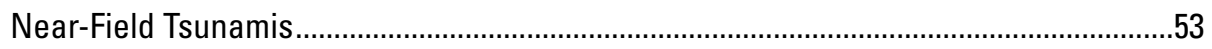


Update to Conclusions from Previous Studies ...............................................................53

Sand Mine Marsh —Crescent City Study Site III.........................................................................5

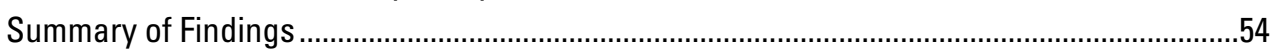

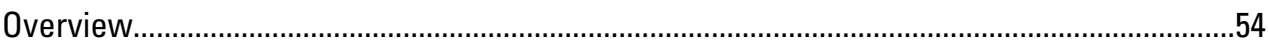

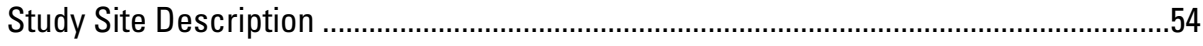

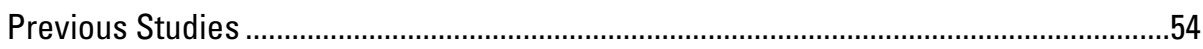

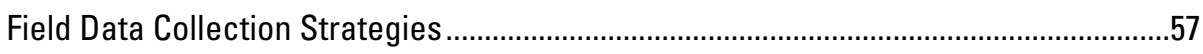

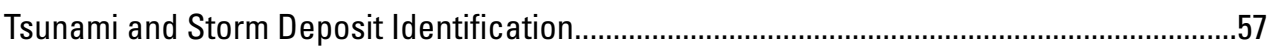

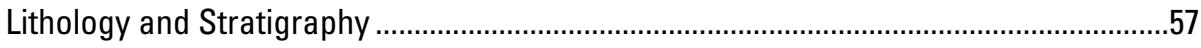

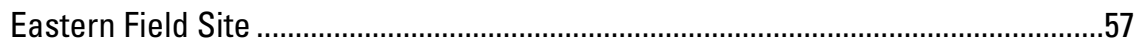

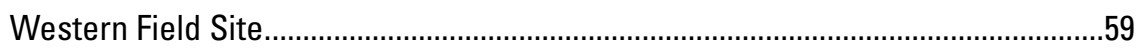

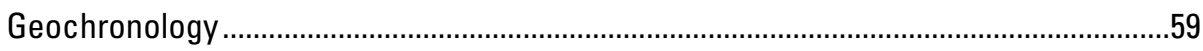

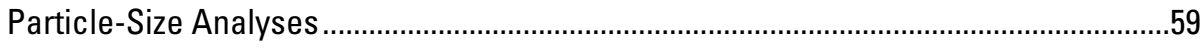

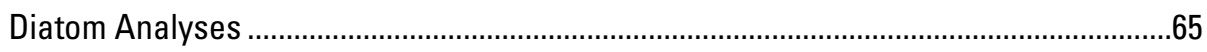

Sand and Sandy Detrital Deposits ....................................................................65

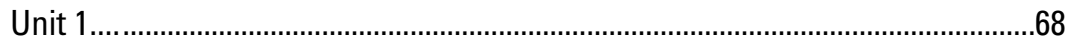

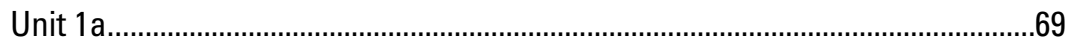

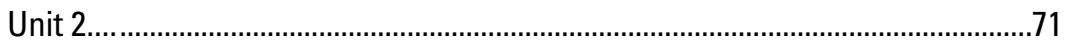

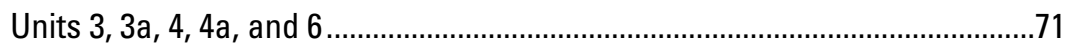

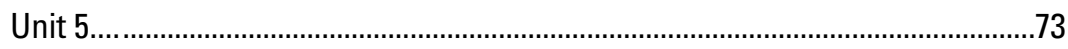

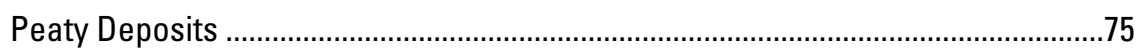

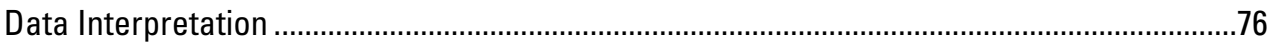

Paleoenvironmental Changes and Coseismic Subsidence .............................................76

Depositional Mechanisms for Siliciclastic and Detrital Deposits ....................................77

Unit 1-1964 Tsunami Deposit.............................................................................

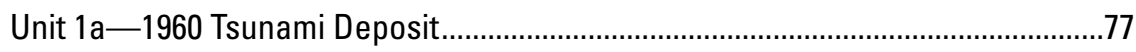

Unit 2 -Berm or Dune Deposit..........................................................................7

Units 3, 4, and 6-Storm Deposits .....................................................................77

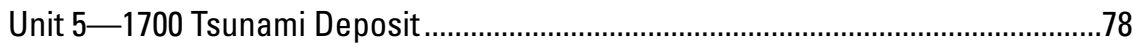

Summary—Tsunami and Storm Deposit Distribution ...........................................................79

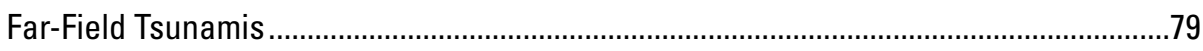

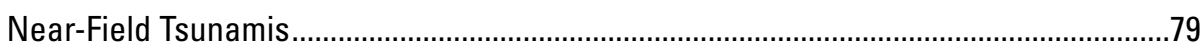

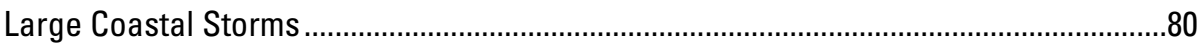

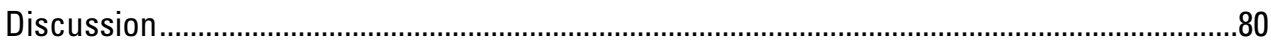

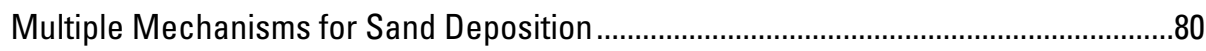

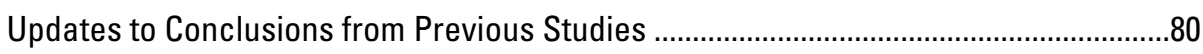

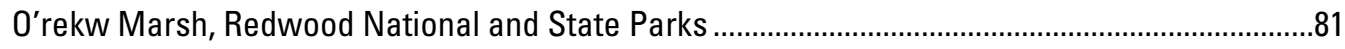

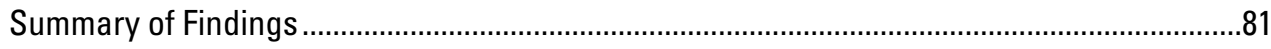

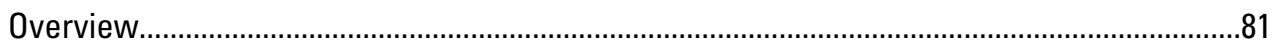

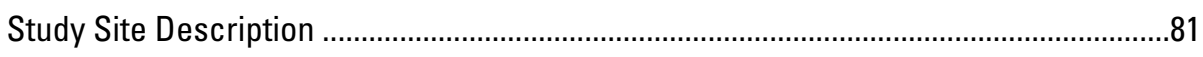

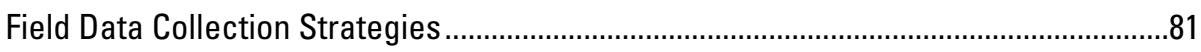

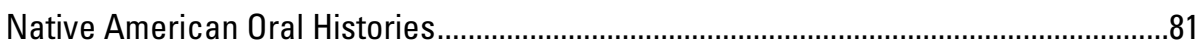

Previous Paleoseismic Studies ...............................................................................85

Eyewitness Accounts of the 1964 Far-Field Tsunami .....................................................8

Large Historical Floods ............................................................................................. 


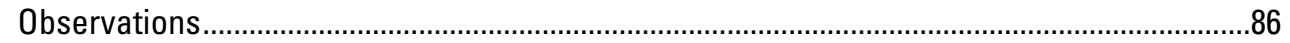

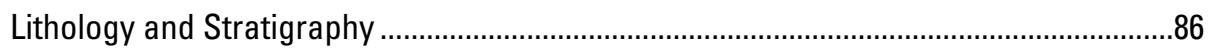

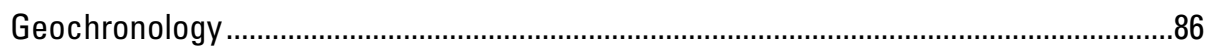

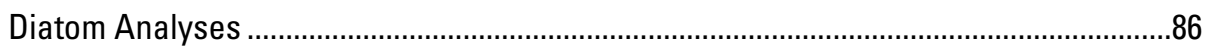

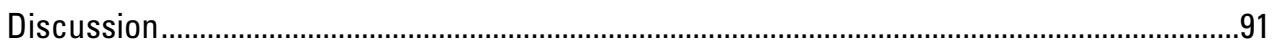

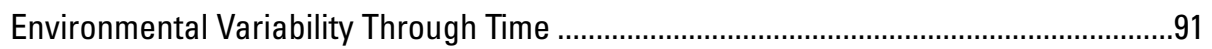

Paleoenvironmental Evidence for Coseismic Subsidence ..............................................91

Lack of Definitive Evidence for Tsunami Deposits .........................................................91

Pillar Point Marsh, San Mateo County ..........................................................................................

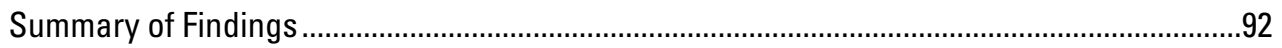

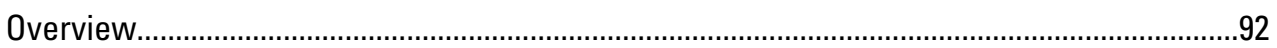

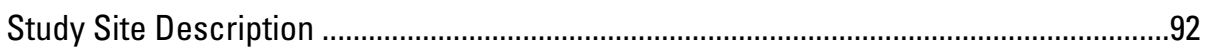

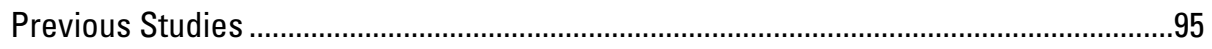

Inundation by the 1946 Far-Field Tsunami...................................................................96

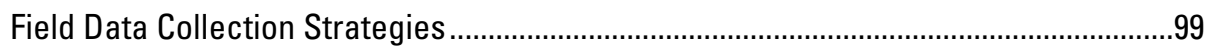

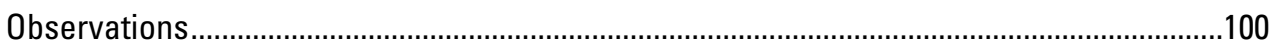

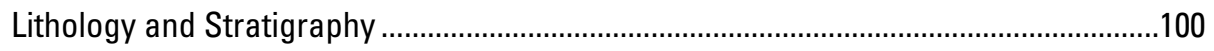

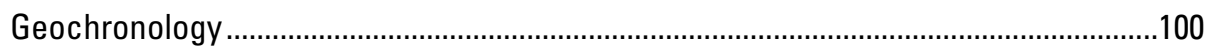

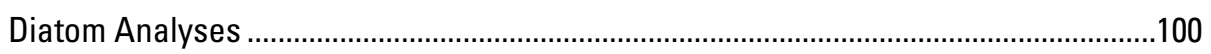

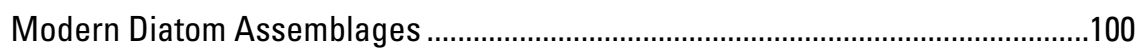

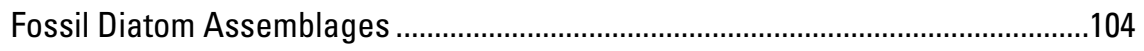

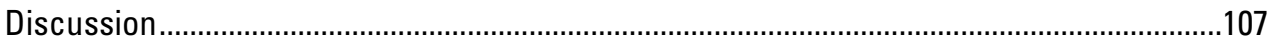

Environmental Changes and Marine Inundation Over the Past 400 Years .................107

Preservation Potential and the Tsunami Record Over the Past 300-350 Years.............109

Suggestions for Future Research ........................................................................................110

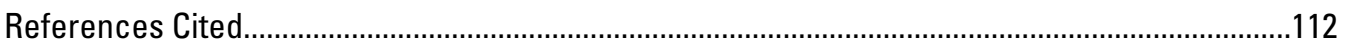

Appendix 1. Locations and Descriptions of Cores and Surface Samples ....................................123

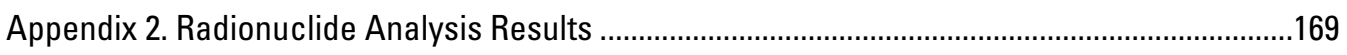

Appendix 3. Particle-Size Analysis Results ............................................................................180

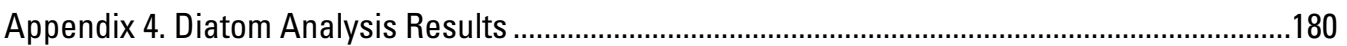

\section{Figures}

1. Map of the five northern California study sites evaluated for tsunami deposits: Marhoffer Creek marsh, Elk Creek wetland, and Sand Mine marsh (all three located in the Crescent City area); O'rekw marsh in Redwood National and State Parks; and Pillar Point marsh in northern Half Moon Bay...

2. Map showing the locations of the Crescent City area study sites in northern California: Marhoffer Creek marsh, Elk Creek wetland, and Sand Mine marsh

3. Aerial image of the Marhoffer Creek marsh study site and adjacent Pebble Beach showing the locations of cores and surface samples.

4. Cross-sectional profiles $D-D^{\prime}$ and $C-C^{\prime}$ showing the elevation of surface samples collected at Pebble Beach and cores collected at Marhoffer Creek marsh...................10

5. Photograph of the Marhoffer Creek marsh study site from the location of core MM1..11

6. Lithologic logs of cores collected from Marhoffer Creek marsh along the shore-normal transect $A-A^{\prime}$.. 
7. Lithologic logs of cores collected from Marhoffer Creek marsh along the shore-parallel transect $B-B^{\prime}$.

8. Lithologic logs of cores collected from Marhoffer Creek marsh along transect $C-C^{\prime} \ldots 14$

9. Stratigraphy and lithology of core MM1 from the seaward side of Marhoffer Creek marsh.

10. Graph showing calibrated ${ }^{14} \mathrm{C}$ age probability distributions for samples from the Marhoffer Creek marsh study site

11. Radionuclide results for core MM16 from Marhoffer Creek marsh ................................19

12. Radionuclide results for core MM16A from Marhoffer Creek marsh..............................19

13. Data for core MM16 from Marhoffer Creek marsh...........................................................20

14. Data for core MM16A from Marhoffer Creek marsh, collected 2 meters from core MM16

15. Data for core MM16B from Marhoffer Creek marsh, collected 3 meters from core MM16.

16. Comparison of median grain size, sorting, and skewness for tsunami and storm-deposit sands from core MM16B with modern beach sands from Pebble Beach.....

17. Graphs showing sand particle-size distributions in core MM16B from Marhoffer Creek marsh and modern beach sands from Pebble Beach

18. Photomicrographs of modern diatoms collected from surface sand in the lower intertidal surf zone at Pebble Beach

19. Photomicrographs of modern diatoms collected from surface sand in the upper intertidal beachface at Pebble Beach

20. Plots showing the distribution of diatoms with depth in core MM16 from Marhoffer Creek marsh.

21. Plots showing the distribution of diatoms with depth in core MM17 from Marhoffer Creek marsh.

22. Plots showing the distribution of diatoms associated with the 1700 C.E. tsunami deposit in core MM20 and the 1,700-1,500 yr B.P. tsunami deposit in core MM19, both from Marhoffer Creek marsh

23. Graph showing Bray-Curtis dissimilarity of marine-diatom-bearing sand samples from tsunami and storm deposits in core MM16 from Marhoffer Creek marsh .....

24 Photomicrographs of marine diatoms and diatom fragments in storm and tsunami deposits in core MM16 from Marhoffer Creek marsh.

25. Photomicrographs of marine diatoms and silicoflagellates from the $\mathbf{1 7 0 0}$ tsunami deposit at 124 centimeters depth in core MM17 from Marhoffer Creek marsh....

26. Photomicrographs of marine diatoms from the 1700 tsunami deposit at 126 centimeters depth in core MM17

27. Photomicrograph of marine diatoms and a silicoflagellate from the 1,700-1,500 year before present tsunami deposit at 138-139 centimeter depth in core MM19.....

28. Photomicrographs showing the variability in assemblages of oligohalobous diatoms in core MM16 from Marhoffer Creek marsh

29. Photomicrographs of oligohalobous diatoms from the black, fine-grained detrital peat that underlies the 1700 tsunami deposit in core MM17 from Marhoffer Creek marsh

30. Photomicrographs of oligohalobous diatoms from brown peat that is located above the 1700 tsunami deposit in core MM17 from Marhoffer Creek marsh............................35

31. Aerial image of the Elk Creek wetland study site showing locations of cores ................39

32. Photograph of the lower Elk Creek alluvial valley...............................................................39

33. Historical views of the Elk Creek valley and Crescent City harbor ....................................40 
34. Historical aerial photographs of the downtown and harbor areas of Crescent City taken in 1962 before the 1964 tsunami and in April 1964 after the tsunami..........................................41

35. Annotated historical aerial photograph of the Elk Creek valley after the 1964 tsunami ..........41

36. Lithologic logs of cores collected from the lower valley of the Elk Creek wetland ........43

37. Lithologic logs of cores from Elk Creek wetland that contain sedimentological

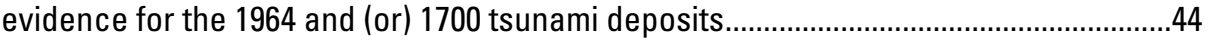

38. Photographs of core sections from core EC2 from Elk Creek wetland ............................45

39. Photographs of core sections from core EC12 from Elk Creek wetland .........................46

40. Photographs of core EC8 from Elk Creek wetland ......................................................4

41. Photographs of core EC6 from Elk Creek wetland ….....................................................48

42. Photomicrographs of allochthonous brackish-marine diatoms from the 1964 tsunami deposit in core EC2 and core EC12 from Elk Creek wetland.

43. Graph showing Bray-Curtis dissimilarity for diatom assemblages in the 1964 and 1700 tsunami samples from Elk Creek wetland

44. Photomicrographs showing changes in diatom assemblages across the stratigraphic interval spanning the 1700 earthquake and tsunami deposit in core EC8 from Elk Creek wetland.

45. Photomicrographs of allochthonous marine diatoms from the 1700 tsunami deposit in core EC8 from Elk Creek wetland

46. Aerial image of the Sand Mine marsh study site showing locations of cores evaluated for paleotsunami deposits

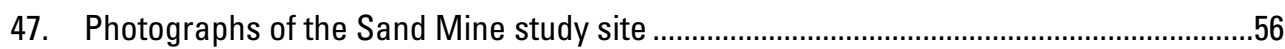

48. Historical and modern-day views of Sand Mine marsh..................................................56

49. Historical aerial photograph taken a few days after the 1964 tsunami ............................57

50. Lithologic logs of cores from Sand Mine marsh..........................................................58

51. Graph showing calibrated ${ }^{14} \mathrm{C}$ age probability distributions for samples from Sand Mine

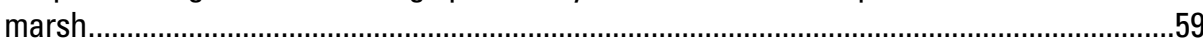

52. Radionuclide results for core SM8 from Sand Mine marsh ...........................................60

53. Lithologic log, photograph, $\mathrm{X}$-ray image, and ${ }^{137} \mathrm{C}$ s radionuclide activity for core SM8 from Sand Mine marsh ............................................................................................62

54. Radionuclide results for core SM11 from Sand Mine marsh ........................................62

55. Lithologic log, photograph, $\mathrm{X}$-ray images, and ${ }^{137} \mathrm{Cs}$ radionuclide activity for core SM11/11x from Sand Mine marsh

56. Graph showing results of particle-size analyses for cores SM11/11x and SM12 from Sand Mine marsh

57. Photomicrographs of sand grains from Units $1-6$ in cores SM11/11x and SM12 from Sand Mine marsh

58. Plots showing the distribution of microfossils with depth in core SM11/11x from Sand Mine marsh

59. Plots showing the distribution of microfossils with depth in core SM12 from Sand Mine marsh

60. Plots showing the distribution of microfossils in core SM8 from Sand Mine marsh......68

61. Diatom evidence for normal grading in the 1964 tsunami deposit in core SM11/11x from Sand Mine marsh

62. Marine diatoms of the 1964 tsunami deposit in core SM11/11x from Sand Mine marsh ........70

63. Photomicrographs of remnant oligohalobous diatoms in a sandy layer that is interpreted as a berm deposit 
64. Photomicrographs of marine diatoms recovered from storm deposits in cores SM11/11x and SM12 from Sand Mine marsh. . .73

65. Photomicrograph of brackish diatoms in core SM11/11x from Sand Mine marsh..........73

66. Photomicrographs of marine diatoms and silic oflagellates in the 1700 tsunami deposit in core SM11/11x from Sand Mine marsh.

67. Graph showing Bray-Curtis dissimilarity for diatom assemblages in clastic deposits in cores from the Sand Mine marsh western field site

68. Photomicrographs of aerophilous diatoms and pollen in compacted brown peat in the lower parts of cores SM11/11x and SM12 from Sand Mine marsh.

69. Graph showing Bray-Curtis dissimilarity among diatom assemblages from clastic deposits collected at Sand Mine marsh, Marhoffer Creek marsh, and Elk Creek wetland.

70. Map showing the location of the O'rekw marsh study site.

71. Aerial image of the O'rekw marsh study site showing locations of cores and real-time kinematic positioning data points along a transect from Redwood Creek Beach to O'rekw marsh

72. Cross-sectional profile $F-F^{\prime}$ showing the elevation of real-time kinematic positioning data and cores $0 \mathrm{M} 1,0 \mathrm{M} 2$, and $0 \mathrm{M} 3$ at 0 'rekw marsh.

73. Lithologic logs of cores $0 \mathrm{M} 1,0 \mathrm{O} 2$, and $\mathrm{OM} 3$ from 0 'rekw marsh .................................84

74. Plots showing the distribution of microfossils with depth in core $0 \mathrm{M} 2$ from O'rekw marsh

75. Photomicrographs of diatoms in core OM2 from O'rekw marsh ...................................88

76. Photomicrographs of microfossils from the reddish humified peat at $90-93$ centimeters depth in core 0M2 from O'rekw marsh.

77. Photomicrographs of well-preserved benthic, epiphytic, and planktonic diatoms from a sand deposit at 132 centimeters depth in core 0M2 from 0'rekw marsh . . .89

78. Photomicrographs of marine and estuarine diatoms from muddy silt and silty sand at 115-120 centimeters depth in core 0M2 from 0'rekw marsh

79. Graph showing Bray-Curtis dissimilarity among marine diatom assemblages from a sandy sample from core $0 \mathrm{M} 2$ and tsunami and storm samples from the Crescent City study sites

80. Map showing the location of the Pillar Point marsh study site in the northern part of Half Moon Bay, California.

81. Aerial image showing locations of cores and surface samples collected from the Pillar Point marsh study site

82. Photographs of the Pillar Point marsh study site .....................................................95 83. Lithologic logs of cores collected from Pillar Point marsh along transect $G-G^{\prime}{ }^{\prime} . \ldots \ldots \ldots . . . . .97$

84. Lithologic logs of cores collected from Pillar Point marsh that include the 1946 tsunami deposit.

5. Historical and modern photographs of Pillar Point marsh

86. Comparison of aerial photographs of Pillar Point before and after the 1946 tsunami ....99

87. Plots showing the distribution of microfossils with depth in core A21 from Pillar Point marsh

88. Observations of the 1946 tsunami deposit in core A20 from Pillar Point marsh ............102

89. Radionuclide results for core A21 from Pillar Point marsh ..........................................102

90. Graph showing calibrated ${ }^{14} \mathrm{C}$ age probability distributions for samples from Pillar Point marsh 
91. Photomicrographs of modern diatoms from Pillar Point marsh and adjacent beach 105

92. Photomicrographs showing the diversity of modern diatoms in sample PD12 from the muddy surface sediment of a remnant shallow lagoon at Pillar Point marsh 106

93. Photomicrographs of marine diatoms from the 1946 tsunami sand layer in core A21 from Pillar Point marsh

94. Photomicrographs of diatoms from the upper part of the 1946 tsunami deposit in core A20 from Pillar Point marsh

\section{Tables}

1. Results of accelerator mass spectrometry radiocarbon age analyses for core samples......... 5

2. Summary of ${ }^{210} \mathrm{~Pb}$ and ${ }^{137} \mathrm{C}$ s radionuclide analyses; details of the analyses are provided in appendix 2

3. ${ }^{210} \mathrm{~Pb}$ and ${ }^{137} \mathrm{Cs}$ radionuclide analysis data for core MM16 from Marhoffer Creek marsh........ 17

4. ${ }^{210} \mathrm{~Pb}$ and ${ }^{137} \mathrm{Cs}$ radionuclide analysis data for core MM16A from Marhoffer Creek marsh..... 18

5. Summary of first-order evidence for tsunami and storm deposits at Marhoffer Creek marsh

6. ${ }^{210} \mathrm{~Pb}$ and ${ }^{137} \mathrm{Cs}$ radionuclide analysis data for core SM8 from Sand Mine marsh .....................60 60

7. ${ }^{210} \mathrm{~Pb}$ and ${ }^{137} \mathrm{Cs}$ radionuclide analysis data for core $\mathrm{SM} 11$ from Sand Mine marsh...................61 61

8. ${ }^{210} \mathrm{~Pb}$ and ${ }^{137} \mathrm{Cs}$ radionuclide analysis data for core A21 from Pillar Point marsh ...................... 103

9. ${ }^{210} \mathrm{~Pb}$ and ${ }^{137} \mathrm{Cs}$ radionuclide analysis data for core A8x from Pillar Point marsh

\section{Conversion Factors}

International System of Units to U.S. customary units

\begin{tabular}{lll}
\hline & \multicolumn{1}{c}{ Multiply } & \multicolumn{1}{c}{ To obtain } \\
\hline & Length & \\
\hline centimeter $(\mathrm{cm})$ & 0.3937 & inch (in.) \\
millimeter $(\mathrm{mm})$ & 0.03937 & inch (in.) \\
micrometer $(\mu \mathrm{m})$ & 0.00003937 & inch (in.) \\
meter $(\mathrm{m})$ & 3.281 & foot (ft) \\
kilometer $(\mathrm{km})$ & 0.6214 & mile (mi) \\
kilometer $(\mathrm{km})$ & 0.5400 & mile, nautical (nmi) \\
meter $(\mathrm{m})$ & 1.094 & yard (yd) \\
\hline & Area & \\
\hline square millimeter $\left(\mathrm{mm}^{2}\right)$ & 0.00155 & square inch (in $\left.{ }^{2}\right)$ \\
square kilometer $\left(\mathrm{km}^{2}\right)$ & 0.3861 & square mile (mi $\left.{ }^{2}\right)$ \\
\hline & Volume & \\
\hline cubic centimeter $\left(\mathrm{cm}^{3}\right)$ & 0.06102 & cubic inch (in $\left.{ }^{3}\right)$ \\
\hline & Mass & \\
\hline gram $(\mathrm{g})$ & 0.03527 & ounce, avoirdupois $(\mathrm{oz})$ \\
\hline
\end{tabular}

Temperature in degrees Celsius $\left({ }^{\circ} \mathrm{C}\right)$ may be converted to degrees Fahrenheit $\left({ }^{\circ} \mathrm{F}\right)$ as ${ }^{\circ} \mathrm{F}=\left(1.8 \times{ }^{\circ} \mathrm{C}\right)+32$.

Temperature in degrees Fahrenheit $\left({ }^{\circ} \mathrm{F}\right)$ may be converted to degrees Celsius $\left({ }^{\circ} \mathrm{C}\right)$ as ${ }^{\circ} \mathrm{C}=\left({ }^{\circ} \mathrm{F}-32\right) / 1.8$. 


\section{Datum}

Vertical coordinate information is referenced to the North American Vertical Datum of 1988 (NAVD 88).

Horizontal coordinate information is referenced to the North American Datum of 1983 (NAD 83).

Altitude, as used in this report, refers to distance above the vertical datum.

\section{Abbreviations}

\begin{tabular}{ll} 
aff. & affinity \\
AMS & accelerator mass spectrometry \\
cal. yr B.P. & calibrated radiocarbon years before present \\
cal. yr C.E. & calibrated calendar years \\
C.E. & current era \\
cf. & compared with \\
CGS & California Geological Survey \\
$\mathrm{cm}$ & centimeter \\
$\mathrm{cm}$ & cubic centimeter \\
$\mathrm{cm} / \mathrm{yr}$ & centimeters per year \\
$\mathrm{CORS}$ & Continuously Operating Reference Stations network \\
$\mathrm{CPs}$ & counts per second \\
$\mathrm{CRS}$ & constant rate of supply \\
$\mathrm{dpm} / \mathrm{g}$ & decays per minute per dry gram \\
$\mathrm{g}$ & gram \\
$\mathrm{g} / \mathrm{cm} 2 / \mathrm{yr}$ & grams per square centimeter per year \\
$\mathrm{GPS}$ & Global Positioning System \\
$\mathrm{HSU}$ & Humboldt State University \\
$\mathrm{keV}$ & kiloelectron volt \\
$\mathrm{km}$ & kilometer \\
$\mathrm{km}$ & square kilometer \\
$\mathrm{m}$ & meter \\
$\mathrm{M}$ & magnitude \\
$\mathrm{MDA}$ & minimum detectable activities \\
$\mathrm{MLLW}$ & mean lower low water \\
$\mu \mathrm{LL}$ & microliter \\
$\mathrm{mm}$ & millimeter \\
\hline
\end{tabular}




$\begin{array}{ll}\mu m & \text { micrometer } \\ \mathrm{mm}^{2} & \text { square millimeter } \\ \text { NAVD88 } & \text { North American Vertical Datum of } 1988 \\ \text { NGS } & \text { National Geodetic Survey } \\ \text { NOAA } & \text { National Oceanic and Atmospheric Administration } \\ \text { NOSAMS } & \text { National Ocean Sciences Accelerator Mass Spectrometry } \\ \text { OPUS } & \text { Online Positioning User Service } \\ \text { rpm } & \text { revolutions per minute } \\ \text { RTK } & \text { real-time kinematic } \\ \text { s.l. } & \text { in the broad sense } \\ \text { sp. } & \text { species (singular) } \\ \text { spp. } & \text { species (plural) } \\ \text { USGS } & \text { U.S. Geological Survey } \\ \text { var. } & \text { variety } \\ \text { yr B.P. } & \text { years before present }\end{array}$




\title{
Recent Sandy Deposits at Five Northern California Coastal Wetlands-Stratigraphy, Diatoms, and Implications for Storm and Tsunami Hazards
}

\author{
By Eileen Hemphill-Haley, ${ }^{1}$ Harvey M. Kelsey, ${ }^{1}$ Nicholas Graehl, ${ }^{1}$ Michael Casso, ${ }^{2}$ Dylan Caldwell, ${ }^{1}$ \\ Casey Loofbourrow, ${ }^{1}$ Michelle Robinson, ${ }^{1}$ Jessica Vermeer, ${ }^{1}$ and Edward Southwick ${ }^{1}$
}

\section{Abstract}

A recent geological record of inundation by tsunamis or storm surges is evidenced by deposits found within the first few meters of the modern surface at five wetlands on the northern California coast. The study sites include three locations in the Crescent City area (Marhoffer Creek marsh, Elk Creek wetland, and Sand Mine marsh), O'rekw marsh in the lower Redwood Creek alluvial valley, and Pillar Point marsh at the northern end of Half Moon Bay.

At Marhoffer Creek marsh, stratigraphic, microfossil, and radiocarbon data provide evidence for two near-field tsunamis from earthquakes in the Cascadia Subduction Zone, one in 1700 C.E. and another around 1,700-1,500 years before present. The 1700 C.E. tsunami deposit is found about 1 meter $(\mathrm{m})$ below the modern freshwater marsh surface, and can be traced inland for at least $500 \mathrm{~m}$. Diatom data show that coseismic subsidence accompanied the 1700 C.E. earthquake at this site. Although there were no eyewitness accounts or previous records of inundation by the 1964 far-field tsunami at Marhoffer Creek, stratigraphic evidence and ${ }^{137} \mathrm{Cs}$ data confirm the presence of thin deposits from the 1964 tsunami within about $100 \mathrm{~m}$ of the modern shoreline. Also, in an area within about $100 \mathrm{~m}$ of the shoreline, are thick deposits of sand and debris, likely recording massive storms in the late 1800 s, that are intercalated stratigraphically between the 1964 far-field and 1700 C.E. near-field tsunami deposits.

At Elk Creek wetland, the 1964 far-field tsunami deposit is present but limited in distribution, confined to the southern edge of the valley closest to the Elk Creek stream channel. The 1700 C.E. deposit is found at a fairly shallow depth (less than $0.5 \mathrm{~m}$ ) below the modern meadow surface. Distinct changes from fresh to brackish-marine diatom assemblages above and below the tsunami deposit provide evidence for coseismic subsidence.
At Sand Mine marsh, ${ }^{137} \mathrm{Cs}$ data provide a chronostratigraphic marker to verify the distribution of the 1964 far-field tsunami deposit. Possible evidence for a second far-field tsunami deposit, consistent with emplacement in May 1960, was observed in one core. The 1700 C.E. near-field tsunami deposit is identified through stratigraphic correlation supported by grain-size and microfossil analyses, but the data also suggest that post-1700 C.E. storm activity has obscured or removed earlier evidence for tsunami inundation in areas closest to the coast, and that deposits and debris from these 19th century storms can be found at least $150 \mathrm{~m}$ inland from the current shoreline.

At O'rekw marsh, at the mouth of Redwood Creek, the data provide no convincing geological or paleontological evidence for tsunami deposits. However, possible flood deposits are evident, and diatom data identify ecological shifts in the past that would be consistent with coseismic subsidence. The stratigraphic, lithologic, and diatom data show that the O'rekw study site occupied a dynamically variable estuarine slough environment through time, with only minimal intervals of marsh development. Thus, the location was probably not a reliable depocenter for the long-term preservation of paleotsunami deposits in the past.

Pillar Point marsh has been the focus of previous investigations on the distribution of the 1946 far-field tsunami deposit as well as past offset across traces of the San Gregorio Fault that cross the marsh. In this report, we use diatom data to document environmental changes at the marsh over the past $\sim 400$ years, including documenting displaced nearshore marine taxa in the 1946 tsunami deposit. A shallow lagoon at Pillar Point marsh, which formed as a result of offset on the San Gregorio Fault in the late 1600 s to mid-1700s, served as an optimum depocenter for the 1946 tsunami deposit. However, although the fine-grained, sandy 1946 tsunami deposit is clearly discernible and can be traced for about $280 \mathrm{~m}$ inland in dark-colored, fine-grained lagoon deposits, we find no evidence for older tsunami deposits over the past few hundred years dating back to the formation of the lagoon.

${ }^{1}$ Humboldt State University.

${ }^{2}$ U.S. Geological Survey. 


\section{Introduction}

Tsunami hazards are a recognized threat in California, with three potential tsunami sources: local tsunamis generated by submarine landslides (McCulloch, 1985; Ryan and others, 2012); tsunamis associated with earthquakes on the Cascadia Subduction Zone (near-field tsunamis) (Wilson and others, 2010; Barberopoulou and others, 2011); and trans-Pacific, or far-field tsunamis, generated by earthquakes in seismotectonic zones around the Pacific Ocean (Ross and others, 2013).

The recurrence and modeled wave heights of tsunamis from these three sources vary. Tsunamis from submarine landslides along coastal California are infrequent, with recurrences measured in thousands of years (Lee and others, 2004), and modeling predicts potential localized wave heights can exceed 10 meters (m) at the coast from such events (Greene and others, 2006). Recurrences for tsunamis generated during megathrust earthquakes in the Cascadia Subduction Zone are estimated at hundreds of years (Atwater and others, 1995; Abramson, 1998; Kelsey and others, 2005; Nelson and others, 2008; Witter and others, 2009, 2011; Peterson and others, 2011, 2013; Goldfinger and others, 2012), with modeled wave heights as high as 4-8 $\mathrm{m}$ in northernmost California proximal to the megathrust and impacts of variable severity projected for beaches and harbors along the rest of the California coast (Wilson and others, 2008, 2010; Castelvechii, 2009; California Geological Survey, 2017).

Tsunamis of remote origin come ashore in California far more often than do those generated during nearby earthquakes or landslides (Lander and others, 1993; Geist and Parsons, 2006). Although wave run-up heights at most localities from far-field tsunamis may be comparatively small, damage from strong currents can be severe to coastal structures, particularly harbors (Ross and others, 2013). For example, since the 1940s, eight far-field tsunamis have caused damage along the California coast totaling more than $\$ 150$ million, with four of the events causing fatalities (see table 1 of Wilson and others, 2014). The most severely affected location for both property damage and loss of life has been Crescent City, along the northernmost California coast (Admire and others, 2014).

Of the numerous potential trans-Pacific sources for far-field tsunamis in California, the eastern Aleutian-Alaska Subduction Zone is recognized as the most problematic because of its geographic orientation and potential to send tsunami wave energy in a direct path across the Pacific Ocean to the entire California coastline (Wilson and others, 2008; Ryan and others, 2012; Kirby and others, 2013; SAFRR Tsunami Modeling Working Group, 2013; von Huene and others, 2016). Of particular concern, based on its location relative to California, is the Semidi segment of the megathrust (see fig. 1 of Nelson and others, 2015). The Semidi segment is known to be tsunamigenic from historical records (Lander and Lockridge, 1989) as well as from paleoseismic and paleotsunami studies at locations within the segment (Nelson and others, 2015) and in the northeast-adjacent Kodiak segment (Briggs and others, 2014). On Chirikof Island, within the Semidi segment, Nelson and others (2015) documented a record of paleotsunami deposits spanning the past 3,500 years, with an average recurrence of 170-255 years. The most recent tsunami deposit, associated with one of possibly two historically documented earthquakes in July and August of 1788, left a deposit on Chirikof Island at $15 \mathrm{~m}$ above sea level and $500 \mathrm{~m}$ inland. On Unga Island in the western Semidi segment, a tsunami may have reached $90 \mathrm{~m}$ above sea level (Lander and Lockridge, 1989; Ryan and others, 2012) - an extreme run-up height probably triggered by a submarine landslide in the area (von Huene and others, 2016).

Although numerous tsunamis have been recorded on the California coast during historical times - including tsunamis in 1812, 1946, 1960, and 1964 that have eyewitness accounts of inland flooding — geological evidence for past tsunami inundation along the California coast is limited (Ryan and others, 2012; Wilson and others, 2014). For example, in 2011 and 2012, a team of collaborators from Humboldt State University (HSU), the U.S. Geological Survey (USGS), and the California Geological Survey (CGS) investigated numerous locations along the California coast, using results of a numerical tsunami model by Wilson and others (2008) as a guide to evaluate locations along the coast with the potential for high tsunami wave heights from a theoretical magnitude $(M) 9$ earthquake rupture in the central AleutianAlaska Subduction Zone. The results of those observations (Wilson and others, 2014) revealed the paucity of existing geological evidence for past tsunami inundation and listed challenges for successfully locating such deposits. Concurrent studies in southern California also attempted to locate and map paleotsunami deposits with little success (Peters and others, 2008; Reynolds and others, 2013, 2015).

In this study, we build on some of the initial findings contributed by HSU researchers and our colleague at the radionuclide laboratory of the USGS Woods Hole Coastal and Marine Science Center to the Wilson and others (2014) report, and describe new findings on tsunami deposits from prehistoric Cascadia Subduction Zone earthquakes and historical far-field tsunamis in 1946, 1960, and 1964. We also describe our attempts to locate any possible field evidence for a far-field tsunami projected to have originated from the central Aleutian-Alaska Subduction Zone in 1788, a very early period in the era of record keeping by early European settlers in California.

This report provides field observations and laboratory analyses completed for each of five study sites between latitudes $42^{\circ}$ and $37.5^{\circ} \mathrm{N}$ on the California coast: three sites near Crescent City (Marhoffer Creek marsh, Elk Creek wetland, and Sand Mine marsh), O'rekw marsh in the lower Redwood Creek alluvial valley, and Pillar Point marsh at the northern end of Half Moon Bay (fig. 1). For each location, we summarize previous paleoseismic and tsunami-related studies and provide an overview of some of the past anthropomorphic changes at the study sites that were necessary to understand to correctly interpret the sedimentary record revealed by coring. New observations include radionuclide analyses - particularly ${ }^{137} \mathrm{Cs}$ - at Marhoffer Creek marsh, Sand Mine marsh, and Pillar Point marsh to establish a chronological marker for identifying historical far-field tsunami deposits, new ${ }^{14} \mathrm{C}$ data at all five study sites, particle-size analyses on modern beach and paleotsunami or storm deposits at the Marhoffer Creek and Sand Mine marsh sites, and diatom analyses at all five study sites to evaluate paleoenvironmental changes over time as well as possible provenance of the different types of sandy 
deposits observed. During the course of our investigation, we also recognized evidence for past deposition by one or more large storms at the Crescent City and O'rekw study sites, a depositional record not previously reported in early tsunami-related studies, but one we propose represents an additional hazard for the northern California coast that warrants further study.

\section{Methods}

\section{Gouge Coring}

The subsurface stratigraphy was evaluated and subsampled at all study sites using hand-driven gouge (auger) cores. The core barrel is $1 \mathrm{~m}$ long and either 3 or 6 centimeters $(\mathrm{cm})$ in diameter, with additional 1-m-long metal rod attachments to extend the coring to greater depths. Most of the cores are between 1 and $2 \mathrm{~m}$ long (appendix 1), which is approximately the depth of penetration $40^{\circ}$ possible under human power at some locations, yet still documents stratigraphy older than at least a few hundred years. Most cores were described and subsampled in the field, with a selection returned to the lab for detailed description and subsampling.

\section{Modern-Analog Samples}

Surface sediment was collected to document modern occurrences of diatoms at various core locations at all five study sites, as well as along a leveled transect from the surf zone to the innermost marsh at Pillar Point (appendix 4). At Pebble Beach, adjacent to Marhoffer Creek marsh, surface samples were collected for both diatoms and particle-size analysis (appendix 3).

\section{GPS and Real-Time Kinematic Surveying}

For all cores, surface samples, and beach profile points, Global Positioning System (GPS) coordinates and elevations relative to the North American Vertical Datum of 1988 (NAVD88) were collected using real-time kinematic (RTK) satellite positioning technology (appendix 1). The survey data are collected by setting up a base station unit and using a mobile "rover" unit to collect data points at core locations and at locations where surface samples were collected on the marsh or along beach transects. We used Topcon GR-3 receivers, which are capable of receiving signals from the American GPS and Global Navigation Satellite System (GLONASS; the Russian equivalent to the American GPS) satellite constellations and giving position solutions within $3.0 \mathrm{~cm}$ horizontally and $5.0 \mathrm{~cm}$ vertically, or better.

RTK positions were post-processed using the proprietary software Topcon Tools 8. Post-processing involved further refining positions using a correction from the National Geodetic Survey (NGS) Continuously Operating Reference Stations (CORS) network. Base station positions for every survey were submitted to the NGS Online Positioning User Service (OPUS). The position corrections returned by the NGS OPUS include a northing, easting, and orthometric elevation and were used to post-process

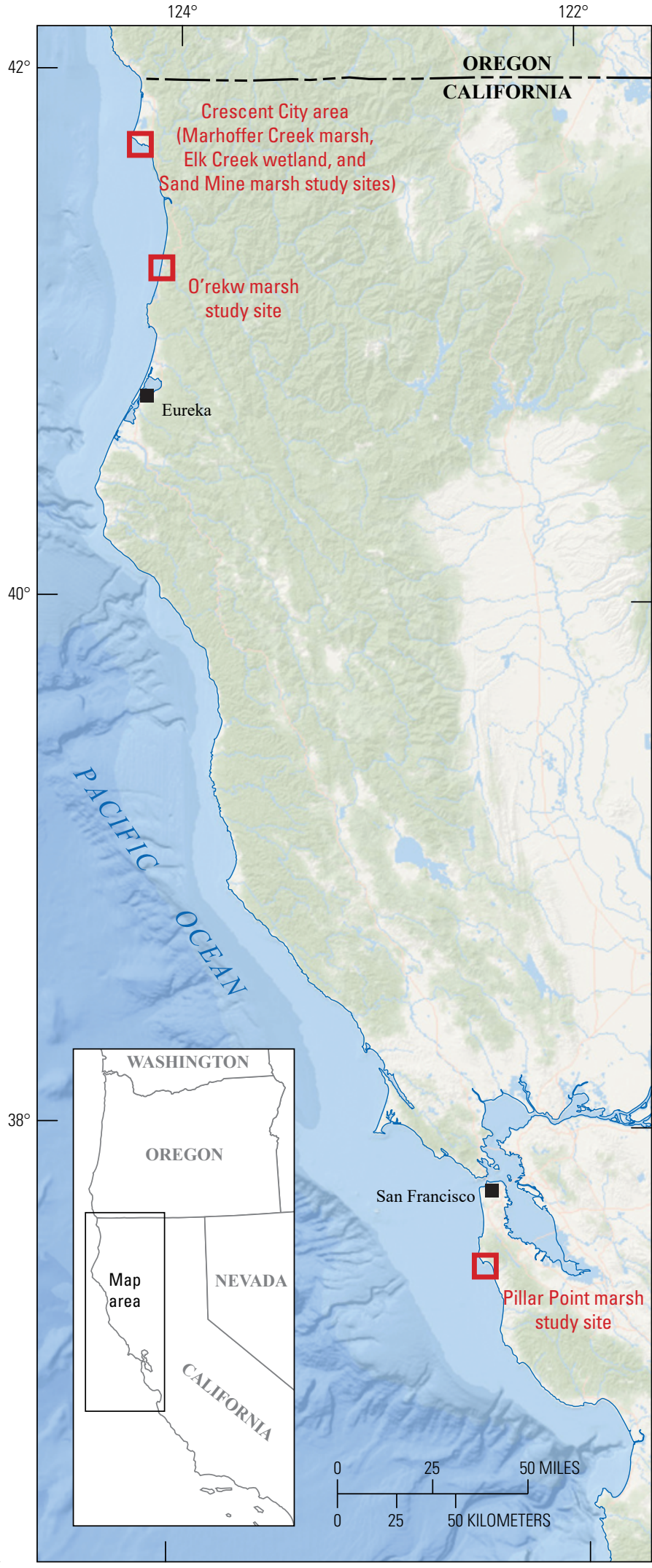

Base from Esri World Topographic Map (c) Esri 2017 and its licensors

Figure 1. Map of the five northern California study sites evaluated for tsunami deposits: Marhoffer Creek marsh, Elk Creek wetland, and Sand Mine marsh (all three located in the Crescent City area); O'rekw marsh in Redwood National and State Parks; and Pillar Point marsh in northern Half Moon Bay. 
all data points. Corrections from OPUS were in the range of decimeters to a few meters.

\section{Radiocarbon Analyses}

${ }^{14} \mathrm{C}$ analyses were applied to this study for two main purposes: (1) to determine if ages of sandy deposits recovered in cores from the Crescent City study sites and O'rekw marsh were consistent with previously reported ages of Cascadia Subduction Zone tsunami deposits (Abramson, 1998; Carver and others, 1998; Peterson and others, 2011), and (2) to attempt to better constrain the age of a stratigraphic contact at Pillar Point marsh interpreted as evidence for land-level changes caused by past rupture on a trace of the San Gregorio Fault (Koehler and others, 2005). Samples were first prepared by gently rinsing in distilled water to disaggregate the sediment and then picking through the residue under a microscope at $10 \times$ to $20 \times$ magnifications. Of more than 30 core samples that we prepared for ${ }^{14} \mathrm{C}$ analyses, 22 samples contained organic material of sufficient quality (for example, individual seeds or small woody stems) to submit to the National Ocean Sciences Accelerator Mass Spectrometry (NOSAMS) facility for analysis (table 1). The IntCal13 calibration curve (Reimer and others, 2013) and the CALIB 7.1 online software program (Stuiver and Reimer, 2016) were used to convert labreported radiocarbon results to calibrated radiocarbon years before 1950 (cal. yr B.P.) and calibrated calendar years (cal. yr C.E.). All radiocarbon results are reported with 2 -sigma uncertainty.

\section{${ }^{210} \mathrm{~Pb}$ and ${ }^{137} \mathrm{Cs}$ Radionuclide Analyses}

Radionuclide analyses were used to evaluate the ages of the uppermost sedimentary deposits in a total of six cores from three of the study sites: cores MM16 and MM16A from Marhoffer Creek marsh, cores SM8 and SM11 from Sand Mine marsh, and cores A21 and A8x from Pillar Point marsh (table 2, appendix 2). ${ }^{210} \mathrm{~Pb}$ analysis is an established technique for determining the ages of sedimentary deposits that have accumulated in the last $\sim 100$ years (Kemp and others, 2012; Sanchez-Cabeza and Ruiz-Fernandez, 2012). ${ }^{137} \mathrm{Cs}$ analysis provides useful chronologic data for sedimentary units deposited since 1954 C.E. because vigorous nuclear bomb testing in the 1950s and 60s caused a predictable spike in detectable levels of ${ }^{137} \mathrm{Cs}$ (Ritchie and McHenry, 1990).

Samples for radionuclide analysis were extracted from cores at $0.5-\mathrm{cm}$ intervals, weighed, and then allowed to dry slowly for several days. Once dry, the samples were reweighed and ground to particles no greater than about 1 millimeter $(\mathrm{mm})$ in diameter. Individual samples weighing $>4$ grams $(\mathrm{g})$ were submitted for analysis; some samples in peaty sections did not meet this minimum weight, and therefore, adjacent $0.5-\mathrm{cm}$ samples were combined with the original material to provide sufficient quantities as needed. Of the $\sim 200$ samples that we prepared for gamma counting, 162 were determined appropriate for analysis based on the minimal-detectable-activity levels of radionuclides in each sample.
Activities of ${ }^{210} \mathrm{~Pb}$ and ${ }^{137} \mathrm{Cs}$ (as well as ${ }^{234} \mathrm{Th},{ }^{214} \mathrm{~Pb}$, and ${ }^{7} \mathrm{Be}$ ) were measured by gamma ray spectroscopy at the USGS Woods Hole Coastal Marine Science Center gamma counting laboratory in Woods Hole, Massachusetts. Samples were analyzed on planar germanium detectors (Canberra Industries, Inc., model GS2020S) for $4-49$ days (15 days on average). The radionuclides ${ }^{210} \mathrm{~Pb},{ }^{234} \mathrm{Th}$, ${ }^{214} \mathrm{~Pb},{ }^{7} \mathrm{Be}$, and ${ }^{137} \mathrm{Cs}$ were measured using net counts of the 46.5 , $63.3,352,477.6$, and 661.6 kiloelectron volt $(\mathrm{keV})$ gamma-ray peaks, respectively. Net counts per second (cps) were converted to disintegrations per minute per dry gram (dpm/g) for each sample. ${ }^{214} \mathrm{~Pb}$ activity at $352 \mathrm{keV}$ was subtracted from the total ${ }^{210} \mathrm{~Pb}$ activity to calculate the excess ${ }^{210} \mathrm{~Pb}$ activity (Joshi, 1987). Excess ${ }^{210} \mathrm{~Pb},{ }^{7} \mathrm{Be}$, and ${ }^{137} \mathrm{Cs}$ were decay-corrected to the core-collection date. The efficiency of the detectors over the energy range 46.5$661.6 \mathrm{keV}$ was calibrated using the U.S. Environmental Protection Agency standard pitchblende ore in the same range of geometry as the samples. Calibration of the detectors specifically for ${ }^{137} \mathrm{Cs}$ was carried out with a certified standard solution from Isotope Products Laboratories. A correction for self-absorption on all of the radionuclides was made based on the geometry of the gammacounted samples (Cutshall and others, 1983). Final results were reported per salt-corrected dry weight. One-sigma raw counting (cps) errors were calculated using the following formula

$$
\text { percent error }=\left(\frac{\sqrt{G+B}}{N}\right) \times 100 \text {, }
$$

where

$$
\begin{array}{ll}
G & \text { is gross counts, } \\
B & \text { is background counts, and } \\
N & \text { is net counts. }
\end{array}
$$

Reported activity errors, in dpm/g, include errors propagated from raw and background counts.

Raw detection limits, or minimum detectible activities (MDA), were calculated as 1.645-sigma errors using the following formula

$$
\mathrm{MDA}=\frac{\left(K^{2}+2 K \times \sqrt{2 B}\right)}{T}
$$

where

$$
\begin{array}{ll}
K & \text { is the MDA sigma value (equal to 1.645) } \\
B & \text { is background counts, and } \\
T & \text { is live time. }
\end{array}
$$

Reported detection limits for results less than the MDA were expressed as a function of sample weight and were calculated as MDA divided by the sample weight, in grams. The accuracy for each sample analyzed was assessed by analysis of standard reference materials.

The maximum ${ }^{137} \mathrm{Cs}$ activity, representing the year 1963 (Health and Safety Laboratory, 1972; Robbins and Edgington, 1975) was evaluated for each core. The ${ }^{137} \mathrm{Cs}$ peak for each core analyzed was used to determine the bulk sediment accumulation rate expressed in either centimeters per year $(\mathrm{cm} / \mathrm{yr})$ or grams per square centimeter per year $\left(\mathrm{g} / \mathrm{cm}^{2} / \mathrm{yr}\right)$. The bulk mass 
Table 1. Results of accelerator mass spectrometry radiocarbon age analyses for core samples.

[cm, centimeter; mm, millimeter; n/a, not applicable; yr B.P., years before present (present is 1950); cal. yr B.P., calibrated years before present; cal. yr C.E., calibrated age in common era]

\begin{tabular}{|c|c|c|c|c|c|c|c|c|}
\hline $\begin{array}{l}\text { Core name } \\
\text { and depth } \\
\text { interval (cm) }\end{array}$ & $\begin{array}{l}\text { Type of organic } \\
\text { material }\end{array}$ & $\begin{array}{c}\text { Stratigraphic } \\
\text { setting }\end{array}$ & $\begin{array}{c}\text { Date } \\
\text { submitted }\end{array}$ & $\begin{array}{l}\text { Accession } \\
\text { number }^{\mathrm{a}}\end{array}$ & $\begin{array}{l}\text { Lab-reported } \\
\text { age }^{a} \\
\text { (yr B.P.) }\end{array}$ & $\begin{array}{l}\text { Calibrated } \\
\text { age }^{\mathrm{b}} \\
\text { (cal. yr B.P.) }\end{array}$ & $\begin{array}{l}\text { Calibrated } \\
\text { age }^{b} \\
\text { (cal. yr C.E.) }\end{array}$ & Interpretation \\
\hline $\begin{array}{l}\text { MM11 } \\
\quad 97-98\end{array}$ & $\begin{array}{l}\text { Seed pods, woody } \\
\text { detritus }\end{array}$ & $\begin{array}{l}\text { Interval } 1 \mathrm{~cm} \\
\text { below sand layer }\end{array}$ & $7 / 1 / 2012$ & OS-97870 & $310 \pm 20$ & $455-304$ & $1496-1646$ & $\begin{array}{l}\text { Maximum limiting age for } \\
\text { sand layer ascribed to } 1700 \\
\text { tsunami }\end{array}$ \\
\hline $\begin{array}{l}\mathrm{MM} 12 \\
\quad 125-126\end{array}$ & $\begin{array}{l}\text { Seed pods, woody } \\
\text { detritus }\end{array}$ & $\begin{array}{l}\text { Interval } 1 \mathrm{~cm} \\
\text { below sand layer }\end{array}$ & $7 / 1 / 2012$ & OS-97871 & $195 \pm 20$ & $293-0$ & $1657-1951$ & $\begin{array}{l}\text { Maximum limiting age for } \\
\text { sand layer ascribed to } 1700 \\
\text { tsunami }\end{array}$ \\
\hline $\begin{array}{l}\text { MM16 } \\
97.5-98.5\end{array}$ & $\begin{array}{l}\text { Seed pods, woody } \\
\text { detritus }\end{array}$ & $\begin{array}{l}\text { Interval } 1 \mathrm{~cm} \\
\text { below sand layer }\end{array}$ & $7 / 1 / 2012$ & OS-97872 & $265 \pm 20$ & $424-284$ & $1526-1795$ & $\begin{array}{l}\text { Maximum limiting age for } \\
\text { sand layer ascribed to } 1700 \\
\text { tsunami }\end{array}$ \\
\hline $\begin{array}{r}\text { MM16B } \\
49-50\end{array}$ & Tiny seeds & $\begin{array}{l}\text { Interval } 1 \mathrm{~cm} \\
\quad \text { below sand layer }\end{array}$ & $4 / 15 / 2015$ & OS-118885 & $85 \pm 20$ & $256-31$ & 1694-1919 & $\begin{array}{l}\text { Maximum limiting age for } \\
\text { deposits ascribed to 19th- } \\
\text { century storms }\end{array}$ \\
\hline $\begin{array}{l}\text { MM17 } \\
\quad 123.5-124\end{array}$ & Redwood cone & $\begin{array}{l}\text { Horizontal position } \\
\text { at top of sand } \\
\text { layer }\end{array}$ & $2 / 28 / 2014$ & OS-110030 & $170 \pm 20$ & $285-0$ & $1615-1950$ & $\begin{array}{l}\text { Minimum limiting age for } \\
\text { sand layer ascribed to } 1700 \\
\text { tsunami }\end{array}$ \\
\hline $\begin{array}{l}\text { MM19 } \\
\qquad 139.5-140\end{array}$ & Twigs with nodes & $\begin{array}{l}\text { Interval within } \\
\text { sand layer }\end{array}$ & $2 / 28 / 2014$ & OS-110031 & $1710 \pm 20$ & $1694-1558$ & $256-392$ & $\begin{array}{l}\text { Maximum limiting age for sand } \\
\text { layer ascribed to the tsunami } \\
1,700-1,500 \text { yr B.P. }\end{array}$ \\
\hline $\begin{array}{l}\text { MM19 } \\
141-141.5\end{array}$ & Twigs, seeds & $\begin{array}{l}\text { From lowermost } 2 \\
\mathrm{~cm} \text { of sand layer }\end{array}$ & $2 / 28 / 2014$ & OS-110033 & $1730 \pm 20$ & $1700-1569$ & $250-381$ & $\begin{array}{l}\text { Maximum limiting age for sand } \\
\text { layer ascribed to the tsunami } \\
1,700-1,500 \text { yr B.P. }\end{array}$ \\
\hline $\begin{array}{l}\text { MM20 } \\
92-93\end{array}$ & $\begin{array}{l}\text { Wood slivers } \\
<5 \mathrm{~mm} \text { long }\end{array}$ & $\begin{array}{l}\text { In black sandy peat } \\
\text { below sand layer }\end{array}$ & $4 / 15 / 2015$ & OS-118884 & $310 \pm 20$ & $454-304$ & $1496-1646$ & $\begin{array}{l}\text { Maximum limiting age for } \\
\text { sand layer ascribed to } 1700 \\
\text { tsunami }\end{array}$ \\
\hline $\begin{array}{l}\text { MM20 } \\
93-94\end{array}$ & $\begin{array}{l}\text { Wood slivers } \\
<5 \mathrm{~mm} \text { long }\end{array}$ & $\begin{array}{l}\text { In black sandy peat } \\
\text { below sand layer }\end{array}$ & $4 / 15 / 2015$ & OS-118883 & $210 \pm 20$ & $301-0$ & 1649-1950 & $\begin{array}{l}\text { Maximum limiting age for } \\
\text { sand layer ascribed to } 1700 \\
\text { tsunami }\end{array}$ \\
\hline $\begin{array}{l}\text { EC8 } \\
\quad 40-41\end{array}$ & Small seeds & $\begin{array}{l}\text { In coarse peat at } \\
\text { base of sand } \\
\text { layer }\end{array}$ & $4 / 15 / 2015$ & OS-118882 & $190 \pm 15$ & $287-0$ & $1663-1950$ & $\begin{array}{l}\text { Maximum limiting age for } \\
\text { sand layer ascribed to } 1700 \\
\text { tsunami }\end{array}$ \\
\hline $\begin{array}{l}\text { SM11x } \\
42-43\end{array}$ & Wood fragment & $\begin{array}{l}\text { In peat } 1 \mathrm{~cm} \text { above } \\
\text { sand }\end{array}$ & $10 / 19 / 2012$ & OS-99972 & $235 \pm 20$ & $281-0$ & $1643-1951$ & $\begin{array}{l}\text { Minimum limiting age for } \\
\text { deposits ascribed to possible } \\
\text { 19th-century storms }\end{array}$ \\
\hline $\begin{array}{l}\text { SM11x } \\
42-43\end{array}$ & $\begin{array}{l}\text { Woody plant } \\
\text { material }\end{array}$ & $\begin{array}{l}\text { In peat } 1 \mathrm{~cm} \text { above } \\
\text { sand layer }\end{array}$ & $10 / 19 / 2012$ & OS-99973 & $170 \pm 15$ & $283-0$ & $1667-1950$ & $\begin{array}{l}\text { Minimum limiting age for } \\
\text { deposits ascribed to possible } \\
\text { 19th-century storms }\end{array}$ \\
\hline $\begin{array}{l}\text { SM11x } \\
\quad 99-100\end{array}$ & $\begin{array}{l}\text { Wood frags; tiny } \\
\text { white seeds and } \\
\text { pods }\end{array}$ & $\begin{array}{l}\text { In peat at base of } \\
\text { sand }\end{array}$ & $10 / 19 / 2012$ & OS-99971 & $150 \pm 20$ & $251-0$ & $1668-1953$ & $\begin{array}{l}\text { Maximum limiting age for } \\
\text { sand layer ascribed to } 1700 \\
\text { tsunami }\end{array}$ \\
\hline $\begin{array}{l}\text { SM12 } \\
\quad 83.5-84\end{array}$ & $\begin{array}{l}\text { Tiny seeds, sticks, } \\
\text { conifer needles }\end{array}$ & $\begin{array}{l}\text { In dark brown peat } \\
\text { directly below } \\
\text { thick sand }\end{array}$ & $6 / 6 / 2015$ & OS-119875 & $155 \pm 15$ & $281-4$ & 1669-1946 & $\begin{array}{l}\text { Minimum limiting age for } \\
\text { deposits ascribed to possible } \\
\text { 19th-century storms }\end{array}$ \\
\hline $\begin{array}{l}\text { SM12 } \\
130-130.5\end{array}$ & $\begin{array}{l}\text { Wood fragments } \\
\text { with nodes, } \\
\text { seeds }\end{array}$ & $\begin{array}{l}\text { In peat at top of } \\
\text { sand layer }\end{array}$ & $2 / 28 / 2014$ & OS-109955 & $890 \pm 25$ & $907-735$ & $1043-1215$ & $\begin{array}{l}\text { Minimum limiting age for } \\
\text { equivocal storm or tsunami } \\
\text { deposit }\end{array}$ \\
\hline $\begin{array}{l}\text { SM12 } \\
164-164.5\end{array}$ & $\begin{array}{l}\text { Seed, conifer } \\
\text { needles, tiny } \\
\text { sticks with bark }\end{array}$ & $\begin{array}{l}\text { In peat at base of } \\
\text { sand layer }\end{array}$ & $6 / 23 / 2015$ & OS-118801 & $1780 \pm 20$ & $1618-1808$ & $332-142$ & $\begin{array}{l}\text { Maximum limiting age for } \\
\text { equivocal storm or tsunami } \\
\text { deposit }\end{array}$ \\
\hline $\begin{array}{l}\text { OM1 } \\
96-98\end{array}$ & $\begin{array}{c}\text { Twigs with nodes, } \\
\text { spruce needles }\end{array}$ & $\begin{array}{l}\text { In peat } 2 \mathrm{~cm} \text { above } \\
\text { sand layer }\end{array}$ & $1 / 15 / 2013$ & OS-101944 & $170 \pm 15$ & $283-0$ & $1667-1950$ & $\begin{array}{l}\text { Minimum limiting age for } \\
\text { equivocal storm or tsunami } \\
\text { deposit }\end{array}$ \\
\hline
\end{tabular}


Table 1.-Continued

\begin{tabular}{|c|c|c|c|c|c|c|c|c|}
\hline $\begin{array}{l}\text { Core name } \\
\text { and depth } \\
\text { interval (cm) }\end{array}$ & $\begin{array}{l}\text { Type of organic } \\
\text { material }\end{array}$ & $\begin{array}{l}\text { Stratigraphic } \\
\text { setting }\end{array}$ & $\begin{array}{c}\text { Date } \\
\text { submitted }\end{array}$ & $\begin{array}{l}\text { Accession } \\
\text { number }^{\mathrm{a}}\end{array}$ & $\begin{array}{c}\text { Lab-reported } \\
\text { age }^{a} \\
\text { (yr B.P.) }\end{array}$ & $\begin{array}{l}\text { Calibrated } \\
\text { age }^{\mathrm{b}} \\
\text { (cal. yr B.P.) }\end{array}$ & $\begin{array}{l}\text { Calibrated } \\
\text { age }^{\mathrm{b}} \\
\text { (cal. yr C.E.) }\end{array}$ & Interpretation \\
\hline $\begin{array}{l}\mathrm{OM} 2 \\
88-89\end{array}$ & $\begin{array}{l}\text { Twigs with nodes, } \\
\text { spruce needles }\end{array}$ & $\begin{array}{l}\text { In peat } 1 \mathrm{~cm} \text { above } \\
\text { sand layer }\end{array}$ & $1 / 15 / 2013$ & OS-101945 & $170 \pm 15$ & $283-0$ & $1667-1950$ & $\begin{array}{l}\text { Minimum limiting age for } \\
\text { equivocal storm or tsunami } \\
\text { deposit }\end{array}$ \\
\hline $\begin{array}{l}\mathrm{A} 21 \\
\quad 45.5-46\end{array}$ & $\begin{array}{l}\text { Plant stems and } \\
\text { roots }\end{array}$ & $\begin{array}{l}\text { In peat } 1 \mathrm{~cm} \text { below } \\
\text { contact with } \\
\text { mud }\end{array}$ & $10 / 19 / 2012$ & OS-99974 & modern & $\mathrm{n} / \mathrm{a}$ & $\mathrm{n} / \mathrm{a}$ & $\begin{array}{l}\text { Maximum limiting age for San } \\
\text { Gregorio Fault offset and } \\
\text { lagoon formation }\end{array}$ \\
\hline $\begin{array}{l}\text { A5x } \\
\quad 60-61\end{array}$ & $\begin{array}{l}\text { Small seeds and } \\
\text { seed husks }\end{array}$ & $\begin{array}{l}\text { In peat } 1 \mathrm{~cm} \text { below } \\
\text { contact with } \\
\text { mud }\end{array}$ & $6 / 6 / 2015$ & OS-119873 & $220 \pm 15$ & $301-0$ & $1649-1950$ & $\begin{array}{l}\text { Maximum limiting age for San } \\
\text { Gregorio Fault offset and } \\
\text { lagoon formation }\end{array}$ \\
\hline $\begin{array}{l}\text { A5x } \\
\quad 60-61\end{array}$ & Charcoal & $\begin{array}{l}\text { In peat } 1 \mathrm{~cm} \text { below } \\
\text { contact with } \\
\text { mud }\end{array}$ & $4 / 15 / 2015$ & OS-118802 & $240 \pm 15$ & $305-154$ & $1645-1796$ & $\begin{array}{l}\text { Maximum limiting age for San } \\
\text { Gregorio Fault offset and } \\
\text { lagoon formation }\end{array}$ \\
\hline $\begin{array}{l}\text { A5x } \\
\quad 61-62\end{array}$ & $\begin{array}{l}\text { Small seeds and } \\
\text { seed pods }\end{array}$ & $\begin{array}{l}\text { In peat } 1-2 \mathrm{~cm} \\
\text { below contact } \\
\text { with mud }\end{array}$ & $6 / 6 / 2015$ & OS-119874 & $275 \pm 15$ & $423-292$ & $1527-1658$ & $\begin{array}{l}\text { Maximum limiting age for San } \\
\text { Gregorio Fault offset and } \\
\text { lagoon formation }\end{array}$ \\
\hline
\end{tabular}

${ }^{a}$ Age determined by the National Ocean Sciences Accelerator Mass Spectrometry (NOSAMS) facility in Woods Hole, Massachusetts. Errors are reported with 2-sigma uncertainty.

${ }^{\mathrm{b} C}$ Calibrated ages determined using CALIB ver. 7.1 (Stuiver and others, 2016), an online radiocarbon calibration program with documentation available at http://calib.qub.ac.uk/calib/. Calibrated ages derived using the IntCal13 calibration dataset (Reimer and others, 2013).

accumulation rate was then used as the basis for one method of estimating the deposition dates for horizons in each core down to the ${ }^{137} \mathrm{Cs}$ maximum, using the depth midpoint. Also, the constant rate of supply (CRS) model (Appleby and Oldfield, 1978) was used with excess ${ }^{210} \mathrm{~Pb}$ activities to calculate deposition dates. Activities of excess ${ }^{210} \mathrm{~Pb}$ in any missing intervals from core sampling were interpolated by averaging the surrounding results. Using the 22.3 year half-life for excess ${ }^{210} \mathrm{~Pb}$, the decay constant $(\lambda)$ is equal to $\ln (2) / 22.3$. The CRS formula (de Souza and others, 2012) was applied as follows to calculate the age of deposition $(t)$

$$
t=\ln \left(\frac{\sum a}{\sum a_{\text {below } x}}\right) / \lambda .
$$

where

$$
\begin{aligned}
a & \text { is all activity, } \\
x & \text { is the depth of the interval, and } \\
a_{\text {below } x} & \text { is the activity below depth } x .
\end{aligned}
$$

The depth at which excess ${ }^{210} \mathrm{~Pb}$ activities become low and variable was used for input into the CRS model to indicate background levels where the integrated range of ${ }^{210} \mathrm{~Pb}$ activity stopped. The date ranges output from the CRS model for each core were determined to a depth for which a valid date and error was possible, excluding deeper samples with errors that exceeded 100 percent.

Uncertainties were calculated for the CRS model dates in the following manner,

$$
\delta \sum a=\sqrt{\sum a^{2}}
$$

$$
\begin{gathered}
\delta \sum a_{\text {below } x}=\sqrt{\left(\sum a_{\text {below } x}{ }^{2}\right)} \\
\frac{\delta \sum a}{\delta \sum a_{\text {below } x}}=\left(\frac{\sum a}{\sum a_{\text {below } x}}\right) \times \sqrt{\left(\frac{\delta \sum a}{\sum a}\right)^{2}+\left(\frac{\delta \sum a_{\text {below } x}}{\sum a_{\text {below } x}}\right)^{2}} \\
\begin{array}{c}
\text { CRS age with } \\
\text { uncertainties applied }
\end{array} \lambda^{-1} \times \ln \left(\left(\frac{\sum a}{\sum a_{\text {below } x}}\right) \pm\left(\frac{\delta \sum a}{\delta \sum a_{\text {below } x}}\right)\right)
\end{gathered}
$$

\section{Particle-Size Analyses}

Particle-size analyses were completed for a total of 141 samples from two study sites: Marhoffer Creek marsh (core MM16B, plus surface samples from Pebble Beach, just west of the marsh), and Sand Mine marsh (cores SM11/SM11x and parts of core SM12) (appendix 3).

Core samples were subsampled in the laboratory at intervals of $0.5 \mathrm{~cm}$. Modern beach samples were collected from the upper few centimeters of surface sediment during December 2012. We specifically collected the surface samples and measured the beach profile during winter conditions to provide the best comparison for sand deposits in the cores likely emplaced either by storms or tsunamis. On average, the most severe storm activity on the northern California coast occurs during the winter season (Griggs and others, 2005; Russell and Griggs, 2012), and the last great Cascadia 
Table 2. Summary of ${ }^{210} \mathrm{~Pb}$ and ${ }^{137} \mathrm{Cs}$ radionuclide analyses; details of the analyses are provided in appendix 2.

[cm, centimeter; C.E., common era; CRS, constant rate of supply]

\begin{tabular}{|c|c|c|c|c|c|c|c|}
\hline Core & Location & $\begin{array}{l}\text { Number of } \\
\text { samples } \\
\text { analyzed }\end{array}$ & $\begin{array}{c}\text { Depth } \\
\text { interval } \\
\text { sampled }(\mathbf{c m})\end{array}$ & $\begin{array}{l}\text { Depth }{ }^{\mathrm{a}} \text { of } \\
1963{ }^{137} \mathrm{Cs} \\
\text { peak }(\mathrm{cm})\end{array}$ & $\begin{array}{c}\text { Depth }^{\mathrm{a}} \text { of } \\
\text { maximum reliable } \\
{ }^{210} \mathrm{~Pb} \text { data }(\mathrm{cm})\end{array}$ & $\begin{array}{l}\text { Estimated age } \\
\text { from CRS model } \\
\text { (year C.E.) }\end{array}$ & $\begin{array}{c}\text { CRS model age } \\
\text { range } \\
\text { (year C.E.) }\end{array}$ \\
\hline MM16 & Marhoffer Creek marsh & 35 & 9 to 47 & 16.5 & 18 & 1952 & 1934-1996 \\
\hline MM16A & Marhoffer Creek marsh & 23 & 8 to 86 & 20 & 28.5 & 1920 & $1902-1964$ \\
\hline SM8 & Sand Mine marsh & 15 & 13 to 26 & 22.5 & 24 & 1942 & $1921-1967$ \\
\hline SM11 & Sand Mine marsh & 33 & 5 to 50 & 12.5 & 16.5 & 1930 & $1912-1970$ \\
\hline A8x & Pillar Point marsh & 22 & 0 to 22 & 8.5 & 8 & 1958 & $1940-2000$ \\
\hline
\end{tabular}

${ }^{a}$ Depth refers to the sample midpoint.

Subduction Zone earthquake and tsunami is estimated to have occurred during the winter of 1700 C.E. from tree-ring data (Jacoby and others, 1997; Yamaguchi and others, 1997), and more specifically on January 26, 1700, based on Japanese written records (Satake and others, 1996, 2003; Atwater and others, 2005).

Samples were prepared for sieving by first removing large organic particles, such as roots and woody pieces, and then soaking the remaining sample in 30-percent hydrogen peroxide $\left(\mathrm{H}_{2} \mathrm{O}_{2}\right)$ to digest fine-grained organic material. Each sample was then rinsed with distilled water, dried in an oven at low temperature $\left(\sim 50^{\circ} \mathrm{C}\right)$, and weighed. The samples were sieved over a size range of $0-500 \varphi$ in $0.25 \varphi$ increments ( 22 intervals per sample) at the HSU Telonicher Marine Laboratory using standard techniques (for example, Ingram, 1971). Each size fraction was weighed to the nearest $0.0001 \mathrm{~g}$ with an automatic balance that compiles the data directly into a spreadsheet format. The spreadsheet data were then imported into the particle-size analysis program GRADISTAT 8.0 (Blott and Pye, 2001) for description and analysis.

\section{Diatom Analyses}

Microscope slides were produced for the diatom analysis by first oxidizing $\sim 0.2-0.5 \mathrm{~g}$ of dried sediment with $\mathrm{H}_{2} \mathrm{O}_{2}$ to remove organic material, followed by several rinses in distilled water using a centrifuge at 1,000 revolutions per minute (rpm) for intervals of 1.5 minutes until the supernatant was clear of chemical residue and clay particles were still in suspension. The cleaned sediment residue was then transferred to a graduated test tube and diluted 10 times in distilled water. For each slide, a $22 \times 30-\mathrm{mm}$ coverslip was first prepared by covering with distilled water to the edges. The sample in the graduated test tube was then agitated to evenly suspend the particles and a 50 microliter $(\mu \mathrm{L})$ aliquot was extracted using a mechanical pipette. The aliquot was then carefully injected into the water layer on the coverslip and agitated to evenly distribute the particles throughout the coverslip area. After drying at room temperature, the coverslip was heated for several minutes at $\sim 75^{\circ} \mathrm{C}$ to ensure complete dryness. The coverslips were then mounted on cleaned and labeled glass slides using Naphrax diatom mountant (refractive index of 1.73).

Diatoms were counted along vertical transects of the slide at a magnification of $650 \times$ using a Nikon Eclipse 80i microscope. All marine taxa were identified and tallied along 30 or 40 transects of the slide. Estimated abundances of background fresh- to slightly brackish-water (oligohalobous) diatoms (in valves per cubic centimeter, valves $/ \mathrm{cm}^{3}$, of sediment) were derived by counting the total number of oligohalobous taxa along one transect and extrapolating to the approximate number of valves in the entire sample aliquot on the slide,

where

$$
\frac{D_{T}}{\left(A \times \frac{C_{O}}{C_{T}}\right)}
$$

$D_{T} \quad$ is the total diatoms counted,

$A$ is the volume of aliquots to make the slide, in $\mathrm{mL}$,

$C_{O} \quad$ is the area of the coverslip observed, in square millimeters $\left(\mathrm{mm}^{2}\right)$, and

$C_{T} \quad$ is the total area of the coverslip, in $\mathrm{mm}^{2}$.

Diatom photomicrographs were captured at magnifications of $400 \times, 650 \times$, and $1,000 \times$ with a Nikon DS-Ri1 digital camera attachment for the Nikon Eclipse 80i microscope. The images were then edited for organization into the report figures using Adobe Photoshop.

Similarities or differences among diatom assemblages observed in sandy deposits from the Crescent City and O'rekw study sites were quantified using the Q-mode cluster analysis capabilities of the online software packages EstimateS (Colwell, 2013) and R (R Development Core Team, 2008). The Bray-Curtis dissimilarity index (Bray and Curtis, 1957) was used as the distance measurement in the analysis because it incorporates species abundance and occurrence to identify similarities between sample pairs. 


\section{Marhoffer Creek Marsh—Crescent City Study Site I}

\section{Summary of Findings}

The Marhoffer Creek study site is a freshwater marsh and swamp located adjacent to Pebble Beach about 5 kilometers (km) north of downtown Crescent City. Subsurface stratigraphy, as revealed in 22 cores collected along shore-normal and shoreparallel transects, shows that the lithology 2-3 m below the marsh surface dominantly consists of fine- to coarse-grained peat ranging in color from dark brown or reddish brown to black. The thick sections of peat are interrupted by distinct and uncommon layers of very fine- to medium-grained gray sand, ranging from 0.5 to $20 \mathrm{~cm}$ thick. This sand is sometimes associated with woody detritus. Based on detailed mapping and stratigraphic correlation, as well as grain-size, microfossil, ${ }^{137} \mathrm{Cs}$, and ${ }^{14} \mathrm{C}$ analyses, we conclude that the sandy deposits record (1) inundation by the 1964 far-field tsunami; (2) coastal storm activity in the late $1800 \mathrm{~s}$, possibly the megastorm of December 1861 to January 1862; and (3) tsunamis from two Cascadia Subduction Zone earthquakes consistent with earthquakes at 250 (1700 C.E.) and 1,700-1,500 yr B.P. that were recorded elsewhere in northern California and the Pacific Northwest. The 1964 tsunami deposit and the sand- and detritus-rich storm deposits are found in the lower creek valley within about $100 \mathrm{~m}$ of Pebble Beach. The Cascadia Subduction Zone tsunami deposits can be traced inland at least $450 \mathrm{~m}$ from the beach.

\section{Overview}

\section{Study Site Description}

Marhoffer Creek marsh is a freshwater wetland on the north side of Crescent City, along the lower reaches of Marhoffer Creek and adjacent to the Pacific Ocean at Pebble Beach (figs. 2-4). The low-gradient lower alluvial valley of Marhoffer Creek extends about $800 \mathrm{~m}$ inland nearly due east from Pebble Beach, and varies in width from about 120 to $200 \mathrm{~m}$. Elevations in the valley range from approximately $3.5 \mathrm{~m}$ on its western end (from field measurements, appendix 1) to nearly $5 \mathrm{~m}$ (based on light detection and ranging [lidar] data) at its eastern end where the valley meets steep tributary drainages and slopes of the adjacent Pleistocene marine terrace.

Marhoffer Creek marsh is identified as a "shrub marsh" in the Del Norte County Local Coastal Program (Del Norte County, 1983). The marsh supports an array of freshwater plants, including dense stands of willows, blackberry, and other woody shrubs, as well as thick ground cover, including sedges, rushes, skunk cabbage, grasses, and silverweed (fig. 5). Spruce snags also are present, indicating the area was at least partly forested in the past. The marsh is seasonally flooded, and in particular, subject to periods of shallow standing water at its western end when the two culverts that drain the marsh under Pebble Beach Drive are plugged by woody debris or blocked by beaver dams.

\section{Previous Studies}

Previous tsunami-related work at Marhoffer Creek is limited to Aalto and others (1999) and our initial observations described in Wilson and others (2014, p. 76-80) under the heading "McNamara marsh." 3 Aalto and others (1999, p. 616) described five cores collected as far inland as $125 \mathrm{~m}$ from Pebble Beach. One core included a section analyzed for diatoms. Unfortunately, the authors did not provide accurate location data for the cores, but describe a 14- to 17-cm-thick deposit of sand and sandy woody detritus intercalated with thick sections of peat. The sand forms a sharp contact with underlying reddish-brown peat that is a few centimeters thick and grades downward to black muddy peat. Diatom analyses show occurrences of brackish-marine taxa in the sand, but not in the surrounding peat. As discussed below, this description by Aalto and others closely matches our observations of the 1700 C.E. tsunami deposit at this site, including the association with the underlying black peat. Their reported core depths for the deposit $(172-217 \mathrm{~cm})$ are $\sim 1 \mathrm{~m}$ deeper than what we observe (appendix 1).

\section{Field Data Collection Strategies}

We focused on Marhoffer Creek marsh in our search for paleotsunami deposits because of its low elevation, coastal fresh wetland environment, and location just north of the inundation zone for the 1964 tsunami at Crescent City, as documented by Magoon (1966). Based on previous observations at Marhoffer Creek by Aalto and others (1999), and at other Crescent City marshes by Peterson and others (2011), we expected to find evidence of prehistoric, near-field tsunamis from Cascadia Subduction Zone earthquakes. Furthermore, although the marsh is at an elevation $>3 \mathrm{~m}$, we also expected there to be a fair possibility of past inundation by far-field tsunamis at least as large as the 1964 tsunami.

We assumed that evidence for inundation by smaller far-field tsunamis would be confined to the more seaward area of the marsh, and particularly, based on previous observations in the Crescent City area by Peterson and others (2011), that evidence of past Cascadia Subduction Zone tsunamis would extend some distance landward within the marsh. Therefore, we collected and described a total of 22 cores along roughly shore-parallel and shore-normal transects (figs. 3, 6-8) to evaluate the areas that could have been impacted by far-field and near-field Cascadia Subduction Zone tsunamis, respectively. The 22 cores include replicate cores collected at site MM16 (cores MM16, MM16A, and MM16B), which were required to provide enough sediment to complete analyses of grain size, diatoms, radiocarbon, and radionuclides $\left({ }^{210} \mathrm{~Pb}\right.$ and $\left.{ }^{137} \mathrm{Cs}\right)$. Coring the Marhoffer Creek stream valley is particularly challenging at upvalley sites where dense stands of willows and other woody shrubs are present, as well as layers of grown-over woody debris on the marsh surface.

\footnotetext{
3"McNamara marsh" was the informal name we previously used for the locality in reference to the landowners who kindly allowed us access to their property.
} 
To compare subsurface samples with potential analogs at the modern ground surface, surface sediment was collected along a transect from the shallow subtidal zone to the berm at Pebble Beach for grain-size analysis (figs. 3, 4; appendix 3), and from the surf zone, upper beach, and at eight marsh locations for diatoms (appendix 4).

Locations and elevations relative to NAVD88 for all cores and surface samples are from RTK positioning (fig. 4; appendix 1). The closest tidal benchmark for Marhoffer Creek marsh is National Oceanic and Atmospheric Administration (NOAA) Station 9419750 , about $5 \mathrm{~km}$ south on Citizens Dock in the Crescent City harbor (NOAA, 2003a; fig. 2). The RTK data show that the cores range from about 3.4 to $4.0 \mathrm{~m}$. The highest observed tidal level for the area, which occurred during an El Niño-Southern Oscillation period in January 1983, was measured at $3.25 \mathrm{~m}$ above mean lower low water (MLLW), which is $3.13 \mathrm{~m}$ at this site - and thus, still lower than the elevation of the marsh.

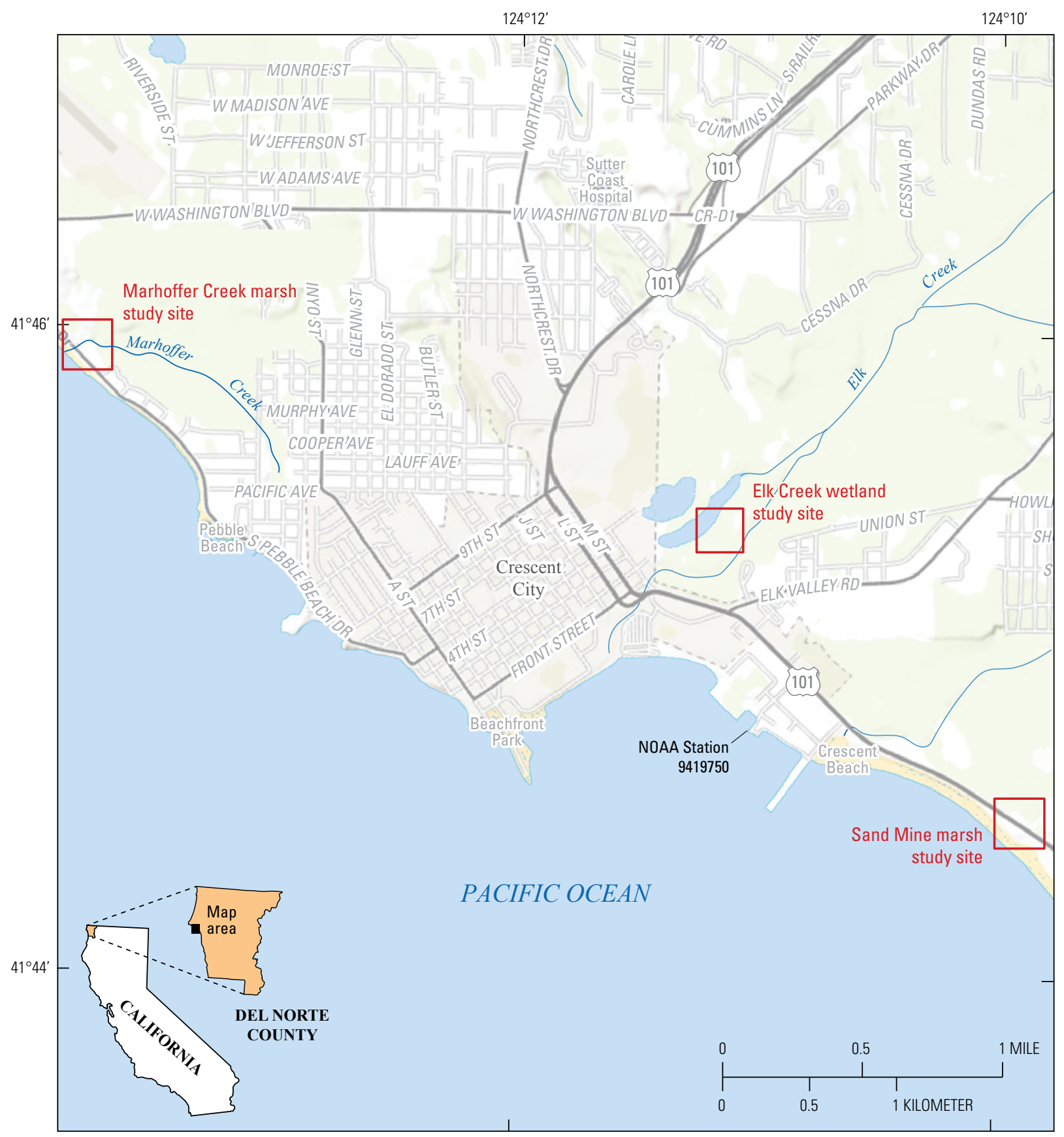

Base from Esri World Topographic Map (c) Esri 2017 and its licensors

Figure 2. Map showing the locations of the Crescent City area study sites in northern California: Marhoffer Creek marsh, Elk Creek wetland, and Sand Mine marsh. 


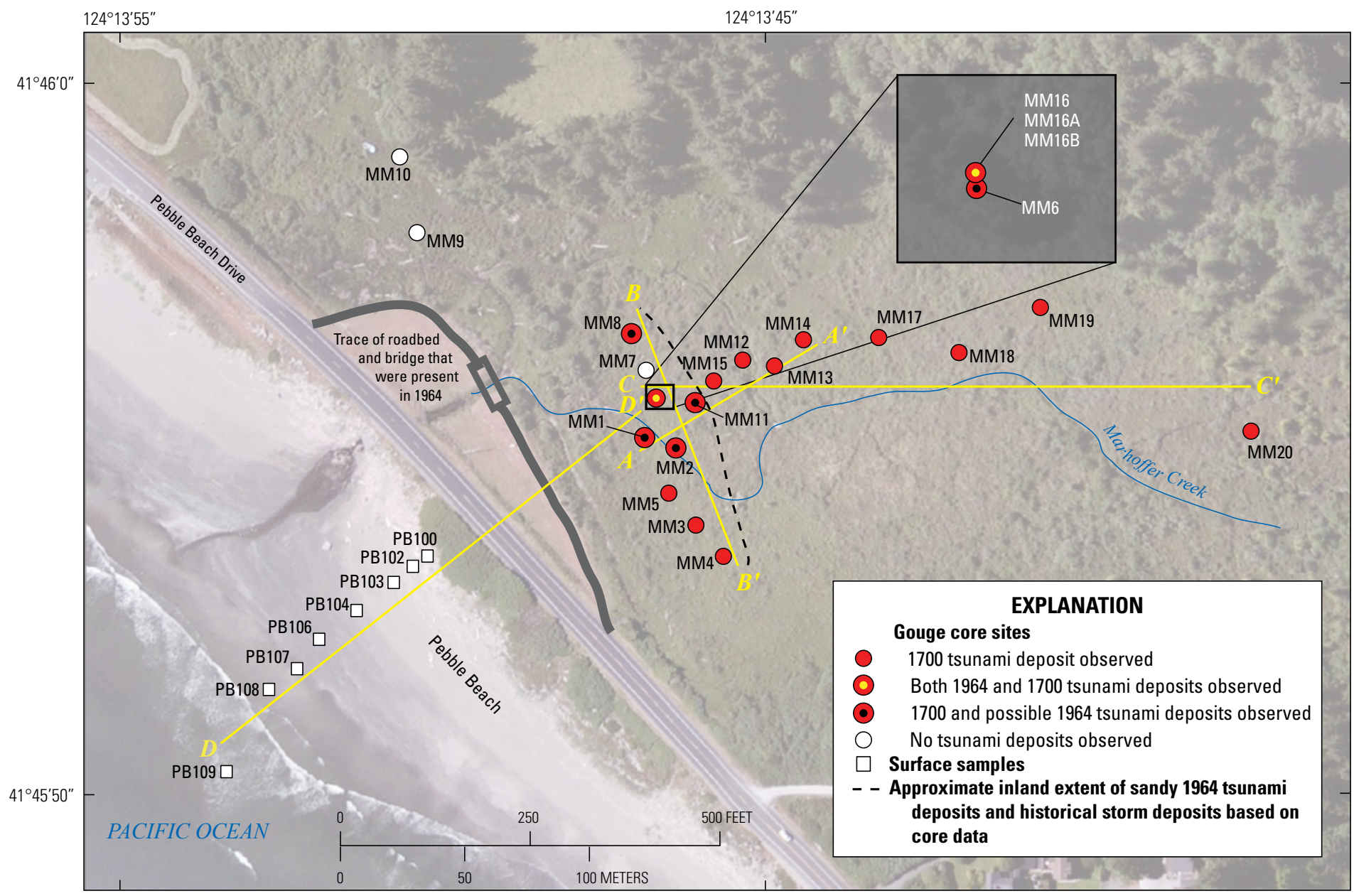

Imagery from Esri (C) 2017 and its licensors

Figure 3. Aerial image of the Marhoffer Creek marsh study site and adjacent Pebble Beach showing the locations of cores and surface samples. Elevational changes along transects $D-D^{\prime}$ and $C-C^{\prime}$ are shown in figure 4 . Details of transects $A-A^{\prime}, B-B^{\prime}$, and $C-C^{\prime}$ are shown in figures 6-8. Pebble Beach Drive was constructed in the 1970s, replacing the old, narrow road and bridge over Marhoffer Creek (shown by the thick gray line) that were present in 1964.

Figure 4. Crosssectional profiles $D-D^{\prime}$ and $C-C^{\prime}$ showing the elevation of surface samples collected at Pebble Beach and cores collected at Marhoffer Creek marsh. Locations are shown in figure 3. Elevations are relative to the North American Vertical Datum of 1988 (NAVD88).

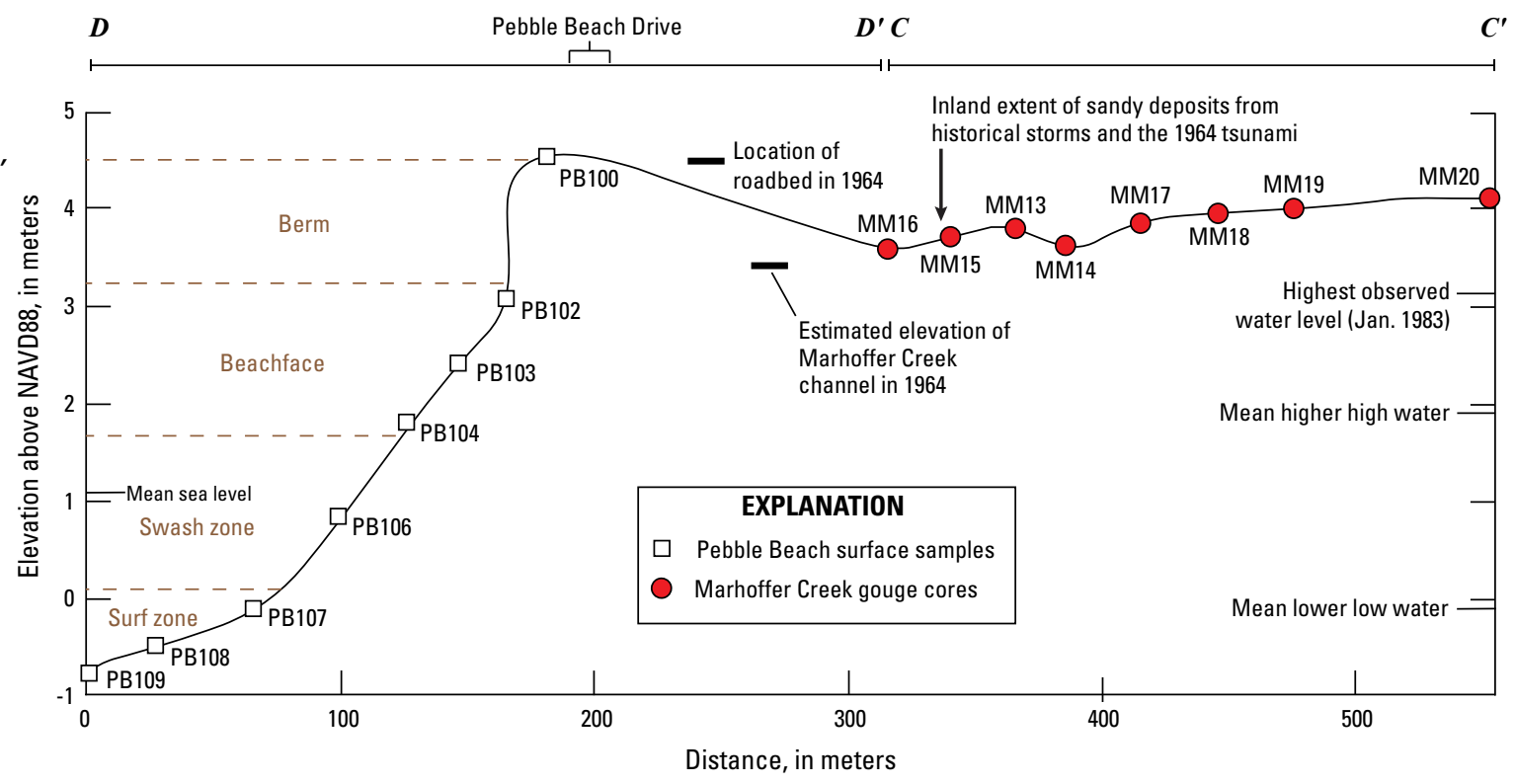




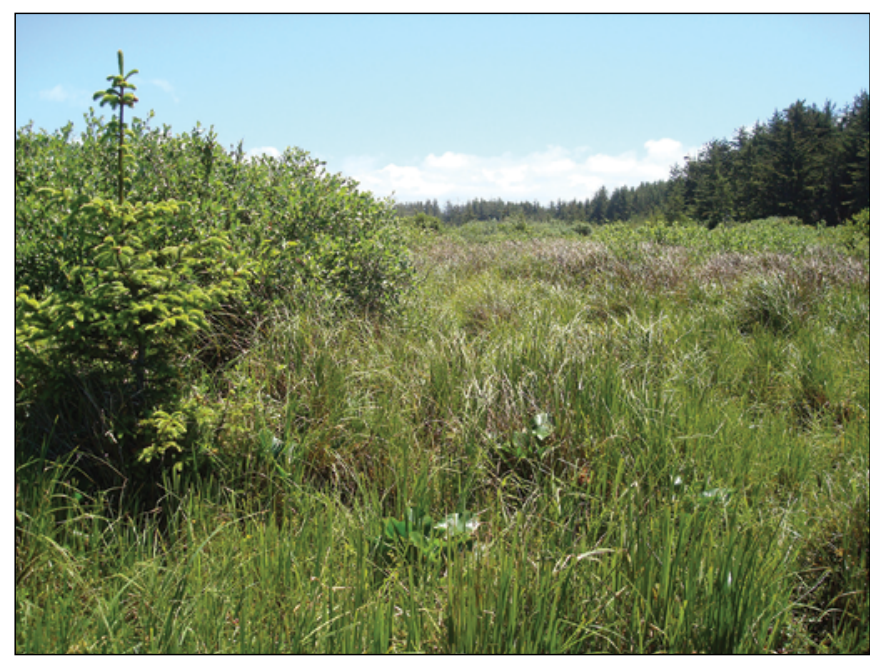

Figure 5. Photograph of the Marhoffer Creek marsh study site from the location of core MM1 (see fig. 3 for location). View is to the east (upvalley). The marsh is densely vegetated with a variety of freshwater plants as well as small spruce trees and willows. For scale, the spruce tree in the left foreground is about 1.5 meters tall.

\section{Tsunami and Storm Deposit Identification}

The stratigraphy revealed in the 22 Marhoffer Creek cores provides baseline evidence of the presence and upvalley distribution of possible Cascadia Subduction Zone tsunami deposits, as well as the more limited distribution of possible storm or far-field tsunami deposits found in close proximity to the shoreline. Using the basic lithologic characteristics and aerial distribution of subsurface clastic deposits as a guide, we acquired age estimates with radiocarbon or radionuclide analyses to compare with the currently accepted chronology for past Cascadia Subduction Zone earthquakes and tsunamis (Goldfinger and others, 2012; Gonzales and others, 2014; Petersen and others, 2014), as well as with historical records of large storms and farfield tsunamis in northern California. We further documented the presence or absence of marine diatoms at different stratigraphic intervals to identify deposits consistent with marine inundation and exclude deposits indicative of fluvial or upland runoff.

\section{Lithology and Stratigraphy}

The core data show that peat is the dominant lithology to subsurface depths of at least $2 \mathrm{~m}$, from the seaward area of the marsh to at least $500 \mathrm{~m}$ inland from the lower beach (figs. 6-8; appendix 1). Silt and mud are minor components in some peaty sections, but unlike other Crescent City marshes cored for this project, there are no recognizable mud layers. Sandy layers stand out in contrast to the dominantly peaty deposits. Sand layers are found throughout the cores located within about $100 \mathrm{~m}$ of Pebble Beach, but only below about $1 \mathrm{~m}$ depth in the upvalley cores. The sandy deposits are pale gray to brownish gray, very fine to medium grained, and range in thickness from $<1$ to $20 \mathrm{~cm}$.
The peat deposits are mostly reddish brown to dark brown, and range from coarse to fine grained based on degree of humification or preservation of large fossil roots. Some of the peat deposits are detrital, evident from coarse plant material and woody detritus. Some sections of fine-grained, strongly decomposed peat lacking coarse material may also be detrital, but may not have been recognized during field descriptions. The detrital nature of some fine-grained peat samples only became evident after being dried in the lab for radiocarbon and microfossil analyses, where subtle differences in texture between probable detrital and in-place peat deposits were noted.

Cores MM1 through MM11, which were collected within about $100 \mathrm{~m}$ of the modern beach, reveal sandy deposits (2-5 layers) mostly within $\sim 0.75 \mathrm{~m}$ of the modern marsh surface (figs. 3, 6-8). Some of the layers are separated by sandy detrital peat. Underlying this upper sandy interval is an uninterrupted section of dense, brown, fibrous to humified peat down to about $1 \mathrm{~m}$ depth, below which 1-3 gray sandy layers stand out in contrast to the otherwise predominantly peaty deposits. For example, in core MM1 (fig. 9), there are five distinct sandy deposits between 25 and $75 \mathrm{~cm}$ depth, some capped by sandy detrital peat, including an 18-cm-thick deposit comprising seven internal laminae discernable by variations in dominant grain size. Lower in the core, between 98 and $135 \mathrm{~cm}$ depth, is an interval including an upper and lower sandy layer with intervening brown to black detrital peat. The lower sandy layer at the base of this interval, between 130 and $134 \mathrm{~cm}$, is $4 \mathrm{~cm}$ thick and consists of pale gray, massive, fine- to mediumgrained sand. The upper sandy layer at the top of the interval is $11 \mathrm{~cm}$ thick, and comparable in composition to the lower sand unit except that it is more detrital rich. The two layers are separated by detrital peat, visibly coarser between 110 and $114 \mathrm{~cm}$ depth, but otherwise fine grained and decomposed, ranging in color from dark brown to black.

Cores farther than about $100 \mathrm{~m}$ from the beach, upvalley from and including core MM15 (fig. 3), do not include sandy deposits shallower than $\sim 1 \mathrm{~m}$ depth. The youngest of these deposits contains a variety of marine diatoms, and can be stratigraphically correlated across the central marsh study area, from the most seaward core, MM5, to the most landward core, MM20 (figs. 6-8).

\section{Geochronology}

Six new accelerator mass spectrometry (AMS) radiocarbon ages were acquired for cores MM11, MM12, MM16, and MM20 (fig. 10, table 1) to evaluate the youngest sandy deposit that can be traced in the subsurface for at least $500 \mathrm{~m}$ inland from the lower beach (figs. 4, 6-8; appendix 1). This deposit varies in thickness from about 5 to $18 \mathrm{~cm}$, and is found at depths of about 1.0-1.2 $\mathrm{m}$ in the western area of the marsh, and a few decimeters shallower (about $0.7 \mathrm{~m}$ below the surface) at upvalley sites. All of the analyses were based on seeds, seedpods, or woody detritus (table 1) collected below the sand layer, and therefore give maximum ages for the deposit. Three of the samples (from cores MM12, MM17, and from 93-94 cm 


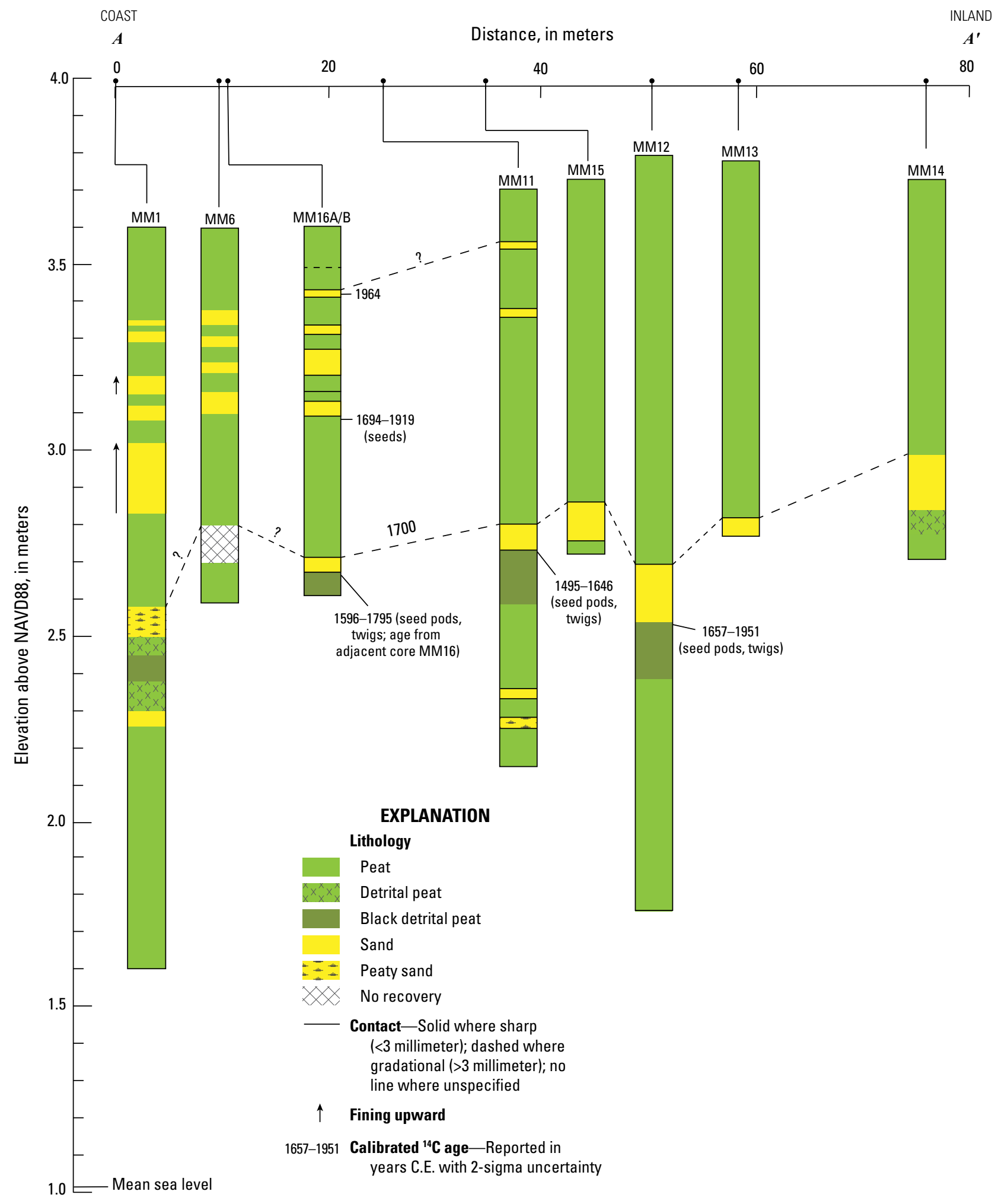

Figure 6. Lithologic logs of cores collected from Marhoffer Creek marsh along the shore-normal transect $A-A^{\prime}$. Core and transect locations shown in figure 3. Elevations are relative to the North American Vertical Datum of 1988 (NAVD88). 


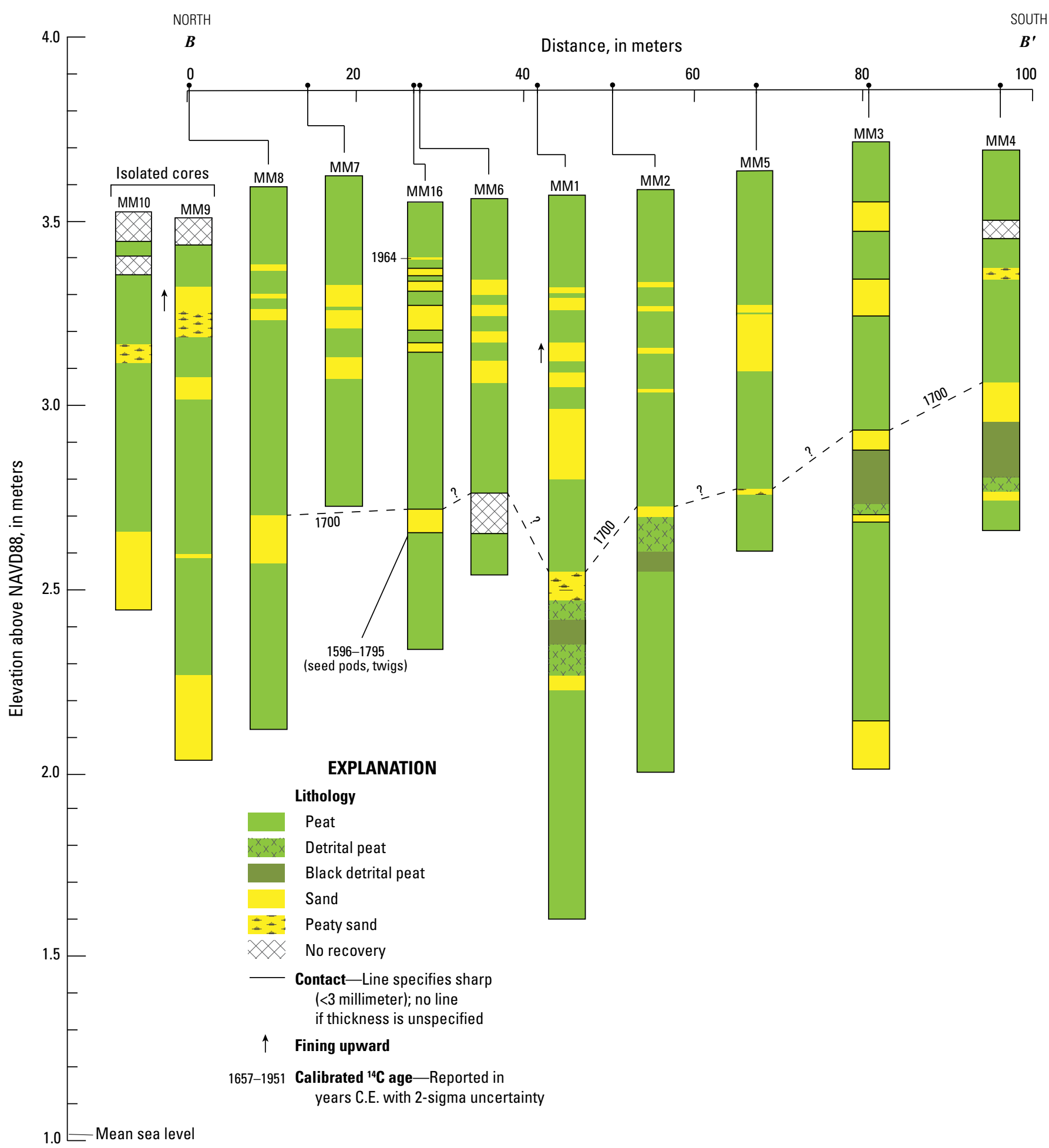

Figure 7. Lithologic logs of cores collected from Marhoffer Creek marsh along the shore-parallel transect $B-B^{\prime}$, including two isolated cores to the northwest (cores MM9 and MM10). Core and transect locations shown in figure 3 . Elevations are relative to the North American Vertical Datum of 1988 (NAVD88). 


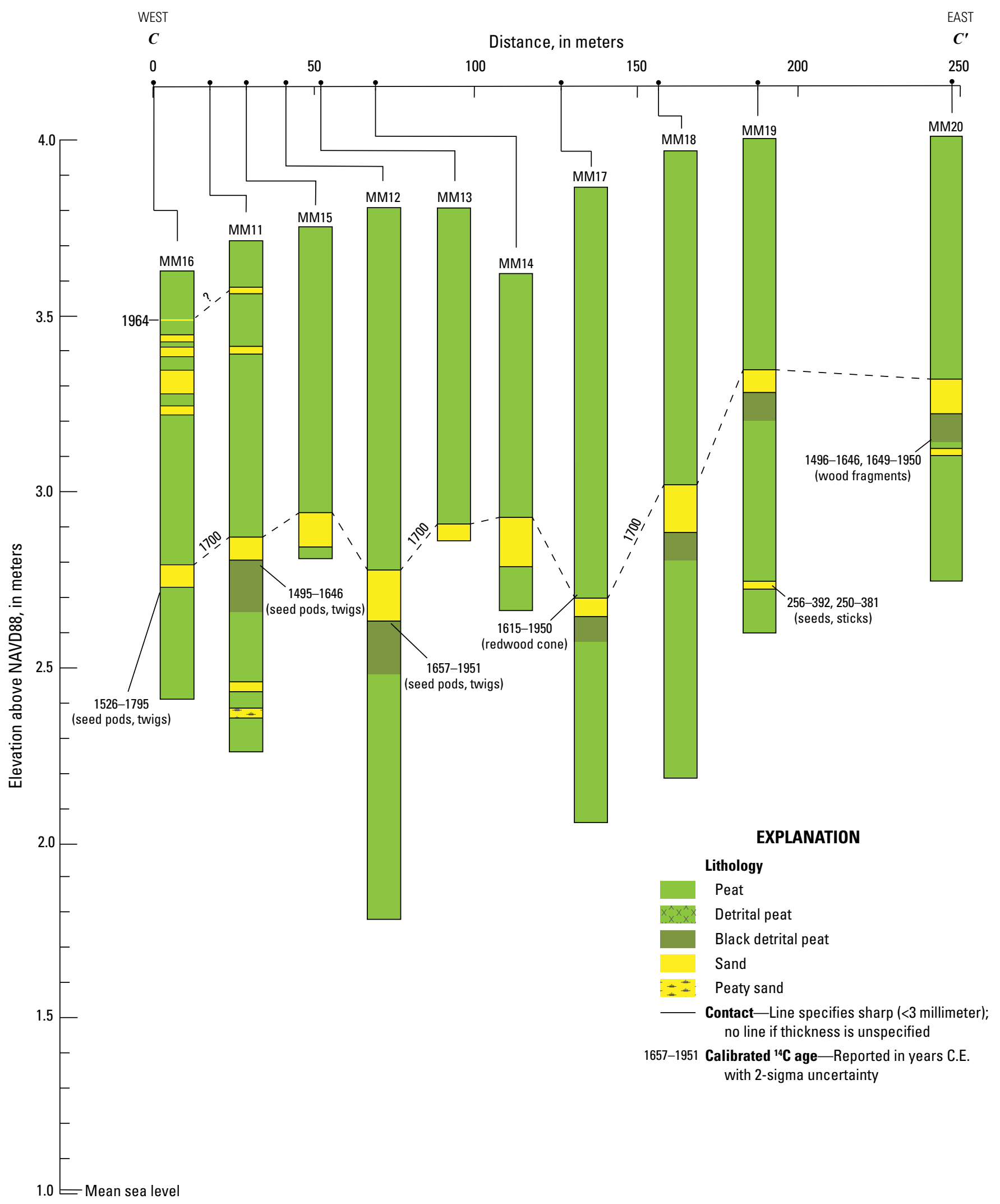

Figure 8. Lithologic logs of cores collected from Marhoffer Creek marsh along transect $C-C^{\prime}$. Core and transect locations shown in figure 3. Elevations are relative to the North American Vertical Datum of 1988 (NAVD88). 


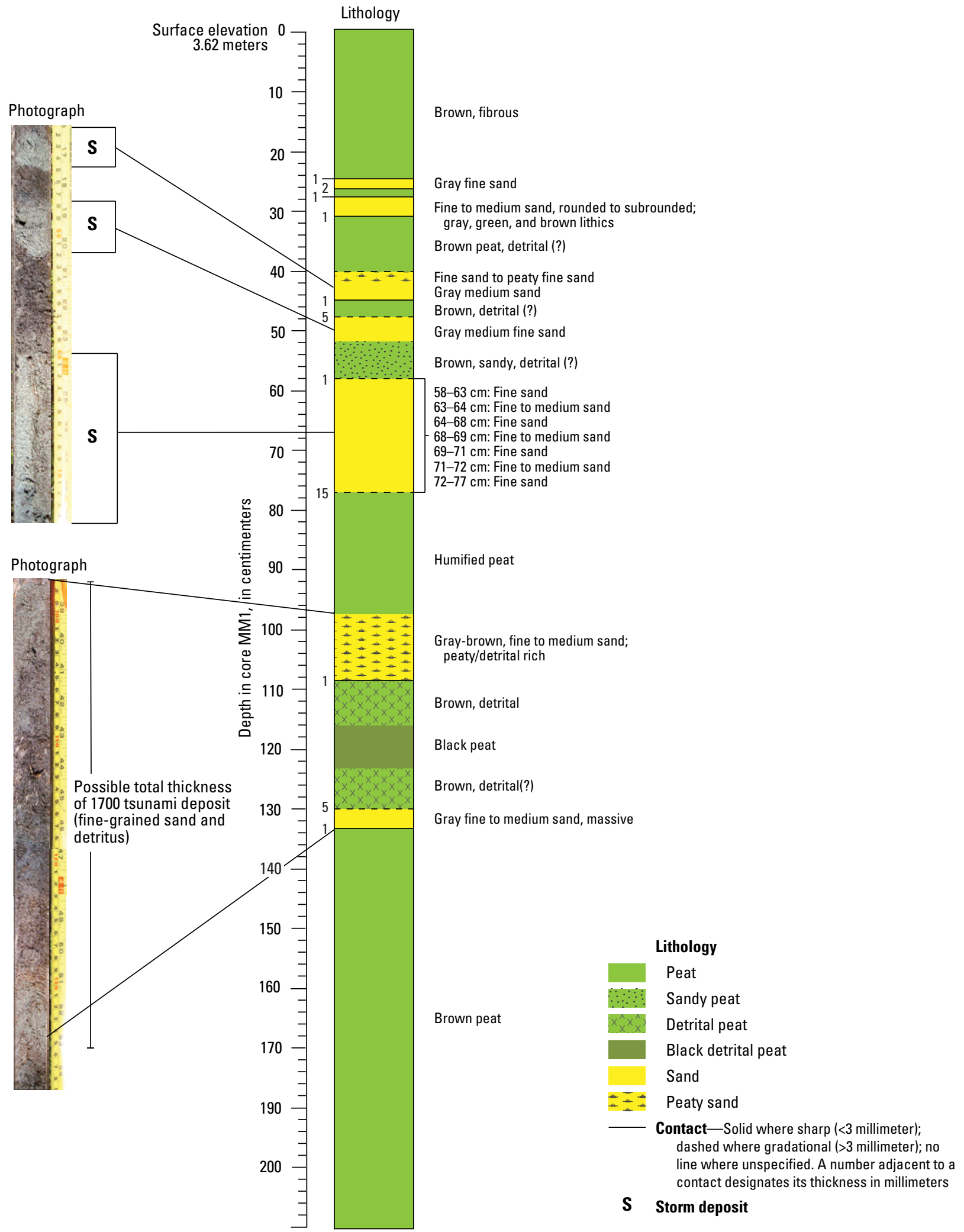

Figure 9. Stratigraphy and lithology of core MM1 from the seaward (western) side of Marhoffer Creek marsh. Lithologic log shows a series of sand layers that contrasts with the dominant peaty lithology. Sand deposits above 80 centimeters $(\mathrm{cm})$ depth are interpreted as primarily storm emplaced, but may include the 1964 tsunami deposit. The 1700 tsunami deposit consists of detrital-rich, peaty sand between 98 and $110 \mathrm{~cm}$. Core photographs show close-up views of storm and tsunami deposits. The upper photograph shows gray sand units separated by dark brown detrital peat. The lower photograph shows the core interval between 98 and $139 \mathrm{~cm}$, including the sandy and detritus-rich 1700 tsunami deposit at 98-110 cm. Elevations are relative to the North American Vertical Datum of 1988. 
in MM20) returned broad calibrated ages extending to 0 cal. yr B.P., an effect of samples with ages falling within the broad ${ }^{14} \mathrm{C}$ calibration curve that covers the last three centuries (Reimer and others, 2013). The remaining three samples returned somewhat narrower calibrated age ranges of 455-304 cal. yr B.P. (MM11), 424-284 cal. yr B.P. (MM16), and 454-304 cal. yr B.P. (92 cm depth in MM20).

Seeds and small sticks collected from within an anomalous sand layer containing marine diatoms at $1.4 \mathrm{~m}$ depth in core MM19, observed $475 \mathrm{~m}$ inland from the lower beach (figs. 3, 8), gave ${ }^{14} \mathrm{C}$ ages of $1,694-1,558 \mathrm{cal}$. yr B.P. and $1,700-1,569 \mathrm{cal}$. yr B.P. (256-392 C.E. and 250-381 C.E.).

Finally, small seeds recovered from peat at $49-50 \mathrm{~cm}$ depth in core MM16B, just below a 25 -cm-thick interval of sand and detrital peat and wood (figs. 6, 10), returned a calibrated age of 256-31 cal. yr B.P. (1694-1919 C.E.).

${ }^{210} \mathrm{~Pb}$ and ${ }^{137} \mathrm{Cs}$ analyses on samples from Marhoffer Creek marsh were used to estimate the ages of deposits in the shallow subsurface $(<0.5 \mathrm{~m}$ depth$)$ in the western area of the marsh (tables 2-4). For this study, ${ }^{137} \mathrm{Cs}$ analyses were particularly useful because a peak in ${ }^{137} \mathrm{Cs}$ activity corresponding to the year 1963 - a result of high levels of ${ }^{137} \mathrm{Cs}$ atmospheric fallout from nuclear weapons testing (Health and Safety Laboratory, 1972; Robbins and Edgington, 1975) - shows the stratigraphic level at which a 1964 tsunami deposit might be found.

Under ideal conditions for accumulation and retention of ${ }^{210} \mathrm{~Pb}$ in sedimentary deposits, the 22-year decay rate of ${ }^{210} \mathrm{~Pb}$ provides a mechanism for estimating the ages of deposits for the past $\sim 100$ years, that is, to the early 1900s (Sanchez-Cabeza and Ruiz-Fernandez, 2012). At Marhoffer Creek marsh, the ${ }^{210} \mathrm{~Pb}$ activities were too low and errors too large to extend age estimates past approximately 1950 C.E. in core MM16 (fig. 11; table 3) and 1938 C.E. in core MM16A (fig. 12; table 4).

The maximum ${ }^{137} \mathrm{Cs}$ activity (“137 $\mathrm{Cs}$ peak") occurs at a depth of $16.5 \mathrm{~cm}$ in core MM16 (figs. 11, 13; table 3) and at $20 \mathrm{~cm}$ in core MM16A (figs. 12, 14; table 4). In both cores, the relatively broad shape of the ${ }^{137} \mathrm{Cs}$ curve — compared to, for example, the sharp ${ }^{137} \mathrm{Cs}$ peaks acquired in fine-grained pond deposits at both Sand Mine and Pillar Point marshes (this study) - is a function of the thickness of the sample interval required in the Marhoffer Creek peat deposits to provide enough sample material for the gamma counting process (appendix 2). Although not a sharp peak, the level of maximum ${ }^{137} \mathrm{Cs}$ activity helps to identify the interval deposited in 1963, which in both cores includes a thin layer of sand and detrital plant fragments interbedded with freshwater peat.

\section{Summary of First-Order Evidence for Tsunami and Storm Deposits}

Stratigraphy, geochronology, and diatom assemblages give evidence at Marhoffer Creek marsh for (1) tsunami deposits associated with Cascadia Subduction Zone earthquakes in 1700 C.E. and 1,700-1,500 cal. yr B.P., (2) limited deposition by the farfield tsunami associated with the M9.2 Alaska earthquake in 1964
Calibrated ${ }^{14} \mathrm{C}$ age, in years C.E.

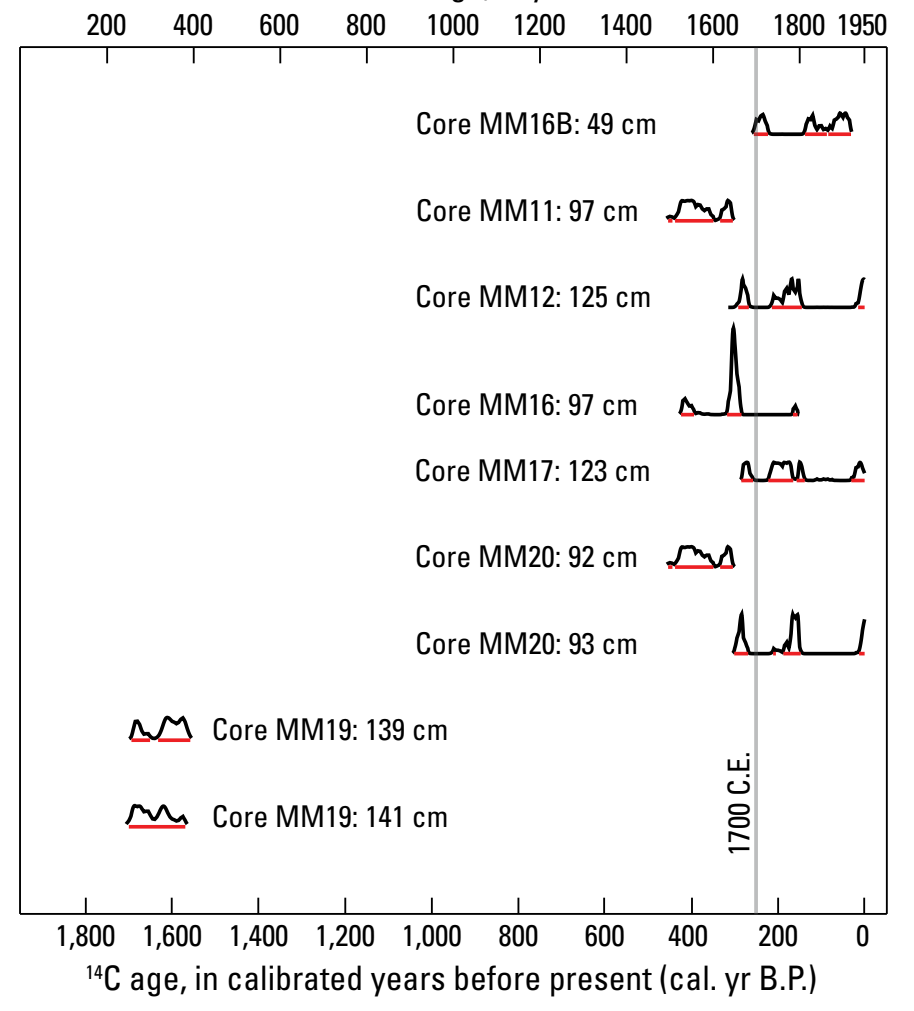

Figure 10. Graph showing calibrated ${ }^{14} \mathrm{C}$ ages probability distributions for samples from the Marhoffer Creek marsh study site. Labels denote the core name and the depth below the surface from which the ${ }^{14} \mathrm{C}$ sample was taken. Red lines show the area under the probability distribution function. See also table 1.

in the lower Marhoffer Creek valley (table 5), and (3) inundation and deposition by large storms during the period after 1700 and before the late 20th century.

The 1700 tsunami deposit at Marhoffer Creek marsh is found about $1 \mathrm{~m}$ below the modern marsh surface and can be traced hundreds of meters inland. ${ }^{14} \mathrm{C}$ ages from several cores are consistent with emplacement in 1700 and prominent occurrences of marine diatoms indicate a marine source. In upvalley cores, the 1700 tsunami deposit consists of a single layer of fine-grained gray sand and plant detritus, but at downvalley core sites the deposit is thicker and more complex (figs. 6-8). For example, at sites MM1, MM3, and MM4, the 1700 tsunami deposit may consist of upper and lower layers of sand separated by centimeters of detrital peat (fig. 7, appendix 1).

An anomalous sand layer at $1.4 \mathrm{~m}$ depth in core MM19, collected $>450 \mathrm{~m}$ inland, is interpreted as recording an older Cascadia Subduction Zone earthquake and tsunami. Prominent marine diatoms in the sand suggest a marine source; only oligohalobous taxa are found in the peaty deposits above and below the sand. The ${ }^{14} \mathrm{C}$ results of 1,694-1,558 and $1,700-1,569$ cal. yr B.P. are consistent in age with Cascadia Subduction Zone tsunami deposits of about 1,700-1,500 cal. yr B.P. that have been recorded at numerous locations in the coastal Pacific Northwest. In northern California, coseismic 
Table 3. $\quad{ }^{210} \mathrm{~Pb}$ and ${ }^{137} \mathrm{Cs}$ radionuclide analysis data for core MM16 from Marhoffer Creek marsh.

[cm, centimeter; $\mathrm{cm}^{2}$, square centimeter; g, gram; dpm/g, decays per minute per salt-corrected dry gram; yr, year; CRS, constant rate of supply; MDA, minimum detectable activity]

\begin{tabular}{|c|c|c|c|c|c|c|c|c|c|}
\hline $\begin{array}{l}\text { Sample } \\
\text { interval } \\
\text { (cm) }\end{array}$ & Lithology & $\begin{array}{l}\text { Excess } \\
{ }^{210} \mathrm{~Pb} \\
(\mathrm{dpm} / \mathrm{g})^{\mathrm{a}}\end{array}$ & $\begin{array}{l}\text { Excess } \\
{ }^{210} \mathrm{~Pb} \\
\text { error } \\
(\mathrm{dpm} / \mathrm{g})^{\mathrm{a}}\end{array}$ & ${ }^{137} \mathrm{Cs}(\mathrm{dpm} / \mathrm{g})^{\mathrm{a}}$ & $\begin{array}{l}{ }^{137} \text { Cs error } \\
(\mathrm{dpm} / \mathrm{g})^{\mathrm{a}}\end{array}$ & $\begin{array}{l}\text { Age from } \\
{ }^{137} \text { Cs bulk } \\
\text { sedimentation } \\
\text { rate (yr) }\end{array}$ & $\begin{array}{l}\text { Age from } \\
\text { excess } \\
{ }^{210} \mathrm{~Pb} \text { CRS } \\
\text { model }(y r)^{b}\end{array}$ & $\begin{array}{l}\text { CRS model } \\
\text { age range } \\
(\mathbf{y r})^{b}\end{array}$ & $\begin{array}{l}\text { Accumulated } \\
\text { weight of dry } \\
\text { sediment per in } \\
\text { situ } \mathbf{c m}^{2}(\mathbf{g})\end{array}$ \\
\hline $0-2$ & Dark-brown fibrous peat & 15.09 & 1.01 & $<0.40183$ & $<\mathrm{MDA}$ & 2011 & 2011 & $2010-2012$ & 0.07 \\
\hline $2-3$ & Dark-brown fibrous peat & 13.41 & 0.64 & 0.78 & 0.13 & 2010 & 2009 & $2008-2010$ & 0.13 \\
\hline $3-4$ & Dark-brown fibrous peat & 14.03 & 0.83 & 1.06 & 0.16 & 2008 & 2007 & $2006-2008$ & 0.18 \\
\hline $4-5$ & Dark-brown fibrous peat & 14.20 & 0.76 & 1.16 & 0.13 & 2006 & 2005 & 2003-2006 & 0.24 \\
\hline $5-6$ & Dark-brown fibrous peat & 11.13 & 0.71 & 0.83 & 0.14 & 2005 & 2003 & 2001-2004 & 0.30 \\
\hline $6-9$ & $\begin{array}{l}\text { Debris deposit; flat } \\
\text { transparent pieces of } \\
\text { blackened leaves or bark }\end{array}$ & & & & & 1997 & 1995 & 1993-1997 & 0.57 \\
\hline $9-11$ & Dark-brown fibrous peat & 5.47 & 0.16 & 3.01 & 0.06 & 1990 & 1989 & 1987-1992 & 0.82 \\
\hline $11-13$ & Dark-brown fibrous peat & 5.36 & 0.17 & 3.37 & 0.06 & 1983 & 1982 & $1978-1986$ & 1.08 \\
\hline $13-15$ & Dark-brown fibrous peat & 4.36 & 0.16 & 4.59 & 0.07 & 1975 & 1974 & $1968-1981$ & 1.37 \\
\hline $15-16$ & Dark-brown fibrous peat & 3.32 & 0.15 & 4.40 & 0.06 & 1969 & 1968 & 1960-1979 & 1.58 \\
\hline $16-17^{\mathrm{c}}$ & Dark-brown fibrous peat & 2.36 & 0.10 & 4.99 & 0.04 & 1964 & 1963 & $1953-1978$ & 1.78 \\
\hline $17-19$ & Dark-brown fibrous peat & 2.72 & 0.11 & 1.21 & 0.03 & & 1952 & 1934-1996 & 2.12 \\
\hline $19-20$ & Gray fine sand & 0.69 & 0.13 & $<0.0191$ & $<$ MDA & & & & 3.04 \\
\hline $20-21$ & Gray fine sand & 0.06 & 0.09 & $<0.02183$ & $<\mathrm{MDA}$ & & & & 4.38 \\
\hline $21-22$ & Brown fibrous peat & 0.79 & 0.09 & $<0.0245$ & $<\mathrm{MDA}$ & & & & 4.69 \\
\hline $22-22.5$ & Brown fibrous peat & 0.65 & 0.11 & $<0.02077$ & $<\mathrm{MDA}$ & & & & 5.00 \\
\hline $22.5-23.5$ & Brown fibrous peat & 0.16 & 0.18 & $<0.03619$ & $<\mathrm{MDA}$ & & & & 5.76 \\
\hline $23.5-24$ & Gray fine sand & 0.00 & 0.00 & $<0.0343$ & $<\mathrm{MDA}$ & & & & 6.20 \\
\hline $24-24.5$ & Gray fine sand & & & & & & & & 6.75 \\
\hline $24.5-25$ & Gray fine sand & 0.19 & 0.09 & $<0.02463$ & $<\mathrm{MDA}$ & & & & 7.60 \\
\hline $25-26$ & $\begin{array}{l}\text { Brown sandy detrital peat } \\
\text { with small }(<1 \mathrm{~cm} \\
\text { diameter) wood fragments }\end{array}$ & & & & & & & & 8.03 \\
\hline $26-27$ & $\begin{array}{l}\text { Brown sandy detrital peat } \\
\text { with one } 2 \times 3-\mathrm{cm} \text { wood } \\
\text { piece }\end{array}$ & 0.56 & 0.11 & $<0.04361$ & $<\mathrm{MDA}$ & & & & 8.25 \\
\hline $27-28$ & $\begin{array}{l}\text { Brown sandy detrital peat } \\
\text { with small }(<1 \mathrm{~cm} \\
\text { diameter) wood fragments }\end{array}$ & & & & & & & & 8.49 \\
\hline $28-29$ & $\begin{array}{l}\text { Brown sandy detrital } \\
\text { peat with }<1-\mathrm{cm} \text { wood } \\
\text { fragments }\end{array}$ & 0.34 & 0.04 & 0.03 & 0.01 & & & & 8.91 \\
\hline $29-30$ & $\begin{array}{l}\text { Transition from brown } \\
\text { detrital peat to gray sand }\end{array}$ & & & & & & & & 9.52 \\
\hline $30-30.5$ & Gray fine sand & 0.01 & 0.09 & $<0.07581$ & $<\mathrm{MDA}$ & & & & 10.07 \\
\hline $30.5-31$ & Gray fine sand & & & & & & & & 10.50 \\
\hline $31-31.5$ & Gray fine sand & & & & & & & & 11.12 \\
\hline $31.5-32$ & Gray fine sand & 0.02 & 0.08 & $<0.05488$ & $<\mathrm{MDA}$ & & & & 11.70 \\
\hline $32-32.5$ & Gray fine sand & & & & & & & & 12.34 \\
\hline $32.5-33.5$ & Gray fine sand & & & & & & & & 13.97 \\
\hline $33.5-34$ & Gray fine sand & & & & & & & & 14.70 \\
\hline $34-34.5$ & Gray fine sand & 0.00 & 0.00 & $<0.07133$ & $<\mathrm{MDA}$ & & & & 15.31 \\
\hline $34.5-35$ & Gray fine sand & & & & & & & & 16.19 \\
\hline $35-35.5$ & Gray fine sand & & & & & & & & 16.99 \\
\hline $35.5-36$ & Gray fine sand & & & & & & & & 17.48 \\
\hline $36-36.5$ & Gray fine sand & 0.00 & 0.00 & $<0.01389$ & $<\mathrm{MDA}$ & & & & 18.25 \\
\hline
\end{tabular}


Table 3.-Continued

\begin{tabular}{|c|c|c|c|c|c|c|c|c|c|}
\hline $\begin{array}{c}\text { Sample } \\
\text { interval } \\
\text { (cm) }\end{array}$ & Lithology & $\begin{array}{l}\text { Excess } \\
{ }^{210} \mathrm{~Pb} \\
(\mathrm{dpm} / \mathrm{g})^{\mathrm{a}}\end{array}$ & $\begin{array}{l}\text { Excess } \\
{ }^{210} \mathrm{~Pb} \\
\text { error } \\
(\mathrm{dpm} / \mathrm{g})^{\mathrm{a}}\end{array}$ & ${ }^{137} \mathrm{Cs}(\mathrm{dpm} / \mathrm{g})^{\mathrm{a}}$ & $\begin{array}{l}{ }^{137} \text { Cs error } \\
(\mathrm{dpm} / \mathrm{g})^{\mathrm{a}}\end{array}$ & $\begin{array}{c}\text { Age from } \\
{ }^{137} \text { Cs bulk } \\
\text { sedimentation } \\
\text { rate (yr) }\end{array}$ & $\begin{array}{l}\text { Age from } \\
\text { excess } \\
{ }^{210} \mathrm{~Pb} \text { CRS } \\
\text { model }(\mathrm{yr})^{\mathrm{b}}\end{array}$ & $\begin{array}{l}\text { CRS model } \\
\text { age range } \\
(y r)^{b}\end{array}$ & $\begin{array}{l}\text { Accumulated } \\
\text { weight of dry } \\
\text { sediment per in } \\
\text { situ } \mathrm{cm}^{2}(\mathrm{~g})\end{array}$ \\
\hline $36.5-38$ & $\begin{array}{l}\text { Brown sandy detrital } \\
\text { peat with }<3 \text {-cm wood } \\
\text { fragments }\end{array}$ & 0.24 & 0.05 & 0.02 & 0.00 & & & & 18.65 \\
\hline $38-39$ & $\begin{array}{l}\text { Brown sandy detrital } \\
\text { peat with }<3-\mathrm{cm} \text { wood } \\
\text { fragments }\end{array}$ & & & & & & & & 18.78 \\
\hline $39-40$ & $\begin{array}{l}\text { Brown sandy detrital } \\
\text { peat with }<3 \text {-cm wood } \\
\text { fragments }\end{array}$ & & & & & & & & 19.32 \\
\hline $40-40.5$ & Gray fine sand & & & & & & & & 19.67 \\
\hline $40.5-41$ & Gray fine sand & 0.00 & 0.00 & $<0.05565$ & $<\mathrm{MDA}$ & & & & 19.94 \\
\hline $41-42$ & Gray fine sand & & & & & & & & 21.33 \\
\hline $42-42.5$ & Gray fine sand & 0.12 & 0.07 & $<0.03058$ & $<\mathrm{MDA}$ & & & & 21.74 \\
\hline $42.5-43$ & Gray fine sand & & & & & & & & 22.07 \\
\hline $43-43.5$ & Gray fine sand & 0.01 & 0.17 & $<0.09287$ & $<\mathrm{MDA}$ & & & & 22.24 \\
\hline $43.5-45$ & Brown fibrous peat & 0.43 & 0.08 & $<0.04035$ & $<\mathrm{MDA}$ & & & & 22.49 \\
\hline $45-47$ & Brown fibrous peat & 0.54 & 0.07 & 0.03 & 0.01 & & & & 22.74 \\
\hline
\end{tabular}

${ }^{\text {a }}$ Values are decay corrected. ${ }^{b}$ Salt-corrected and decay-corrected values. ${ }^{c}$ Maximum ${ }^{137} \mathrm{Cs}$ activity occurs at this depth interval.

Table 4. ${ }^{210} \mathrm{~Pb}$ and ${ }^{137} \mathrm{Cs}$ radionuclide analysis data for core MM16A from Marhoffer Creek marsh.

$\left[\mathrm{cm}\right.$, centimeter; $\mathrm{cm}^{2}$, square centimeter; g, gram; dpm/g, decays per minute per salt-corrected dry gram; yr, year; CRS, constant rate of supply; MDA, minimum detectable activity]

\begin{tabular}{|c|c|c|c|c|c|c|c|c|c|}
\hline $\begin{array}{c}\text { Sample } \\
\text { interval } \\
\text { (cm) }\end{array}$ & Lithology & $\begin{array}{l}\text { Excess } \\
{ }^{210} \mathrm{~Pb} \\
(\mathrm{dpm} / \mathrm{g})^{\mathrm{a}}\end{array}$ & $\begin{array}{l}\text { Excess } \\
{ }^{210} \mathrm{~Pb} \\
\text { error } \\
(\text { dpmg) } \\
\end{array}$ & $\begin{array}{c}{ }^{137} \mathrm{Cs} \\
(\mathrm{dpm} / \mathrm{g})^{\mathrm{a}}\end{array}$ & $\begin{array}{l}{ }^{137} \text { Cs error } \\
(\mathrm{dpm} / \mathrm{g})^{\mathrm{a}}\end{array}$ & $\begin{array}{c}\text { Age from } \\
{ }^{137} \text { Cs bulk } \\
\text { sedimentation } \\
\text { rate (yr) }\end{array}$ & $\begin{array}{c}\text { Age from } \\
\text { excess }{ }^{210} \mathrm{~Pb} \\
\text { CRS model } \\
(y r)^{b}\end{array}$ & $\begin{array}{c}\text { CRS model } \\
\text { age range } \\
(y r)^{b}\end{array}$ & $\begin{array}{l}\text { Accumulated } \\
\text { weight of dry } \\
\text { sediment per } \\
\mathbf{c m}^{2}(\mathbf{g})\end{array}$ \\
\hline $8-10$ & Brown peat & 7.6014 & 0.3554 & 1.7341 & 0.094 & 1995.8 & & & 0.90 \\
\hline $10-12$ & Dark-brown humified peat & 6.1911 & 0.3620 & 2.2037 & 0.110 & 1992.4 & & & 1.08 \\
\hline $16-17$ & Dark-brown humified peat & & & & & 1978.3 & & & 1.82 \\
\hline $17-19$ & Dark-gray peaty sand & 1.6769 & 0.1258 & 4.6445 & 0.066 & 1970.0 & & & 2.26 \\
\hline $19-21^{\mathrm{c}}$ & Brown humified peat & 2.1347 & 0.2684 & 9.3672 & 0.200 & 1963.6 & 1963.5 & $1960-1967$ & 2.60 \\
\hline $21-23$ & Light-brown humified peat & 3.1980 & 0.2295 & 7.8286 & 0.129 & & 1951.1 & $1945-1958$ & 2.88 \\
\hline $23-24$ & Light-brown humified peat & 2.3816 & 0.3631 & 6.1366 & 0.214 & & 1942.8 & $1935-1954$ & 3.06 \\
\hline $27-28$ & Gray fine sand & 0.1250 & 0.0833 & 0.1049 & 0.013 & & 1921.8 & 1904-1964 & 4.92 \\
\hline $28-29$ & Gray fine sand & 0.0887 & 0.1020 & $<0.02073$ & $<$ MDA & & 1919.9 & 1902-1964 & 5.42 \\
\hline $29-30$ & Brown humified peat & & & & & & & & 5.63 \\
\hline $30-32$ & Brown humified peat & 1.1370 & 0.2142 & $<0.07256$ & $<\mathrm{MDA}$ & & & & 5.87 \\
\hline $32-34$ & Brown humified peat & & & & & & & & 6.30 \\
\hline $34-35$ & Gray fine to medium sand & 0.0861 & 0.0863 & $<0.01576$ & $<\mathrm{MDA}$ & & & & 6.84 \\
\hline $35-36$ & Gray fine to medium sand & 0.0000 & 0.0000 & $<0.01517$ & $<\mathrm{MDA}$ & & & & 7.57 \\
\hline
\end{tabular}

${ }^{a}$ Values are decay corrected. ${ }^{b}$ Salt-corrected and decay-corrected values. ${ }^{c}$ Maximum ${ }^{137} \mathrm{Cs}$ activity occurs at this depth interval. 


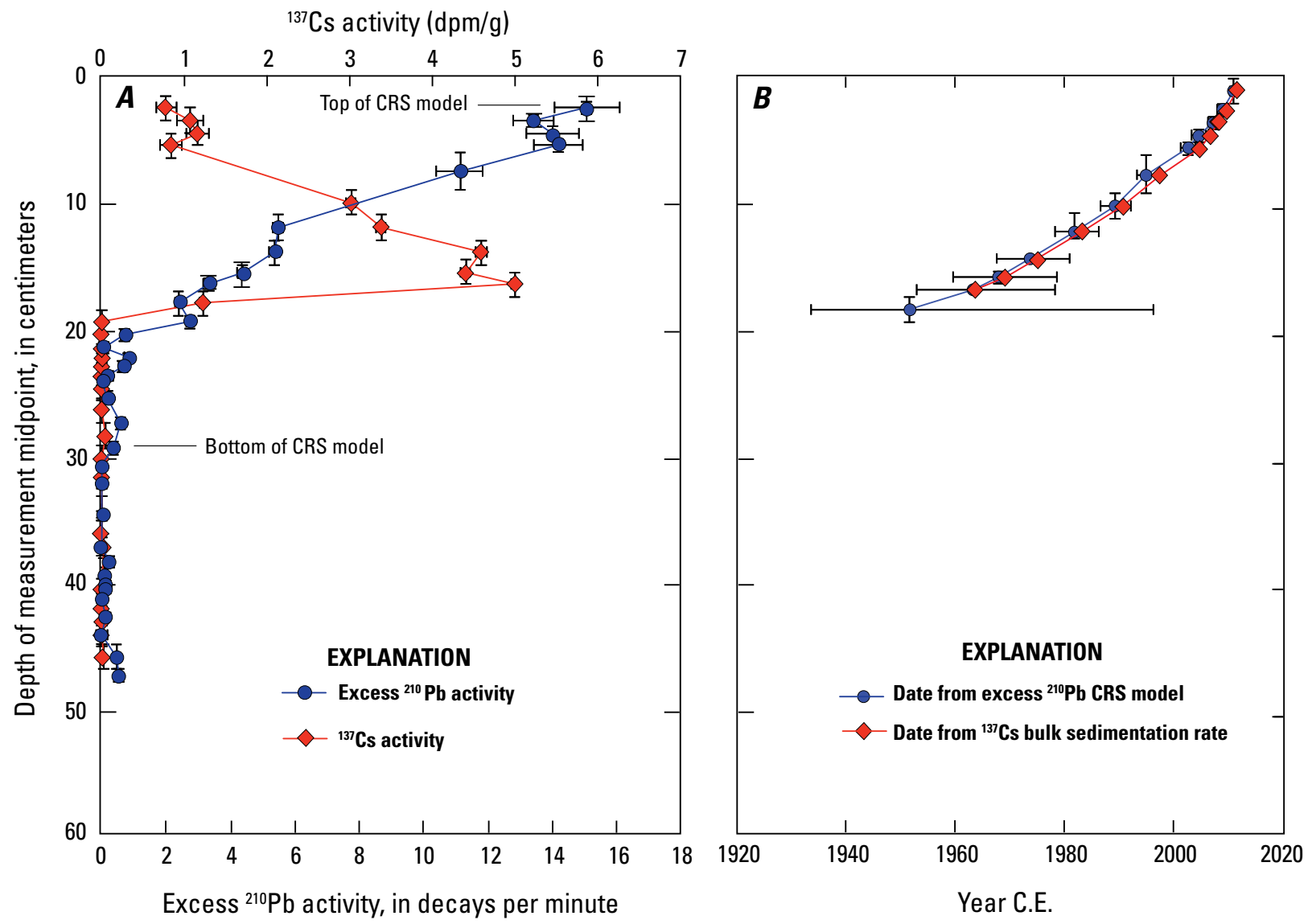

Figure 11. Radionuclide results for core MM16 from Marhoffer Creek marsh. $A$, Graph of ${ }^{137} \mathrm{Cs}$ and excess ${ }^{210} \mathrm{~Pb}$ radionuclide activities. $B$, Age estimates based on the bulk sedimentation rate (in grams per year) derived from ${ }^{137} \mathrm{Cs}$ (red) and the ${ }^{210} \mathrm{~Pb}$ constant rate of supply (CRS) model (blue). ${ }^{210} \mathrm{~Pb}$ CRS model dates are graphed as deep as 100 percent error. per dry gram $(\mathrm{dpm} / \mathrm{g})$
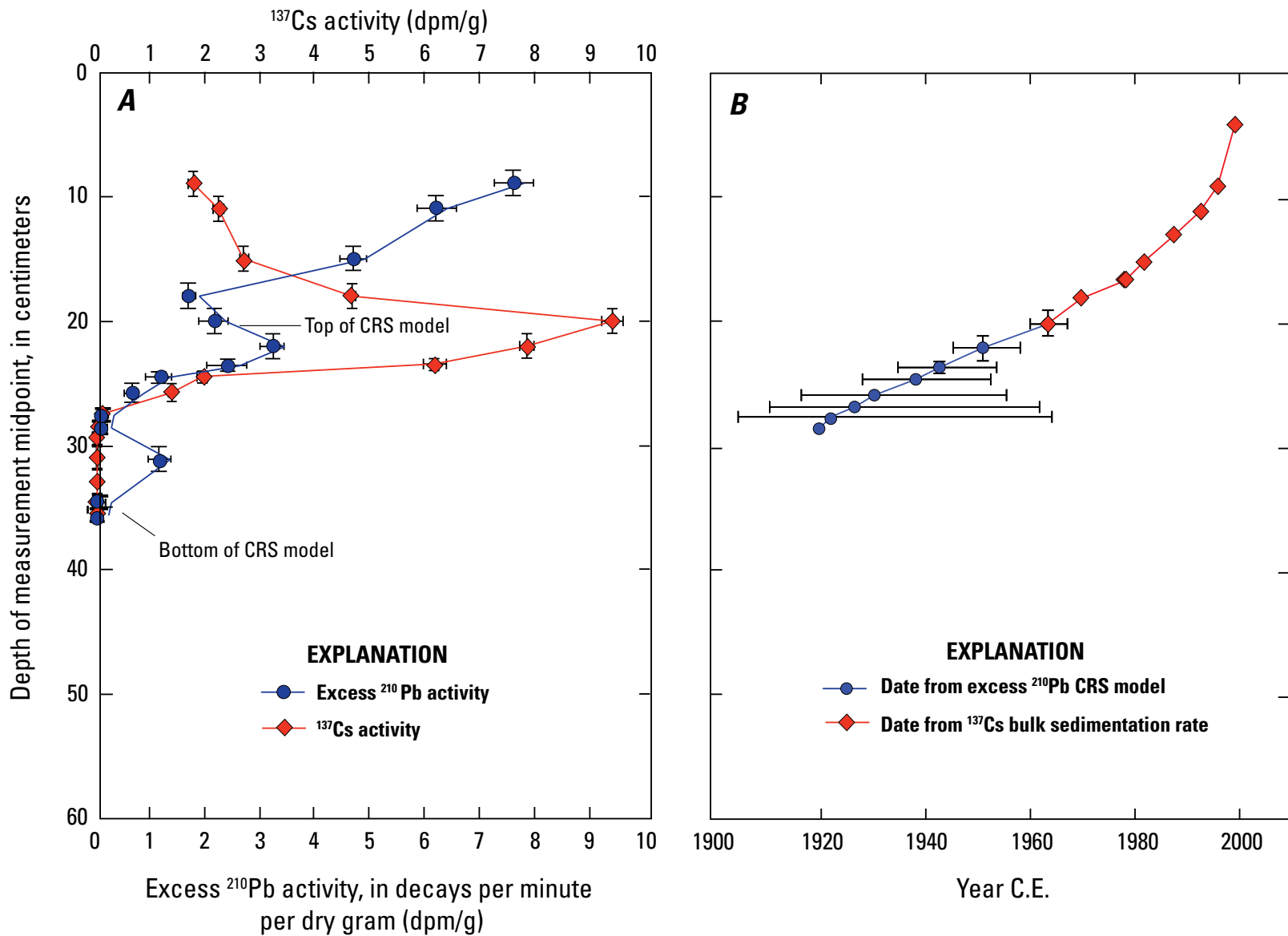

Figure 12. Radionuclide results for core MM16A from Marhoffer Creek marsh. A, Graph of ${ }^{137} \mathrm{Cs}$ and excess ${ }^{210} \mathrm{~Pb}$ radionuclide activities. $B$ Age estimates based on the bulk sedimentation rate (in grams per year) derived from ${ }^{137} \mathrm{Cs}$ and the ${ }^{210} \mathrm{~Pb}$ constant rate of supply (CRS) model. ${ }^{210} \mathrm{~Pb}$ CRS model dates are based on the estimated value of 10 decays per minute per gram (dpm/g) for the uppermost interval in the core and are plotted as deep as 100 percent error. ${ }^{137} \mathrm{Cs}$ dates are plotted to the depth of the $1963{ }^{137} \mathrm{Cs}$ peak. 


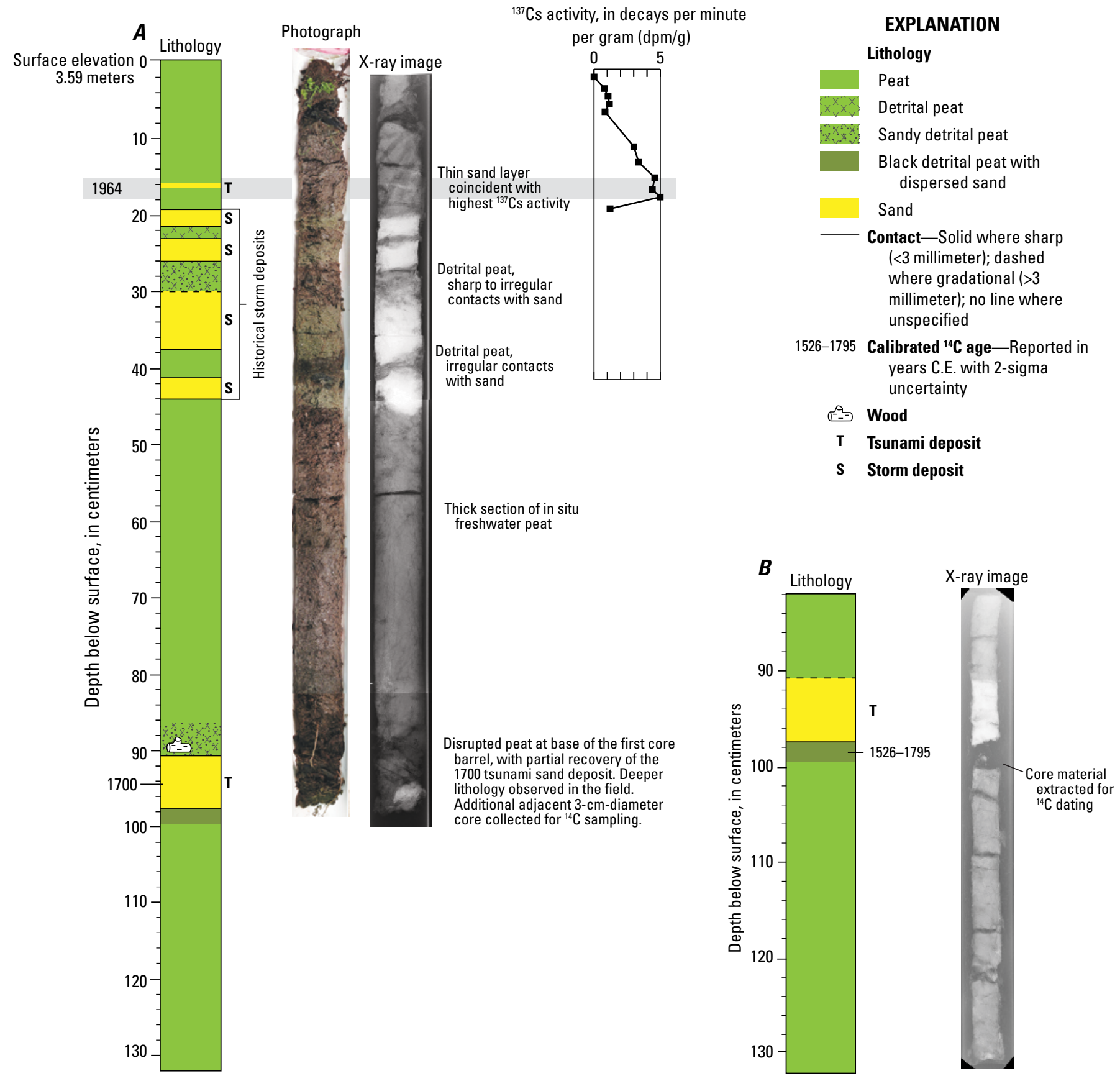

Note cores in $A$ and $B$ are at different scales

Figure 13. Data for core MM16 from Marhoffer Creek marsh. $A$, Lithologic log, photograph, and X-ray image showing the dominant peaty lithology intercalated with several sand layers. Based on ${ }^{14} \mathrm{C}$ analysis from an adjacent, auxillary 3-centimeter-diameter core (core MM16.1; shown in part B), the sand layer at 90-98 centimeters (cm) depth is the 1700 Cascadia Subduction Zone tsunami deposit. At right is a plot of ${ }^{137} \mathrm{Cs}$ radionuclide activity. The highest activity of ${ }^{137} \mathrm{Cs}$ in the core is coincident with a thin sand layer near $12 \mathrm{~cm}$ depth (recognizeable in the X-ray image at right), which is interpreted as the 1964 tsunami deposit. B, Lithologic log and X-ray image of core MM16.1. Elevations are relative to the North American Vertical Datum of 1988. 


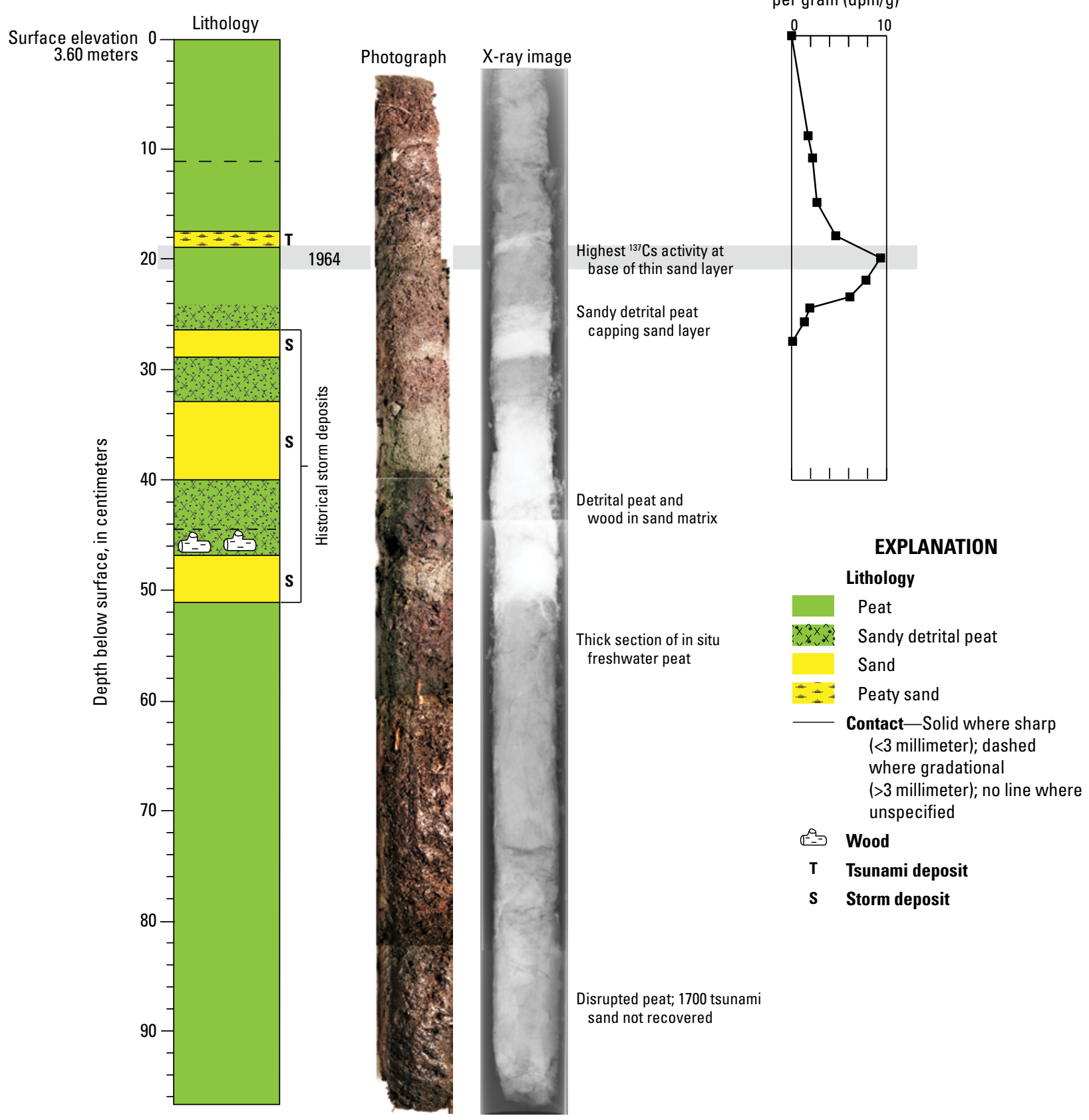

Figure 14. Data for core MM16A from Marhoffer Creek marsh, collected 2 meters from core MM16. Lithologic log, photograph, and X-ray image show sand layers intercalated in peat. The 1964 tsunami deposit is about 1 centimeter thick and coincident with the highest ${ }^{137} \mathrm{Cs}$ activity (shown in plot at right). The 1700 tsunami deposit was not recovered in this core. Elevations are relative to the North American Vertical Datum of 1988. 
Table 5. Summary of first-order evidence for tsunami and storm deposits at Marhoffer Creek marsh.

[cal. yr C.E., calibrated years in common era; yr B.P., years before present; cal. yr B.P., calibrated years before present; cm, centimeters; m, meters]

\begin{tabular}{|c|c|c|c|}
\hline Inundation Event & $\begin{array}{c}{ }^{14} \text { C } \text { age }^{\mathrm{b}} \\
\text { (cal. yr C.E.) }\end{array}$ & Stratigraphic position and correlation & Marine diatoms \\
\hline 1964 far-field tsunami ${ }^{\mathrm{a}}$ & & $\begin{array}{l}\text { Thin sand layers observed in a few cores in the } \\
\text { lowermost stream valley near the } 1964 \text { location of the } \\
\text { Marhoffer Creek natural channel }\end{array}$ & $\begin{array}{l}\text { Present but sparse and } \\
\text { poorly preserved }\end{array}$ \\
\hline $\begin{array}{l}\text { Late-19th century to } \\
\text { early-20th century } \\
\text { storms }\end{array}$ & $\begin{array}{l}\text { Weakly supporting result of } \\
1694-1919\end{array}$ & $\begin{array}{l}\text { Thick sand and detritus deposits at the seaward end } \\
\text { of the marsh; irregular thickness and distribution; } \\
\text { separated from overlying }{ }^{137} \mathrm{Cs} \text { peak by } 2-10 \mathrm{~cm} \text { of } \\
\text { in situ peat and from underlying } 1700 \text { C.E. tsunami } \\
\text { deposit by }>40 \mathrm{~cm} \text { of in situ peat }\end{array}$ & $\begin{array}{l}\text { Present but sparse and } \\
\text { poorly preserved }\end{array}$ \\
\hline $\begin{array}{l}1700 \text { Cascade } \\
\text { Subduction Zone } \\
\text { tsunami }\end{array}$ & $\begin{array}{l}\text { Maximum ages of } 1495-1646, \\
\quad 1596-1725,1496-1646 \\
\text { Additional broad ages of } 1657-1951 \text {, } \\
\quad 1615-1950,1649-1950\end{array}$ & $\begin{array}{l}\text { Fine-grained sand layer found about } 1 \mathrm{~m} \text { below the } \\
\text { marsh surface intercalated in thick, continuous } \\
\text { sections of peat; correlated among numerous cores to } \\
>500 \mathrm{~m} \text { inland from the lower beach }\end{array}$ & $\begin{array}{l}\text { Prominent and diverse, } \\
\text { numerous offshore } \\
\text { species }\end{array}$ \\
\hline
\end{tabular}

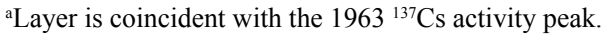

${ }^{\mathrm{b}}$ Ages reported with 2-sigma uncertainty.

subsidence associated with an earthquake of this approximate age has been documented along northern Humboldt Bay (Valentine and others, 2012; Engelhart and others, 2016) and tsunami deposits have been documented at Hookton Slough in southern Humboldt Bay ("sand 3" of Patton, 2004); at Lagoon Creek, $6 \mathrm{~km}$ north of the Klamath River mouth (sand above "soil S" of Abramson, 1998); and in marshes south of Crescent City (sand above "soil 4" in figure 7 of Peterson and others, 2011). To date, this tsunami deposit is only verified in core MM19 from Marhoffer Creek marsh, but may correlate to sand layers in the lower parts of cores MM1 and MM11. Compared to the 1,700-1,500 cal. yr B.P. tsunami deposit in MM19, a thin sand layer at 97-99 cm depth in core MM20 (fig. 8), $<15 \mathrm{~cm}$ below the 1700 tsunami deposit, contains none of the diverse marine taxa observed in MM19, but instead dense accumulations of tiny pennate diatom taxa, consistent with accumulation in a stream channel. Therefore, this anomalous sand layer is likely an isolated freshwater deposit associated with a past small channel in the marsh.

The coincidence of thin ( $<2-\mathrm{cm}$-thick) sand and detritus layers in cores MM16 and MM16A with the $1963{ }^{137} \mathrm{Cs}$ peak, as well as occurrences of marine diatoms, suggests the 1964 far-field tsunami inundated the lower Marhoffer Creek valley. The presence of marine diatoms and the limited inland extent of the thin sandy deposits help to discount deposition associated with the December 1964 "Christmas Flood"- another great disaster of 1964 in the northwestern United States, where climatic conditions converged to produce extreme runoff and the highest flood stages of the 20th century along major streams of coastal northern California (Harden, 1995). Although Marhoffer Creek might have experienced high runoff for its size because of the short period of intense rainfall, we found no evidence for coarse-grained flood deposits or obvious disruption in peat accumulation in the shallow subsurface of any upvalley sites, including core MM18, which adjoins the creek at an outside bend (figs. 3, 4, 8 ). And although marine diatoms are found in both tsunami and storm deposits, the presence of marine diatoms in this case is better explained by tsunami transport because the massive 1964 flooding was a terrestrial runoff event and did not coincide with unusually high storm surges. These data together support inundation into at least a limited area of the lower Marhoffer Creek valley by the 1964 tsunami, even in the absence of historical documentation of the event.

Sand and detritus deposits of variable thicknesses are found in the shallow subsurface (less than $\sim 0.8 \mathrm{~m}$ depth) of the seaward part of the marsh within about $100 \mathrm{~m}$ of the beach. In cores with both ${ }^{137} \mathrm{Cs}$ and ${ }^{14} \mathrm{C}$ data available, the deposits 
are positioned stratigraphically between what we interpret as the 1700 and 1964 tsunami deposits. Although the ${ }^{210} \mathrm{~Pb}$ activities were too low to develop a chronology extending beyond the mid-1900s (figs. 11, 12), historical records provide reason to infer that these deposits record inundation from unusually large storms, possibly one or more of the highly destructive storms that impacted the California coast during the second half of the 19th century (Bearss, 1982; Engstrom, 1994, 1996). For example, the 43-day-long atmospheric winter storm system during December 1861 and January 1862the model for the 2011 USGS ARkStorm scenario (Porter and others, 2011) — wreaked havoc throughout California and the Pacific Northwest (Wells, 1949; Engstrom, 1996; Porter and others, 2011), and greatly impacted the Crescent City coastline (Bledsoe, 1881; Bearss, 1982). The core data show that these storm deposits are at least many decades younger, and likely more than a century younger, than the 1700 tsunami deposit, based on a long period $(>40 \mathrm{~cm})$ of peat accumulation following emplacement of that deposit (figs. 6-8, 13). The long quiescent period of peat accumulation following emplacement of the 1700 tsunami deposit, as well as a comparable period preceding that event, not only suggests that the 1700 tsunami was an anomalous depositional event in the marsh, but that the subsequent storm deposits represent anomalous events as well.

\section{Particle-Size Analyses}

Sediment particle-size analyses have been used in numerous studies to scrutinize tsunami and storm deposits (for example, Komatsubara and others, 2008; Switzer and Jones, 2008; Matsumoto and others, 2010; Phantuwongraj and Choowong, 2012) or estimate flow parameters, such as speed or depth, of past tsunami inundation (for example, Abramson, 1998; Spiske and others, 2010; Witter and others, 2012).

Grain-size analyses for sandy intervals in core MM16B show variability in particle size, sorting, and skewness in possible tsunami and storm deposits. Isotopic results from adjacent cores show that the 1964 tsunami deposit consists of a sandy and sandy detritus deposit between $\sim 15$ and $20 \mathrm{~cm}$ in core MM16B, and the 1700 tsunami deposit consists of $\sim 5 \mathrm{~cm}$ of light gray sand overlying black peat between 89 and $94 \mathrm{~cm}$ depth (fig. 15). The storm deposits consist of layers of sandy and sandy detrital peat between $\sim 26$ and $48 \mathrm{~cm}$ depth. Additional grain-size analyses for surface samples from Pebble Beach (surf zone to berm) provide modern-analog data to compare with the core samples (figs. 3, 15-17).

Three parameters - D50 (median) grain size, sorting, and skewness - reveal similarities and differences among sandy samples in core MM16B (fig. 15), as well as between the core samples and modern beach deposits (fig. 16). In core MM16B, the 1964 tsunami deposit consists of a fine sand and sandy detrital peat at 14-20 cm depth; the late-19th century storm deposits include three layers of sand with intervening detrital peat and wood at 28-48 cm depth; and the 1700 tsunami deposit consists of fine gray sand at 89-94 cm depth and underlying black detrital peat at 94-99 $\mathrm{cm}$ depth. Compared to the storm deposits, the 1700 tsunami deposit is finer grained and better sorted, and the upper part of the 1700 tsunami deposit is more finely skewed compared to the storm-deposited sands (figs. 15, 16). The D50 data reveal a slight change in grading - first inverse, then normal - in the 1700 tsunami deposit. A similar pattern of inverse to normal grading is evident in the lower two sandy storm deposits at 43-49 $\mathrm{cm}$ depth and particularly at 32-37 cm depth. Based on a limited analysis of two sediment samples, the 1964 tsunami deposit is comparable to the storm samples with respect to median grain size, but is more poorly sorted and negatively skewed. It is distinctly coarser and more poorly sorted than the 1700 tsunami deposit.

Modern beach samples show a wide range of values for median grain size, sorting, and skewness (fig. 16). The D50 data for two of the three lower intertidal surf-zone samples are comparable to the 1700 tsunami deposits in core MM16B. The single swash-zone sample is comparable to the 1964 samples, but sorting and skewness are not similar among the same sample combinations. An overview of all core sample particle-size data and the three surf-zone samples, PB107, PB108, and PB109 (fig. 17), emphasizes the similarities in grain size between the 1964 tsunami and storm samples, as well as similarities in grain size between the 1700 tsunami and modern surf-zone samples. However, the data also show distinct dissimilarities in sorting and skewness between the different deposit types.

\section{Diatom Analyses}

Modern and fossil diatom assemblages from Marhoffer Creek marsh provide insight into the paleoenvironment of the marsh as well as past pulses of sedimentation into the study site. Diatoms are particularly useful for evaluating the paleoenvironmental record at Marhoffer Creek marsh because they proliferate in freshwater wetlands as well as in coastal marine environments, with distinctly different species found in each.

\section{Modern Diatom Assemblages}

Surface samples from the lower to upper intertidal areas of Pebble Beach include marine benthic and planktonic taxa distinct from the oligohalobous taxa found in the marsh, located just beyond the beach berm (appendix 4; figs. 4.1, 4.2; table 4.1). There is some overlap in the types of species found in surface 

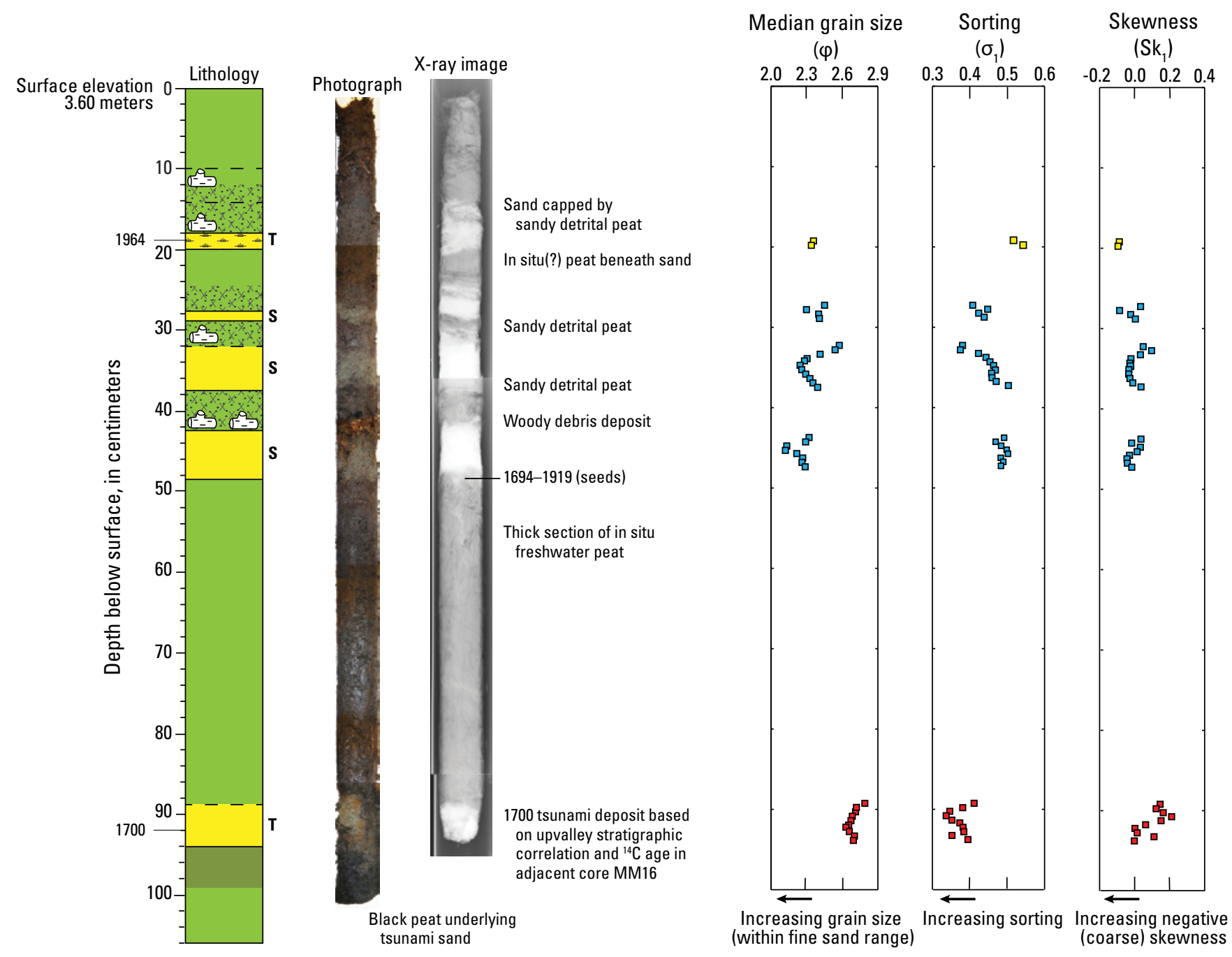

\section{EXPLANATION}
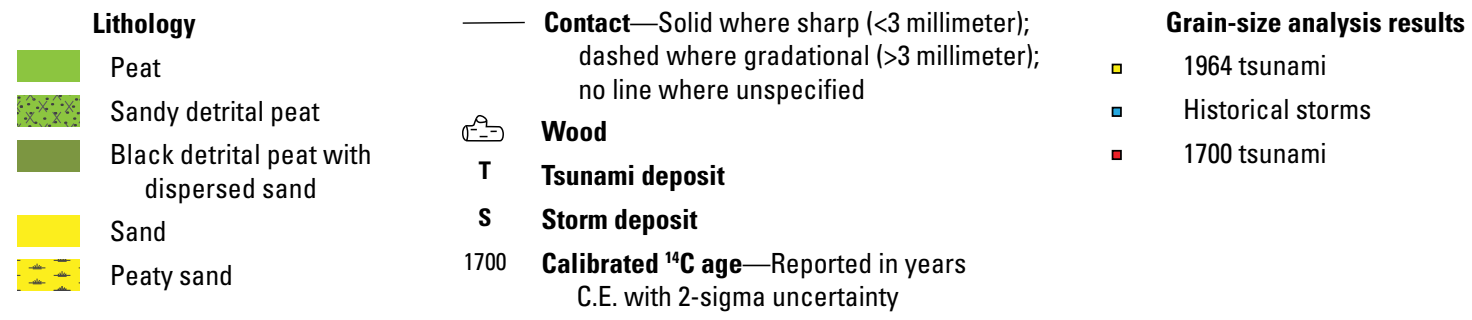

Figure 15. Data for core MM16B from Marhoffer Creek marsh, collected $~ 3$ meters from core MM16. Lithologic log, photograph, and $\mathrm{X}$-ray image show sand layers intercalated in peat. Note that the abrupt color changes in the core photograph near 20,60 , and 86 centimeters $(\mathrm{cm})$ depth are an artifact of merging different photographs together that have different exposures. Grain-size analysis results for sandy deposits in the core show median grain size, sorting, and skewness. The color symbols correspond to the 1964 tsunami (yellow), historical storms (blue), and the 1700 tsunami (red). Elevations are relative to the North American Vertical Datum of 1988. 
$\boldsymbol{A}$
Median grain size

$(\varphi)$
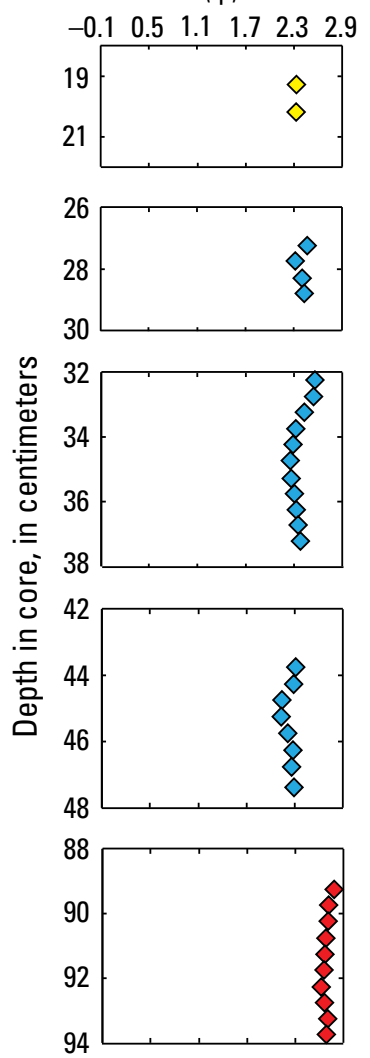

B

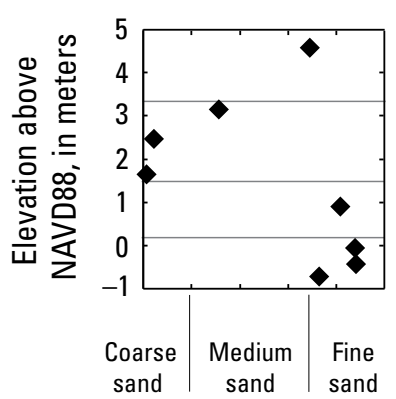

Sorting

$\left(\sigma_{1}\right)$
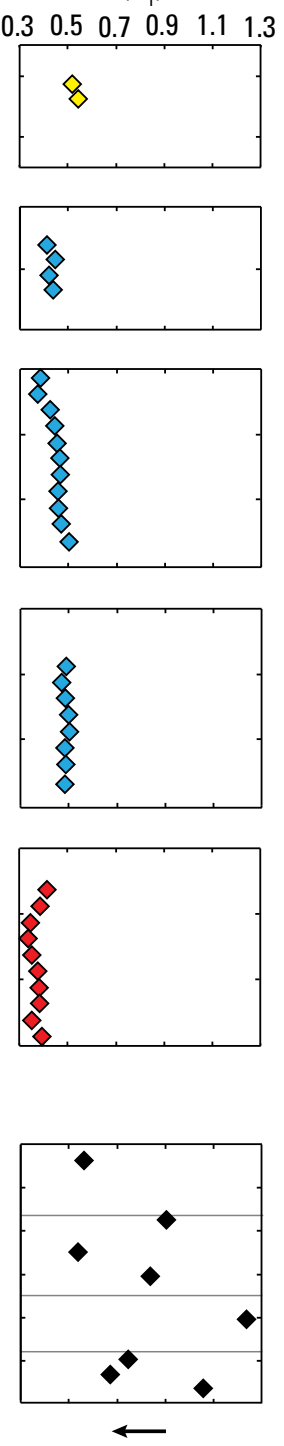

Increasing sorting

\section{EXPLANATION}
$\diamond 1964$ tsunami
$\diamond$ Historical storms
$\diamond 1700$ tsunami
- Modern beach

Skewness

(Sk)
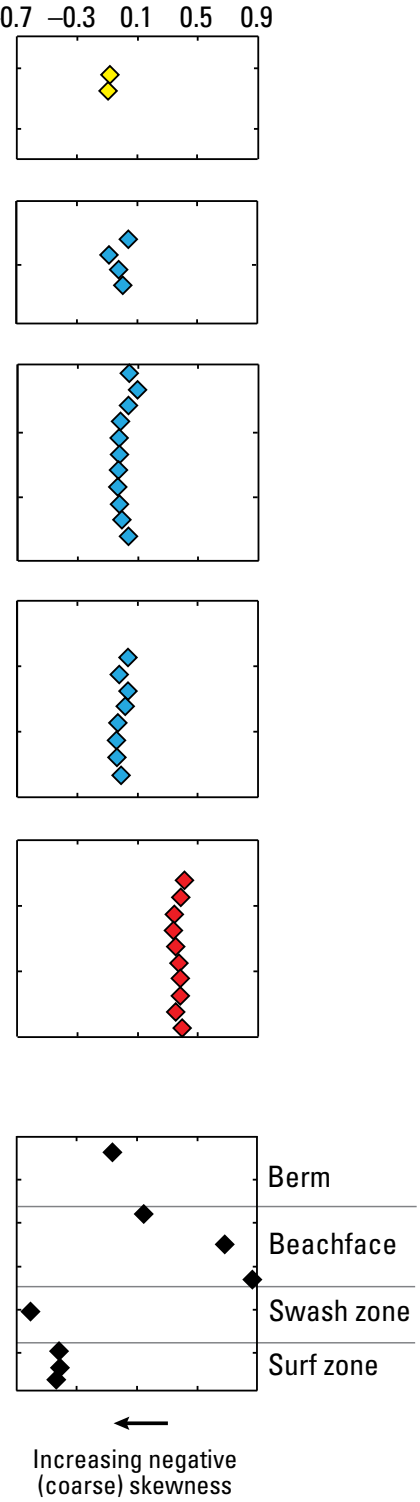

Figure 16. Comparison of median grain size, sorting, and skewness for tsunami and storm-deposit sands from core MM16B with modern beach sands from Pebble Beach. $A$, Tsunami and storm deposit sands in core MM16B from Marhoffer Creek marsh. $B$, Modern beach sands from Pebble Beach, differentiated by depositional environment. Elevations are relative to the North American Vertical Datum of 1988 (NAVD88).

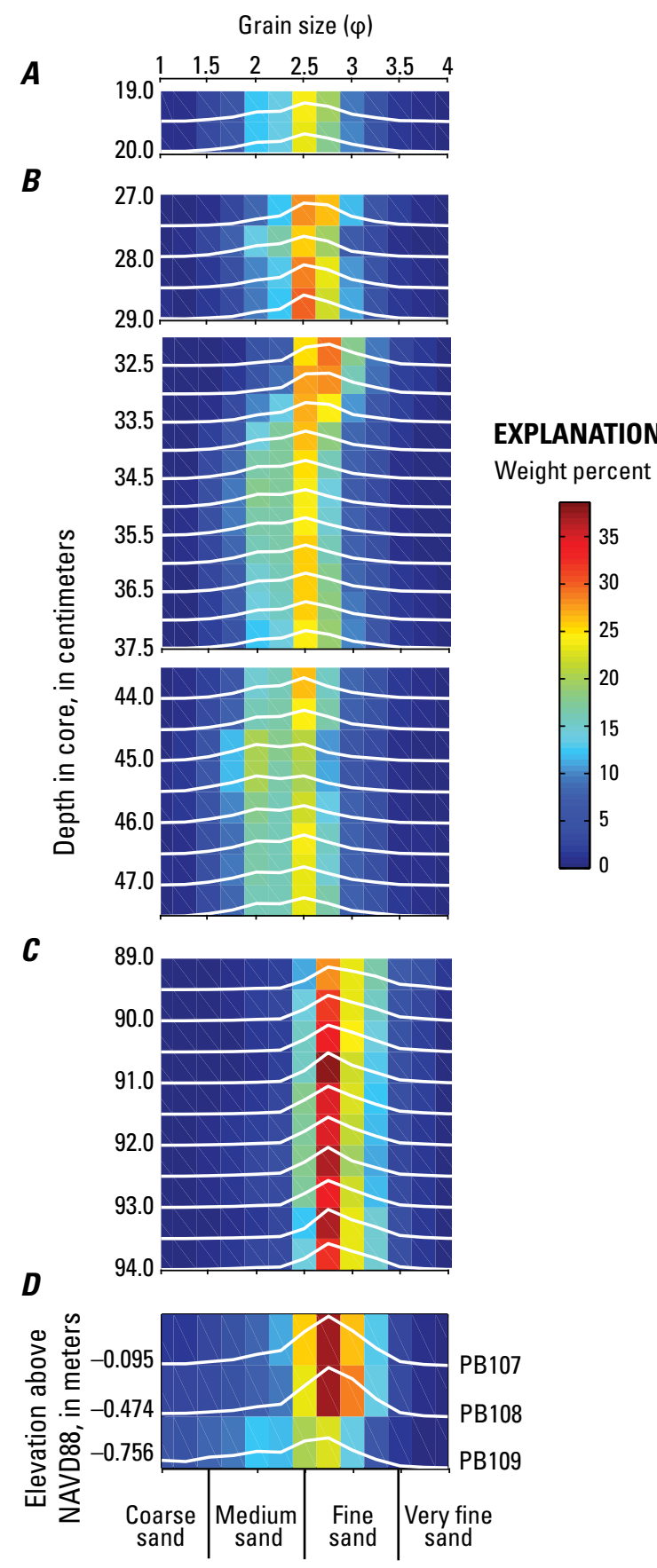

Figure 17. Graphs showing sand particle-size distributions (white lines) in core MM16B from Marhoffer Creek marsh and modern beach sands from Pebble Beach. A, 1964 tsunami deposit (18-20 centimeters, cm). $B$, Three sand deposits (27-29 $\mathrm{cm}, 32-37.5 \mathrm{~cm}$, and $43.5-47.5 \mathrm{~cm}$, respectively) separated by detrital peat, interpreted as storm deposits. $C, 1700$ tsunami deposit (89-94 cm). D, Modern surf zone sand samples (PB107, PB108, and PB109) from Pebble Beach. Elevations are relative to the North American Vertical Datum of 1988 (NAVD88). 
sediment from the surf zone (sample MD1, fig. 18) and upper beach face (sample MD2, fig. 19), but coastal planktonic and tychoplanktonic taxa (for example, Thalassiosira spp., Thalassionema nitzschioides, Rhaphoneis amphiceros, Paralia sulcata, Chaetoceros spp.) are more common in the surf zone and large benthic taxa (Caloneis brevis, Pinnularia cf. rectangulata) dominate the upper beach assemblage. Specimens shown in figures 18 and 19 are fairly pristine, but broken valves are present in both samples, comprising about 25 percent of the assemblage in sample MD1 and 50 percent in MD2. The better preservation in surf-zone sample MD1 is the result of high abundance of small, centric planktonic taxa like Thalassiosira spp. that dropped out of seawater to accumulate on the sand surface prior to collecting. Although these centric taxa are finely ornamented and are generally delicate in appearance, they have the advantage of a disk-shaped valve that makes them more resilient to breakage than taxa with elongate valves, even if they are more thickly silicified.

The modern marsh supports prolific, diverse populations of oligohalobous taxa, a small sampling of which is discussed in appendix 4 . The modern samples show that diatom populations vary across the marsh in response to the presence or absence of standing water, which affects the type and density of surface vegetation and, thus, the amount of sunlight reaching the ground surface where diatoms are growing.

Recognizing the variability in modern assemblages at the marsh, even though all contain oligohalobous taxa, is necessary for accurately documenting paleoenvironmental changes in the marsh that may have accompanied past earthquakes, tsunamis, or upland flooding. Within the modern marsh, diatom populations vary greatly depending on local subenvironments. For example, in the well-drained but fairly dry areas of the marsh (for example, sample site MD3), diatom diversity and abundance are low, and aerophilous pennate taxa, such as Hantzschia amphioxys and species of Pinnularia, dominate (appendix 4, fig. 4.3). Diatom abundance and diversity increase in areas that are well drained but the soil remains moist (appendix 4, fig. 4.4), and are greatest in marsh samples from areas where the water table is close to the surface and the surface is persistently wet, with indicative taxa such as Aulacoseira spp., Epithemia spp., and Gomphonema spp. (appendix 4, fig. 4.5). In shallow channels in the marsh, dense populations of tiny pennate taxa accumulate (for example, Martyana martyi; appendix 4, fig. 4.3) to create an assemblage distinct from other assemblages within the overall marsh environment.
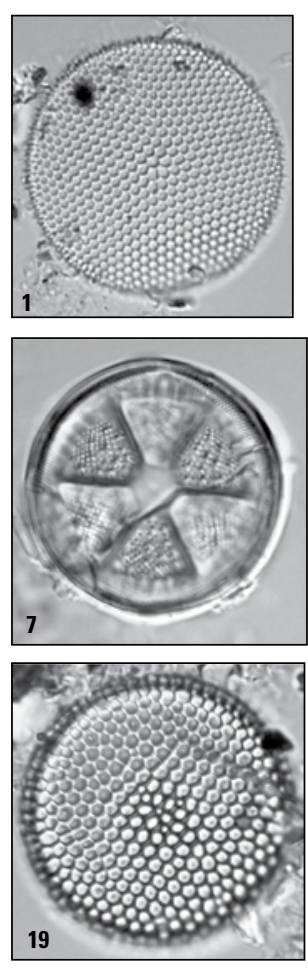
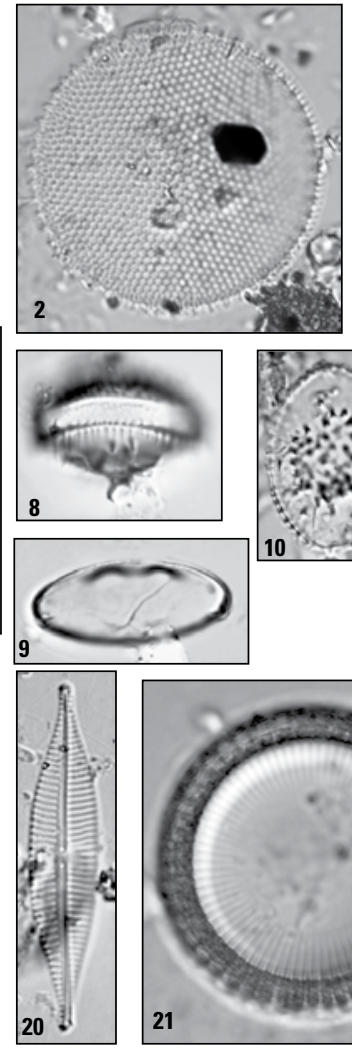
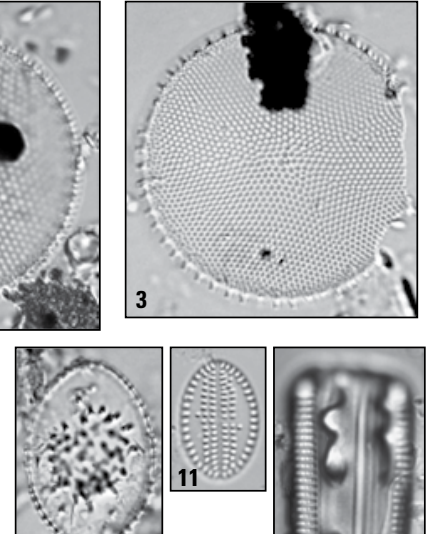

10
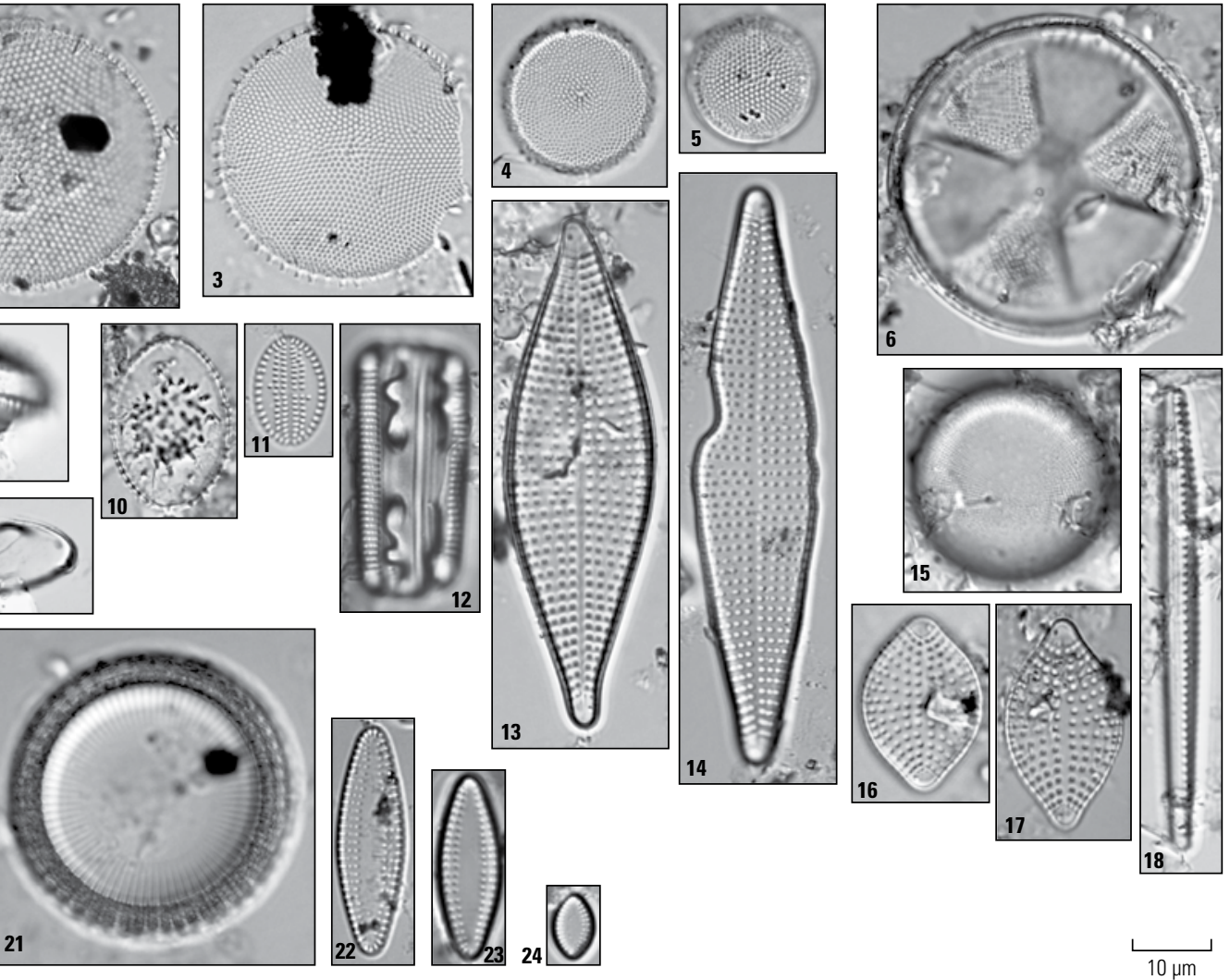

Figure 18. Photomicrographs of modern diatoms collected from surface sand in the lower intertidal surf zone at Pebble Beach. 1-2, Thalassiosira eccentric; 3-5, Thalassiosira sp.; 6-7, Actinoptychus senarius; 8-10, Chaetoceros spp. resting spores; 11, Cocconeis californica (pseudoraphe valve); 12, Grammatophora angulosa var. islandica; 13-14, Rhaphoneis amphiceros var. 1; 15, Ehrenbergia granulosa; 16-17, Rhaphoneis amphiceros; 18, Thalassionema nitzschioides; 19, Stephanopyxis sp.; 20, Navicula (?) sp.; 21, Paralia sulcata; 22-23, Delphineis karstenii (small valves); 24, Delphineis margaritalimbata. $\mu \mathrm{m}$, micrometers. 


\section{Fossil Diatom Assemblages}

Diatom counts for sections of cores MM16, MM17, MM19, and MM20 (figs. 20-22) show that a freshwater environment has persisted in the Marhoffer Creek valley for at least $\sim 1,800$ years, although it was likely drier than the current wet marsh to willow swamp for an interval of time preceding emplacement of the 1700 tsunami deposit (figs. 3, 8, 20, 21). There is no evidence from diatom data that the site was ever intertidal or regularly flooded by saltwater. The full extent of the record will require additional coring to greater depths, which, based on exploratory coring, may
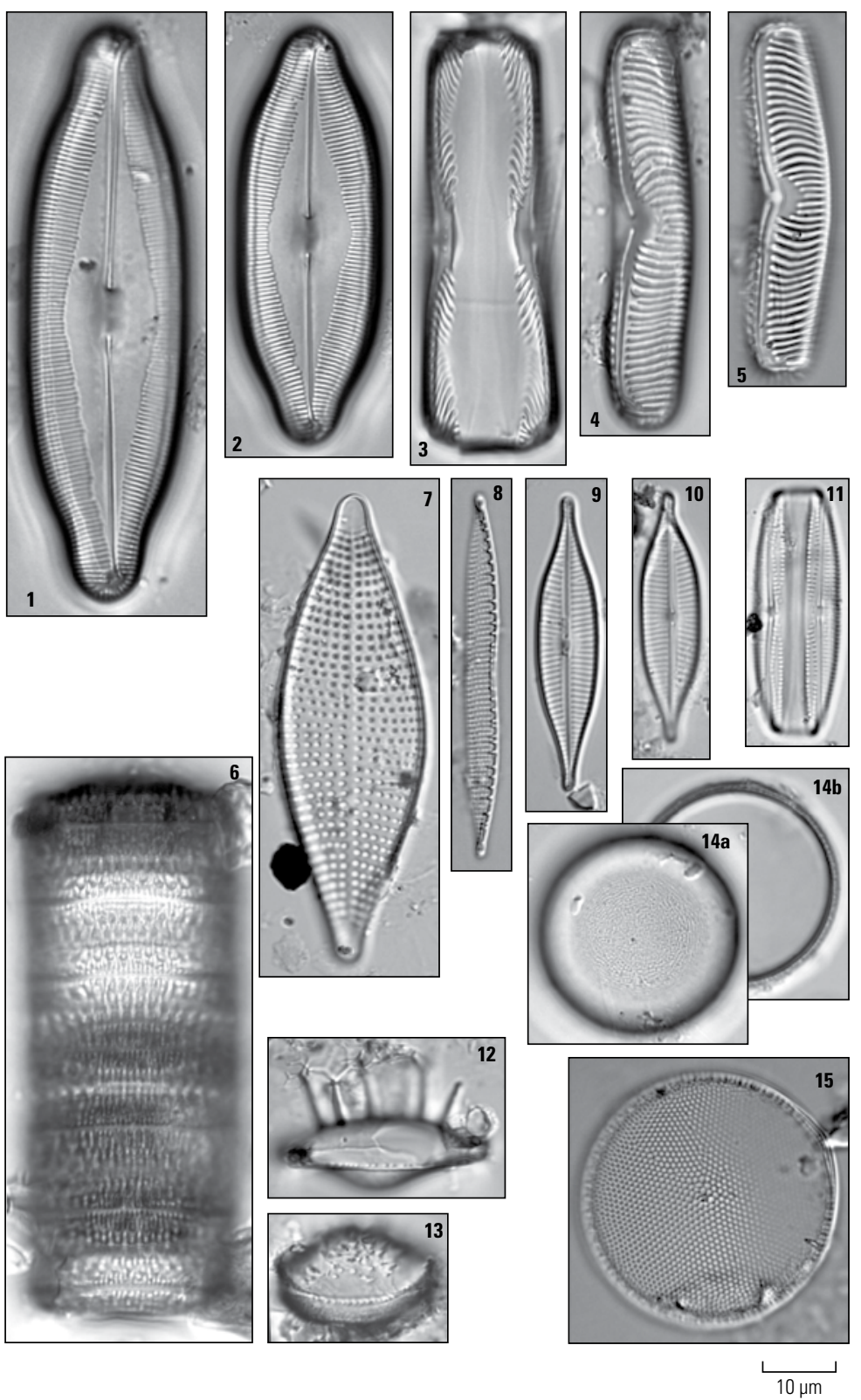

Figure 19. Photomicrographs of modern diatoms collected from surface sand in the upper intertidal beachface at Pebble Beach. 1-2, Caloneis brevis; 3-5, Pinnularia cf. rectangulata; 6, chain of Paralia sulcata frustules; 7, Rhaphoneis amphiceros, 8, Hantzschia virgata; 9-10, Navicula (?) sp.; 11, Amphora sp.; 12-13, Chaetoceros spp. resting spores; 14, Ehrenbergia granulosa: (a) focus on center, (b) focus on margin; 15, Thalassiosira sp. $\mu \mathrm{m}$, micrometers. exceed $4 \mathrm{~m}$, or at a minimum, twice the record of MM19. The continuous freshwater record at this site simplifies the recognition of paleotsunami and storm-surge deposits, because any marine diatoms observed in the deposits must be transported and not locally derived. In coastal and estuarine deposits containing only brackish and marine taxa, differentiating truly transported from possibly locally derived taxa in a paleotsunami deposit can be challenging (for example, Hemphill-Haley, 1995a; Shennan and others, 1996; Hutchinson and others, 1997, 2013). Furthermore, beyond a realistic inland distance for storm-surge inundation, identifying anomalous sandy tsunami deposits intercalated in mostly organic peat deposits is greatly simplified when the tsunami deposit is preserved in a freshwater environment.

Marine diatoms are confined to the sandy deposits and adjacent detritus in the Marhoffer Creek cores, and absent from in-place freshwater peat deposits (appendix 4, tables 4.2, 4.3). However, where marine diatoms occur, they are far outnumbered by oligohalobous diatoms (figs. 20-22), a consequence of seawater and sediment containing sparse marine taxa deposited in an environment with massive in-place accumulations of oligohalobous taxa. Although diatoms proliferate in the marine environment, they grow in greater numbers in freshwater wetlands, as exemplified by differences in abundance of modern taxa in samples from the surf zone and beach compared to the marsh (appendix 4, figs. 4.2-4.5).

\section{Comparison of Tsunami and Storm Deposits}

Marine diatoms and silicoflagellates are present in what we interpret as both tsunami and storm deposits at Marhoffer Creek marsh (figs. 20-23), either in parts of the fine-grained sand or detrital material associated with the deposits. Differences between assemblages found in the near-field tsunami deposits, as compared to assemblages in storm and far-field tsunami deposits, is driven by the likely source of the sediment, whether offshore or proximal to the beach.

In both the storm deposits and the 1964 far-field tsunami deposit in cores MM16 and MM16A, marine taxa are present but rare, and poorly preserved in most cases (figs. 20,24A). The diatom assemblages overlap considerably between the deposits of the 1861-62 storms and those of the 1964 tsunami. This similarity is expressed in a Q-model cluster analysis (fig. 23), which shows that the storm deposits cluster closely together and form a larger cluster with the 1964 tsunami deposit, owing to the types and abundances of the marine taxa observed. The cluster formed by the 1964 tsunami and 1861-62 stormdeposit samples is statistically separate from the cluster formed by the remaining Cascadia Subduction Zone tsunami deposit samples. Therefore, although the diatom data in the far-field tsunami and storm deposits are useful for indicating a marine source for the sandy deposits, there 


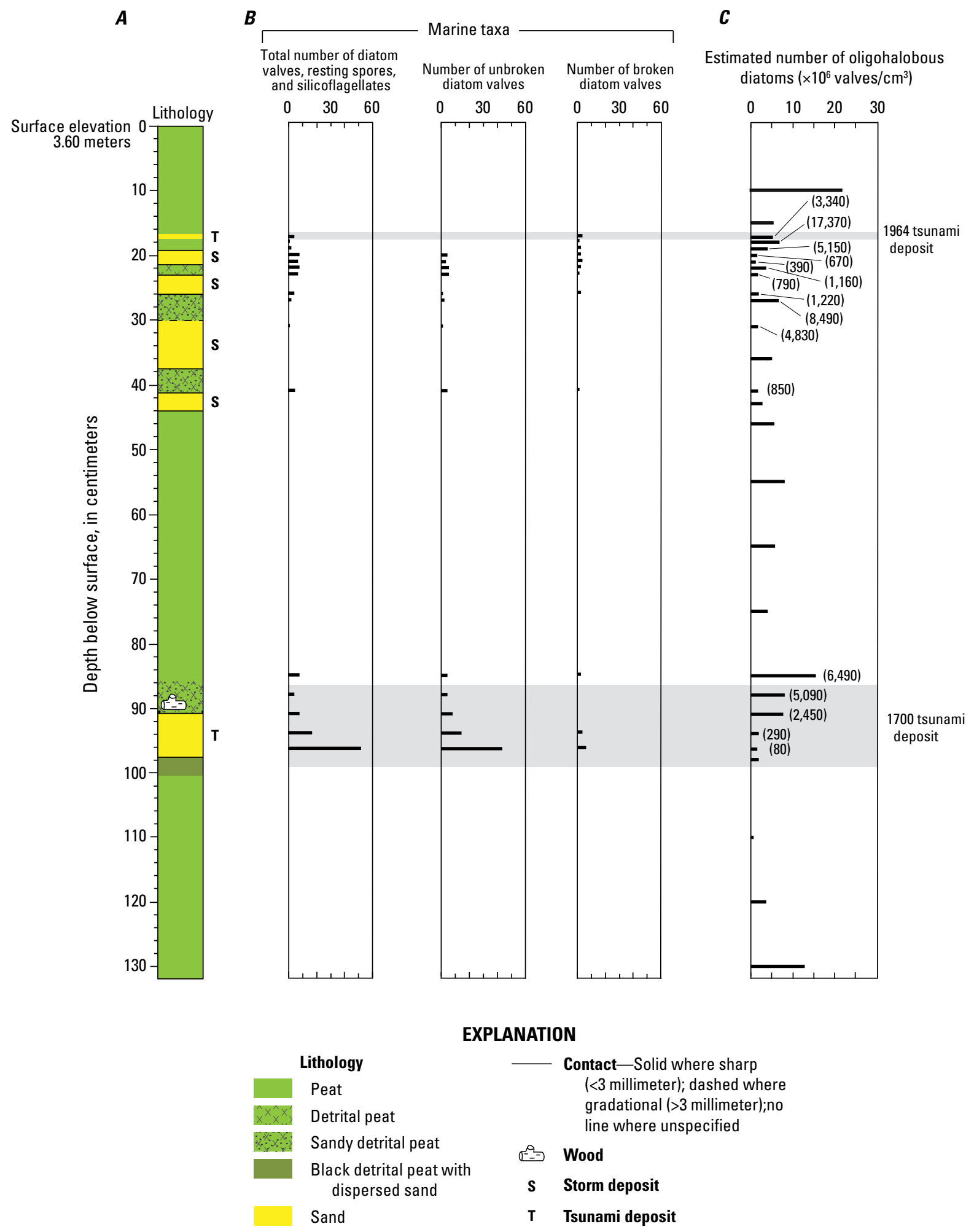

Figure 20. Plots showing the distribution of diatoms with depth in core MM16 from Marhoffer Creek marsh. A, Lithologic log of core MM16. $B$, Number of marine diatoms, determined as the number of specimens observed in 30 traverses of the microscope slide at $650 \times$ magnification. Marine taxa are split into three categories: 1) diatom valves, resting spores, and silicoflagellates; 2) unbroken diatom valves; and 3) broken diatom valves. Marine taxa are prominent in the 1700 tsunami deposit but sparse in historical storm deposits and the 1964 tsunami deposit. $C$, Estimated abundance of oligohalobous diatoms (in millions of valves per cubic centimeter of sediment, $\times 10^{6} \mathrm{valves} / \mathrm{cm}^{3}$ ). Oligohalobous diatoms are abundant in the upper part of the 1700 tsunami deposit and overlying coarse-grained peat, but are rare in the middle and lower parts of the sand deposit as well as in underlying fine-grained black peat. The values in parentheses represent the estimated number of oligohalobous diatoms for every marine diatom in the sample, where applicable, and show that oligohalobous diatoms far outnumber marine diatoms in all samples. Diatom results for the 1964 tsunami deposit are compiled from cores MM16 and MM16A. Elevations are relative to the North American Vertical Datum of 1988. 


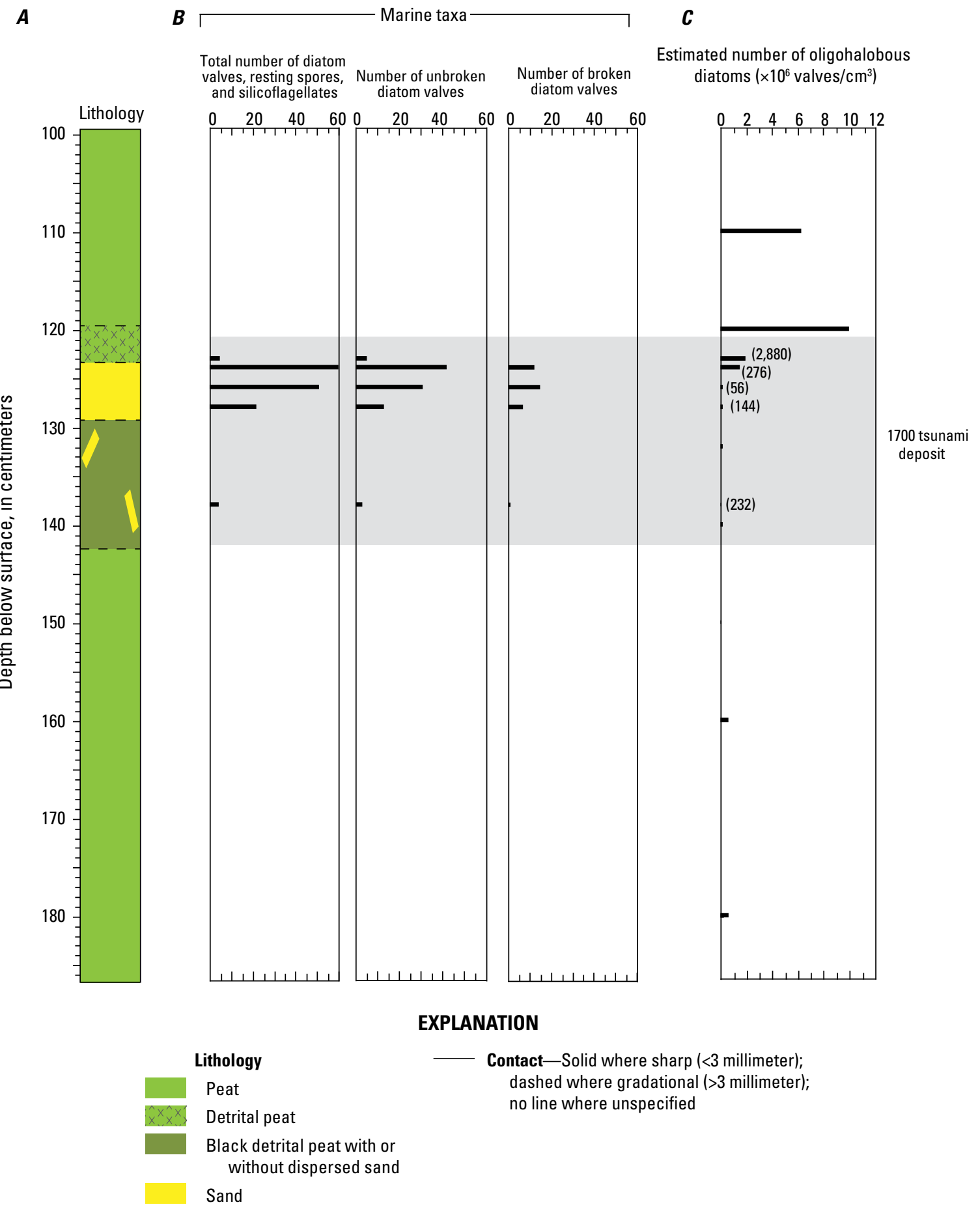

Figure 21. Plots showing the distribution of diatoms with depth in core MM17 from Marhoffer Creek marsh. $A$, Lithologic log of core MM17 between depths of 115 and 135 centimeters. $B$, Number of marine diatoms, determined as the number of specimens observed in 30 traverses of the microscope slide at 650× magnification. Marine taxa are split into three categories: 1) diatom valves, resting spores, and silic oflagellates; 2) unbroken diatom valves; and 3) broken diatom valves. Marine diatoms are prominent in the 1700 tsunami deposit, mostly represented by unbroken valves. Marine taxa are absent in underlying and overlying peat. $C$, Estimated abundance of oligohalobous diatoms (in millions of valves per cubic centimeter of sediment, $\times 10^{6}$ valves $/ \mathrm{cm}^{3}$. The values in parentheses indicate the estimated number of oligohalobous diatoms for every marine diatom in the sample, where applicable. With the exception of the sample in fine-grained peat near $110 \mathrm{~cm}$, oligohalobous diatoms are abundant throughout core MM17, including the upper part of the sand and capping detrital peat of the 1700 tsunami deposit. 
$\boldsymbol{A}$

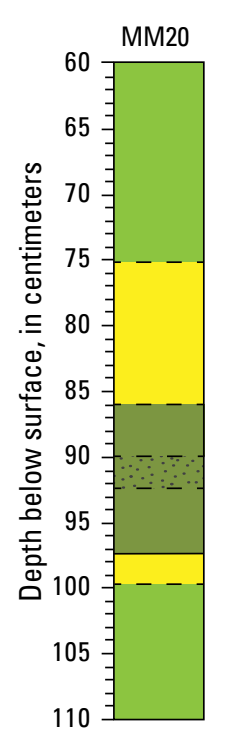

$B$

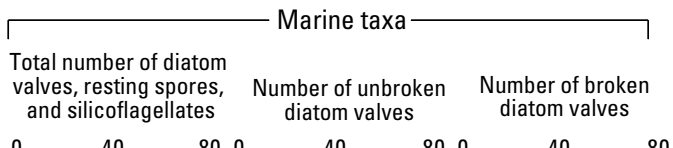

$c$

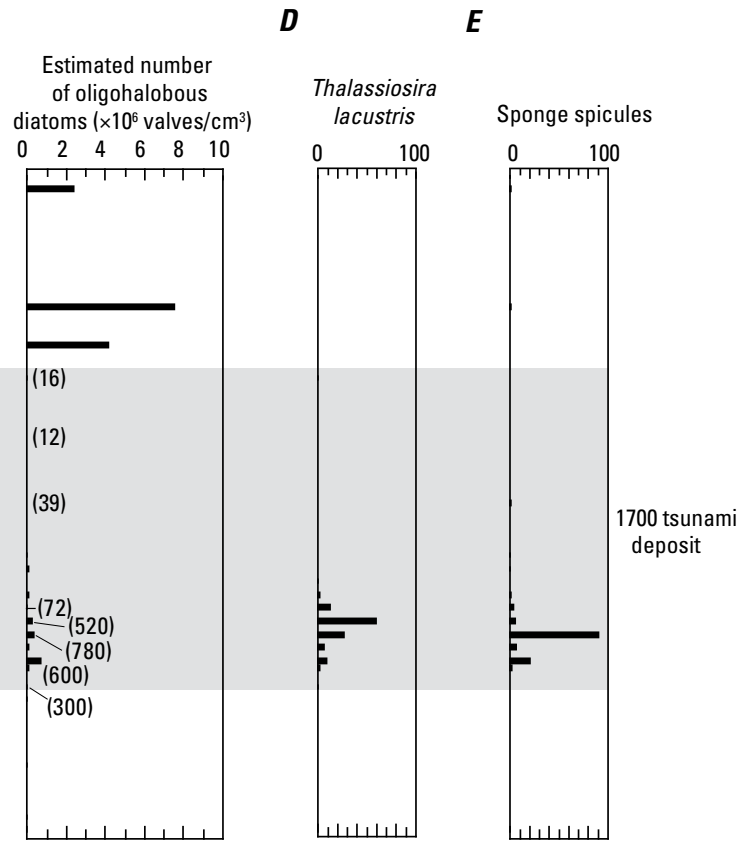

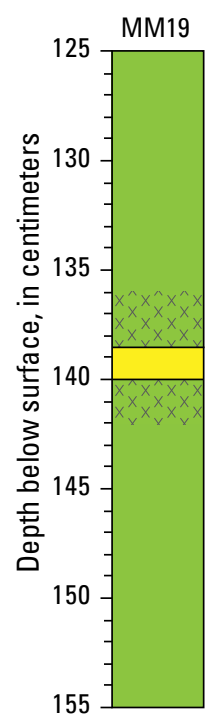

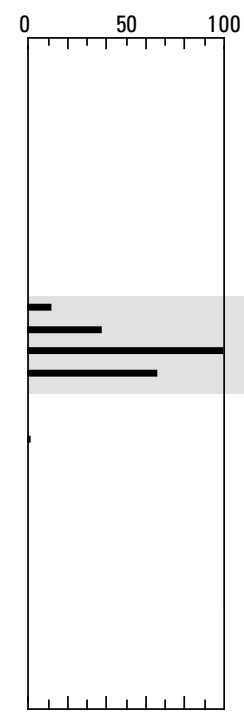

$800 \quad 40 \quad 800$
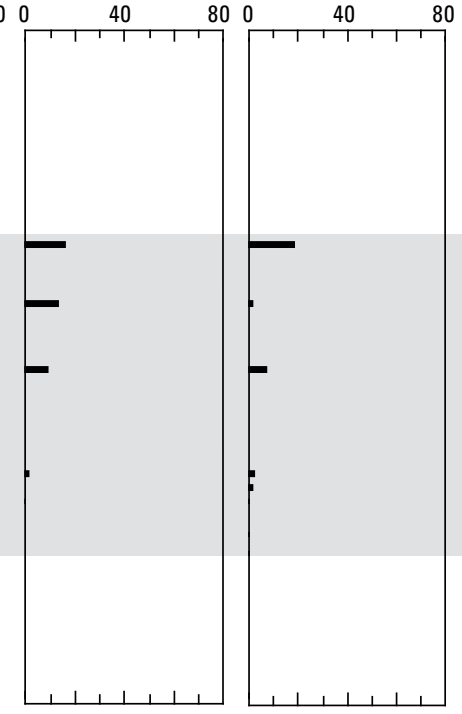
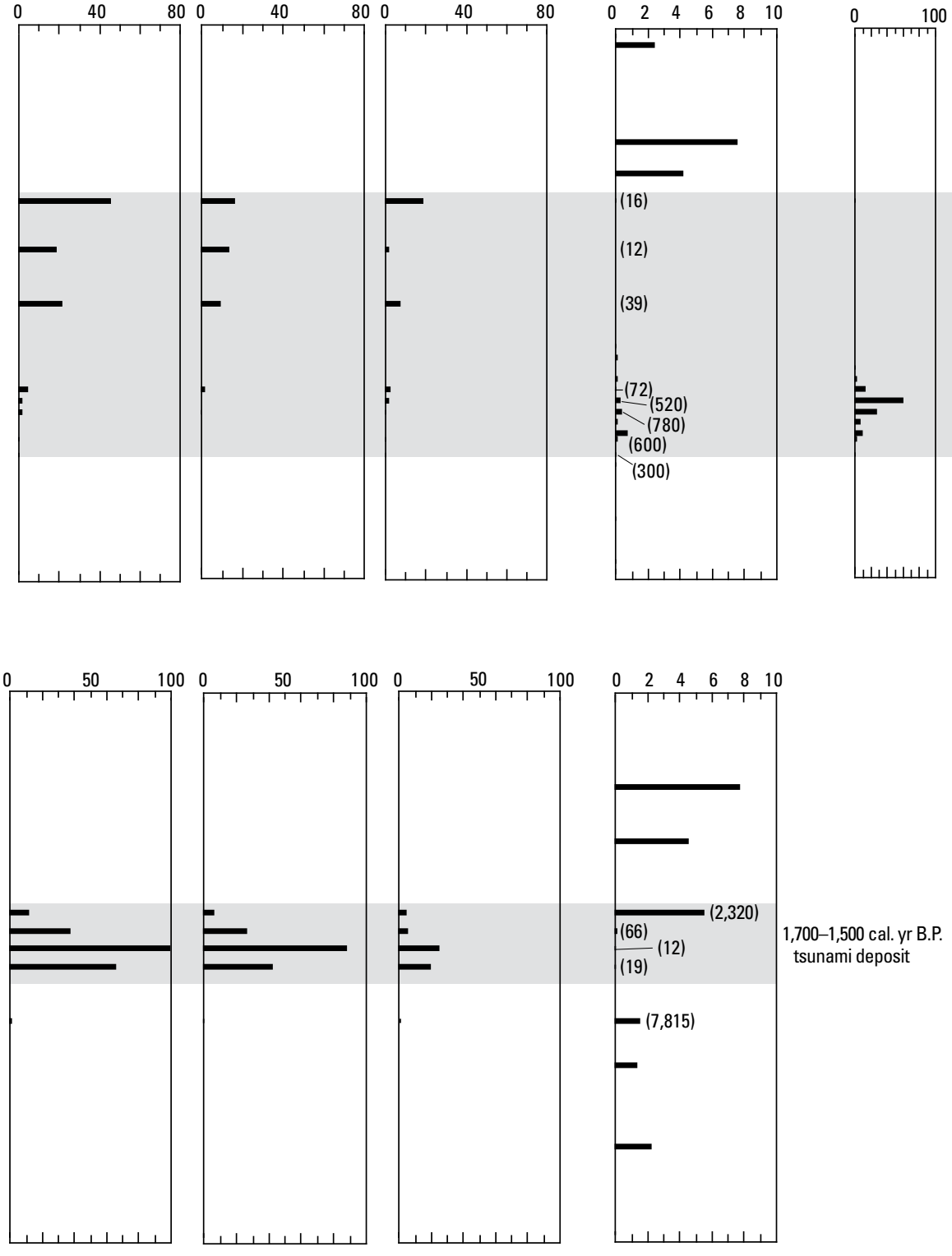

\begin{tabular}{|l|}
\hline \multicolumn{1}{|c|}{ EXPLANATION } \\
Lithology \\
Peat \\
Detrital peat \\
Black detrital peat \\
Black sandy detrital peat \\
Sand \\
Contact-Solid where sharp \\
$\quad<3$ millimeter); dashed \\
where gradational \\
$(>3$ millimeter); no line \\
where unspecified
\end{tabular}

Figure 22. Plots showing the distribution of diatoms associated with the 1700 C.E. (250 years before present [yr B.P.]) tsunami deposit in core MM20 and the 1,700-1,500 yr B.P. tsunami deposit in core MM19, both from Marhoffer Creek marsh. A, Lithologic illustration of core MM20 between depths of 60 and 110 centimeters (above) and core MM19 between depths of 125 to 155 centimeters (below). $B$, Number of marine diatoms, determined as the number of specimens observed in 30 traverses of the microscope slide at 650x magnification. Marine taxa are split into three categories: 1) diatom valves, resting spores, and silicoflagellates; 2) unbroken diatom valves; and 3) broken diatom valves. $C$, Estimated abundance of oligohalobous diatoms (in millions of valves per cubic centimeter of sediment, $\times 10^{6} \mathrm{valves} / \mathrm{cm}^{3}$ ). The values in parentheses indicate the estimated number of oligohalobous diatoms for every marine diatom in the sample, where applicable. $D$, Number of planktonic marine diatoms (Thalassiosira lacustris). $E$, Number of sponge spicules. Values plotted in $D$ and $E$ are determined as the number of specimens observed in 3 traverses of the microscope slide at $650 \times$ magnification. In core MM20, marine diatoms are prominent in the upper, sandy part of the tsunami deposit. An unusual concentration of sponge spicules and the planktonic diatom Thalassiosira lacustris is found in detrital peat in the lower part of the deposit. Oligohalobous diatoms are only abundant in peat that accumulated after the 1700 C.E. earthquake and tsunami. In core MM19, marine diatoms are prominent in fine sand and detritus deposited by the 1,700-1,500 yr B.P. tsunami. Oligohalobous diatoms are prominent in peat deposited both before and after this tsunami. 
is nothing distinct enough about the assemblages to help determine the mode of deposition - that is, far-field tsunami or storm. Furthermore, the similar characteristics of the deposits suggest a similar origin for both types of deposits, likely nearshore or beach.

Unlike the storm and far-field tsunami deposits, diatom assemblages of near-field tsunami deposits contain many valves derived from offshore and coastal planktonic taxa (figs. 20-27). Rhaphoneis psammicola, a benthic species reported from sandy benthos in estuaries as well as from offshore deposits (Riznyk, 1973; Whiting and Schrader, 1985; Hemphill-Haley and Fourtanier, 1995), is prominent in the near-field tsunami deposits (figs. 24-26). This taxon was not observed in the sandy environments of the modern lower beach and surf zone (appendix 4, table 4.1, fig. 4.1), although the grain size from that environment and the 1700 tsunami deposit are comparable (fig. 17).

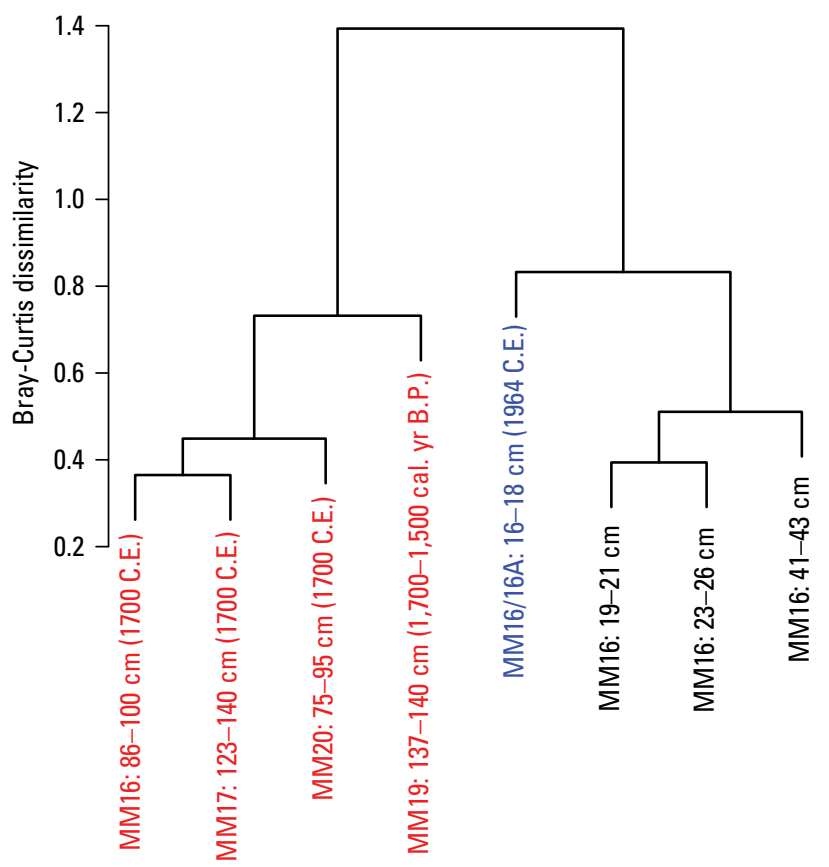

Figure 23 (above). Graph showing Bray-Curtis dissimilarity (results of Q-mode cluster analysis) of marine-diatom-bearing sand samples from tsunami and storm deposits in core MM16 from Marhoffer Creek marsh. Diatom sample labels identify the core name and depth of sampling (in centimeters, $\mathrm{cm}$ ). The age of the deposit (in either C.E. or calibrated years before present [cal. yr B.P.]) is also given, if known. Red labels indicate near-field tsunami deposits, blue labels indicate far-field tsunami deposits, and black labels indicate storm deposits. The agglomerative coefficient is 0.64 .

Figure 24 (right). Photomicrographs of marine diatoms and diatom fragments in storm and tsunami deposits in core MM16 from Marhoffer Creek marsh. A, Poorly preserved diatom valves from late-1800s storm-deposited sand from 18-44 centimeters (cm) depth. 1-2, Odontella aurita; 3, Cyclotella striata; 4, Cocconeis costata; 5, Paralia sulcata; 6, Actinoptychus senarius, 7, Rhaphoneis amphiceros, 8, Coscinodiscus obscurus, 9 , Chaetoceros sp. resting spore. B, Both well-preserved (images 1-13; above black line) and poorly preserved (images 14-23; below black line) diatoms from the 1700 tsunami deposit from 90-96 cm depth. 1-2, Paralia sulcata; 3, Stephanopyxis cf. turris, 4, Coscinodiscus radiatus, 5-6, Thalassiosira sp.; 7-11, Rhaphoneis psammicola; 12, Grammatophora angulosa var. islandica; 13, Huttoniella reichardtii, 14-16, Paralia sulcata; 17, Rhaphoneis psammicola; 18-19, Rhaphoneis amphiceros, 20-21, Coscinodiscus radiatus, 22-23, Chaetoceros spp. resting spores. $\mu \mathrm{m}$, micrometers.

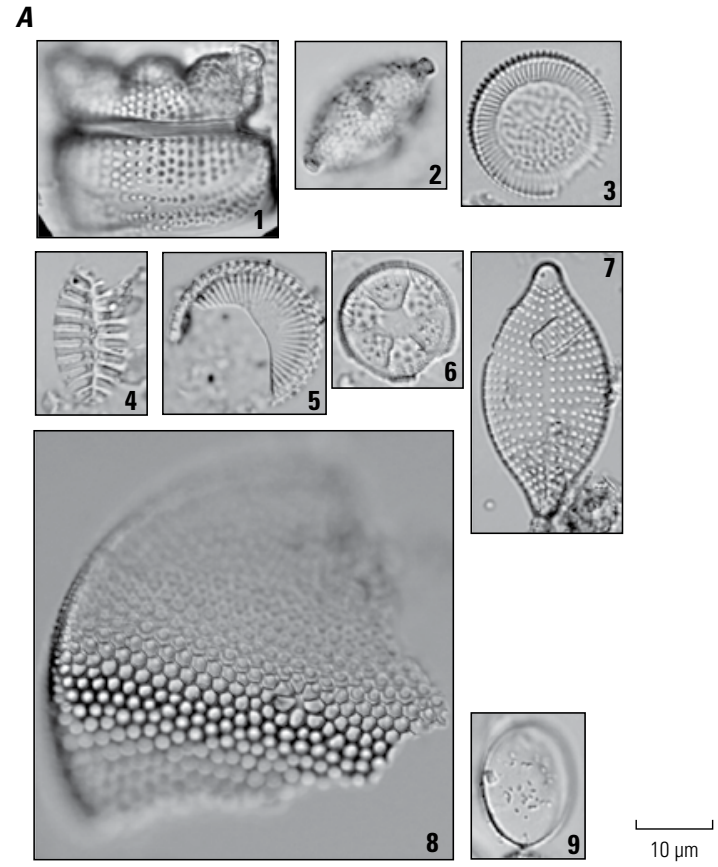

B
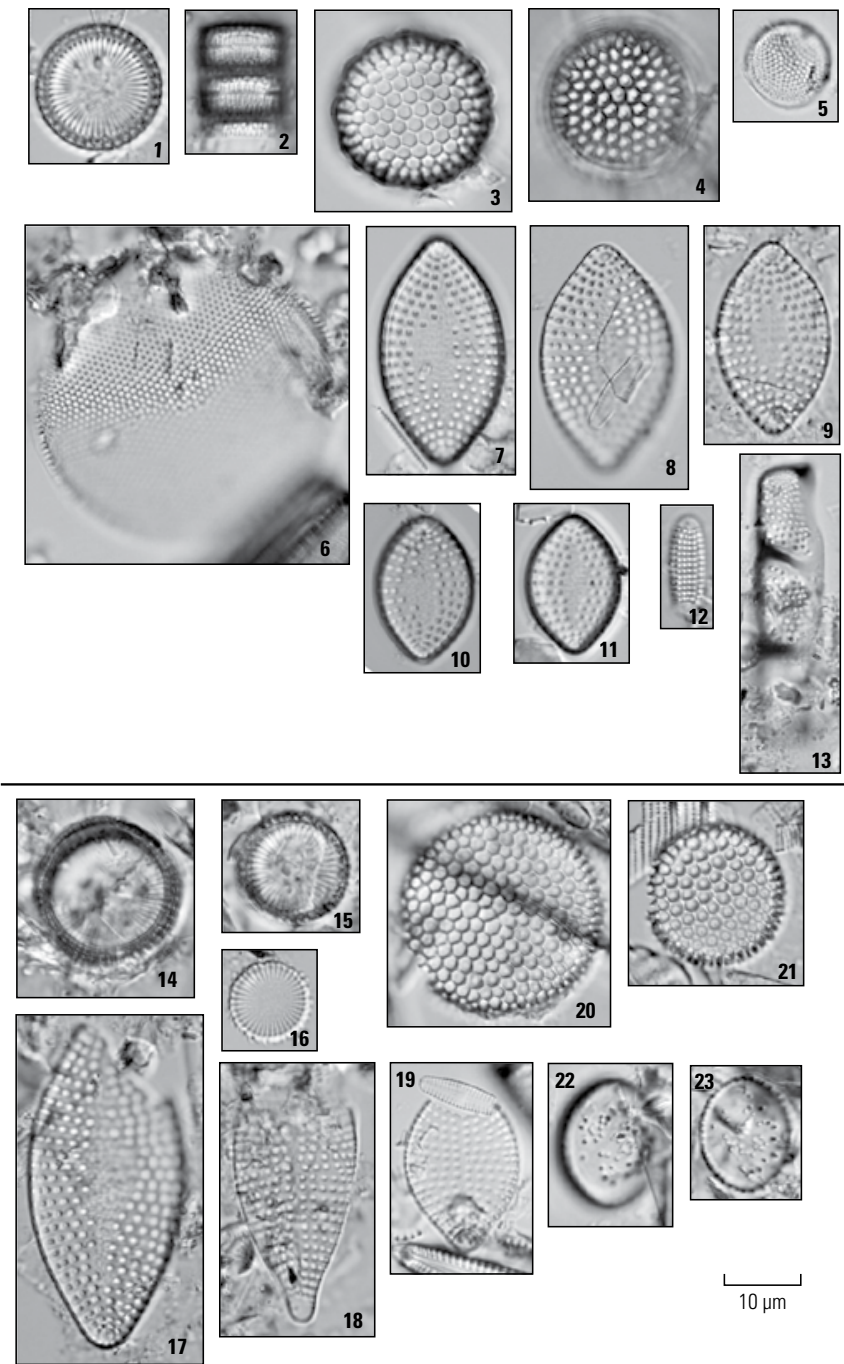
Assemblages of marine diatoms in the 1700 C.E. and 1,700-1,500 cal. yr B.P. near-field Cascadia Subduction Zone tsunami deposits differ slightly in that marine taxa, including the planktonic group Thalassiosira spp., are more concentrated in the older deposit than in the 1700 deposit (fig. 27). This difference is shown by the results of the Q-mode cluster analysis (fig. 23), which shows that 1700 tsunami deposit samples from different cores cluster closely together, whereas the $1,700-1,500 \mathrm{cal}$. yr B.P. deposit forms a larger, slightly less statistically robust cluster with those samples. In general, however, diatom assemblages in the near-field tsunami samples form a group that is statistically separate from assemblages in the 1964 far-field tsunami and storm-deposit samples.

Although the assemblages in the Cascadia Subduction Zone tsunami deposits show differences, the marine taxa in these deposits are more diverse, better preserved, and about an order of magnitude more abundant than marine taxa in the 1964 tsunami or storm deposits (figs. 20-22). The 1964 tsunami and storm deposits contain few marine diatoms for the same sample size, with assemblages dominated by diatom fragments and taxa with heavily silicified valves, such as the sturdy coastal tychoplanktonic diatoms Odontella aurita and Paralia sulcata, or small benthic species like Cocconeis costata (fig. 24A).

Although it may seem counterintuitive that well-preserved diatoms should be found in Cascadia Subduction Zone tsunami deposits, similar evidence for good diatom preservation in tsunami deposits has been recorded elsewhere (Hemphill-Haley,
1996; Nanayama and others, 2007; Sawai and others, 2009; Witter and others, 2009, 2016). For some tsunami-deposit assemblages, such as those at Marhoffer Creek marsh, good valve preservation may be explained in part by the types of diatoms that are transported with the marine silt and sand. For example, Rhaphoneis psammicola and many other epipsammic species have thickly silicified valves with small length-to-width ratios, Paralia sulcata and Stephanopyxis spp. have sturdy disk-shaped valves, and the buoyant valves of planktonic taxa like Thalassiosira spp. may benefit from being suspended longer, and settling out more slowly, than diatoms of other shapes and densities that may be entrained with abrasive sediment particles. The overall good preservation of the tsunami-deposit assemblages may also be a result of rapid suspension and redeposition of diatoms in a tsunami surge, which, although is a turbulent flow, may be comparatively less damaging to diatom valves than is continuous sediment abrasion in coastal intertidal or beach environments. The prominence of marine diatoms in the Cascadia Subduction Zone tsunami deposits at Marhoffer Creek marsh may be, in part, a result of finer grain size (mostly fine sand and silt), compared with the slightly coarser grained 1964 tsunami and storm deposits (fine to medium sand) in which diatoms were much more sparse. Regardless, the composition and preservational characteristics of the marine diatom assemblages in the Cascadia Subduction Zone tsunami deposits at Marhoffer Creek marsh are distinct enough to differentiate these tsunami deposits from far-field tsunami or storm deposits at the same location.
Figure 25. Photomicrographs of marine diatoms and silicoflagellates from the 1700 tsunami deposit at 124 centimeters depth in core MM17 from Marhoffer Creek marsh. Well-preserved valves are shown in images 1-17 (above black line) and poorly preserved valves are shown in images 18-25 (below black line). 1, Paralia sulcata; 2-3, Stephanophyxis turris; 4-5, Thalassiosira pacifica; 6, Delphineis karstenii; 7, Rhaphoneis amphiceros; 8-15, Rhaphoneis psammicola; 16-17, silic oflagellate Distephanus speculum; 18-20, Paralia sulcata; 21, Cyclostephanus novazeelandica: (a) focus on margin, (b) focus on center; 22-23, Rhaphoneis amphiceros; 24, Thalassionema nitzschioides s.l.; 25, silicoflagellate Distephanus speculum. $\mu \mathrm{m}$, micrometers.
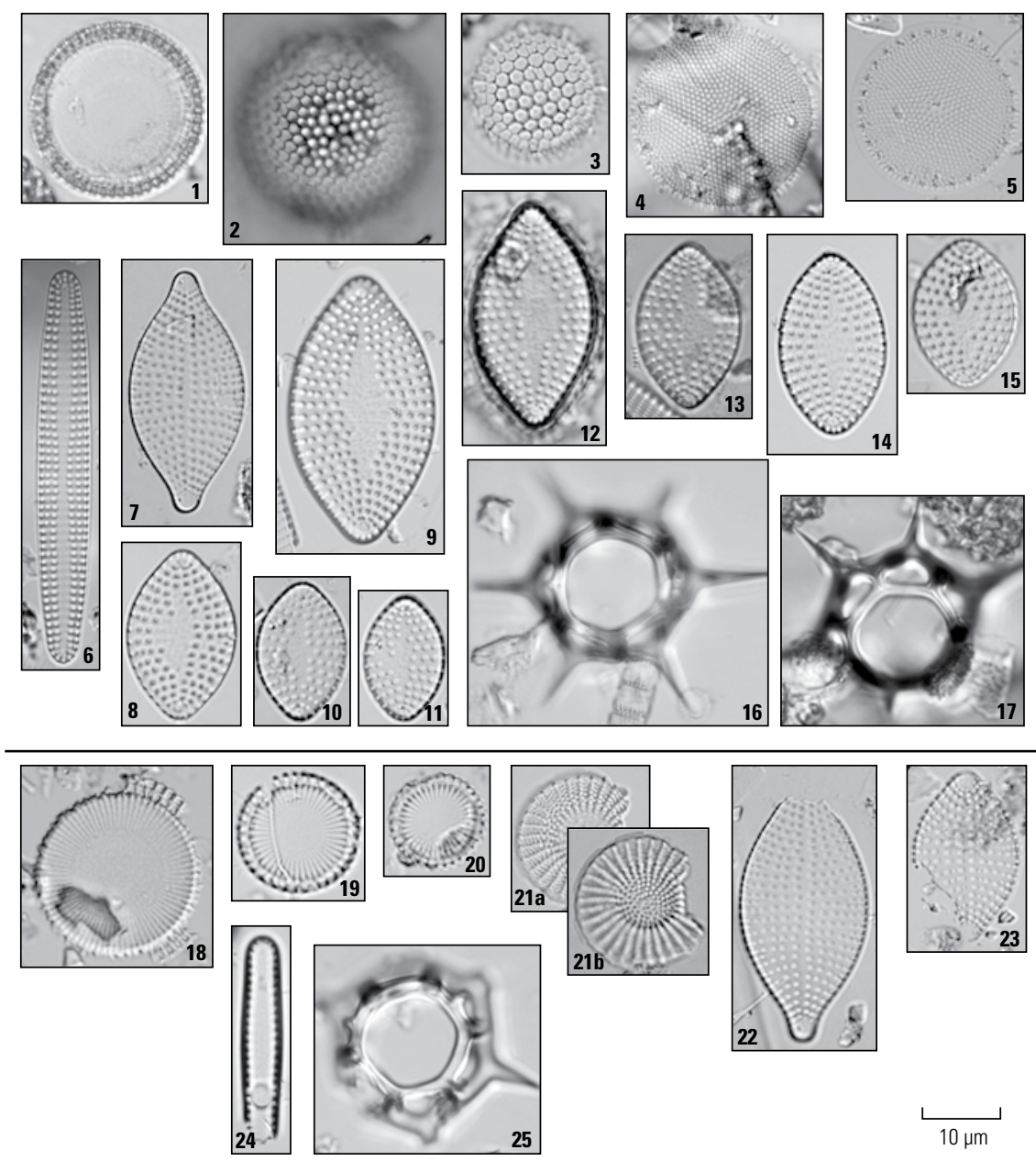

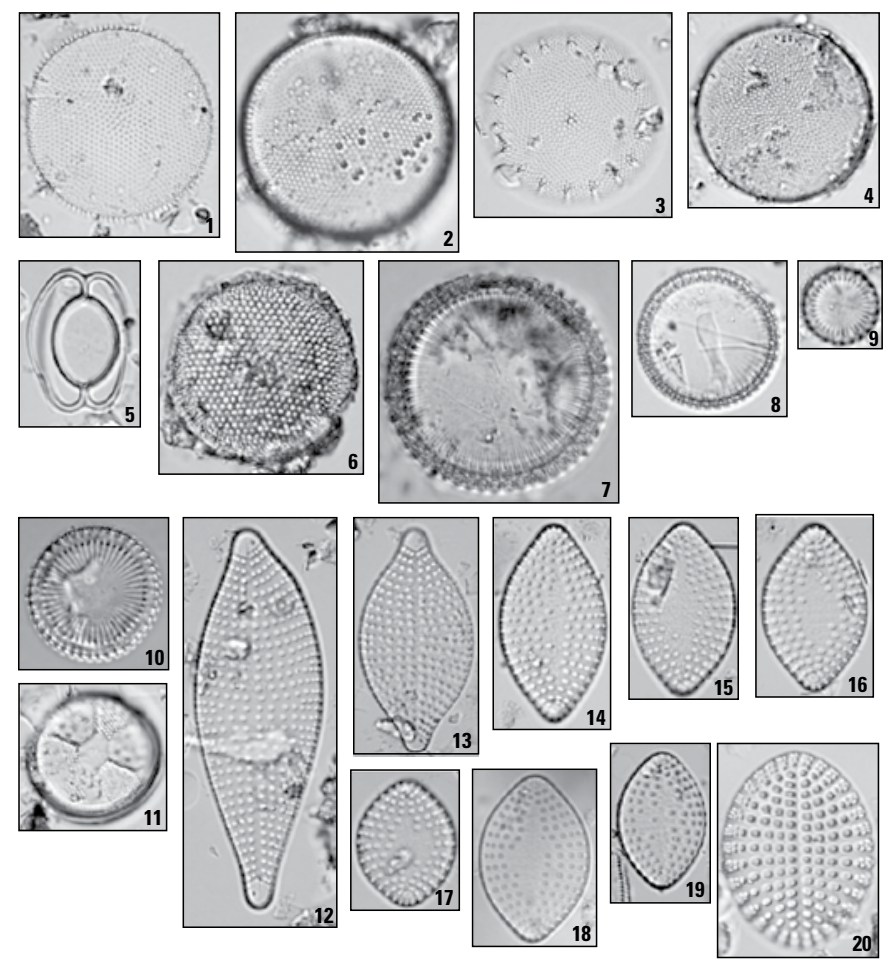
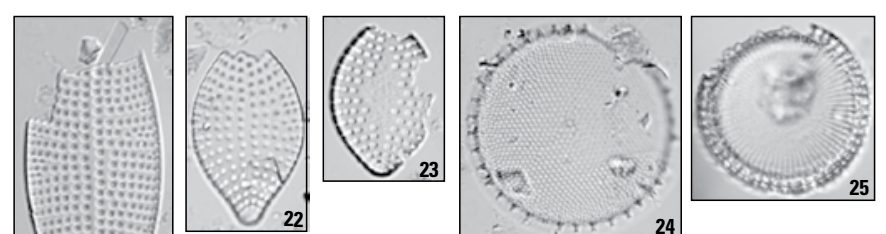

21
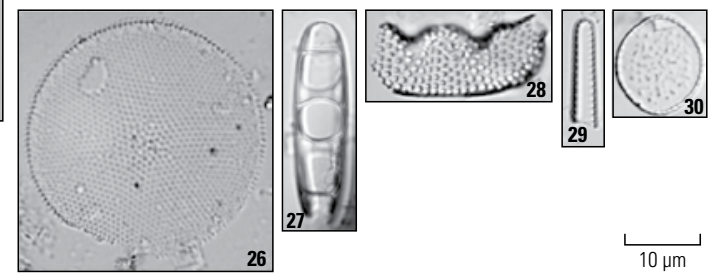

Figure 26. Photomicrographs of marine diatoms from the 1700 tsunami deposit at 126 centimeters depth in core MM17. Well-preserved valves are shown in images 1-20 (left of black line) and poorly preserved valves are shown in images 21-30 (right of black line). 1, Thalassiosira pacifica; 2, Thalassiosira cf. lineata; 3, Thalassiosira nordenskioeldii;, 4, Actinocyclus sp.; 5, Chaetoceros radicans; 6, Coscinodiscus (?) sp.; 7-10, Paralia sulcata; 11, Actinoptychus senarius; 12-13, Rhaphoneis amphiceros; 14-19, Rhaphoneis psammicola; 20, Cocconeis speciose; 21-22, Rhaphoneis amphiceros; 23, Rhaphoneis psammicola; 24, Thalassiosira pacifica; 25, Paralia sulcata; 26, Thalassiosira sp.; 27, Grammatophora marina; 28, Odontella aurita; 29, Thalassionema nitzschioides; 30 , Chaetoceros $\mathrm{sp}$. resting spore. $\mu \mathrm{m}$, micrometers.
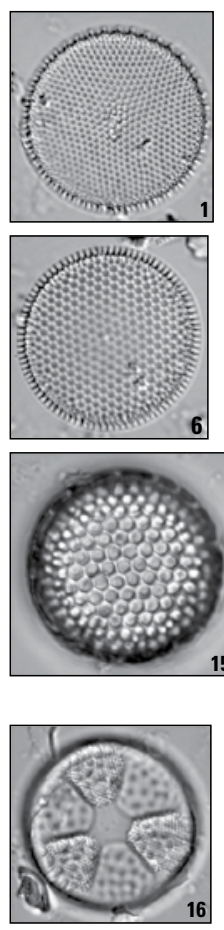
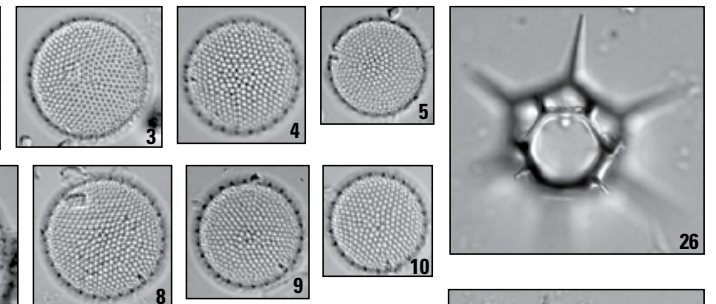

26
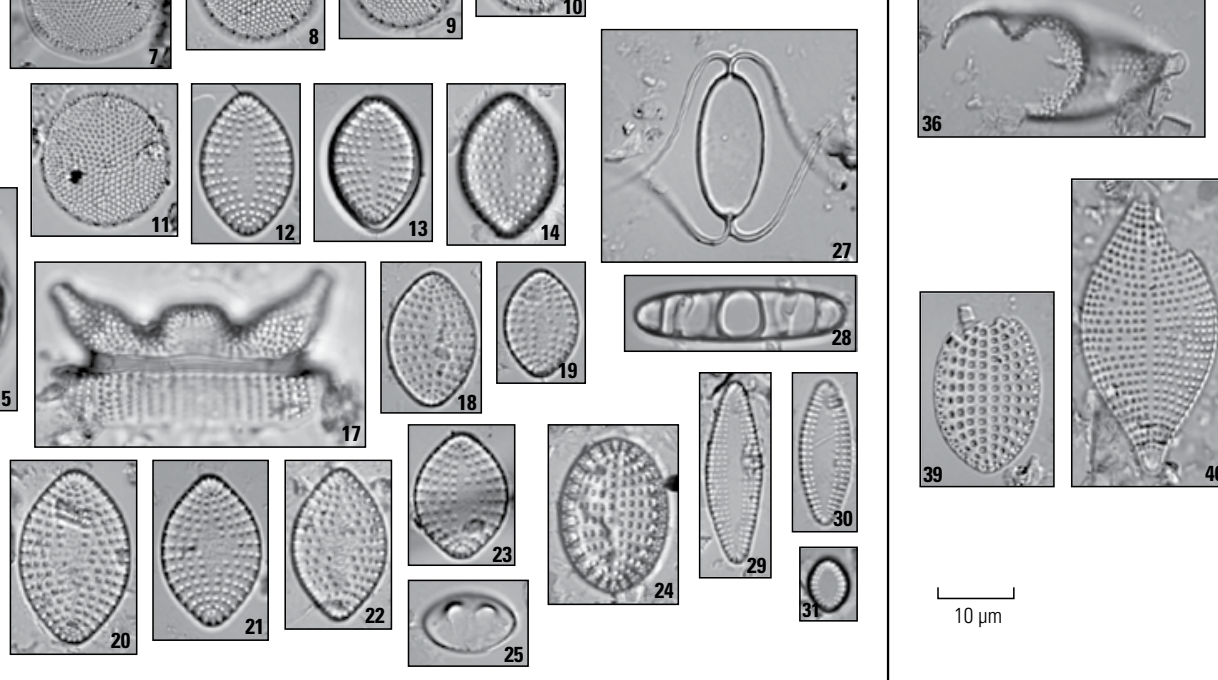
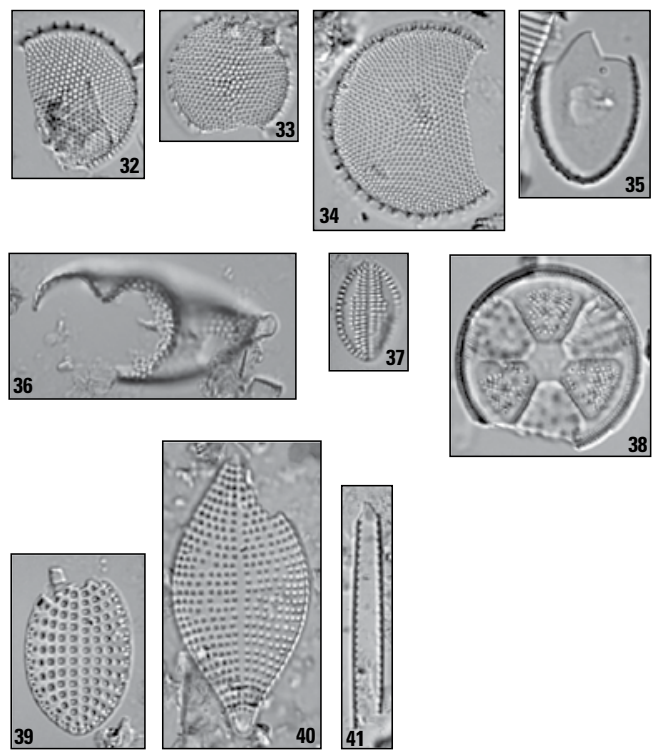

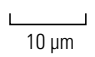

Figure 27. Photomicrograph of marine diatoms and a silic oflagellate from the 1,700-1,500 year before present tsunami deposit at 138-139 centimeter depth in core MM19. Well-preserved valves are shown in images 1-31 (left of black line) and poorly preserved valves are shown in images 32-41 (right of black line). 1-11, Thalassiosira spp.; 12-14, Rhaphoneis psammicola; 15, Endictya hendeyi, 16, Actinoptychus senarius, 17, Odontella aurita; 18-23, Rhaphoneis psammicola; 24, Cocconeis speciosa; 25, Chaetoceros spp. resting spore; 26, silicoflagellate Distephanus speculum; 27, Chaetoceros radicans, 28, Grammatophora oceanica; 29-30, Delphineis surirella; 31, Delphineis sp.; 32-34, Thalassiosira spp.; 35, Chaetoceros sp. resting spore; 36, Odentella aurita; 37, Cocconeis californica; 38, Actinoptychus senarius, 39, Cocconeis speciosa; 40, Rhaphoneis amphiceros; 41 , Thalassionema nitzschioides. $\mu \mathrm{m}$, micrometers. 


\section{Evidence for Coseismic Subsidence}

Differences in oligohalobous diatom assemblages in peat above and below the 1700 tsunami deposit may provide evidence for coseismic subsidence at Marhoffer Creek marsh coincident with the 1700 Cascadia Subduction Zone earthquake (figs. 28-30).

Coseismic subsidence accompanying the 1700 earthquake has been posited for coastal locations along the length of the Cascadia Subduction Zone (Darienzo and others, 1994; Atwater and others, 1995; Hemphill-Haley, 1995a; Shennan and others, 1996, 1998; Nelson and others, 1996, 2006, 2008; Atwater and Hemphill-Haley, 1997; Kelsey and others, 2002; Witter and others, 2009; Hawkes and others, 2011; Graehl and others, 2015; Dura and others, 2016), including the northern California coast in the Crescent City area (Peterson and others, 2011) and Humboldt Bay (Valentine and others, 2012; Engelhart and others, 2016). At many estuarine locations in the Pacific Northwest, subsidence resulted in the conversion of fringing marshes or forests into tidal flats, producing a distinctive stratigraphic pattern in which an organic-rich soil is abruptly capped by dense inorganic mud. At Marhoffer Creek marsh, the stratigraphic evidence for subsidence is subtle because there was no major change in lithology, but rather peat continued to accumulate after the earthquake as it had before (for example, figs. 9, 12). However, differences in oligohalobous diatom assemblages above and below the 1700 tsunami deposit in core MM16 suggest a change to wetter conditions more conducive to diatom growth after the earthquake.

For cores MM17, MM19, and MM20, which are farther inland, the change in diatom assemblages is even more distinctive, suggesting a change from a drier, meadow-like setting prior to the earthquake to a wet marsh setting after the earthquake. These three cores are separated by distances of 50 to more than $150 \mathrm{~m}$ (fig. 3), indicating that the apparent environmental change before and after the 1700 event was not confined to a single location within the marsh. Although it could be argued that a similar change from a drier to wetter environment could be achieved by damming fresh water in the valley by mechanisms other than coseismic

Figure 28. Photomicrographs showing the variability in assemblages of oligohalobous diatoms in core MM16 from Marhoffer Creek marsh. Samples span the stratigraphic boundary of the 1700 earthquake and tsunami deposits. $A$, Low-abundance assemblage in fine-grained peat at 120 centimeters $(\mathrm{cm})$ depth. This assemblage underlies the 1700 tsunami deposit (that is, it represents the marsh surface before the earthquake) and indicates a dry environment at Marhoffer Creek prior to the 1700 earthquake. $B$, Oligohalobous diatoms accumulated in fine sand at the top of the 1700 C.E. tsunami deposit at $91 \mathrm{~cm}$ depth. Large intact valves suggest diatoms settled out of suspension following the cessation of turbulent flow. $C$ and $D$, High-abundance oligohalobous diatom assemblages in detrital peat at $85 \mathrm{~cm}$ depth-the transition to in situ (post-earthquake) marsh deposits. Comparable species are found above and below the tsunami deposit, but assemblages at $85 \mathrm{~cm}$ depth show a marked increase in diatom growth and species diversity in this location following the earthquake, indicating a change to a wet marsh environment in the Marhoffer Creek valley after the 1700 C.E. earthquake. $\mu \mathrm{m}$, micrometers.
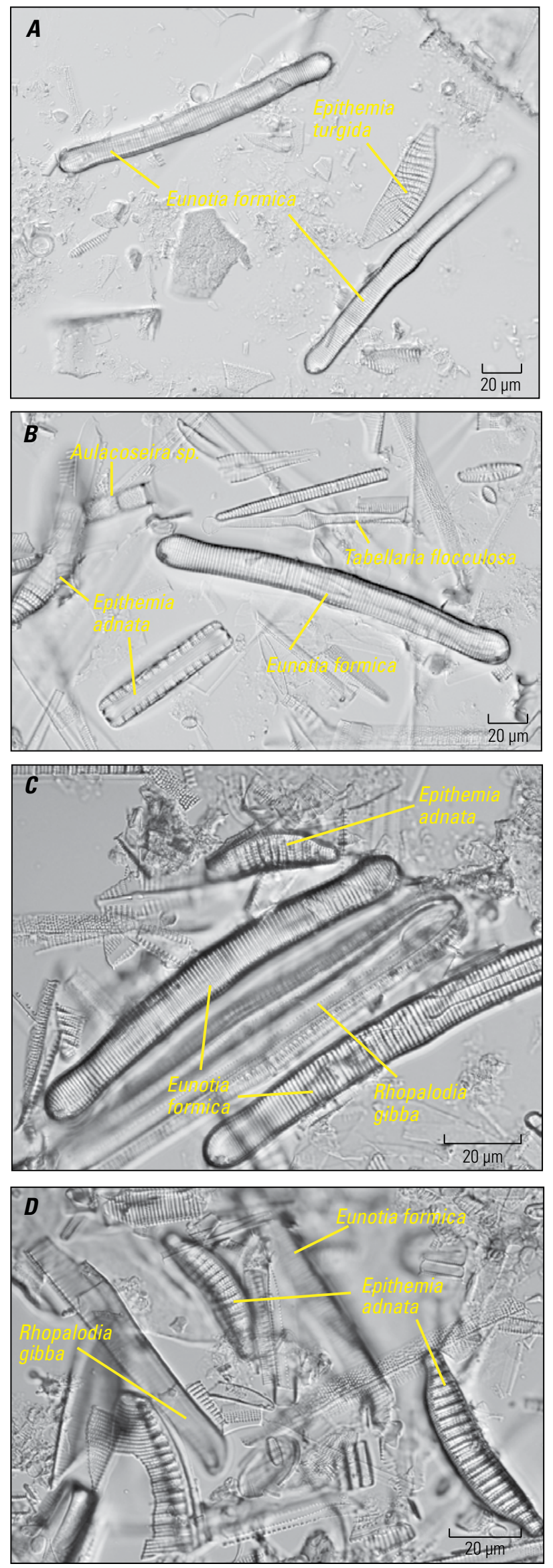


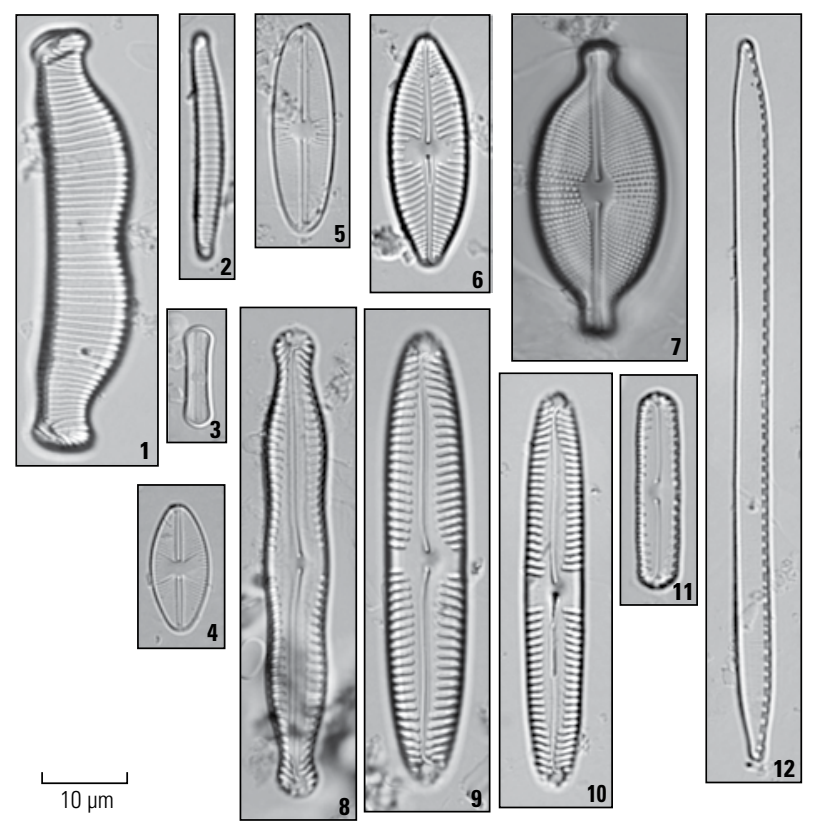

Figure 29. Photomicrographs of oligohalobous diatoms from the black, fine-grained detrital peat (132 centimeters depth) that underlies the 1700 tsunami deposit in core MM17 from Marhoffer Creek marsh. These taxa were likely redeposited by the tsunami with plant material from the marsh and show that the pre-earthquake environment was probably a well-drained marsh and more like a meadow than a wet marsh. 1, Eunotia praerupta var. bidens; 2, Eunotia incisa; 3, Humidophila (Diadesmis) contenta; 4, Cavinula lapidosa; 5, Cavinula variostriata; 6, Placoneis elginensis var. cuneata; 7, Cosmioneis pusilla; 8, Pinnularia nodosa; 9, Pinnularia gibba; 10, Pinnularia gibba var. lineata; 11, Pinnularia lagerstedtii; 12, Nitzschia terrestris. $\mu \mathrm{m}$, micrometers.
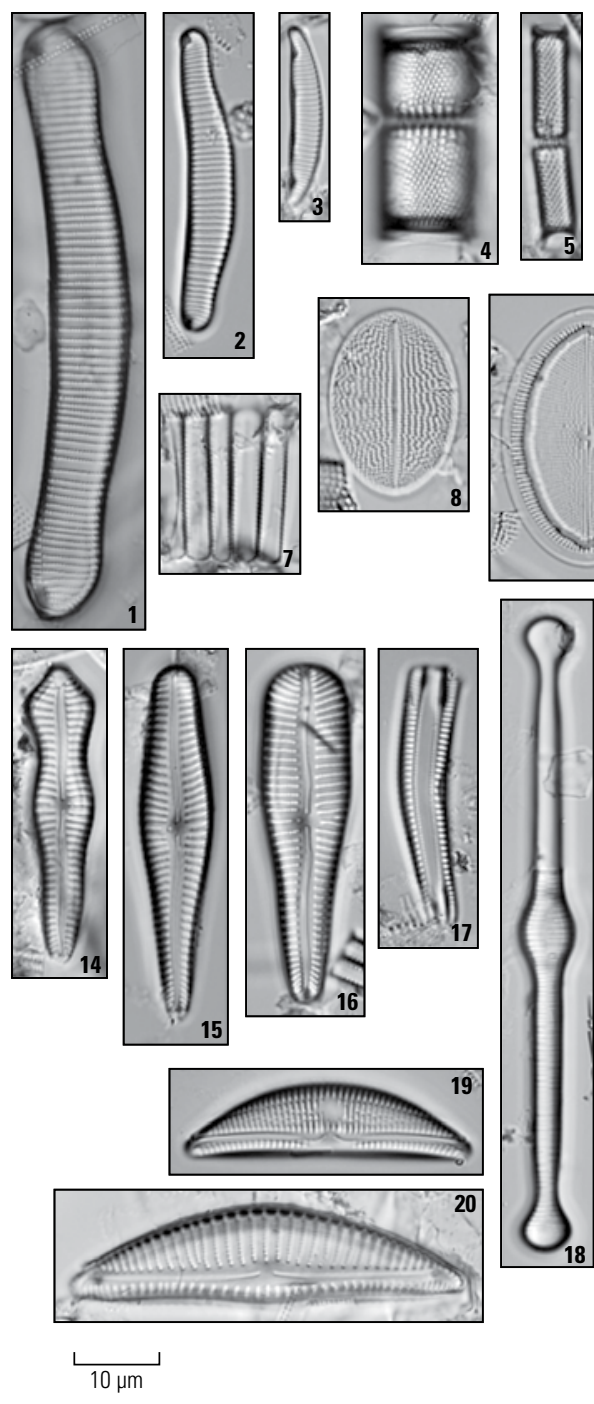
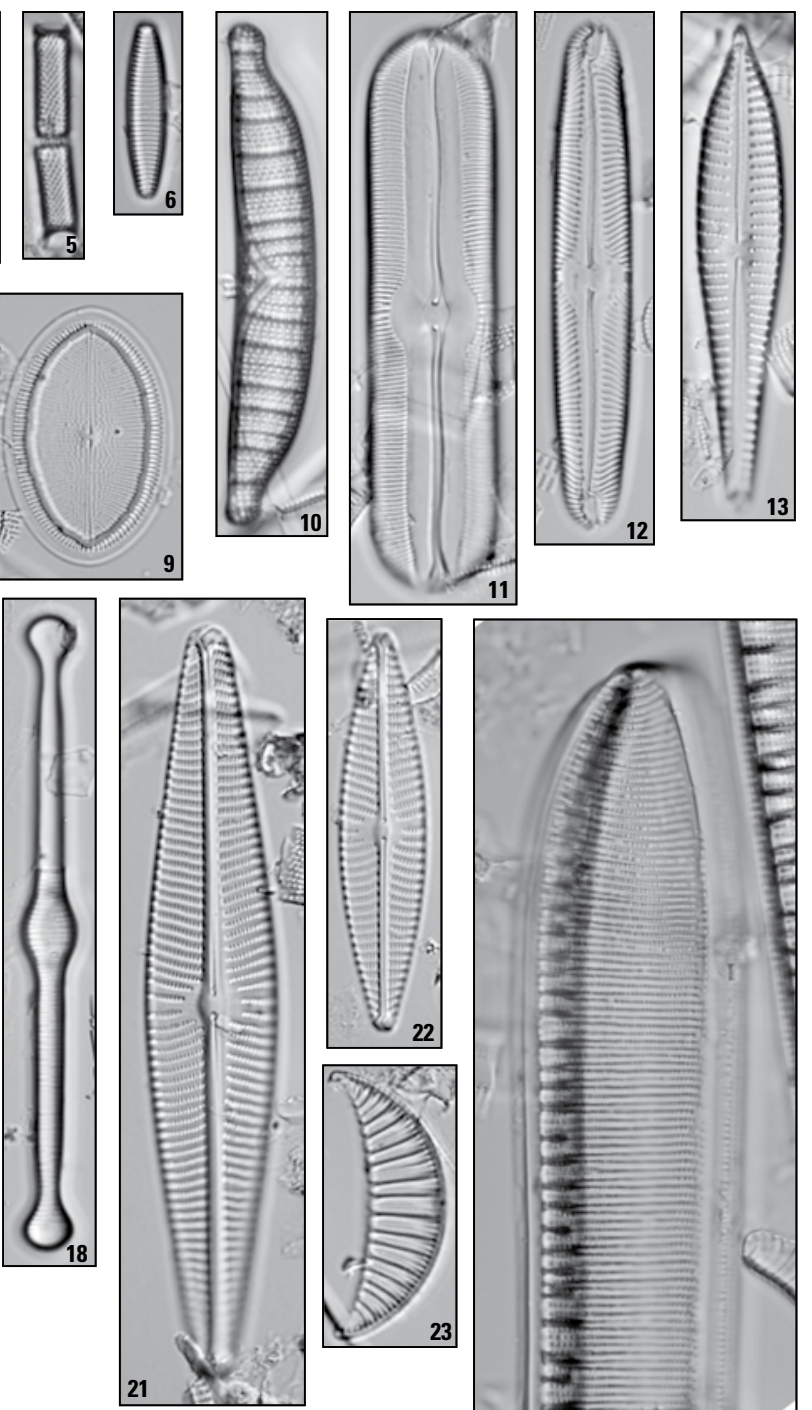
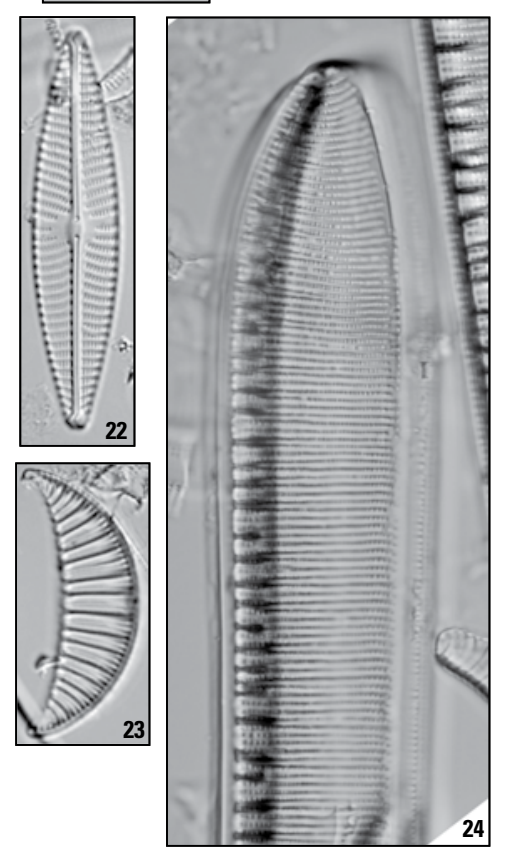

Figure 30. Photomicrographs of oligohalobous diatoms from brown peat (120 centimeters [cm] depth) that is located $10 \mathrm{~cm}$ above the 1700 tsunami deposit in core MM17 from Marhoffer Creek marsh. These taxa show a change to a wet freshwater marsh at this location following the 1700 earthquake and tsunami. 1, Eunotia formica; 2, Eunotia minor, 3, Eunotia incisa; 4-5, Aulacoseira ambigua; 6-7, Fragilaria virescens; 8 , Cocconeis placentula (rapheless valve); 9, Cocconeis placentula (raphe valve); 10, Epithemia adnata; 11, Sellaphora americana; 12, Pinnularia divergens; 13 , Gomphonema augurvar. turris; 14, Gomphonema coronata; 15 , Gomphonema clavatum; 16, Gomphonema truncatum; 17, Rhoicosphenia abbreviata; 18, Tabellaria fenestrata; 19, Amphora libyca; 20, Encyonema mesianum; 21, Navicula peregrinopsis; 22, Navicula vaneii; 23, Rhopalodia musculus; 24, Tryblionella scalaris (view is of one end; complete valve is $>300$ micrometers [ $\mu \mathrm{m}]$ long). 
subsidence, the possibility of subsidence at Marhoffer Creek marsh is a reasonable conclusion that has also been documented at other sites around Crescent City by Peterson and others (2011), and is evident in the subsurface stratigraphy we examined at Elk Creek wetland, as discussed in the next section. The diatom data for Marhoffer Creek marsh show the wet marsh environment that became established after the 1700 earthquake has persisted until present, and that there is no evidence over the intervening 300 years that the site reverted to the drier environment that persisted in the valley prior to the earthquake.

\section{Discussion}

\section{Far-Field Tsunamis}

Evidence for inundation by the 1964 tsunami at Marhoffer Creek marsh is based most firmly on the coincidence of the 1963

${ }^{137} \mathrm{Cs}$ peak with thin sand layers in two cores, MM16 and MM16A. These cores were collected about $100 \mathrm{~m}$ inland from the beach berm, and less than $50 \mathrm{~m}$ from the lower channel of Marhoffer Creek as it would have existed in 1964 (figs. 3, 4). Although recent dredging to direct drainage into culverts has influenced the pathway of the lower creek, the main stream channel in 1964 likely followed the path shown by the dashed blue line in figure 3 .

Thin sandy deposits in the upper stratigraphy of several cores that are proximal to the Marhoffer Creek channel (MM1, MM2, MM6, MM8, and MM11; figs. 6, 7), occur at low elevations, and may similarly record the 1964 tsunami. However, with the possible exception of core MM11, there is a lack of clear separation between these youngest sand layers and underlying sandy, chaotic deposits that were likely emplaced by storms. Therefore, in the absence of ${ }^{137} \mathrm{Cs}$ data, the identification of these deposits as 1964 tsunami deposits is possible but not definitive.

Three cores from the western end of the marsh and close to the beach, MM3, MM4, and MM5, show no evidence of the 1964 tsunami deposit, but in addition to being off-line from direct flooding from the creek mouth, they are also at a slightly higher elevation than cores that include the deposit. The absence of evidence for the 1964 tsunami deposit in core MM7, which is proximal to the mouth of the creek and located near other cores containing the deposit, is likely the result of deposition around dense, obtrusive vegetation and large woody debris at the site, preventing deposition of a more evenly distributed or sheetlike deposit. This is supported by observations from additional exploratory coring within a few meters of core MM7 that revealed discontinuous sand units at depth, which likely accumulated around wood wrack.

Even where convincingly identified in cores MM16 and MM16A, the coarse-grained (sandy) component of the 1964 tsunami deposit ranged from several millimeters to about $1 \mathrm{~cm}$ thick; possible similar deposits in other cores do not exceed a few centimeters in thickness. We conclude that additional coring could locate further evidence of the 1964 tsunami at this site, however, we expect that the deposit will be of variable thickness because of the uneven marsh surface topography, a feature we also observed for both the Cascadia Subduction Zone tsunami and storm deposits at this location. Furthermore, the 1964 tsunami deposit will likely be absent from locations in the marsh within the inundation zone where vegetation in 1964 was dense and high or included accumulations of woody debris.

The absence of eyewitness accounts of the 1964 tsunami at Marhoffer Creek, and its exclusion from post-tsunami inundation maps (Magoon, 1966), is likely because the event occurred at a late hour (the largest waves arrived between about midnight and 1:45 a.m. PST) (Tudor, 1964; Dengler and Magoon, 2005) and because, understandably, focus was on documenting damage to the town and harbor a few kilometers to the south. In 1964, the roadbed for Pebble Beach was about $0.5 \mathrm{~m}$ lower in elevation than at present (figs. 3, 4), and instead of the two culverts that currently pass under the road to drain the marsh, there was a narrow bridge over the Marhoffer Creek outlet. ${ }^{4}$ Following the tsunami, there was no damage to the bridge, nor anomalous amounts of debris on the roadway. This information, in conjunction with our observations that the 1964 tsunami deposit is apparently confined to cores proximal to the Marhoffer Creek mouth, suggests that at least one of the larger tsunami waves, ${ }^{5}$ which arrived within a few hours of high tide, surged up the creek channel and under the bridge to spread out in the marsh. The grain-size and diatom data are consistent with the tsunami suspending and redepositing sediment from close to shore (for example, lower beach or surf zone). The maximum run-up elevation at the marsh was about $3.5 \mathrm{~m}$, which was about 1.5 to $>2 \mathrm{~m}$ above the ambient high tide during the time in which the wave series arrived (Tudor, 1964). Assuming the youngest sand layer in core MM11 was deposited by the tsunami, the inundation extended at least $70 \mathrm{~m}$ into the marsh, measured from the former bridge location at the creek mouth (fig. 3).

We could find no geological evidence for other far-field tsunami deposits in addition to the 1964 deposit at Marhoffer Creek marsh. For example, we found no evidence for inundation at Marhoffer Creek marsh by the May 1960 trans-Pacific tsunami, generated during the M9.5 Chile earthquake, that flooded parts of Crescent City as well as a narrow zone along Crescent Beach to the south of the town. Based on instrumental data, the largest wave from that tsunami reached a maximum height of $1.7 \mathrm{~m}$ above the predicted tide at Crescent City (table 7 of Lander and others, 1993), resulting in an inundation area comparable to the first-toarrive, and second-largest, tsunami wave in 1964 (Magoon, 1966; Dengler and Magoon, 2005, 2006). We surmise that, if present at Marhoffer Creek marsh, a 1960 deposit would have been evident subjacent to the level of highest ${ }^{137} \mathrm{Cs}$ activity in cores MM16 and MM16A, in the same way that the 1964 deposit is observed above that interval (figs. 12, 13).

The 1700 tsunami deposit, which is widely distributed and correlatable at Marhoffer Creek marsh, provided a chronostratigraphic marker to search for geological evidence that a far-field tsunami associated with a tsunamigenic earthquake in the central Aleutian-Alaska Subduction Zone may have reached

\footnotetext{
${ }^{4}$ Information provided by the landowner, Mr. Terry McNamara, who was a teenager in 1964.

${ }^{5}$ The fifth wave was the largest and inflicted most of the damage in Crescent City (Tudor, 1964; Magoon, 1966; Dengler and Magoon, 2005).
} 
the northern California coast in 1788. We conclude that there is no evidence for a 1788 tsunami deposit, as there are no anomalous deposits interrupting decimeters of fine-grained freshwater peat overlying the 1700 tsunami deposit, either visible to the eye or in X-ray images (figs. 13-15), including in the area of the lower marsh that was later flooded by late-19th-century storms as well as the 1964 far-field tsunami (figs. 6-8).

\section{Near-Field Tsunamis}

Based on this initial work as well as additional reconnaissance coring in 2014, Marhoffer Creek marsh is a good location to document the history of large paleotsunamis for the southern extent of the Cascadia Subduction Zone. The stream valley lies adjacent to the ocean, with a fairly flat valley floor that extends about $800 \mathrm{~m}$ inland, and currently ranges in elevation from about 3.5 to $5 \mathrm{~m}$. The 1700 Cascadia Subduction Zone tsunami deposit is found about $1 \mathrm{~m}$ below the modern marsh surface; we traced it $>500 \mathrm{~m}$ inland to core MM20, the farthest upvalley core in this study area, and observed it another $\sim 175 \mathrm{~m}$ inland in reconnaissance cores collected in 2014. An interesting aspect of the 1700 Cascadia Subduction Zone tsunami deposit at Marhoffer Creek marsh is that it does not become consistently thinner landward, but rather varies in thickness of about 5-18 cm from core to core (figs. 7, 8). This variability is consistent with the tsunami deposit draping the hummocky surface of a freshwater wetland with variable vegetation over short distances, where naturally occurring plants may have grown in slightly elevated clumps (for example, skunk cabbage, sedges, and small shrubs).

In addition to a 1700 tsunami deposit, we propose that an earlier deposit from about 1,700-1,500 years ago is present in at least one of our cores, MM19, at a depth of about 135-140 cm below the marsh surface. The calibrated ${ }^{14} \mathrm{C}$ ages $(1,694-1,558$ and 1,700-1,569 cal. yr B.P.; figs. 8, 10; table 1) are consistent with ages of Cascadia Subduction Zone tsunami deposits previously reported in the region (Abramson, 1998; Patton, 2004; Peterson and others, 2011), as well as with the age of a Cascadia Subduction Zone earthquake identified by a buried soil at Humboldt Bay (Valentine and others, 2012; Engelhart and others, 2016).

Additional tsunami deposits of intermediate ages between the 1700 C.E. and $~ 1,700-1,500$ cal. yr B.P. deposits were reported by Peterson and others (2011) at low-elevation marshes south of Crescent City, as well as at Lagoon Creek, $18 \mathrm{~km}$ farther down the coast. At Marhoffer Creek marsh, however, we found no evidence for tsunami deposits of this intermediate age. In several cores (MM1, MM3, MM4, and MM20), what we interpret as the 1700 deposit includes a thin lower layer of sand separated from a thicker upper layer of sand by intervening detrital peat. From our observations to date, we conclude that this represents a single event, and not a merged deposit from two depositional events - that is, an earlier event overprinted by erosion and deposition by the 1700 tsunami. We evaluated this in detail in core MM20 (fig. 22), and came to the conclusion that it is located too far inland to be reached by storm surges. Close evaluation of core samples, which we dried and inspected in the lab, showed that the material between the sand layers consists of sandy, brown to black detrital peat, and that there was no evidence for undisturbed peat accumulation in the interval that would indicate a break in time between emplacement of the two sandy deposits. The diatom data are consistent with a tsunami deposit in the upper sand layer, including prominent marine taxa, and a few valves were also observed in the sandy detritus between the layers (fig. 22). The lower sand layer contains common sponge spicules but no marine diatoms. The diatom Thalassiosira lacustris was observed in the detrital material a few centimeters above the lower sand; T. lacustris is commonly found in estuaries (Hasle and Lange, 1989) and in high-conductivity coastal streams (Smucker and others, 2008). Kelsey and others (2005) recorded high numbers of T. lacustris ${ }^{6}$ in sediment deposited after inundation by past tsunamis into Bradley Lake, Oregon, recording increased species growth in the lake in response to higher conductivity from mixing with seawater.

The apparent absence of evidence for additional tsunami deposits between the 1700 C.E. and 1,700-1,500 cal. yr B.P. events at Marhoffer Creek marsh may suggest that any other tsunamis that possibly occurred during this interval were not large enough to leave a recognizable and lasting sedimentary record. This would be particularly true in the higher elevation upvalley areas where Cascadia Subduction Zone tsunami deposits are distinctive as the only coarse-grained marine deposits preserved in peat.

\section{Large Coastal Storms}

In addition to recording tsunamis, both far-traveled and triggered nearby, sandy deposits near Marhoffer Creek marsh give evidence for flooding from the sea during unusual storms. The inferred inundation areas overlap, particularly for the 1964 Alaskan tsunami and the storms of 1861-62. Compared to the 1964 tsunami deposit, the storm deposits are more massive and chaotic, with decimeters of sand and detritus at some sites, and are associated with large woody debris in the subsurface that frequently blocked penetration by the core barrel. The deposits are found shallower than about $60 \mathrm{~cm}$ depth in most cores seaward of core MM11 (figs. 3, 6-8), that is, cores located within about $100 \mathrm{~m}$ of the modern beach. Based on historical storm data for northernmost California (Harden, 1995), several atmospheric storms since the 1860s included storm-surge inundation as well as large-scale fluvial flooding. However, no far-field tsunamis comparable to the 1964 event were reported during this time.

We infer that the storm-surge deposits at Marhoffer Creek marsh record anomalously large events, and that at least the older (lowermost) part of the deposits records the 1861-62 megastorm (Engstrom, 1996), which was the model for the 2011 USGS ARkStorm scenario (Porter and others, 2011). The 1861-62 event was an atmospheric winter storm system formed by a nearly continuous series of cyclones over a 43 -day period

\footnotetext{
${ }^{6}$ Kelsey and others (2005) recorded this species as "Thalassiosira bramaputrae," but based on the Smucker and others (2008) taxonomic study, the correct identification is T. lacustris.
} 
during December 1861 and January 1862, during the highest tides of the year.

Other large storms after 1862 may also have contributed to deposition in Marhoffer Creek marsh - notably storms in 1867, 1891, and 1943. Each of these storms were associated with moderate to strong El Niño events, unlike the 1861-62 storm which was associated with cooler than normal conditions (Engstrom, 1996). All of these events included elevated sea levels, but the 1861-62 event involved an unusually long duration of continuous storm activity, and as a result inflicted a greater amount of damage.

Based on historical data, little is known about occurrences of megastorms on the northern California coast at Crescent City prior to the 1861-62 event because the earliest European settlers had arrived only a decade prior, in 1851 . Bledsoe (1881, p. 74) was able to extend the record some decades earlier by interviewing elder Native Americans, all of whom reported no storms of similar magnitude during their lifetimes.

The results of our sediment core analyses at Marhoffer Creek marsh suggest there were no storms of similar magnitude to the 1861-62 megastorm between 1700 and that event, and furthermore that the 1861-62 storm was the first storm after the 1700 tsunami large enough to inundate the marsh. This conclusion is based on the thick section of uninterrupted freshwater peat overlying the 1700 tsunami deposits in cores also containing the storm deposits. We estimate a sedimentation rate of about 0.3 centimeters per year $(\mathrm{cm} / \mathrm{yr})$ for post- 1700 peaty deposits at Marhoffer Creek marsh, based primarily on core MM15, which is the most seaward core with uninterrupted peat deposits between the 1700 tsunami deposit and the modern surface (figs. 3, 8). Using a rate of $\sim 0.3 \mathrm{~cm} / \mathrm{yr}$, the thicknesses of peat between the 1700 tsunami deposit and the base of the storm deposits in various cores is consistent with an interval of 162 years, with some expected variability associated with erosion or compaction in the marsh by storm deposition. For example, the thickest intervening peat deposits in cores MM16 $(\sim 47 \mathrm{~cm})$ and MM8 $(\sim 50 \mathrm{~cm})$ suggest a time interval of about $150-170$ years.

The stratigraphic record of storms - as well as far-field tsunamis - at Marhoffer Creek marsh prior to 1700 needs further examination, especially in light of diatom data that suggest the marsh subsided in 1700, and therefore was possibly accessible only by unusually large events (like Cascadia Subduction Zone tsunamis) prior to that time. Paleoclimate data from a number of locations in California, including the Santa Barbara Basin, indicate that the penultimate megastorm for coastal California to the 1861-62 event occurred in 1605 (Ingram and MalamudRoam, 2013). This time interval is certainly captured within the decimeters of peat underlying the 1700 tsunami deposit in some cores. Several cores from the western marsh (MM1, MM3, MM4, MM11) include thin, anomalous sand layers within $10-40 \mathrm{~cm}$ of the 1700 deposit, identified by stratigraphic correlation (figs. 7, 8), but we see no thick accumulations of sand and debris like those found in the upper $60 \mathrm{~cm}$ of the cores, which we attributed to the 1861-62 storm or later events.

\section{Elk Creek Wetland-Crescent City Study Site II}

\section{Summary of Findings}

The Elk Creek study site is located in the flat, lowelevation alluvial valley of Elk Creek, just northeast of downtown Crescent City and the Crescent City harbor. Subsurface stratigraphy revealed in 12 cores shows a boundary between deposits in the southeastern part of the field area primarily consisting of artificial fill (an artifact of industrial activities since possibly the 1800s) and deposits farther upvalley that were less impacted by industrial development. The upvalley cores include estuarine and marsh deposits at depth that are consistent with a former natural estuary or lagoon environment. Where natural deposits are found, the stratigraphic record that includes evidence for paleotsunami deposits is short. The record consists of $0.5-0.8 \mathrm{~m}$ of peat that grades downward to decimeters of coarse sandy lagoon deposits. We found evidence for two past tsunamis within the peaty interval: the 1700 near-field (Cascadia Subduction Zone) tsunami and the 1964 far-field tsunami. The 1700 deposit is found about $0.3-0.5 \mathrm{~m}$ below the surface and is identified as centimeters of gray sand capped by detritus. Diatoms in the tsunami deposit and surrounding peat show a marine source for the sand and record an abrupt environmental change before and after the event, consistent with coseismic subsidence. The 1964 tsunami deposit is only observed in two cores collected near the Elk Creek channel and consists of a sparse fine sand and silt deposit found $<10 \mathrm{~cm}$ below the modern surface.

\section{Overview}

\section{Study Site Description}

A primary goal of this project was to evaluate the preservation potential of far-field tsunami deposits in addition to the 1964 tsunami deposit within the lower Elk Creek watershed. The Elk Creek Wetlands Wildlife Area is a California Department of Fish and Wildlife preserve to the northeast of the Crescent City harbor (figs. 2, 31-35). The wildlife area encompasses the low-lying, flat alluvial valley of Elk Creek, the main axis of which, based on lidar data, extends nearly $5 \mathrm{~km}$ inland without exceeding $4 \mathrm{~m}$ of elevation. The habitat of the lower Elk Creek valley includes freshwater meadows, marshes, swamps, and ponds, including reclaimed log ponds - artifacts of lumber mills that operated in the lower valley from the 1870 s to 1980s. Our field work focused on an area of marshes and grassy meadows within approximately $1 \mathrm{~km}$ of the harbor and downtown Crescent City; the maximum elevation for our cores are 2.3-2.4 m (figs. 32, 33; appendix 1). 


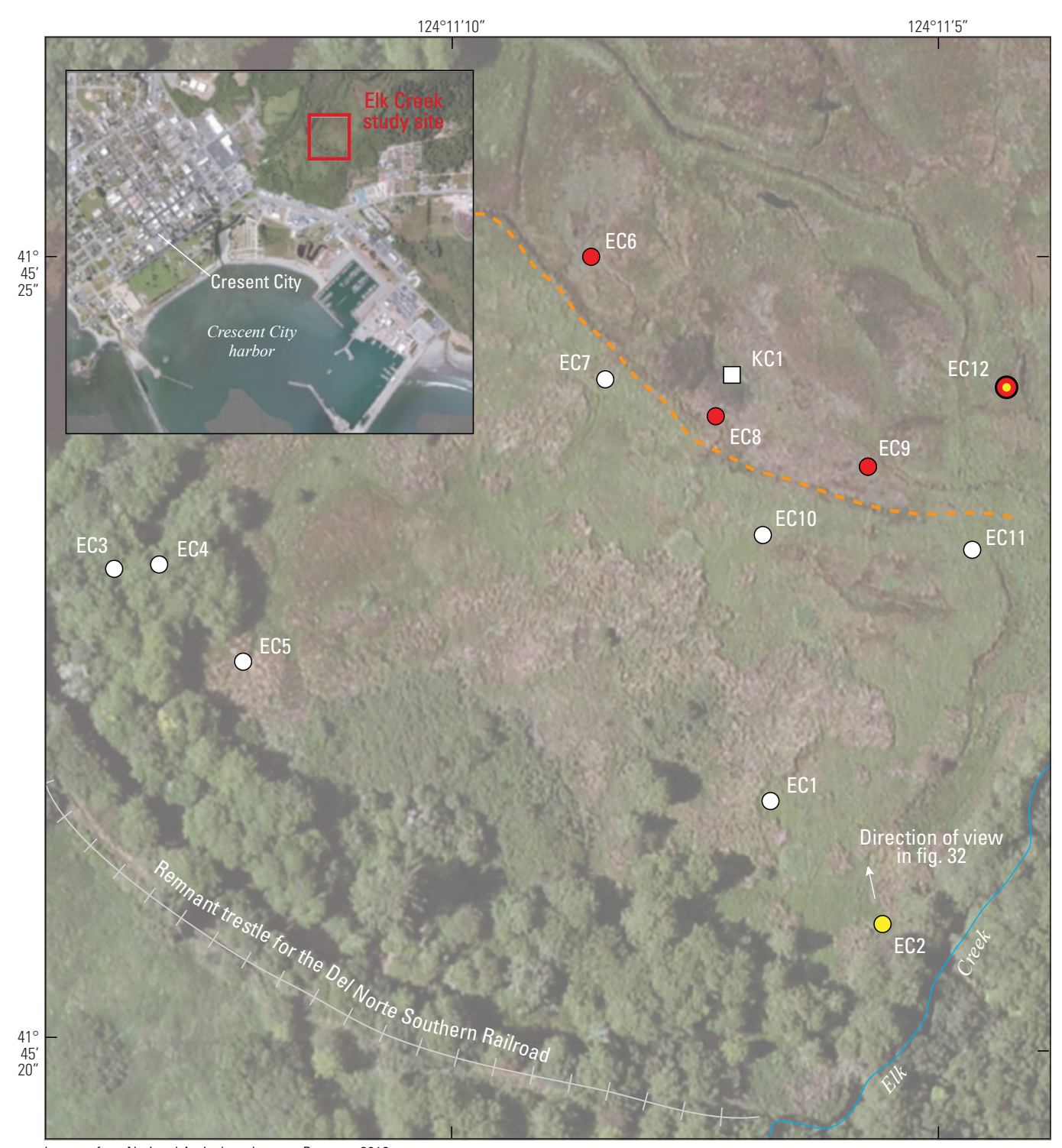

Figure 31. Aerial image of the Elk Creek wetland study site showing locations of cores. Inset image shows the location of the study area relative to downtown Crescent City and the Crescent City harbor. The dashed line marks the approximate downvalley extent of undisturbed subsurface deposits. To the north of this line, paleomarsh deposits are $>50$ centimeters thick. To the south of this line, modern peat deposits are $<15$ centimeters thick and overlie industrial-fill and paleolagoon deposits.

\section{EXPLANATION}

\section{Gouge core sites}

O 1964 tsunami deposit observed

- 1700 tsunami deposit observed

B. Both 1964 and 1700 tsunami deposits observed

No tsunami deposits observed

$\square \quad$ Approximate location of core KC1 (Peterson and others, 2011)

- - Approximate downvalley extent of undisturbed subsurface deposits
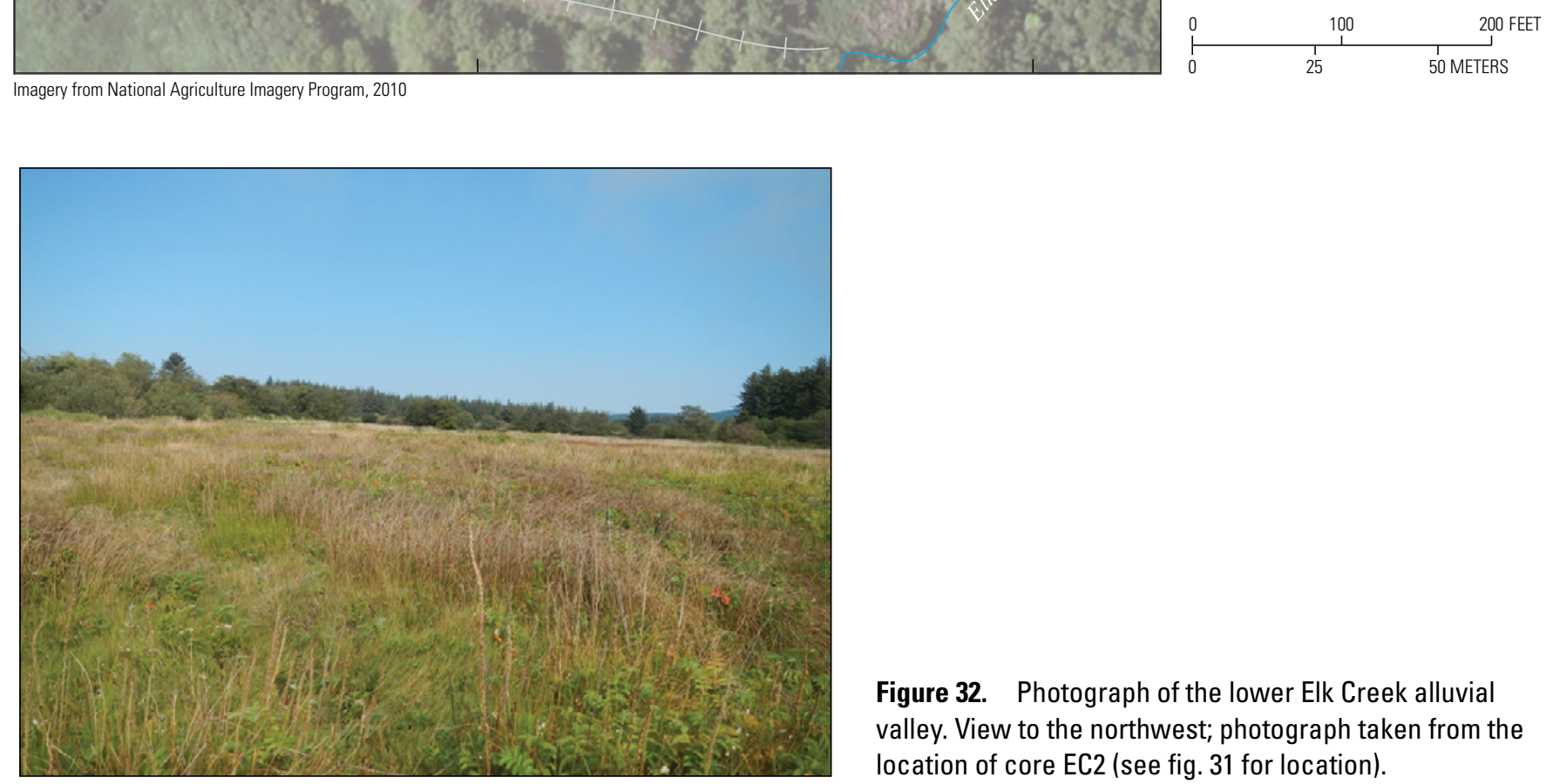

Figure 32. Photograph of the lower Elk Creek alluvial valley. View to the northwest; photograph taken from the location of core EC2 (see fig. 31 for location). 

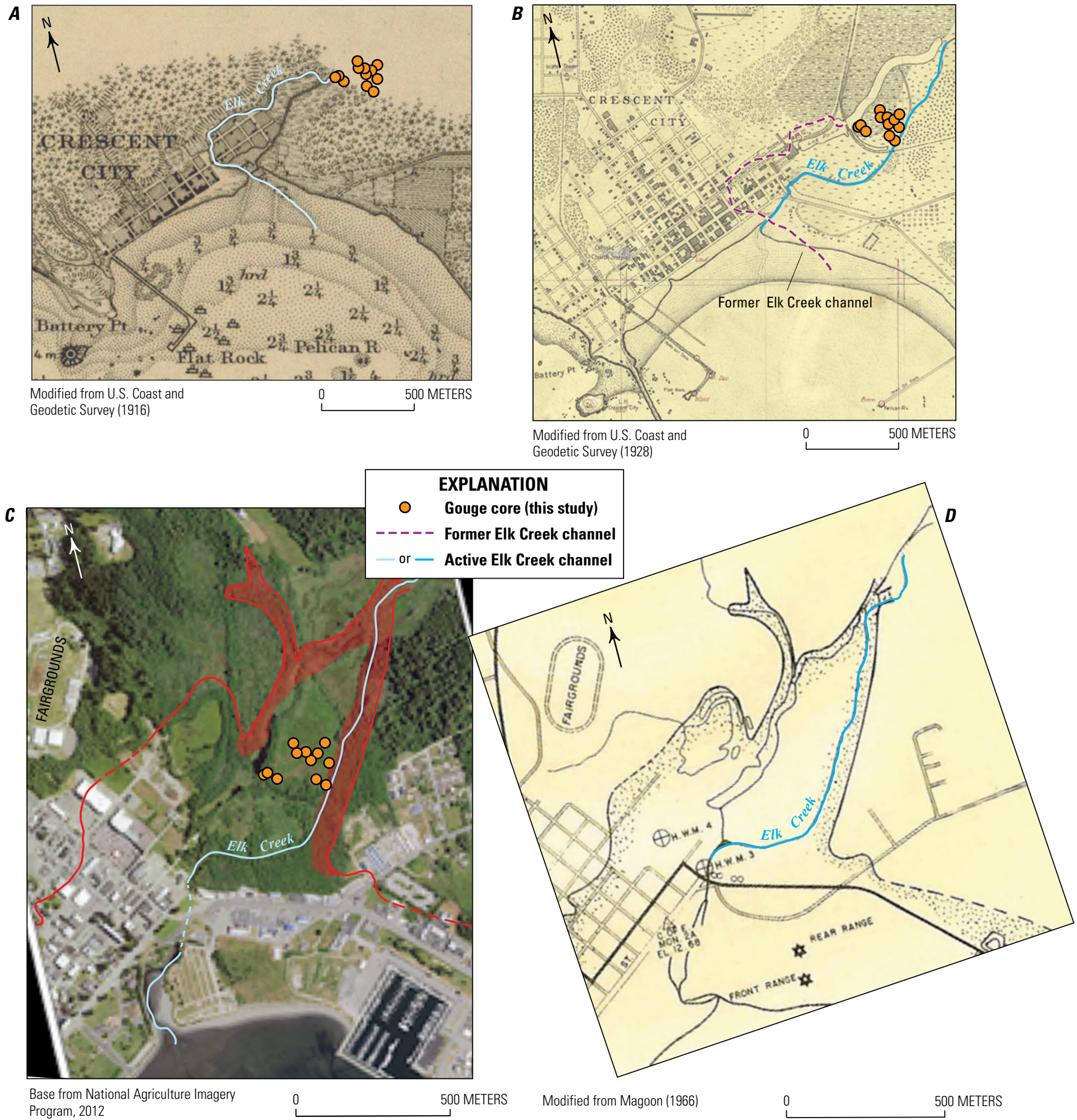

Figure 33. Historical views of the Elk Creek valley and Crescent City harbor. Orange circles show the approximate locations of cores collected during this study (see fig. 31). A, A 1916 U.S. Coast and Geodetic Survey map (chart 5895) shows the lower Elk Creek channel in what was probably its natural channel as the town was built around it. B, U.S. Coast and Geodetic Survey chart from 1928. By this time, log ponds have been dredged along the former Elk Creek channel on the northwest side of the valley and a new stream channel has been created along the southeast margin of the valley. The shoreline has been built out tens of meters and the former lower estuary of Elk Creek has been completely filled in to expand city streets. $C$, Modern aerial image of Crescent City from 2012. The upper Elk Creek channel remains confined to the southeast side of the valley and the lower channel is directed through a culvert under city streets (dotted line) before reaching its terminus at the harbor. The shoreline has been artificially extended several hundred meters seaward. Red lines and shading show the maximum extent of inundation from the 1964 tsunami, primarily following former or current stream channels at the valley margins (Magoon, 1966). D, Part of O.T. Magoon's (1966) map showing inundation from the 1964 tsunami in Elk Creek valley. The active channel of Elk Creek shown in blue. The maximum inundation limit for the 1964 tsunami is shown with stippled shading (line is solid where known and dashed where estimated). The solid line showing inundation at the Elk Creek valley was interpreted in the past to indicate flooding across the Elk Creek valley floor, rather than along the edges of the valley. 

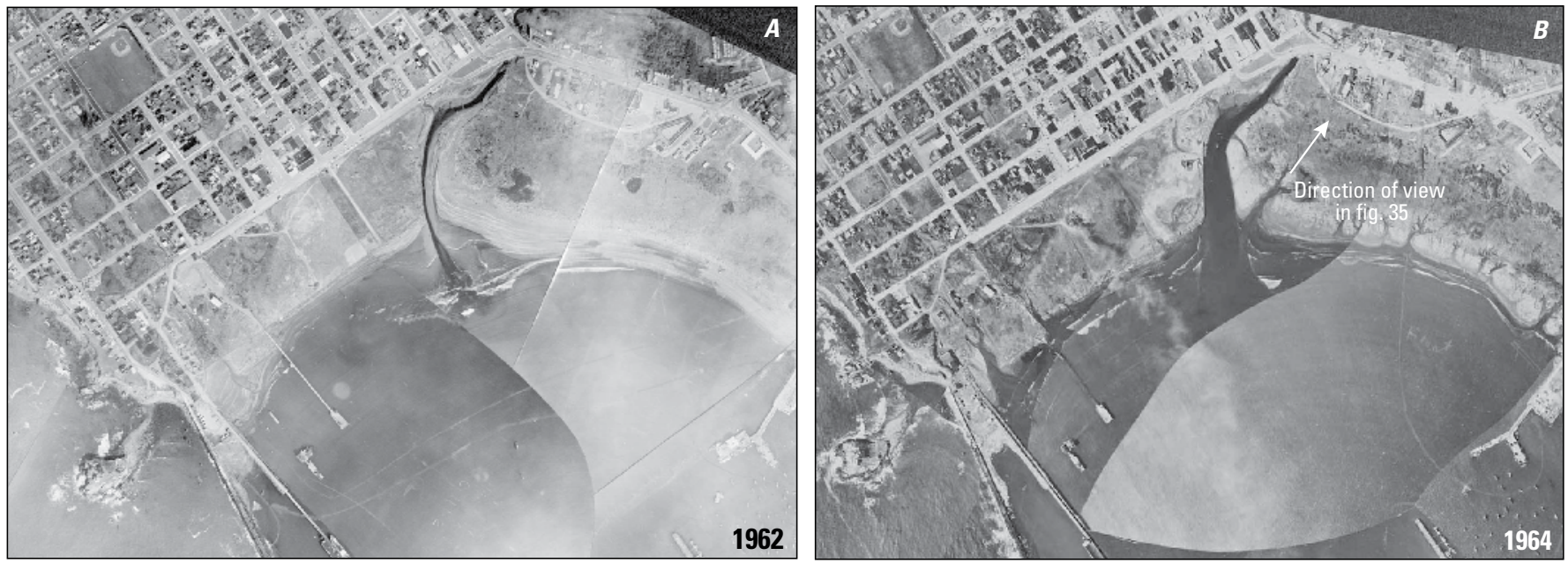

300 METERS

Figure 34. Historical aerial photographs of the downtown and harbor areas of Crescent City taken in 1962 before the 1964 tsunami $(A)$ and in April 1964 after the tsunami (B). Photographs from figure 2 of Dengler and Magoon (2006), reproduced with permission.

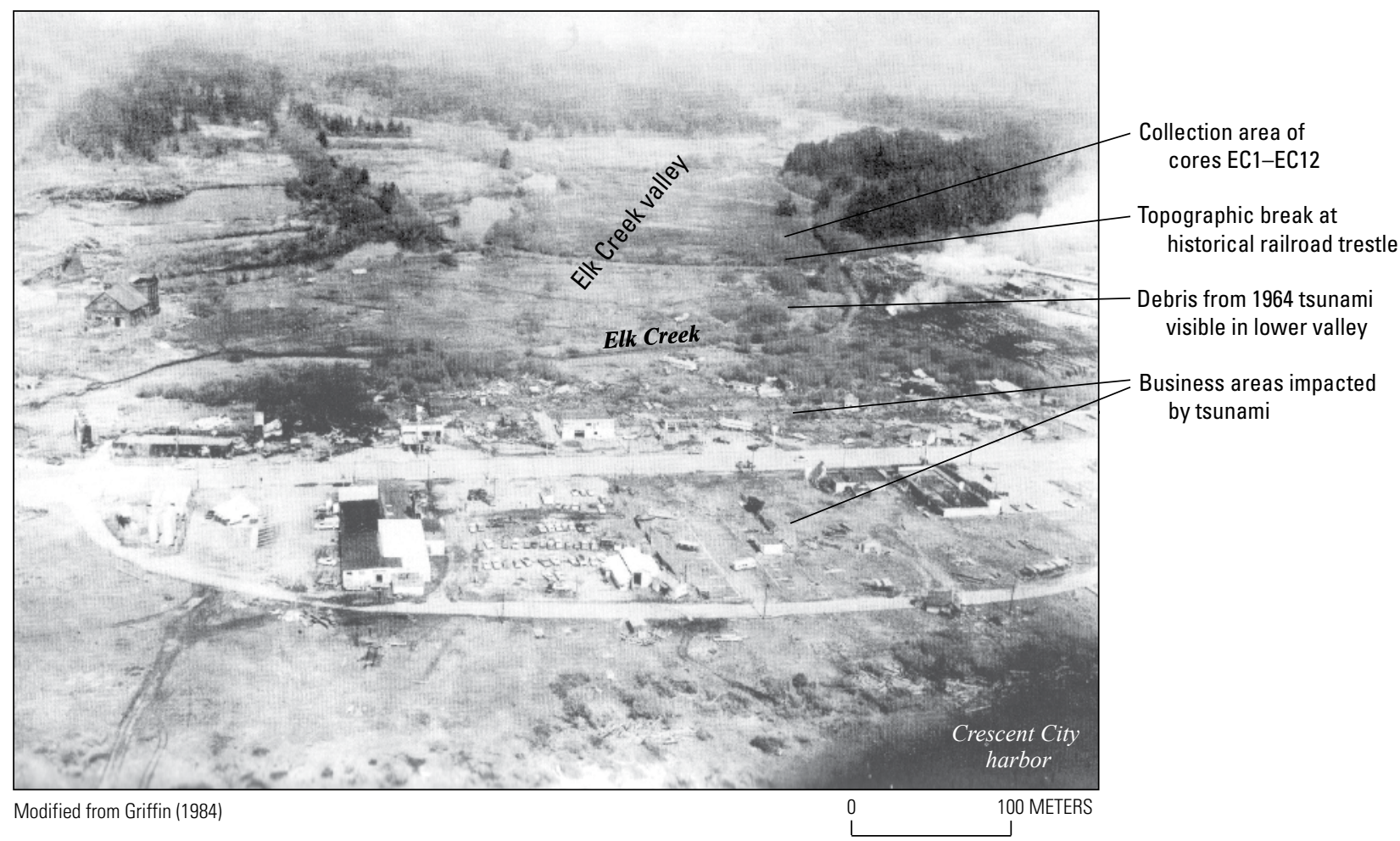

Figure 35. Annotated historical aerial photograph of the Elk Creek valley after the 1964 tsunami. View is to the northeast. Photograph from Griffin (1984, p. 144), reproduced with permission. 


\section{Natural Morphology and Subsequent Modifications}

Since the beginning of European settlement in the 1850s, human impacts on the Crescent City coastline - and in the Elk Creek valley - have been substantial. The 1859 T-sheet for Crescent City (U.S. Coast Survey, 1859), and later the 1916 navigational chart for Crescent City and vicinity (U.S. Coast and Geodetic Survey, 1916) (fig. 33A), show a strongly impacted lower Elk Creek estuary with an estuarine wetland area gridded into city streets along the lower stream channel. During this time, the Elk Creek stream channel followed its natural path inland along the northwest edge of the stream valley. Additionally, there was no buffer between the beach and the edge of downtown (at Front Street) and forested areas extended to the shore in some locations (fig. 33A). By 1928, based on historical T-sheet 4402 (U.S. Coast and Geodetic Survey, 1928) (fig. 33B), the original lower Elk Creek estuary was completely filled in and a new, narrow channel for Elk Creek was dredged on the opposite (southeastern) margin of the alluvial valley. To support timber mill operations, a large, elongate log pond was dredged along several hundred meters of the original stream channel (in an area that was likely tidally influenced or possibly hosted a seasonal or ephemeral lagoon in the undisturbed stream valley). A levy and railroad trestle for the Del Norte and Southern Railroad, owned and operated by the timber mill, was constructed across the valley (just south of our core locations; figs. 31, 33B, 35). The shoreline was extended seaward by tens of meters along the entire harbor area, creating an artificial buffer of beach between Front Street and the harbor. None of the extensive woodlands that were present on the 1916 map are evident on the 1928 map. Not evident from the maps, but indicated in our cores and supported by U.S. Fish and Wildlife Service studies (National Marine Fisheries Service, 2014), the wetlands in the lower Elk Creek valley had been dredged, filled, and elevated by 1928 to provide suitable land for livestock and agriculture. By 1964, the Elk Creek valley was separated from the ocean, with a seawall and a 200-m-wide land buffer separating Front Street from the harbor. By this time, Elk Creek had been reduced to a minor stream, having been dammed and diked along its upper reaches and tributaries (National Marine Fisheries Service, 2014), and flowed through a $\sim 150$-m-long culvert under city streets and Highway 101 before reaching its mouth at the harbor-at least $100 \mathrm{~m}$ seaward of where it was in 1916. The lowermost part of the Elk Creek valley consisted of treeless pastureland in 1964 (fig. 35). That area has since been converted into riparian habitat, including freshwater marshes, ponds, and dense willow swamps, by the California Department of Fish and Wildlife.

By taking account of the extensive land-use changes in the Crescent City area, and reconstructing the approximate presettlement and natural setting of Elk Creek valley, much insight is gained into the past depositional settings and likelihood for preservation of paleotsunami deposits at this site. For example, the Elk Creek valley at the time of the 1700 earthquake and tsunami would have been low and broad as today, but, as indicated by the 1859 and 1916 maps, was densely forested at its margins as well as in freshwater reaches of the valley floor. An interesting account of the former forests surrounding Crescent City is provided in an 1864 description by W.H. Brewer (Farquhar, 1930, p. 492),

Crescent City lies on a little plain of a few miles in extent that juts out from the hills into the sea. A little cove, but no harbor exists here. A town was built up here ten years ago, which grew rapidly, but like too many Californian towns it has passed its zenith of prosperity and is on its decline... A dense forest of tall firs and spruce once grew just back of the place, but this was killed by fire, and now the dead and blackened trunks, many of them over two hundred feet high, hundreds in number, stand like specters haunting the city.

It is likely that the lower estuary of Elk Creek was more extensive in 1700 than is mapped on the 1859 or 1916 charts (fig. 33), and comparable to other streams along this reach of the northern California coast, the mouth of the stream may have been blocked seasonally or occasionally by a sand spit to form a shallow lagoon. Near our study site, emergent marshes had been established for a number of centuries based on thicknesses of peat grading upwards from non-vegetated sandy alluvial or estuarine deposits.

\section{Previous Studies}

Earlier tsunami-related studies in the Elk Creek area include post-1964 tsunami surveys by Tudor (1964), who focused on structural damage in and around Crescent City, and Magoon (1966), who used debris evidence, aerial photograph analysis, and eyewitness accounts to construct a map of maximum inundation. Magoon's (1966) map shows inundation as far as $1.5 \mathrm{~km}$ inland in the Elk Creek valley, and though not clearly specified on the map, our observations suggest that most of the inundation was probably confined to narrow zones along stream channels at the valley margins (figs. 33C, D). Magoon (1966, p. 53) noted that, at locations around Crescent City, the maximum tsunami inundation tended to follow the $+20-\mathrm{ft}$ (6.1-m) contour line above MLLW, which is well above the maximum valley floor elevation of $\sim 4 \mathrm{~m}$. Dengler and Magoon (2005) report maximum inundation to be $\sim 800$ meters ( 0.5 miles) into the Elk Creek valley south of the Del Norte County Fairgrounds. Further discussed below, this is the approximate inland distance of recognizable debris in historical photographs, primarily near the mill sites on the valley's lower northwest side.

In the first geologic search for tsunami traces at Elk Creek wetland, Peterson and others (2011) ascribed certain sandy deposits and woody debris to the 1964 tsunami, and compared them with underlying sandy deposits from cores $0.5-2.5 \mathrm{~km}$ from the present shoreline. They related these underlying sand deposits to the 1700 Cascadia Subduction Zone tsunami and inferred at least one prior Cascadia tsunami as well. They equated the age of a pre-1700 sand layer with the age of apparently underlying peat to be $960-790 \mathrm{cal}$. yr B.P. (2-sigma error) (site KC9 of Peterson and others, 2011). 
Our initial observations for this study site are provided in Wilson and others (2014, p. 80-82) under the heading "Elk Creek Marsh.” In this report, we refine our initial conclusions based on additional observations of stratigraphy, historical land-use changes in the Elk Creek valley, and diatoms associated with the 1964 and 1700 tsunami deposits.

\section{Field Data Collection Strategies}

We focused on the lower $1 \mathrm{~km}$ of the Elk Creek valley where Peterson and others (2011) previously reported finding the 1964 tsunami deposit. Unlike our other Crescent City study sites that are adjacent to the ocean (Marhoffer Creek and Sand
Mine marshes; fig. 2), the Elk Creek study site is far enough inland to be reasonably inaccessible by storm surges despite its low elevation, negating the need to differentiate far-field tsunami deposits from storm-surge deposits in areas where the inundation zones for each overlap.

A total of 12 cores were described in the field, EC1-EC12 (figs. 31, 36, 37; appendix 1, figs. 1.11-1.14), with additional exploratory cores used to verify observations of the lateral distribution of subsurface units. Cores EC2, EC6, EC8, and EC12 were subsampled for diatoms (appendix 4, fig. 4.6, table 4.7). The RTK data show that the 4 upvalleymost cores (EC6, EC8, EC9, and EC12) ranged in elevation from $\sim 2.05$ to $2.15 \mathrm{~m}$, several decimeters lower than the 8 remaining downvalley cores (figs. 36, 37).

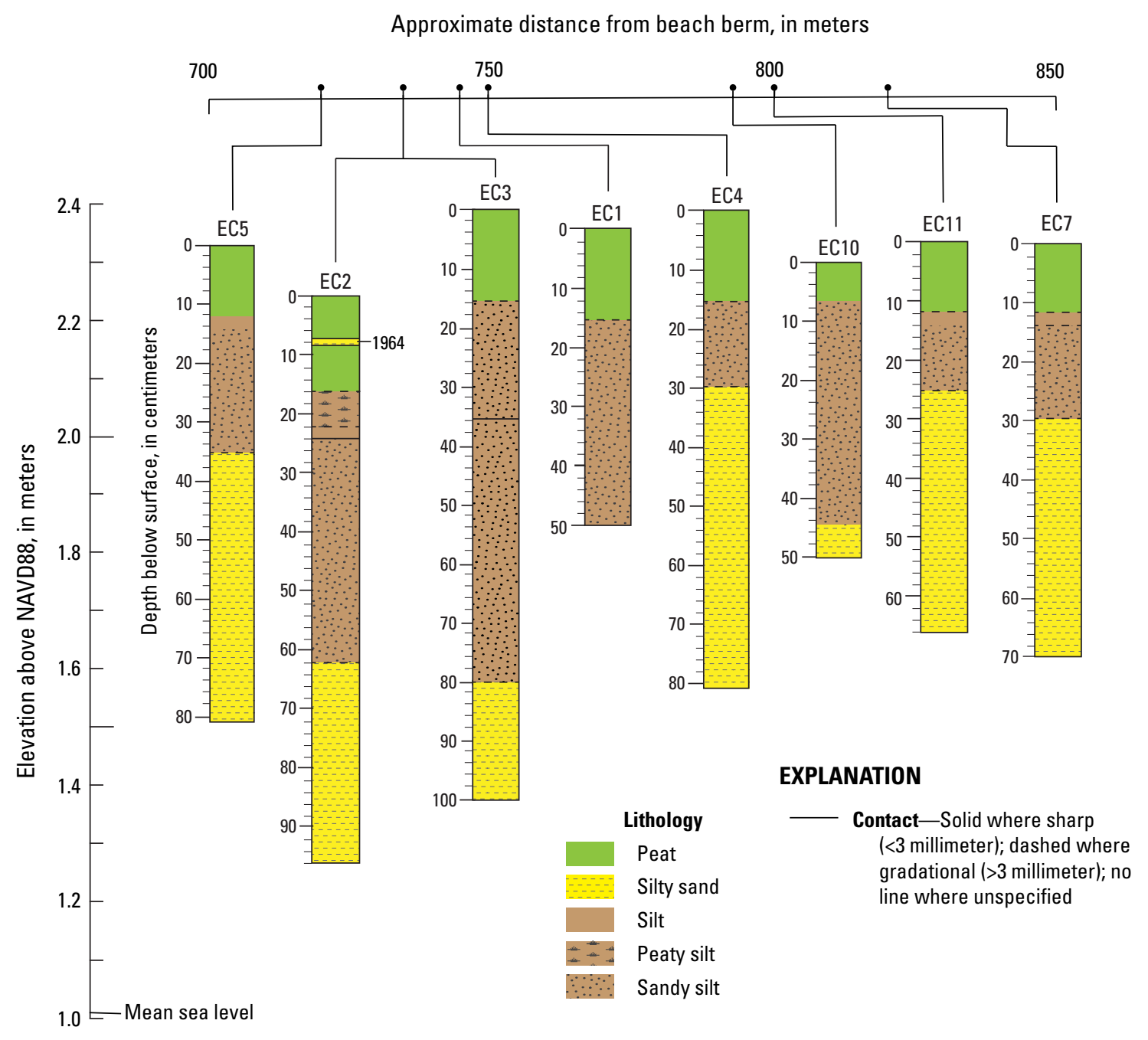

Figure 36. Lithologic logs of cores collected from the lower valley of the Elk Creek wetland. Cores are plotted by distance from the beach berm southwest of the valley mouth. Elevations are relative to the North American Vertical Datum of 1988 (NAVD88). The stratigraphy shows $~ 15$ centimeters of modern peat capping artificial-fill deposits associated with agricultural and industrial operations in the valley beginning in the 1870s. Deeper sandy deposits in some cores may be paleolagoon deposits. Sedimentological evidence for the 1964 tsunami is observed as a thin layer of silt and very fine sand in core EC2, which is located within 10 meters of the Elk Creek channel and is at a slightly lower elevation than the other cores. 


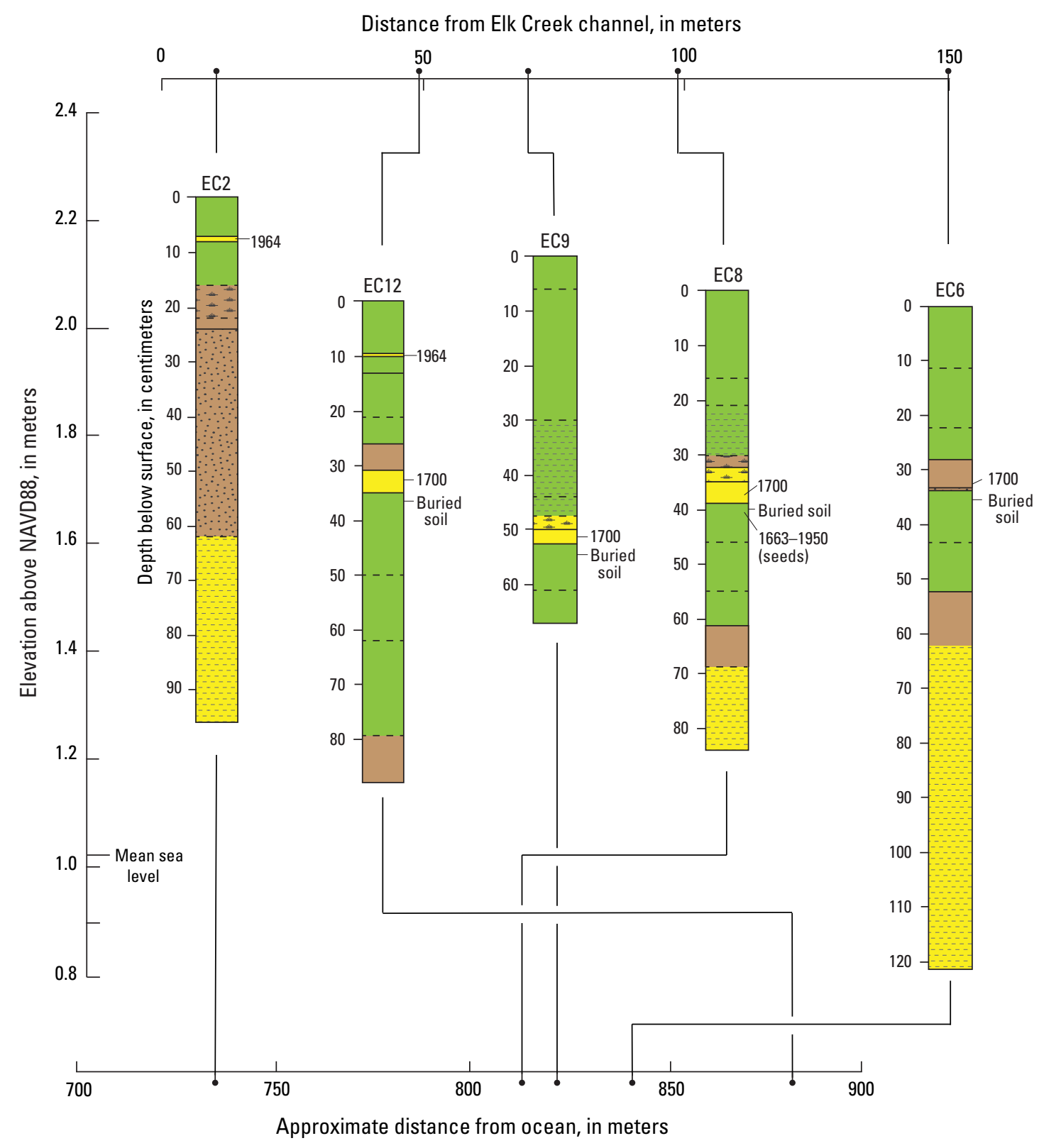

EXPLANATION
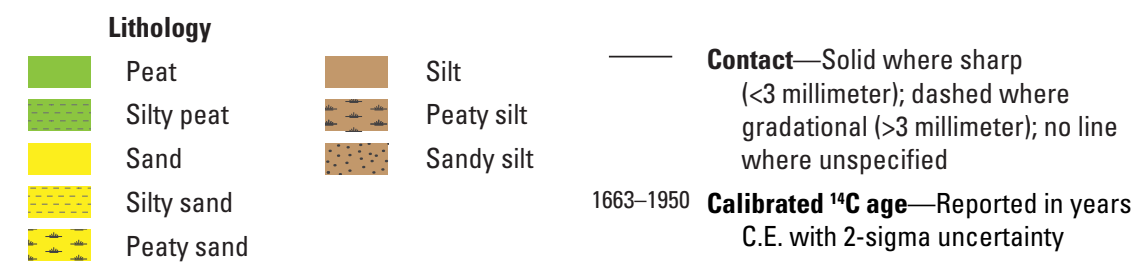

Figure 37. Lithologic logs of cores from Elk Creek wetland that contain sedimentological evidence for the 1964 and (or) 1700 tsunami deposits. The distance of each core from the Elk Creek channel and the ocean are also shown. Elevations are relative to the North American Vertical Datum of 1988 (NAVD88). The 1700 earthquake and tsunami is recorded in several cores as reddish-brown, coarsely rooted peat in sharp upper contact with gray fine sand and (or) silt, which is overlain by mud and (or) muddy fine-grained peat. Sedimentological evidence for the 1964 tsunami is observed in core EC2 as a 1-centimeter-thick layer of silt and very fine sand between 6.5 and 7.5 centimeters $(\mathrm{cm})$ depth and in core EC12 as a $~ 0.5-\mathrm{cm}$-thick discontinuous deposit of very fine sand near $9.5 \mathrm{~cm}$ depth. Cores EC2 and EC12, which include the 1964 deposit, are located close to the Elk Creek channel (about 10 and 50 meters, respectively). Core EC12 is the farthest upvalley core, at 860 meters, but contains the 1964 tsunami deposit and the 1700 deposit because of its proximity to Elk Creek. 


\section{Tsunami Deposit Identification}

\section{Lithology and Stratigraphy}

On the basis of previous work and the historical record of marine incursions into the Crescent City harbor area, we expected to find evidence of at least 2 deposits that record marine incursions: one deposited by the 1964 tsunami and one associated with the 1700 Cascadia Subduction Zone earthquake. In the following lithology descriptions, we refer to specific deposits as the 1964 deposit or the 1700 deposit, recognizing that these identifications need to be substantiated by diatom and stratigraphic data, which are provided in the subsequent sections.

The Elk Creek wetland core data reveal a geographic boundary, shown by the dashed orange line in fig. 31, between subsurface deposits that provide a reasonably undisturbed record of past depositional events in the valley and those deposits that have been strongly impacted by industrial or agricultural practices, presumably since the late $1800 \mathrm{~s}$. The 8 downvalley cores (EC1-EC5, EC7, EC10, and EC11) consistently show $\sim 15 \mathrm{~cm}$ of dark-brown fibrous peat overlying decimeters of gray and oxidized grayishorange sandy silt and silty sand (figs. 36, 38; appendix 1, figs. 1.11-1.14). The same stratigraphy was observed in a reconnaissance core collected in a wet, low-lying marsh $\sim 100 \mathrm{~m}$ downvalley from the study site. We infer that the massive silt and sand deposits are dredge-and-fill deposits emplaced to elevate and drain the lower marshy areas of the valley to support livestock, produce more useable land, and accommodate large log ponds for the timber mills. The silt units grade downward to coarser grained, gray, muddy sand deposits, which were difficult to penetrate with our hand-driven gouge cores. It is possible that some of the deeper, sandier deposits are estuarine or lagoon deposits from pre-settlement times, but most of the material is likely redistributed fill.

The stratigraphy revealed in cores upvalley of the artificial fill (that is, EC6, EC8, EC9, and EC12) consists of darkgray silty sand and brownish-gray mud grading upward to decimeters of reddish-brown or brown fibrous to humified peat (fig. 38; appendix 1, figs. 1.12, 1.13, 1.14). The lower sandy and muddy deposits are consistent with natural estuarine or lagoon deposits, as also observed by Peterson and others (2011). The overlying peaty deposits range from $\sim 50 \mathrm{~cm}$ thick at site EC6 to $\sim 80 \mathrm{~cm}$ thick at the upvalleymost site, EC12. The variability in color and texture of the peat indicates past changes in the dominant types of plants growing in the area.
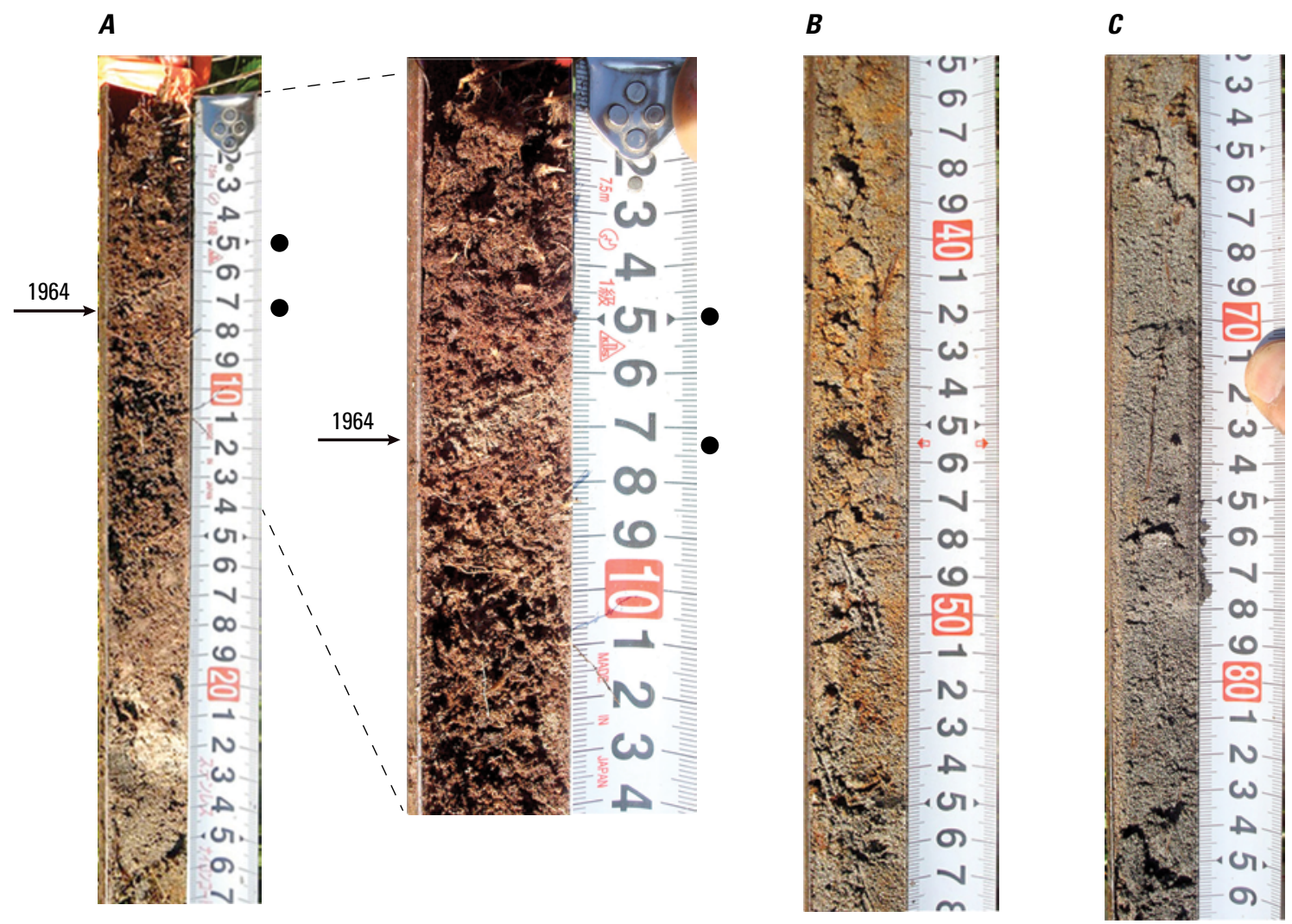

Figure 38. Photographs of core sections from core $\mathrm{EC} 2$ from Elk Creek wetland. $A$, Core section between 0 and 27 centimeters (cm) depth and a close-up view of 0-14 cm depth. Sections show the 1964 tsunami deposit (marked by black arrow), which consists of a 1-cm-thick deposit of brown silt and very fine sand at $7 \mathrm{~cm}$ depth. Black dots show which intervals were sampled for diatoms. $B$, Sandy silt between 35 and $58 \mathrm{~cm}$ depth shows orange mottling from oxidation. Most of this material is probably industrial-fill or dredge-spoil deposits from former logging mill operations in the lower valley. C, Gray, sandy deposits below about $70 \mathrm{~cm}$ depth are either artificial-fill or paleolagoon deposits. 
The 1700 tsunami is evidenced in each of the four upvalley cores at depths of $30-50 \mathrm{~cm}$ by a muddy cap, which suggests post-tsunami submergence by tides. In cores EC8, EC9, and EC12, the 1700 tsunami deposit consists of gray sand capped by mud and detritus. In core EC6, it is composed of a thin $(\sim 2-3 \mathrm{~mm})$ basal layer of sand overlain by $3-4 \mathrm{~cm}$ of grayish-brown sandy silt (figs. 37, 39-41). Differences in peat deposits below and above the inferred sandy-silty tsunami deposits suggest an abrupt change in environment, consistent with coseismic subsidence. Peat underlying the 1700 tsunami deposit in cores EC8, EC9, and EC12 is dark brown with coarse roots (figs. 39, 40). In contrast, the peat above the deposit is fine-grained and muddy, with roots mostly $<2 \mathrm{~mm}$ in diameter. At site EC6, the underlying and overlying peats are not as lithologically different from one another as in other cores (fig. 41). Both are fine-grained and lacking coarse roots, but the overlying (post-earthquake) peat is muddier.
Unlike the stratigraphically distinct deposits of the inferred 1700 tsunami deposit, sedimentological evidence for the 1964 tsunami is sparse and subtle, consisting of thin ( $<1 \mathrm{~cm}$ thick) layers of brown silt with minor amounts of very fine sand found in a limited depositional area. It was only observed in 2 of the 12 Elk Creek wetland cores (EC2 and EC12), both of which are located on the southeast side of the valley close to the Elk Creek channel (figs. 31, 38, 39). The deposits are found in brown fibrous peat at depths shallower than $10 \mathrm{~cm}$, and are more accurately described as dispersed within the peat rather than as distinctly separate deposits. In core EC2, the silt layer is at an angle in the core (fig. 38), possibly an artifact of the coring process or possibly the result of deposition on an uneven marsh surface. In core EC12, the inferred 1964 tsunami deposit is discontinuous (fig. 39), a result of the low sediment volume deposited and preserved in the peaty stratigraphic record. We closely inspected all cores visually for any indication of thin or indistinct non-peat deposits in the upper few
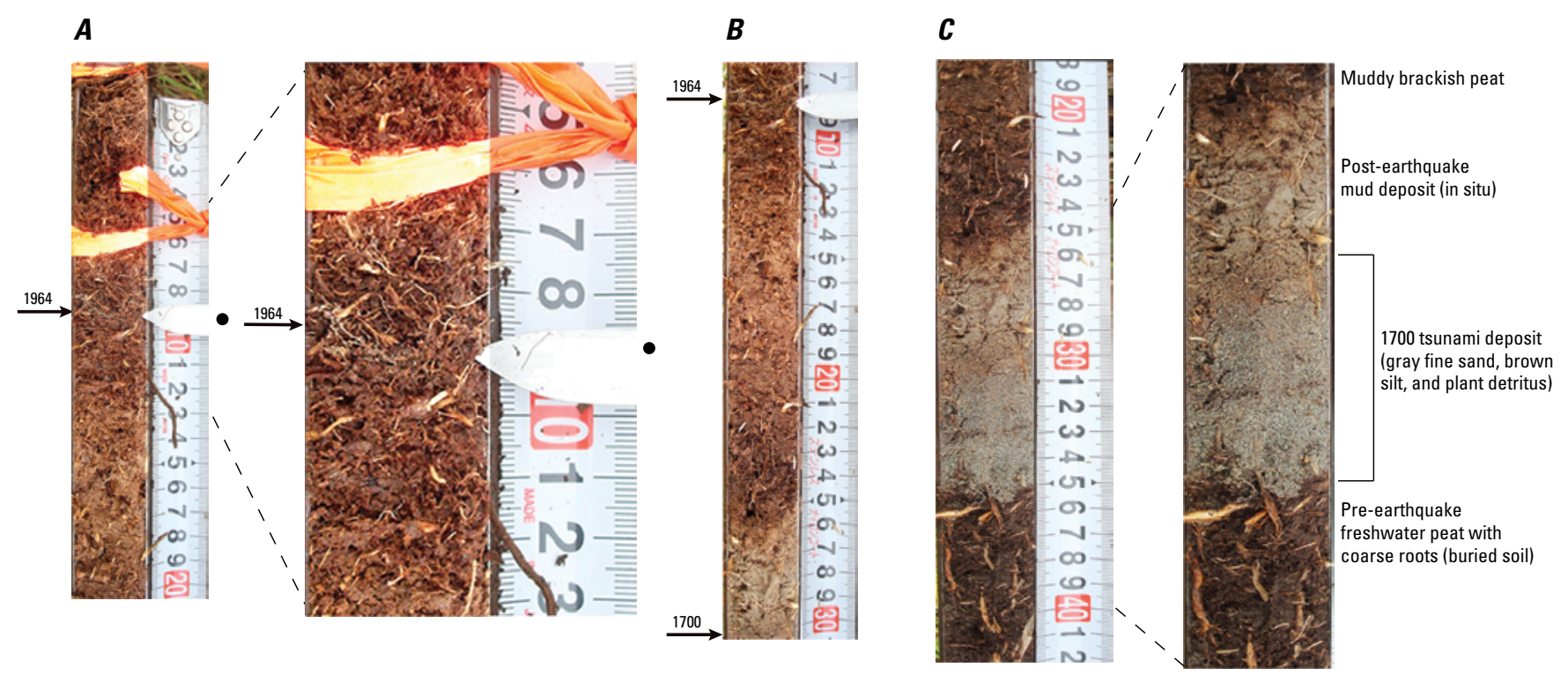

D

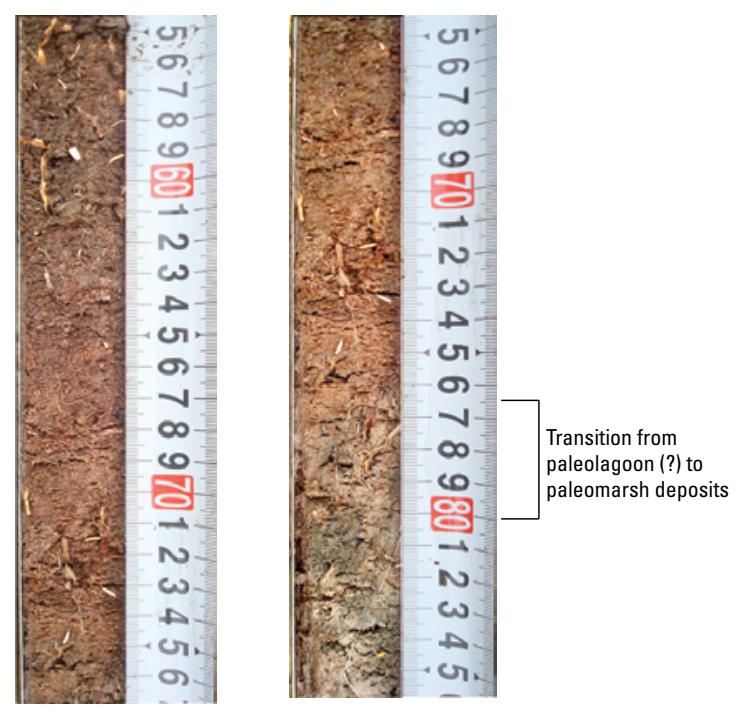

Figure 39. Photographs of core sections from core EC12 from Elk Creek wetland. $A$, Core segment between 0 and 20 centimeters (cm) depth and a close-up view of 4-13 cm depth. The 1964 deposit (marked by the arrow at 8-9 cm depth) at this site consists of a discontinuous layer of very fine sand, likely dispersed by bioturbation. Black dot shows the interval sampled for diatoms. $B$, Core section from 7 to $30 \mathrm{~cm}$ depth shows the stratigraphic thickness of only $\sim 25-30 \mathrm{~cm}$ that separates the 1700 and 1964 tsunami deposits. $C$, Core section between 18 and $42 \mathrm{~cm}$ depth and an annotated close-up view of $24-40 \mathrm{~cm}$ depth. Stratigraphy documents the 1700 earthquake and tsunami. A coarsely rooted freshwater peat below $35 \mathrm{~cm}$ is separated from brown mud and brackish muddy peat above $29 \mathrm{~cm}$ by the tsunami deposit-an anomalous deposit of gray to brown sand, silt, and detritus. $D$, Core section from 55 to $85 \mathrm{~cm}$ depth (split into two photographs). Peaty deposits below the 1700 buried soil and tsunami deposit are uninterrupted until a transition to possible paleolagoon deposits near $70 \mathrm{~cm}$ depth. 
A

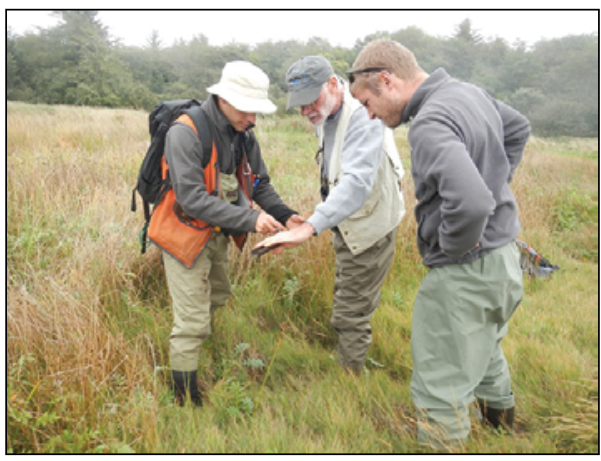

B

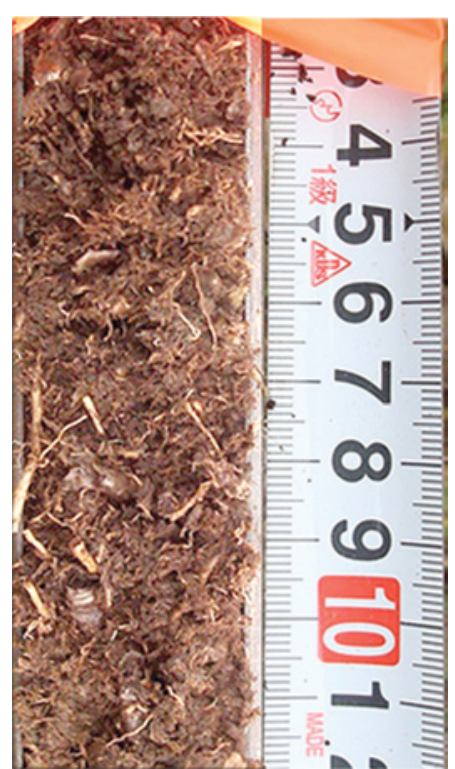

C (27 centimeters)
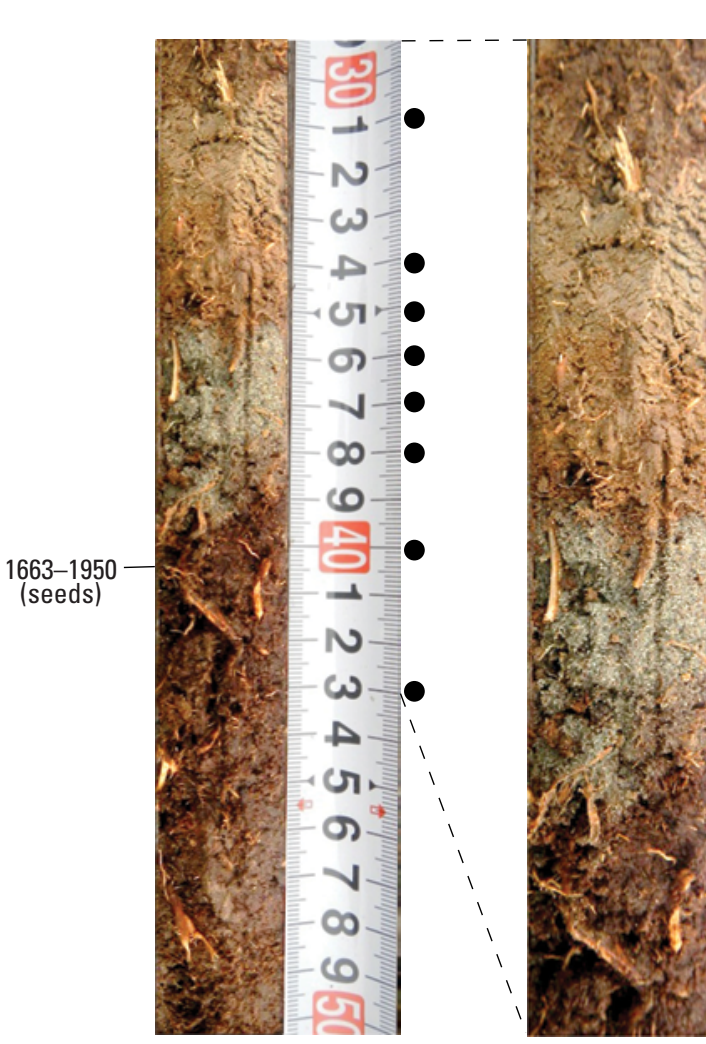

Muddy brackish peat

Post-earthquake mud deposit

(in situ)

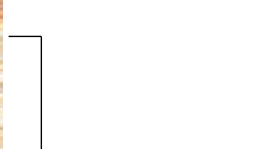

1700 tsunami deposit - (gray fine sand brown silt, and plant detritus)

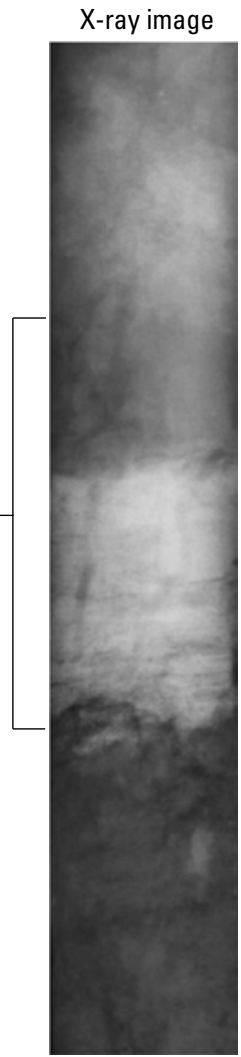

Figure 40. Photographs of core EC8 from Elk Creek wetland. $A$, View of the core site showing surface vegetation dominated by salt grass (Distichlis spicata). Based on reconnaissance coring, we observed that recovering the 1700 buried soil and tsunami deposit was best achieved at sites where Distichlis $\mathrm{sp}$. was the dominant surface vegetation. $B$, Core section between 3 and 12 centimeters $(\mathrm{cm})$ depth. We observed no obvious sedimentological evidence for the 1964 tsunami. $C$, Annotated photographs and X-ray image of $29-50 \mathrm{~cm}$ depth in core. The 1700 buried soil and tsunami deposit are comparable in appearance to site EC12 (see fig. 35). Black dots show the intervals sampled for diatoms. The age shown at $40 \mathrm{~cm}$ is a ${ }^{14} \mathrm{C}$ age reported in calibrated years C.E. with 2-sigma uncertainty. 
decimeters, but hand-lens inspections in the field could find no similar evidence for the 1964 tsunami deposit in any cores other than EC2 and EC12 (figs. 36, 37, 40, 41).

\section{Diatom Analyses}

Variability in diatom assemblages observed in the Elk Creek wetland cores provides evidence for inundation by the 1964 tsunami, as well as tsunami inundation and coseismic subsidence associated with the Cascadia Subduction Zone earthquake in 1700.
The modern, well-drained marsh to meadow environment supports diverse, but low-abundance, populations of aerophilous diatoms - for example, Hantzschia amphioxys, Nitzschia terrestris, and Pinnularia spp. (appendix 4, fig. 4.7). Samples from the intervals that contain the thin 1964 tsunami deposits in cores EC2 and EC12 (figs. 38, 39) dominantly contain oligohalobous diatoms, though anomalous occurrences of brackish and marine taxa provide evidence for marine water incursion (fig. 42; appendix 4, table 4.6). Saline diatoms include the benthic taxa Hyalodiscus laevis, Endictya hendeyi, Tryblionella navicularis,
$\boldsymbol{A}$

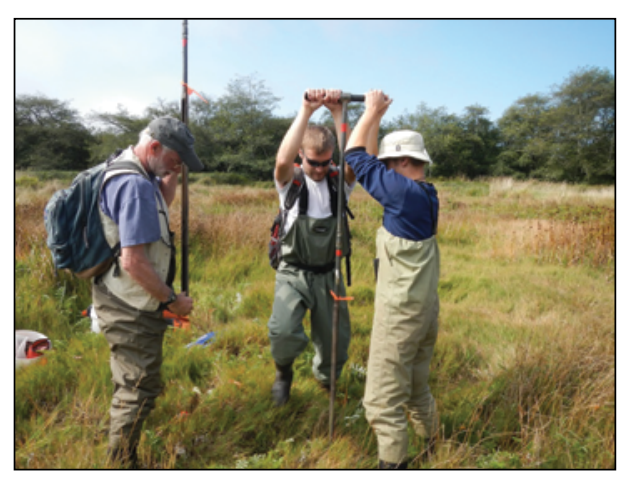

$\boldsymbol{B}$

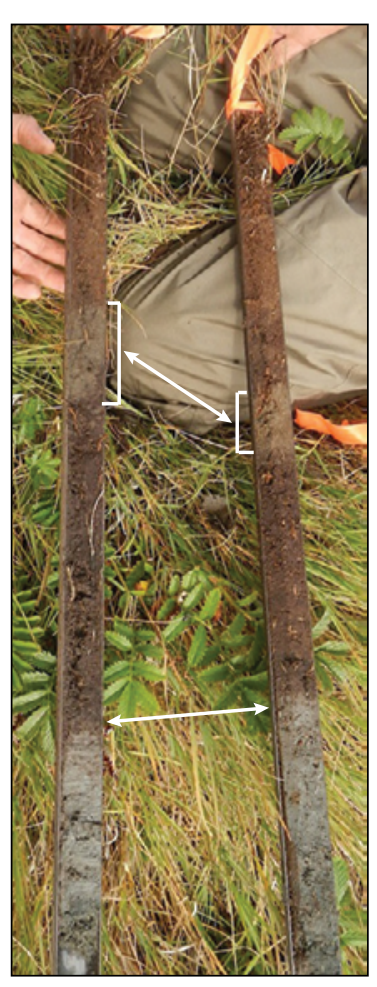

D
$\boldsymbol{C}$

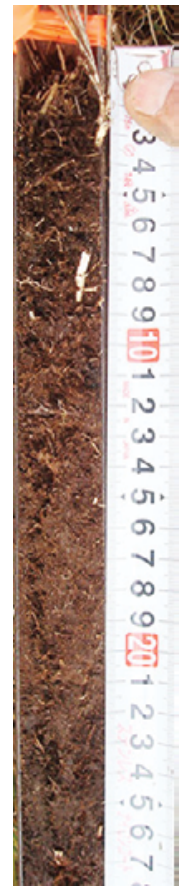

Figure 41. Photographs of core EC6 from Elk Creek wetland. $A$, View of the core site in low-standing surface vegetation dominated by salt grass (Distichlis spicata). $B$, Replicate cores from a few meters apart show similar deposits. The transition from paleolagoon to marsh deposits is marked by the horizontal white arrow and the 1700 tsunami deposit is bracketed and correlated across the two cores. Note the difference in the thickness and depth-below-surface of the 1700 tsunami deposit, likely an artifact of uneven topography on a thickly vegetated paleomarsh surface. $C$, Core section between 0 and $28 \mathrm{centimeters} \mathrm{(cm)} \mathrm{depth.} \mathrm{There}$ is no obvious evidence for a 1964 tsunami deposit. $D$, Core section between 13 and $44 \mathrm{~cm}$ depth and an annotated close-up view of 19-38 cm depth. The 1700 tsunami deposit consists of about $5 \mathrm{~cm}$ of brown sandy silt and lacks the distinctive gray fine sand observed in cores EC8, EC9, and EC12. Black dots show the intervals sampled for diatoms. 
A
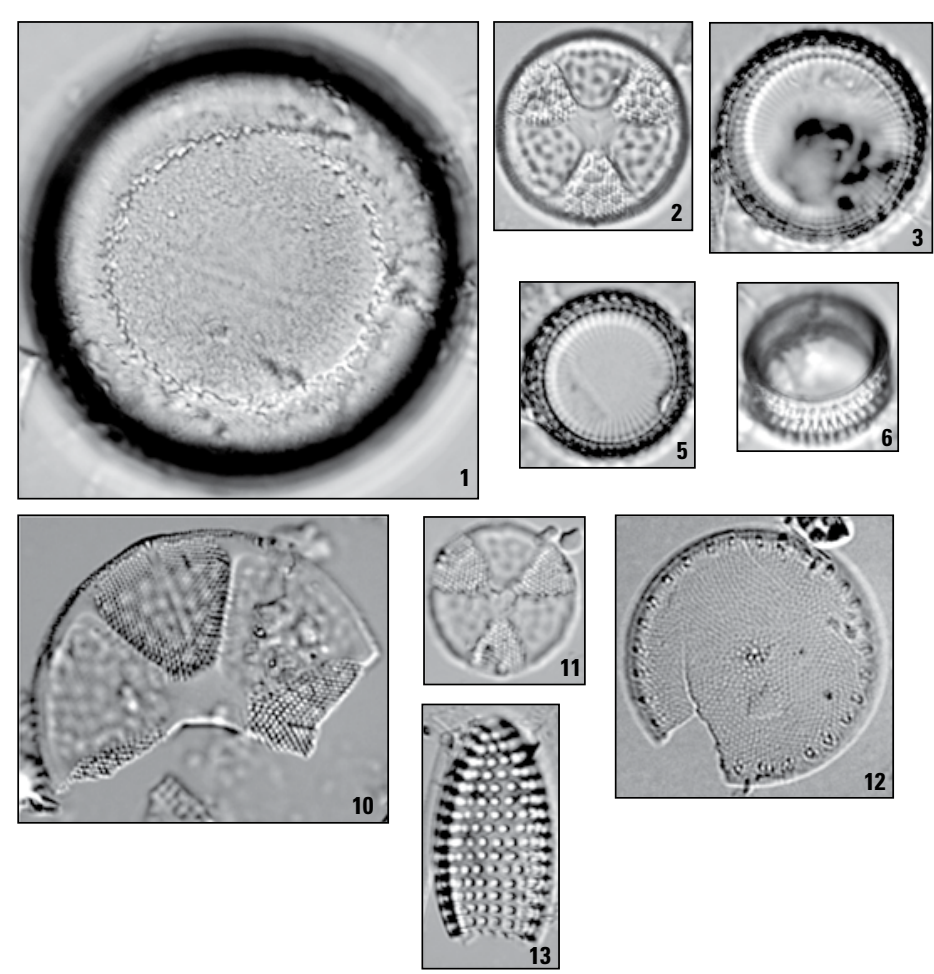

B
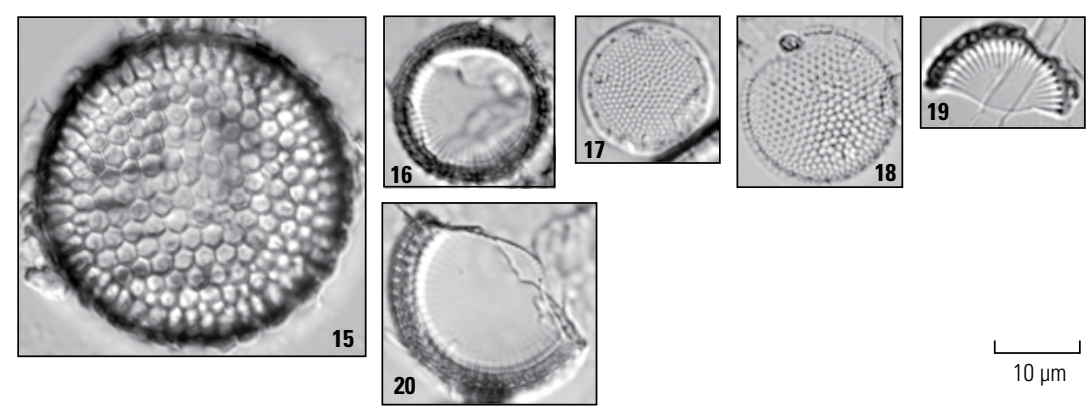

and Tryblionella granulata, as well as ubiquitous coastal taxa such as Actinoptychus senarius and Paralia sulcata. As a group, these taxa are consistent with a down-estuary or nearshore source for the deposit. ${ }^{7}$ Comparing the 1964 tsunami samples from Elk Creek wetland to the collection of tsunami and storm samples from Marhoffer Creek marsh, Q-mode cluster analysis shows comparable compositions in the low-abundance assemblages in each of the 1964 tsunami deposit samples, but also that these assemblages are indistinguishable from those recovered from storm deposits (fig. 43).

Diatoms across the stratigraphic interval that includes the 1700 tsunami deposit in core EC8 (fig. 39; appendix 4, table 4.6), show evidence for coseismic subsidence as well as deposition of marine sediment. Diatoms in dark-brown peat

\footnotetext{
${ }^{7}$ It is evident from the tsunami-damaged area that the tsunami surged across the beach and overland before entering the lower valley; it is not clear if flow continued across the valley floor or followed the low-elevation channels along the valley margins. The sparse diatoms in the 1964 deposit are not inconsistent with taxa found in the nearshore, but would also be consistent with reworked valves from the lower tidal reach of the Elk Creek channel.
}
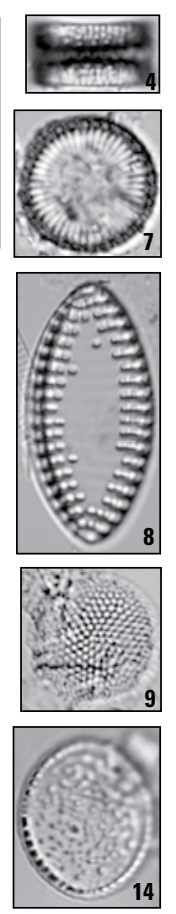

Figure 42 (left). Photomicrographs of allochthonous brackish-marine diatoms from the 1964 tsunami deposit in core EC2 $(A$, images 1-14) and core $\mathrm{EC12}(B$, images 15-20) from Elk Creek wetland. These taxa are consistent with having been derived from a low estuary or coastal environment and dissimilar to the oligohalobous diatoms found in the peaty soil encasing the deposits. 1, Hyalodiscus laevis; 2, Actinoptychus senarius, 3-7, Paralia sulcata; 8, Tryblionella navicularis, 9, Thalassiosira sp.; 10-11, Actinoptychus senarius, 12, Thalassiosira cf. nordenskioeldii; 13, Tryblionella granulata; 14, Chaetoceros sp. resting spore; 15, Endictya hendeyi, 16, Paralia sulcata; 17-18, Thalassiosira spp.; 19-20, Paralia sulcata. $\mu \mathrm{m}$, micrometers.

Figure 43 (below). Graph showing Bray-Curtis dissimilarity (results of Q-mode cluster analysis) for diatom assemblages in the 1964 and 1700 tsunami samples from Elk Creek wetland combined with assemblages in the tsunami and storm samples from Marhoffer Creek marsh. Diatom sample labels identify the core name (EC for Elk Creek wetland; MM for Marhoffer Creek marsh) and depth of sampling (in centimeters, $\mathrm{cm}$ ). The age of the deposit (in either C.E. or calibrated years before present [cal. yr B.P.]) is also given, if known. Red labels indicate near-field tsunami deposits, blue labels indicate far-field tsunami deposits, and black labels indicate storm deposits. The agglomerative coefficient is 0.64 .

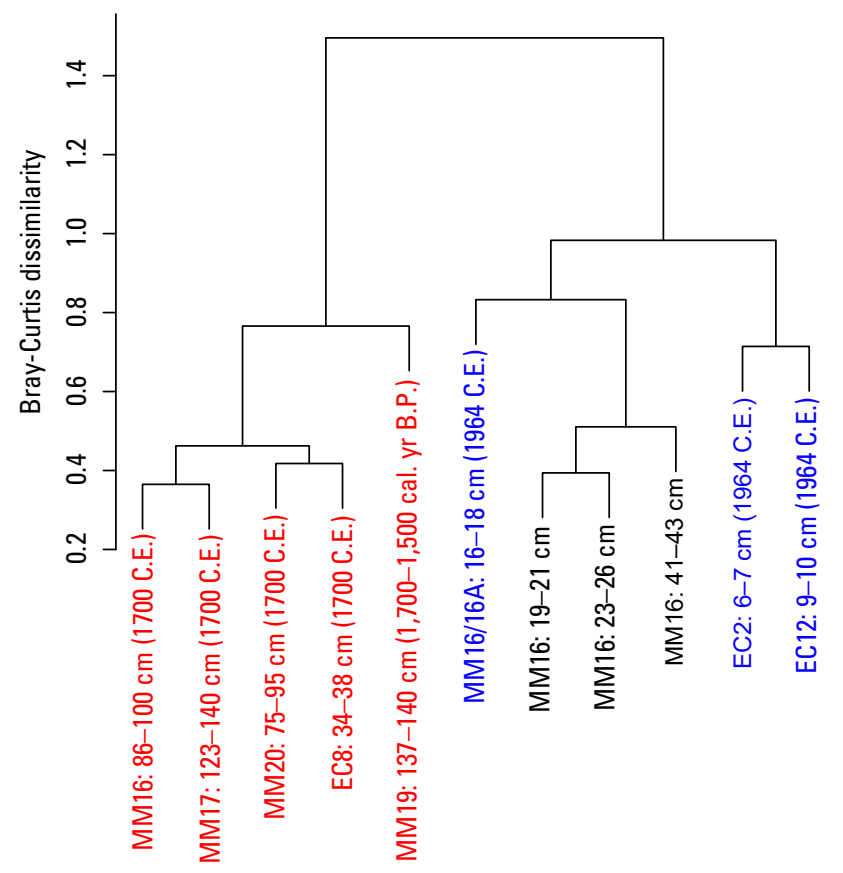


below the tsunami deposit consist of taxa indicative of a fresh or fresh-brackish marsh (for example, large Pinnularia spp.; fig. 44; appendix 4, table 4.6). In contrast, diatoms in deposits overlying the tsunami deposit-light-brown mud grading upward to light-brown muddy peat—include taxa largely found in saline mudflats and salt marshes. For example, benthic taxa in mud at $31 \mathrm{~cm}$ depth in core EC8 show that the first environment following subsidence was muddy and unvegetated, evidenced by abundant and well-preserved valves of Navicula digitoradiata, Nitzschia sigma (fig. 44E), Mastogloia elliptica, Achnanthes intermedia, and Actinoptychus senarius, as well as well-preserved planktonic taxa including Actinocyclus curvatulus, Thalassiosira spp., and Pseudoeunotia doliolus (appendix 4, table 4.6). The build-up to salt-marsh peat is shown by continued occurrences of diatoms consistent with that environment, such as Navicula peregrinopsis, Diploneis interrupta, and Cosmioneis pusilla, among others (fig. $44 F$ ). Marine diatoms are diverse in the gray silt and sand, and most abundant at the upper, fine-grained part of the sandy deposit at $35 \mathrm{~cm}$ depth in core EC8 (fig. 45; appendix 4, table 4.6). Prominent taxa include Rhaphoneis psammicola, Rhaphoneis amphiceros, Endictya hendeyi, Thalassionema spp., Thalassiosira spp., large valves of Paralia sulcata, Chaetoceros spp. resting spores, and silicoflagellate skeletons. The assemblage found in the 1700 tsunami deposit at Elk Creek wetland is comparable to those found in samples from the 1700 deposit at Marhoffer Creek marsh. In a Q-mode cluster analysis, the 1700 assemblage from Elk Creek wetland shares a cluster with the 1700 samples from Marhoffer Creek marsh, showing the closest affinity to the assemblage in core MM20 from Marhoffer Creek marsh (fig. 43).

Diatom assemblages in core EC6 suggest that the 1700 tsunami initiated a lasting change from a fresh or fresh-brackish marsh to a salt marsh in the northwestern part of Elk Creek wetland (appendix 4, table 4.6). The buried soil, a brown peat at $35 \mathrm{~cm}$ depth, contains oligohalobous taxa including Pinnularia elegans, Navicula aff. rhyncocephala var. elongata, Surirella amphioxys, and Rhopalodia brebissonii. The occurrence of species with brackish affinities in both the pre- and post-earthquake marsh soils suggests that a saline environment persisted in the northwest part of the field area (near core EC6), a result of the close proximity to the natural pre-development Elk Creek estuary. Diatoms in the tsunami deposit - brown sandy silt capping the soil - consist of abundant brackish intertidal or lagoon taxa, including Navicula digitoradiata, Melosira nummuloides, and mostly fragmented species with elongated valves, such as Gyrosigma and Nitzschia spp. There are also rare occurrences of possibly allochthonous taxa including Petroneis granulata, Odontella aurita, Thalassiosira eccentrica, and the test of a juvenile planktonic foraminifer. All of these taxa, however, do not preclude redeposition of estuarine or lagoon sediment. The tsunami assemblage in core EC6, for example, does not include distinctly anomalous saline diatoms mixed with local oligohalobous taxa, as observed in the gray sandy tsunami deposit in core EC8 (figs. 44, 45), or in the 1700 deposit intercalated in freshwater peat deposits at Marhoffer Creek marsh.
Diatoms above the tsunami deposit in muddy brownish-gray peat at $24 \mathrm{~cm}$ depth in core EC6, include abundant and wellpreserved taxa consistent with a regularly flooded low salt marsh, including Navicula digitoradiata, Caloneis westii, Scoliopleura tumida and abundant individual valves and intact frustules of the epiphytic taxa Melosira nummuloides. These taxa are prominent components of low salt marshes bordering northern Humboldt Bay (Engelhart and others, 2016).

\section{Discussion}

\section{Far-Field Tsunamis}

Like tsunamis of nearby origin, far-field tsunamis from before the mid-19th century would have had unfettered access to the lower Elk Creek valley (fig. 33). The 1964 tsunami flooded a landscape that was much altered from its natural state-including an artificially built-out shoreline that created a 200-m-wide buffer between the ocean and the mouth of the valley. It is reasonable to expect that other far-field tsunamis of comparable magnitude to the 1964 event would have had the potential to leave a recognizable deposit in the stratigraphic record even though, like the 1964 deposit, inundation would have occurred in the absence of coseismic subsidence and rapid burial to help preserve the deposit.

The Elk Creek wetland provides surprisingly little evidence of the 1964 tsunami. Although the tsunami is reported to have inundated nearly $1.5 \mathrm{~km}$ inland here (Magoon, 1966; fig. 33C), only 2 of 12 cores from the inundation area (EC2 and EC12; figs. 31, 38, 39) display very fine sand and silt that both contain marine diatoms and probably date to the mid-20th century.

The inundation distance for the 1964 tsunami in Elk Creek valley was later reevaluated by Dengler and Magoon (2005, 2006 ), who proposed overland flow extended inland $\sim 800 \mathrm{~m}$ into the lower valley based on reviews of aerial photographs and eyewitness accounts (fig. 33C). Our field data concur with this observation. A historical aerial photograph (fig. 35) from 1964 shows the damage sustained by a commercial and industrial area between the Elk Creek channel at the mouth of the valley and the harbor. The photograph shows debris along the lower stream channel just beyond the damaged industrial area, approximately $500 \mathrm{~m}$ inland from the beach berm. There is no distinguishable debris any closer than about 200-300 m from our core locations, nor is there any debris visible in the central part of the lower valley, which was open pastureland in 1964 . The central part of the valley has such low elevations that it is hard to believe it was not flooded to some extent, but the post-tsunami surveys do not seem to support it.

Based on numerous eyewitness accounts, inflow velocities of the 1964 tsunami were fairly slow. This is consistent with our observations that the 1964 tsunami deposit is very fine grained and only present proximal to the stream channel, as compared to the near-field 1700 Cascadia Subduction Zone tsunami deposit that is coarse grained and broadly distributed across the valley. Based on 

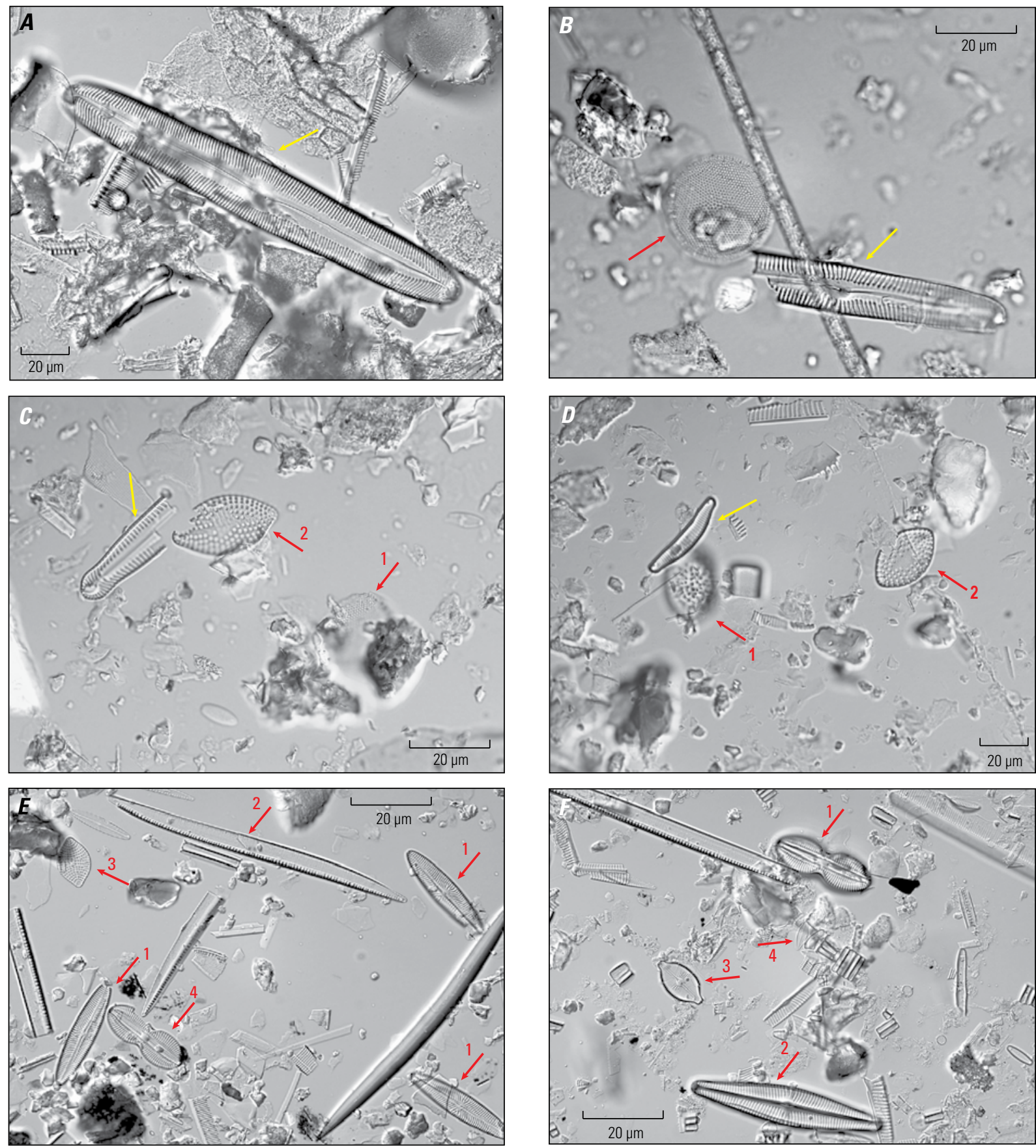

Figure 44. Photomicrographs showing changes in diatom assemblages across the stratigraphic interval spanning the 1700 earthquake and tsunami deposit in core EC8 from Elk Creek wetland. $A$, At 40 centimeters $(\mathrm{cm})$ depth, diatoms in pre-earthquake peat (buried soil) indicate a fresh or fresh-brackish wetland (for example, Pinnularia major, marked by the yellow arrow). $B$, At $37 \mathrm{~cm}$ depth in a tsunami deposit of gray fine sand, diatom assemblages include reworked oligohalobous taxa such as Pinnularia sp. (yellow arrow) and allochthonous marine taxa such as Thalassiosira cf. pacifica (red arrow). C, At $35 \mathrm{~cm}$ depth, also in the gray fine sand tsunami deposit, diatoms include reworked oligohalobous taxa (for example, Pinnularia sp., yellow arrow) and allochthonous marine taxa, shown by the red arrows: (1) Thalassiosira sp. and (2) Rhaphoneis psammicola. D, At the same interval as in $C$, reworked oligohalobous taxa include Eunotia minor (yellow arrow) and allochthonous marine taxa (red arrows) include (1) Chaetoceros sp. resting spore and (2) Rhaphoneis psammicola. E, At $31 \mathrm{~cm}$ depth in post-earthquake and post-subsidence mud, oligohalobous diatom assemblages have been replaced by taxa commonly found in brackish-marine intertidal or lagoon environments (shown by the red arrows): (1) several valves of Navicula digitoradiata, (2) Nitzschia sigma, (3) Rhaphoneis amphiceros, and (4) Diploneis interrupta. The majority of the diatom valves are very well preserved, suggesting in situ accumulation in the new environment rather than transport and redeposition. $F$, At $27 \mathrm{~cm}$ depth in post-earthquake and post-subsidence peat, diatom assemblages are dominated by taxa consistent with a brackish marsh environment (shown by the red arrows): (1) Diploneis interrupta, (2) Navicula peregrinopsis, (3) Cosmioneis pusilla, and (4) Planothidium spp. $\mu \mathrm{m}$, micrometers. 

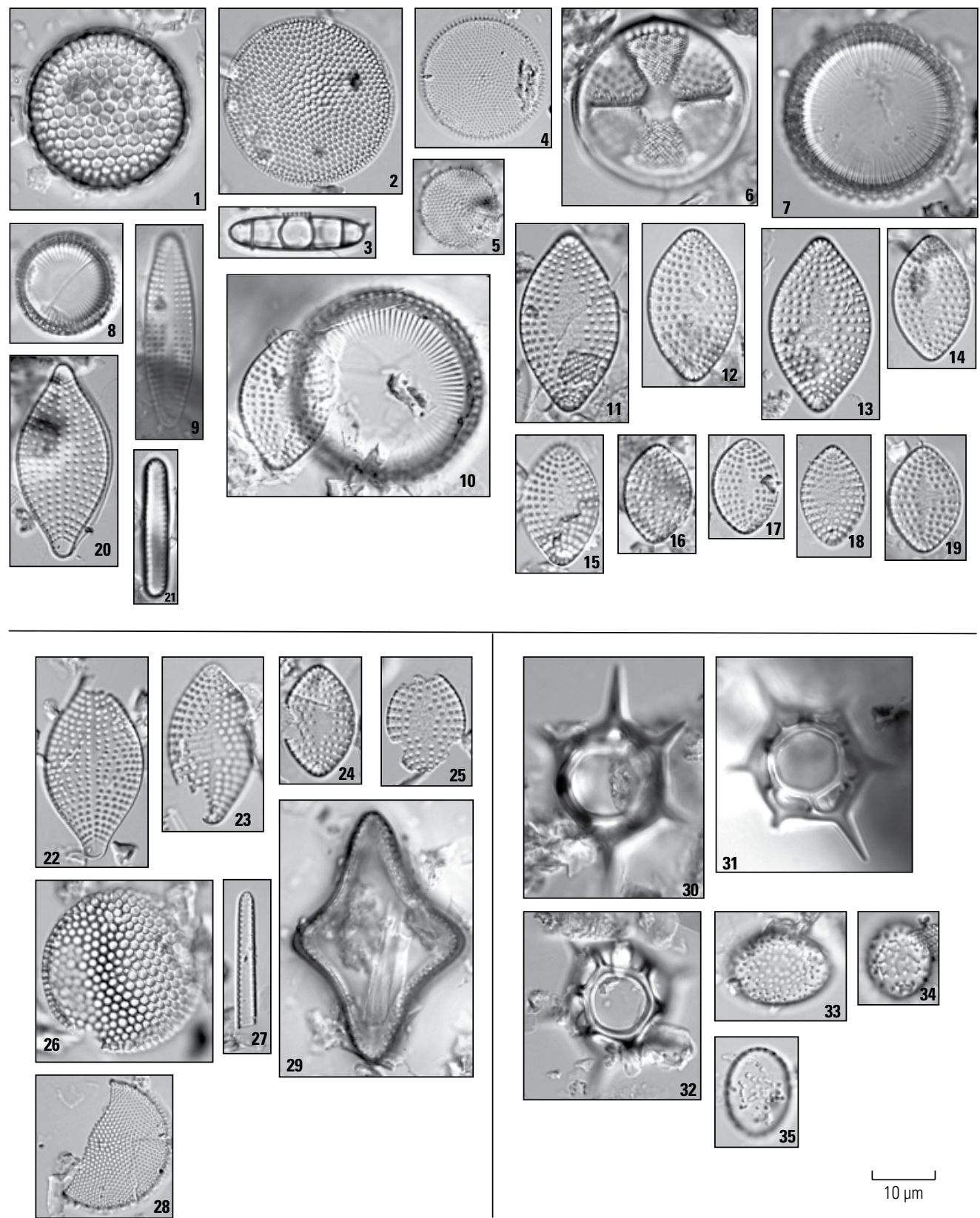
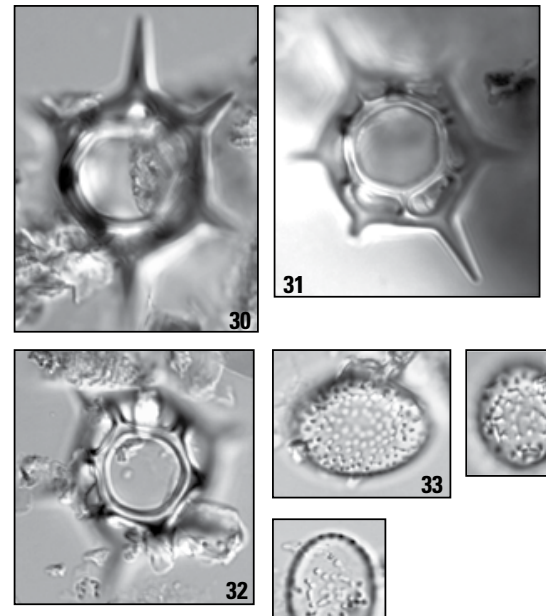

.

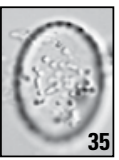

Figure 45. Photomicrographs of allochthonous marine diatoms from the 1700 tsunami deposit in core EC8 from Elk Creek wetland. Well-preserved valves are shown in images 1-21 (top), poorly preserved valves are shown in images 22-29 (bttom left), and silicoflagellates and Chaetoceros spp. resting spores are shown in images 30-35 (bottom right). 1, Endictya hendeyi, 2, Thalassiosira cf. eccentrica; 3, Grammatophora oceanica; 4-5, Thalassiosira cf. pacifica; 6, Actinoptychus senarius; 7-8, Paralia sulcata; 9, Delphineis karstenii; 10 , Rhaphoneis psammicola adjacent to a large Paralia sulcata; 11-19, Rhaphoneis psammicola; 20, Rhaphoneis amphiceros; 21, Thalassionema nitzschioides s.l.; 22, Rhaphoneis amphiceros; 23-25, Rhaphoneis psammicola; 26, Stephanopyxis sp.; 27, Thalassionema nitzschioides; 28, Thalassiosira cf. pacifica; 29, Biddulphia reticulata var. rhombica; 30-32, silic oflagellates Distephanus speculum; 33-35, Chaetoceros spp. resting spores. $\mu \mathrm{m}$, micrometers. numerous interviews, Dengler and Magoon (2006, p. 1) reported, "Eyewitnesses described a relatively gentle inflow with water elevation increasing at the rate of about 0.3 meters/minute reaching a peak of about 3 meters above the land surface followed by stronger outflow that scoured rills into the margins of the harbor."

In contrast to the gentle inflow velocities, outflow velocities were swift; most of the structural damage in the city was attributed to the force of the outflow rather than inflow flooding (Dengler and Magoon, 2005, 2006). Outflow from the lower Elk Creek valley significantly contributed to damage and loss of life. At one point, an area of several city blocks experienced flooding from two directions simultaneouslyinflow from the sea and outflow from the valley (Tudor, 1964). Gullies eroded across the beach berms to the south of the valley are distinct in a comparison of aerial photographs taken before and after the event (Dengler and Magoon, 2005, 2006) (fig. 34). High-velocity outflow along the lower Elk Creek channel contributed to the loss of five lives when the force of the flow capsized a small boat and pinned the passengers against a drainage grate piled with debris (Griffin, 1984). ${ }^{8}$

\footnotetext{
8“'Gary Clawson's Story" (Griffin, 1984, p. 79) provides the tragic account of the attempt by seven citizens to escape the flooding on the south side of Crescent City using a small boat. They set out in a slack period between waves, only to be caught once underway by the high-velocity outflow. The currents were so strong that they were unable to steer their small boat away from the lower Elk Creek channel, and were swept under the highway bridge and trapped against a storm grate already blocked by large woody debris. Mr. Clawson's account ends with the curious statement: "Scientific equipment of the Coast Guard recorded that the water had receded at 350 miles per hour." Although misconstrued, that is probably what it felt like to the citizens fighting for their lives against the current that night.
} 
Our observations on the 1964 tsunami deposit in Elk Creek valley differ from Peterson and others (2011, figs. 6, 9). For example, in core KC1, Peterson and others (2011) attribute the 1964 tsunami deposit to a "tsunami sand layer" that is several centimeters thick, a few decimeters below the modern surface, and intercalated in peaty deposits that extend to $\sim 0.5 \mathrm{~m}$ below the surface. Because core $\mathrm{KC} 1$ was collected in our same field area (fig. 31), we suggest that their proposed 1964 deposit is actually the 1700 tsunami deposit. The only thick and sandy deposits we observed in the field were also associated with evidence for coseismic subsidence, which is not obvious from lithological differences in peat at all locations, but is verified by diatom analyses.

Based on these initial analyses, we did not find evidence for other far-field tsunami deposits in our cores. For example, core EC12 would have provided the appropriate stratigraphic interval between 1700 and 1964, in which a possible 1788 tsunami deposit could have been found. However, comparable to the record at Marhoffer Creek marsh, there is no evidence for an anomalous deposit in this interval.

\section{Near-Field Tsunamis}

The 1700 Cascadia Subduction Zone tsunami deposit in the Elk Creek wetland study site consists of a stratigraphically distinct accumulation of sand, silt, and detritus at depths of about $30-50 \mathrm{~cm}$ below the modern marsh or meadow surface. The shallow depth below the surface for the 1700 tsunami deposit in the Elk Creek wetland study site (fig. 33) is in contrast to the $\sim 1 \mathrm{~m}$ or more depth to the same deposit at Marhoffer Creek marsh (for example, fig. 8). The difference is likely the result of peat accumulation in a persistently wet freshwater marsh at Marhoffer Creek marsh compared to a drier, better drained surface - and possibly desiccated subsurface - at Elk Creek wetland resulting from modern land-use practices. Compared to sedimentation (peat accumulation) rates of $\sim 0.3 \mathrm{~cm} / \mathrm{yr}$ at Marhoffer Creek marsh, post-1964 rates at Elk Creek wetland are lower, estimated at $0.14-0.18 \mathrm{~cm} / \mathrm{yr}$ using the 1964 deposit as a chronostratigraphic marker at depths of 7 and $9 \mathrm{~cm}$ in cores $\mathrm{EC} 2$ and EC12, respectively. Based on those sedimentation rates, the total thickness of the peat-capping fill deposits in cores from the southern part of the field area-about $15 \mathrm{~cm}$ (fig. 36) equates to about 100 years of peat accumulation (or revegetation since the early part of the 20th century), consistent with historical dredge-and-fill activities underway in the lower valley. How these peat-accumulation rates compare to the time period before and after the 1700 earthquake will require more analysis because the diatom data show that the well-drained, grassy environment present since at least 1964, with its populations of characteristic aerophilous taxa, is unlike the wet, fresh- to salt-marsh environment that existed before and after the 1700 earthquake.

Diatoms in the 1700 tsunami deposit at Elk Creek wetland (fig. 45) include a number of taxa in common with those found in the 1700 tsunami deposit at Marhoffer Creek marsh - particularly Rhaphoneis psammicola (for example, figs. 24-26). The similarity in assemblages is illustrated statistically by the results of a Q-mode cluster analysis, in which the 1700 tsunami deposit from Elk Creek wetland clusters closely with those from Marhoffer Creek marsh, particularly for core MM20 (fig. 43).

In addition, our observations suggest that the pre- 1700 marsh environment varied from more saline on the northwestern side of the valley to less saline on the southeastern margin. This suggests a natural (pre-settlement) Elk Creek estuary or lagoon was present on the western side of the valley, as supported by the 1859 and 1916 maps (fig. 31). Based on diatom analyses from core $\mathrm{EC} 12$, the pre-1700 marsh on the eastern margin was wet but fairly fresh, hosting oligohalobous diatoms indicative of fresh to slightly brackish marshes (appendix 4, table 4.7). There are similarities, for example, in taxa observed in the pre-1700 soil in core EC12 with modern taxa from a sedge- and willow-dominated area of Marhoffer Creek marsh (particularly Marhoffer Creek marsh surface sample MD9; appendix 4, fig. 4.6, table 4.1). In contrast, diatoms in the post-1700 muddy peat in core EC12 are indicative of a salt marsh environment. Such a distinct change in environment is not evident in core EC6, as both the pre- and post-1700 peats contain diatoms indicative of saline environments. Coseismic subsidence is supported by the presence of diatoms that indicate an elevated marsh environment in the pre-earthquake soil and diatoms that show a change to a lower, muddier intertidal environment in peat deposited after the earthquake.

An additional characteristic of the 1700 tsunami deposit in the Elk Creek wetland study site is how distinct and well preserved it appears in the subsurface, with little evidence for bioturbation (for example, figs. 39-41). The fine-grained brown mud capping the sandy gray deposits is noteworthy. The diatom data suggest that, in conjunction with emplacement of the sandy tsunami deposit, coseismic subsidence allowed mud to accumulate in a low-energy environment, negating the need to interpret the mud as a late-stage depositional unit of the tsunami deposit. The dense, fine-grained mud is similar to muddy intertidal deposits that cap and help to preserve the 1700 tsunami deposit at other locations in the Pacific Northwest (for example, Atwater and Hemphill-Haley, 1997, p. 47).

\section{Update to Conclusions from Previous Studies}

Additional observations and analyses completed after publication of Wilson and others (2014) result in the following updates to our preliminary conclusions for the Elk Creek wetland study site.

In Wilson and others (2014, p. 81), we described the boundary between undisturbed upvalley subsurface deposits and the dredge-and-fill downvalley deposits as the downvalley extent of fringing marshes at the time of the 1700 tsunami. We now conclude that this is an artificial boundary created by dredging and filling, and that before and after the 1700 event, fringing marshes would likely have reached farther downvalley than is evident in the altered subsurface stratigraphic record. Comparatively, we also revise the interpretation of the silty deposits underlying the modern soil in core EC2, which is labeled as "pre-1900s tidal embayment deposits" in figure 60 of Wilson and others (2014). We now interpret most or all of the inorganic deposits underlying the thin 
layer of modern peat as artificial fill emplaced to reclaim the lower valley for agricultural use.

In Wilson and others (2014, p. 89), we reported that stratigraphic evidence for the 1964 tsunami was not found farther upvalley than the core EC2 location (fig. 31). New observations from core EC12 suggest the 1964 tsunami reached $150 \mathrm{~m}$ inland from core EC2 (figs. 31, 37). Our core data suggest that the 1964 deposit is found at least $850-900 \mathrm{~m}$ inland from the beach berm and is confined to low-elevation sites proximal to the Elk Creek channel.

\section{Sand Mine Marsh-Crescent City Study Site III}

\section{Summary of Findings}

The Sand Mine marsh study site is a freshwater marsh, willow swamp, and residual lagoon located landward of Crescent Beach, $2.5 \mathrm{~km}$ south of downtown Crescent City. In an effort to evaluate the distribution and characteristics of far-field tsunami deposits, we focused most of our efforts in the westernmost marsh area, a back-berm marsh and cattail pond on the west side of Highway 101, where we collected 16 cores. Three cores were also described from the willow swamp on the east side of Highway 101, within 50-170 m of the beach. The subsurface stratigraphy in the western field site is heterogeneous, with layers of fine to medium sand of varying thicknesses, and intervals of peat and detrital peat that are difficult or impossible to correlate even over short distances. Two thin clastic deposits present in the upper $25 \mathrm{~cm}$ of most cores, however, show a consistent distribution across the western field site. The first is a fine sand deposit, typically a few centimeters thick, that was deposited by the March 1964 far-field tsunami. Underlying the 1964 tsunami deposit is a thin, distinctive, grayish-brown clay layer that is probably indicative of land-use changes near the marsh in the 1940-50s. In a core from the south end of the study site, a layer of fine sand containing marine diatoms between the 1964 tsunami deposit and the brown clay layer is interpreted as having been emplaced by the May 1960 far-field tsunami. Based on stratigraphic correlation, as well as grain-size, microfossil, ${ }^{137} \mathrm{Cs}$, and ${ }^{14} \mathrm{C}$ analyses, we conclude that most of the subsurface sandy deposits in cores from the western field site are the result of storm deposition or berm migration. The 1700 Cascadia Subduction Zone tsunami deposit is evident near $85-100 \mathrm{~cm}$ depth in one core, and is probably present at slightly shallower depths in two of the three cores collected from the eastern field site. The cores in the eastern field site may also include sandy storm deposits, including a core that is $>150 \mathrm{~m}$ from the beach.

\section{Overview}

\section{Study Site Description}

The informally named "Sand Mine marsh" is a back-berm wetland on the south side of Crescent City adjacent to Crescent Beach (figs. 2, 46, 47). The marsh is part of the Crescent City Marshes Wildlife Area, owned and managed by the California Department of Fish and Wildlife, and consists of a range of freshwater environments including cattail marshes, willow swamps, a remnant lagoon, and other ponded areas that are typically 1-2 m deep during most of the year. The Sand Mine marsh moniker, derived from the marsh's location near the intersection of Sand Mine Road and Highway 101 (fig. 48), was assigned in the 1990 s by Dr. Gary Carver, who was the first to recognize tsunami deposits at this location.

The Sand Mine marsh has existed as a freshwater wetland and lagoon since at least the early 1900s, based on diatom data (discussed below) and a historical T-sheet from 1928 (U.S. Coast and Geodetic Survey, 1928) (fig. 48). Since 1928, the marsh has been impacted by upgrades to Highway 101, particularly engineered changes to the length and pathway of the outflow channel, but the size and extent of the wetland has changed little since at least that time.

\section{Previous Studies}

Carver and others (1998) provided the first observations of tsunami deposits at the Sand Mine marsh study site, based on a series of 14 cores and vibracores collected across the marsh and lagoon, extending from the beach berm to $>400 \mathrm{~m}$ inland. They used a floating platform to acquire cores from the central lagoon area where standing water typically exceeds $1 \mathrm{~m}$. Some of the data from that study were later published by Peterson and others (2011) as part of a larger analysis of paleotsunami deposits at three locations in the Crescent City area. The Peterson and others (2011) study expanded the study area landward to include gouge cores from the upland floodplain on the eastern margin of the Sand Mine marsh area, in addition to providing new radiocarbon and sedimentological analyses for the cores collected by Carver and others in 1996-98 (Peterson and others, 2011). Our initial observations for this location, which we refine here, are provided in Wilson and others (2014) under the heading "Sand Mine Marsh."

As documented by eyewitness accounts and historical photos, the 1964 tsunami inundated the western part of Sand Mine marsh, carrying numerous large driftlogs landward and damaging local structures (Magoon, 1966; Griffin, 1984; fig. 49). Our core location, normally a cattail marsh, appears to be filled to capacity with standing water at this time. Geological evidence for the 1964 tsunami was previously reported by 
Carver and others (1998) and later by Peterson and others (2011). Carver and others (1998) also interpreted a deposit in three of their cores as the 1960 tsunami deposit without presenting chronological or biostratigraphic data to support their interpretation. The primary goal of this study at Sand Mine marsh was to look closely at the 1964 deposit and determine the feasibility for preservation of other far-field tsunami deposits at this locality, including the 1960 deposit as well as a possible 1788 deposit, which was proposed from numerical modeling by Wilson and others (2008).

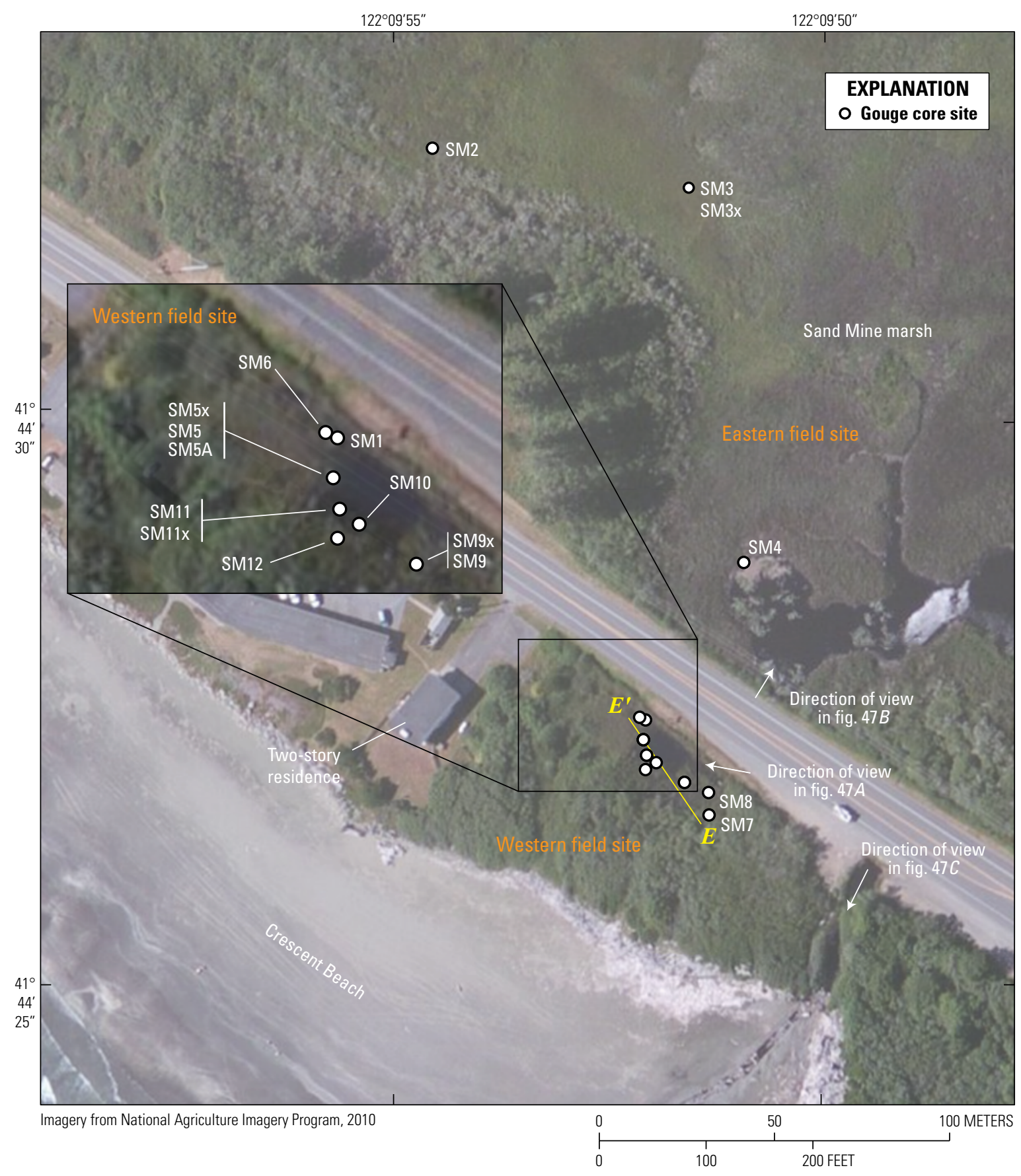

Figure 46. Aerial image of the Sand Mine marsh study site showing locations of cores evaluated for paleotsunami deposits. Cores SM2-SM4 were collected in a ponded area and willow swamp on the east side of Highway 101. Cores SM1 and SM5-SM12 were collected in a small Typha (cattail) marsh on the west side of the highway, within the 1964 tsunami inundation zone (see also fig. 49). White arrows show the direction of view for photographs in figure 47. 

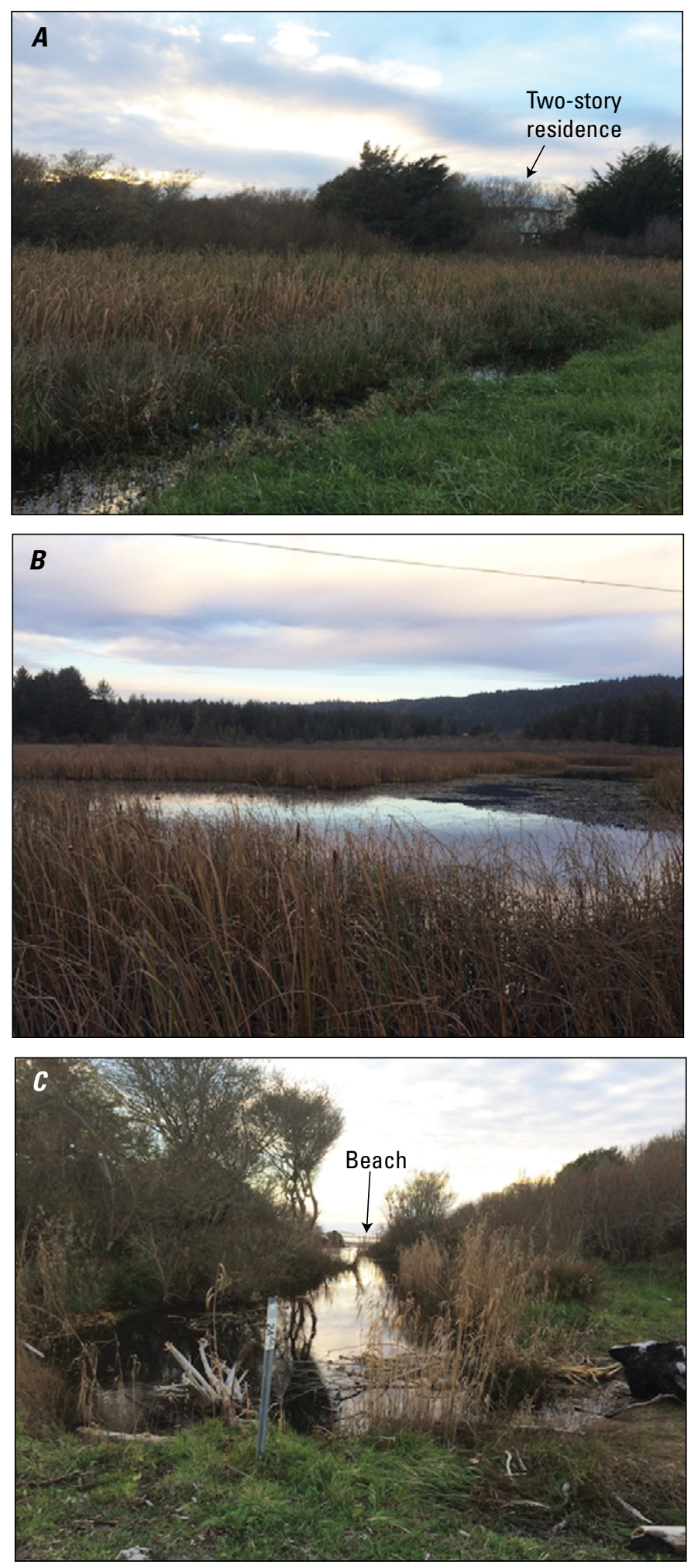

Figure 47. Photographs of the Sand Mine study site (see fig. 46 for locations). $A$, Marsh and pond of the western field site; view is to the west. Note the two-story residence, visible in figures 46 and 49 , that withstood the 1964 tsunami. $B$, Eastern field site; view is to the northeast. $C$, Marsh drainage channel (on the south side of the western field site and across Highway 101 from the eastern field site; view is to the southwest. Photographs were taken during fall 2016 after a period of heavy rainfall, causing deep-standing water to pool in the field sites.
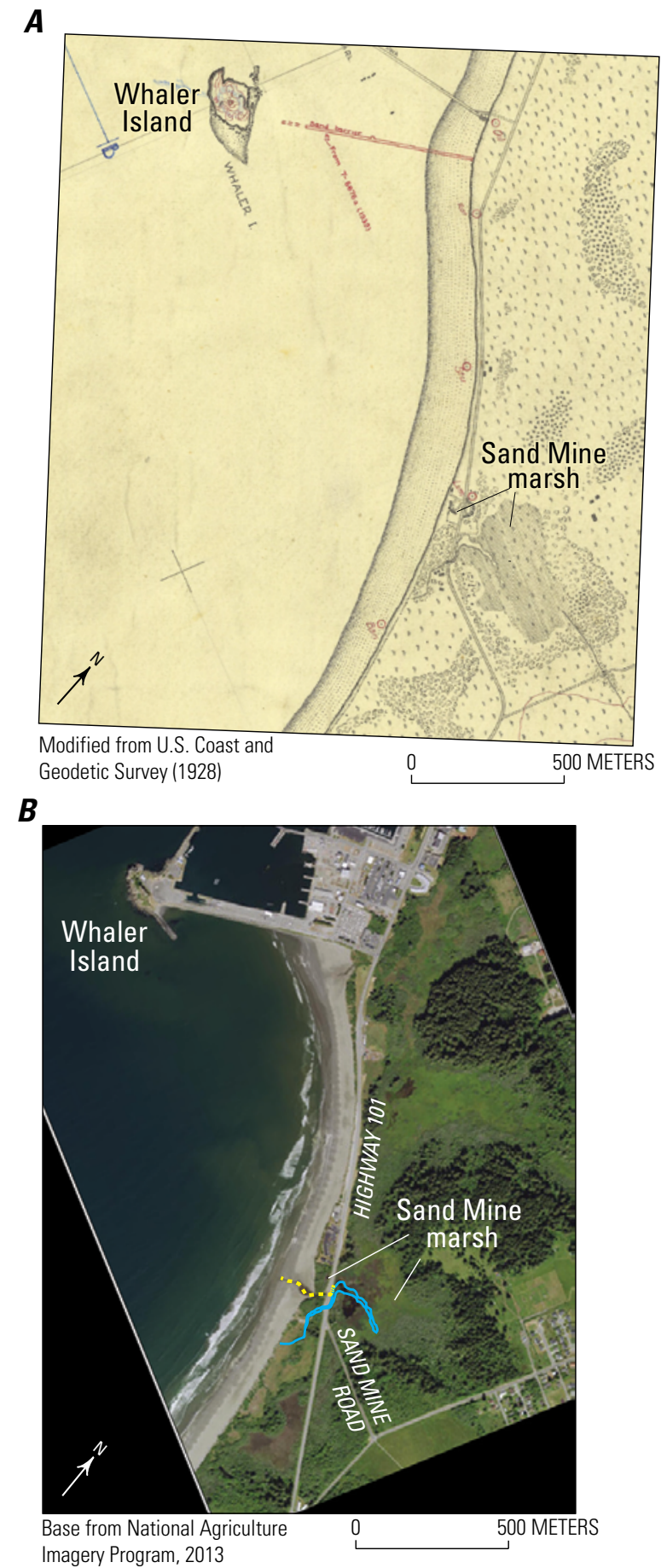

Figure 48. Historical and modern-day views of Sand Mine marsh. A, The U.S. Coast and Geodetic Survey chart T-4402 from 1928. The coastal roads that will later be upgraded into Highway 101 and Sand Mine Road already exist. A bridge on the roadway spans the natural outflow channel of Sand Mine marsh, which extends several hundred meters to the southwest from the main marsh before draining onto the beach. The jetty has not yet been constructed between Whaler Island and the mainland. B, A 2012 aerial image of Sand Mine marsh. The location of the main Sand Mine marsh study site, a small Typha marsh, is located on the west side of Highway 101. The blue line outlines the main (deep-water) part of the wetland and outflow channel as depicted on the 1928 chart in $A$. The dashed yellow line shows the current, shortened pathway of the outflow channel, which now passes through a culvert under Highway 101 before draining onto the beach. 


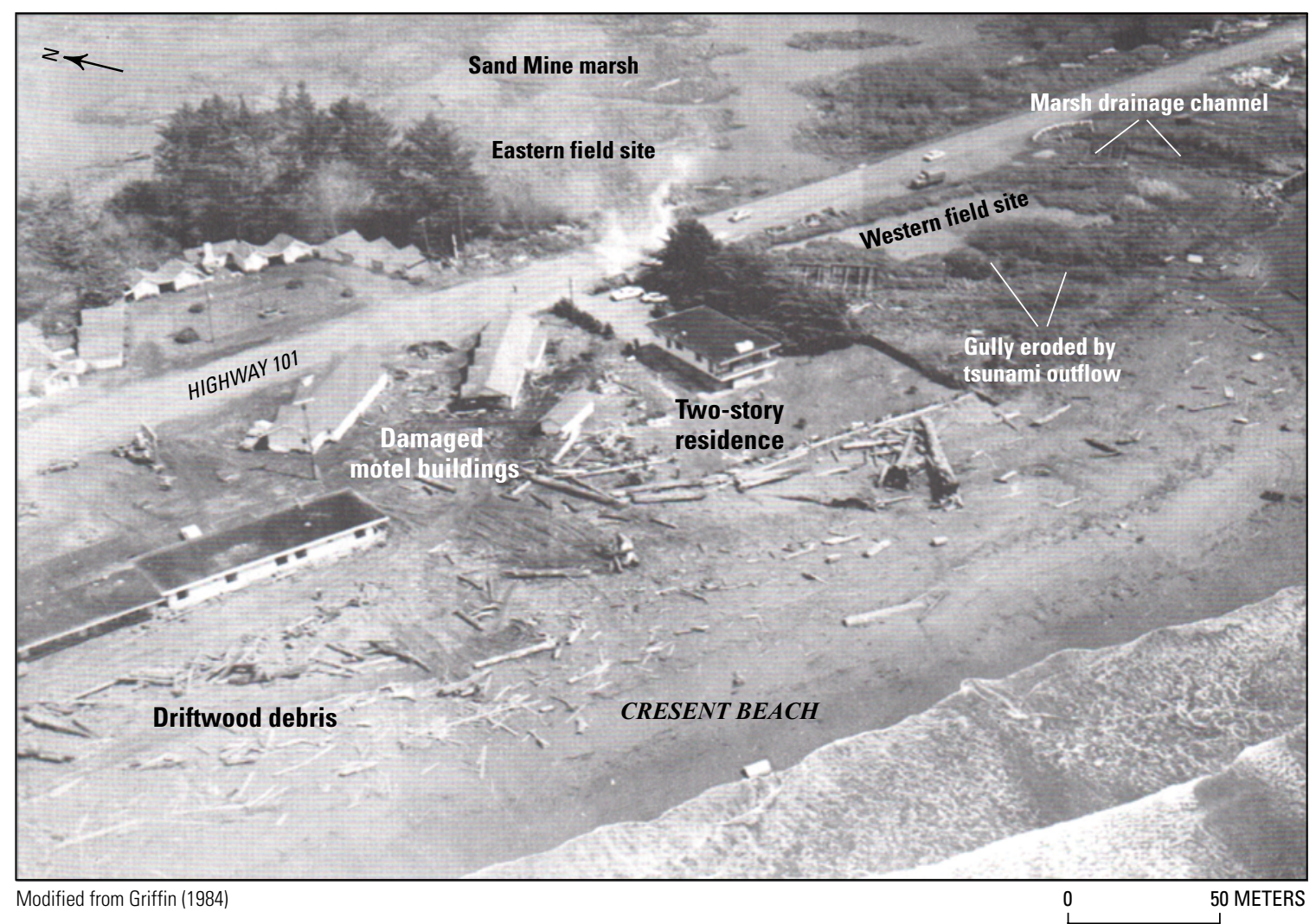

Figure 49. Historical aerial photograph taken a few days after the 1964 tsunami, showing structural damage and large amounts of debris near the western Sand Mine marsh study site. Note the two-story residence that survived the tsunami, also visible in figures 46 and 47 . The marshy pond where the cores were collected is full of water and at least one gully created by the tsunami outflow is visible cutting across the berm. The thickness of the 1964 tsunami deposit is greatest in the southern part of the ponded area, closest to a channel emplaced to help drain the marsh. Photograph from Griffin (1984, p. 150), reproduced with permission.

\section{Field Data Collection Strategies}

Sixteen cores were collected and described from Sand Mine marsh: three cores (SM2-SM4) from the freshwater marsh and swamp on the east side of Highway 101 (termed the eastern field site) (figs. 46, 47) and a transect of cores (SM1 and SM5-12) from a small marsh and pond on the west side of Highway 101 (termed the western field site). Replicate cores were collected at sites SM3, SM5, SM9, and SM11 (figs. 46, 50; appendix 1, figs. 1.15-1.23). Cores SM8, SM11/11x, and SM12 were returned to the lab for grain-size, radiocarbon, radionuclide, and microfossil analyses.

The closest tidal benchmark for Sand Mine marsh is NOAA Station 9419750, located about $1.5 \mathrm{~km}$ to the north on Citizens Dock in the Crecent City harbor (NOAA, 2003a) (fig. 2). The RTK positioning data show that all cores, with the exception of the two landwardmost cores (SM2 and SM3) were recovered from elevations less than $3.0 \mathrm{~m}$ (fig. 50). All but core SM2 are below the highest observed water level for the area, measured at $3.13 \mathrm{~m}$ during a major El Niño-Southern Oscillation event in January 1983. The vegetated berm separating the western field site from Crescent Beach is about $4-6 \mathrm{~m}$ high (figs. 46, 47, 50).

\section{Tsunami and Storm Deposit Identification}

\section{Lithology and Stratigraphy}

The subsurface stratigraphy differs substantially between the eastern and western field sites (fig. 50, appendix 1). The subsurface stratigraphy revealed in the 3 eastern cores (SM2, $\mathrm{SM} 3$, and SM4), collected $\sim 50-150 \mathrm{~m}$ from the beach, consists predominantly of peaty deposits interrupted by a few sand layers less than about $10 \mathrm{~cm}$ thick. In comparison, cores from the western field site (SM1, SM5-SM12) show a heterogeneous subsurface stratigraphy consisting of organic-rich and clastic deposits of varying thickness and texture. Lithologic units in the western field site are difficult to correlate with certainty across even the short distances $(\sim 4-5 \mathrm{~m})$ between some cores.

\section{Eastern Field Site}

In cores SM2, SM3, and SM4 from the eastern field site (figs. 46, 50), sandy deposits ranging from about $4-10 \mathrm{~cm}$ thick stand out in contrast to the predominantly organic-rich deposits, 

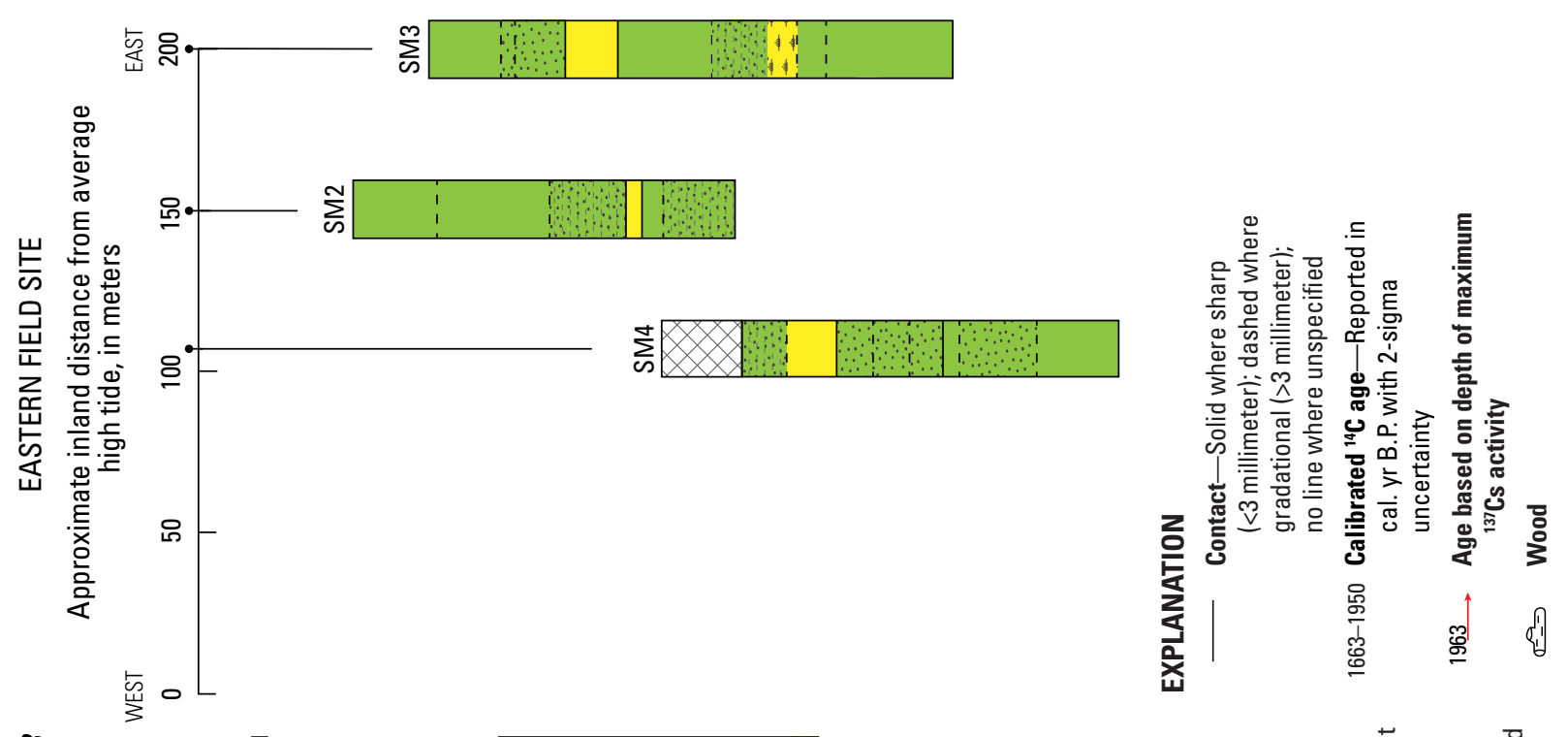

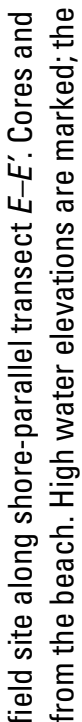

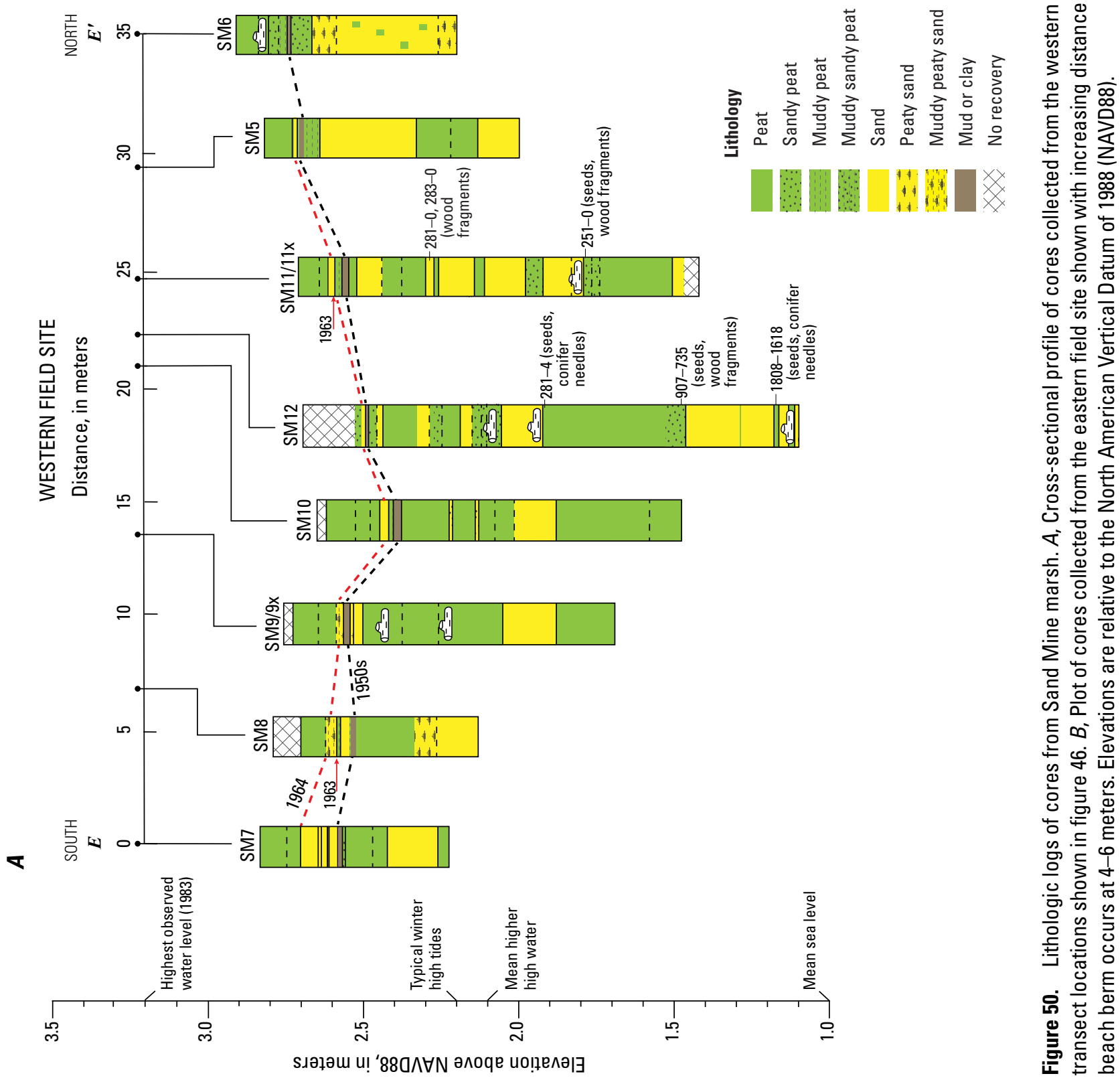


which range from finely to coarsely rooted peat, are dark-brown to reddish-brown in color, and contain sections of humified muddy peat and sandy peat (appendix 1, figs. 1.15-1.17).

Grayish-brown, detrital-rich sand layers at 80-87 cm depth in core SM3, 70-80 cm depth in core SM3x, and 65-69 cm depth in core SM4 are each underlain by fine-grained to fibrous reddish-brown peat and overlain by grayish-brown muddy peat (fig. 50; appendix 1, figs. 1.16, 1.17). In contrast, for sand layers that occur closer to the ground surface $(30-40 \mathrm{~cm}$ depth) in cores SM3 and SM4, we observe no distinct change in the color or texture of under- or overlying peaty deposits (fig. 50; appendix 1, figs. 1.16, 1.17).

\section{Western Field Site}

In the western field site, peaty deposits make up most of the subsurface lithologies, although there are prominent sandy deposits in all cores ranging from a few to $>25 \mathrm{~cm}$ thick (fig. 50, appendix 1). The sands are fine grained, pale to brownish gray, and most appear to lack laminae or grading. Detrital peat and wood is evident in some cores, for example, between sand layers in the middle sections of cores SM11/11x and SM12.

The stratigraphically youngest sand layer, found $\sim 10-20 \mathrm{~cm}$ below the modern surface, can be correlated across most cores in the western field site (figs. 46, 50). The deposit is thicker on the south end of the marsh nearest the drainage channel, thinning substantially from the southernmost core (SM7) to the northernmost core (SM5), where we were able to identify it visually in the field. Underlying this sand layer is a distinctive lithologic unit found in each of the cores from the western field site. It is a thin, light-grayish-brown layer of silty clay found $\sim 5-15 \mathrm{~cm}$ below the sand layer and, because of its unique color and texture, it served as a useful correlation marker between cores (fig. 50).

\section{Geochronology}

Six new AMS ${ }^{14} \mathrm{C}$ ages were acquired from the western field site of Sand Mine marsh, three each from cores SM11/11x and SM12 (figs. 50, 51; table 1). In SM11/11x, three ${ }^{14} \mathrm{C}$ ages bracketing a 55-cm-thick section composed of sand layers separated by peat and detrital peat returned equivalent results of $281-0,283-0$, and $251-0$ cal. yr B.P. An equivalent age of 281-4 cal. yr B.P. was acquired at the base of a detrital-rich sand layer at $83 \mathrm{~cm}$ depth in core SM12. Two older ${ }^{14} \mathrm{C}$ ages in core SM12, 907735 and 1,808-1,618 cal. yr B.P., bracket a 30-cm-thick section of fine-grained, well-sorted sand between 134 and $164 \mathrm{~cm}$ depth.

${ }^{210} \mathrm{~Pb}$ and ${ }^{137} \mathrm{Cs}$ analyses were completed for the upper sections of cores SM8 and SM11/11x (figs. 52-55, table 2, appendix 2). As at Marhoffer Creek marsh, the ${ }^{210} \mathrm{~Pb}$ activities were too low and the errors too large to extend age estimates past the early 1960s in core SM8 (fig. 52; table 6) and between the late 1930s and late 1950s in core SM11/11x (fig. 54, table 7). However, the ${ }^{210} \mathrm{~Pb}$ activities warrant an approximate age of $1940-50 \mathrm{~s}$ for the gray-brown clay layer observed in cores from the western field

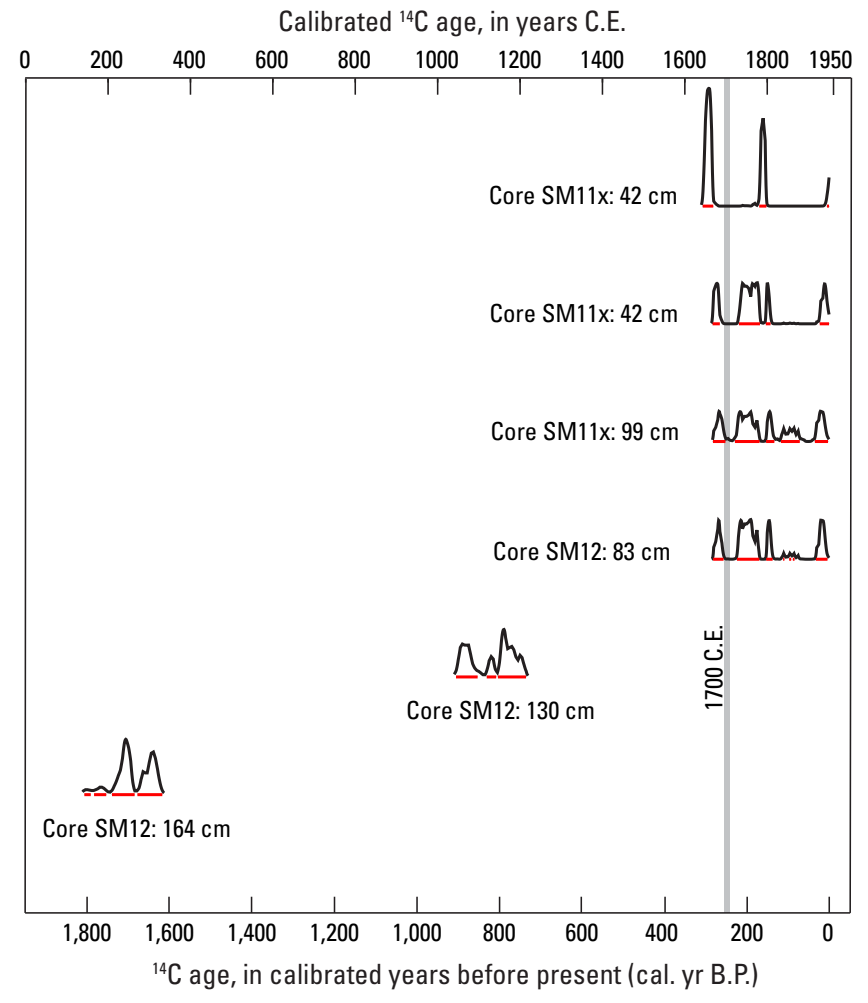

Figure 51. Graph showing calibrated ${ }^{14} \mathrm{C}$ age probability distributions for samples from Sand Mine marsh. Labels denote the core name and the depth below the surface from which the ${ }^{14} \mathrm{C}$ sample was taken. Red lines show the area under the probability distribution function. See also table 1.

site of Sand Mine marsh, based on the CRS model age range of 1938-58 C.E. (midpoint 1946 C.E.) in muddy peat just above the clay in core SM11/11x (table 7).

The maximum ${ }^{137} \mathrm{Cs}$ activity coincident with the year 1963 occurs at a depth of $22-23 \mathrm{~cm}$ in core SM8 (figs. 52, 53; table 6) and at 12-13 cm in core SM11/11x (figs. 54, 55 ; table 7). In both cores this peak occurs just below a thin sand layer containing marine diatoms and 5-8 $\mathrm{cm}$ above the distinct grayish-brown clay layer identified in most of the western cores. In SM8, a second sand layer containing marine diatoms is present above the grayish-brown clay layer but stratigraphically below the ${ }^{137} \mathrm{Cs}$ peak.

\section{Particle-size Analyses}

Particle-size analyses were used to evaluate the sandy intervals in cores SM11/11x and SM12, labeled "Unit 1" through "Unit 6" on fig. 59, and compare these data with the grain-size characteristics of the 1700 tsunami deposit at Marhoffer Creek marsh (fig. 56; appendix 3, tables 3.6, 3.8).

Unit 1 is a 2-cm-thick deposit of fine gray sand bracketed above and below by detrital peat. The grain-size analysis included 
Table 6. ${ }^{210} \mathrm{~Pb}$ and ${ }^{137} \mathrm{Cs}$ radionuclide analysis data for core SM8 from Sand Mine marsh.

[cm, centimeter; $\mathrm{cm}^{2}$, square centimeter; g, gram; dpm/g, decays per minute per salt-corrected dry gram; yr, year; CRS, constant rate of supply; MDA, minimum detectable activity]

\begin{tabular}{|c|c|c|c|c|c|c|c|c|c|}
\hline $\begin{array}{c}\text { Sample } \\
\text { interval } \\
\text { (cm) }\end{array}$ & Lithology & $\begin{array}{c}\text { Excess } \\
{ }^{210} \mathrm{~Pb} \\
(\mathrm{dpm} / \mathrm{g})^{\mathrm{a}}\end{array}$ & $\begin{array}{l}\text { Excess } \\
{ }^{210} \mathrm{~Pb} \text { error } \\
(\mathrm{dpm} / \mathrm{g})^{\mathrm{a}}\end{array}$ & $\begin{array}{c}{ }^{137} \mathrm{Cs} \\
(\mathrm{dpm} / \mathrm{g})^{\mathrm{a}}\end{array}$ & $\begin{array}{l}{ }^{137} \text { Cs error } \\
(\mathrm{dpm} / \mathrm{g})^{\mathrm{a}}\end{array}$ & $\begin{array}{c}\text { Age from } \\
{ }_{137} \text { Cs bulk } \\
\text { sedimentation } \\
\text { rate (yr) }\end{array}$ & $\begin{array}{l}\text { Age from } \\
\text { excess } \\
{ }^{210} \mathrm{~Pb} \text { CRS } \\
\text { model (yr) }\end{array}$ & $\begin{array}{c}\text { CRS model } \\
\text { age range } \\
(y r)^{b}\end{array}$ & $\begin{array}{l}\text { Accumulated } \\
\text { weight of dry } \\
\text { sediment per } \\
\mathbf{c m}^{2}(\mathbf{g})\end{array}$ \\
\hline $16-17$ & Humified peat & 7.3106 & 1.2428 & 2.8085 & 0.0994 & 1976 & & & 1.18 \\
\hline $17-18$ & Humified peat & 3.6517 & 0.6573 & 2.6473 & 0.1067 & 1974 & & & 1.48 \\
\hline $20-20.5$ & Sand with plant detritus & 0.3706 & 0.0760 & 2.0746 & 0.1039 & 1968 & & & 3.09 \\
\hline $20.5-21$ & Sand with plant detritus & 0.0273 & 0.0057 & 0.9958 & 0.1025 & 1967 & & & 3.40 \\
\hline $21-21.5$ & Sand with plant detritus & 0.7086 & 0.1524 & 1.8985 & 0.0873 & 1966 & & & 3.61 \\
\hline $21.5-22$ & Sand with plant detritus & 0.0537 & 0.0118 & 2.4104 & 0.1147 & 1965 & & & 3.83 \\
\hline $25-25.5$ & Gray fine sand & 0.1660 & 0.0423 & $<0.13813$ & $<\mathrm{MDA}$ & & & & 6.97 \\
\hline $25.5-26$ & Gray fine sand & 0.0000 & 0.0000 & $<0.08423$ & $<\mathrm{MDA}$ & & & & 8.29 \\
\hline
\end{tabular}

${ }^{a}$ Values are decay corrected.

${ }^{\mathrm{b}}$ Salt-corrected and decay-corrected values.

${ }^{\mathrm{c}}$ Maximum ${ }^{137} \mathrm{Cs}$ activity occurs at this depth interval.
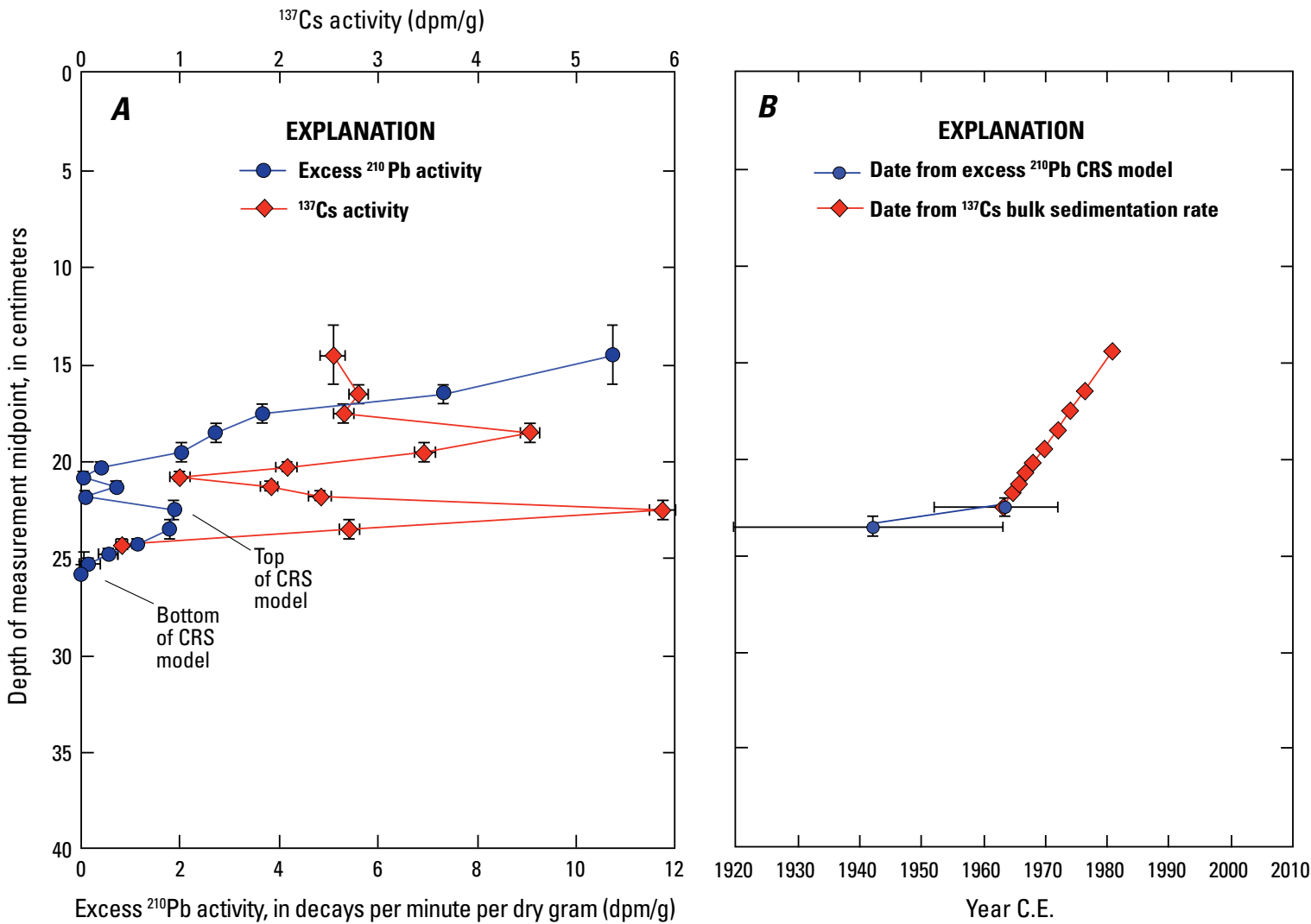

Figure 52. Radionuclide results for core SM8 from Sand Mine marsh. A, Graph of ${ }^{137} \mathrm{Cs}$ and excess ${ }^{210} \mathrm{~Pb}$ radionuclide activities. $B$, Age estimates based on the bulk sedimentation rate (in grams per year) derived from ${ }^{137} \mathrm{Cs}$ (red) and the ${ }^{210} \mathrm{~Pb}$ constant rate of supply (CRS) model (blue) ${ }^{210} \mathrm{~Pb}$ CRS model ages are based on the estimated value of 20 decays per minute per gram $(\mathrm{dpm} / \mathrm{g})$ for the uppermost interval in the core and are graphed as deep as 100 percent error. ${ }^{137} \mathrm{Cs}$ ages are graphed to the depth of the $1963{ }^{137}$ Cs peak. 
Table 7. ${ }^{210} \mathrm{~Pb}$ and ${ }^{137} \mathrm{Cs}$ radionuclide analysis data for core SM11 from Sand Mine marsh.

[cm, centimeter; $\mathrm{cm}^{2}$, square centimeter; g, gram; dpm/g, decays per minute per salt-corrected dry gram; yr, year; CRS, constant rate of supply; MDA, minimum detectable activity]

\begin{tabular}{|c|c|c|c|c|c|c|c|c|c|}
\hline $\begin{array}{c}\text { Sample } \\
\text { interval } \\
\text { (cm) }\end{array}$ & Lithology & $\begin{array}{l}\text { Excess } \\
{ }^{210} \mathrm{~Pb} \\
(\mathrm{dpm} / \mathrm{g})^{\mathrm{a}}\end{array}$ & $\begin{array}{c}\text { Excess } \\
{ }^{210} \mathrm{~Pb} \text { error } \\
(\mathrm{dpm} / \mathrm{g})^{\mathrm{a}}\end{array}$ & $\begin{array}{c}{ }^{137} \mathrm{Cs} \\
(\mathrm{dpm} / \mathrm{g})^{\mathrm{a}}\end{array}$ & $\begin{array}{l}{ }^{137} \text { Cs error } \\
(\mathrm{dpm} / \mathrm{g})^{\mathrm{a}}\end{array}$ & $\begin{array}{c}\text { Age from } \\
{ }^{137} \text { Cs bulk } \\
\text { sedimentation } \\
\text { rate (yr) }\end{array}$ & $\begin{array}{c}\text { Age from } \\
\text { excess }{ }^{210} \mathrm{~Pb} \\
\text { CRS model } \\
(y r)^{b, c}\end{array}$ & $\begin{array}{c}\text { CRS model } \\
\text { age range } \\
(y r)^{b, c}\end{array}$ & $\begin{array}{l}\text { Accumulated } \\
\text { weight of dry } \\
\text { sediment per } \\
\mathrm{cm}^{2}(\mathrm{~g})\end{array}$ \\
\hline $5-7$ & Peat & 11.9206 & 0.3872 & 2.5356 & 0.099 & 1995 & & & 1.18 \\
\hline $7-9$ & Humified peat & 4.0536 & 0.1922 & 4.3324 & 0.078 & 1991 & & & 1.48 \\
\hline $9-10$ & Sandy peat & 0.6022 & 0.1274 & 1.3577 & 0.038 & 1981 & & & 2.15 \\
\hline $10-11$ & Gray fine sand & 0.8167 & 0.1394 & 1.2441 & 0.039 & 1974 & & & 2.67 \\
\hline $11-12$ & Gray fine sand & 1.6066 & 0.1736 & 4.1396 & 0.080 & 1968 & & & 3.09 \\
\hline $12-13^{\mathrm{d}}$ & Muddy fine sand & 2.8398 & 0.2867 & 6.1841 & 0.142 & 1963 & 1963 & 1959-1969 & 3.40 \\
\hline $13-14$ & Muddy peat & 2.4861 & 0.2294 & 1.5788 & 0.066 & & 1955 & 1949-1963 & 3.61 \\
\hline $14-15$ & Muddy peat & 2.1320 & 0.2623 & 0.3087 & 0.047 & & 1946 & $1938-1958$ & 3.83 \\
\hline $15-16$ & Gray clay & 1.5187 & 0.2177 & 0.2481 & 0.041 & & 1937 & $1925-1958$ & 4.04 \\
\hline $16-17$ & Gray clay & 1.1331 & 0.2021 & 0.2582 & 0.039 & & 1929 & $1912-1970$ & 4.26 \\
\hline $17-19$ & Humified peat & 0.9510 & 0.1802 & $<0.02884$ & $<\mathrm{MDA}$ & & & & 4.61 \\
\hline $19-20$ & Peaty sand & 0.3390 & 0.1129 & 0.0878 & 0.017 & & & & 5.19 \\
\hline $20-22$ & Fine sand & & & & & & & & 6.97 \\
\hline $22-23$ & Fine sand & 0 & 0 & $<0.0277$ & $<\mathrm{MDA}$ & & & & 8.29 \\
\hline $23-25$ & Fine sand & & & & & & & & 11.07 \\
\hline $25-26$ & Medium sand & 0.0627 & 0.0667 & $<0.0289$ & $<\mathrm{MDA}$ & & & & 12.53 \\
\hline $26-27$ & Medium sand & & & & & & & & 13.75 \\
\hline $27-28$ & Medium sand & 0 & 0 & $<0.0417$ & $<\mathrm{MDA}$ & & & & 14.74 \\
\hline $28-29$ & Peat & 0.4745 & 0.1498 & 0.0817 & 0.019 & & & & 14.95 \\
\hline $29-31$ & Peat & 0.3446 & 0.1131 & 0.2657 & 0.026 & & & & 15.27 \\
\hline $31-33$ & Peat & 0.5749 & 0.1171 & $<0.0624$ & $<\mathrm{MDA}$ & & & & 15.57 \\
\hline $33-34$ & Peat & 0.0997 & 0.1493 & $<0.0381$ & $<\mathrm{MDA}$ & & & & 15.75 \\
\hline $34-35$ & Peat & 0.5436 & 0.1975 & $<0.0927$ & $<\mathrm{MDA}$ & & & & 15.95 \\
\hline $35-37$ & Peat & 0.1694 & 0.1201 & 0.1033 & 0.023 & & & & 16.22 \\
\hline $37-40$ & Peat & 0.3636 & 0.1428 & $<0.0544$ & $<\mathrm{MDA}$ & & & & 16.61 \\
\hline $40-42$ & Peat & 0.4820 & 0.1507 & $<0.0733$ & $<\mathrm{MDA}$ & & & & 16.87 \\
\hline $42-44.5$ & Peat & 0.2786 & 0.1137 & $<0.0597$ & $<\mathrm{MDA}$ & & & & 17.27 \\
\hline $44.5-45.5$ & Very fine sand & 0 & 0 & $<0.0760$ & $<\mathrm{MDA}$ & & & & 17.75 \\
\hline $45.5-46.5$ & Very fine sand & 0 & 0 & $<0.0434$ & $<\mathrm{MDA}$ & & & & 18.53 \\
\hline $48-50$ & Humified peat & 0.0127 & 0.1504 & $<0.0495$ & $<\mathrm{MDA}$ & & & & 19.41 \\
\hline
\end{tabular}

avalues are decay corrected

${ }^{b}$ Excess ${ }^{210} \mathrm{~Pb}$ CRS model dates for core SM11 uses interpolated values for any missing intervals; ages are reported to the depth at which error $<100$ percent.

${ }^{\mathrm{c}}$ For core SM11 the ${ }^{210} \mathrm{~Pb}$ CRS model uses integrated activities over the depth range $12-23 \mathrm{~cm}$; the interval at $12-13 \mathrm{~cm}$ is tied to 1963 , based on the ${ }^{137} \mathrm{Cs}$ peak.

${ }^{\mathrm{d}}$ Maximum ${ }^{137} \mathrm{Cs}$ activity occurs at this depth interval.

four samples, two in the sand layer and one each in the upper and lower sandy peat. The D50 results show an average decrease in grain size (fining upward) from the lower to upper part of the deposit. The fining upward texture is also reflected in the shallower samples, which are slightly better sorted and more finely skewed.

Unit 2 is an 8-cm-thick deposit of dark-gray fine sand with minor detritus. It is generally coarser grained in the lower part of the deposit compared to the upper part (figs. 55A-B, 56). Overall, it is better sorted and more finely skewed than any of the other lithologic units evaluated.
Units 3, 4, and 5 encompass three separate deposits within a zone of unusually thick sand and detrital peat accumulation between 45 and $100 \mathrm{~cm}$ depth in core SM11/11x (figs. 55D, 56). The sand layers are fine grained and separated mostly by humified, sandy detrital peat. The D50 data show that both Units 3 and 4 are massive, though Unit 3 is slightly finer grained on average. In comparison, Unit 5 is distinctly graded - normally graded in the lower part of the deposit between 90 and $100 \mathrm{~cm}$ depth and inversely graded in the upper part of the deposit between 84 and $90 \mathrm{~cm}$ depth. Unit 5 is moderately well sorted throughout and the skewness pattern follows the fining- to coarsening-upward pattern. 


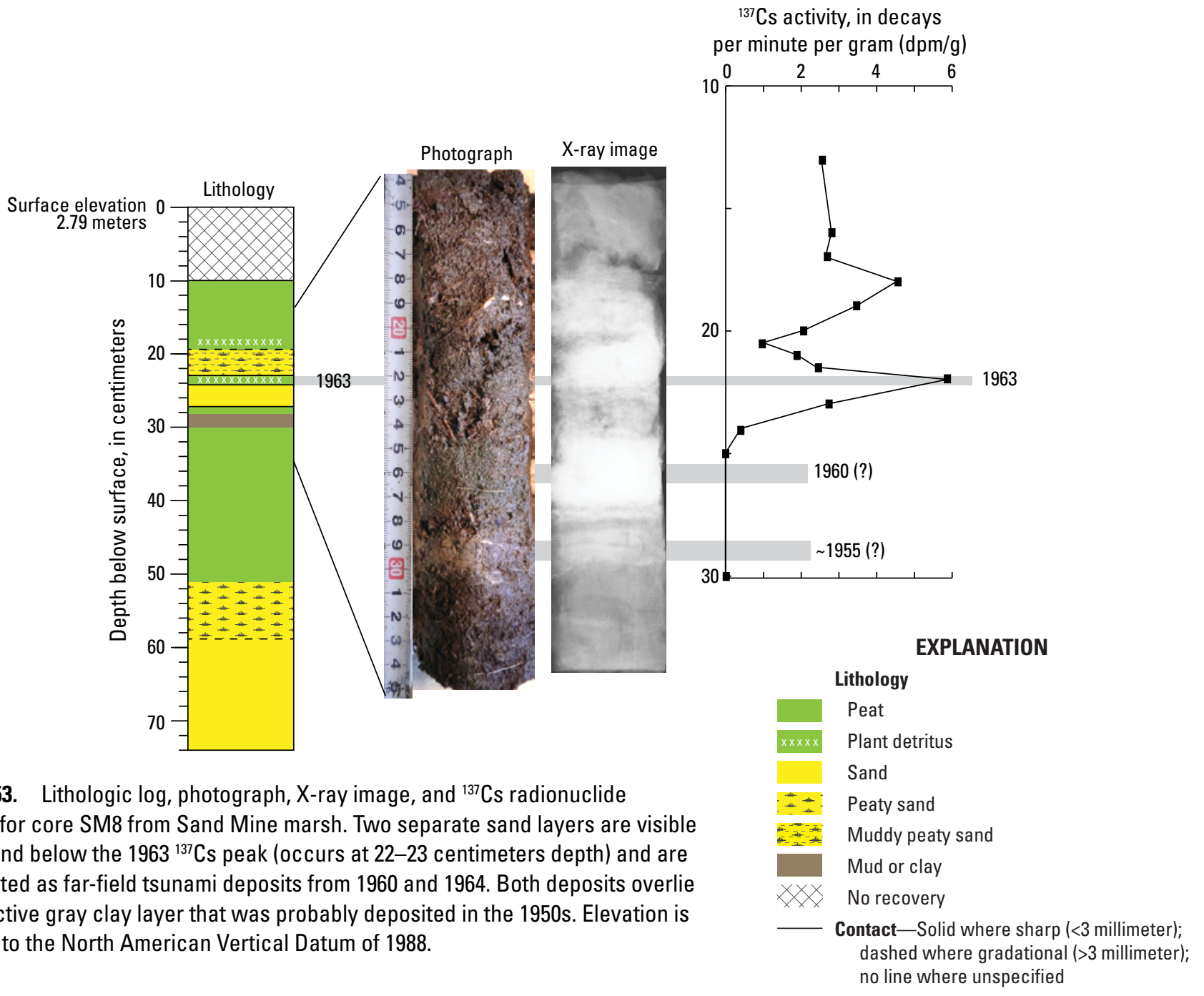

Figure 53. Lithologic log, photograph, $\mathrm{X}$-ray image, and ${ }^{137} \mathrm{Cs}$ radionuclide activity for core SM8 from Sand Mine marsh. Two separate sand layers are visible above and below the $1963{ }^{137} \mathrm{Cs}$ peak (occurs at 22-23 centimeters depth) and are interpreted as far-field tsunami deposits from 1960 and 1964. Both deposits overlie a distinctive gray clay layer that was probably deposited in the 1950s. Elevation is relative to the North American Vertical Datum of 1988. no line where unspecified
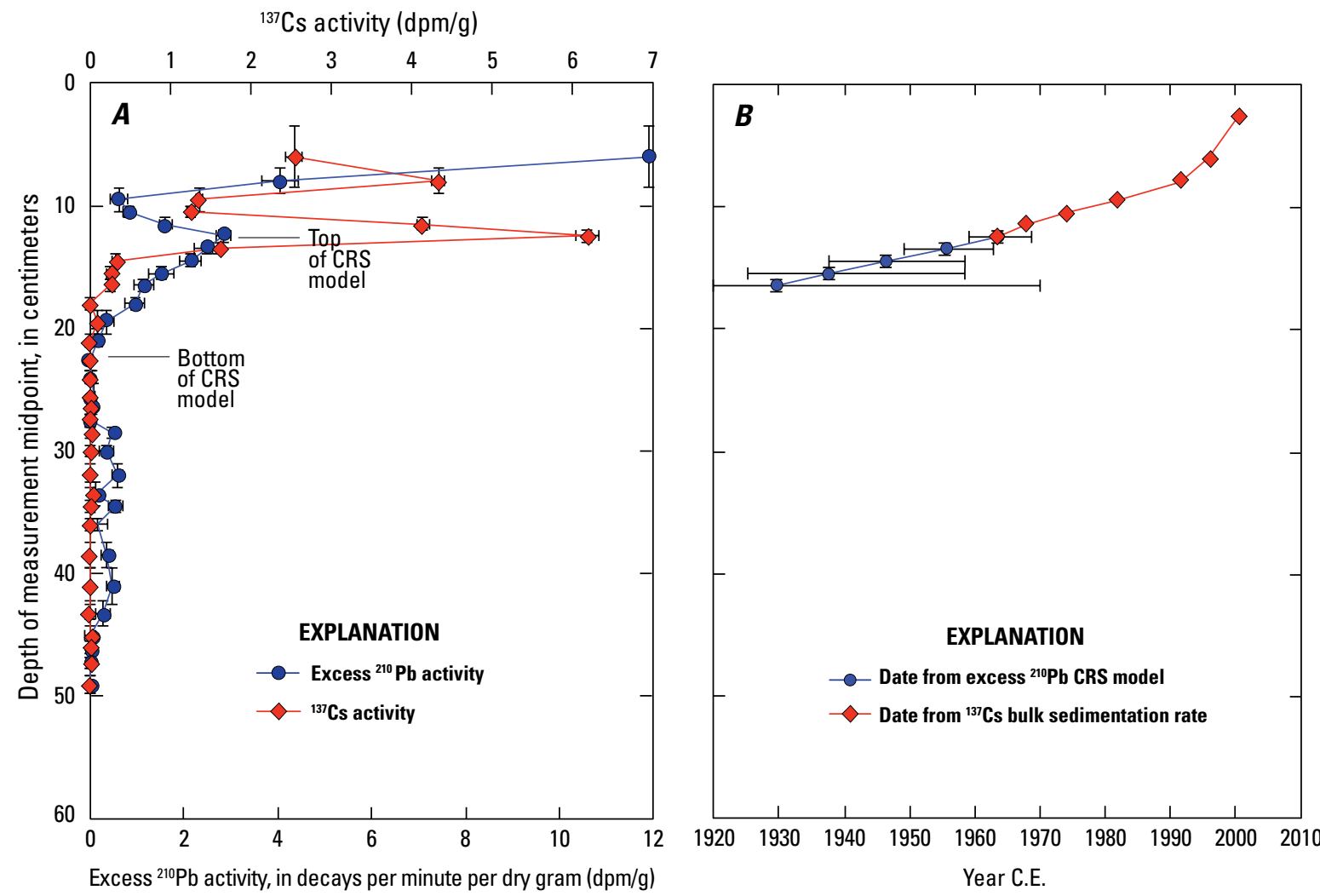

Figure 54. Radionuclide results for core SM11 from Sand Mine marsh. $A$, Graph of ${ }^{137} \mathrm{Cs}$ and excess ${ }^{210} \mathrm{~Pb}$ radionuclide activities. $B$, Age estimates based on bulk sedimentation rate (in grams per year) derived from ${ }^{137} \mathrm{Cs}$ (red) and the ${ }^{210} \mathrm{~Pb}$ constant rate of supply (CRS) model (blue). ${ }^{210} \mathrm{~Pb}$ CRS model ages are based on the estimated value of 20 decays per minute per gram $(\mathrm{dpm} / \mathrm{g})$ for the uppermost interval in the core and are graphed as deep as 100 percent error. ${ }^{137} \mathrm{Cs}$ ages are graphed to the depth of the $1963{ }^{137} \mathrm{Cs}$ peak. 
Unit 6, sampled in core SM12, consists of $30 \mathrm{~cm}$ of massive fine sand, well sorted and mostly finely skewed.

Compared to the 1700 tsunami deposit from Marhoffer Creek marsh (fig. 56B), all of the sandy deposits in the Sand Mine marsh cores (with the exception of Unit 3) are dominantly of comparable grain size, that is, fine sand between about 2.6 and $2.8 \varphi$. The 1700 deposit at Marhoffer Creek marsh is well sorted, as are Units 1, 2, 3, and 6 from Sand Mine marsh. The finely skewed texture of the 1700 tsunami deposit is not matched by any of the Sand Mine marsh deposits.

Particle-size grading is evident in both Unit 5 and the 1700 tsunami deposit from Marhoffer Creek marsh, but the normal and reverse patterns are a mirror image. Unit 5 in core SM11/11x is normally graded (fines upward) between 90 and $100 \mathrm{~cm}$ depth

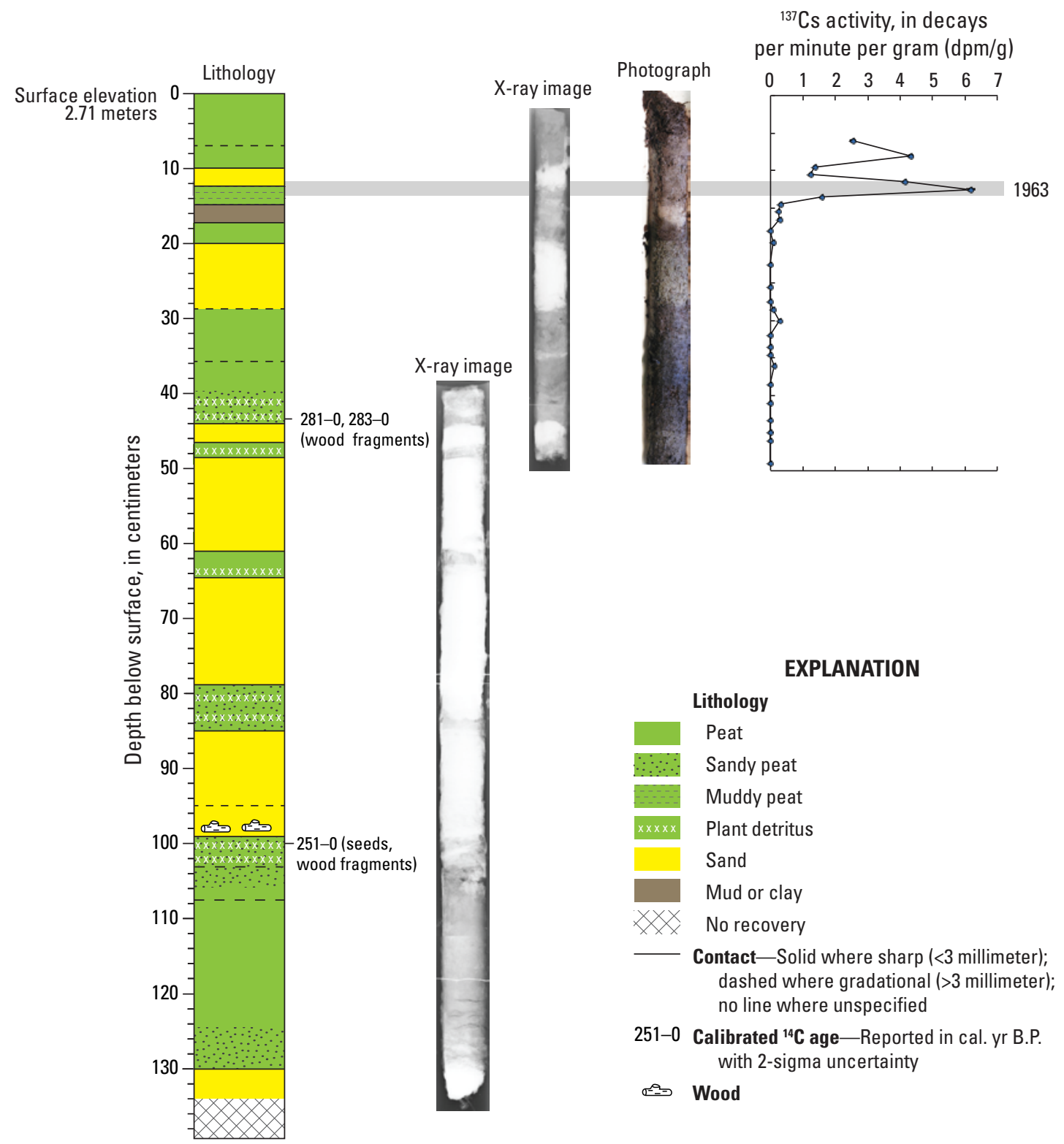

Figure 55. Lithologic log, photograph, X-ray images, and ${ }^{137} \mathrm{Cs}$ radionuclide activity for core SM11/11x from Sand Mine marsh. Numerous sandy deposits are present in the core, including the 1964 tsunami deposit at 10-12 centimeters $(\mathrm{cm})$ depth. The photograph and X-ray image of the upper part of core SM11 (4-50 cm depth) show the sandy 1964 tsunami deposit, the 1950s gray clay layer, and several older sandy deposits that probably record berm migration and storm deposition. The longer $X$-ray image shows thick sections of sand and detrital peat between 45 and $100 \mathrm{~cm}$ depth, capping a section of dense peat and an additional sand unit at the base of the recovered core. Maximum ${ }^{137} \mathrm{Cs}$ activity occurs at $12-13 \mathrm{~cm}$ depth. Elevation is relative to the North American Vertical Datum of 1988. 


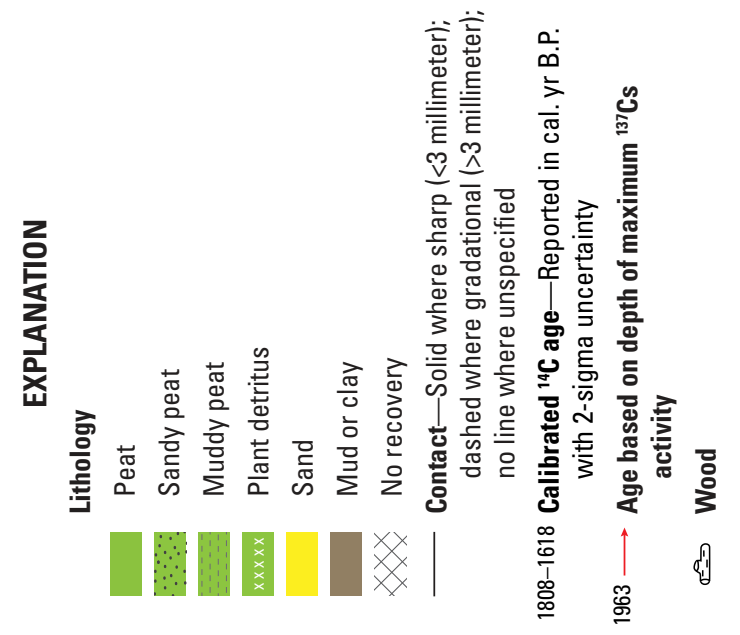

$\infty$

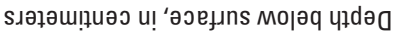
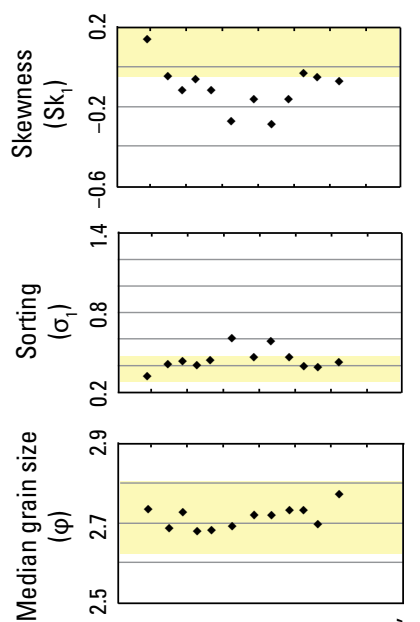
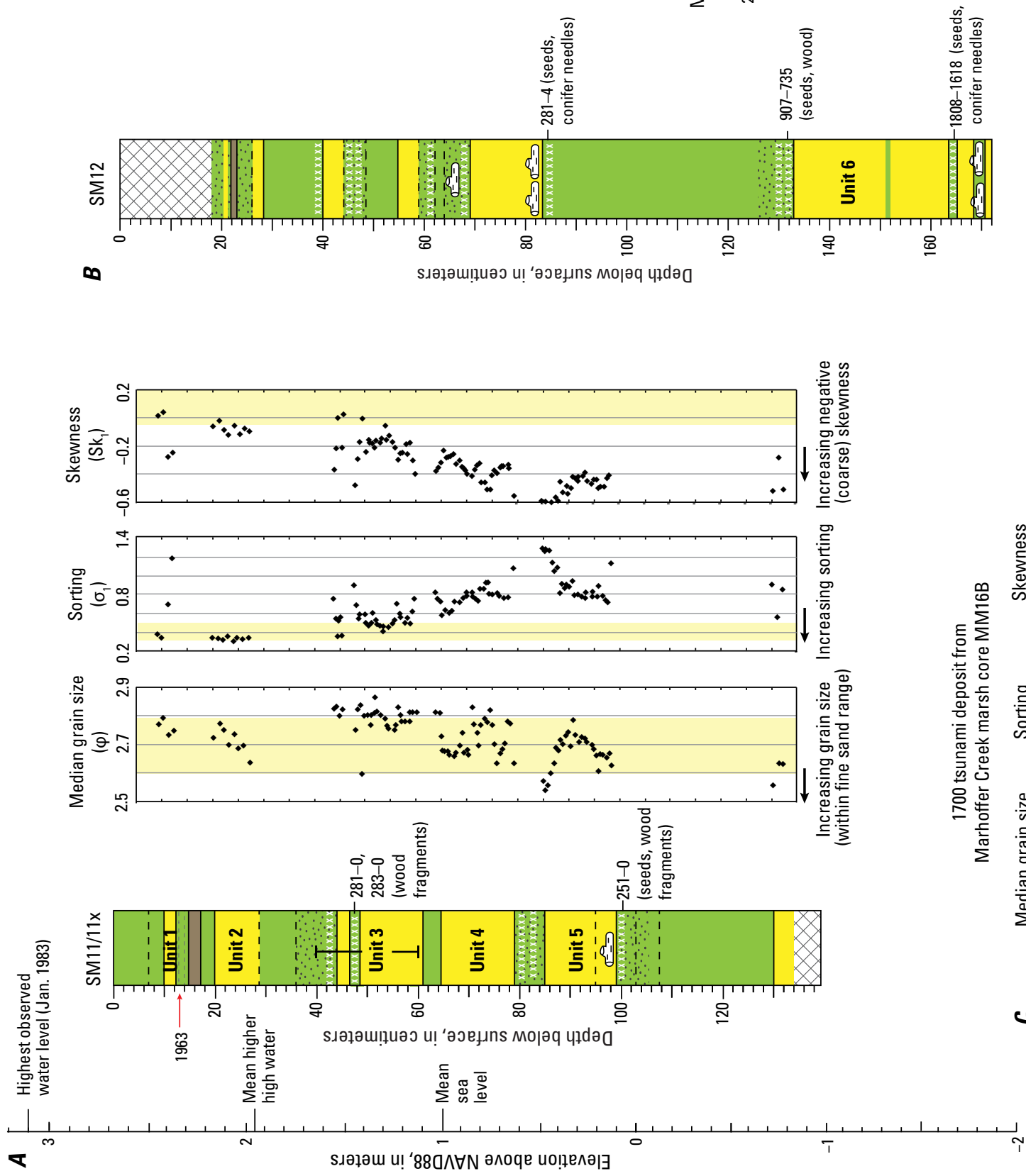
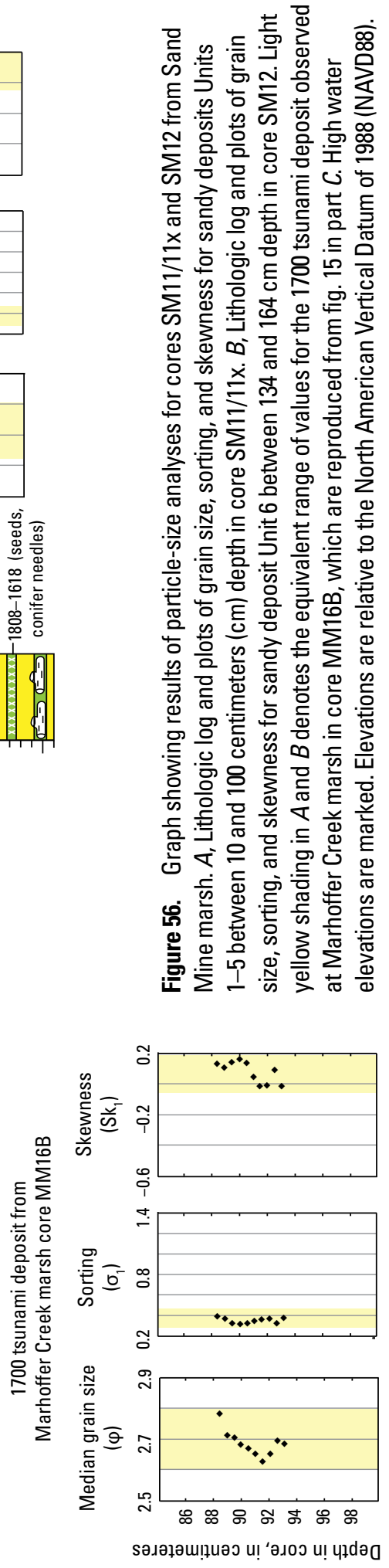

$\bigcup$ 
and is reversely graded (coarsens upward) from 85 to $90 \mathrm{~cm}$ at the top of the sand layer. In comparison, the 1700 tsunami deposit shows reverse grading in the lower part of the deposit and normal grading in the upper part. Storm-deposited sand in core MM16B at Marhoffer Creek marsh (fig. 14) also exhibits a normal-thenreverse grading pattern, which is comparable to the 1700 tsunami deposit at that location, but inverse of the grading pattern in Unit 5 from Sand Mine marsh.

In addition to the detailed grain-size analysis, the sphericity and smoothness of a number of sand grains - observed as background particles on diatom slides at $650 \times$ magnificationwere also qualitatively recorded from each of the different deposits (fig. 57). The sand grains observed in Units 1, 2, 3, 4, and 6 are dominantly subangular to subrounded with smooth edges. In contrast, most of the sand grains observed in Unit 5 are angular with jagged or unabraded edges.

\section{Diatom Analyses}

\section{Sand and Sandy Detrital Deposits}

Diatoms were analyzed in each of the sand and sandy detrital peat units that were part of the particle-size analysis as well as in additional samples from cores SM8 and SM12 (figs. 58-60).
A

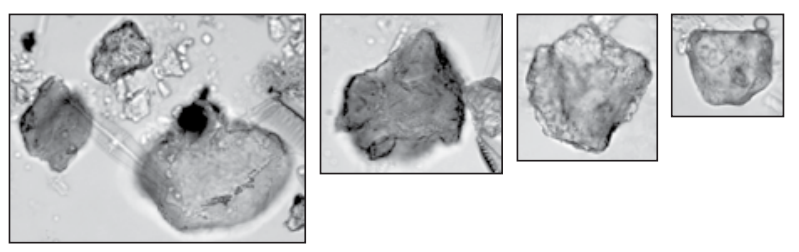

C
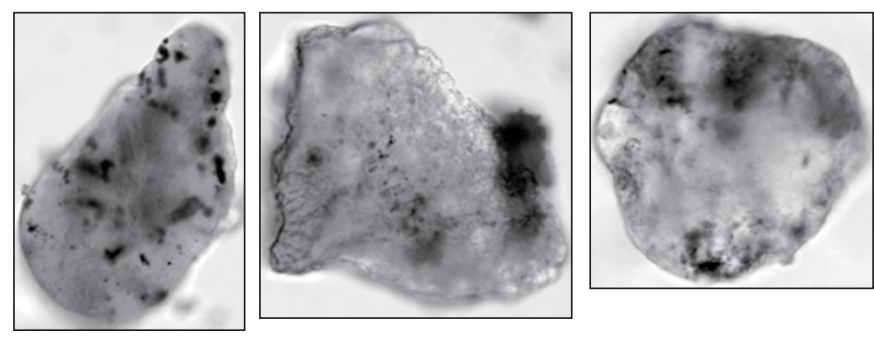

E
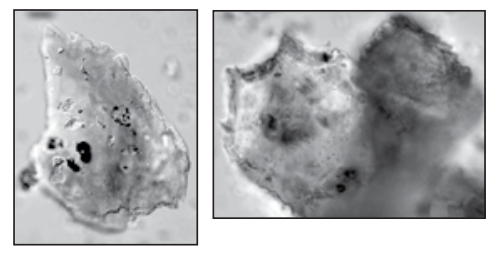

$\boldsymbol{B}$
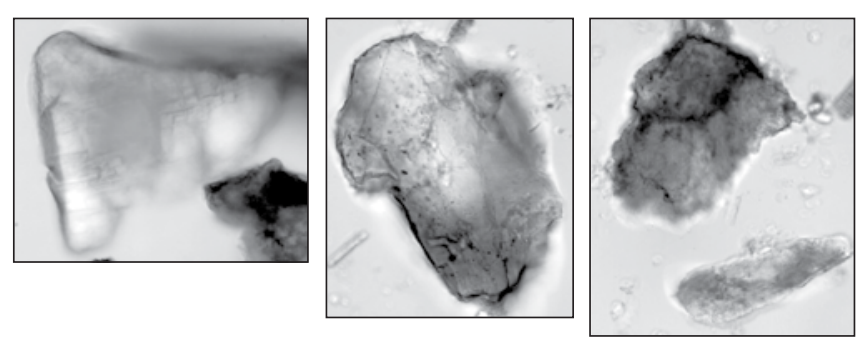

D
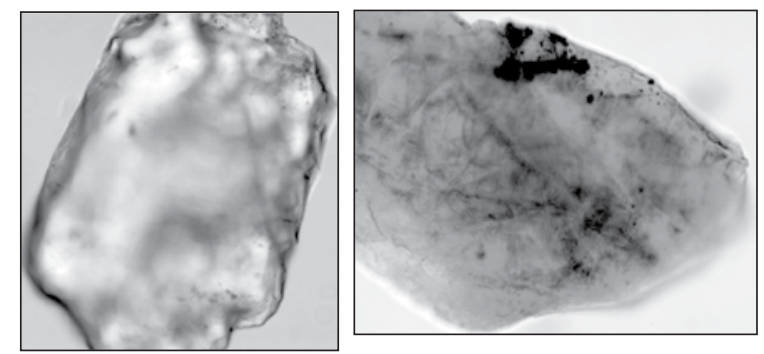
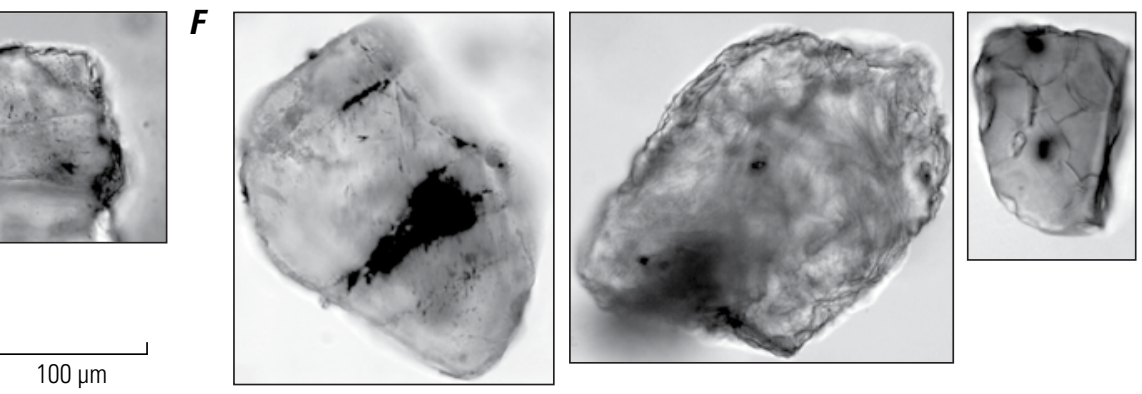

Figure 57. Photomicrographs of sand grains from Units 1-6 in cores SM11/11x and SM12 from Sand Mine marsh (see also fig. 56). $A$, Unit 1 sand grains from 11 centimeters $(\mathrm{cm})$ depth in core SM11/11x. Grains are from the 1964 tsunami deposit; textures are subangular to subrounded with smooth edges. $B$, Unit 2 sand grains from $24 \mathrm{~cm}$ depth in core SM11/11x. Grains are from a berm deposit; textures are angular to subrounded with smooth edges. $C$, Unit 3 sand grains from $50 \mathrm{~cm}$ depth in core SM11/11x. Grains are from a storm deposit; textures are subrounded with smooth edges. $D$, Unit 4 sand grains from $72 \mathrm{~cm}$ depth in core SM11/11x. Grains are from a storm deposit; textures are subangular to subrounded with smooth edges. $E$, Unit 5 sand grains from $90 \mathrm{~cm}$ depth in core SM11/11x. Grains are from the 1700 tsunami deposit; textures are angular with jagged edges. $F$, Unit 6 sand grains from $132 \mathrm{~cm}$ depth in core SM12. Grains are from a storm or beach deposit; textures are subangular to subrounded with smooth edges. $\mu \mathrm{m}$, micrometers. 


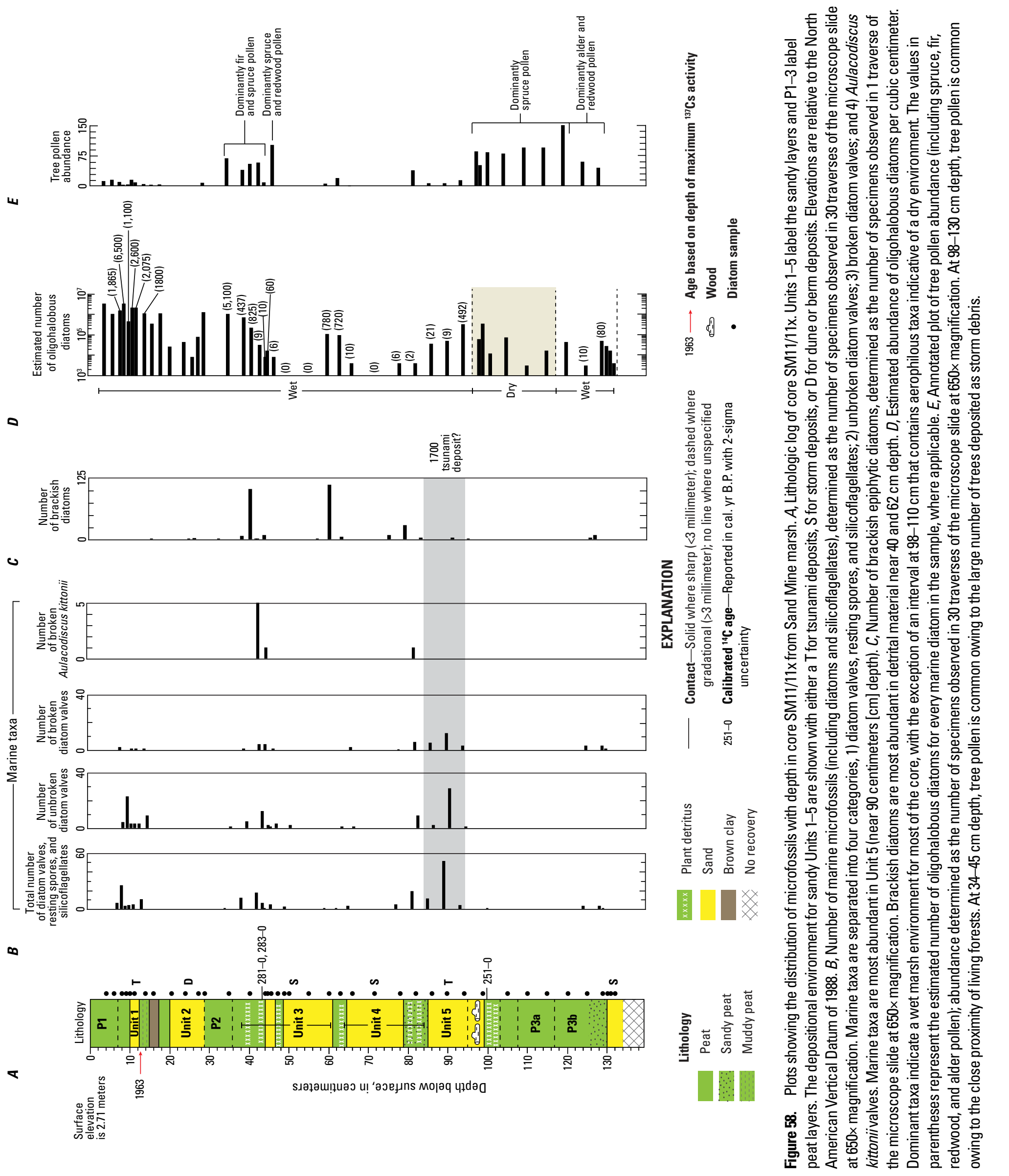




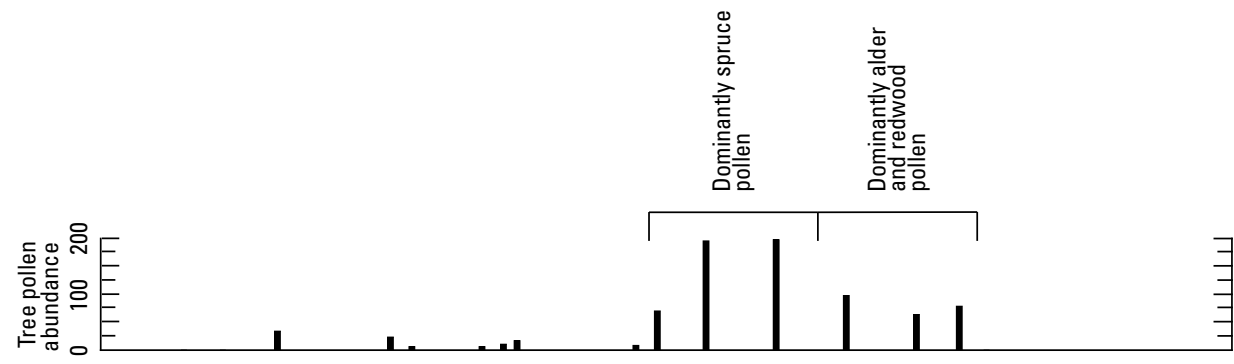

山

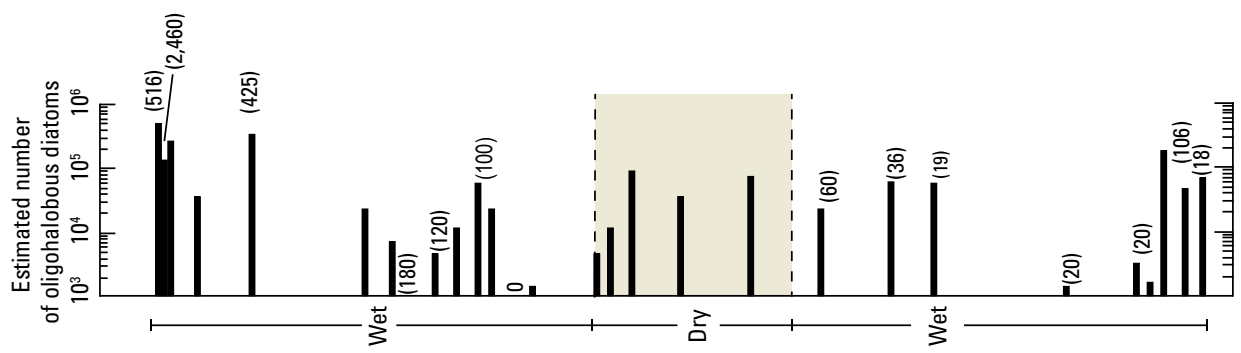

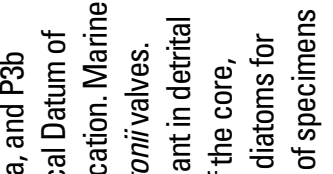

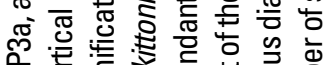

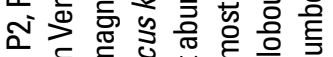

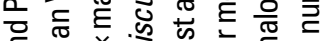

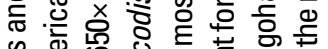

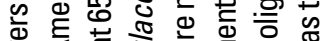

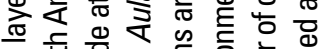
츨 흥 宇 质 ब 는

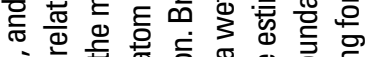

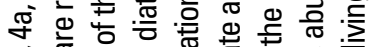

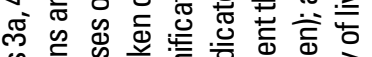

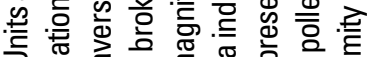

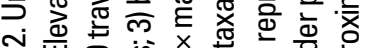
N के 立 O

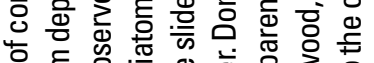

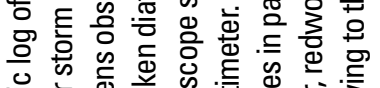

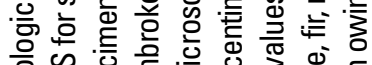

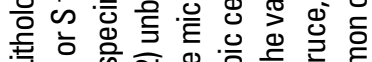

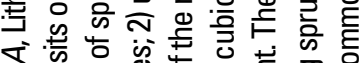
ए

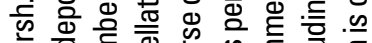

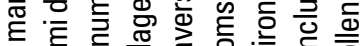
要

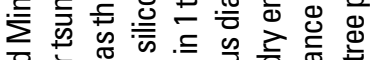

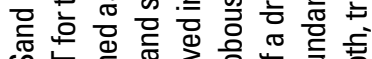
心

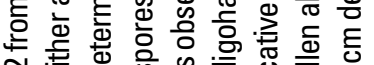

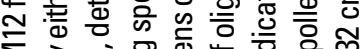
$\sum_{\infty}$ 文的宁

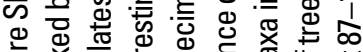
क 한

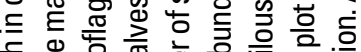
동

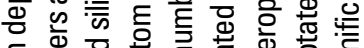

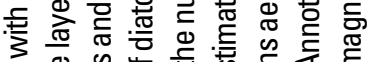

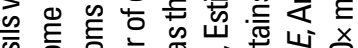

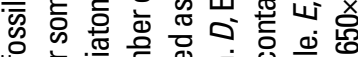

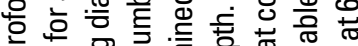

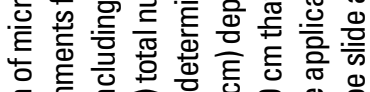

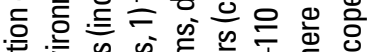

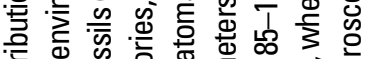

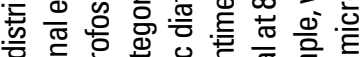

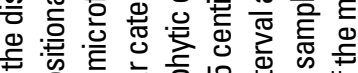

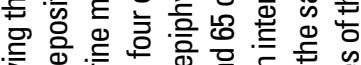
娄造

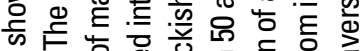

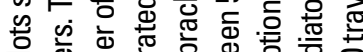

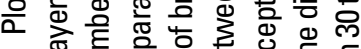

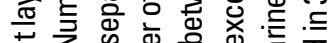

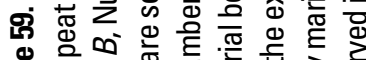

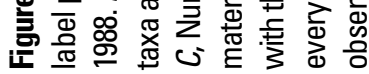


$\boldsymbol{A}$

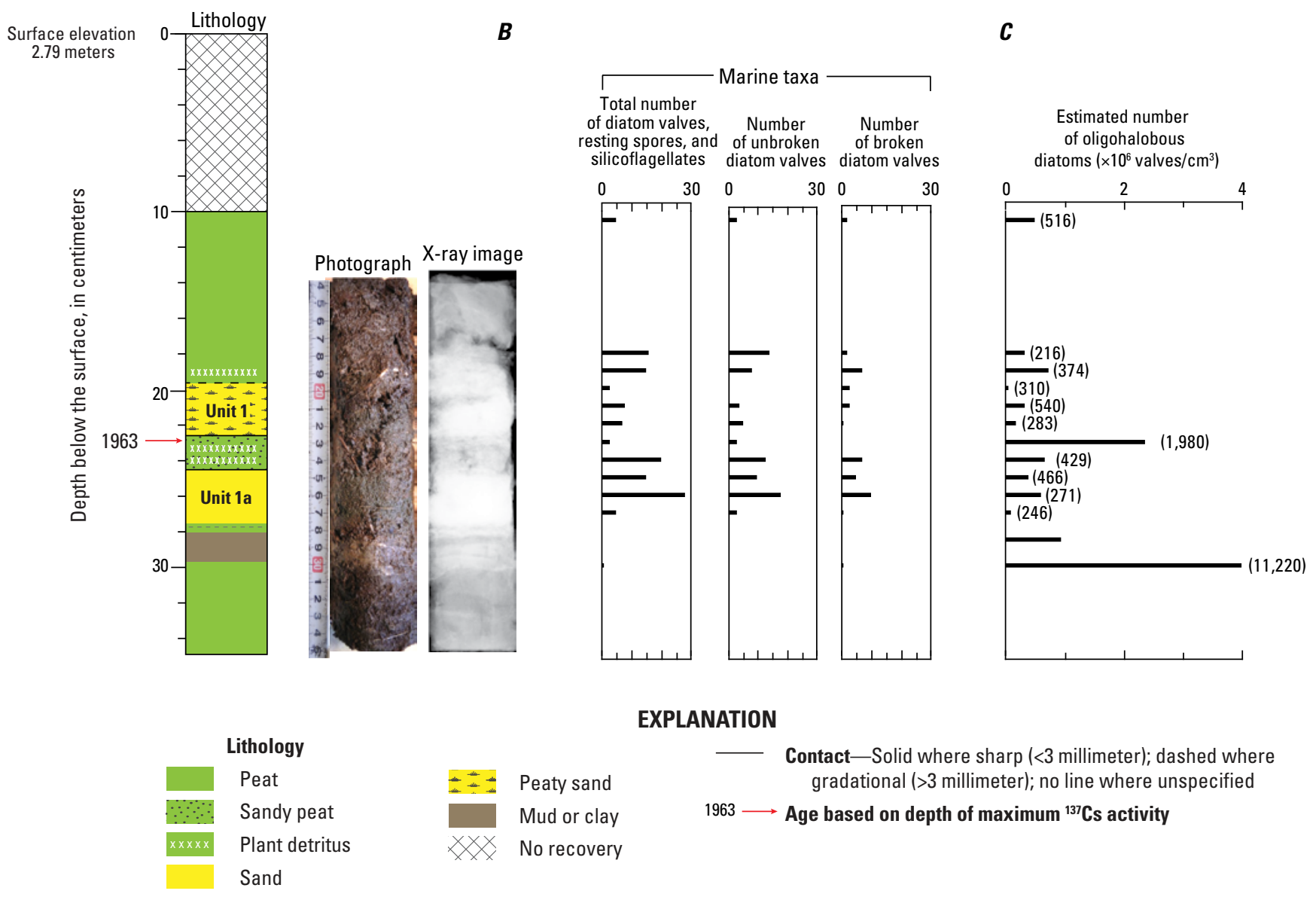

Figure 60. Plots showing the distribution of microfossils in core SM8 from Sand Mine marsh. A, Lithologic log, photograph, and X-ray image of core SM8. The 1964 tsunami deposit (Unit 1) consists of detritus and a layer of detritus-rich sand between 18 and 24 centimeters (cm) depth. The 1960 tsunami deposit (Unit 1a) is interpreted as a subjacent layer of fine sand between 25 and $27 \mathrm{~cm}$ depth. Slight differences in marine diatom assemblages and stratigraphic position relative to the maximum ${ }^{137} \mathrm{Cs}$ activity help to differentiate the two units as separate tsunami deposits. Elevations are relative to the North American Vertical Datum of 1988. $B$, Number of marine microfossils (including diatoms and silicoflagellates), determined as the number of specimens observed in 30 traverses of the microscope slide at 650x magnification. Marine taxa are separated into three categories: 1) total number of diatom valves, resting spores, and silicoflagellates; 2) unbroken diatom valves; and 3) broken diatom valves. $C$, Estimated abundance of oligohalobous diatoms, in millions of valves per cubic centimeter $\left(\times 10^{6}\right.$ valves $\left./ \mathrm{cm}^{3}\right)$. The values in parentheses represent the estimated number of oligohalobous diatoms for every marine diatom in the sample, where applicable.

In core SM8, a layer of sand and detritus between 18 and $22 \mathrm{~cm}$ depth is interpreted as correlative to Unit 1 in core SM11/11x, owing to its similar position just above the ${ }^{137} \mathrm{Cs}$ peak (figs. 58,60). A second sand and detritus deposit, referred to here as Unit 1a, occurs just below the ${ }^{137} \mathrm{Cs}$ peak in core SM8 (fig. 60) and contains marine diatoms. In core SM12, we refer to two sand and detritus intervals as Units $3 a$ and $4 a$ because they occur at comparable stratigraphic depths to Units 3 and 4 in SM11/11x (fig. 59), but we do not propose an exact correlation.
Unit 1

Diatoms in Unit 1 from cores SM11/11x and SM8 dominantly consist of prolific assemblages of oligohalobous taxa, consistent with accumulation in a low-salinity marsh or shallow pond. The most abundant oligohalobous species in the upper part of core SM11/11x is Sellaphora pupula. It occurs in combination with a diverse array of mostly pennate taxa, including Pseudostaurosira, Fragilaria, Eunotia, Navicula, Craticula, Neidium, Gomphonema, Pinnularia, Stauroneis, and Nitzschia species. 
Within the sand and capping detritus of Unit 1, the oligohalobous assemblages show a distinct fining-upward trend, with large valves of Stauroneis phoenicenteron, Craticula cuspidata, Nitzschia scalaris, and Pinnularia spp. concentrated in the lower part of the sand layer compared to the upper part of the sand layer and capping detritus (fig. 61A). A tally of the valve lengths of Sellaphora pupula specimens observed between 4 and $18 \mathrm{~cm}$ depth in core SM11/11x demonstrates the fining-upward trend of valve size within Unit 1, as well as the variability in the most frequent valve length (mode) between Unit 1 and adjacent deposits in the core (fig. 61B). Specimens of Sellaphora pupula in deposits above and below Unit 1 are dominantly about $35-37$ micrometers $(\mu \mathrm{m})$ long. In comparison, the mode of valve length in the lower part of the sand layer is $45 \mu \mathrm{m}$, which decreases to $40-41 \mu \mathrm{m}$ in the upper part of the sand layer and decreases further to $33-34 \mu \mathrm{m}$ in the capping detritus, where the smallest valves are concentrated.

Allochthonous marine diatoms and diatom fragments are present in Unit 1, although they are rare in comparison to the abundant background oligohalobous populations (figs. 58, 60). Prominent marine taxa in Unit 1 in both cores SM11/11x and SM8 include Thalassiosira pacifica and other small, similar species of Thalassiosira, as well as Odontella aurita, Actinoptychus senarius, Coscinodiscus radiatus, Thalassionema nitzschioides, and Endictya hendeyi (fig. 62). Diatoms in the detrital deposits of Unit 1 are, on average, better preserved than specimens in the sand layer (figs. 58, 62).

\section{Unit 1a}

Similar to Unit 1, allochthonous marine diatoms are present in Unit 1a in core SM8, although oligohalobous taxa are vastly more abundant — estimated to be several hundred to more than one thousand times more abundant than marine diatoms (fig. 60). Diatoms in Unit 1a include Odontella aurita, Actinoptychus senarius, and Coscinodiscus radiatus, similar to Unit 1, but, unlike Unit 1, Thalassiosira spp. are neither prominent nor diverse in Unit 1a. Taxa that are absent in Unit 1 but observed in Unit la
$\boldsymbol{A}$

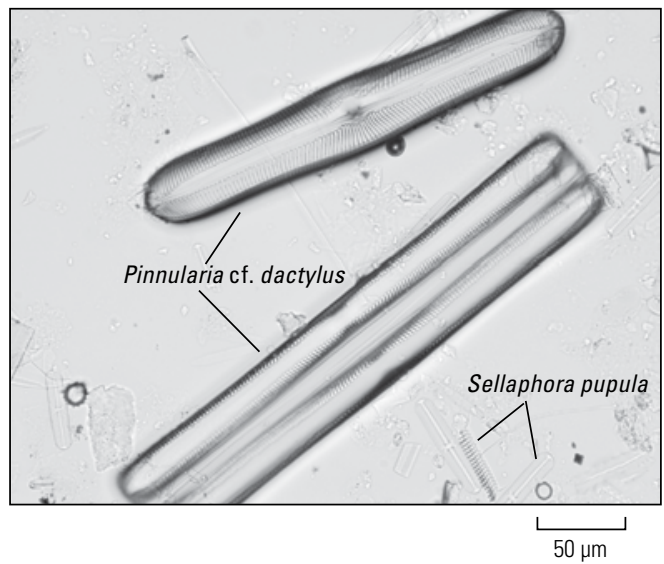

EXPLANATION

Lithology

Rooted muddy peat

Detrital peat or muddy peat

Fine sand

Brown clay

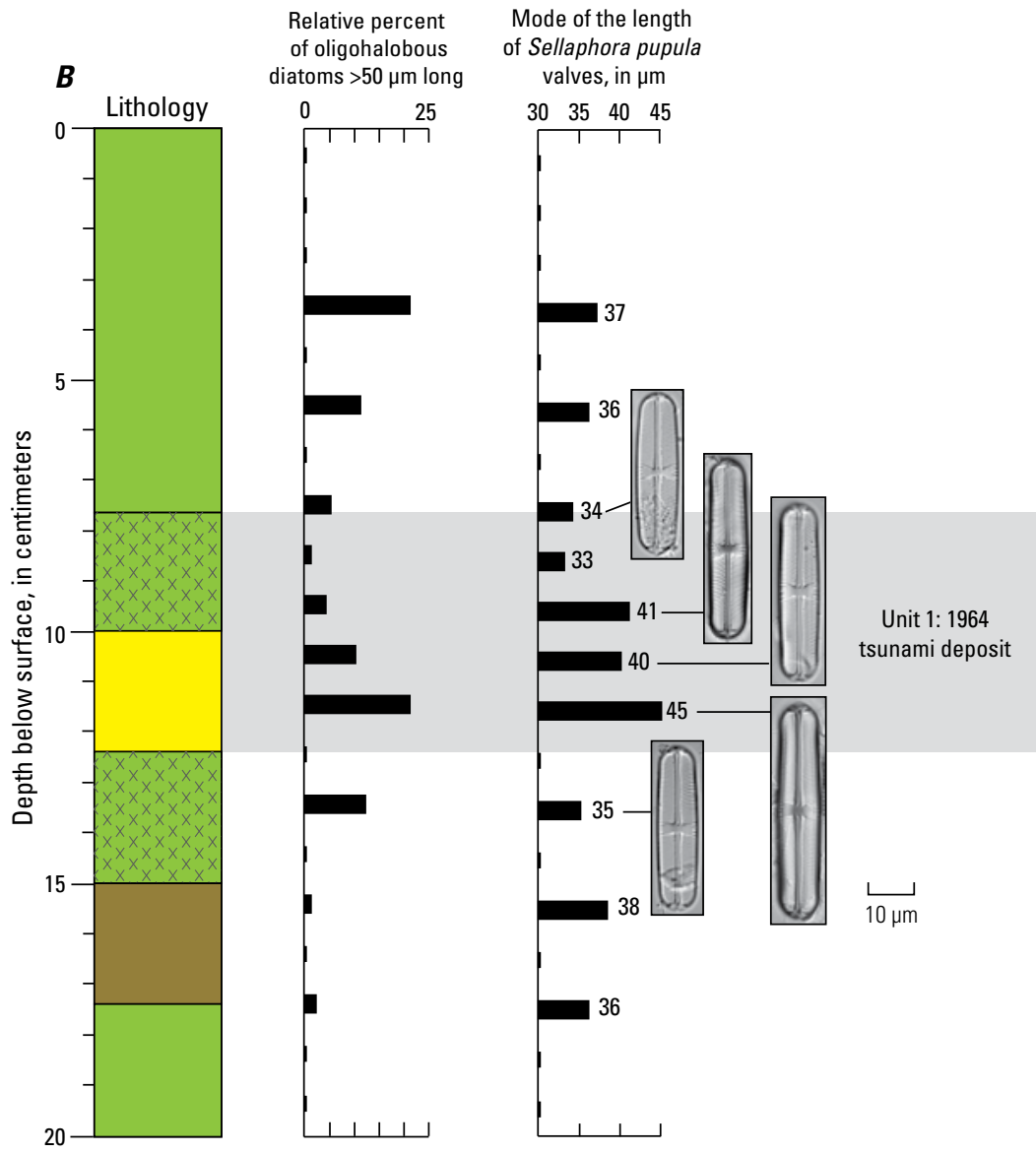

Figure 61. Diatom evidence for normal grading in the 1964 tsunami deposit in core SM11/11x from Sand Mine marsh. $A$,

Photomicrograph showing examples of exceptionally large Pinnularia cf. dactylus diatom valves that are concentrated in the sand layer at 12 centimeters $(\mathrm{cm})$ depth. The Sellaphora pupula valves at lower right are typical of the size of pennate taxa found throughout the core. $B$, Lithologic log and plots showing diatom distribution in the upper $20 \mathrm{~cm}$ of core SM11/11x. Progressively decreasing numbers of large (>50-micrometers $[\mu \mathrm{m}]$ long) oligohalobous diatoms and decreasing valve sizes for Sellaphora pupula from the base of the sand layer to the capping detritus reveals normal grading in the 1964 tsunami deposit. 


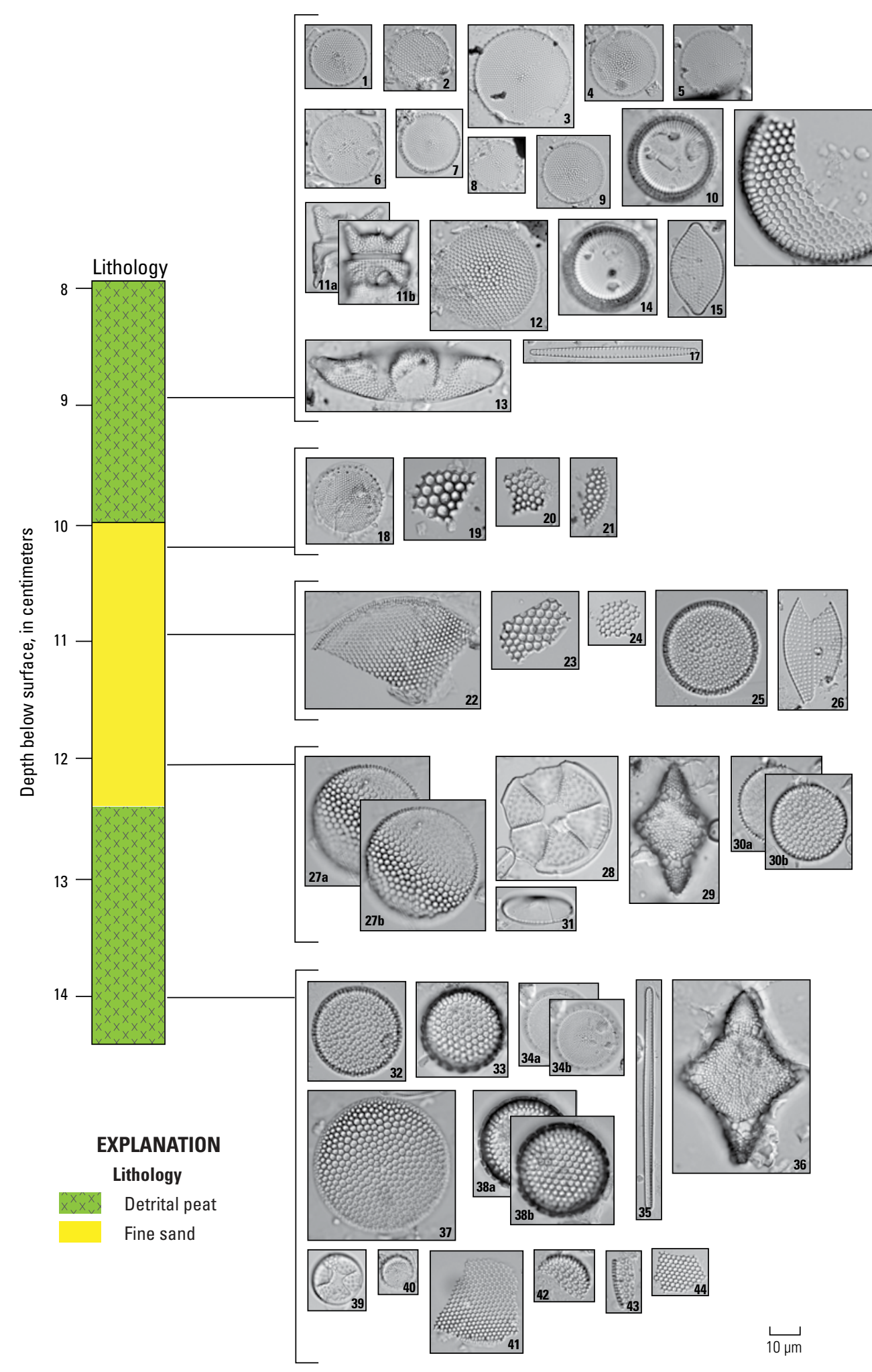

Figure 62. Marine diatoms of the 1964 tsunami deposit in core SM11/11x from Sand Mine marsh. At left, lithologic log of the detrital peat and fine sand that compose the 1964 tsunami depoit. At right, photomicrographs of marine diatoms from several layers of the 1964 tsunami deposit. Small planktonic taxa are prominent in the detrital peat that caps the sand layer. Photomicrographs with parts $a$ and $b$ focus on (a) margins and (b) interior structures of diatom valves. $1-9$, Thalassiosira pacifica; 10, Paralia sulcata; 11, Odontela aurita; 12, Thalassiosira eccentrica; 13, Odontella sp.; 14, Paralia sulcata; 15, Rhaphoneis amphiceros; 16, Endictya oceanica; 17, Thalassionema nitzschioides; 18, Thalassiosira pacifica; 19-24, diatom fragments; 25, Coscinodiscus radiatus; 26, Rhaphoneis amphiceros; 27, Coscinodiscus radiatus; 28, Actinoptychus senarius; 29, Biddulphia reticulata var. rhombica; 30, Coscinodiscus radiatus; 31 , Chaetoceros $\mathrm{sp}$. resting spore; 32 , Coscinodiscus radiatus; 33, Endictya hendeyi; 34, Thalassiosira nordenskioldii; 35 , Thalassionema nitzschioides; 36 , Biodulphia reticulata var. rhombica; 37, Coscinodiscus radiatus; 38 , Endictya hendeyi; 39, Actinoptychus senarius; 40 , Thalassiosira sp.; $41-44$, diatom fragments. $\mu \mathrm{m}$, micrometers. 
include Rhaphoneis amphiceros, Delphineis karstenii, Roperia tesselata, Stephanopyxis turris, and several species of Cocconeis.

\section{Unit 2}

Diatoms were examined in three samples across the 8-cm-thick deposit of well-sorted fine sand in Unit 2 of core SM11/11x (fig. 58). Diatoms are sparse in Unit 2, consisting entirely of oligohalobous taxa, the majority of which are poorly preserved (fig. 63). Marine diatoms are absent. Some of the rare oligohalobous taxa observed include species of Pinnularia and Eunotia, as well as aerophilous taxa typical of aerobic environments, such as Cosmioneis pusilla, Pinnularia lagerstedtii, Hantzschia amphioxys, and Cavinula lapidosa.

\section{Units 3, 3a, 4, 4a, and 6}

Diatoms assemblages show similar characteristics in Units 3 and 4 in core SM11/11x and in Unit 6 in core SM12. Similar assemblages are also observed in a section of sand and detrital peat in Units 3a and 4a, located between 40 and $85 \mathrm{~cm}$ depth in core SM12 (fig. 59). Most of the diatoms observed in these two units were recovered from sandy detrital peat because the majority of the clastic sand samples were devoid of diatoms.

Oligohalobous diatoms are present in Units 3, 3a, 4, 4a, and 6 , although they are 1-2 orders of magnitude less abundant than the prolific populations observed in the upper few decimeters of cores SM11/11x and SM12 (figs. 58, 59; appendix 4, tables $4.8,4.9)$. Marine diatoms are also present, but, where they occur, are still far outnumbered by oligohalobous diatoms. The marine taxa include an array of benthic, planktonic, and tychoplanktonic species found in nearshore and estuarine environments, including Aulacodiscus kittonii (images 9, 10, 27, and 47 of fig. 64), a surfzone species found along the U.S. West Coast and in temperate coastal zones worldwide (Campbell, 1996; Odebrecht and others, 2010). Sturdy benthic and tychoplanktonic taxa present include Actinoptychus senarius, Actinoptychus vulgaris, Paralia sulcata, Endictya hendeyi, and several species of Budulphia. Also present is Hyalodiscus laevis, a large centric diatom (images 29-31 and $37-40$ of fig. 64) that is epiphytic on seaweed, but also found in large numbers among coastal plankton (Edwards, 1904) as well as on estuarine tidal flats (Tynni, 1986), including Humboldt Bay (Hemphill-Haley, unpub. data).

Brackish benthic diatoms also occur in the sandy detrital peat deposits of Units 3, 4, and 6 in cores SM11/11x and SM12 (figs. 58, 59, 65), as well as in plant detritus encased in the massive sand deposit of Unit 6 at $148 \mathrm{~cm}$ depth in core SM12 (images 11 and 12 of fig. 65).

The presence of the brackish taxa is enigmatic because, unlike freshwater- or salt-marsh assemblages that are typically composed of many different species, this assemblage primarily consists of seven different species: Cocconeis scutellum, Cocconeis scutellum var. parva, Ctenophora pulchella, Diploneis smithii, and most abundantly, Mastogloia elliptica, Mastogloia smithii, and Mastogloia cf. monodon. The first three taxa are epiphytes; Cocconeis scutellum and Cocconeis
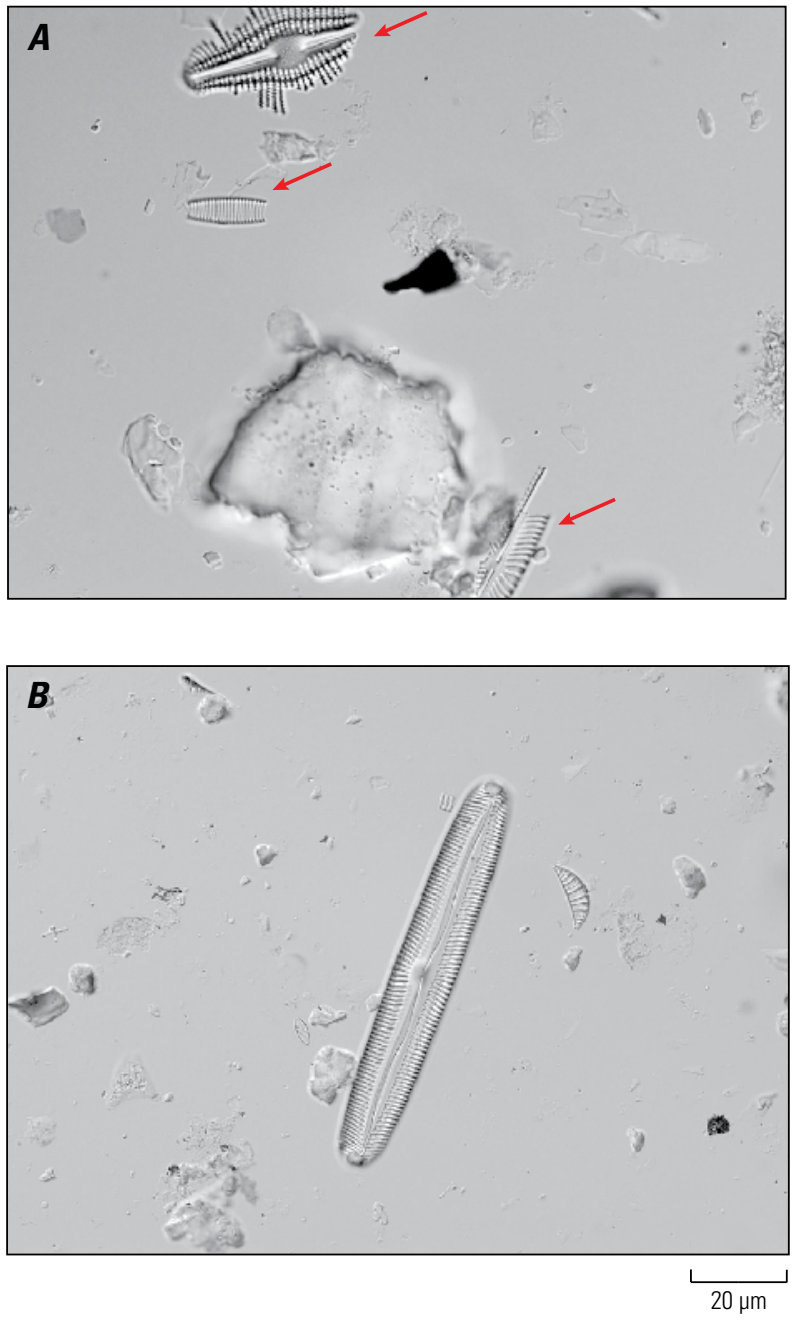

Figure 63. Photomicrographs of remnant oligohalobous diatoms in a sandy layer that is interpreted as a berm deposit. Diatoms from Unit 2 at 20-28 centimeters depth in core SM11/11x from Sand Mine marsh. $A$, Most oligohalobous diatoms are preserved as eroded fragments in the deposit (red arrows). B, A large, well-preserved valve of Pinnularia cf. viridiformis. $\mu \mathrm{m}$, micrometers.

scutellum var. parva are commonly found attached to eelgrass and other seaweed (Main and McIntire, 1974; Sawai, 2001). The remaining taxa are cosmopolitan epipelic or periphytic species that are found on muddy or other kinds of solid substrate (Hameed, 2003; Pennesi and others, 2011, 2012), as well as in the diverse assemblages common in low brackish marshes (Haubois and others, 2005; Roe and others, 2009; Engelhart and others, 2016). To date, we have not identified a modern analog for deposits containing this kind of lowdiversity brackish assemblage, even after sampling modern nearshore soil deposits and seaweed debris along the coast south of the Sand Mine marsh study site, as well as brackish ditches along the shore of northern Humboldt Bay. 
A

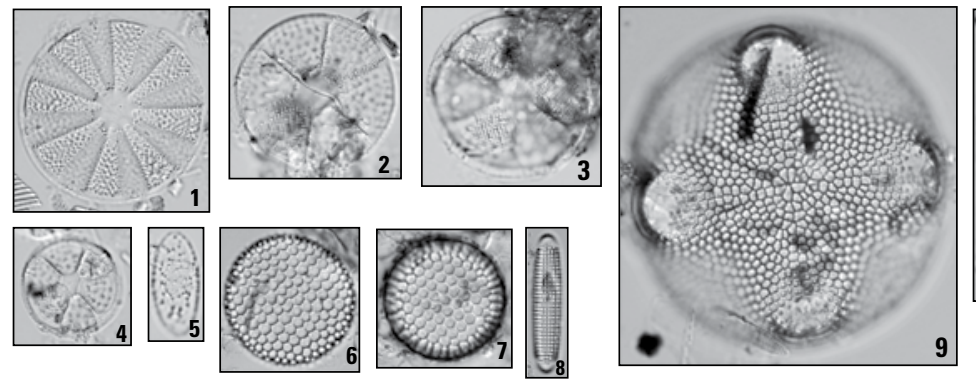

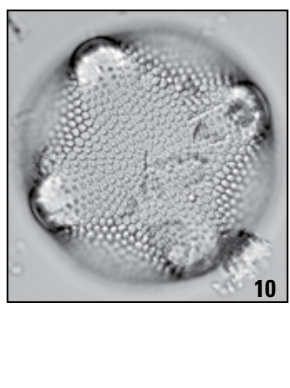
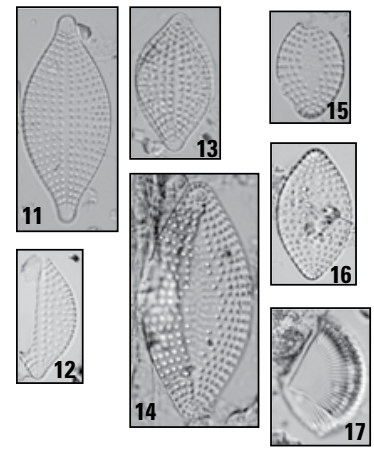

B
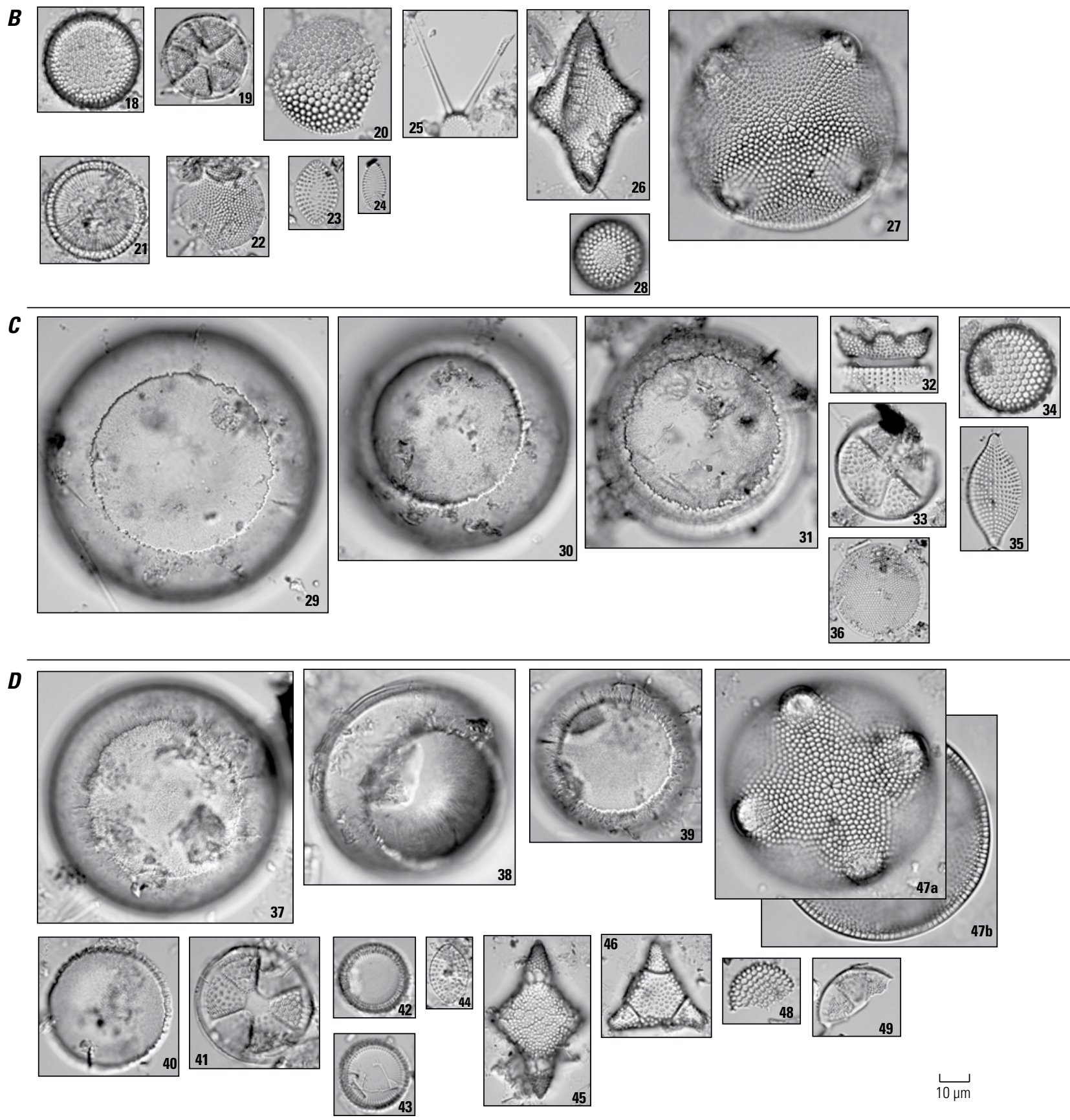

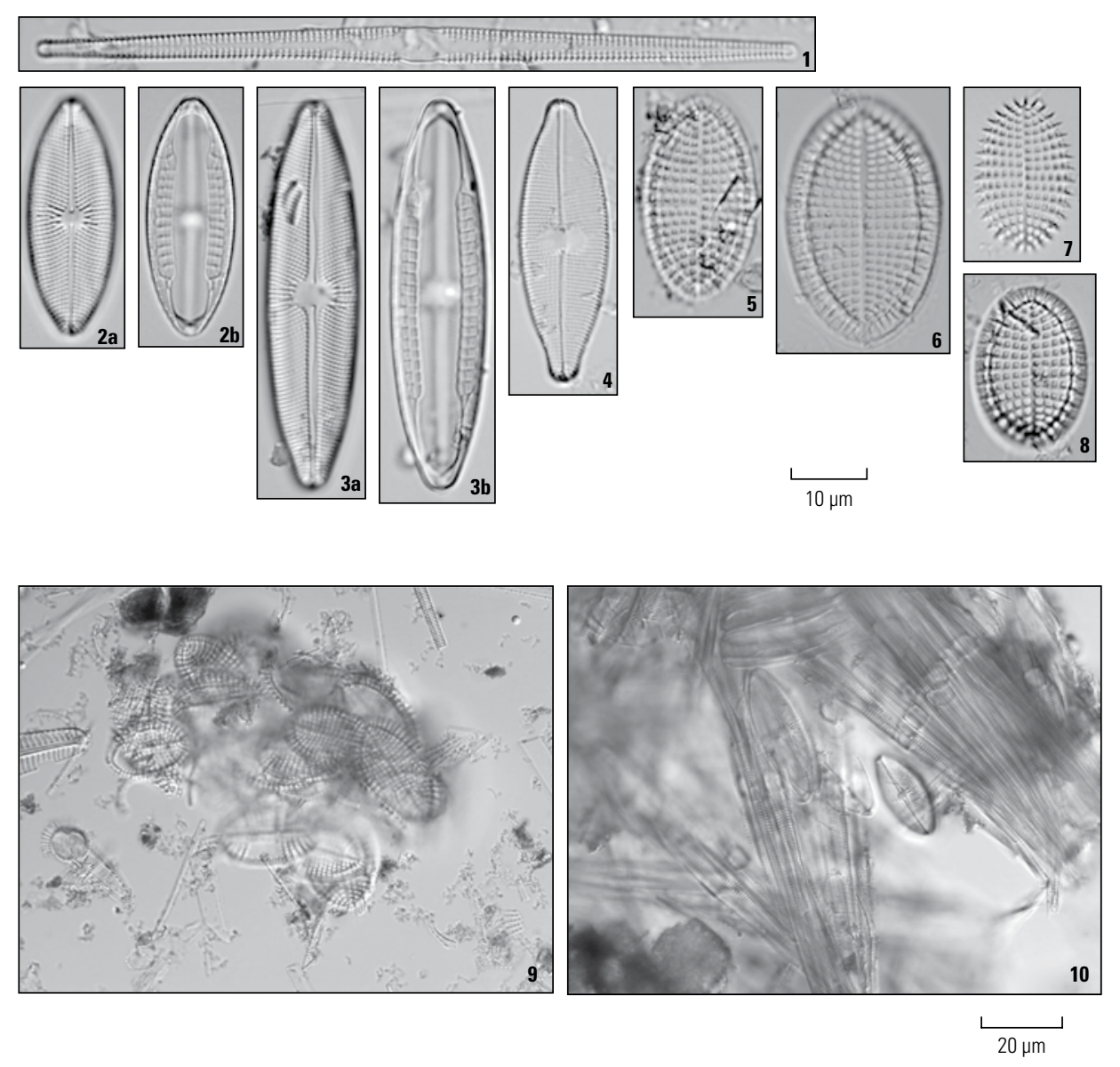

Figure 65. Photomicrograph of brackish diatoms in core SM11/11x from Sand Mine marsh. 1, Ctenophora pulchella; 2-3, Mastogloia elliptica, focus on (a) exterior and (b) interior structures of the same valve; 4, Mastogloia cf. monodon; 5-6, Cocconeis scutellum (rapheless valves), 7-8, Cocconeis scutellum var. parva (rapheless valves); 9, cluster of Cocconeis scutellum var. parva in detrital peat clast; 10, cluster of Ctenophora pulchella with a few Mastogloia elliptica from a detrital peat clast. $\mu \mathrm{m}$, micrometers.

\section{Unit 5}

Similar to Units 3,4 , and 6 , diatoms in Unit 5 in core SM11/11x include low concentrations of miscellaneous oligohalobous diatoms. Marine diatoms are also present, but the assemblage differs strongly from those assemblages in Units 3, 4, and 6. The majority of the marine taxa in Unit 5 are smaller and show better preservation, and, in fine sand at $90 \mathrm{~cm}$ depth in core SM11/11x, are several times more abundant than in any of the marine diatom bearing samples in Units 3, 4, or 6.

Prominent marine taxa in Unit 5 include benthic species commonly found on sandy substrate, such as Rhaphoneis psammicola and Endictya oceanica, and taxa common among coastal plankton such as Rhaphoneis amphiceros, Anaulus birostratus, and the silicoflagellate Distephanus speculum (fig. 66).

A Q-mode cluster analysis of samples from Units 1-6 that contain marine diatoms shows the overall similarities and differences of the assemblages emplaced at different times in the core record (fig. 67). Samples from Unit 1 in cores SM11 and SM8 contain similar assemblages, and therefore cluster together. They form a larger cluster with the assemblages in Units 1a and 3. Two different samples from Unit 6 in core SM12 cluster together and form a larger cluster with samples from Units 4 and $4 \mathrm{a}$. The sample from Unit 5 is isolated from the other samples - a result of the dissimilarity between the assemblage of marine taxa observed in this sample and the types and abundances of taxa present in the other samples.

Figure 64. Photomicrographs of marine diatoms recovered from storm deposits in cores SM11/11x and SM12 from Sand Mine marsh. $A$, Diatoms from 47-49 centimeters (cm) depth in core SM11/11x. 1, Actinoptychus vulgairs, 2-4, Actinoptychus senarius, 5, Chaetoceros sp. resting spore; 6, Coscinodiscus radiatus, 7, Endictya hendeyi, 8, Grammatophora sp.; 9-10, Aulacodiscus kittonii, 11-13, Rhaphoneis amphiceros. 14-16, Rhaphoneis psammicola; 17, Paralia sulcata fragment. B, Diatoms from $82 \mathrm{~cm}$ depth in core SM11/11x. 18, Endictya hendeyi, 19, Actinoptychus senarius, 20, Coscinodiscus radiatus, 21, Paralia sulcata; 22, Thalassiosira sp.; 23, Rhaphoneis psammicola; 24, Delphineis aff. margaritalimbata; 25, Odontella sp. fragment; 26, Biddulphia reticulata var. rhombica; 27, Aulacodiscus kittonii, 28, Stephanopyxis sp. C, Diatoms from $43 \mathrm{~cm}$ depth in core SM12. 29-31, Hyalodiscus laevis, 32, Odontella aurita; 33, Actinoptychus senarius, 34, Endictya hendeyi, 35, Rhaphoneis amphiceros; 36, Thalassiosira cf. pacifica. D, Diatoms from $131 \mathrm{~cm}$ depth in core SM12. 37-39, Hyalodiscus laevis, 40, eroded remnant of Hyalodiscus laevis; 41, Actinoptychus senarius, 42-43, Paralia sulcata; 44, Rhaphoneis psammicola; 45, Biddulphia reticulata var. rhombica; 46, Biddulphia alternans; 47, Aulacodiscus kittonii, focus on (a) interior and (b) marginal structures; 48, Stephanopyxis fragment; 49, Actinoptychus senarius fragment. $\mu \mathrm{m}$, micrometers. 


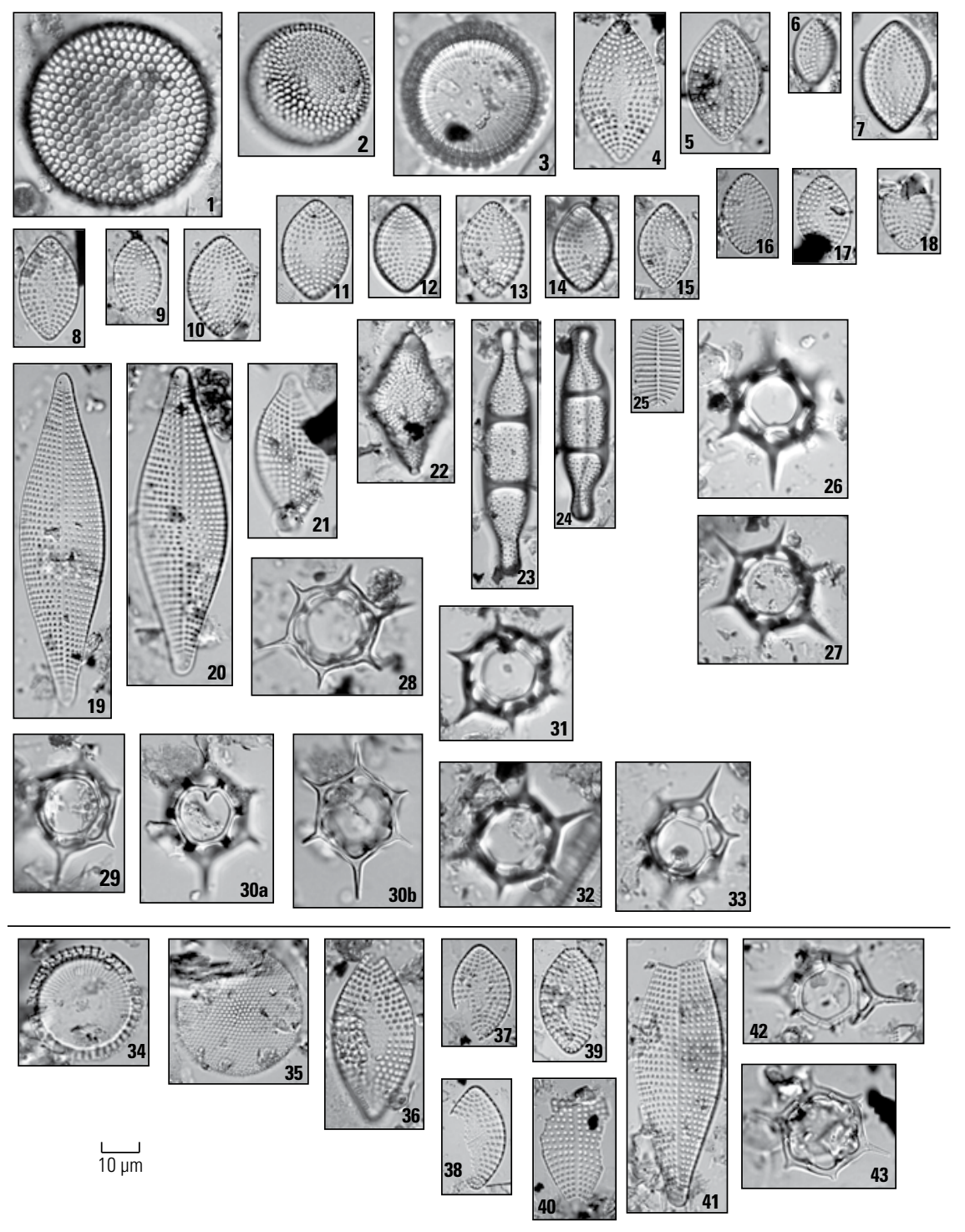

Figure 66. Photomicrographs of marine diatoms and silicoflagellates in the 1700 tsunami deposit in core SM11/11x from Sand Mine marsh. Well-preserved valves are shown in images 1-33 (above solid black line), poorly preserved valves are shown in images 34-43 (below solid black line). 1, Endictya oceanica; 2, Stephanopyxis sp.; 3, Paralia sulcata; 4-18, Rhaphoneis psammicola; 19-21, Rhaphoneis amphiceros; 22, Biddulphia reticulata var. rhombica; 23-24, Anaulus birostratus; 25, Cocconeis costata; 26-33, silic oflagellate Distephanus speculum; 34, Paralia sulcata; 35, Thalassiosira cf. lineata; 36-39, Rhaphoneis psammicola; 40-41, Rhaphoneis amphiceros; 42-43, Distephanus speculum. $\mu \mathrm{m}$, micrometers.

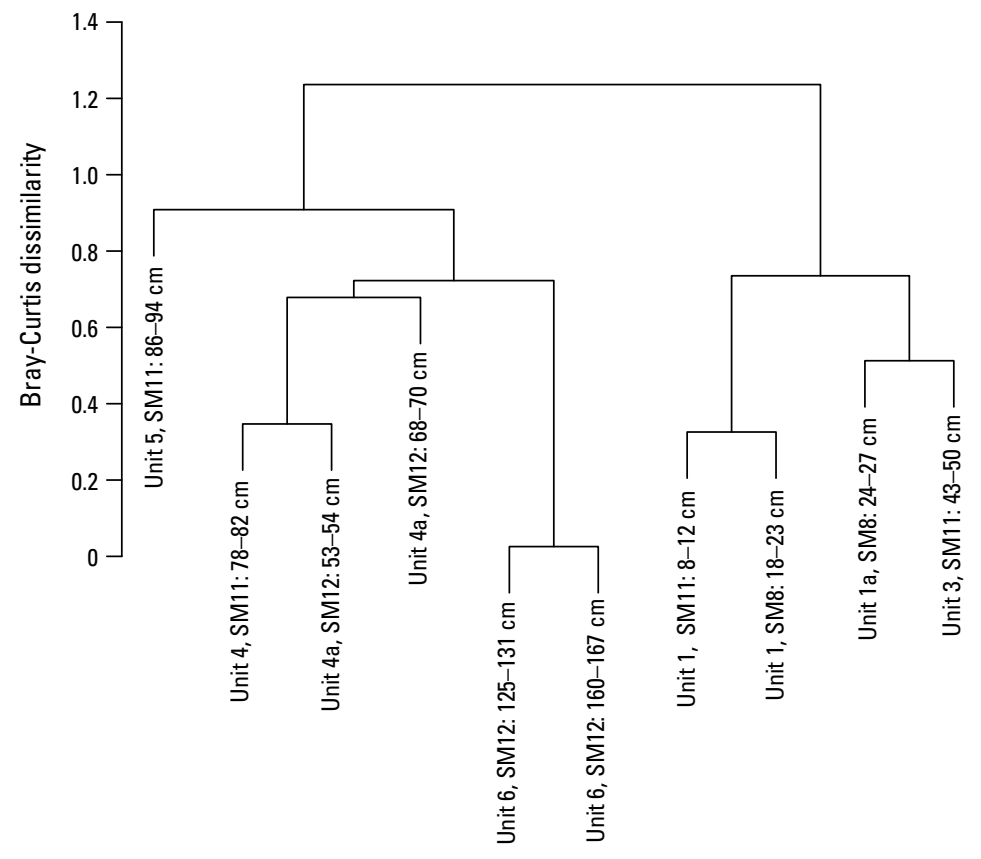

Figure 67. Graph showing Bray-Curtis dissimilarity (results of Q-mode cluster analysis) for diatom assemblages in clastic deposits in cores from the Sand Mine marsh western field site. Diatom sample labels identify the unit name, core name, and depth of sampling (in centimeters, $\mathrm{cm}$ ). The agglomerative coefficient is 0.68 . 


\section{Peaty Deposits}

Diatom assemblages found in peaty sections of cores SM11, SM11x, and SM12 help to identify the types of paleoenvironments in existence at the time that various sandy deposits were emplaced, and also provide paleontological evidence for coseismic subsidence.

Non-detrital marsh peat in cores SM11, SM11x, and SM12 can be divided into three units, labeled P1, P2, and P3 (figs. 58, 59). P1 consists of weakly consolidated modern peat deposits in the uppermost $10 \mathrm{~cm}$ of core SM11/11x. This unit was observed but not retained during core extraction in core SM12. P2 refers to the fine-grained, reddish-brown peat at $30-36 \mathrm{~cm}$ depth in core SM11/11x and 30-38 cm depth in core SM12. P3 consists of fineto coarse-grained, crumbly brown peat between 105 and $130 \mathrm{~cm}$ depth in core SM11/11x and between 85 and $130 \mathrm{~cm}$ depth in core SM12. We further subdivide P3 into upper (P3a) and lower (P3b) sections based on additional diatom data.

Oligohalobous diatoms are prominent throughout both cores, suggesting that the study site has persisted as a lowsalinity environment for at least the past 1,600-1,800 years, based on ${ }^{14} \mathrm{C}$ age data from the lower part of core SM12 (fig. 59, table 1). Oligohalobous taxa are absent from a few sandy deposits in both cores, but are present in all deposits interpreted as in place. Abundances of oligohalobous taxa vary throughout the core record, but in the majority of samples where oligohalobous taxa are present, they either compose 100 percent of the assemblage or far outnumber any co-occurring brackish or marine taxa. Although no effort was made to enumerate in detail the diverse assemblages of oligohalobous species in these deposits, qualitative observations on the variability of dominant taxa in different parts of the cores provide insight into broad environmental changes at the site over time.

Diverse and prolific oligohalobous diatom assemblages in peat sections $\mathrm{P} 1, \mathrm{P} 2$, and $\mathrm{P} 3 \mathrm{~b}$ are consistent with a persistently wet, freshwater marsh or swamp environment. Prominent taxa include Sellaphora pupula, Nitzschia scalaris, Eunotia cf. glacialis, and a variety of large specimens of Pinnularia and Stauroneis species. The presence of abundant, small fragilarioid diatoms (including Pseudostaurosira brevistriata, Pseudostaurosira americana, and Fragilariforma exigua), in combination with a variety of large benthic taxa (such as Navicula peregrinopsis, Eunotia formica, Diploneis finnica, and Diploneis smithii var. dilatata), is also consistent with accumulation in a low-salinity marsh (Otte and Bellis, 1985; Roe and others, 2009). Diatoms in peat section P3b, between 115 and $130 \mathrm{~cm}$ depth in core SM11/11x and between 110 and $130 \mathrm{~cm}$ depth in core SM12, are not as well preserved as in the upper peat units, but similarly include taxa that are consistent with a freshwater wetland (for example, Sellaphora pupula, Nitzschia scalaris, Eunotia formica, and Psuedostaurosira americana).

In contrast to the diatom assemblages in these peat units, taxa in peat section P3a, at 99-115 cm depth in core SM11/11x and $85-110 \mathrm{~cm}$ depth in core SM12, indicate a dry, well-drained environment rather than a wet, fresh marsh or pond. Prominent taxa include Pinnularia gibba, Pinnularia lagerstedtii, Eunotia bidens, Eunotia cf. implicata, Cosmioneis pusilla, and Nitzschia terrestris (fig. 68).
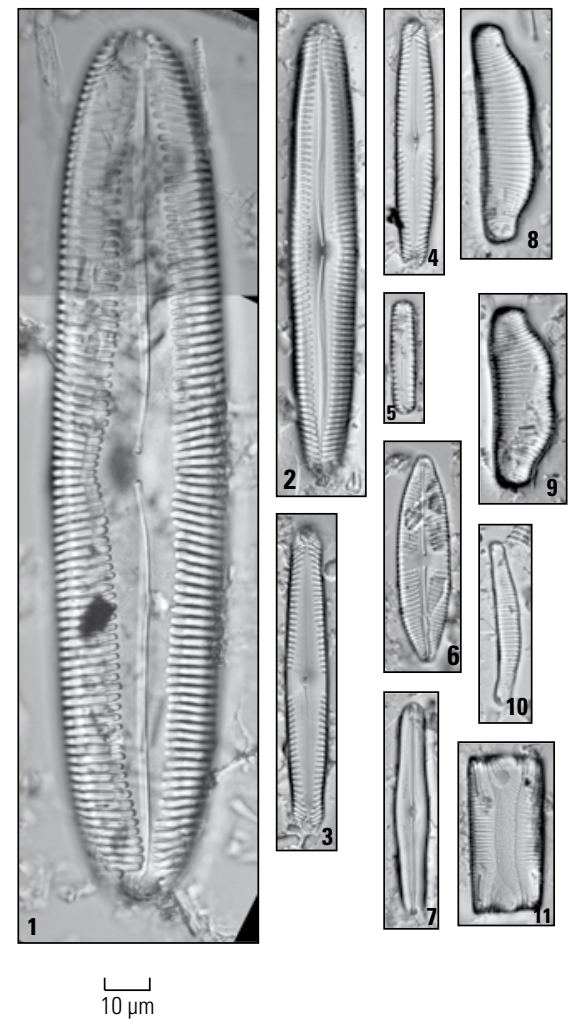

\section{2}

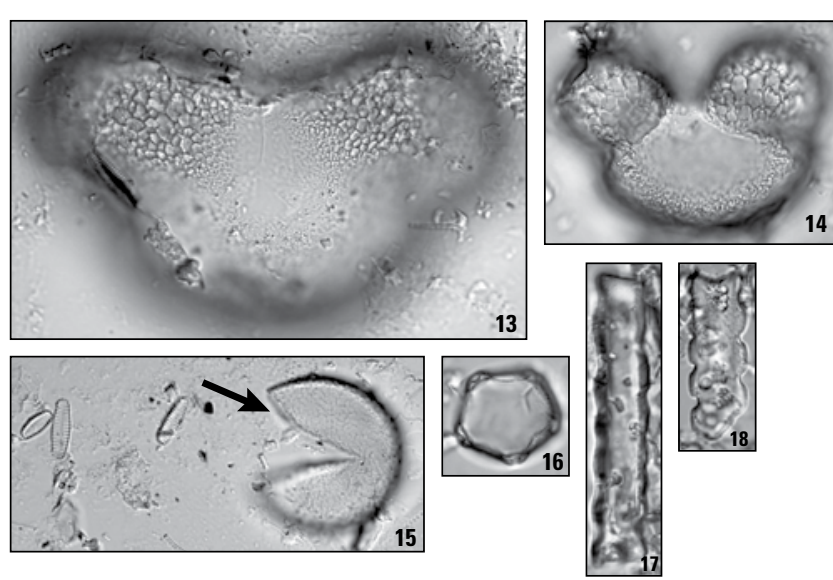

Figure 68. Photomicrographs of aerophilous diatoms, pollen, and phytoliths in compacted brown peat in the lower parts of cores SM11/11x and SM12 from Sand Mine marsh. 1, Pinnularia viridis; 2, Pinnularia cf. viridiformis; 3-4, Pinnularia gibba; 5 , Pinnularia lagerstedtii; 6 , Placoneis sp.; 7, Caloneis sp.; 8-9, Eunotia bidens; 10-11, Eunotia implicata; 12, lower magnification field of view showing Eunotia bidens (arrows) and overall sparse diatom occurrence relative to background particles, including diatom fragments; 13 , spruce pollen grain; 14 , fir pollen grain; 15 , redwood pollen grain (arrow); 16, alder pollen grain; 17-18, phytoliths. $\mu \mathrm{m}$, micrometers. 
Phytoliths ${ }^{9}$ and spruce pollen, observed as background particles on diatom slides, are also prominent in peat section P3a, particularly at 101-110 cm depth in core SM11/11x and $88-95 \mathrm{~cm}$ depth in core SM12 (figs. 58E, 59E). The phytoliths in this peat interval are dominantly of the "smooth elongate" form and secondarily of the "sinuate elongate" form, both of which are indicative of grasses found in coastal marshes ( $\mathrm{Lu}$ and Liu, 2005). Although pollen grains can be transported long distances, the coincidence of the higher concentrations of tree pollen in unit P3a is more consistent with forests encroaching closer to the core location than if it were a lower and wetter marsh or swamp. Therefore, the higher concentrations of phytoliths and pollen in peat section P3a also suggest that the site was dry and emergent for some period of time preceding emplacement of the overlying sand and detritus deposits.

\section{Data Interpretation}

\section{Paleoenvironmental Changes and Coseismic Subsidence}

The diatom data from the western field site at Sand Mine marsh show that the study site persisted as a low-salinity environment for the past $\sim 1,800$ years. There is no evidence that the locality converted to a sustained intertidal or otherwise saline environment during this time interval. Furthermore, the diatom data show that, for most of the record, the locality was a wet freshwater marsh or swamp, comparable to the modern Sand Mine marsh environment. The only exception is a period of time during which the locations of cores SM11 and SM12 - and possibly a larger area of the marsh ${ }^{10}$ - were drier and more emergent relative to the local water table than at present (figs. 58D, 59D), suggested by common occurrences of aerophilous diatoms, as well as phytoliths and greater concentrations of spruce pollen. A possible comparable modern analog for this former emergent environment might be the well-drained, dry meadows of the Elk Creek wetland study site (for example, see figs. $40 A$ and $41 A$ ).

With no evidence of a significant change in salinity at the field site over time, explaining the presence of brackish diatoms in detrital deposits in cores SM11/11x and SM12 is difficult (figs. 58C, 59C). Sporadic occurrences of brackish epiphytic diatoms do suggest instances of elevated salinity, but the low-diversity assemblages are consistent with growth on seaweed, mud, or periphytic surfaces, and differ from the kinds of diverse benthic assemblages typical of salt marshes

\footnotetext{
${ }^{9}$ Phytoliths are siliceous microfossils formed by silica precipitation in the cells of terrestrial plants. They are particularly associated with plants in the grass family (Gramineae) (Lu and Liu, 2003; 2005).

${ }^{10} \mathrm{We}$ do not have data from cores collected in the eastern field site (SM2, SM3, and SM4) to show if this period of an emergent environment was widespread or only applicable to the western field site. However, Carver and others (1998) describe a comparable interval of "compacted peat" in their cores that extends inland across the marsh and underlies a widespread sand unit they describe as sand layer W. This compacted peat interval is at a comparable depth to what we observe in cores SM11/11x and SM12, and we propose that it is correlative, suggesting that a former emergent surface was widespread and not restricted to the western field site.
}

(for example, Hemphill-Haley, 1993, 1995b; Sherrod, 1999; Horton and others, 2006; Engelhart and others, 2016; Sawai and others, 2016, 2017). Although we have yet to identify similar modern-analog examples of the brackish assemblages, a possible scenario could be accumulation in short-lived brackish pools or on storm wrack produced by intense storm activity. We therefore interpret the occurrence of brackish taxa as temporary populations associated with detrital deposition, rather than evidence for a sustained change to a saline environment.

In core SM11/11x, the spike in the brackish epiphytes in detrital deposits between $\sim 36$ and $50 \mathrm{~cm}$ depth is correlative to high numbers of spruce, redwood, and fir pollen (fig. 58). In this case, the co-occurrence of brackish diatoms and tree pollen is interpreted as a result of massive accumulation of trees and debris along the shoreline following storm inundation, as occurred in the 1800s based on historical accounts for the area (Farquhar, 1930; Bearss, 1982).

The apparent persistence of a freshwater environment at the Sand Mine marsh study site, however, does not preclude coseismic subsidence at this location. In the eastern field site, where there are only a few distinctive sand layers intercalated in primarily organic-rich peaty deposits (fig. 50), there is lithostratigraphic evidence for coseismic subsidence: an abrupt transition from a well-developed, lithic-poor peat (buried soil) underlying a sand layer with abundant plant detritus to muddy peat above the sand layer. This stratigraphic sequence is observed in cores SM2, SM3, and SM3x at depths of about $0.7-0.8 \mathrm{~m}$ below the surface (fig. 50, appendix 1).

In the western field site, where the stratigraphy is more heterogeneous and has numerous sandy deposits intercalated in peaty deposits, the evidence for coseismic subsidence is more subtle, involving a change from a peat that accumulated in a dry, emergent environment to a peat that accumulated in a wet marsh or swamp. In cores SM11/11x and SM12, such an environmental transition occurs at the top of peat unit P3a (figs. 58, 59). The ${ }^{14} \mathrm{C}$ age data for cores SM11/11x and SM12 suggest that the mechanism for the observed subsidence was the 1700 Cascadia Subduction Zone earthquake.

There are mechanisms other than coseismic subsidence that could explain a shift from a dry to wet environment at the study site, such as blocking stream outflow and damming fresh water in the valley. The coincidence of accumulation of siliciclastic and detrital deposits containing marine diatoms with the environmental shift to a submerged freshwater wetland, however, seems more consistent with the area becoming lower and more susceptible to occasional flooding by tsunamis or storm surges, rather than becoming more separated and protected from marine inundation.

Coseismic subsidence associated with the 1700 earthquake and tsunami is also evidenced by changes in environment (based on diatom records) at Marhoffer Creek marsh and Elk Creek wetland. Subsidence roughly coincident with the 1700 tsunami is indicated at Elk Creek wetland by a change from freshwater marsh to salt marsh, and perhaps also at Marhoffer Creek marsh by a change from dry to wet without an accompanying increase in salinity, similar to that inferred above. 


\section{Depositional Mechanisms for Siliciclastic and Detrital Deposits}

Based on the results of the particle-size, diatom, and radionuclide analyses, the following depositional mechanisms are interpreted to explain occurrences of siliciclastic (sand, silt, and clay) and detrital peat deposits in Units 1-6 from cores collected in the western field site.

\section{Unit 1-1964 Tsunami Deposit}

Unit 1 in cores SM8 and SM11/11x is interpreted as the 1964 far-field tsunami deposit. This is based on the stratigraphic position of Unit 1 just above the $1963{ }^{137} \mathrm{Cs}$ peak as well as the presence of marine diatoms (figs. 52-55, 58, 60). The deposit can be correlated between cores along the length of the western field site as the most recent sand and detritus deposit (fig. 50), and represents the best example of the 1964 tsunami deposit that we observed among the three Crescent City study sites.

Compared to over- and underlying deposits that contain only oligohalobous diatoms, Unit 1 is characterized by occurrences of rare, allochthonous marine diatoms consistent with nearshore plankton and surface deposits (fig. 62) that were washed into the freshwater marsh and pond. A Q-mode cluster analysis (fig. 67) shows that among all assemblages of marine diatoms in different clastic deposits from the western field site at Sand Mine marsh, the two 1964 samples cluster together - a result of the two samples containing comparable diatom assemblages and supporting the conclusion that they record the same depositional event.

Although only a few centimeters thick, the 1964 tsunami deposit in core SM11/11x shows normal grading based on particle-size and diatom analyses (figs. 56, 61). The fining-upward trend observed in the diatom valve size is revealed by separately counting large and small specimens of abundant oligohalobous taxa that were suspended and redeposited in the pond with the arrival of the tsunami. The result is a deposit with large taxa concentrated at the bottom of the sand layer and progressively smaller valves present in the upper sand and capping detritus.

\section{Unit 1a-1960 Tsunami Deposit}

Unit 1a in core SM8 is interpreted as a far-field tsunami deposit from the Chilean earthquake of May 22, 1960. It is a 4-cm-thick layer of fine sand and silt containing marine diatoms that is stratigraphically subjacent to the $1963{ }^{137} \mathrm{Cs}$ peak (figs. 52, $53,60)$.

Because of its position below the ${ }^{137} \mathrm{Cs}$ peak, we conclude that it preceded the 1964 tsunami and records a separate event (in 1960), instead of representing a lower, sandy layer of a thick 1964 deposit. The interpretation that this deposit is distinct from the 1964 tsunami deposit (Unit 1) is further supported by statistical differences, based on Q-mode cluster analysis, between the diatom assemblage in this deposit and those in Unit 1 from cores SM8 and SM11/11x (fig. 67). These differences in marine diatom assemblages are great enough that, although the two 1964 samples from Unit 1 cluster together, the Unit 1a sample clusters with samples other than the 1964 samples. This suggests that the two Unit 1 deposits in cores SM8 and SM11/11x have more in common with each other than the Unit 1 and 1a deposits do within the same core (SM8), supporting the conclusion that Unit 1a was deposited at a different time - that is, probably in 1960.

In other cores from the western field site, we could not identify any other sand layers that are clearly separate from the 1964 deposits to suggest the presence of a 1960 deposit. In most cores only a single sand layer, the probable 1964 deposit, is evident between the modern surface and the gray clay correlation unit. For example, in core SM11/11x collected about 20 m northwest of core SM8 (fig. 46), a single sand layer occurs between the modern surface and the gray clay layer: the 1964 deposit, which is also stratigraphically superjacent to the ${ }^{137} \mathrm{Cs}$ peak (fig. 55). The limited distribution of the 1960 deposit on the coast at Crescent City, including at the western field site at Sand Mine marsh, is likely a result of the limited inundation from that event. Inundation from the 1960 tsunami was reported as approximately equivalent to the first wave of the 1964 tsunami, which flooded across Highway 101, but did not have the depth or the destructive impact of the largest wave that arrived about 2 hours after the first (Magoon, 1966; Dengler and Magoon, 2005).

\section{Unit 2-Berm or Dune Deposit}

Based on particle-size and diatom analyses, Unit 2 of core SM11/11x (fig. 56) is consistent with a berm or dune deposit. It is $8 \mathrm{~cm}$ thick and consists of well-sorted, negatively skewed fine sand. The deposit can probably be traced in the four northernmost cores of the western field site (SM5, SM6, SM11/11x, and SM12) (figs. 46, 50). Its emplacement in the marsh and pond is likely the result of migration or slumping of the adjacent berm, as opposed to sediment transport via storm surge or tsunami.

The absence of marine diatoms and low abundances of mostly poorly preserved oligohalobous diatoms (fig. 63A; appendix 4, table 4.8) suggests a berm or dune environment where diatom growth is limited to moist spots associated with larger plants and abrasion is pervasive owing to the shifting sand. Some of the better preserved oligohalobous taxa observed in Unit 2 samples belong to the genera Eunotia and Pinnularia (fig. 64B), some species of which may be found in moss on the sides and swales of sand dunes (Van de Vijver and Beyens, 1997; Nováková and Poulíčková, 2004), in addition to other aerophilous or fresh epiphytic environments (Krammer and Lange-Bertalot, 1986).

\section{Units 3, 4, and 6-Storm Deposits}

Based on particle-size and diatom analyses, we infer that the thick sand and coarse detritus deposits with sparse marine diatoms that make up Units 3, 4, and 6 represent storm-surge deposits. If that is true, the bulk of the subsurface sandy deposits observed in the western field site of Sand Mine marsh were emplaced by storms, not tsunamis. Thus, in the longest two cores, we infer that intervals at 42 to $80 \mathrm{~cm}$ depth in core SM11/11x, 50 to $80 \mathrm{~cm}$ depth in core SM12, and below $130 \mathrm{~cm}$ in both cores (fig. 56) probably all respresent storm surge deposits. 
Particle-size analysis shows that Units 3, 4, and 6 are massive deposits lacking consistent patterns in sorting or skewness (fig. 56). Under high magnification, the mineral grains show smooth, abraded edges, and are mostly subrounded to subangular in shape (fig. 57).

Marine diatoms in Units 3, 4, and 6 are present in sandy detrital deposits, but either are very rare or absent from the organic-poor sand layers (figs. 58, 59; appendix 4, tables 4.8, 4.9). The absence of marine diatoms in these sand deposits is not likely a function of the coarse grain size, because the sandy 1700 tsunami deposit at Marhoffer Creek marsh (fig. 56B), which contains prominent well-preserved marine taxa (figs. 20, 24-26), has similar grain size to Units 3, 4, and 6. A plausible explanation for the absence of marine diatoms is that the sand in these deposits was sourced from the beach and intervening berm, where marine diatoms are rare or absent (for example, Unit 2 in core SM11/11x), rather than from the offshore, shallow shelf environment, where benthic and planktonic diatoms accumulate in bottom sediment.

Marine diatoms in the storm deposits in cores SM11/11x and SM12 are typically sturdy taxa found in nearshore and estuarine environments (fig. 64). Q-mode cluster analysis confirms similarities in the assemblages observed in the stormsurge samples at Sand Mine marsh, particularly between Unit 6 (lower thick sand deposit) in core SM12 and parts of Units 3 and 4 in cores SM11/11x and SM12 (fig. 67). An exception to this observation is the mostly detrital-rich sample at $43-50 \mathrm{~cm}$ depth in core SM11, which forms a separate cluster based on compositional similarities with the 1960 tsunami deposit (fig. 67).

Some of the marine diatoms in the storm deposits at Sand Mine marsh, such as Rhaphoneis amphiceros, Actinoptychus senarius, and Paralia sulcata, are also present in the modern lower beach and swash zone at Pebble Beach (figs. 3, 18) as well as in storm-surge deposits in core MM16 from Marhoffer Creek marsh (figs. 20, 24). However, some taxa observed in the Sand Mine marsh storm deposits were not observed at Marhoffer Creek marsh — notably Aulacodiscus kittonii and Hyalodiscus laevis (fig. 64). As a result, a Q-mode cluster analysis of a combined dataset of assemblages in clastic deposits from both Sand Mine marsh and Marhoffer Creek marsh (fig. 69) show that, although all of the storm deposits are generally grouped together, samples of storm deposits from the same location cluster more closely together than storm deposit samples from different sites (that is, Sand Mine marsh versus Marhoffer Creek marsh).

\section{Unit 5-1700 Tsunami Deposit}

Of all the clastic deposits evaluated in cores SM11/11x and SM12, Unit 5 (located at 84-100 cm depth in core SM11/11x) is the most likely candidate for a near-field Cascadia Subduction Zone tsunami deposit. The calibrated ${ }^{14} \mathrm{C}$ age of $1668-1953$ C.E. (251-0 cal. yr B.P.) from seeds and wood fragments found below the sand at $100 \mathrm{~cm}$ depth (fig. 56, table 1) permits designating Unit 5 as the 1700 Cascadia Subduction Zone tsunami deposit.

In addition, sediment texture and sand-grain angularity support our conclusion that the clastic deposit is the 1700 tsunami deposit. Compared to the other clastic deposits, Unit 5 is distinctly graded (fig. 59), a texture commonly observed in, but not restricted to, tsunami deposits (Bourgeois, 2009; Shanmugan, 2012). At high magnification (fig. 57), sand grains in Unit 5 tend to be more angular and have sharper edges than grains from other sandy units. Costa and others (2012), in a scanning electron microscopy analysis of thousands of sand grains, reported higher occurrence of angular grains in tsunami deposits compared to storm or modern beach deposits.

The abundances and diversity of marine diatoms in Unit 5 are also consistent with a tsunami deposit. Compared to other clasticrich deposits in cores from Sand Mine marsh, marine diatoms in Unit 5 are more frequent and better preserved, consistent with having originated farther offshore than the surf zone or beach (figs. 58, 66; appendix 4, table 4.8). A Q-mode cluster analysis of clastic samples analyzed from Sand Mine marsh shows the dissimilarity between the marine diatom assemblage in Unit 5 and the 1964 tsunami (Unit 1), 1960 tsunami (Unit 1a), and storm deposits (Units 3, 4, and 6) (figs. 67, 69).

In contrast, the assemblage of marine diatoms in Unit 5 is comparable to that in the 1700 tsunami deposits at Marhoffer Creek marsh and Elk Creek wetland, particularly in the prominent

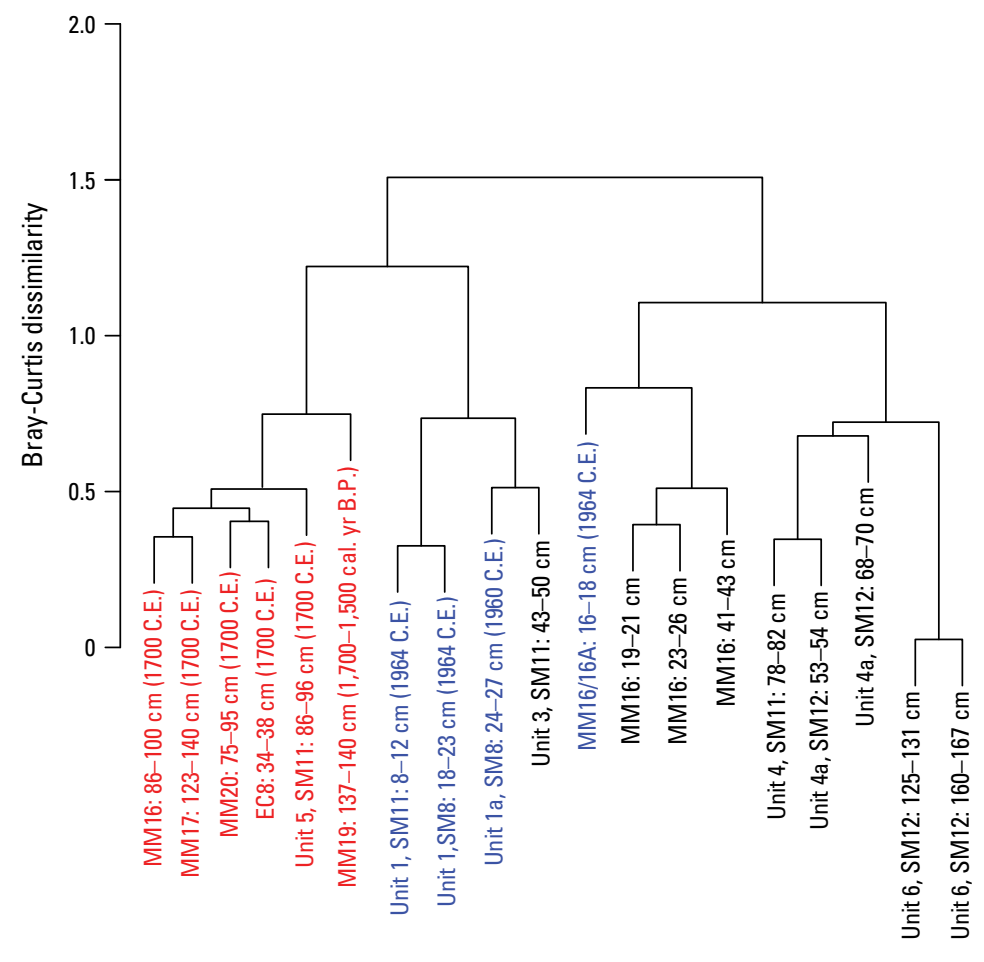

Figure 69. Graph showing Bray-Curtis dissimilarity (results of Q-mode cluster analysis) among diatom assemblages from clastic deposits collected at Sand Mine marsh, Marhoffer Creek marsh, and Elk Creek wetland. Diatom sample labels identify the unit name (only for Sand Mine marsh cores), core name (SM for Sand Mine marsh; EC for Elk Creek wetland; MM for Marhoffer Creek marsh), and depth of sampling (in centimeters, cm). The age of the deposit (in either C.E. or calibrated years before present [cal. yr B.P.]) is also given, if known. Red labels indicate nearfield tsunami deposits, blue labels indicate far-field tsunami deposits, and black labels indicate storm deposits. The agglomerative coefficient is 0.72 . 
occurrence of the marine epipsammic species Rhaphoneis psammicola. Unit 5, however, differs from those samples in that it contains greater numbers of silicoflagellates and fewer small planktonic taxa (fig. 66). The strong similarity between the diatom assemblage in Unit 5 and that in other 1700 tsunami deposits is shown by a cluster analysis of all Sand Mine and Marhoffer Creek marsh samples plus the 1700 tsunami deposit from Elk Creek wetland (fig. 69). The Unit 5 sample clusters more closely with the 1700 tsunami samples from the other study sites than with the far-field tsunami or storm samples, further supporting our interpretation that Unit 5 formed during the 1700 tsunami.

These combined observations suggest that the 1700 tsunami deposit is present in core SM11/11x of the western field site at Sand Mine marsh (figs. 50, 56). Only the sandy deposit at $\sim 86-100 \mathrm{~cm}$ depth is interpreted to represent the 1700 tsunami, whereas the thick overlying sand and detritus deposits were possibly emplaced by storms some time after 1700 . The presence of storm deposits just above the 1700 tsunami deposit in core SM11/11x suggests that the 1700 tsunami deposit may be obscured in other parts of the western field site because subsequent storm activity could have eroded or reworked the deposit beyond recognition. Based on diatom data in core SM12, we conclude that a 1700 tsunami deposit is absent and that the sand and detritus layer between $\sim 70$ and $80 \mathrm{~cm}$ depth is consistent with a storm deposit. We do not have sufficient data to fully evaluate cores SM9 or SM10, the next two longest cores from the western field site (fig. 50), but because of the thickness and ubiquitous occurrence of storm deposits in the other cores, we suspect that the single sandy layers near $70 \mathrm{~cm}$ depth in both cores SM9 and SM10 may also be the result of storm deposition.

\section{Summary - Tsunami and Storm Deposit Distribution}

\section{Far-Field Tsunamis}

We recognize evidence for two far-field tsunami deposits at Sand Mine marsh, one from 1960 and one from 1964. In cores from the western field site, the 1964 tsunami deposit is the stratigraphically youngest layer of sand and detritus, found $\sim 10-20 \mathrm{~cm}$ below the modern surface. We are confident in our interpretation because of the coincidence of this deposit just above the $1963{ }^{137}$ Cs peak in cores SM8 and SM11/11x (figs. 52-55, 58, 60 ) and our ability to correlate the deposit across a number of closely spaced cores (fig. 50). Prominent occurrences of coastal marine diatoms and evidence for sediment sorting further supports the identification as a tsunami deposit. Although well-distributed in the western field site, the 1964 tsunami deposit is not evident in cores collected from the eastern field site at Sand Mine marsh (east side of Highway 101), where the uppermost deposits are highly saturated with groundwater and loosely consolidated.

A 1960 tsunami deposit may also be present in the western field site at Sand Mine marsh, though its apparent distribution is more limited than the 1964 tsunami deposit, as it is only identified in one core (SM8) at the south end of the field site (figs. 46, 60).
We identify the 1960 tsunami deposit as a thin sand layer containing marine diatoms that predates, and is clearly separate from, the overlying 1964 deposit.

\section{Near-Field Tsunamis}

Geological evidence for coseismic subsidence and near-field tsunami inundation at Sand Mine marsh is supported by earlier studies (Carver and others, 1998; Peterson and others, 2011) as well new observations presented here.

The 1700 tsunami deposit is more evident in the eastern field site than the western field site. The deposit is located $75-100 \mathrm{~m}$ inland and about $0.7-0.8 \mathrm{~m}$ below the modern surface and, at the eastern field site, the tsunami deposit is associated with evidence for coseismic subsidence, such that the sand layer is intercalated between a buried peaty soil and overlying muddy peat. Although the 1700 tsunami deposit is also present in the western field site, occurrences are more ambiguous, not associated with clear lithologic evidence for subsidence, and co-occur with other siliciclastic and detrital-rich deposits that are not associated with tsunami inundation.

The best evidence for the 1700 tsunami deposit is in core SM11/11x from the western field site (figs. 46, 50, 56, 58). Here, the deposit consists of a graded, detrital-rich sand layer containing an assemblage of marine diatoms comparable to that in the 1700 tsunami deposits from the Marhoffer Creek marsh and Elk Creek wetland study sites. Based on diatom data, evidence for coseismic subsidence associated with this deposit is not a change from one freshwater environment to another, but rather from an elevated dry environment to a low, wet freshwater marsh or swamp.

We are uncertain of the origin of the sand unit captured in the lowermost part of cores SM11/11x and SM12, because the ${ }^{14} \mathrm{C}$ ages bracketing the deposit in core SM12 (907-735 and 1,808-1,618 cal. yr B.P.) are perplexing. These ages were derived from seeds and twigs in peaty deposits above and below the 30-cm-thick section of fine-grained, well-sorted sand (figs. 50, 59). The 907-735 cal. yr B.P. age is comparable with those reported from Sand Mine marsh: (1) 1,005-778 cal. yr B.P. at $130 \mathrm{~cm}$ depth in a core collected within meters of core SM12; and (2) 923-743 and 954-784 cal. yr B.P. above sand layers at 75 and $85 \mathrm{~cm}$ depth in cores collected about $200 \mathrm{~m}$ inland of core SM12 (see table 1 and figs. 7-8 of Peterson and others, 2011). Peterson and others (2011) also report an age of 960-790 cal. yr B.P. from the Elk Creek valley above a sand layer at $88 \mathrm{~cm}$ depth in a core collected near the valley margin $>2 \mathrm{~km}$ from the beach. The tsunami record at Lagoon Creek, located $17 \mathrm{~km}$ south of Sand Mine marsh, does not include an event of this age (Abramson, 1998; Garrison-Laney, 1998; Peterson and others, 2011), and no evidence for a deposit of this age was observed at Marhoffer Creek marsh (fig. 10, table 1).

The ${ }^{14} \mathrm{C}$ age of $1,808-1,618$ cal. yr B.P. near the base of core SM12 is collected from a thin layer of possibly detrital peat intercalated in sand at $164 \mathrm{~cm}$ depth and overlaps with two ${ }^{14} \mathrm{C}$ ages (1,694-1,558 and 1,700-1,569 cal. yr B.P.) from tsunamideposited sand in core MM19 at Marhoffer Creek marsh (figs. 10, 51). No comparable ${ }^{14} \mathrm{C}$ ages were previously reported for Sand 
Mine marsh (Peterson and others, 2011), but at Lagoon Creek, three ${ }^{14} \mathrm{C}$ ages of $1,720-1,400 ; 1,710-1,290$; and $1,820-1,510 \mathrm{cal}$. yr B.P. were used to correlate tsunami sand "S" (Abramson, 1998). Peterson and others (2013) used the 1,710-1,290 cal. yr B.P. age from Lagoon Creek as a substitute for the actual unknown age of their "Tsunami Sand Layer 4" from Sand Mine marsh, the fourth of six sand layers that they attribute to tsunami deposition. For core SM12, the significance of the 1,808-1,618 cal. yr B.P. age at the base of the sand unit at $164 \mathrm{~cm}$ depth is unclear because it is much older than the age at the top of the sand unit at $134 \mathrm{~cm}$ depth (907-735 cal. yr B.P.), and there is no discernible stratigraphic evidence for a depositional hiatus or unconformity within the single sand deposit. It is possible that the ${ }^{14} \mathrm{C}$ age reflects older reworked material and the broad overlap with ages at Marhoffer Creek marsh and Lagoon Creek is coincidental.

\section{Large Coastal Storms}

We conclude that most of the sandy and detrital-rich deposits in the western field site record storm activity rather than inundation by near- or far-field tsunamis. Furthermore, based on occurrences of the 1700 tsunami deposit in cores SM2, SM3, SM3x, and SM11/11x, we infer that there are no near-field Cascadia Subduction Zone tsunami deposits shallower than about $0.7 \mathrm{~m}$ below the modern surface. Although the 1700 tsunami deposit is as thick as $\sim 15 \mathrm{~cm}$ in core SM11/11x, the 1964 and 1960 far-field tsunamis left fairly thin layers of sand and detritus - consistenty less than a few centimeters thick, except at the south end of the study site. We, therefore, suggest that the thick sandy and detrital deposits in the upper parts of cores from the western field site, as well as in the upper decimeters of cores SM2, SM3, and SM3x from the eastern field site, are storm-surge deposits (figs. 46, 50). This implies that storm-related deposits may be found as far as $\sim 150 \mathrm{~m}$ inland at the Sand Mine marsh study site, consistent with historical reports of storm debris scattered $200 \mathrm{~m}$ inland after the winter megastorm of 1861-62 (Farquhar, 1930; Bearss, 1982).

\section{Discussion}

\section{Multiple Mechanisms for Sand Deposition}

Based on our results from the western field site at Sand Mine marsh, we conclude that various modes of deposition are responsible for the emplacement of the sand and detritus deposits in the subsurface record. We compare our results to the detailed core descriptions from Sand Mine marsh by Carver and others (1998), as well as the more generalized core descriptions by Peterson and others (2011). In both of these studies, every thick sandy deposit older than the youngest layer, which was assumed to be the 1964 tsunami deposit, was attributed to tsunami deposition. Carver and others (1998) also proposed that a number of thin, silt-to-sand laminae in cores from the western field site were the result of far-field tsunami events of unknown ages, although Peterson and others (2011) acknowledge the possibility of other depositional mechanisms for these layers, including storm deposition. From our observations, we suggest that most of the clastic deposits in cores from the western field site are storm deposits, and evidence for past storm deposition may extend $>150 \mathrm{~m}$ inland from the beach. Strong evidence for the 1700 Cascadia Subduction Zone tsunami deposit is limited to one of our cores (SM11/11x) from the western field site, and is possibly present at depths $>60 \mathrm{~cm}$ below the surface in the eastern field site. It is reasonable to assume that a more extensive sedimentary record of the 1700 tsunami may have existed at one time in the western field site, but subsequent storm inundation and erosion, with storm flooding aided by a lowered land elevation after coseismic subsidence, may have overprinted or erased evidence of the event at this site.

We agree with Carver and others (1998) and Peterson and others (2011) on the distribution of the 1964 tsunami deposit, which we verified via radionuclide analysis and correlated among our closely spaced cores. We only recognized a possible 1960 far-field tsunami deposit in one core (SM8) and did not see evidence for clearly separated deposits of the same stratigraphic level as reported by Carver and others (1998), although we are not certain of the exact locations of their cores relative to ours. It is clear, however, that the distributions of the 1964 and possible 1960 events coincide with zones of past storm inundation. Without a distinguishing chronological marker like the $1963{ }^{137} \mathrm{Cs}$ peak, it is difficult to identify with certainty the occurrence of older far-field tsunami deposits, unless they could be correlated continuously among a series of closely spaced cores, similar to the 1964 deposit.

\section{Updates to Conclusions from Previous Studies}

Wilson and others (2014, p. 83) proposed that the 1700 tsunami deposit could be present in each of the three cores from the eastern field site - cores SM2, SM3, and SM4. Based on further analysis and comparison with cores from the western field site, we show that the 1700 tsunami deposit is probably present at $67 \mathrm{~cm}$ depth in core SM2 and at 70-80 cm depth in replicate cores SM3 and SM3x. These sandy layers are each associated with a change from underlying fibrous peat to overlying muddy peat that is consistent with coseismic subsidence. Sand layers present at shallower depths in cores SM3 $(32-44 \mathrm{~cm})$, SM3x $(37-46 \mathrm{~cm})$, and SM4 $(30-40 \mathrm{~cm})$ (fig. 50, appendix 1) are probably associated with climatic events later than 1700 , such as storm activity in the 1800 s.

Additionally, Wilson and others (2014, p. 85) proposed that the 1700 tsunami emplaced the entire section of sand and detrital peat between 45 and $100 \mathrm{~cm}$ depth in core SM11/11x. After completing detailed grain-size and diatom analyses through this section, we now propose that the 1700 tsunami deposit may only compose the lower detrital-rich sand layer between 86 and $100 \mathrm{~cm}$ depth, and that the overlying thick sand and detrital peat layers are remnant storm deposits. We also suggested that evidence for coseismic subsidence associated with emplacement of the deposit consisted of a change from a freshwater to brackish environment, based on changes in diatom assemblages (Wilson and others, 2014). We revise that slightly to suggest 
that there is diatom evidence for coseismic subsidence, but that the data suggest that the land level prior to the 1700 earthquake and tsunami was not only freshwater but probably well drained and subaerial - certainly well above inundation by tides. The brackish diatoms found in the peaty deposits above and below the sand layers between 44 and $84 \mathrm{~cm}$ depth in core SM11/11x are enigmatic in that they show an influence of salt water, yet do not indicate a change to a saline vegetated environment, such as a salt marsh. This issue still needs to be resolved, but for now we propose that the brackish diatoms are evidence for brackish pools associated with emplacement of storm wrack, suggesting that the site became lower and more proximal to the shoreline as a result of coseismic subsidence.

\section{O'rekw Marsh, Redwood National and State Parks}

\section{Summary of Findings}

The O'rekw marsh study site is a small freshwater marsh and ephemeral pond located on the south side of the Redwood Creek alluvial valley, $200 \mathrm{~m}$ inland from the ocean and about $2.5 \mathrm{~km}$ west of Orick, Calif. Three cores were collected in a sedge and cattail marsh and swamp, penetrating to a maximum depth of $\sim 1.7 \mathrm{~m}$ below the surface before reaching core refusal in dense, sandy substrate. The stratigraphy in all three cores is comparable, with individual clastic and organic-rich units correlatable among the cores. The lithology is dominantly silty mud intercalated by four or five coarser grained deposits that consist of poorly sorted muddy to clean sand and muddy detritus-rich sand. There is very little peat in each core. Thin peat deposits occur at $\sim 1 \mathrm{~m}$ depth and a few decimeters depth, the younger of which represents accumulation in the modern marsh. Although the lower Redwood Creek valley is a nexus for Native American oral history concerning the 1700 earthquake and tsunami, we conclude that there is possible evidence for coseismic subsidence at this time in the O'rekw marsh study site, but no definitive evidence of tsunami deposits associated with the event. Furthermore, we found O'rekw marsh to have poor preservation potential of older Cascadia Subduction Zone earthquake and tsunami deposits. In support of these conclusions, we find that: (1) in the past, O'rekw marsh was variously connected to the lower Redwood Creek estuary as part of a freshwater or brackish lagoon or slough and subjected to dynamic depositional processes associated with that environment; (2) this lagoon and (or) slough environment was not conducive to the growth and accumulation of continuous marsh sequences where evidence for coseismic subsidence could help differentiate between a possible tsunami deposit and a seismic event; and (3) the site has been episodically impacted by flooding of Redwood Creek that not only deposited sediment and debris at the site, but also could have eroded or obscured evidence for past earthquakes or tsunamis.

\section{Overview}

\section{Study Site Description}

The informally named O'rekw ${ }^{11}$ marsh is a small wetland in the lower alluvial valley of Redwood Creek, approximately $2.5 \mathrm{~km}$ west of Orick, Calif. (figs. 2, 70). It is located approximately $200 \mathrm{~m}$ east (landward) of Redwood Creek Beach (figs. 70, 71; appendix 1) at an elevation of $\sim 2.5-2.8 \mathrm{~m}$, and is separated from the beach by the two-lane Highway 101 and a well-developed, vegetated berm at 7-8 m elevation ${ }^{12}$ (fig. 72). The closest tidal benchmark for O'rekw marsh is NOAA Station 9419059 , about $25 \mathrm{~km}$ to the south at Trinidad Harbor (NOAA, 2003b) (fig. 2).

The O'rekw marsh study site is within the bounds of Redwood National and State Parks, but because it is located near the ancient Yurok settlement of O'rekw, access to the property is prohibited without the permission and oversight of the Yurok Tribal Council.

\section{Field Data Collection Strategies}

Three cores were extracted from an area of dense stands of sedges, bulrush, and cattails in the central part of the marsh (figs. 71, 73; appendix 1, figs. 1.24, 1.25). The westernmost part of the O'rekw marsh study site is underlain by medium- to coarse-grained sandy substrate, a remnant extent of the beach berm prior to highway construction, which was impenetrable with our hand-driven gouge core. Vegetation capping the sandy substrate consists of a variety of grasses and low-lying plants such as wild strawberry (Fragaria sp.). Farther inland from the central study site, to the northeast, the marsh gives way to a dense swamp in a narrow zone between the highway and the hillslope base. The depth of fresh water in the marsh and swamp varies on a seasonal basis, and is strongly impacted by rainfall as well as blockage of the culvert under Highway 101 (about $85 \mathrm{~m}$ northeast of the study site) by beaver dams. When we conducted our fieldwork, the water depth at the core sites was $\sim 0.5-1 \mathrm{~m}$.

\section{Native American Oral Histories}

When cultural anthropologist Alfred L. Kroeber traveled to northern California in 1902 to document the language and customs of the Yurok People, he had no way of knowing he was interviewing people possibly only four generations removed from eyewitnesses of the great Cascadia Subduction Zone earthquake and tsunami of 1700 . Of the numerous oral legends

\footnotetext{
${ }^{11} \mathrm{O}$ 'rekw is the translated English spelling accepted by the Yurok Tribe. Other spellings that may be found in the literature include Orekw, Oreq-w, Oreqw, Orckw, and Orek (Kroeber, 1976; Zuber and others, 1985).

${ }^{12}$ The fairly high elevation of the RTK data points on the beach reflects a summer beach profile with thick sand accumulation and a well-developed berm leading to a steep lower beach face.
} 


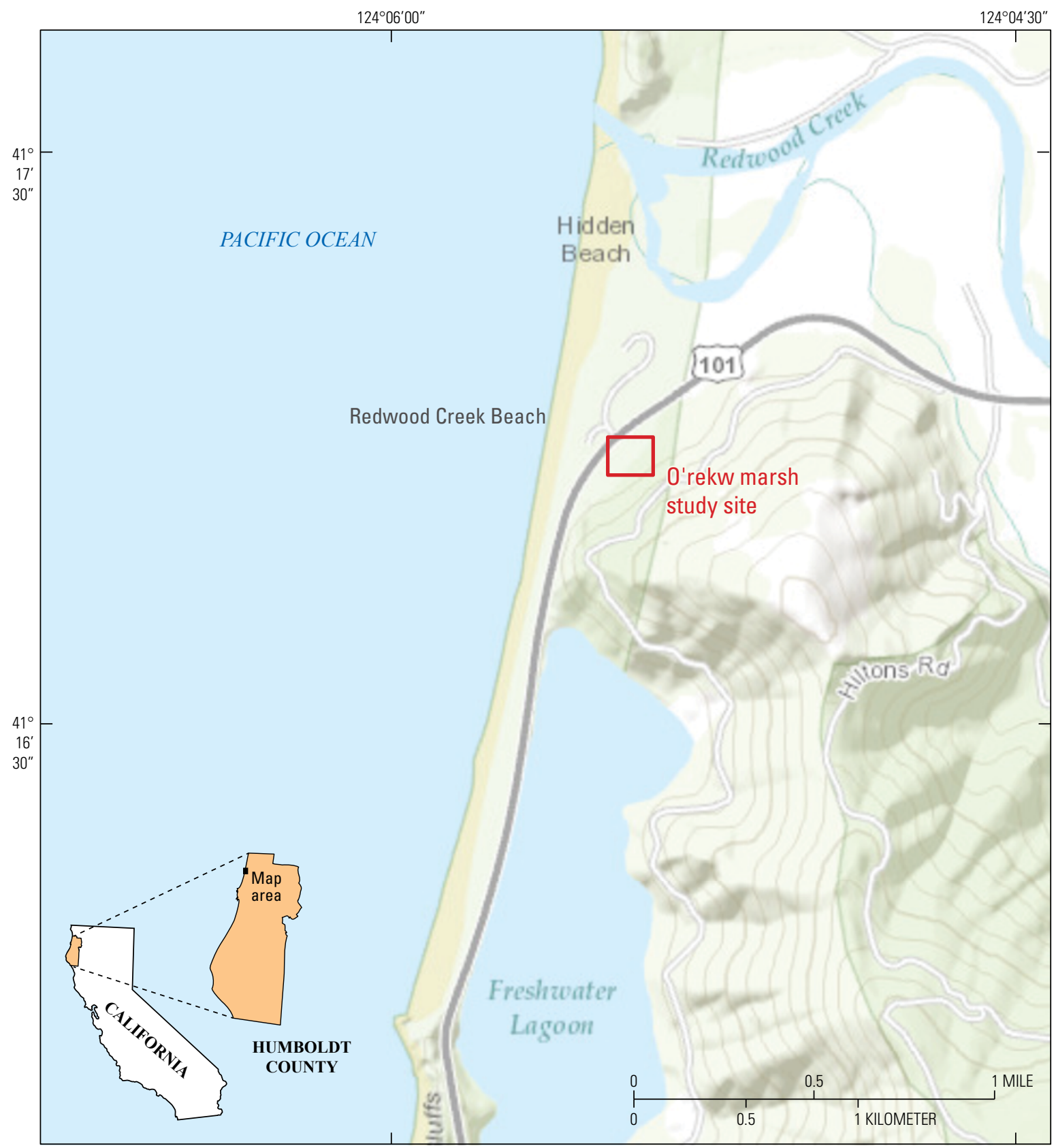

Base from Esri World Topographic Map (C) Esri 2017 and its licensors

Figure 70. Map showing the location of the 0'rekw marsh study site in northern California. The marsh is adjacent to Highway 101, at the base of hillslopes along the southern edge of the Redwood Creek alluvial valley.

shared by members of the Yurok Tribe that Kroeber compiled and later published in the book "Yurok Myths," two stories in particular are interpreted as recounting earthquakes and tsunamis (Kroeber, 1976; Carver, 1998). These oral histories, as told to Kroeber by a tribal elder known as "Tskerkr of Espeu,"13 are titled "Earthquakes and Thunder" and "A Flood” (Kroeber, 1976, p. 162). "Earthquakes and Thunder" relates the reality of living on a seismically active coast and experiencing occasional temblors

\footnotetext{
${ }^{13}$ In his book "Yurok Geography," T.T. Waterman (1920) refers to Tskerkr as "Skirk," probably an approximate English pronunciation of the Yurok word.
}

both large and small. "A Flood" is presented as if referring to a particular event, and is interpreted as referring to the 1700 tsunami, one of a number of such legends passed down through generations in different Native American Tribes in the U.S. Pacific Northwest and southwestern Canada (Ludwin and others, 2005).

Tskerkr was born in Espeu (now called Gold Bluffs Beach, located about $10 \mathrm{~km}$ north of Redwood Creek) but moved to his wife's Yurok community when they married. By the time Kroeber interviewed Tskerkr in 1902-07, Tskerkr was about 70-75 years old and living in a small frame house at the base of the hillslope, near the beach on the south side 


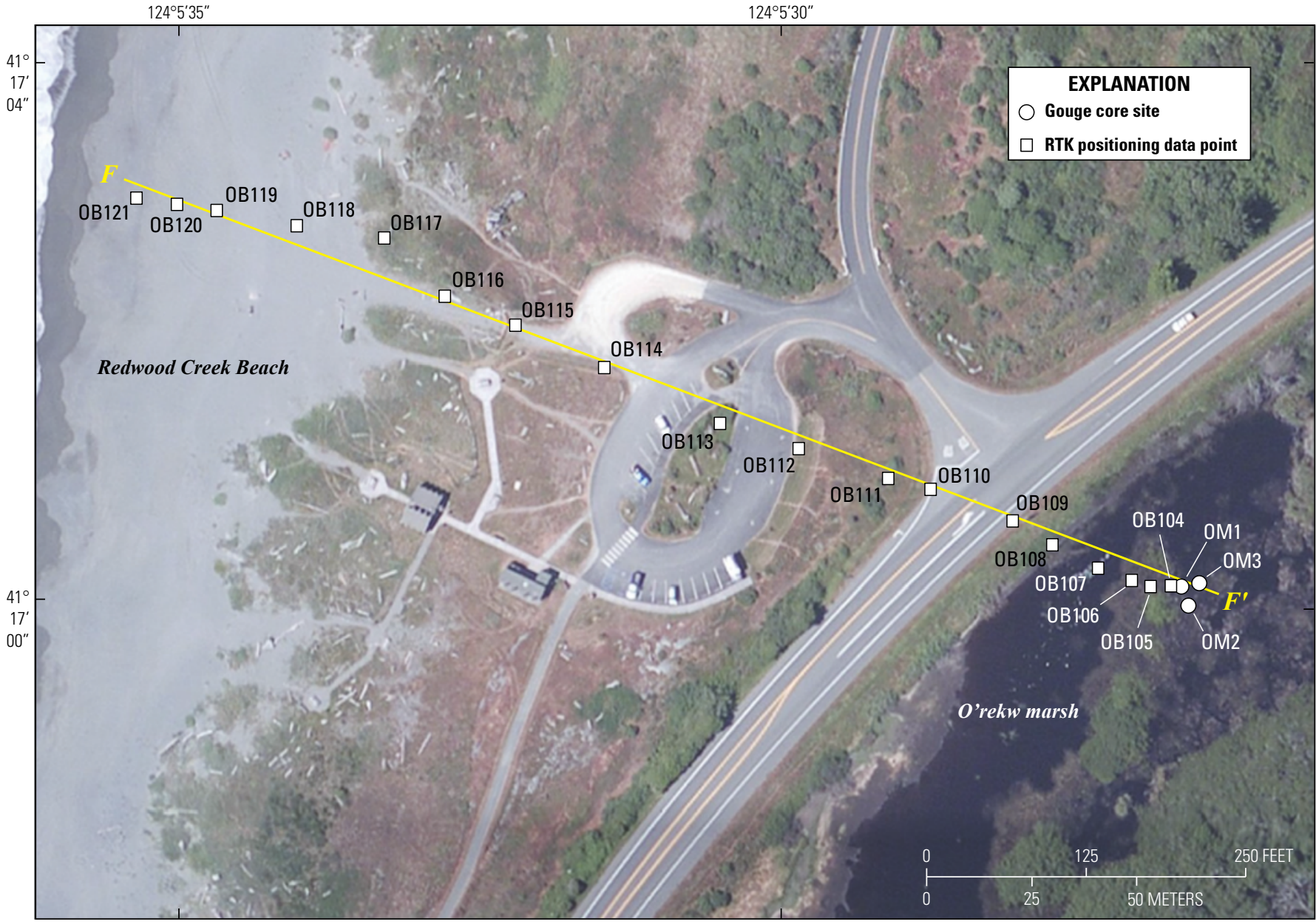

Imagery from Esri World Topographic Map (C) Esri 2017 and its licensors

Figure 71. Aerial image of the O'rekw marsh study site showing locations of cores and real-time kinematic (RTK) positioning data points along a transect from Redwood Creek Beach to O'rekw marsh.

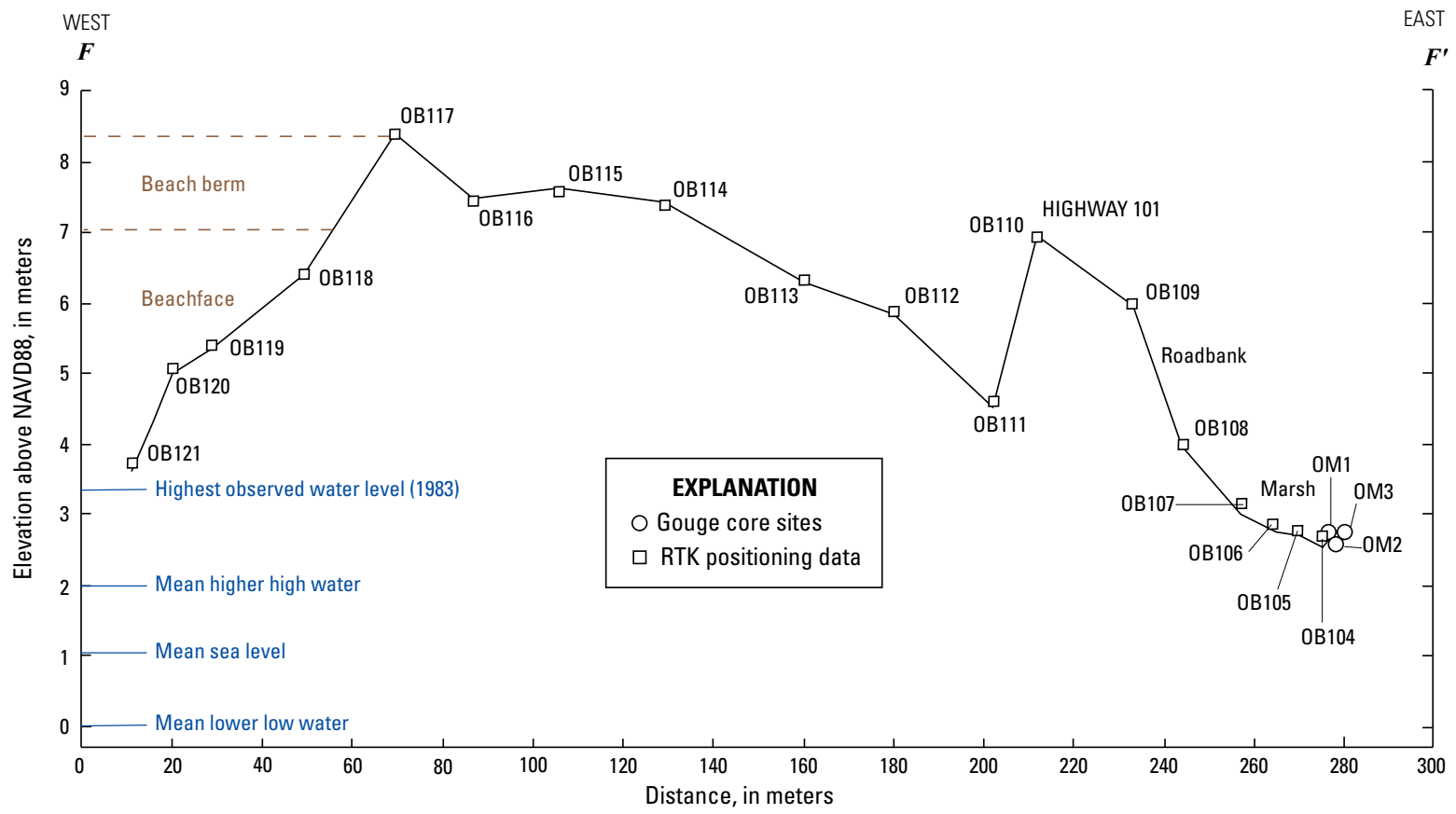

Figure 72. Crosssectional profile $F-F^{\prime}$ showing the elevation of realtime kinematic (RTK) positioning data and cores $0 \mathrm{M} 1,0 \mathrm{M} 2$, and $0 \mathrm{M} 3$ at O'rekw marsh. Locations are shown in figure 71. Elevations are relative to the North American Vertical Datum of 1988 (NAVD88). 


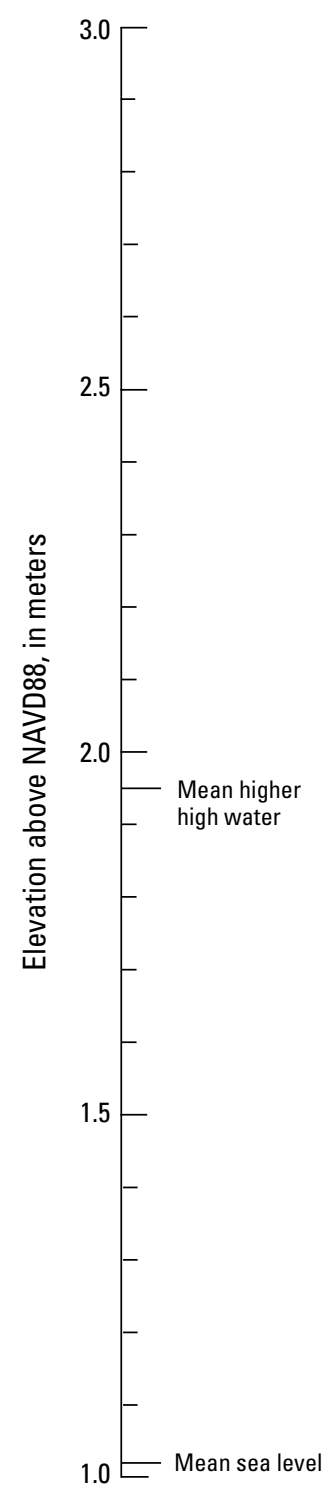

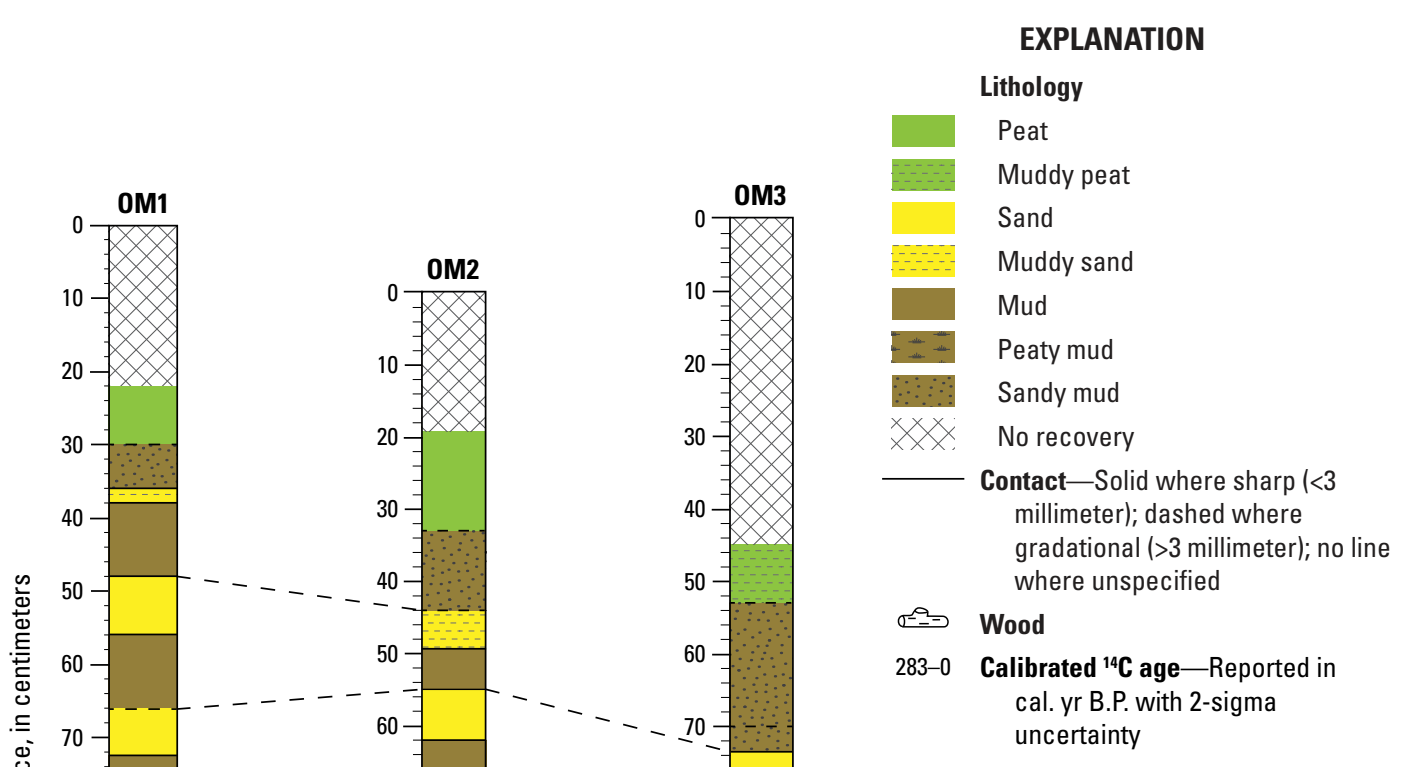

Figure 73. Lithologic logs of cores OM1, OM2, and OM3 from 0'rekw marsh. Locations shown in figure 71 . The beach berm occurs at 7-8 meters. Elevations are relative to the North American Vertical Datum of 1988 (NAVD88). of Redwood Creek valley and below the site of the former village of O'rekw. ${ }^{14}$ Kroeber (1976, p. 162) described Tskerkr and his family as the last occupants of "the native town of O'rekw," which by 1902 consisted of Tskerkr's home at the base of the hillslope and his sweathouse on the beach berm a few hundred meters to the north. The traditional village site on the hillside was, by this time, overgrown and abandoned. In his story, "A Flood," Tskerkr describes, in traditional storytelling style, the impact of the tsunami on the settlement of O'rekw, as well as the village of Siwitsu, which, according to Tskerkr, was located down the beach from O'rekw, close to where he built his sweathouse. Tskerkr's account was translated as, "Then the ocean began to turn rough... A breaker came over the settlement [of Siwitsu], washed the whole of it away, and drowned everyone. Then all the people of O'rekw ran off to

\footnotetext{
${ }^{14}$ Based on historical photographs in "Yurok Geography" (Waterman, 1920), the location of Tskerkr's home was about 200 m southwest of our core sites.
}

the top of the hill, wearing their woodpecker-crest headbands, they were afraid." In his analysis of this story, Kroeber (1976, p. 186) expresses skepticism of Tskerkr's description of the location of Siwitsu, writing, "Siwitsu (or Siwetsu)... is on the sandbar that separates the sea from Redwood Creek lagoon. It is perhaps 300 yards north of O'rekw. About 1901-1906, Tskerkr, the narrator, had his sweathouse a little beyond there... There could not well have been a town on so exposed and low a spot. Every few winters a storm is likely to wash over it. It is probably a house site, and is ordinarily counted as an outlying part of O'rekw. However, Tskerkr kept speaking of it as a town." It is possible that Tskerkr was correct about the location and sizeable population of Siwitsu, because what Kroeber could not have known was the possibility that coseismic subsidence accompanied the earthquake in 1700 , which not only would have lowered the elevation of the former village site, but also made the site more proximal to the high tide line, and thus more likely to be inundated by winter storm waves. 
Another version of the events at O'rekw and Siwitsu appears as a short article entitled "Legend of Orick by Mrs. Eloise Nelson, 1950" in the book "Oreq-w: Orick Then and Now" (Zuber and others, 1985, p. 22). An interesting aspect of Mrs. Nelson's account is the frequency in which village sites are abandoned for various reasons, including the need to move to higher ground. The story first talks about a settlement on the opposite side of the same hill that O'rekw occupied, overlooking Freshwater Lagoon to the south. She states,

Years later on the north side of the same hill, other tribes made a settlement, this time overlooking the beautiful beach where Redwood Creek meets the sea. This settlement also died out and the remaining settlers moved to the flat beach between the hills and the mouth of the creek...About this time another chose the opposite side of the creek mouth where a hill jets from the sea to shelter from wind and waves. This village on the north side of the creek was called "Aw-tmek-quar" or "where the water came rushing in," for it was here according to an old Indian legend that after the 40 days and nights of the great flood that the water of the ocean came to the top of the hill and came rushing in over the land..$^{15}$ All the men of this village were old men and as they died their wives returned to their own tribes - the Klamath. So the village soon became extinct...Shortly after, a great flood or tidle [sic] wave wiped out the settlement on the south side of the creek and the people who had settled on the beach were forced to high land again, and so once again a settlement was made on the side of the hill...

Assuming both Tskerkr's and Mrs. Nelson's stories refer to the 1700 tsunami, Mrs. Nelson appears to support Tskerkr's account that Siwitsu was a relatively large community on the beach at the time of the tsunami. It also appears to suggest that the remnants of the village of O'rekw, mapped on the hillslope by T.T. Waterman in the early 1900s (Waterman, 1920), became the preferred habitation site on the south side of Redwood Creek after the earthquake and tsunami in 1700 , and may not have been inhabited when the earthquake struck in 1700.

\section{Previous Paleoseismic Studies}

Carver and others (1998) first suggested the presence of possible tsunami deposits at O'rekw marsh based on two cores collected in the central part of the marsh. They report the subsurface stratigraphy to a depth of about $1.3 \mathrm{~m}$ consisting of "intact marsh sequences with three layers characteristic of tsunami deposition" (Carver and others, 1998, p. 1-8). They interpreted the second deepest sandy deposit, near $0.5 \mathrm{~m}$ depth

\footnotetext{
${ }^{15}$ Although it is unknown if this story refers to a specific flood, the floodproducing megastorm in the winter of 1861-62 continued uninterrupted for 43 days. Paleoclimate data show that the penultimate megastorm to the winter 1861-62 event occurred in approximately the year 1600 C.E. (Dettinger and Ingram, 2013) - that is, about 100 years before the 1700 Cascadia Subduction Zone earthquake and tsunami.
}

in both cores, as the 1700 tsunami deposit. In their core O-1, this sandy unit consists of three thin, upward-fining layers of coarse to fine sand and is capped by an organic-debris layer.

\section{Eyewitness Accounts of the 1964 Far-Field Tsunami}

The 1964 tsunami did not reach the O'rekw marsh study site, as documented by eyewitness accounts from local residents who observed the tsunami arrival just past 1 a.m. on the morning of March 28, 1964 (Zuber and others, 1985, p. 182). The residents gathered at a lookout point on Old State Highway Road near the top of the hill overlooking O'rekw marsh, Redwood Creek Beach, and the ocean beyond. Under a bright moon, they observed the initial drawdown and subsequent tsunami surge, which they reported as extending halfway up the beach before receding, well below the elevation necessary to top the beach berm. With the exception of a tsunami surge that backed up water in the Redwood Creek channel for hundreds of meters, there was apparently no impact to the lower Redwood Creek valley from this event.

\section{Large Historical Floods}

Redwood Creek is a major coastal stream in northern California, draining a narrow and steep 725 square kilometer $\left(\mathrm{km}^{2}\right)$ watershed (Nolan and Marron, 1995). The geomorphology in the lowermost Redwood Creek valley reflects influences from three anthropomorphic impacts: excessive sedimentation from upstream logging and land use, particularly since the 1950s; large-scale earth moving to construct a large saw mill and log pad on the south side of the creek outlet in the early 1950s; and levee construction in the late 1960s to straighten and confine the lower Redwood Creek channel for flood control (Ricks, 1979, 1985; Zuber and others, 1985; Laird, 2009). Prior to these anthropomorphic impacts, the sand spit regularly closed off the mouth of Redwood Creek, forming a large lagoon on the landward side of the beach berm that, even in historical times, extended for hundreds of meters up the impounded channel (Waterman, 1920 , p. 398, plate 13).

Numerous large floods have impacted the lower Redwood Creek valley since record keeping began after European settlement in the mid-1800s. The late 1800s included two exceptionally large storms: the multi-week megastorm of December 1861-January 1862 that included four large pulses of flooding and a second, shorter-duration, but also damaging, event in 1890 (Harden and others, 1978; Ricks, 1979, 1995). In the 20th century, the floods of 1955 and 1964 both fully submerged the lower Redwood Creek valley-historical photographs show inundation at O'rekw marsh during both floods. The 1964 flood was larger than that in 1955, depositing twice as much sand and silt in the lower floodplain, including a thin layer of silt on the O'rekw marsh surface (Ricks, 1979, p. 57). Of these large historical floods, the 1862 storm was probably the greatest in terms of duration and precipitation amount (Harden, 1995; Harden and others, 1978). Ricks 
(1995) noted that, based on evidence from dendrochronology, the 1861-62 flooding may have been forceful enough to completely erode stands of old-growth spruce from islands in the lower river channel.

\section{Observations}

\section{Lithology and Stratigraphy}

The stratigraphy is comparable in each of the three O'rekw marsh cores (figs. 73, 74; appendix 1). The lithology dominantly consists of light-brown to gray mud and sandy silt, intercalated with four to six deposits of gray sand ranging in texture from fine-grained and massive to poorly sorted muddy fine and medium sand. These sand layers correlate well between the cores (fig. 73), which are spaced about $5 \mathrm{~m}$ apart. The sand layers near 80-90 cm depth in cores OM2 and OM3 include abundant woody detritus; there is a $10-\mathrm{cm}-$ long piece of wood in clayey silt at $75 \mathrm{~cm}$ depth in core OM2. Peaty deposits constitute a minor lithologic component in these cores. Plant-rich deposits are only found in the upper $30 \mathrm{~cm}$ of the cores (that is, representing peat accumulation in the modern freshwater wetland) and in a narrow interval about 2-10 cm thick near $100 \mathrm{~cm}$ depth in each of the three cores.

\section{Geochronology}

We acquired AMS ${ }^{14} \mathrm{C}$ ages from twigs and conifer needles at $98 \mathrm{~cm}$ depth in core OM1 and $89 \mathrm{~cm}$ depth in core OM2, collected from the base of a sand and detritus layer that caps peat (figs. 73, 74; table 1). Both samples returned calibrated ages of 283-0 cal. yr B.P. (1667-1950 cal. yr C.E.), which are not precise enough to distinguish between 1700 tsunami inundation and 19th-century storm deposition.

\section{Diatom Analyses}

At O'rekw marsh, diatom analyses were used to evaluate the paleoenvironmental variability of the site through time and look for any evidence for allochthonous deposits consistent with tsunami deposition. All analyses are from core OM2 (fig. 74), which, in addition to containing distinct layers of sand, silty mud, and peat to muddy peat, also showed good stratigraphic correlation to the other two cores recovered from the marsh (figs. 73).

Diatoms are abundant, exceeding an estimated $10^{5}$ valves $/ \mathrm{cm}^{3}$ of sediment, except in a few samples at $55-65 \mathrm{~cm}$ depth (fig. 74; appendix 4, table 4.10). Changes in diatom assemblages show that there were periods of dominantly brackish or dominantly freshwater conditions, and a few intervals of mixed assemblages (fig. 75).

There is evidence for dominantly freshwater conditions at two intervals in the core record: modern deposits at the top of the core and in a section between 89 and $115 \mathrm{~cm}$ depth (fig. 74). The presence of less than $25 \mathrm{~cm}$ of freshwater deposits at the top of the core suggests that the modern marsh and swamp is likely a recent development associated with the 1949 construction of an elevated part of Highway 101 and consequent changes in local hydrology. The earlier freshwater period, shown by deposits between 89 and $115 \mathrm{~cm}$ depth, is evidenced by two types of freshwater populations: (1) prolific occurrences of taxa indicative of wet freshwater marshes and ponds observed in mud and muddy peat at $\sim 93-115 \mathrm{~cm}$ depth; and (2) taxa indicative of dry fresh to fresh-brackish marshes in the uppermost, reddish humified peat at $89-93 \mathrm{~cm}$ depth. The assemblages between 93 and $115 \mathrm{~cm}$ depth are comparable to those observed in the back-berm marsh and pond at the Sand Mine marsh study site, and include large species of Pinnularia, Cymbella, and Stauroneis, along with Tabellaria fenestrata, Eunotia formica, Eunotia glacialis, and a diverse array of smaller pennate epiphytic taxa (fig. 75B). Freshwater sponge spicules are also common. In the reddish humified peat at 89-93 cm depth, diatoms are about an order of magnitude less abundant and the assemblage is composed dominantly of aerophilous marsh taxa including Eunotia minor, Eunotia bidens, Nitzschia terrestris, Cosmioneis pusilla, Hantzschia amphioxys, Humidophila (Diadesmis) contenta, Pinnularia gibba var. linearis, Pinnularia lagerstedtii, and Pinnularia borealis (fig. 76A). Spores of Dryopteris arguta (western wood fern), a common wetland species in coastal California (Calflora Database, 2016), are also prominent (fig. 76B).

Abundant brackish epipelic taxa (species that live on fine-grained substrate) as well as epiphytic and planktonic taxa are found in muddy and silty to sandy deposits at $\sim 30-90$ and $\sim 115-140 \mathrm{~cm}$ depth in core OM2 (figs. 74, 77). The assemblages are diverse, with prominent taxa including Diploneis pseudovalis, Diploneis smithii var. recta, Navicula peregrinopsis, Navicula cincta, abundant well-preserved specimens of Gyrosigma kutzingii and other Gyrosigma spp., Mastogloia monodii, Mastogloia elliptica, Tabularia fasciculata, Melosira nummuloides, and Cyclotella meneghiniana.

Marine diatoms are found in low abundance throughout the core, with a greater concentration in gray silt and sand at $115-120 \mathrm{~cm}$ depth than occur elsewhere in core OM2 (figs. 74, 78). Most of the species included in this category are planktonic and common in coastal waters (for example, Rhaphoneis amphiceros, Thalassionema nitzschioides, Rhizosolenia spp., and Chaetoceros spp.; fig. 78), but these taxa are also widely found in saline estuarine environments, and therefore could be found in the lower tidal reaches of the Redwood Creek estuary as well as in the coastal open ocean. A Q-mode cluster analysis comparing the marine diatom assemblage in this deposit from core OM2 with samples from tsunami and storm deposits analyzed at the three Crescent City study sites (fig. 79) shows that, based on the types and abundances of taxa present, the O'rekw marsh sample from core OM2 is comparable to storm deposit samples from the Sand Mine marsh study site and dissimilar to all of the Cascadia Subduction Zone tsunami deposit samples from all Crescent City study sites. 


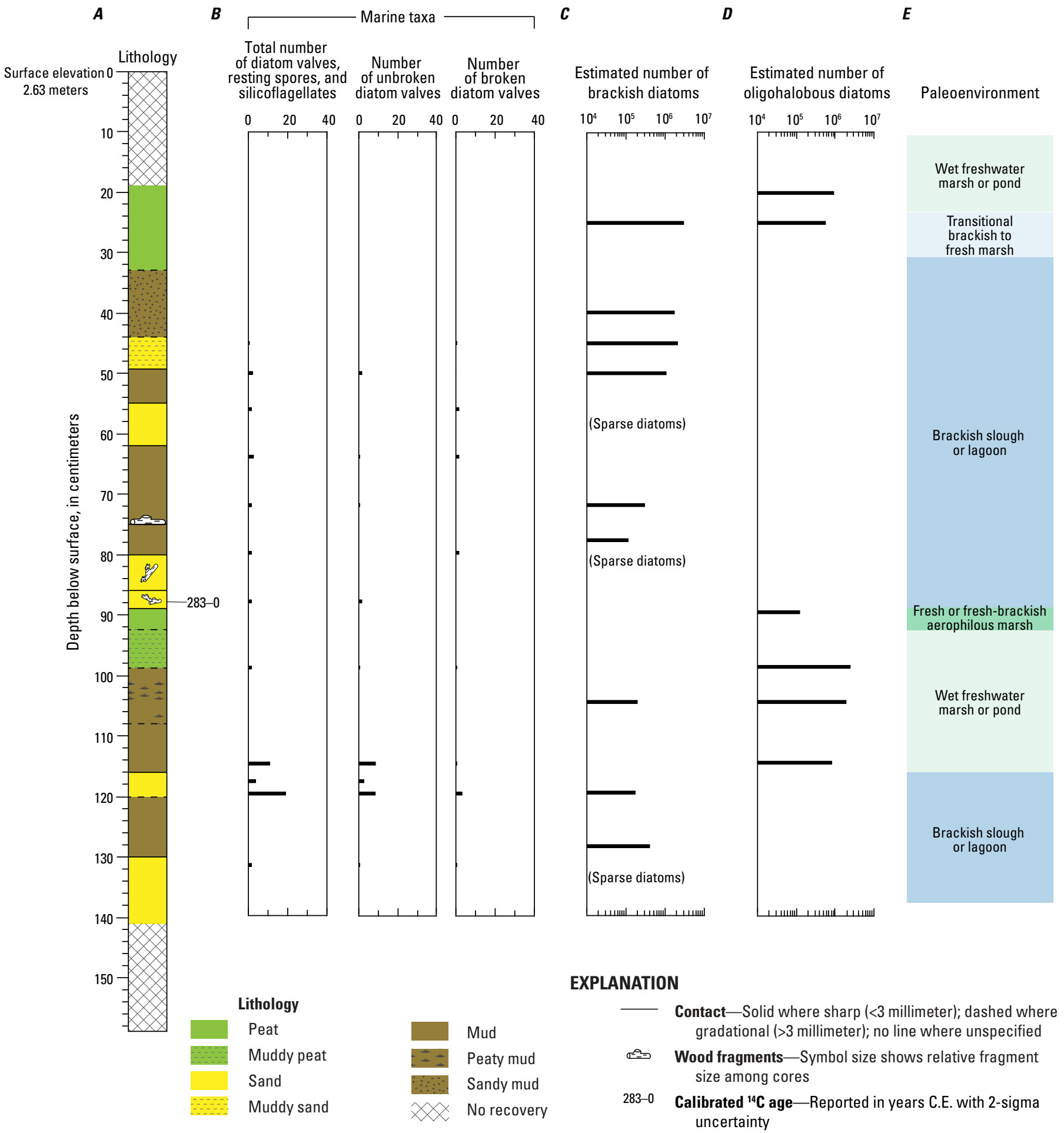

Figure 74. Plots showing the distribution of microfossils with depth in core $0 \mathrm{M} 2$ from 0 'rekw marsh. $A$, Lithologic log of core OM2. Elevations are relative to the North American Vertical Datum of 1988. $B$, Number of marine microfossils (including diatoms and silicoflagellates), determined as the number of specimens observed in 20 traverses of the microscope slide at 650x magnification. Marine taxa are separated into three categories: 1) diatom valves, resting spores, and silic oflagellates; 2 ) unbroken diatom valves; and 3) broken diatom valves. $C$, Estimated abundance of brackish diatoms per cubic centimeter of sediment. $D$, Estimated abundance of oligohalobous diatoms per cubic centimeter of sediment. $E$, Inferred paleoenvironment from microfossil assemblages. 
$\boldsymbol{A}$

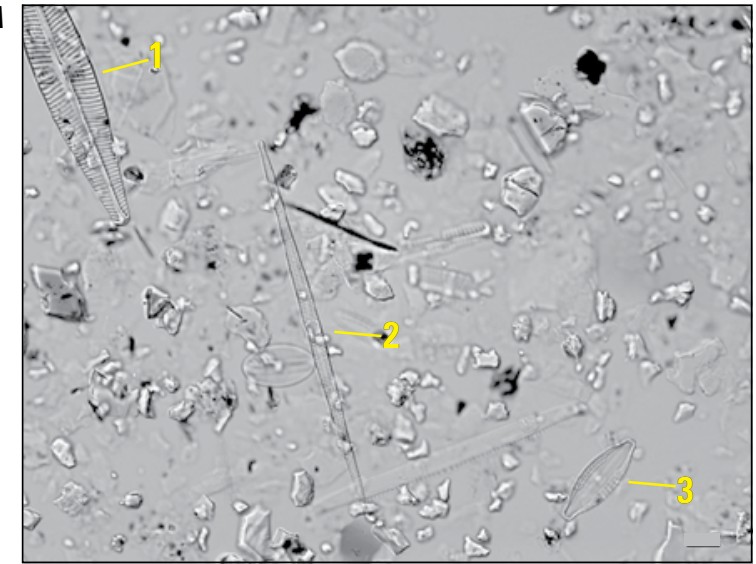

B

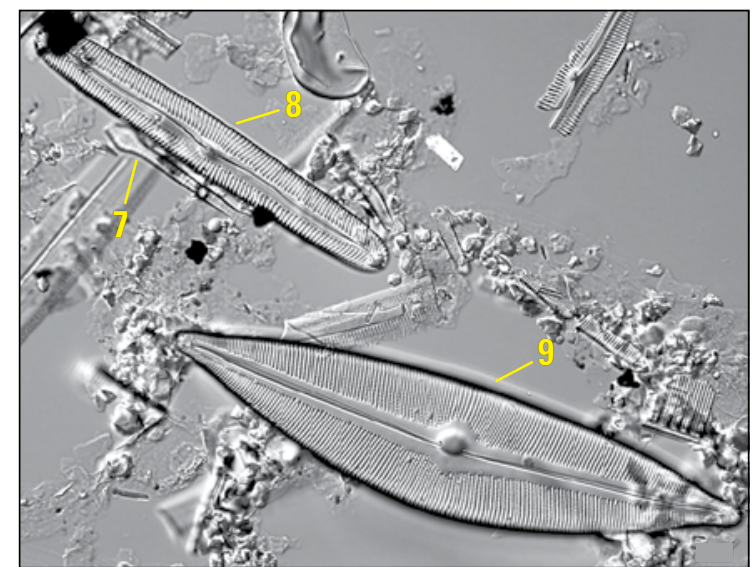

C

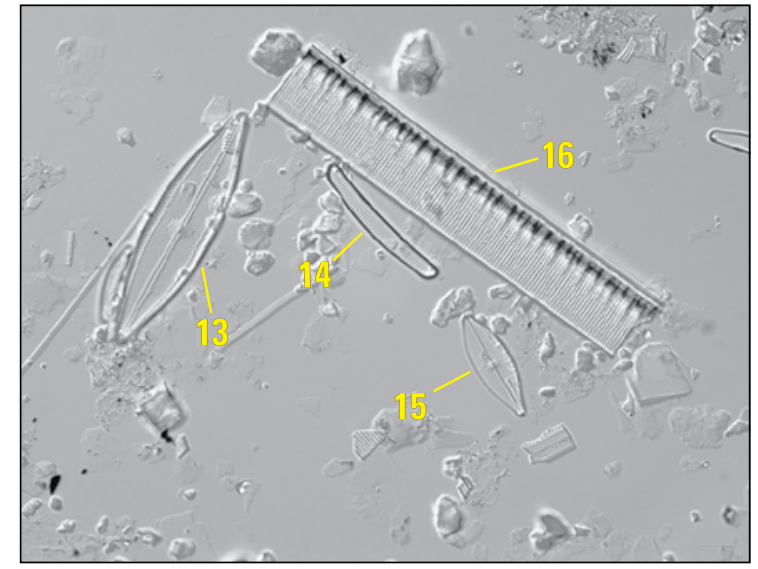

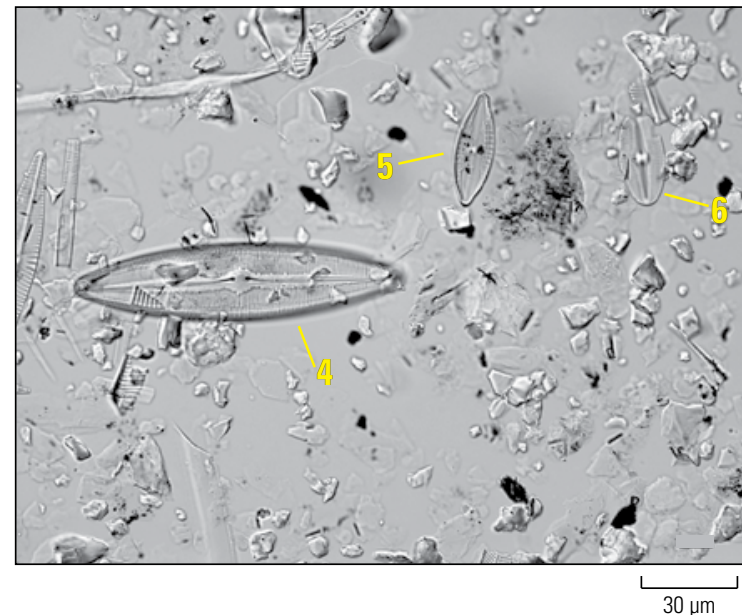
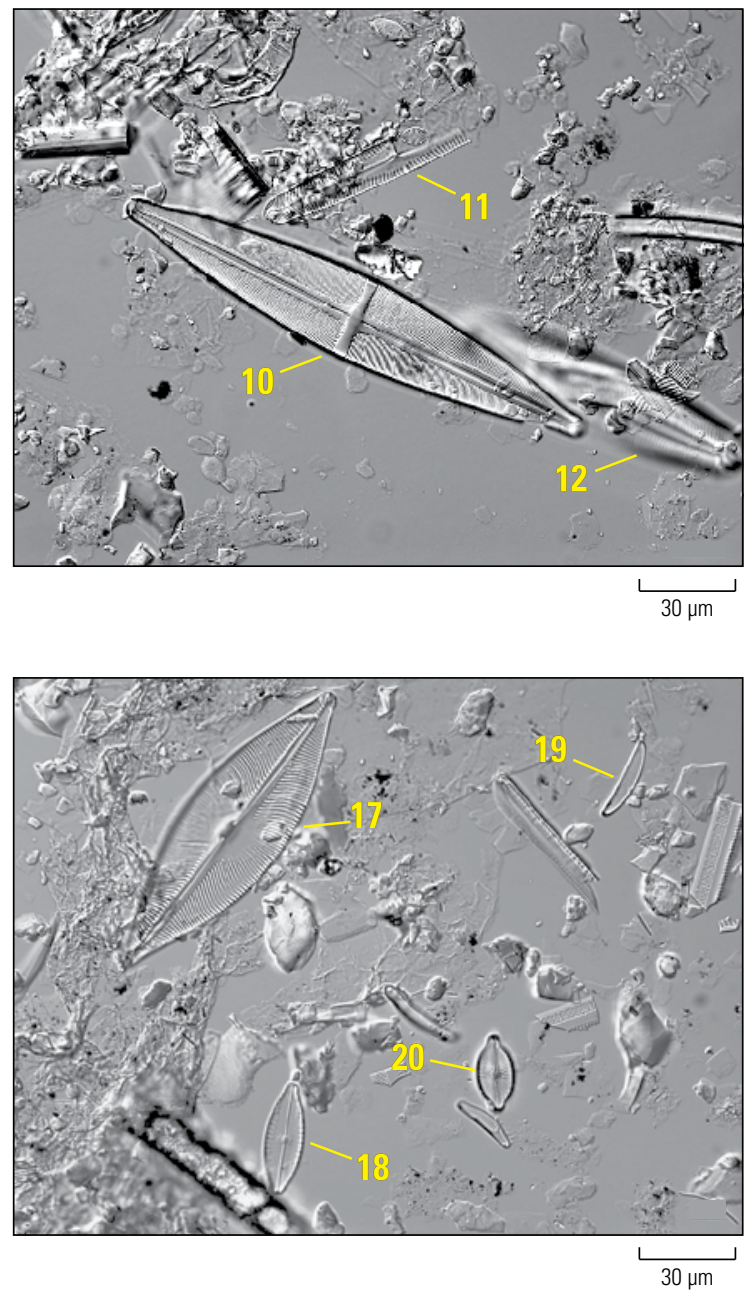

Figure 75. Photomicrographs of diatoms in core $0 \mathrm{M} 2$ from O'rekw marsh. $A$, Diatom assemblages from sandy silt at 45 centimeters depth in core OM2 dominantly consist of brackish taxa. 1, Navicula peregrina; 2, Ctenophora pulchella; 3 , Mastogloia cf. monodii, 4, Caloneis westir, 5 , Mastogloia cf. monodii, 6 , Diploneis pseudovalis. $B$, Diatoms in muddy peat at $99 \mathrm{~cm}$ depth indicate accumulation in a ponded freshwater environment. 7, Tabellaria flocculosa; 8, Pinnularia viridis, 9, Cymbopleura subrostrata; 10, Stauroneis heinii, 11-12, large Pinnularia spp. C, Diatom assemblages in peaty mud at $105 \mathrm{~cm}$ depth consist of a mix of taxa found in fresh and (or) brackish water. 13, Neidium affine; 14, Eunotia glacialis; 15, Mastogloia cf. monodii, 16, large fragment of Nizschia scalaris, 17, Pinnuavis elegans; 18, Mastogloia cf. monodii, 19, Eunotia incisa; 20, Cosmioneis pusilla. $\mu \mathrm{m}$, micrometers. 
$\boldsymbol{A}$

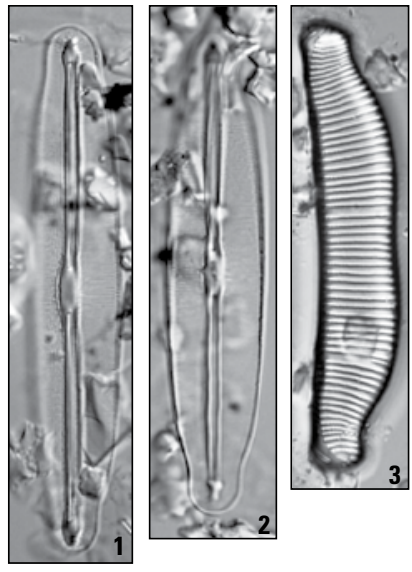

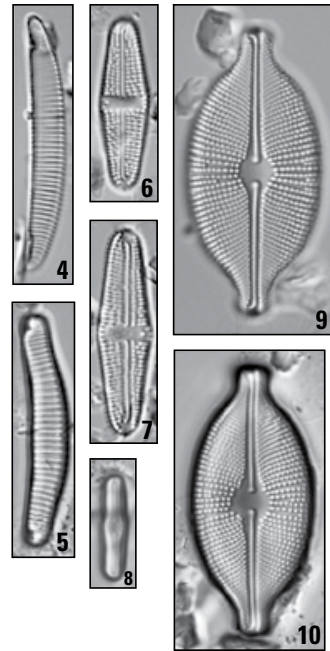
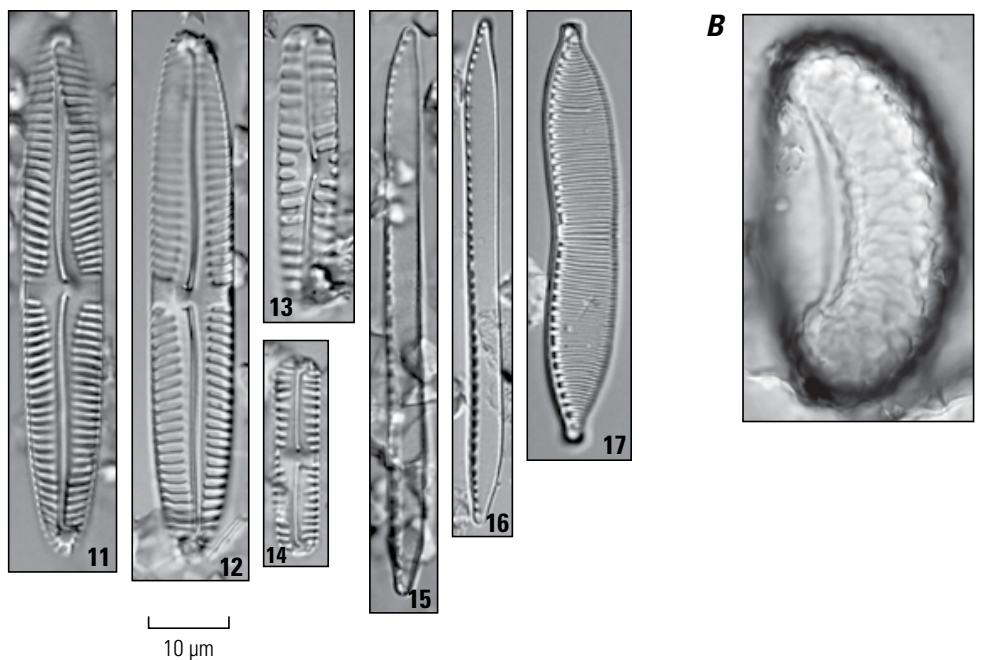

Figure 76. Photomicrographs of microfossils from the reddish humified peat at 90-93 centimeters depth in core 0M2 from 0'rekw marsh. A, Oligohalobous (fresh to fresh-brackish) diatoms. 1-2, Frustulia vulgaris, 3, Eunotia bidens, 4, Eunotia incisa; 5, Eunotia minor, 6-7, Lutica cf. suecorum; 8, Humidophila contenta; 9-10, Cosmioneis pusilla; 11-12, Pinnularia gibba var. linearis, 13, Pinnularia borealis, 14, Pinnularia lagerstedtii, 15-16, Nitzschia terrestris, 17, Hantzschia amphioxys. B, Spore of Dryopteris arguta, the western wood fern. $\mu \mathrm{m}$, micrometers.
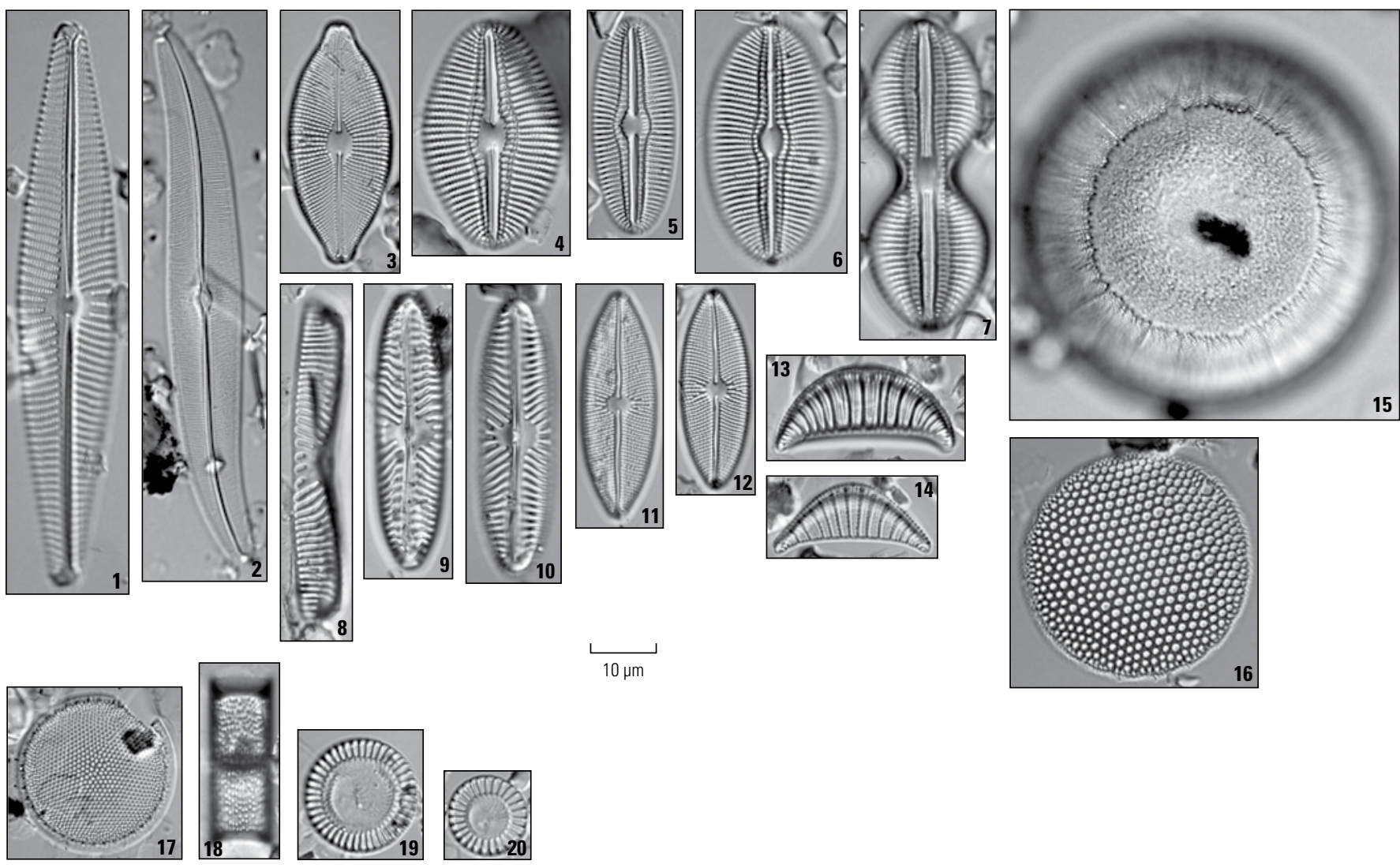

Figure 77. Photomicrographs of well-preserved benthic, epiphytic, and planktonic diatoms from a sand deposit at 132 centimeters depth in core $0 \mathrm{M} 2$ from 0 'rekw marsh. These taxa are consistent with accumulation in a lagoon or slough with variable salinity. Benthic taxa are shown in images 1-12, epiphytic taxa in images 13-15, and planktonic taxa in images 16-20. 1, Navicula peregrina; 2, Gyrosigma kutzingii; 3, Cosmioneis pusilla; 4, Diploneis smithii, 5, Diploneis smithii var. recta; 6, Diploneis pseudovalis, 7, Diploneis interrupta; 8-10, Navicula aff. digitoconvergens, 11-12, Mastogloia elliptica; 13, Rhopalodia constricta; 14, Rhopalodia pacifica; 15, Hyalodiscus laevis, 16, Roperia tesselata; 17, Thalassiosira sp.; 18, Aulacoseira sp.; 19-20, Cyclotella meneghiniana. um, micrometers. 

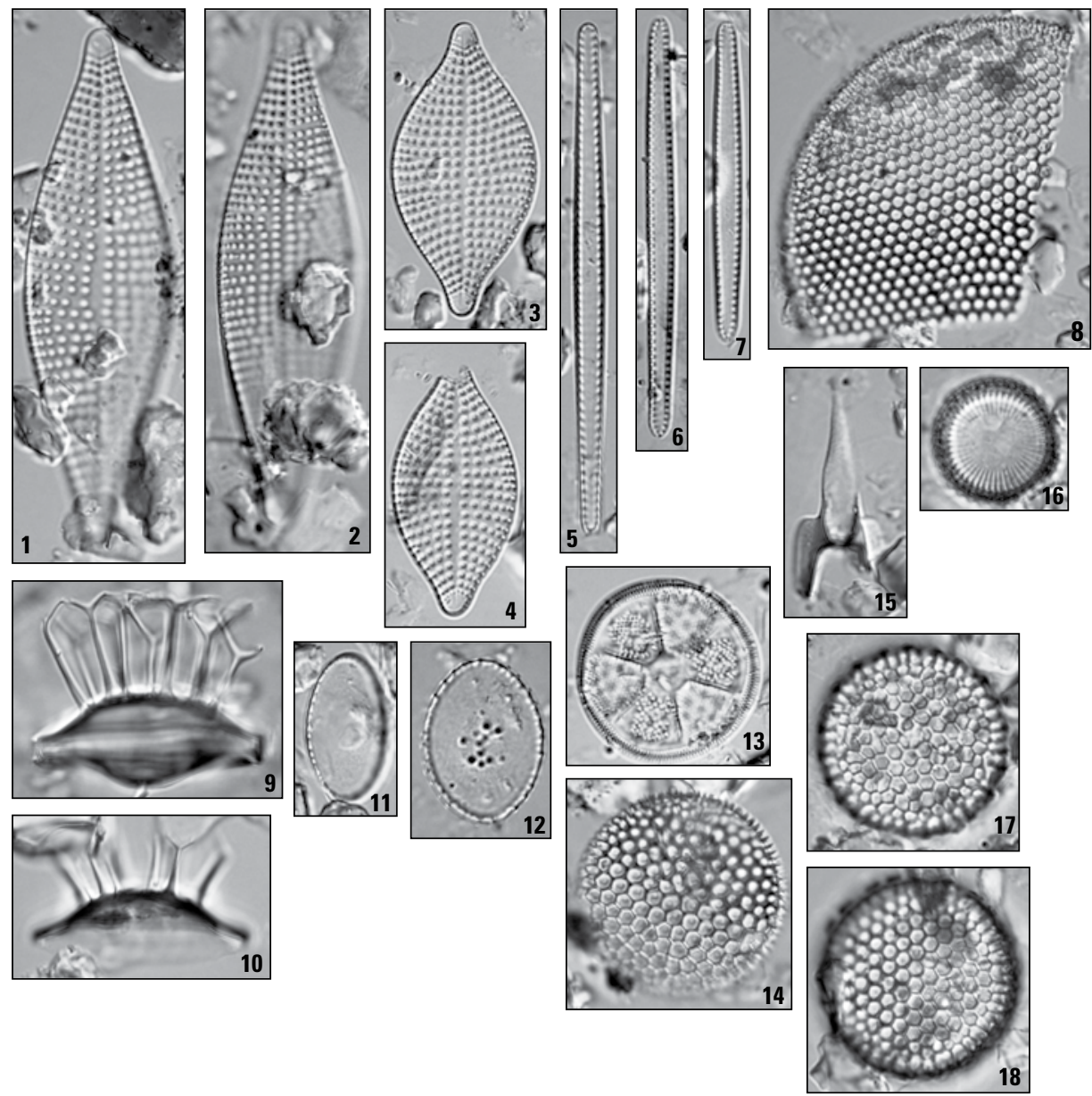

Figure 78. Photomicrographs of marine and estuarine diatoms from muddy silt and silty sand at 115-120 centimeters depth in core $0 \mathrm{M} 2$ from 0'rekw marsh. Planktonic or tychoplanktonic taxa are shown in images 1-16 and benthic taxa are shown in images 17-18. 1-4, Rhaphoneis amphiceros; 5-7, Thalassionema nitzschioides; 8 , Thalassiosira eccentrica (broken valve); 9-12, Chaetoceros spp. resting spores; 13, Actinoptychus senarius; 14, Coscinodiscus radiatus; 15 , Rhizosolenia styliformis; 16, Paralia sulcata; 17-18, Endictya hendeyi. $\mu \mathrm{m}$, micrometers.

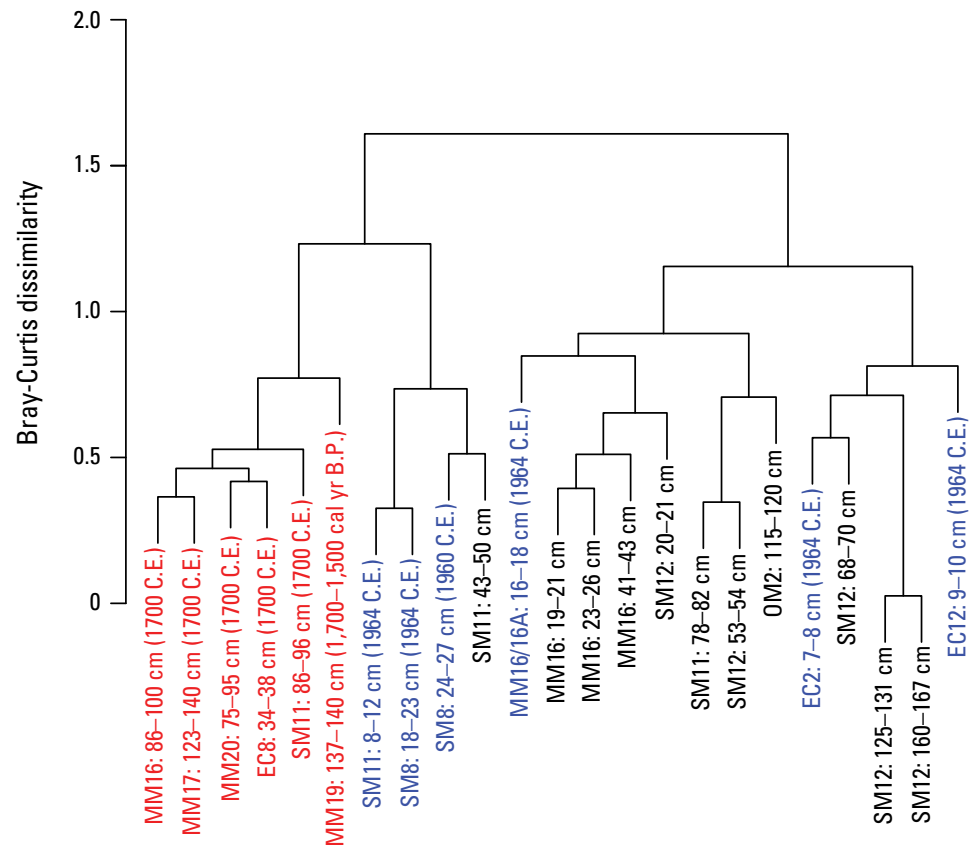

Figure 79. Graph showing BrayCurtis dissimilarity (results of Q-mode cluster analysis) among marine diatom assemblages from a sandy sample from core 0M2 and tsunami and storm samples from the Crescent City study sites. Diatom sample labels identify the core name (OM for O'rekw marsh; SM for Sand Mine marsh; EC for Elk Creek wetland; MM for Marhoffer Creek marsh) and depth of sampling (in centimeters, $\mathrm{cm}$ ). The age of the deposit (in either C.E. or calibrated years before present [cal. yr B.P.]) is also given, if known. Red labels indicate near-field tsunami deposits, blue labels indicate far-field tsunami deposits, and black labels indicate storm deposits. The agglomerative coefficient is 0.71 . 
Four other sand and muddy sand layers are present in core OM2 in addition to the sandy unit near $120 \mathrm{~cm}$ depth that includes an accumulation of marine taxa (fig. 74). Each of the sandy layers is correlatable among the three O'rekw marsh cores (fig. 73). Brackish diatoms are abundant in muddy sand at $45-50 \mathrm{~cm}$ depth; diatoms are sparse in the other sand layers. Marine diatoms, including species that could have originated in the lower Redwood Creek estuary, are present but very rare in the sand layers as well as in the surrounding silty deposits (fig. 74). The sand layer at 80-89 $\mathrm{cm}$ depth, which overlies the well-developed reddish peat, is rich in detritus and includes rare specimens of the aerophilous marsh taxa and fern spores that are similarly found in the underlying peat (figs. 73, 74).

\section{Discussion}

\section{Environmental Variability Through Time}

The lithologic and diatom data for core OM2 show that a peat-accumulating marsh environment persisted at the O'rekw marsh study site for only two short periods: (1) for a short interval more than 280 years ago (based on a ${ }^{14} \mathrm{C}$ age from an overlying unit) indicated lithologically by peat and muddy peat in the core at 89-99 cm depth (figs. 73, 74), and (2) possibly since the site was isolated by the construction of Highway 101 in 1949. The dominant lithology in the core is gray clayey silt, which is intercalated with layers or poorly sorted fine- to medium-grained sand or muddy sand. Predominantly brackish diatom assemblages are found in these deposits (figs. 74, 76), with the exception of a silty clay interval between 99 and $115 \mathrm{~cm}$ depth (underlying the freshwater muddy peat interval) where freshwater diatoms are dominant. These lithologic data are consistent with sediment accumulation in fresh to brackish slough or lagoon environments, probably natural depocenters in a pre-settlement, dynamic lower Redwood Creek estuary. The transition from inorganic mud to muddy peat containing freshwater diatoms $(90-115 \mathrm{~cm}$ depth; fig. 74) is consistent with sediment buildup along a freshwater lagoon, with a deep-water muddy environment giving way to development of a vegetated marsh along the lagoon margins.

\section{Paleoenvironmental Evidence for Coseismic Subsidence}

A distinct biostratigraphic shift, inferred from diatoms, is observed above and below the layer of detrital-rich sand at 80-89 $\mathrm{cm}$ depth in core $\mathrm{OM} 2$, where a vegetated freshwater environment is replaced by a muddy brackish one (fig. 74). At numerous estuarine locations in the Pacific Northwest (for example, those documented by Atwater and others, 1995; Nelson and others, 1996; and Kelsey and others, 2002), as well as in Humboldt Bay (Patton, 2004; Pritchard, 2004; Engelhart and others, 2016), an abrupt stratigraphic change from a marsh or upland soil to a capping deposit of intertidal mud has widely been used as an indicator of coseismic subsidence. At the O'rekw marsh study site, we interpret a change from a reddish, well-developed peat containing aerophilous diatoms to overlying silty deposits containing diverse brackish diatoms as an environmental shift from an emergent marsh to a brackish slough or lagoon. We interpret this change, in which an elevated environment (the fresh marsh) is replaced by a low-elevation environment (the brackish slough or lagoon), as consistent with coseismic subsidence. The radiocarbon age of 283-0 cal. yr B.P. from the top of the peat permits interpretation that this seismic subsidence occurred during the 1700 Cascadia Subduction Zone earthquake.

We recognize that other mechanisms in the lower Redwood Creek estuary could explain the erosive encroachment of a slough or lagoon into a marsh at the margin of the valley, and possibly create a stratigraphic contact of similar appearance. For example, even in historical times, the location of the river mouth has shifted north and south along the barrier spit by as much as $0.5 \mathrm{~km}$ (Ricks, 1985, 1995), and the location and areal extent of semi-permanent lagoons or slough channels have fluctuated over time (Waterman, 1920; Carver and others, 1998; Laird, 2009). However, the subsurface depth of the contact $(\sim 0.9 \mathrm{~m})$ in combination with the ${ }^{14} \mathrm{C}$ age is comparable to chronostratigraphic evidence for coseismic subsidence in 1700 both to the north (see sections on the Crescent City study sites; Peterson and others, 2011) and to the south (Pritchard, 2004; Engelhart and others, 2016) of the O'rekw marsh study site, supporting our conclusion that the environmental shift records coseismic subsidence.

\section{Lack of Definitive Evidence for Tsunami Deposits}

Despite stratigraphic evidence for coseismic subsidence associated with a buried soil at $89 \mathrm{~cm}$ depth in core OM2 (figs. 73, 74), we did not recognize convincing evidence for a tsunami deposit associated with that contact or at any other intervals in the O'rekw marsh cores.

About $10 \mathrm{~cm}$ of woody detrital-rich sand overlies the buried soil in core OM2 and is overlain by decimeters of sandy mud. A similar stratigraphy is observed at comparable depths in cores OM1 and OM3 (fig. 73). A lithologic pattern of peat capped by a layer of silt or sand that is overlain by mud has been shown to record incidents of coseismic subsidence and tsunami deposition at other locations in the coastal Pacific Northwest (for example, Atwater and others, 1995; Nelson and others, 1996). In similar studies, occurrences of diatoms consistent with transport from a seaward direction support the interpretation that a tsunami emplaced the sandy deposit in the sequence (for example, Hemphill-Haley, 1995a; Shennan and others, 1996, 1998; Garrison-Laney, 1998; Kelsey and others, 2002; Nelson and others, 2008). At O'rekw marsh, however, instead of lower estuarine or marine diatoms suggesting a seaward source, the woody detritus-rich sand layer in core OM2 contains oligohalobous marsh diatoms and spores of freshwater plants, suggesting a flood deposit and reworked material from terrestrial sources. Possible sources for the microfossils might include marshy areas that existed to the south of the lower Redwood 
Creek valley before the land was reclaimed for farming (Ricks, 1995). Therefore, although the sandy deposit that caps the buried soil at O'rekw marsh appears stratigraphically consistent with a near-field tsunami deposit, the microfossil evidence suggests that it is more consistent with a storm-related flood deposit. Although there are examples of tsunami deposits lacking marine components (for example, Szczuciński and others, 2012), the absence of marine diatoms in this deposit of core OM2 is contrary to observations from other Cascadia Subduction Zone tsunami deposits in coastal northern California, including at the three Crescent City study sites described in this report. Instead, we interpret the sand and detrital-rich deposit in core OM2 as most analogous to sandy deposits in core SM12 from Sand Mine marsh (this study), in that, although they cap a possible 1700 buried soil, they are interpreted as recording post-1700 storm inundation rather than tsunami inundation.

In contrast to the deposit at $89 \mathrm{~cm}$ depth, rare but well-preserved marine diatoms are found in a sand layer at 115-120 cm depth in core OM2 (figs. 73, 74). The types of dominantly planktonic species observed (figs. 74, 77) are found in the coastal ocean, but are also expected to occur in the saline lower reaches of the Redwood Creek estuary, suggesting that their presence in the sand layer does not necessarily imply landward transport from the ocean. Furthermore, the sand layer is intercalated in silty deposits - consistent with accumulation in a brackish slough (figs. 73, 74) - and does not cap a subsided soil surface, and thus lacks possible supporting evidence linking the deposit to an earthquake event.

Therefore, although the low elevation of the O'rekw marsh study site ( 1.8 $\mathrm{m}$ above mean sea level) and Native American oral histories both support tsunami inundation in the late Holocene, we observe that evidence for recognizable tsunami deposits is lacking, probably because the site is a poor location to preserve such deposits. These findings differ from those of Carver and others (1998), who proposed their interpretations based on cores collected at approximately the same location. However, the work of Carver and others (1998) preceded the availability of GPS location data that would allow precise comparison of core stratigraphy between the two studies.

\section{Pillar Point Marsh, San Mateo County}

\section{Summary of Findings}

The Pillar Point marsh study site is a coastal salt marsh to freshwater wetland at the northern end of Half Moon Bay, Calif. Subsurface stratigraphy, revealed in 27 cores collected along a shore-normal transect, show distinct lithologies associated with changes in marsh vegetation and the formation of a shallow lagoon created by offset of San Gregorio Fault splays about 250-350 years ago. In the uppermost $10-30 \mathrm{~cm}$ of most cores, a layer of pale gray, fine-grained sand or muddy sand containing beach and nearshore marine diatoms records inundation by the
April 1, 1946, far-field tsunami, which was generated during a M8.6 earthquake in the Unimak segment of the eastern Aleutian-Alaska megathrust. The 1946 tsunami deposit at Pillar Point marsh can be correlated across closely spaced cores approximately $300 \mathrm{~m}$ inland from the beach. It is commonly less than 4-6 cm thick along the core transect, except in topographically low spots of the marsh, where it is as thick as $20 \mathrm{~cm}$. The 1946 tsunami deposit is particularly well preserved at Pillar Point marsh where it was deposited in the shallow lagoon and buried by dark-colored, clay-rich organic mud. Our observations suggest it is the only tsunami deposit preserved since lagoon formation. The lagoon environment was suitable for recording a far-field tsunami in 1788, associated with largemagnitude rupture on the Aleutian-Alaska megathrust, but we observe no such sandy deposit in the lagoon stratigraphy at the appropriate interval.

\section{Overview}

\section{Study Site Description}

Pillar Point marsh is a salt marsh to freshwater wetland in coastal San Mateo County, Calif. (figs. 1, 80). It is located at the north end of Half Moon Bay, bordered to the west by steep hillslopes of the Pillar Point promontory and to the east by the town of Princeton. Pillar Point marsh forms the southeasternmost extent of the Fitzgerald Marine Reserve, a California marine protected area, and is managed by San Mateo County Parks Department and the California Department of Fish and Wildlife.

The observations and analyses reported here are from the salt to brackish marsh on the south side of West Point Avenue, which is the access road to the parking area for the Pillar Point marsh and hiking trails (fig. 81). The marsh is fairly flat in this area (figs. $82 A-C$ ), and a narrow slough cuts from west to east across the lower third of the marsh, draining to the beach at the southeast end of the marsh (figs. 81, 82B). With the exception of the area near the mouth of the slough, the marsh is separated from Pillar Point Harbor by a vegetated beach berm, which, at the location of transect $G-G$ ' (fig. 81), measures $3.0 \mathrm{~m}$ above NAVD88 (appendix 1), or approximately 2.1 meters above mean sea level. The beach adjacent to the marsh is gently sloping, and, at the time of our study, was about 25-35 m wide at low tide. We observed thick stands of seaweed across much of the swash zone and dried seaweed litter scattered on the upper beachface. The beach and nearshore environments have been impacted by accelerated sand accretion, as well as decreased wave action, since construction the Pillar Point Harbor breakwater in 1959-61 (Questa Engineering, 1991; San Mateo County Harbor District, 2018). However, a comparison of the 2016 NOAA nautical chart (U.S. Department of Commerce, 2016) with historical charts from 1863 (U.S. Coast Survey, 1863) and 1947 (U.S. Coast and Geodetic Survey, 1947) show that the shelf was equally as shallow before and after construction of the breakwater; water depths do not exceed 3-4 m as far as $500 \mathrm{~m}$ offshore. 
The marsh vegetation at the study site dominantly consists of low-lying but dense stands of pickleweed (Salicornia). The marsh surface was moist but not wet, and had a few centimeters of dry plant duff at the base of the living plants and covering the soil surface from which samples were collected for diatom analysis. At the northern edge of the marsh, proximal to surface sample PD13 (fig. 81), the marsh transitions to a brackish environment, supporting stands of Juncus sp. (salt rush), Potentilla sp. (silverweed), and minor occurrences of Typha sp. (cattail) and Scirpus sp. (tule) (Questa Engineering, 1991).
A prominent feature at Pillar Point marsh is a large, shallow, remnant lagoon with a muddy non-vegetated floor (figs. 81, 82C). It currently extends over an area of about $7,500 \mathrm{~m}^{2}$, but was more extensive in the past, as evident on historic U.S. Coast Survey charts (U.S. Coast Survey, 1861, 1863), the 1929 U.S. Coast and Geodetic Survey chart (U.S. Coast and Geodetic Survey, 1929) and 1940s aerial photographs (figs. 81, 83). Although locally referred to as a lagoon, and identified as such on some maps (for example, see figs. 1 and 2 in Questa Engineering, 1991), it is currently cut off from the ocean and therefore probably more accurately described as a shallow ephemeral pond or marsh pan.

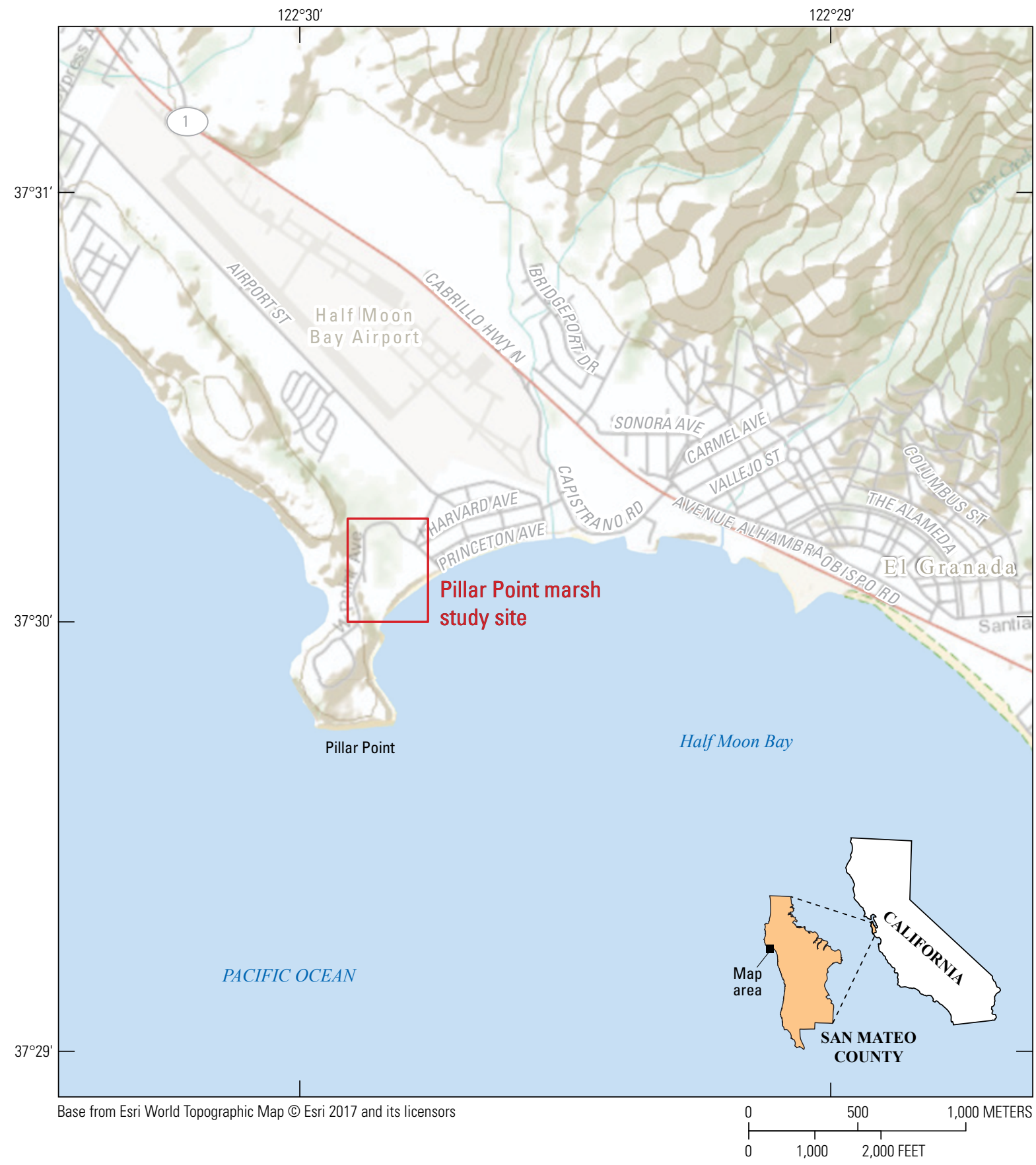

Figure 80. Map showing the location of the Pillar Point marsh study site in the northern part of Half Moon Bay, California. 


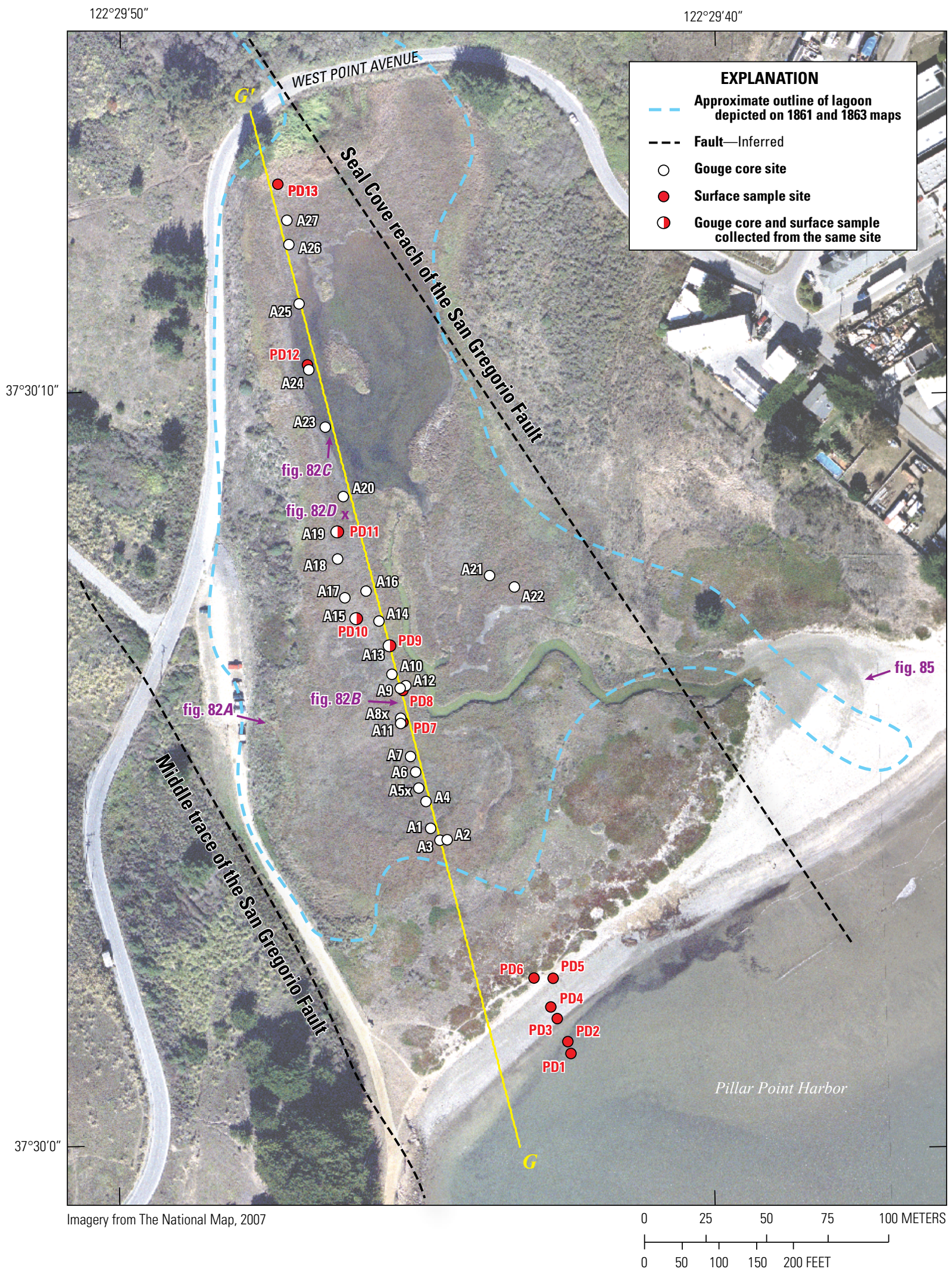

Figure 81. Aerial image showing locations of cores and surface samples collected from the Pillar Point marsh study site. Outlined in blue is the approximate area of a former lagoon, as depicted on a historical T-sheet (U.S. Coast Survey, 1863). Purple arrows show the location and direction of view for photographs in figures 82 and 85 . The purple " $x$ " indicates the location of the sedimentary sample shown in figure 82D. Black dashed lines show splays of the San Gregorio Fault (Koehler and others, 2005). 

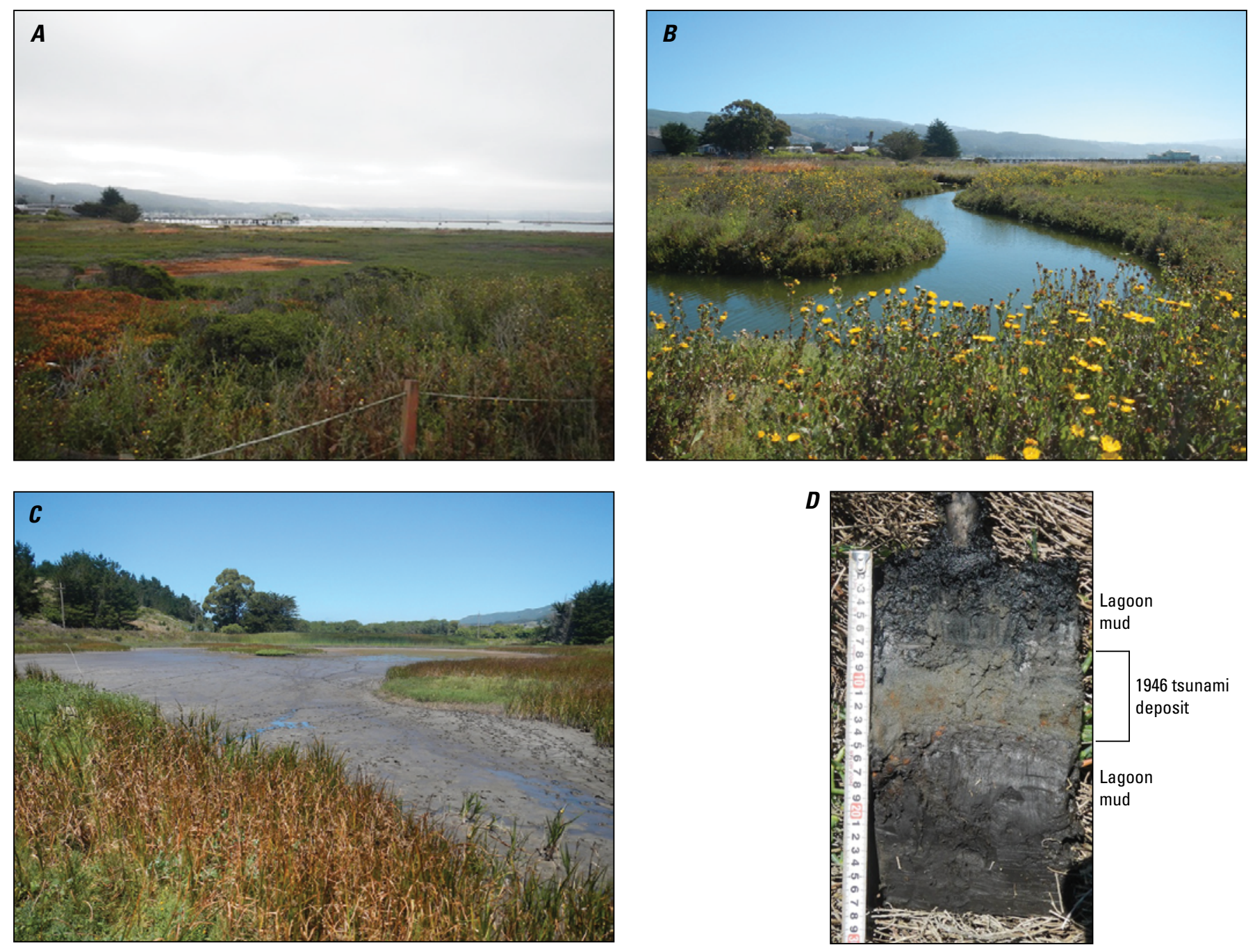

Figure 82. Photographs of the Pillar Point marsh study site. A, View to the southeast across Pillar Point marsh, towards the pier at Pillar Point Harbor. The linear structure visible in the right background is the breakwater constructed between 1959 and 1961 . $B$, View of the slough transecting the lower part of Pillar Point marsh. As shown in this photograph, the slough is often full at all tide levels when sand build-up on the beach prohibits tidal exchange. $C$, View to the northeast across the remnant lagoon area. This photograph was taken after the dry period in the summer and fall. $D$, Annotated photograph of sediment collected with a spade in a remnant area of the lagoon (now a marsh pan) located between core sites A19 and A20. The pale gray sandy 1946 tsunami deposit stands out in stark contrast to the under- and overlying dark brown to black clay-rich lagoon deposits.

Seasonally, the muddy floor of the lagoon ranges from desiccated in the late summer and early fall (fig. $82 C$ ) to submerged by a few decimeters of water during wetter times of the year, depending on the amount of groundwater upwelling or drainage from the wetland area on the north side of West Point Avenue (Questa Engineering, 1991).

\section{Previous Studies}

Following preliminary paleoseismic studies at Pillar Point marsh by Simpson and Knudsen (2000) and Koehler and others (2004), Koehler and others (2005) completed a detailed paleoseismic study and provided a chronology of past ruptures along the northern San Gregorio Fault Zone. Their project included a coring, stratigraphic, and biostratigraphic analysis at the marsh and a trenching study on the north side of the Seal Cove bluffs about $10 \mathrm{~km}$ up the coast (northwest) from Pillar Point marsh (see fig. 2 of Koehler and others, 2005). Koehler and others (2005) proposed that two or possibly three earthquakes along the northern San Gregorio Fault Zone caused extension between splays that cross the marsh, resulting in coseismic subsidence and subsequent abrupt changes in subsurface lithology. They suggested that the current salt marsh and remnant lagoon are consequences of the most recent rupture of the northern San Gregorio Fault Zone, in which subsidence between two right-stepping splays converted what was an aerobic, oligohalobous (fresh to slightly brackish) wetland to a brackish-marine or euryhaline lagoon and fringing salt marsh. Stratigraphic evidence for the subsidence, supported by diatom data, is observed as a sharp contact between an underlying coarse-grained peat (the former fresh wetland) and 
overlying dense, gray to black clay or mud (the post-subsidence lagoon). Schwartz and others (2014) proposed that the most recent fault offset and coseismic subsidence at Pillar Point marsh occurred in the early to mid-1700s, as discussed below.

Previous tsunami-related studies at Pillar Point include the 1946 post-tsunami survey by Bascom (1946) and evaluations of historical documents and eyewitness accounts by Lander and Lockridge (1989) and Lander and others (1993). The first geological evaluation of tsunami deposits at Pillar Point marsh was completed by Wilson and others (2014), who documented the shallow subsurface distribution of the 1946 far-field tsunami deposit — a mostly landward-thinning layer of pale brownish-gray sand (figs. 82D, 83, 84) - and discussed different possible origins of other sandy layers visible in some cores (see p. 88 and fig. 64 of Wilson and others, 2014). The core data collected by Wilson and others (2014) across the marsh to document the distribution of the 1946 tsunami deposit, including cores A1-A27 described in greater detail here (figs. 83, 84; appendix 1, figs. 1.26-1.39), also provided further documentation of the peat-to-lagoon-mud stratigraphic contact that marks the most recent fault rupture and coseismic subsidence described by Simpson and Knudsen (2000) and Koehler and others (2005).

\section{Inundation by the 1946 Far-Field Tsunami}

On April 1, 1946, a M8.6 earthquake in the eastern AleutianAlaska Subduction Zone triggered a Pacific Ocean-wide tsunami, recorded as far away as Antarctica (López and Okal, 2006; Ryan and others, 2012; von Huene and others, 2016). Within the United States and its territories, the tsunami inflicted severe damage and loss of life, both locally in the Aleutian Islands as well as more than 4,000 km away in Hawaii (Shepard and others, 1950). The traumatic damage and high number of fatalities from this event triggered a call to action and establishment of the Pacific Tsunami Warning Center in 1948 and "the promotion of research and international cooperation" (Lander and others, 1993, p. 69). Along the conterminous U.S. West Coast, the 1946 tsunami was observed to varying degrees from Washington State to southern California, with one fatality in Santa Cruz (Bascom, 1946; Lander and others, 1993; U.S.C. Tsunami Research Group, 2016). The greatest wave heights and inundation distance in this region were recorded at Pillar Point and Pillar Point Harbor at the northern end of Half Moon Bay.

At Half Moon Bay, the first wave of the April 1, 1946, tsunami arrived at about 9:15 a.m. under "a bright sun and from a sea calm and as smooth as glass" (Lander and others, 1993, p. 75). A total of 11 waves arrived at roughly 12 - to 15 -minute intervals over the next two hours (Bascom, 1946; Lander and others, 1993). The sixth wave, arriving during high tide at about 10:30 a.m., caused the most damage, flooding the town and dislodging fishing boats from their moorings (fig. 85). At least one boat was left stranded about $300 \mathrm{~m}$ inland (Bascom, 1946, p. 18; Lander and Lockridge, 1989, figs. 52, 53). Eyewitnesses reported that the sixth wave swept across Pillar Point marsh and flooded West Point Avenue (figs. 81, 86) (Bascom, 1946; Wilson and others, 2014, p. 88). Rocks and boulders "weighing as much as 150 [pounds]" (Bascom, 1946, p. 16) were scattered on the seaside frontage road (Lander and others, 1993, fig. 15). ${ }^{16}$ The narrow beach along Pillar Point Harbor was denuded of sand, exposing the underlying marine mudstone bedrock (Bascom, 1946, p. 15). The beach adjacent to Pillar Point marsh was similarly eroded (fig. 86).

Various eyewitnesses provided a range of estimates for the maximum height of the tsunami (Lander and others, 1993). Bascom (1946, p. 4) reported that it "was definitely stated that the highest water came to the top of a concrete tank and the pier stringers. This was made the reference for the measurements of the wave height." That height was $14.8 \mathrm{ft}$ (4.5 m) above MLLWequivalent to a tsunami wave height of $10.1 \mathrm{ft}(3.1 \mathrm{~m})$ arriving on the waning high tide of $4.7 \mathrm{ft}(1.4 \mathrm{~m})$ above MLLW. As noted by Wilson and others (2014), the depth of the sixth wave as it crossed the marsh is not known, but it flowed at least $350 \mathrm{~m}$ across the marsh to the elevation of West Point Avenue (3.5-4 m above MLLW) before receding. Erosion from the receding wave carved rills in the berm and upper beachface (fig. 85), comparable to the rills in the beachface at Crescent City that were cut by the 1964 far-field tsunami (fig. 45).

Although not reported by any eyewitness account, Bascom's 1946 report implies a possibility that, in addition to the largest wave that arrived at 10:30 a.m., the smaller preceding wave at 10:15 a.m. may have been high enough to inundate some of the marsh. Bascom's report (1946, p. 5) includes a reprint of a report by E.O. McMahon, who on the morning of April 1, 1946, was coincidentally leading an engineering survey crew at Pillar Point Harbor. McMahon provided visual estimates of water levels relative to the known elevations of their survey markers.

The records do not indicate why McMahon did not observe the earlier waves starting at 9:15 a.m., as reported by eyewitnesses on the pier, but rather first noticed the tsunami activity by a strong draw-down of the sea at 10:05 a.m. McMahon reported that from a predicted high-tide level of about $5.0 \mathrm{ft}(1.5 \mathrm{~m})$ above MLLW, the sea quickly receded to near $0.0 \mathrm{ft}(0.0 \mathrm{~m})$, "showing a considerable amount of beach" (Bascom, 1946, p. 5). Soon after, at 10:15 a.m., a wave topped their survey point "A.P. \#11," which was at an elevation of $10.6 \mathrm{ft}(3.2 \mathrm{~m})$ above MLLW. Using A.P. \#11 as a datum,

\footnotetext{
${ }^{16}$ Some confusion may exist concerning the location and distribution of rocks and boulders transported by the 1946 tsunami. Bascom $(1946$, p. 5) reported that the largest tsunami wave at 10:30 a.m. "washed over the road (Route 1) and carried rocks with it, stalled engines, and caved in the side of one automobile." It is likely that Bascom was actually referring to Capistrano Road, the frontage road along the shoreline at Pillar Point Harbor, and not the modern State Route 1, which is no closer than $150 \mathrm{~m}$ from the shore in this area. In a photograph that shows damage to the pier as well as to buildings on Capistrano Road, Bascom (1946, p. 16) refers to large rocks displaced by the tsunami in the photograph caption, which reads "Near gas station road was covered with rocks, some weighing as much as 150 [pounds]." On the following page, Bascom includes a photograph showing rocks scattered on Capistrano Road, near the small building that housed Hazel's Sea Food, which was dislodged about $0.6 \mathrm{~m}$ by the tsunami. Lander and Lockridge (1989, p. 184) appear to have later interpreted Bascom's (1946) observations to mean that rocks and boulders were transported the rather far distance to S.R. 1 when they reported, "At nearby Princeton huge boulders weighing up to 70 kilograms were washed as far away as the highway..." If rocks and boulders were actually transported as far as S.R. 1, we could find no photographs or other historical evidence to support it.
} 


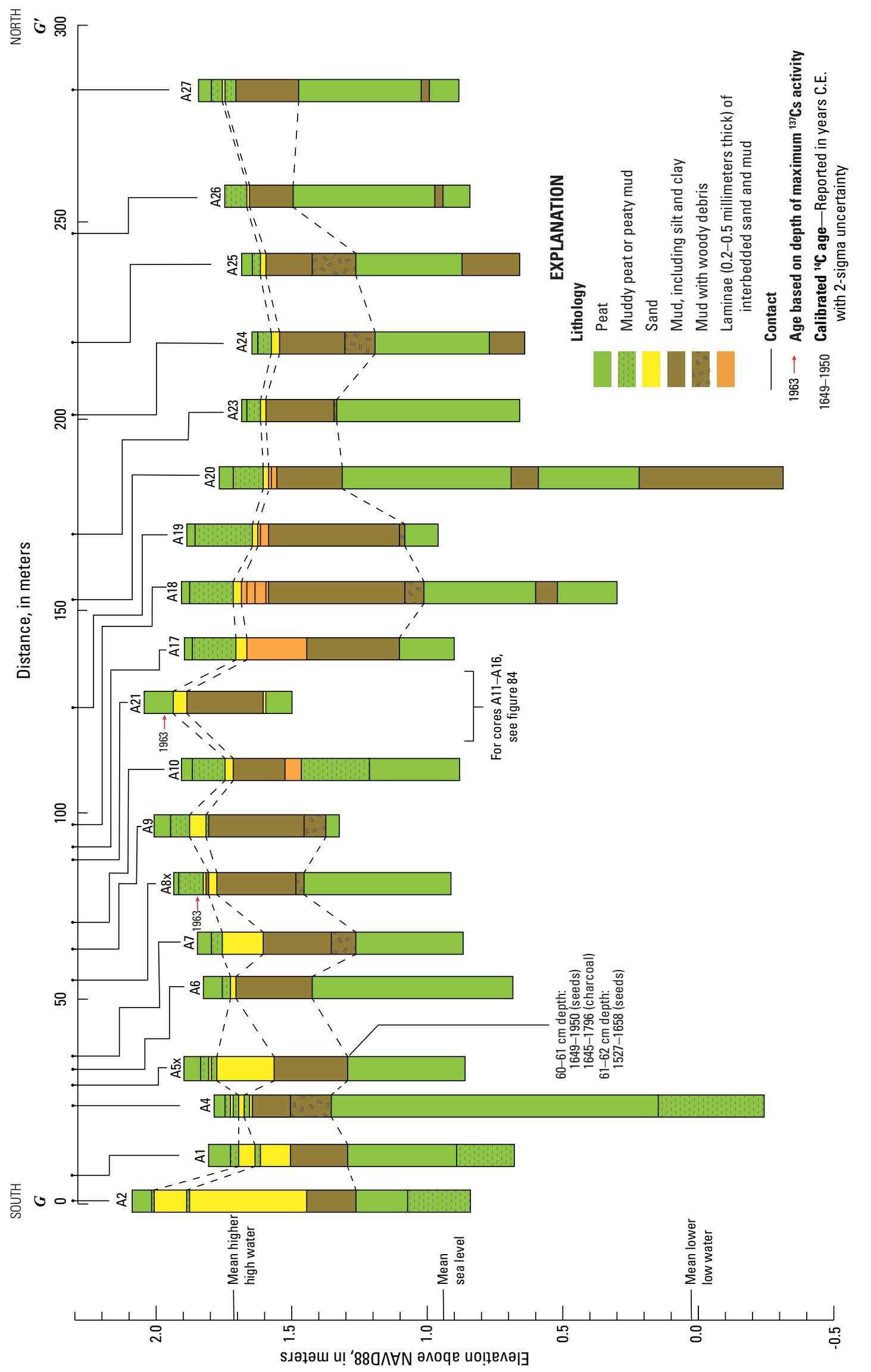

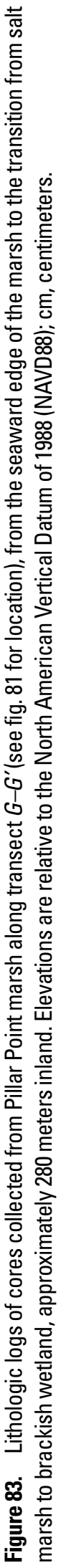




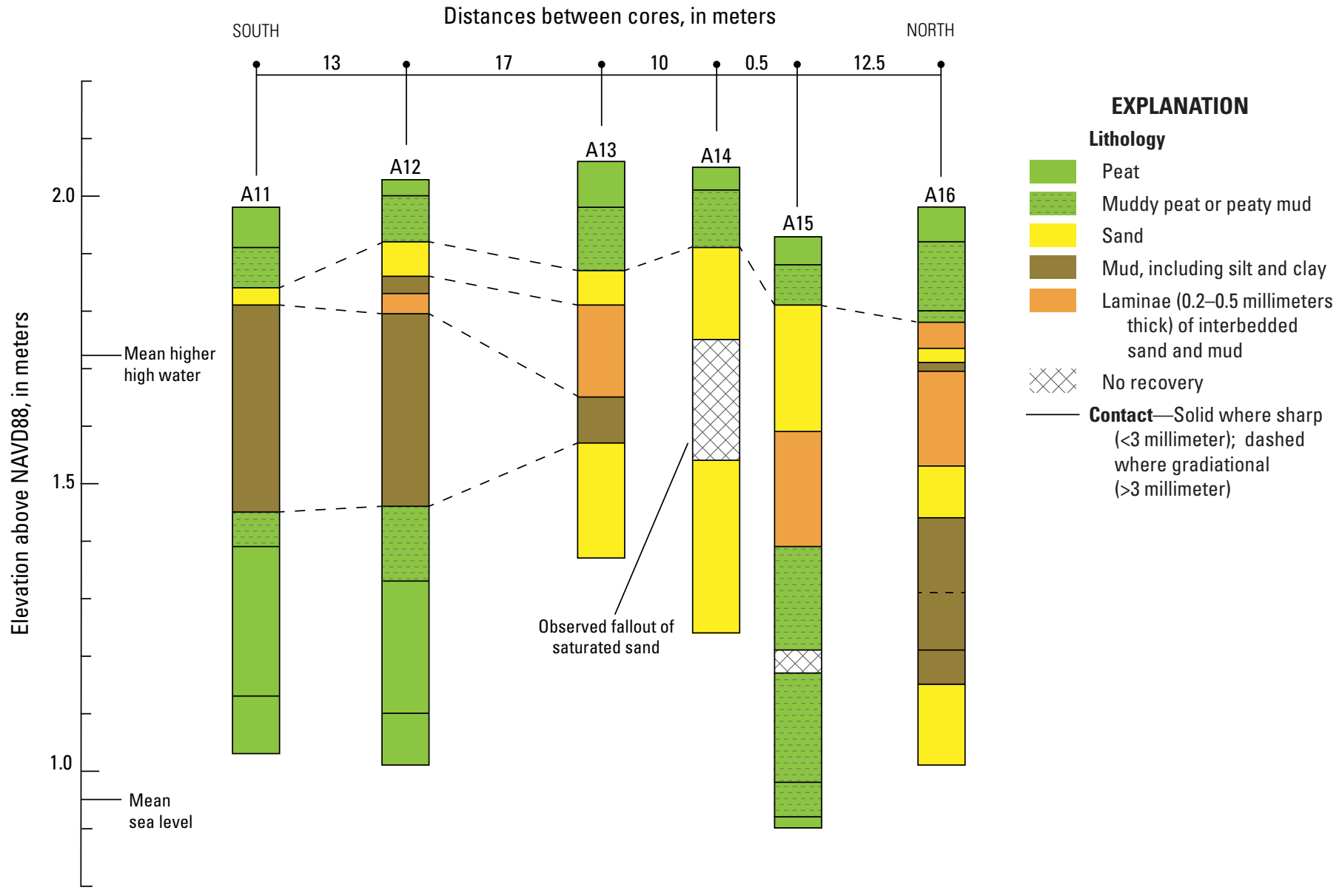

Figure 84. Lithologic logs of cores collected from Pillar Point marsh that include the 1946 tsunami deposit. Cores A11 and A12 show distinct stratigraphic evidence for the tsunami deposit as a single, anomalous layer of sand intercalated in black, organic-rich lagoon deposits, but the tsunami deposit in cores A13-A16 may be obscured by sandy overbank deposits from the slough in the central marsh area. The distance between cores is given at the top of the figure. Elevations are relative to the North American Vertical Datum of 1988 (NAVD88).
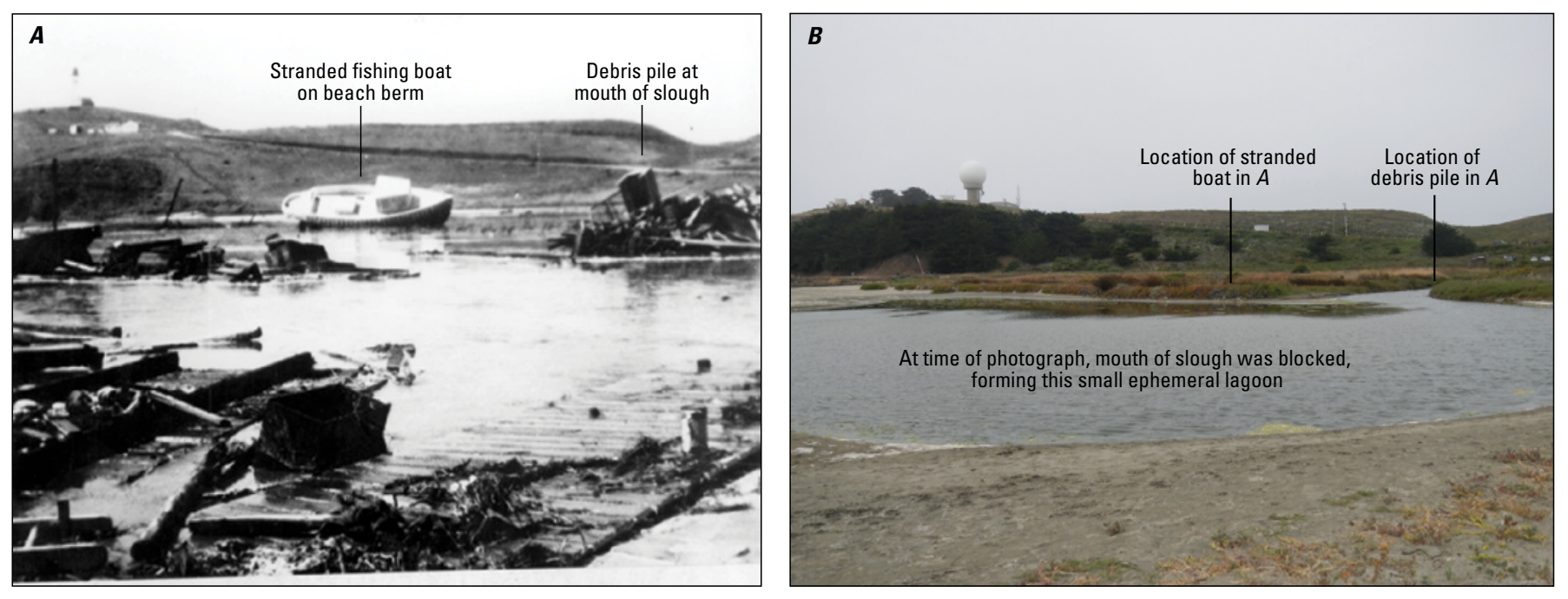

Figure 85. Historical and modern photographs of Pillar Point marsh. Each photograph is taken from approximately the same vantage point; see figure 81 for location. A, Photograph from April 1,1946, after the tsunami, showing large debris, including a stranded fishing boat, piled along the shore near the mouth of the slough that drains Pillar Point marsh. National Oceanic and Atmospheric Administration's National Centers for Environmental Information photograph by Howard Anderson. B, Photograph from August 10, 2012, showing the same area near the mouth of the slough. 

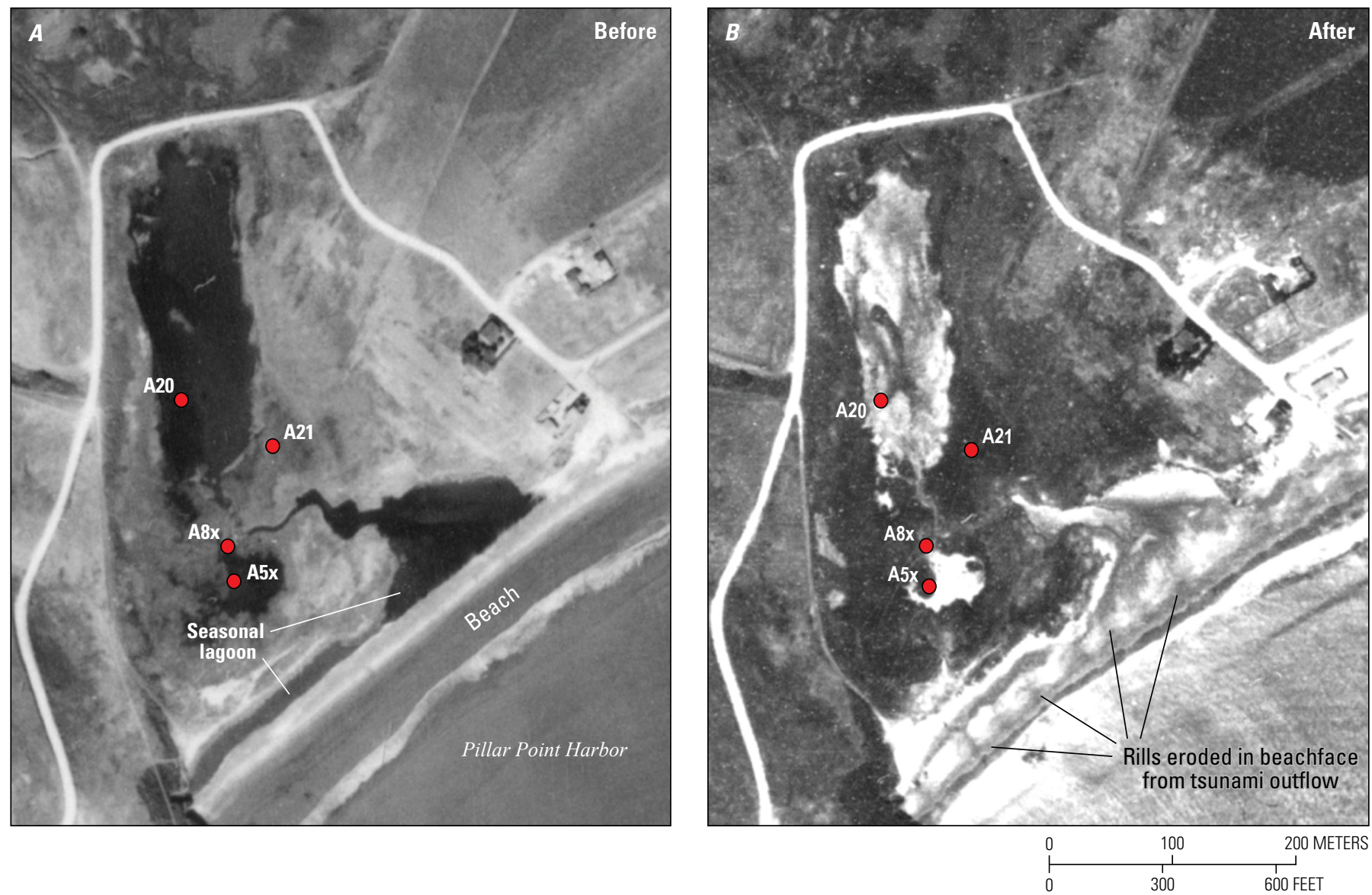

Figure 86. Comparison of aerial photographs of Pillar Point before and after the 1946 tsunami. Gouge core sites from this study are shown by the red dots. A, Aerial photograph of Pillar Point marsh in 1943, showing the extent of the natural seasonal lagoon and shallow-water areas on the marsh surface. $B$, Aerial photograph of Pillar Point marsh taken a few months after the April 1, 1946, tsunami. Bright areas show distribution of sand on the marsh surface, particularly evident in the ponded areas. Rills eroded in the beachface by tsunami outflow are visible along the sand spit. Photographs provided and georectified by Steve Watt, U.S. Geologcial Survey.

McMahon estimated the wave height at $12.5 \mathrm{ft}(3.8 \mathrm{~m})$ above MLLW. This was followed by what others described as the sixth wave, but what McMahon reported as the "second" and largest wave, at 10:30 a.m. McMahon described this wave as reaching a height of $15.0 \mathrm{ft}(4.6 \mathrm{~m})$ at survey point A.P. \#11. McMahon's estimate of $15.0 \mathrm{ft}(4.6 \mathrm{~m})$ is very close to Bascom's estimate that the maximum wave height was $14.8 \mathrm{ft}$ (4.5 $\mathrm{m}$ ) above MLLW, based on the measured flooding at the pier. It was this largest wave at 10:30 a.m. that McMahon and others reported as flooding the full distance across the marsh to West Point Avenue. However, assuming that McMahon's estimate for the height of the 10:15 a.m. wave was accurate, the 10:15 a.m. wave likely also would have exceeded $\sim 3.5 \mathrm{~m}$, plausibly high enough to flood into the lower slough channel, if not top the beach berm, which is currently at an elevation of about $3 \mathrm{~m}$ MLLW (appendix 1). Regardless of whether or not a smaller amount of flooding preceded inundation by the largest wave, the tsunami left clear geologic evidence of the event: anomalous accumulations of sand across the marsh, particularly visible in low spots and the unvegetated shallow lagoon from a 1946 aerial photograph (fig. 86).

\section{Field Data Collection Strategies}

The goals of this part of the study were twofold: (1) to document the subsurface distribution and lithological and paleontological characteristics of the 1946 far-field tsunami deposit at Pillar Point marsh and (2) to search for possible evidence for comparable far-field tsunami deposits that have accumulated at the location since lagoon formation, which, based on previous studies (Schwartz and others, 2012) and our radiocarbon analyses (see below), occurred approximately $250-350$ years ago.

The subsurface stratigraphy was recorded in 27 cores collected along a shore-normal transect from the landward side of the berm to about $280 \mathrm{~m}$ inland, across the marsh and along the western edge of the current lagoon (figs. 81, 83, 84; appendix 1). The initial stratigraphy for these cores was previously reported in Wilson and others (2014, fig. 65). ${ }^{17}$ All cores were described in the field, and several cores and core sections were returned to the lab

\footnotetext{
${ }^{17}$ Figure 65 in Wilson and others (2014) also includes descriptions for deeper stratigraphy at cores sites A1, A6, A8, A10, A13, and A17. Those data are based on additional vibracoring by our USGS colleagues and are not included as part of our analysis here.
} 
to subsample for ${ }^{210} \mathrm{~Pb},{ }^{137} \mathrm{Cs},{ }^{14} \mathrm{C}$, and diatoms. Surface-sediment samples were also collected along a transect from the lowermost intertidal zone to the transition to the brackish marsh near West Point Avenue to document the distributions of modern diatoms (fig. 81).

We used a hand-held GPS unit and an automatic level to map the locations and the relative elevations of the cores and surface samples. The automatic-level data were then converted to elevations relative to NAVD88 based on an RTK measurement of our temporary transect benchmark provided by our USGS colleagues (Wilson and others, 2014). The closest tidal benchmark for the Pillar Point marsh study site is NOAA Station 9414131, located $1 \mathrm{~km}$ east of the study site on the Pillar Point Harbor pier (NOAA, 2003c). The RTK data show that the cores were recovered from elevations less than $2.1 \mathrm{~m}$ above NAVD88 (figs. 83, 84; appendix 1).

\section{Observations}

\section{Lithology and Stratigraphy}

Subsurface deposits to depths of about 1-1.5 m, where we focused our analyses, ${ }^{18}$ can be divided into four basic lithologies, where freshwater peat, salt-marsh peat, and clay-rich deposits represent the natural marsh environment, and an allochthonous layer of sand and muddy sand represent deposits emplaced by the 1946 tsunami (figs. 83-84, 87-88; appendix 1). The modern salt-marsh peat and peaty mud forms a thin layer (less than about $0.2 \mathrm{~m}$ thick) in the western part of the marsh where we collected our cores. Underlying the modern salt marsh peat is $\sim 0.2-0.5 \mathrm{~m}$ of dark brown to black, organic-rich, silty mud and clay, indicating accumulation on the lagoon floor. The lagoon deposits in some cores show intervals of dense concentrations of fine roots, suggesting periods of aquatic plant growth. Some cores also show sections of millimeter-scale alternating laminae of mud and fine sand within the dominantly clay-rich deposits (figs. 83, 84, appendix 1). However, the lagoon unit is distinguishable for the most part by the decimeters of dense, dark-gray clay and mud. The clastic lagoon deposits are underlain by brown, fine- to coarsegrained peat that accumulated in a former freshwater wetland that existed prior to subsidence and lagoon formation.

In most cores, the 1946 far-field tsunami deposit was found intercalated in the upper part of the lagoon deposits. In some cores, for example, core A21 (fig. 87A), the tsunami deposit forms a layer in the subsurface at the transition between the lagoon mud and overlying modern peat. The tsunami deposit is composed of pale gray, clean fine sand, which stands out in contrast to the dark-gray to black, clay-rich lagoon deposits (figs. 82D, 87B). The tsunami sand is typically less than $4-6 \mathrm{~cm}$ thick along the core transect, except where it accumulated in topographically low spots on the marsh-for example, in cores A5x and A7, it is as thick as $20 \mathrm{~cm}$ (figs. 81, 83). The tsunami

\footnotetext{
${ }^{18}$ Longer and older subsurface stratigraphic records are discussed by Koehler and others (2005) and Wilson and others (2014).
}

deposit can be traced inland across the marsh, although its presence is ambiguous in cores A14 and A15, which were collected near the slough channel (figs. 81, 84). These cores contain anomalously thick sandy deposits that may or may not be associated solely with the 1946 tsunami. The thickness of the deposit varies slightly relative to the paleotopography of the marsh and lagoon. Although the deposit maintains a fairly constant thickness of 4-6 cm where it was deposited within the lagoon, the deposit shows an overall landward-thinning trend and pinches out just landward of core A27, about $300 \mathrm{~m}$ from the beach (figs. 81, 83).

\section{Geochronology}

Cores A21 and A8x were analyzed for ${ }^{210} \mathrm{~Pb}$ and ${ }^{137} \mathrm{Cs}$ radionuclide activities (figs. 87, 89, tables 8, 9; appendix 2). ${ }^{210} \mathrm{~Pb}$ activities were too low in both cores to provide reliable results below about $10-20 \mathrm{~cm}$ depth. The $1963{ }^{137} \mathrm{Cs}$ peak was distinct in each core, identified at a depth of $8.5 \mathrm{~cm}$ in both.

Three AMS ${ }^{14} \mathrm{C}$ ages from core $\mathrm{A} 5 \mathrm{x}$ were acquired from seeds and charcoal that were extracted from fibrous peat just below the contact with the overlying lagoon deposits at $60 \mathrm{~cm}$ depth (figs. 81, 83, 90; table 1). At 60-61 cm depth, a charcoal sample yielded a 2-sigma calibrated age of 1649-1796 C.E. (305-155 cal. yr B.P.). A similar analysis on small seeds from the same depth gave a less precise result of 1649-1950 C.E. (301-0 cal. yr B.P.). A sample of small seeds from peat at 61-62 cm depth returned a calibrated age of 1527-1658 C.E. (423-292 cal. yr B.P.).

Schwartz and others (2014) reanalyzed radiocarbon data from Simpson and Knudsen (2000) and Koehler and others (2005) to propose an age of 1700-1776 C.E. (with a mean of 1759 C.E.) for the graben-forming rupture on the San Gregorio Fault System at Pillar Point marsh (fig. 90). The maximum age, 1776, is inferred from the absence of any historical reports of an earthquake of appropriate magnitude after 1776 from Mission Delores in San Francisco, which was founded that year. Our ${ }^{14} \mathrm{C}$ age results allow for a minimum age a few decades before 1700 , but we also recognized the likely maximum age of 1776 (fig. 90) for graben subsidence and lagoon formation at Pillar Point marsh.

\section{Diatom Analyses}

\section{Modern Diatom Assemblages}

Samples along a shore-normal transect (fig. 81), observed qualitatively, show that the surfaces of the marsh, lagoon, and beach at Pillar Point support prolific and distinctive populations of diatoms (figs. 91, 92).

The modern salt marsh supports diverse populations of pennate diatoms, including species typically found in temperatezone high salt marshes (Witkowski and others, 2000), such as Cosmioneis pusilla, Luticola mutica, Tryblionella debilis, Humidophila diadesmis, and Nitzschia vitrea (fig. 91). Diatom 

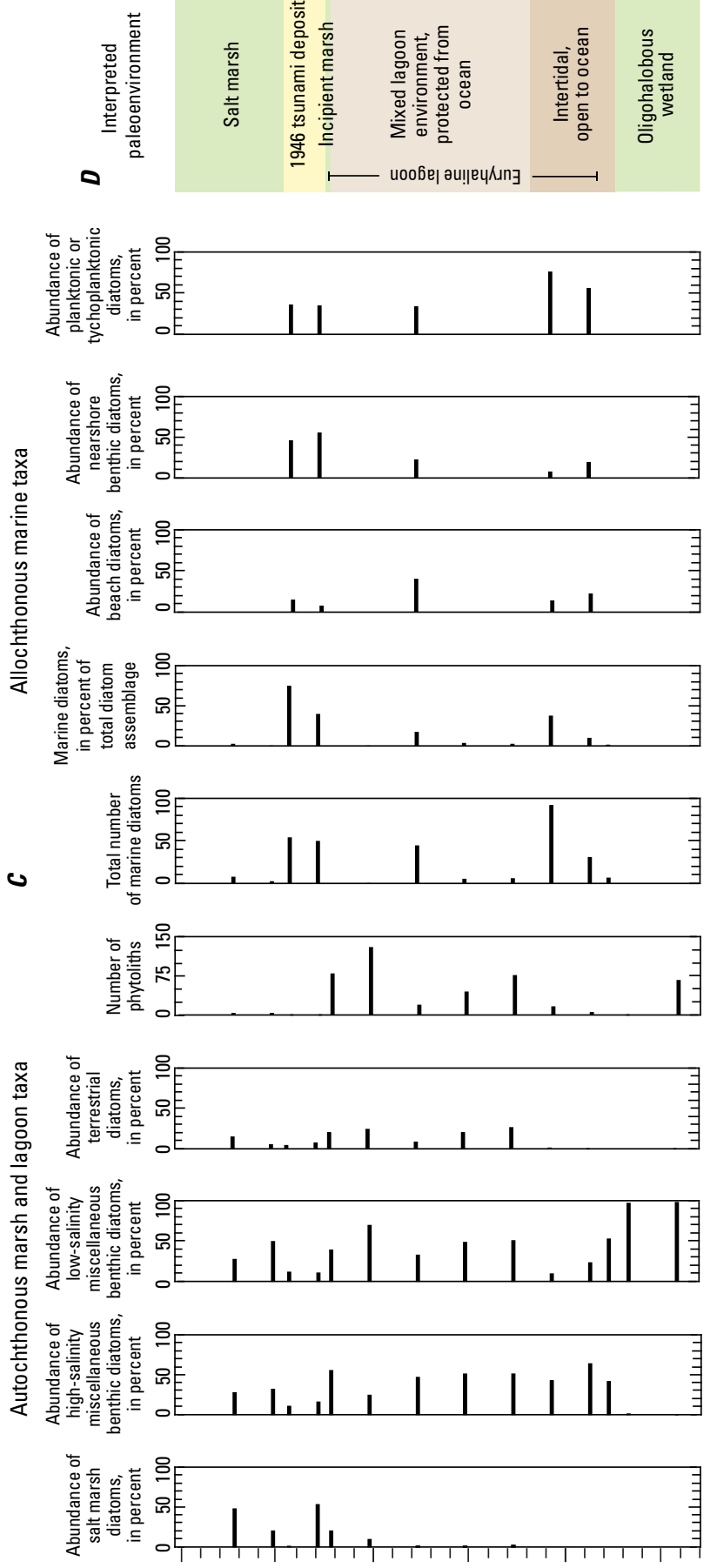

$\infty$

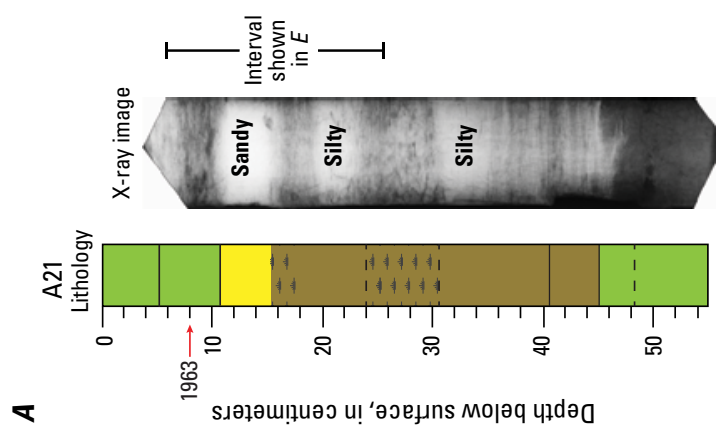

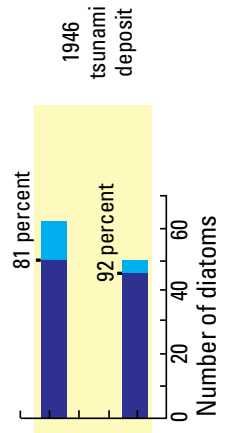

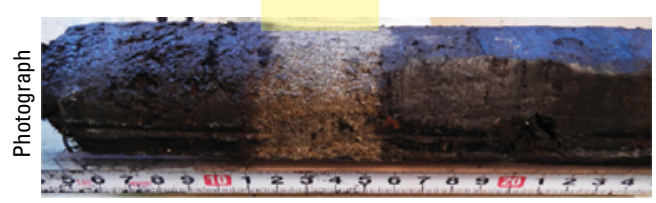

$w$

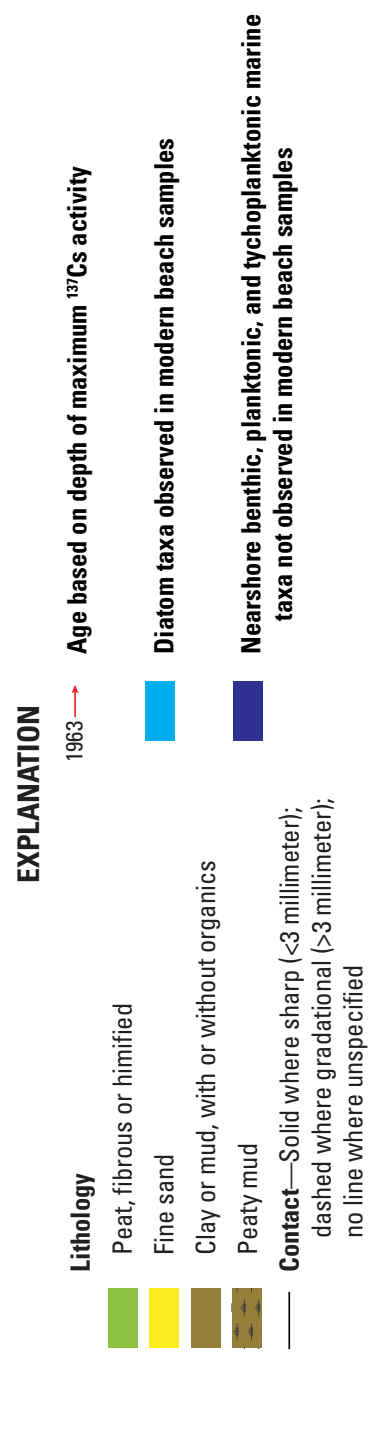

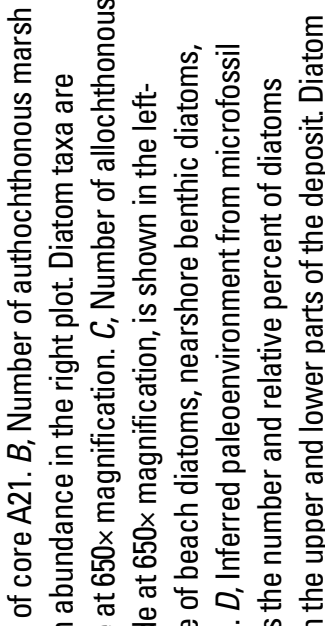

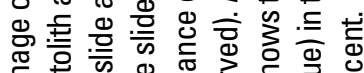

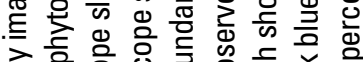

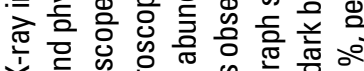
$\times$ 둥

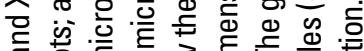
음 당

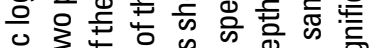
呟 응

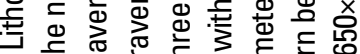

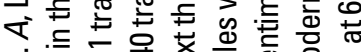

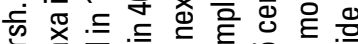

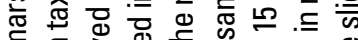
就

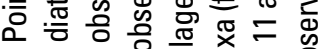

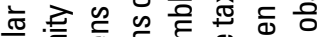
言竎离离 ธ్

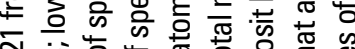

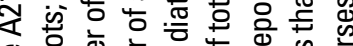

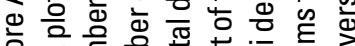

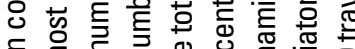

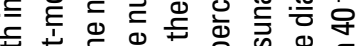

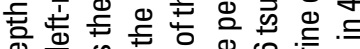
응

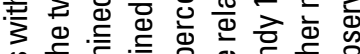

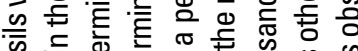

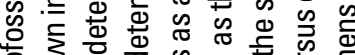
인

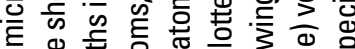

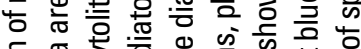

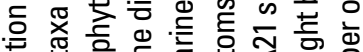
흔

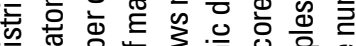

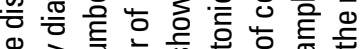

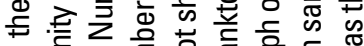

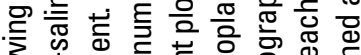
3엉

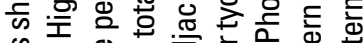

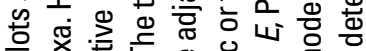
음 希 ஸे

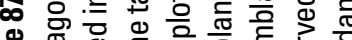

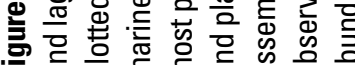



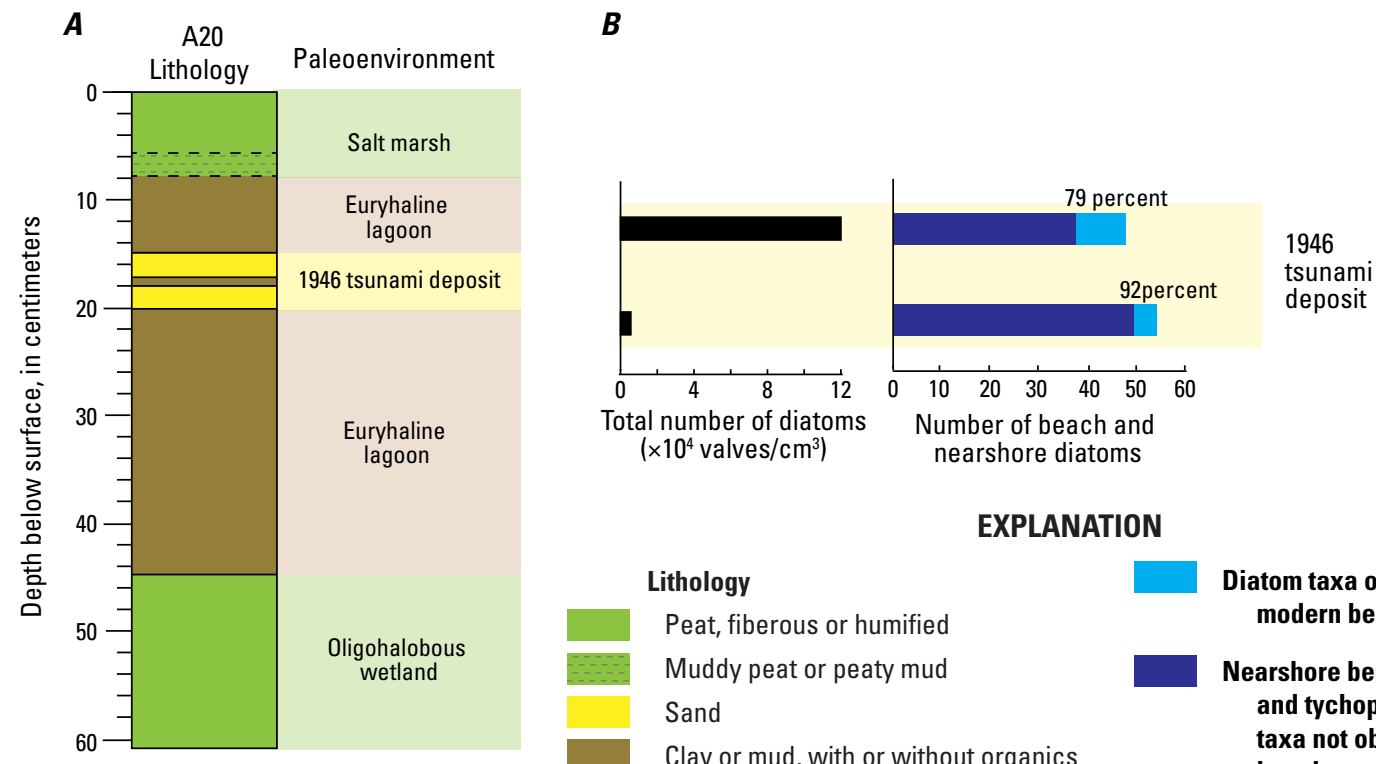

\section{EXPLANATION}

Lithology

Peat, fiberous or humified

Muddy peat or peaty mud

Sand

Clay or mud, with or without organics

Contact-Solid where sharp

( $<3$ millimeter); dashed where

gradiational (>3 millimeter)
1946

tsunami

Figure 88. Observations of the 1946 tsunami deposit in core A20 from Pillar Point marsh. $A$, Lithologic log of core A20 and interpreted paleoenvironment represented by the core deposits. $B$, Estimated diatom abundance in the upper and lower sands of the 1946 tsunami deposit. Total diatom estimates (in $10^{4}$ valves per cubic centimeter of sediment, $\times 10^{4}$ valves $/ \mathrm{cm}^{3}$ ) are plotted on the left. The number of beach and nearshore diatoms (determined as the number of specimens observed in 30 traverses of the microscope slide at 650x magnification) are plotted on the right. Light blue shows diatom taxa observed in modern beach samples from Pillar Point. Dark blue shows nearshore benthic, planktonic, and tychoplanktonic marine taxa that do not occur in modern Pillar Point beach samples. \%, percent.

Figure 89. Radionuclide results for core $\mathrm{A} 21$ from Pillar Point marsh. A, Graph of ${ }^{137} \mathrm{Cs}$ and excess ${ }^{210} \mathrm{~Pb}$ radionuclide activities. $B$, Age estimates based on the bulk sedimentation rate (in grams per year) derived from ${ }^{137} \mathrm{Cs}$ (red) and the ${ }^{210} \mathrm{~Pb}$ constant rate of supply (CRS) model (blue). ${ }^{210} \mathrm{~Pb}$ CRS model ages are based on the estimated value of 10 decays per minute per gram (dpm/g) for the uppermost interval in the core and are graphed as deep as 100 percent error. ${ }^{137} \mathrm{Cs}$ ages are graphed to the depth of the $1963{ }^{137} \mathrm{Cs}$ peak.

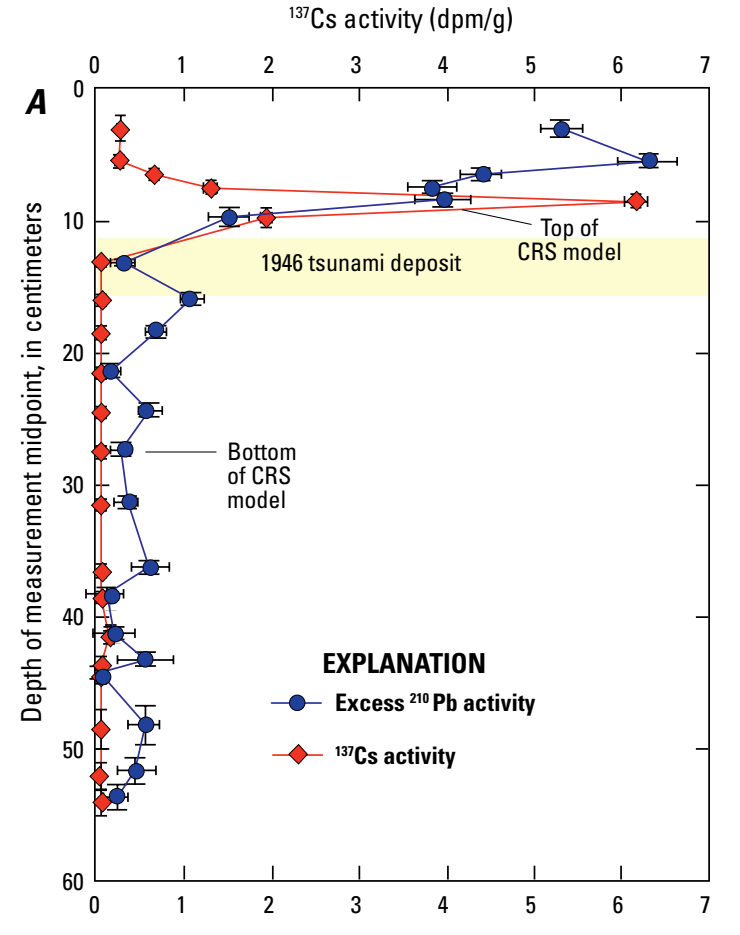

Excess ${ }^{210} \mathrm{~Pb}$ activity, in decays per minute per dry gram (dpm/g)

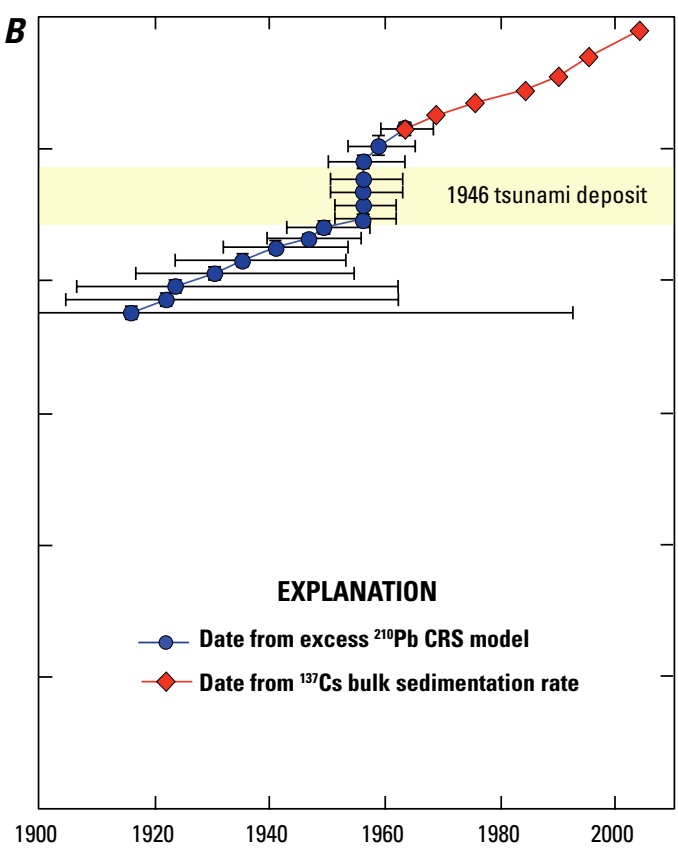

Year C.E. 
Table 8. ${ }^{210} \mathrm{~Pb}$ and ${ }^{137} \mathrm{Cs}$ radionuclide analysis data for core $\mathrm{A} 21$ from Pillar Point marsh.

$\left[\mathrm{cm}\right.$, centimeter; $\mathrm{cm}^{2}$, square centimeter; g, gram; dpm/g, decays per minute per salt-corrected dry gram; yr, year; CRS, constant rate of supply; MDA, minimum detectable activity]

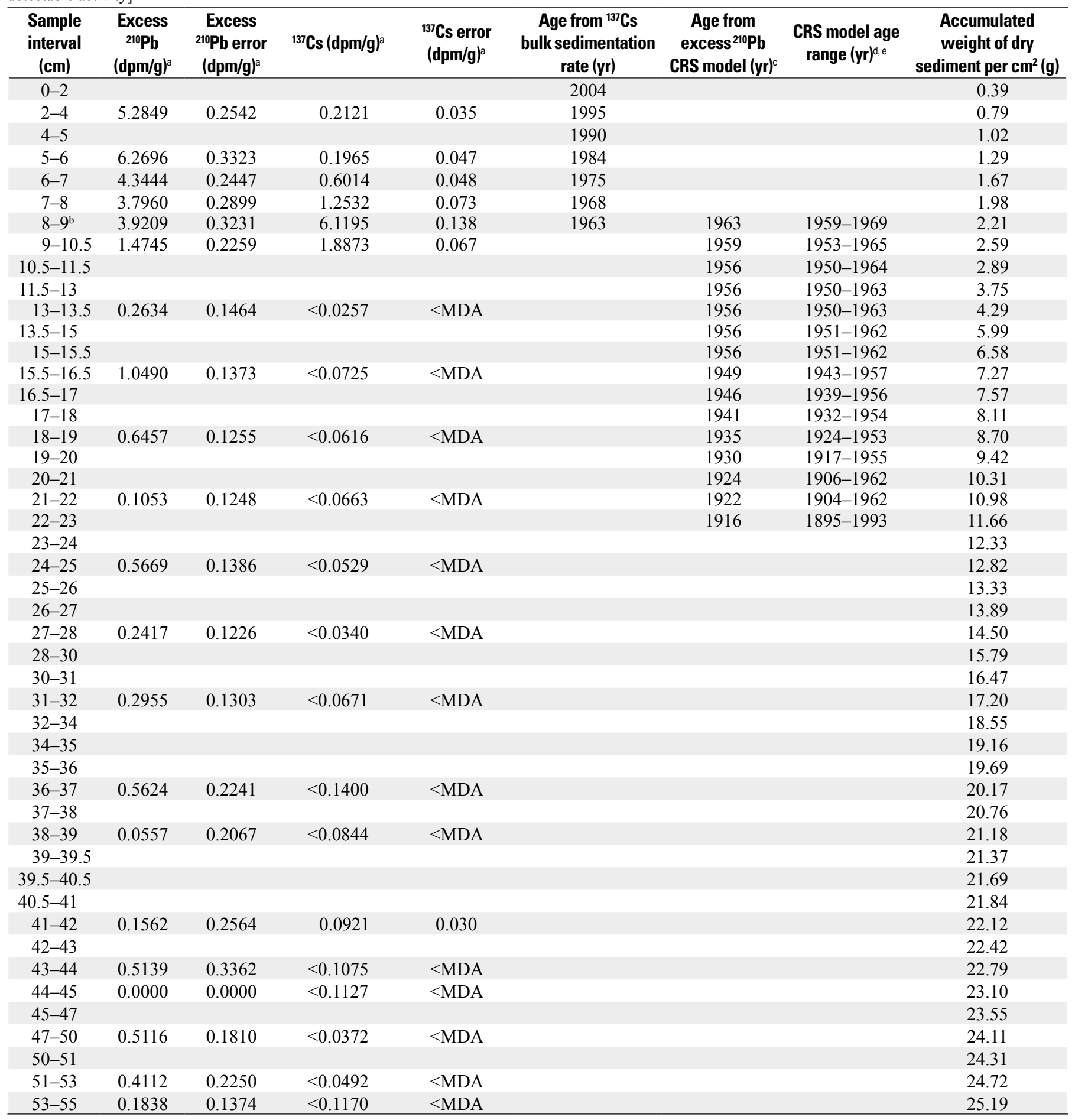

avalues are decay corrected.

${ }^{\mathrm{b}}$ Maximum ${ }^{137} \mathrm{Cs}$ activity occurs at this depth interval.

${ }^{\mathrm{c}}$ Excess $\mathrm{Pb}^{210} \mathrm{CRS}$ model dates for core $\mathrm{A} 21$ uses interpolated values for any missing intervals; ages are reported to the depth at which the error is $<100$ percent.

${ }^{\mathrm{d}}$ For core A21, the ${ }^{210} \mathrm{~Pb}$ CRS model uses integrated activities over the depth range $8-28 \mathrm{~cm}$; the interval at $8-9 \mathrm{~cm}$ is tied to 1963 , based on the ${ }^{137} \mathrm{Cs}$ peak.

${ }^{\mathrm{e}}$ For core $\mathrm{A} 21$, the ${ }^{210} \mathrm{~Pb}$ CRS model ignores ${ }^{210} \mathrm{~Pb}$ activity in the depth range $11.5-15.5 \mathrm{~cm}$, which is interpreted as the geologically instantaneous 1946 tsunami deposit. 
Table 9. ${ }^{210} \mathrm{~Pb}$ and ${ }^{137} \mathrm{C}$ s radionuclide analysis data for core A8x from Pillar Point marsh.

$\left[\mathrm{cm}\right.$, centimeter; $\mathrm{cm}^{2}$, square centimeter; g, gram; dpm/g, decays per minute per salt-corrected dry gram; yr, year; CRS, constant rate of supply; MDA, minimum detectable activity]

\begin{tabular}{|c|c|c|c|c|c|c|c|c|}
\hline $\begin{array}{c}\text { Sample } \\
\text { interval } \\
\text { (cm) }\end{array}$ & $\begin{array}{l}\text { Excess }{ }^{210} \mathrm{~Pb} \\
(\mathrm{dpm} / \mathrm{g})^{a}\end{array}$ & $\begin{array}{l}\text { Excess }{ }^{210} \mathrm{~Pb} \\
\text { error }(\mathrm{dpm} / \mathrm{g})^{\mathrm{a}}\end{array}$ & $\begin{array}{c}{ }^{137} \mathrm{Cs} \\
(\mathrm{dpm} / \mathrm{g})^{\mathrm{a}}\end{array}$ & $\begin{array}{l}{ }^{137} \text { Cs error } \\
(\mathrm{dpm} / \mathrm{g})^{2}\end{array}$ & $\begin{array}{c}\text { Age from }{ }^{137} \mathrm{Cs} \text { bulk } \\
\text { sedimentation rate } \\
\text { (yr) }\end{array}$ & $\begin{array}{c}\text { Age from } \\
\text { excess } \\
{\text { CRS model }(\mathrm{yr})^{\mathrm{c}}}^{\mathrm{c}}\end{array}$ & $\begin{array}{l}\text { CRS model age } \\
\text { range }(y r)^{c}\end{array}$ & $\begin{array}{l}\text { Accumulated weight } \\
\text { of dry sediment per } \\
\mathbf{c m}^{2}(\mathbf{g})\end{array}$ \\
\hline $0-1$ & 13.5063 & 0.4376 & 0.7976 & 0.0723 & 2009 & 2006 & 2004-2008 & 0.16 \\
\hline $1-2$ & 8.5539 & 0.3715 & $<0.1289$ & $<\mathrm{MDA}$ & 2005 & 2001 & 1998-2003 & 0.33 \\
\hline $2-3$ & 7.5867 & 0.3487 & $<0.1466$ & $<$ MDA & 2001 & 1995 & 1992-1998 & 0.51 \\
\hline $3-4$ & 5.0399 & 0.3200 & 0.3128 & 0.0541 & 1997 & 1990 & 1986-1995 & 0.69 \\
\hline $4-5$ & 3.0023 & 0.3716 & 0.2998 & 0.0574 & 1990 & 1985 & 1980-1991 & 0.99 \\
\hline $5-6$ & 5.1725 & 0.2818 & 1.5570 & 0.0680 & 1984 & 1976 & 1968-1986 & 1.22 \\
\hline $6-7$ & 3.2751 & 0.3143 & 3.6103 & 0.1235 & 1979 & 1968 & 1957-1985 & 1.46 \\
\hline $7-8$ & 2.7179 & 0.2801 & 5.0991 & 0.1193 & 1972 & 1958 & $1940-2000$ & 1.76 \\
\hline $8-9^{b}$ & 2.7864 & 0.3243 & 6.2949 & 0.1605 & 1964 & & & 2.12 \\
\hline $9-10$ & 1.0878 & 0.2430 & 2.1796 & 0.0782 & & & & 2.60 \\
\hline $10-11$ & 0.3290 & 0.2605 & 0.4198 & 0.0476 & & & & 3.14 \\
\hline $11-11.5$ & 0.3780 & 0.2131 & 0.1410 & 0.0294 & & & & 3.55 \\
\hline $11.5-12$ & 0.4319 & 0.3505 & $<0.1599$ & $<$ MDA & & & & 3.81 \\
\hline $12-12.5$ & 0.1315 & 0.1584 & 0.6842 & 0.1864 & & & & 4.55 \\
\hline $12.5-13$ & & & & & & & & 4.97 \\
\hline $13-13.5$ & 0.2078 & 0.2232 & $<0.0692$ & $<$ MDA & & & & 5.48 \\
\hline $13.5-14$ & & & & & & & & 6.06 \\
\hline $14-14.5$ & 0.4535 & 0.2292 & $<0.0842$ & $<\mathrm{MDA}$ & & & & 6.74 \\
\hline $14.5-15$ & & & & & & & & 7.40 \\
\hline $15-15.5$ & 0.0000 & 0.0000 & $<0.1038$ & $<$ MDA & & & & 7.78 \\
\hline $15.5-16$ & 0.2108 & 0.1561 & $<0.0614$ & $<\mathrm{MDA}$ & & & & 8.49 \\
\hline $16-16.5$ & 0.4416 & 0.1843 & $<0.1035$ & $<$ MDA & & & & 8.98 \\
\hline $16.5-17$ & 0.4860 & 0.2829 & $<0.1374$ & $<$ MDA & & & & 9.27 \\
\hline $17-18$ & 0.9656 & 0.2100 & $<0.1045$ & $<$ MDA & & & & 9.70 \\
\hline $18-19$ & 0.2136 & 0.1634 & $<0.0725$ & $<$ MDA & & & & 10.48 \\
\hline $19-20$ & 0.4433 & 0.1460 & $<0.0630$ & $<$ MDA & & & & 11.16 \\
\hline $20-21$ & 0.6883 & 0.1570 & $<0.0874$ & $<\mathrm{MDA}$ & & & & 11.59 \\
\hline $21-22$ & 0.5483 & 0.1760 & $<0.0834$ & $<\mathrm{MDA}$ & & & & 12.04 \\
\hline
\end{tabular}

${ }^{a}$ Values are decay corrected.

${ }^{\mathrm{b}}$ Maximum ${ }^{137} \mathrm{Cs}$ activity occurs at this depth interval.

'Salt-corrected and decay-corrected values.

populations from the muddy floor of the lagoon are exceptionally abundant and diverse, and include an array of large and small epipelic and epiphytic taxa (fig. 92). Euryhaline conditions in the lagoon are shown by the co-occurrence of species commonly found in brackish water with those typical of fresher conditions. Prominent brackish-water taxa include Surirella striatula, Caloneis westii, Tryblionella hungarica, Navicula peregrinopsis, Achnanthes intermedia, Melosira nummuloides, and Melosira moniliformis (figs. 92A, 92B). Representative low-salinity taxa include species of Synedra, Eunotia, Cocconeis, Pinnularia, Stauroneis, and various small fragilariod taxa (figs. 92C, 92D)

Compared to the high-diversity assemblages from the modern salt marsh and lagoon, modern diatoms from sand and seaweed collected on the beach compose a low-diversity assemblage of benthic and planktonic taxa. Prominent diatoms from this environment include the sand-associated taxa Odontella spp., Opephora spp., Grammatophora spp., and the epiphytic taxa Cocconeis costata, Cocconeis californica, and Cocconeis scutellum (fig. 91). Most taxa observed in lower beach samples were also present in upper beach samples. Exceptions were Hantzschia virgata (fig. 91, images 13 and 14) and Fallacia cf. david-manni (fig. 91, image 16), which were only observed in sediment from the uppermost beach face.

\section{Fossil Diatom Assemblages}

Fossil diatom assemblages in core A21 are divided into two main groups: (1) in-place, or autochthonous, taxa indicative of the marsh and lagoon environments that have existed at the site of core A21 through time (fig. 87B) and (2) transported, or 
Figure 90. Graph showing calibrated ${ }^{14} \mathrm{C}$ age probability distributions for samples from Pillar Point marsh. See also table 1. Gray area highlights the estimated age range of the last San Gregorio Fault Zone rupture in this area (Schwartz and others, 2012). Labels denote the core name, depth below the surface from which the ${ }^{14} \mathrm{C}$ sample was taken, and the type of carbon sample. Red lines show the area under the probability distribution function.

Calibrated ${ }^{14} \mathrm{C}$ age, in years C.E.

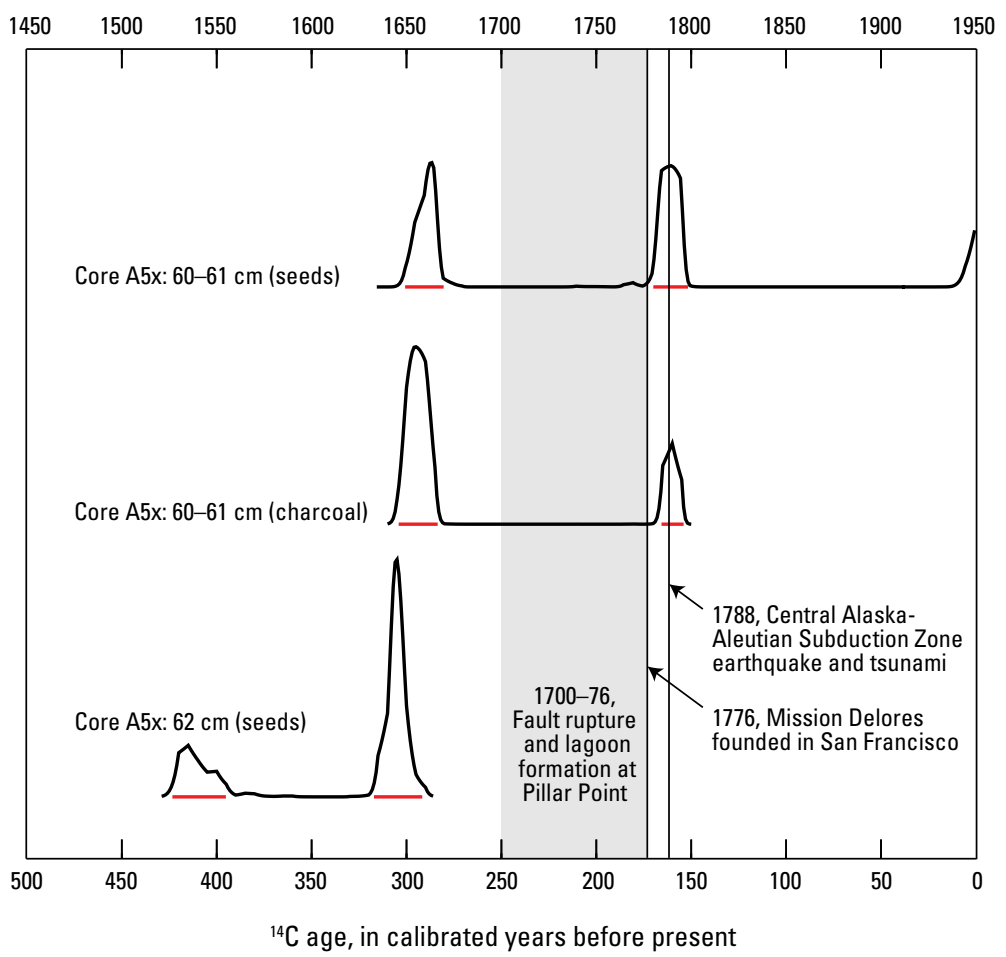

$\boldsymbol{A}$
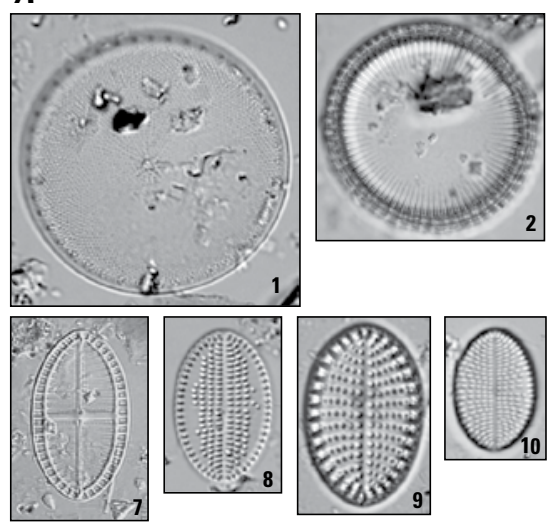

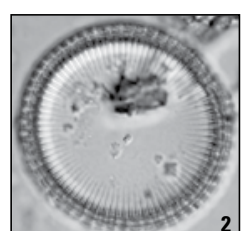

2

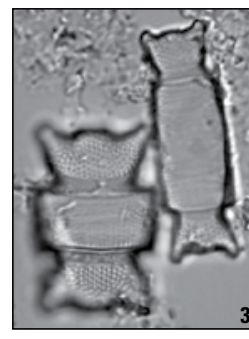

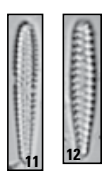
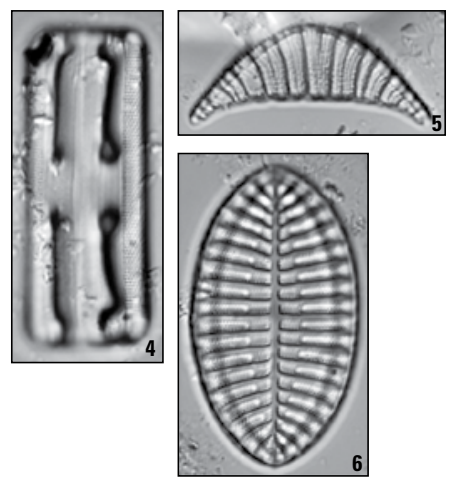

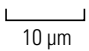

B
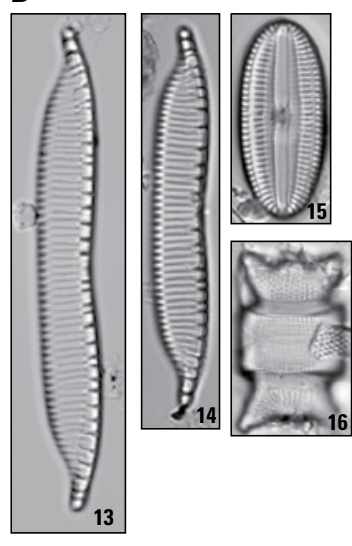

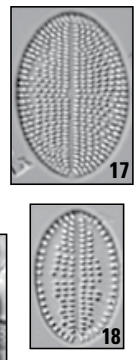

Figure 91. Photomicrographs of modern diatoms from Pillar Point marsh and adjacent beach. $A$, Diatoms from the lower beach and swash zone. 1, Thalassiosira auguste-lineata; 2, Paralia sulcata; 3, Odontella aurita; 4, Grammatophora oceanica; 5, Rhopalodia pacifica; 6 , Cocconeis costata (rapheless valve); 7, Cocconeis californica (raphe valve); 8, Cocconeis californica (rapheless valve); 9 , Cocconeis scutellum (rapheless valve); 10 , Cocconeis carminata (rapheless valve); 11, Gomphonemopsis obscurum; 12, Opephora cf. pacifica. B, Diatoms from the upper beach. 13-14, Hantzschia virgata; 15, Fallacia david-manni, 16,

C
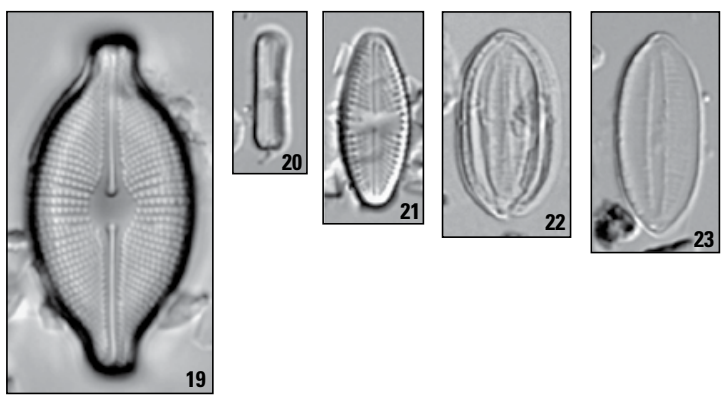

19

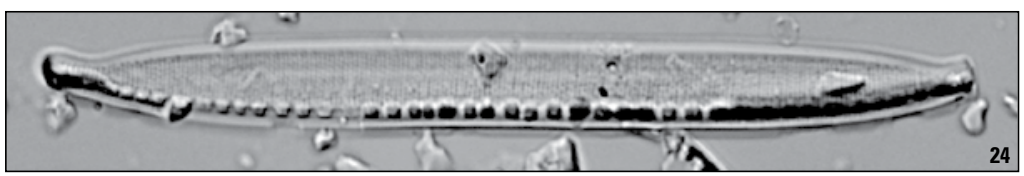

debilis, 24, Nitzschia vitrea. $\mu \mathrm{m}$, micrometers. 

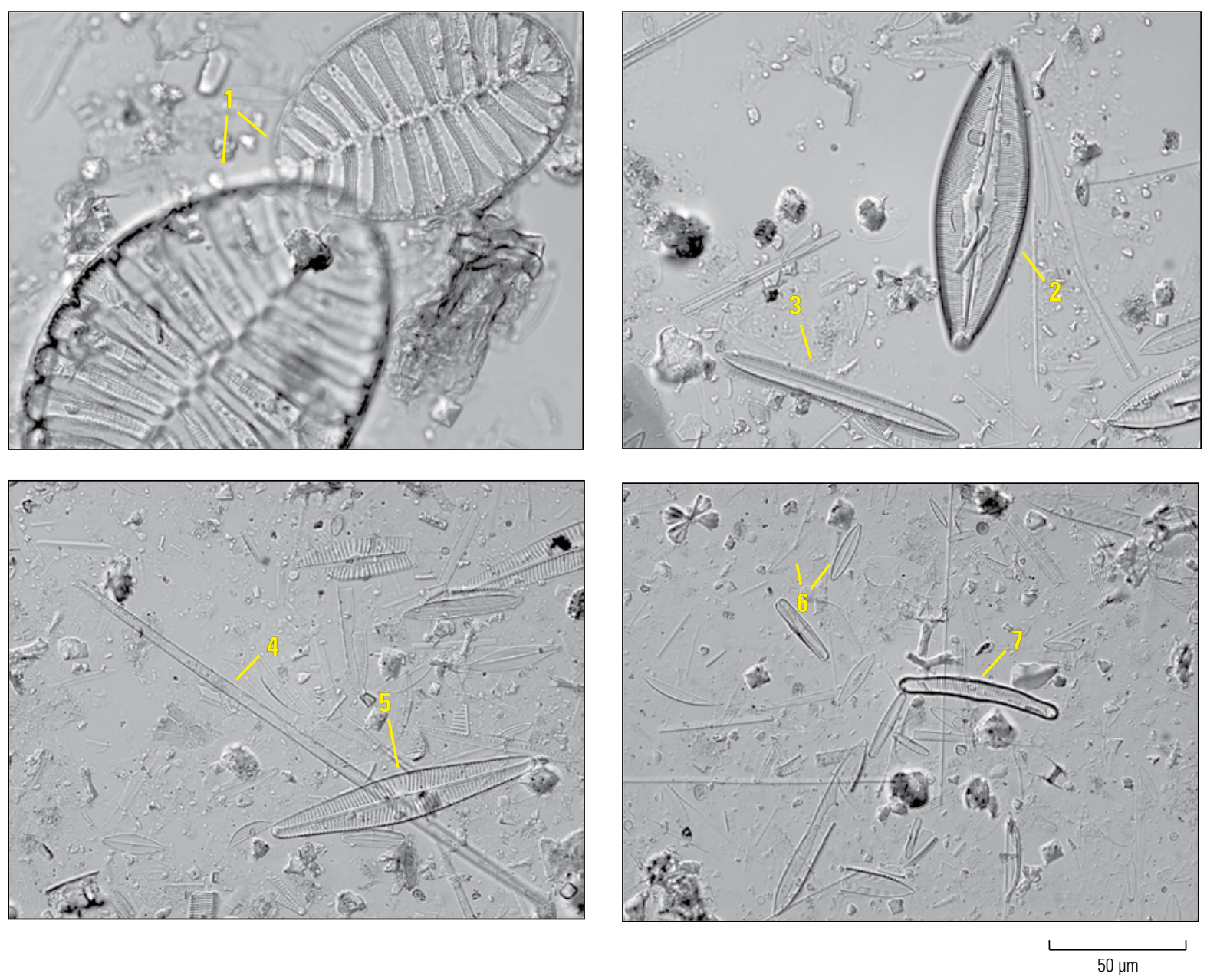

Figure 92. Photomicrographs showing the diversity of modern diatoms in sample PD12 from the muddy surface sediment of a remnant shallow lagoon at Pillar Point marsh (see also fig. 81). Numbered arrows label different diatom species. 1, Surirella striatula; 2, Caloneis westii; 3, Tryblionella hungarica; 4, Synedra sp.; 5, Navicula peregrinopsis; 6 , various smaller species of Navicula; 7, Eunotia formica. $\mu \mathrm{m}$, micrometers.

allochthonous, taxa interpreted as primarily indicating beach, nearshore, or surf-zone environments seaward of the core site (fig. 87C).

Diatoms in core A21 show that Pillar Point marsh has experienced large environmental shifts over the past $\sim 400$ years (fig. 87, appendix 4), the approximate length of time represented by the core interval (based on ${ }^{14} \mathrm{C}$ ages for correlative stratigraphic units in core $\mathrm{A} 5 \mathrm{x}$ ). In coarse-grained peat from the lower part of core A21 (45-55 cm depth), sole occurrences of oligohalobous benthic diatoms, such as Pinnularia spp., Stauroneis spp., and Eunotia spp., record a time when the site was a freshwater wetland separated from the ocean. This lower peat is capped by decimeters of dark-gray to black organicrich mud containing diverse assemblages of brackish-marine epipelic and epiphytic diatoms, which suggests a major shift from the former freshwater wetland to a muddy, saline coastal lagoon. Between 35 and $45 \mathrm{~cm}$ depth, the lagoon mud is laminated (fig. 87A) and includes diatoms commonly found in coastal intertidal environments, such as Melosira moniliformis,
Melosira nummuloides, Tabularia tabulata, Gyrosigma balticum, Navicula salinarum, and Tryblionella spp.

At $35 \mathrm{~cm}$ depth, the dominantly brackish, possibly intertidal, assemblages change to mixed assemblages of high- and lowsalinity taxa, indicative of a euryhaline environment. Higher concentrations of phytoliths and diatoms indicative of drier terrestrial environments, particularly Hantzschia amphioxys, are also observed in this interval (fig. 87B).

Diatoms that are observed in surface samples from the modern salt marsh (for example, Nitzschia vitrea, Cosmioneis pusilla, Luticola mutica, and Tryblionella debilis) first become common at about $16 \mathrm{~cm}$ depth, approximately $1 \mathrm{~cm}$ below the base of the 1946 tsunami deposit (fig. 87B).

The allochthonous marine diatoms in the downcore record include taxa observed in the modern beach samples, as well as other species that would be consistent with landward translation from nearshore surface water or shallow subtidal benthos, based on published autecology or distribution data (fig. 87C). Prominent marine taxa observed in core A21, but absent in the modern beach 
samples, include the benthic species Diplomenora cocconeiformis, Rhaphoneis psammicola, Cocconeis speciosa, Trigonian alternans, and a taxonomic variety of Rhaphoneis amphiceros (fig. 93; appendix 4, fig. 4.8). The most common planktonic or tychoplanktonic species are Actinoptychus senarius and the surfzone species Aulacodiscus kittonii. ${ }^{19}$ Other coastal planktonic taxa include Coscinodiscus spp., Thalassiosira spp., and Chaetoceros spp. resting spores.

Beach and (or) nearshore marine taxa were observed in 10 of the 14 samples examined from core A21, but were only common in samples from three intervals: (1) faintly laminated muddy lagoon deposits at 39-43 cm depth; (2) clay-rich organic mud at $25 \mathrm{~cm}$ depth; and (3) the sandy 1946 tsunami deposit at $11-15 \mathrm{~cm}$ depth (fig. $87 C$ ). Of the three intervals, marine diatoms occurred most abundantly in muddy laminated sediment at $39 \mathrm{~cm}$ depth, where they composed about a third of the total diatom assemblage (fig. 87C). The dominant marine taxa at $39 \mathrm{~cm}$ depth were Aulacodiscus kittonii, Thalassiosira pacifica, Actinoptychus senarius, Rhaphoneis psammicola, Cocconeis costata, and Chaetoceros spp. resting spores. The most abundant marine taxa observed in organic-rich (rooty) clay at $25 \mathrm{~cm}$ depth are Actinoptychus senarius, Rhaphoneis psammicola, Cocconeis costata, and Paralia sulcata.

Diatom abundance is low in the sandy 1946 tsunami deposit at $11-15 \mathrm{~cm}$ depth in core A21, but marine taxa stand out relative to the sparse occurrences of other taxa, comprising 70 percent of the total assemblage in the upper part of the deposit, and 40 percent in the lower part of the deposit, where marsh taxa occur in higher abundance (fig. 87C; appendix 4). The most common marine diatom in the 1946 tsunami deposit is Diplomenora cocconeiformis, a distinction between the tsunami deposit and the marine-taxa-bearing deposits at 25 and $39 \mathrm{~cm}$ depth. After Diplomenora cocconeiformis, the most abundant marine taxa in the tsunami deposit are the benthic taxa Rhaphoneis amphiceros and Rhaphoneis psammicola, and the tychoplanktonic taxa Aulacodiscus kittonii and Actinoptychus senarius (appendix 4, fig. 4.8). A total of 12 different marine species were observed in the tsunami deposit, the majority of which are nearshore benthic or tychoplanktonic taxa (fig. 87D; appendix 4, fig. 4.8).

Diatoms were additionally evaluated in the 1946 tsunami deposit from core A20. In 1946, the site of core A20 was within the shallow muddy lagoon (fig. 86), and as such the tsunami deposit consists of mud and sand layers (fig. 88), in contrast to the single layer of clean fine sand in core A21. Comparable groups of allochthonous marine diatoms are observed in the 1946 tsunami deposits in both cores A20 and A21, with the same five prominent marine taxa present in both cores, as well as taxa representative of the nearshore benthos and plankton outnumbering taxa associated with the beach (fig. 88B). But, whereas all diatoms are sparse in

\footnotetext{
${ }^{19}$ Aulacodiscus kittonii is one of only a few diatom species particularly adapted to the turbulent conditions in the surf zone, and cycles through the water column and underlying sandy sediment where it provides a major food source for shellfish (Lewin and others, 1989; Talbot and others, 1990; Odebrecht and others, 2010, 2014). It is also commonly observed as brown foam in the swash zone during episodic blooms (Holmes and Mahood, 1980).
}

the sandy tsunami deposit in core A21, only the lower part of the deposit in core A20 has sparse diatoms. The top of the deposit contains marine diatoms and abundant valves of lagoon taxa that were likely entrained and then settled out of suspension within the lagoon following the tsunami disturbance (figs. 88, 94).

\section{Discussion}

\section{Environmental Changes and Marine Inundation Over the Past $\sim 400$ Years}

The variability in fossil diatom assemblages over the past $\sim 400$ years at Pillar Point marsh reveal an abrupt change in environmental setting associated with offset on a part of the San Gregorio Fault Zone and at least one incident of marine inundation by a far-field tsunami. Diatoms in core A21 are abundant, diverse, and primarily consist of autochthonous taxa indicative of the marsh or lagoon environments that existed at the core site over time. Allochthonous marine diatoms indicative of beach or nearshore environments are also present, but only prevalent at three intervals in the core: the 1946 tsunami deposit at $11-15 \mathrm{~cm}$ depth, a muddy deposit at $25 \mathrm{~cm}$, and a muddy deposit at $39-43 \mathrm{~cm}$ depth (fig. 87).

The diatom data in core A21 support previous observations by Simpson and Knudsen (2000) and Koehler and others (2005) of an abrupt paleoenvironment change, consistent with coseismic subsidence and the formation of a lagoon at Pillar Point marsh. In peat at the core's base, sole occurrences of oligohalobous diatoms show that the site was a subaerial freshwater wetland (fig. 87B). Above the peat, at $45 \mathrm{~cm}$ depth, coincident with an abrupt change in lithology to organic-rich mud and clay (fig. 87A), the assemblage of oligohalobous marsh diatoms is replaced by an array of mesohalobous benthic and epiphytic taxa that indicate an intertidal brackish-marine environment persisted at this time - consistent with a lagoon that is in open exchange with the ocean. An intertidal environment is suggested by the laminated lithology (fig. 87A) and influxes of planktonic and tychoplanktonic marine taxa suggest open exchange with seawater (fig. 87C). In lagoon deposits above $35 \mathrm{~cm}$ depth, the presence of low-salinity and terrestrial diatoms, increased concentrations of silt, and high numbers of phytoliths indicate a transition to an isolated lagoon environment. An influx of marine taxa, comprising about 20 percent of the total diatom assemblage, is observed in rooty mud at $25 \mathrm{~cm}$ depth. The marine diatoms include a mix of beach, nearshore benthic, and planktonic or tychoplanktonic taxa (fig. 87C), and possibly represent storm activity that could have transported marine taxa into the lagoon through surges of storm waves or sea spray.

Marine diatoms in the 1946 tsunami deposit between 11 and $15 \mathrm{~cm}$ in core A21 dominantly consist of nearshore benthic taxa, particularly Diplomenora cocconeiformis, as well as planktonic or tychoplanktonic taxa (figs. 87C, 93; appendix 4), and suggest the tsunami transported sediment at least partly from the shallow shelf off Pillar Point marsh. By 1946, a salt marsh had become established at the location of core A21 

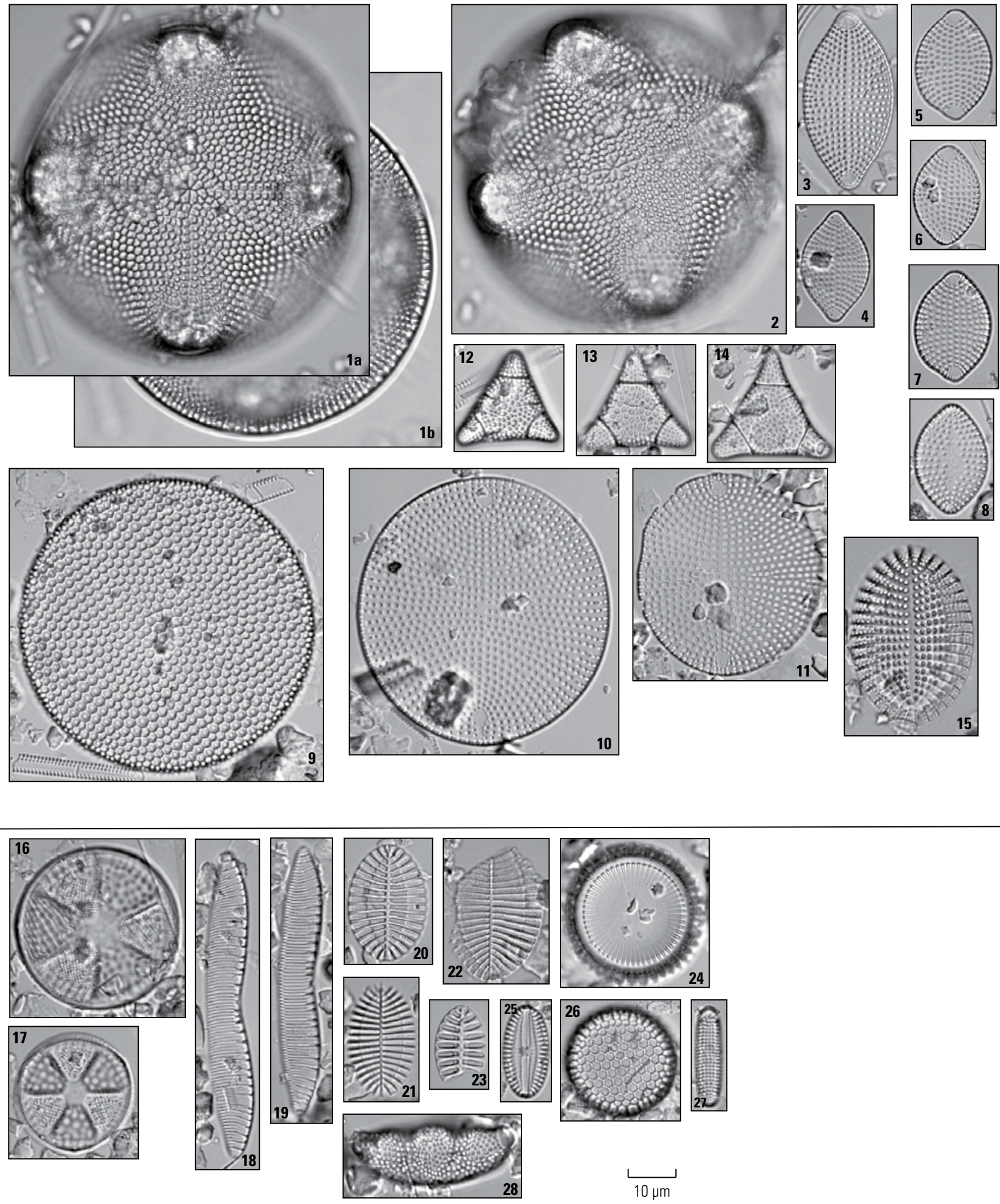

Figure 93. Photomicrographs of marine diatoms from the 1946 tsunami sand layer in core A21 from Pillar Point marsh. Images 1-15 (above solid black line) show nearshore diatoms that are absent from the modern Pillar Point beach sediment; images 16-28 (below solid black line) show taxa that are present in both the tsunami deposit and the modern beach sediment. 1-2, Aulacodiscus kittoniiin image 1, focus is on (a) interior and (b) exterior structures of the same valve; $3-7$, Rhaphoneis amphiceros variety; 8 , Rhaphoneis psammicola; 9, Coscinodiscus radiatus, 10-11, Diplomenora cocconeiformis, 12-14, Biddulphia alternans, 15, Cocconeis speciosa; 16-17, Actinoptychus senarius, 18-19, Hantzschia virgata; 20-23, Cocconeis costata; 24, Paralia sulcata; 25, Diploneis sp.; 26, Endictya hendeyi, 27, Grammatophora sp.; 28, Odontella aurita. $\mu \mathrm{m}$, micrometers. 
(fig. 86), and the lower part of the tsunami deposit includes salt marsh taxa that were incorporated into the deposit as the tsunami swept across the marsh.

Marine diatoms in the 1946 tsunami deposit in core A20 similarly consist primarily of nearshore benthic, planktonic, and tychoplanktonic taxa (figs. 88, 93; appendix 4). In 1946, the site of core A20 was within the area of a shallow lagoon (fig. 86). Diatoms are an order of magnitude more abundant at the top of the sandy tsunami deposit than at the base of the deposit, likely a result of lagoon taxa settling out of suspension after emplacement of the tsunami deposit. Broken and unbroken specimens of marine taxa are present but rare at the top of the tsunami deposit, in contrast to the abundant lagoon taxa (fig. 94).

The observation that allochthonous marine diatoms are not confined to the tsunami deposit in the recent stratigraphic record is not surprising when the environment of deposition is consideredthat is, an intertidal or episodically interconnected lagoon adjacent to the ocean. The tsunami deposit is different in that it includes not just anomalous coarse-grained sediment but also benthic taxa indicative of displacement from the shallow offshore shelf. In contrast, the marine assemblages in lagoon deposits at $25 \mathrm{~cm}$ and 39-43 cm depth in core A21 consist mainly of planktonic or tychoplanktonic taxa, suggesting flooding by waves or storm surges into the lagoon, without accompanying coarse-grained sediment transport.

\section{Preservation Potential and the Tsunami Record Over the Past 300-350 Years}

Of significance to this study, rupture along local traces of the San Gregorio Fault Zone 350-250 years ago (Schwartz and others, 2014) changed the preservation potential of tsunami deposits at Pillar Point marsh. It converted a dry subaerial marsh or meadow with poor preservation potential to a shallow lagoon or coastal pond setting with much higher preservation potential. The presence of the lagoon or pond at the site, which, based on diatom data, probably contained shallow standing water most of the time, would have served to protect a far-field tsunami deposit from the erosional effects of wind and rain, which can erase tsunami deposits distributed on exposed land surfaces (Szczuciński, 2012; Spiske and others, 2013; Bahlburg and Spiske, 2015). Our data show, consistent with the observations of Wilson and others (2014), that the 1946 tsunami deposit is best recognized across Pillar Point marsh where it was deposited either within the lagoon (as it existed in 1946), or in low-lying areas of an incipient, muddy salt marsh that had begun to fill in the larger area once covered by the lagoon (figs. 81, 86). For example, the well-preserved deposit in core A21 accumulated in what was a low-lying area in 1946 that had only recently been encroached by salt marsh plants, as evidenced by lithologic and diatom data (fig. 87) and inferred from the variability in shading of vegetated areas in black-and-white historical aerial photographs (fig. 86). It is unclear whether a comparable thin far-field tsunami deposit would be preserved if it was deposited at the location of core A21 today, where the surface is dry and densely vegetated with marsh plants as tall as $30 \mathrm{~cm}$ (fig. 82).
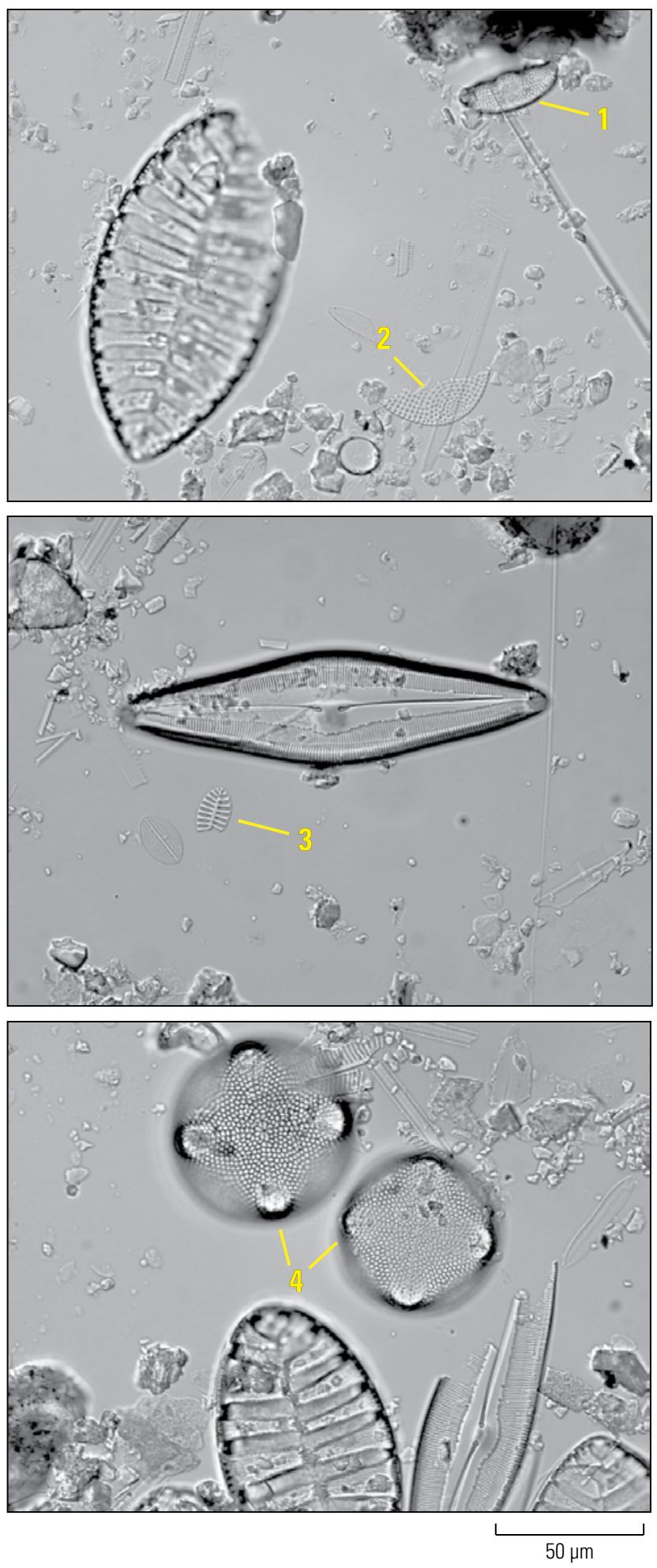

Figure 94. Photomicrographs of diatoms from the upper part of the 1946 tsunami deposit in core A20 from Pillar Point marsh, showing a mix of taxa that are consistent with accumulation in lagoon mud with allochthonous diatoms from the beach and nearshore. Benthic lagoon taxa dominate, but displaced marine taxa are also present. Numbers label displaced marine diatom species. 1, Odontella aurita; 2, Diplomenora cocconeiformis valve fragment; 3 , broken Cocconeis costata valve; 4 , two specimens of Aulacodiscus kittonii. $\mu \mathrm{m}$, micrometers. 
Therefore, the persistent presence of a shallow lagoon or pond at Pillar Point marsh for the past several hundred years has resulted in the location possessing an unusually high potential for preserving far-field tsunami deposits, at least compared to the many marshes and wetlands along the California coast that were similarly investigated to determine the feasibility of preserving such deposits (Wilson and others, 2014). Geochronological and historical evidence suggests that the depositional environment favorable to preserving tsunami deposits at Pillar Point marsh extends as far back as the late 1600 s or early 1700 s, but certainly earlier than the founding of Mission Dolores in 1776. Yet, within this time interval, we only find evidence for a 1946 tsunami deposit, and no other sedimentary deposits of comparable composition, thickness, and aerial distribution. Therefore, although historical and sedimentary data provide evidence for tsunami inundation in the Aleutian Islands associated with rupture along the Alaska-Aleutian Subduction Zone in 1788 (Lander and Lockridge, 1989; Ryan and others, 2012; Kirby and others, 2013; Nelson and others, 2015), we find no evidence that a tsunami reached the California coast with enough size and force to leave evidence for inundation in 1788 at Pillar Point marsh.

We emphasize that the absence of evidence for the 1788 tsunami deposit at Pillar Point marsh does not decrease the possibility of future trans-Pacific tsunamis from large-magnitude earthquakes in the eastern Aleutian-Alaska Subduction Zone, particularly in light of recent observations that the Semidi segment megathrust is structurally comparable to the subduction margin off Japan that generated the 2011 M9.0 earthquake and tsunami (Kirby and others, 2013; von Huene and others, 2016) and that the plate interface may be mostly locked (Freymueller and others, 2008; Ryan and others, 2012). Rather, our findings suggest that a tsunami of at least the size and sediment-transporting capacity of the 1946 tsunami did not impact the California coast at Pillar Point in 1788. The above observations may contribute to a better understanding of the rupture and tsunami propagation characteristics associated with those particular eastern AleutianAlaska Subduction Zone events.

\section{Suggestions for Future Research}

Although this and earlier studies have identified evidence of tsunami deposits along the northern California coast and the implications for future tsunami hazards are evident, we recommend that more attention to the geologic record of past megastorms be incorporated into future studies concerning the distribution and chronology of tsunami deposits.

Paleoclimate studies show that megastorms the size of the 1861-62 event have occurred about every 200 years in the past (Dettinger and Ingram, 2013; Ingram and Malamud-Roam, 2013). This is comparable to the frequency of tsunami-generating megathrust earthquakes in the central Aleutian-Alaska Subduction Zone (170-255 years; Nelson and others, 2015), which is the worst-case far-field tsunami source region for California (Wilson and others, 2008; SAFRR Tsunami Modeling Working Group, 2013; von Huene and others, 2016). Although the frequencies of potential megastorms and larger far-field tsunamis may be comparable, other anticipated effects from these two natural hazards are strongly dissimilar. For example, the size of geographical areas that might be affected by meagastorms and far-field tsunamis differ greatly. The foci of major damage from the far-field tsunamis in 1946 and 1964 were confined to small segments of the coastline, specifically the south-facing, northern ends of coastal embayments in Half Moon Bay and Crescent City. In contrast, the projected damage to property and infrastructure from a megastorm comparable to the 1861-62 event-from flooding, coastal erosion and landslides, strong onshore winds, and storm-surge inundation compounded with elevated sea level - could encompass the entirety of the California coastline, as well as large swaths of inland areas in California and the Pacific Northwest (Porter and others, 2011).

There are also large differences in the duration of megastorms compared to far-field tsunamis. A far-field tsunami may include numerous waves of variable force recorded over many hours at a single location (for example, Dengler and Magoon, 2005; Admire and others, 2014). In contrast, a megastorm may inflict damage over many weeks. For example, historical documents show the 1861-62 storm continued unabated for 43 days in the coastal northern California region (Dettinger and Ingram, 2013).

Finally, there are large projected differences in financial impacts to California from these hazards. Since 1940, far-field tsunamis have caused more than $\$ 150$ million in damage to coastal California, particularly to harbors (Wilson and others, 2014). Damage to California harbors from the 2011 (M9.0 Tohoku earthquake) far-field tsunami exceeded $\$ 50$ million alone (Wilson and others, 2013; Admire and others, 2014). But because of the large region expected to sustain damage from the next megastorm, the estimated costs statewide for California are projected to run in the hundreds of billions of dollars (Porter and others, 2011).

The USGS ARkStorm Scenario (Porter and others, 2011) was a complex, multidisciplinary study to investigate the potential effects of a megastorm on California. This highly informative study provided important new data to raise public concern and organize new efforts for hazard preparation. Its focus was on the southern and central part of the State, however, and it did not include many details on anticipated effects for the northern California coast.

That a megastorm comparable to the 1861-62 storm should be at the forefront of concern for hazards preparation in coastal northern California is supported by historical accounts of the event. Documents from the U.S. Army describe massive fluvial flooding that wiped out communities and stopped all transportation along the coast between Humboldt Bay and the Oregon border (Bearss, 1982). In "History of Del Norte County, California," Bledsoe (1881, p. 73) describes - in rather eloquent fashion - the impact of the storm along the Crescent City coast:

[The] flood-gates of heaven were opened, the rain poured down in torrents, and fierce gales from the ocean added their terrors to the scene. The month of December witnessed the worst of these storms. Rain fell in enormous quantities... and aided by the wind, 
the mighty waves of the ocean at high tide forced themselves over drift-wood, bulk heads and breakwater, into the streets of Crescent City, extending in some places as far back as Second Street. Huge logs were carried up on the sidewalks, crashing into Front Street buildings, breaking windows and doors, and doing other damage. On the beach, the drift-wood was piled up to great height, whole trees being carried in by the tide. From one end of the beach to the other, huge redwood, spruce and fir trees were piled one upon another in inextricable confusion. ... The sea and tide were immense, and had it not been for the piles of drift-wood on the beach in front of town, Crescent City would have undoubtedly been almost destroyed by the tide.

Some of Bledsoe's descriptions of damage at Crescent City caused by logs crashing into buildings rival descriptions of damage from logs ramming buildings during the 1964 tsunami. Crescent City, however, would have been more susceptible to storm damage in the 1860s when the edge of town abutted the beach, and lacked the broad buffer of man-made fill between the harbor and town that exists today. ${ }^{20}$ However, the massive accumulations of logs for large distances along the shore probably exceeds the problems experienced in 1964 by displaced debris, as weeks of torrential rainfall during the megastorm triggered high rates of erosion in local watersheds that helped transport many trees downstream to be deposited in massive piles along the coast (Bearss, 1982). The accumulation of woody debris along Crescent Beach following the 1861-62 storm, including in the vicinity of the Sand Mine marsh study site, was reported as several meters high and covering an area as wide as 200 meters from the beach in some places. In 1864, W.H. Brewer described the massive amounts of wood along the shore south of Crescent City that remained after the 1861-62 storm (Farquhar, 1930, p. 495),

The floods of two years ago brought down an immense amount of driftwood from all the rivers along the coast, and it was cast up along this part of the coast in quantities that stagger belief. It looked to me as if I saw enough in ten miles along the shore to make a million cords of wood. It is thrown up in great piles, often half a mile long, and the size of some of these logs is tremendous.

It is interesting to note that the massive deposition of logs and debris along the shoreline that accompanied this storm occurred prior to the onset of extensive logging in the region, showing how even the natural, non-anthropologically impacted watersheds were greatly destabilized by such a highintensity storm system. Descriptions of giant, uprooted trees floating downriver are similarly part of the description of the

\footnotetext{
${ }^{20}$ The 1864 description of Cresent City by W.H. Brewer includes the following passage regarding the proximity of the town to the bay, "The main business street lies on the sandy beach, so close to the water that it has houses on but one side, and the water of extreme high tides comes up across the streets to the very stores, which look out on the lovely cove" (Faquhar, 1930, p. 492).
}

storm damage along the Trinity River in northern California by Carr (1891). However, although massive erosion in coastal watersheds is likely to occur during future events that are comparable to the 1861-62 megastorm, there will be fewer giant redwood trees comprising the debris because the vast majority have since been extracted from the region.

We encountered abundant stratigraphic evidence for storm-surge deposits at two of the Crescent City study sites, Marhoffer Creek marsh and Sand Mine marsh, including accumulations of sand and woody debris more than $100 \mathrm{~m}$ from the modern shoreline (figs. 4, 50). At Marhoffer Creek marsh, deposits of sand and detritus that stratigraphically overlie the 1700 Cascadia Subduction Zone tsunami deposit, and would be consistent with having been emplaced by the 1861-62 megastorm, are not only found more than $100 \mathrm{~m}$ inland, but are also perched at elevations of 3-3.5 m above MLLW (figs. 6, 7). At Sand Mine marsh, a low-lying back-berm marsh and relict lagoon, what we interpret as storm-emplaced sand deposits are found at elevations of 2-3 m above MLLW at least $150 \mathrm{~m}$ from the beach (fig. 50). At both locations, it is likely that post-1700 storm activity has obscured a possible sedimentary record of the 1700 tsunami, and it is only in cores collected farther than about 100-150 $\mathrm{m}$ inland that the distribution of tsunami deposits becomes more possible to discern with confidence. For example, in all cores from the western field site at Sand Mine marsh, we conclude that the vast majority of coarse-grained deposits shallower than about $0.8 \mathrm{~m}$ depth are storm-surge deposits - excluding the uppermost thin sandy layers in some cores that were emplaced by the far-field tsunamis in 1960 or 1964. Therefore, we recommend that future studies of near-field (Cascadia Subduction Zone) paleotsunamis in the Crescent City area focus on locations that would be beyond inundation not just by typical storms, but by the potentially massive storms that rival inundation distances of large far-field tsunamis.

At the O'rekw marsh study site, in the lower Redwood Creek alluvial valley, we did not recognize storm-surge deposits, but rather conclude that some coarse-grained and debris-rich deposits in cores were likely storm-related flood deposits. Although it is highly plausible that a tsunami in 1700 struck this location, we could not identify with confidence lithologic, stratigraphic, or micropaleontological evidence of the event. One possibility is that the natural setting of the study site in the lower Redwood Creek estuary in 1700 did not include a marsh or other confined area to serve as a long-term catchment or preservational depocenter of geological evidence for the tsunami. It is also possible that the massive flooding associated with the 1861-62 megastorm - and possibly other late-1800s storms - removed evidence of older tsunamis through erosion and redeposition along the margins of the stream valley.

Therefore, although further research into tsunami hazards for northern California is imperative and we strongly recommend continued tsunami resilience efforts in public education, we also recommend that the inevitability of future megastorms similarly become a forefront of concern in ongoing hazard research and planning for coastal communities. 


\section{References Cited}

Aalto, K.R., Aalto, R., Garrison-Laney, C.E., and Abramson H.F., 1999, Tsunami(?) sculpturing of the Pebble Beach wave-cut platform, Crescent City area, California: The Journal of Geology, v. 107, p. 607-622, https://doi.org/10.1086/314365.

Abramson, H.F., 1998, Evidence for tsunamis and earthquakes during the last 3500 years from Lagoon Creek, a coastal freshwater marsh, northern California: Arcata, Calif., Humboldt State University, M.S. thesis, 76 p., 2 apps.

Admire, A.R., Dengler, L.A., Crawford, G.B., Uslu, B.U., Borrero, J.C., Greer, S.D., and Wilson, R.I., 2014, Observed and modeled currents from the Tohoku-oki, Japan and other recent tsunamis in Northern California: Pure and Applied Geophysics, v. 171, no. 12, p. 3385-3403, https://doi.org/10.1007/s00024-014-0797-8.

Appleby, P.G., and Oldfield, F., 1978, The calculation of lead210 dates assuming a constant rate of supply of unsupported ${ }^{210} \mathrm{~Pb}$ to the sediment: Catena, v. 5, p. 1-8, https://doi. org/10.1016/S0341-8162(78)80002-2.

Atwater, B.F., and Hemphill-Haley, E., 1997, Recurrence intervals for great earthquakes of the past 3,500 years at northeastern Willapa Bay, Washington: U.S. Geological Survey Professional Paper 1576, 108 p., https://pubs.er.usgs. gov/publication/pp1576.

Atwater, B.F., Musumi-Rokkaku, S., Satake, K., Tsuji, Y., Ueda, K., and Yamaguchi, D.K., 2005, The orphan tsunami of 1700_-Japanese clues to a parent earthquake in North America: U.S. Geological Survey Professional Paper 1707, 133 p., http://pubs.usgs.gov/pp/pp1707/.

Atwater, B.F., Nelson, A.R., Clague, J.J, Carver, G.A., Yamaguchi. DK., Bobrowsky, P.T., Bourgeois, J., Darienzo, M.E., Grant, W.C., Hemphill-Haley, E., Kelsey, H.M., Jacoby, G.C., Nishenko, S.P., Palmer, S.P., Peterson, C.D, and Reinhart, M.A., 1995, Summary of coastal geologic evidence for past great earthquakes at the Cascadia subduction zone: Earthquake Spectra, v. 11, p. 1-18, https://doi.org/10.1193/1.1585800.

Bahlburg, H., and Spiske, M., 2015, Styles of early diagenesis and the preservation potential of onshore tsunami deposits - A re-survey of Isla Mocha, Central Chile, 2 years after the February 27, 2010, Maule tsunami: Sedimentary Geology, v. 326, p. 33-44, https://doi.org/10.1016/j. sedgeo.2015.06.009.

Barberopoulou, A., Borrero, J.C., Uslu, B., Legg, M.R., and Synolakis, C.E., 2011, A second generation of tsunami inundation maps for the State of California: Pure and Applied Geophysics, v. 168, no. 11, p. 2133-2146, https://doi.org/10.1007/s00024-011-0293-3.
Bascom, W., 1946, Effect of seismic sea wave on California Coast: University of California Berkeley, Department of Engineering, Fluid Mechanics Laboratory, Navy Department Bureau of Ships Contract NObs 2490, Laboratory Memorandum HE-116-204, 23 p.

Bearss, E.C., 1982, History basic data-Redwood National Park, Del Norte and Humboldt Counties, California: Washington, D.C., U.S. Department of the Interior, National Park Service, Office of Archaeology and Historical Preservation, $265 \mathrm{p}$.

Bledsoe, A.J., 1881, History of Del Norte County, California, with a business directory and traveler's guide: Eureka, California, Humboldt Times Prints, Wyman and Company, $184 \mathrm{p}$.

Blott, S.J. and Pye, K., 2001, GRADISTAT; a grain size distribution and statistics package for the analysis of unconsolidated sediments: Earth Surface Processes and Landforms, v. 26, p. 1237-1248, https://doi.org/10.1002/ esp.261.

Bourgeois, J., 2009, The geologic effects and records of tsunamis, in Bernard, E.N., and Robinson, A.R., eds., Tsunamis: Cambridge, Mass., Harvard University Press, The sea, v. 15, p. 55-91.

Bray, J.R., and Curtis, J.T., 1957, An ordination of upland forest communities of southern Wisconsin: Ecological Monographs, v. 27, p. 325-349, https://doi.org/10.2307/1942268.

Briggs, R.W., Engelhart, S.E., Nelson, A.R., Dura, T., Kemp, A.C., Hausseler, P.J., Corbett, D.R., Angster, S.J., and Bradley, L.A., 2014, Uplift and subsidence reveal a nonpersistent megathrust rupture boundary (Sitkinak Island, Alaska): Geophysical Research Letters, v. 41, no. 7, p. 22892296, https://doi.org/10.1002/2014GL059380.

Calflora Database, 2016, Calflora-Information on wild California plants for conservation, education, appreciation, with data contributed by public and private institutions and individuals, including the Consortium of California Herbaria, accessed June 1, 2016, at http://www.calflora.org.

California Geological Survey, 2017, Official tsunami inundation maps, accessed May 2, 2017, at http://www.conservation. ca.gov/cgs/geologic_hazards/Tsunami/Inundation_Maps.

Campbell, E.E., 1996, The global distribution of surf diatom accumulations: Revista Chilena de Historia Natural, v. 69, p. 495-501, accessed May 5, 2012, at http://rchn. biologiachile.cl/pdfs/1996/4/Campbell_1996.pdf.

Carr, J., 1891, Pioneer days in California: Eureka, Calif., Times Publishing Company, $452 \mathrm{p}$.

Carver, D.H., 1998, Native Stories of Earthquake and Tsunamis Redwood National Park, California: National Park Service, Redwood National and State Parks, 112 p. 
Carver, G.A., Abramson, H.A., Garrison-Laney, C.E., and Leroy, T.H., 1998, Investigation of paleotsunami evidence along the north coast of California: Humboldt State University Department of Geology report prepared for Pacific Gas and Electric Company, 238 p., accessed June 1, 2016, at http://www2.humboldt.edu/geology/images/uploads/Carver_ and_others_1998.pdf.

Castelvechii, D., 2009, New map reveals tsunami risk in California: Scientific American, December 18, 2009, accessed July 15, 2016, at https://www.scientificamerican. com/article/new-maps-reveal-tsunami-california/.

Colwell, R.K., 2013, EstimateS-Statistical estimation of species richness and shared species from samples, version 9.1.0, accessed June 2, 2016, at http://viceroy.eeb.uconn. edu/estimates/.

Costa, P.J.M., Andrade, C., Dawson, A.G., Mahaney, W.C., Freitas, M.C., Paris, R., and Taborda, R., 2012, Microtextural characteristics of quartz grains transported and deposited by tsunamis and storms: Sedimentary Geology, v. 275-276, p. 55-69, https://doi.org/10.1016/j. sedgeo.2012.07.013.

Cutshall, N.H., Larsen, I.L., and Olsen, C.R., 1983, Direct analysis of ${ }^{210} \mathrm{~Pb}$ in sediment samples-Self-absorption corrections: Nuclear Instruments and Methods in Physics Research, v. 206, no. 1-2, p. 309-312, https://doi. org/10.1016/0167-5087(83)91273-5.

Darienzo, M.E., Peterson, C.D., and Clough, C., 1994. Stratigraphic evidence for great subduction-zone earthquakes at four estuaries in northern Oregon, U.S.A.: Journal of Coastal Research, v. 10, p. 850-876, http://www.jstor.org/stable/4298281.

Del Norte County, 1983, Del Norte County General Plan, Coastal Element, Local Coastal Program, 376 p, accessed June 18, 2018, at https://docs.google.com/viewer? a=v\&pi$\mathrm{d}=$ sites\&srcid=Y28uZGVsLW5venR1LmNhLnVzfGRuY29 8Z3g6ZjAyYTYyMzVmMjU2MzZh.

Dengler, L.A., and Magoon, O.T., 2005, The 1964 tsunami in Crescent City, California-A 40-year retrospective: Solutions to Coastal Disasters Conference 2005, Proceedings, p. 639648, https://doi.org/10.1061/40774(176)64.

Dengler, L.A., and Magoon, O.T., 2006, Reassessing Crescent City, California's tsunami risk: Proceedings of the 100th Anniversary Earthquake Conference paper R1577, 10 p.

de Souza, V.L.B., Rodrigues, K.R.G., Pedroza, E.H., de Melo, R.T., de Lima, V.L., Hazin, C.A., de Almeida, M.G.O., and do Nascimento, R.K., 2012, Sedimentation rate and ${ }^{210} \mathrm{~Pb}$ sediment dating at Apipucos Reservoir, Recife, Brazil: Sustainability, v. 4, p. 2419-2429, http://doi.org/10.3390/ su4102419.
Dettinger, M.D., and Ingram, B.L., 2013, Megastorms could drown massive portions of California: Scientific American, v. 308, p. 64-71, accessed January 10, 2016, at https://www. scientificamerican.com/article/megastorms-could-downmassive-portions-of-california/.

Dura, T., Hemphill-Haley, E., Sawai, Y., and Horton, B., 2016, The application of diatoms to reconstruct the history of subduction zone earthquakes and tsunamis: Earth-Science Reviews, v. 152, p. 181-197, https://doi.org/10.1016/j.earscirev.2015.11.017.

Edwards, A.M., 1904, Trochiscia moniliformis, E. C. M., a form of Bacillaria, in Giovanni Battista de Toni, ed., La Nuova Notarisia, v. 15-17, p. 54-58.

Engelhart, S., Hemphill-Haley, E., Kelsey, H., and Padgett, S.J., 2016, Refined estimates of coseismic subsidence along the southern Cascadia subduction zone in northern Humboldt Bay (Arcata Bay) - Collaborative research with the University of Rhode Island and Humboldt State University: U.S. Geological Survey National Earthquakes Hazards Reduction Program Final Technical Report G14AP00128/G14AP00129, 38 p.

Engstrom, W.N., 1994, Nineteenth-century coastal gales of southern California: Geographical Review, v. 84, no. 3, p. 305-315, http://www.jstor.org/stable/215455.

Engstrom, W.N., 1996, The California storm of January 1862: Quaternary Research, v. 46, p. 141-148, https://doi. org/10.1006/qres.1996.0054.

Farquhar, F.P. (ed.), 1930, Up and Down California in 18601864; The Journal of William H. Brewer, Professor of Agriculture in the Sheffield Scientific School from 1864 to 1903: New Haven, Yale University Press, 708 p.

Folk R.L., and Ward, W.C., 1957, Brazos River bar-A study in the significance of grain size parameters: Journal of Sedimentary Petrology, v. 27, p. 3-26, https://doi. org/10.1306/74D70646-2B21-11D7-8648000102C1865D.

Freymueller, J.T., Woodard, H., Cohen, S., Cross, R., Elliott, J., Larsen, C., Hreinsdottir, S., and Zweck, C., 2008, Active deformation processes in Alaska, based on 15 years of GPS measurements, in Freymueller, J.T., Haeussler, P.J., Wesson, R., and Ekstrom, G., eds., Active tectonics and seismic potential of Alaska: Washington, D.C., American Geophysical Union Geophysical Monograph 179, p. 1-42, https://doi.org/10.1029/179GM02.

Garrison-Laney, C.E., 1998, Diatom evidence for tsunami inundation from Lagoon Creek, a coastal freshwater pond, Del Norte County, California: Arcata, Calif., Humboldt State University, M.S. thesis, 97 p.

Geist, E.L., and Parsons, T., 2006, Probabilistic analysis of tsunami hazards: Natural Hazards, v. 37, p. 277-314, https://walrus.wr.usgs.gov/reports/reprints/Geist_NH_37.pdf. 
Goldfinger, C., Nelson, C.H., Johnson, J.E., Morey, A.E., Guitérrez-Pastor, J., Karabanov, E., Eriksson, A.T., Gràcia, E., Dunhill, G., Patton, J., Enkin, R., Dallimore, A., and Vallier, T., 2012, Turbidite event history-Methods and implications for Holocene paleoseismicity of the Cascadia subduction zone: U.S. Geological Survey Professional Paper 1661-F, 170 p., http://pubs.usgs.gov/pp/pp1661f/.

Gonzalez, F.I., LeVeque, R.J., Adams, L.M., Goldfinger, C., Priest, G.R., and Wang, K., 2014, Probabilistic tsunami hazard assessment (PTHA) for Crescent City, CA; Final report September 11, 2014: University of Washington Department of Earth and Space Sciences Faculty Papers, 101 p., accessed July 1, 2017, at http://hdl.handle. net/1773/25916.

Graehl, N.A., Kelsey, H.M., Witter, R.C., Hemphill-Haley, E., and Engelhart, S.E., 2015, Stratigraphic and microfossil evidence for a 4500-year history of Cascadia subduction zone earthquakes and tsunamis at Yaquina River estuary, Oregon, USA: Geological Society of America Bulletin, v. 127, no. 1-2, p. 211-226, https://doi.org/10.1130/B31074.1.

Greene, H.G., Murai, L.Y., Watts, P., Maher, N.A., Fisher, M.A., Paull, C.E., and Eichhubl, P., 2006, Submarine landslides in the Santa Barbara Channel as potential tsunami sources: Natural Hazards and Earth System Science, v. 6, no. 1, p. 63-88, https://doi.org/10.5194/nhess-6-63-2006.

Griffin, W.H., 1984, Crescent City's Dark Disaster; Tsunami, Crescent City, California, March 27-28, 1964 and 20 Years Later: Crescent City Publishing and Del Norte County Historical Society, 188 p.

Griggs, G., Patsch, K., and Savoy, L., 2005, Living with the Changing California Coast: Berkeley, Calif., University of California Press, 549 p.

Hameed, H.A., 2003, The colonization of periphytic diatom species on artificial substrates in the Ashar canal, Basrah, Iraq: Limnologica-Ecology and Management of Inland Waters, v. 33, no. 1, p. 54-61, https://doi.org/10.1016/ S0075-9511(03)80007-5.

Harden, D.R., 1995, A comparison of flood-producing storms and their impacts in northern California, in Nolan, K.M., Kelsey, H.M., and Marron, D.C., eds., Geomorphic processes and aquatic habitat, Redwood Creek basin, northwestern California: U.S. Geological Survey Professional Paper 1454, p. D1-D9, https://pubs.er.usgs.gov/ publication/pp1454.

Harden, D.R., Janda, R.J., and Nolan, K.M., 1978, Mass movement and storms in the drainage basin of Redwood Creek, Humboldt County, California-A progress report: U.S. Geological Survey Open-File Report 78-486, 161 p., https://pubs.er.usgs.gov/publication/ofr78486.
Hasle, G.R. and Lange, C.R., 1989, Freshwater and brackish water Thalassiosira (Bacillariophyceae): taxa with tangentially undulated valves: Phycologia, v. 28, p. 120 135, https://doi.org/10.2216/i0031-8884-28-1-120.1.

Haubois, A.-G., Sylvestre, F., Guarini, J.-M., Richard, P., and Blanchard, G.F., 2005, Spatio-temporal structure of the epipelic diatom assemblage from an intertidal mudflat in Marennes-Oléron Bay, France: Estuarine, Coastal and Shelf Science, v. 64, no. 2-3, p. 385-394, https://doi. org/10.1016/j.ecss.2005.03.004.

Hawkes, A.D., Horton, B.P., Nelson, A.R., Vane, C.H., and Sawai, Y., 2011, Coastal subsidence in Oregon, USA, during the giant Cascadia earthquake of AD 1700: Quaternary Science Reviews, v. 30, no. 3-4, p. 364-376, https://doi. org/10.1016/j.quascirev.2010.11.017.

Health and Safety Laboratory, 1972, Fallout Program Quarterly Summary Report, Appendix: U.S. Atomic Energy Commission HASL-258, A-40-41, A-93-94, 436 p.

Hemphill-Haley, E., 1993, Occurrences of recent and Holocene intertidal diatoms (Bacillariophyta) in northern Willapa Bay, Washington: U.S. Geological Survey OpenFile Report 93-284, 94 p., https://pubs.er.usgs.gov/ publication/ofr93284.

Hemphill-Haley, E., 1995a, Diatom evidence for earthquake-induced subsidence and tsunami $300 \mathrm{yr}$ ago in southern coastal Washington: Geological Society of America Bulletin, v. 107, no. 3, p. 367-378, https://doi. org/10.1130/0016-7606(1995)107<0367:DEFEIS >2.3 . $\mathrm{CO} ; 2$.

Hemphill-Haley, E., 1995b, Intertidal diatoms from Willapa Bay, Washington-Application to studies of small-scale sea-level changes: Northwest Science, v. 69, no. 1, p. 29-45, accessed June 10, 2018, at https://research.wsulibs.wsu.edu/ xmlui/handle/2376/1328.

Hemphill-Haley, E., 1996, Diatoms as an aid in identifying late Holocene tsunami deposits: The Holocene, v. 6, no. 4, p. 439-448, https://doi.org/10.1177/095968369600600406.

Hemphill-Haley, E., and Fourtanier, E., 1995, A diatom record spanning 114,000 years from Site 893, Santa Barbara Basin, in Kennett, J.P., Baldauf, J.G., and Lyle, M., eds., Proceedings of the Ocean Drilling Program, Scientific Results, v. 146 (pt. 2), p. 233-249, accessed December 15, 2017, at http://www-odp.tamu.edu/publications/146_2_SR/ VOLUME/CHAPTERS/sr146pt2_17.pdf.

Holmes, R.W., and Mahood, A.D., 1980, Aulacodiscus kittonii Arnott-distribution and morphology on the West Coast of the United States: British Phycological Journal, v. 15, no. 4, p. 377-389, http://doi.org/10.1080/00071618000650381. 
Horton, B.P., Corbett, R., Culver, S.J., Edwards, R.J., and Hillier, C., 2006, Modern saltmarsh diatom distributions of the Outer Banks, North Carolina, and the development of a transfer function for high resolution reconstructions of sea level: Estuarine, Coastal and Shelf Science, v. 69, no. 3-4, p. 381-394, https://doi.org/10.1016/j.ecss.2006.05.007.

Hutchinson, I., Clague, J.J., and Mathewes, R.W., 1997, Reconstructing the tsunami record on an emerging coast-A case study of Kanim Lake, Vancouver Island, British Columbia, Canada: Journal of Coastal Research, v. 13, no. 2, p. 545-553, http://www.jstor.org/stable/4298646.

Hutchinson, I., Peterson, C.D., and Sterling, S.L., 2013, Late Holocene tsunami deposits at Salt Creek, Washington, USA: Science of Tsunami Hazards, v. 21, no. 4, p. 221-235, accessed October 5, 2013, at http://pdxscholar.library.pdx. edu/cgi/viewcontent.cgi? article $=1036 \&$ context $=$ anth_fac.

Ingram, R.L., 1971, Sieve Analysis, in Carver, R.E. (ed.), Procedures in Sedimentary Petrology: Wiley-Interscience, New York, p. 49-67.

Ingram, B.L., and Malamud, F., 2013, The west without waterWhat past floods, droughts, and other climatic clues tell us about tomorrow: Berkeley, Calif., Unversity of California Press, 289 p.

Jacoby, G.C., Bunker, D.E., and Benson, B.E., 1997, Treering evidence for an A.D. 1700 Cascadia earthquake in Washington and northern Oregon: Geology, v. 25, no. 11, p. 999-1002, https://doi.org/10.1130/00917613(1997)025<0999:TREFAA > 2.3.CO;2.

Joshi, S.R., 1987, Nondestructive determination of lead-210 and radium-226 in sediments by direct photon analysis: Journal of Radioanalytical and Nuclear Chemistry, v. 116, no. 1, p. 169-182, http://doi.org/10.1007/BF02037220.

Kelsey, H.M., Nelson, A.R., Hemphill-Haley, E., and Witter, R.C., 2005, Tsunami history of an Oregon coastal lake reveals a $4600 \mathrm{yr}$ record of great earthquakes on the Cascadia subduction zone: Geological Society of America Bulletin, v. 117, no. 7-8, p. 1009-1032, https://doi. org/10.1130/B25452.1.

Kelsey, H.M., Witter, R.C., Hemphill-Haley, E., 2002, Plateboundary earthquakes and tsunamis of the past $5500 \mathrm{yr}$, Sixes River estuary, southern Oregon: Geological Society of America Bulletin, v. 114, p. 298-314, https://doi. org/10.1130/0016-7606(2002)114<0298:PBEATO>2.0.CO;2.

Kemp., A.C., Sommerfield, C.K., Vane, C. H., Horton, B.P., Cherey, S., Anisfeld, S. and Nikitina, D., 2012, Use of lead isotopes for developing chronologies in recent salt-marsh sediments: Quaternary Geology, v. 12, p. 40-49, https://doi. org/10.1016/j.quageo.2012.05.004.
Kirby, S., Scholl, D., von Huene, R., and Wells, R., 2013, Alaska earthquake source for the SAFRR tsunami scenario, chap. B in Ross, S.L., and Jones, L.M., eds., The SAFRR (Science Application for Risk Reduction) Tsunami Scenario: U.S. Geological Survey Open-File Report 2013-1170, 40 p., http://pubs.usgs.gov/of/2013/1170/b/.

Krammer, K., and Lange-Bertalot, H., 1986, Bacillariophyceae 1, Naviculaceae, in Ettl, H., Gerloff, J., Heynig, H., and Mollenhauer, D., eds., Süsswasserflora von Mitteleuropa: Fischer, Stuttgart, v. 2, no. 1, 440 p.

Koehler, R.D., Simpson, G.D., Witter, R.C., Hemphill-Haley, E., and Lettis, W.R., 2004, Paleoseismic investigation of the northern San Gregorio Fault at Pillar Point marsh near Half Moon Bay, California: U.S. Geological Survey National Earthquake Hazards Reduction Program Final Technical Report, 64 p.

Koehler, R., Witter, R., Simpson, G., Hemphill-Haley, E. and Lettis, W., 2005, Paleoseismic investigation of the northern San Gregorio fault, Half Moon Bay, California: U.S. Geological Survey National Earthquake Hazards Reduction Program Final Technical Report, 29 p.

Komatsubara, J., Fujiwara, O., Takada, K., Sawai, Y., Than Tin Aung, T.T., and Kamataki, T., 2008, Historical tsunamis and storms recorded in a coastal lowland, Shizuoka Prefecture, along the Pacific Coast of Japan: Sedimentology, v. 55, p. 1703 1716, https://doi.org/10.1111/j.1365-3091.2008.00964.x.

Kroeber, A.L., 1976, Yurok Myths: Berkeley, Calif., University of California Press, 488 p.

Laird, A., 2009, Lower Redwood Creek land use study, prepared for the California State Coastal Conservancy, $44 \mathrm{p}$.

Lander, J.F., and Lockridge, P.A., 1989, United States tsunamis (including United States possessions) 1690-1988: National Oceanic and Atmospheric Administration Publication 41-2, $243 \mathrm{p}$.

Lander, J., Lockridge, P.A., and Kozuch, J., 1993, Tsunamis affecting the west coast of the United States 1806-1992: National Oceanic and Atmospheric Administration, National Geophysical Data Center Key to Geophysical Research Documentation No. 29, v. 29, 242 p.

Lee, H.J., Normark, W.R., Fisher, M.A., Greene, H.G., Edwards, B.D., and Locat, J., 2004, Timing and extent of submarine landslides in southern California: Offshore Technology Conference paper 16744, 11 p., https://doi. org/10.4043/16744-MS.

Lewin, J., Schaefer, C.T., Winter, D.F., 1989, Surf-zone ecology and dynamics, chap. 12 in Landry, M. R. and Hickey, B.M., eds., Elsevier Oceanography Series, v. 47, p. 567-594, https://doi.org/10.1016/S0422-9894(08)70356-8. 
López, A.M., and Okal, E.A., 2006, A seismological reassessment of the source of the 1946 Aleutian "tsunami" earthquake: Geophysical Journal International, v. 165, no. 3, p. 835-849, https://doi.org/10.1111/j.1365246X.2006.02899.x.

Lu, H., and Liu, K., 2003, Phytoliths of common grasses in the coastal environments of southeastern USA: Estuarine, Coastal and Shelf Science, v. 58, no. 3, p. 587-600, https:// doi.org/10.1016/S0272-7714(03)00137-9.

Lu, H-Y., and Liu, K., 2005, Phytolith assemblages as indicators of coastal environmental changes and hurricane overwash deposition: The Holocene, v. 15, no. 7, p. 965972, https://doi.org/10.1191/0959683605h1870ra.

Ludwin, R.S., Dennis, R., Carver, D., McMillan, A.D., Losey, R., Clague, J., Jonientz-Trisler, C., Bowechop, J., Wray, J., and James, K., 2005, Dating the 1700 Cascadia earthquake - Great coastal earthquakes in native stories: Seismological Research Letters, v. 76, no. 2, p. 140-148, https://doi.org/10.1785/gssrl.76.2.140.

Magoon, O.T., 1966, Structural damage by tsunamis, in Coastal Engineering Santa Barbara Specialty Conference, October 1965: American Society of Civil Engineers, p. 35-68.

Main, S.P., and Mclntire, C.D., 1974, The distribution of epiphytic diatoms in Yaquina Estuary, Oregon (U.S.A.): Botanica Marina, v. XVII, p. 88-99, https://doi.org/10.1515/ botm.1974.17.2.88.

Matsumoto, D., Shimamoto, T., Hirose, T., Gunatilake, J., Wickramasooriya, A., DeLile, J., Young, S., Rathnayake, C., Ranasooriya, J., and Murayama, M., 2010, Thickness and grain-size distribution of the 2004 Indian Ocean tsunami deposits in Periya Kalapuwa Lagoon, eastern Sri Lanka: Sedimentary Geology, v. 230, p. 95-104, https://doi. org/10.1016/j.sedgeo.2010.06.021.

McCulloch, D.S., 1985, Evaluating tsunami potential, in Ziony, J.I., ed., Evaluating earthquake hazards in the Los Angeles region - an Earth science perspective: U.S. Geological Survey Professional Paper 1360, p. 375-413, https://pubs.er.usgs.gov/publication/pp1360.

Nanayama, N., Furukawa, R., Shigeno, K., Makino, A., Soeda, Y. and Igarashi, Y., 2007, Nine unusually large tsunami deposits from the past 4000 years at Kiritappu marsh along the southern Kuril trench: Sedimentary Geology, v. 200, p. 275-294, https://doi.org/10.1016/j.sedgeo.2007.01.008.

National Marine Fisheries Service, 2014, Elk Creek population, chap. 16 of Final recovery plan for the southern Oregon/northern California coast evolutionarily significant unit of coho salmon (Oncorhyncus kisutch): National Marine Fisheries Service, p. 16-1-16.
National Oceanic and Atmospheric Administration [NOAA], 2003a, Crescent City, CA, station ID 9419750: NOAA tides and currents database, accessed August 4, 2016, at https://tidesandcurrents.noaa.gov/datums.html?id=9419750.

National Oceanic and Atmospheric Administration [NOAA], 2003b, Trinidad Harbor, CA, station ID 9419059: NOAA tides and currents database, accessed August 4, 2016, at http://tidesandcurrents.noaa.gov/datums.html?id=9419059.

National Oceanic and Atmospheric Administration [NOAA], 2003c, Pillar Point Harbor, CA, station ID 9414131: NOAA tides and currents database, accessed August 4, 2016, at http://tidesandcurrents.noaa.gov/datums.html?id=9414131.

Nelson, A.R., Briggs, R.W., Dura, T., Engelhart, S.E., Gelfenbaum, G., Bradley, L.-A., Forman, S.L., Vane, C.H., and Kelley, K.A., 2015, Tsunami recurrence in the eastern Alaska-Aleutian arc-A Holocene stratigraphic record from Chirikof Island, Alaska: Geosphere, v. 11, no. 4, p. 1172-1203, https://doi.org/10.1130/GES01108.1.

Nelson, A.R., Kelsey, H.M., and Witter, R.C., 2006, Great earthquakes of variable magnitude at the Cascadia subduction zone: Quaternary Research, v. 65, p. 354-365, https://doi.org/10.1016/j.yqres.2006.02.009.

Nelson, A.R., Sawai, Y., Jennings, A.E., Bradley, L., Gerson, L., Sherrod, B.L., Sabean, J., and Horton, B.P., 2008, Greatearthquake paleogeodesy and tsunamis of the past 2,000 years at Alsea Bay, central Oregon coast, USA: Quaternary Science Reviews, v. 27, p. 747-768, https://doi.org/10.1016/j. quascirev.2008.01.001.

Nelson, A.R., Shennan, I., and Long, A.J., 1996, Identifying coseismic subsidence in tidal-wetland stratigraphic sequences at the Cascadia subduction zone of western North America: Journal of Geophysical Research, v. 101, no. B3, p. 6115-6135, https://doi.org/10.1029/95JB01051.

Nolan, K.M., and Marron, D.C., 1995, History, causes, and significance of changes in the channel geometry of Redwood Creek, northwestern California, 1936 to 1982, in Nolan, K.M., Kelsey, H.M., and Marron, D.C. eds., Geomorphic processes and aquatic habitat in the Redwood Creek basin, northwestern California: U.S. Geological Survey Professional Paper 1454, p. N1-N22, https://pubs.er.usgs.gov/publication/pp1454.

Nováková, J., and Poulíčková, A., 2004, Moss diatom (Bacillariophyceae) flora of the Nature Reserve AdršpašskoTeplické Rocks (Czech Republic): Czech Phycology, Olomouc, v. 4, p. 75-86, https://fottea.czechphycology.cz/pdfs/ fot/2004/01/07.pdf.

Odebrecht, C., Bergesch, M., Rörig, L.R., and Abreu, P.C., 2010, Phytoplankton interannual variability at Cassino Beach, southern Brazil (1992-2007), with emphasis on the surf zone diatom Asterionellopsis glacialis: Estuaries and Coasts, v. 33, no. 2, p. 570-583, https://doi.org/10.1007/s12237-009-9176-6. 
Odebrecht, C., Du Preez, D.R., Abreu, P.C., and Campbell, E.E., 2014, Surf zone diatoms - A review of the drivers, patterns and role in sandy beaches food chains: Estuarine, Coastal and Shelf Science, v. 150, p. 24-35, https://doi.org/10.1016/j. ecss.2013.07.011.

Otte, A.M., and Bellis, V.J., 1985, Edaphic diatoms of a low salinity estuarine marsh system in North Carolina-A comparitive floristic study: Journal of the Elisha Mitchell Scientific Society, v. 101, no. 2, p. 116-124, http://www.jstor. org/stable/24333329.

Patton, J.R., 2004, Late Holocene coseismic subsidence and coincident tsunamis, southern Cascadia subduction zone, Hookton Slough, WIGI (Humboldt Bay), California: Arcata, Calif., Humboldt State University, M.S. thesis, 76 p.

Pennesi, C., Poulin, M., De Stefano, M., Romagnoli, T., and Totti, C., 2011, New insights to the ultrastructure of some marine Mastogloia species section Sulcatae (Bacillariophyceae), including M. neoborneensis sp. nov.: Phycologia, v. 50, no. 5, p. 548-562, https://doi.org/10.2216/10-39.1.

Pennesi, C., Poulin, M., De Stefano, M., Romagnoli, T., and Totti, C., 2012, Morphological studies of some marine Mastogloia (Bacilarriophyceae) belonging to the section Sulcatae, including the description of new species: Journal of Phycology, v. 48, no. 5, p. 1248-1264, https://doi.org/10.1111/j.15298817.2012.01215.x.

Peters, R., Jaffe, B.E., Buckley, M., and Watt, S.G., 2008, Candidate tsunami deposits at Carpinteria salt marsh, southern California [abs.]: Eos Transactions American Geophysical Union, v. 89, no. 53, abstract OS53A-1292.

Petersen, M.D., Moschetti, M.P., Powers, P.M., Mueller, C.S., Haller, K.M., Frankel, A.D., Zeng, Y., Rezaeian, S., Harmsen, S.C., Boyd, O.S., Field, N., Chen, R., Rukstales, K.S., Luco, N., Wheeler, R.L., Williams, R.A., and Olsen, A.H., 2014, Documentation for the 2014 update of the United States national seismic hazard maps: U.S. Geological Survey Open-File Report 2014-1091, 243 p., http://pubs.usgs.gov/ of/2014/1091/.

Peterson, C.D., Carver, G.A., Cruikshank, K.M., Abramson, H.F., Garrison-Laney, C.E., and Dengler, L.A., 2011, Evaluation of the use of paleotsunami deposits to reconstruct inundation distance and runup heights associated with prehistoric inundation events, Crescent City, southern Cascadia margin: Earth and Surface Processes and Landforms, v. 36, no. 7, p. 967-980, https://doi.org/10.1002/ esp.2126.

Peterson, C.D., Clague, J.J., Carver, G.A., and Cruikshank, K.M., 2013, Recurrence intervals of major paleotsunamis as calibrated by historic tsunami deposits in three localities-Port Alberni, Cannon Beach, and Crescent City, along the Cascadia margin, Canada and USA: Natural Hazards, v. 68, no. 2, p. 321-336, https://doi.org/10.1007/s11069-013-0622-1.
Phantuwongraj, S., and Choowong, M., 2012, Tsunamis versus storm deposits from Thailand: Natural Hazards, v. 63, p. 31-50, https://doi.org/10.1007/s11069-011-9717-8.

Porter, K., Wein, A., Alpers, C., Baez, A., Barnard, P., Carter, J., Corsi, A., Costner, J., Cox, D., Das, T., Dettinger, M., Done, J., Eadie, C., Eymann, M., Ferris, J., Gunturi, P., Hughes, M., Jarrett, R., Johnson, L., Dam Le-Griffin, H., Mitchell, D., Morman, Z., Neiman, P., Olsen, A., Perry, S., Plumlee, G., Ralph, M., Reynolds, D., Rose, A., Schaefer, K., Serakos, J., Siembieda, W., Stock, J., Strong, D., Sue Wing, I., Tang, A., Thomas, P., Topping, K., Wills, C., Jones, L., and Cox, D., 2011, Overview of the ARkStorm scenario: U.S. Geological Survey Open-File Report 2010-1312, 183 p. and appendixes., https://pubs.usgs.gov/of/2010/1312/of2010-1312_text.pdf.

Pritchard, C. J., 2004, Late Holocene relative sea level changes, Arcata Bay, California - Evaluation of freshwater syncline movement using coseismically buried soil horizons: Arcata, Calif., Humboldt State University, M.S. thesis, 56 p.

Questa Engineering, 1991, Report on biological monitoring, Pillar Point marsh, Half Moon Bay, California, appendix II of Half Moon Bay/Pillar Point marsh ground-water basin report, Phase II: Luhdorff and Scalmanini Consulting Engineers and Earth Science Associates, 16 p., accessed on December 18, 2017, at http://www.sanmateorcd.org/links/LSCE_ESA_1991_HMB_ GW_Basin.pdf.

R Development Core Team, 2008, R-A language and environment for statistical computing: R Foundation for Statistical Computing, Vienna, Austria, http://www.Rproject.org.

Reimer, P., Bard, E., Bayliss, A., Beck, J., Blackwell, P., Ramsey, C.B., Buck, C., Cheng, H., Edwards, R., Friedrich, M., Grootes, P., Guilderson, T., Haflidason, H., Hajdas, I., Hatté, C., Heaton, T., Hoffmann, D., Hogg, A., Hughen, K., Kaiser, K., Kromer, B., Manning, S., Niu, M., Reimer, R., Richards, D., Scott, E., Southon, J., Staff, R., Turney, C., and van der Plicht, J., 2013, IntCal13 and Marine13 radiocarbon age calibration curves 0-50,000 years cal BP: Radiocarbon, v. 55, no. 4, p. 1869 1887, https://doi.org/10.2458/azu_js_rc.55.16947.

Reynolds, L., Simms, A., King, B.L., Rockwell, T.K., Ejarque, A., Anderson, R., and Peters, R.B., 2013, Sedimentological evidence of the 1812 Santa Barbara tsunami in Carpinteria marsh, CA [abs.]: American Geophysical Union Fall Meeting, abstract NH44A-05.

Reynolds, L.C., Simms, A.R., Rockwell, T.K., and Peters, R., 2015, Holocene evolution of Carpinteria marsh, southern California - A story of storms and subsidence [abs.]: INQUA International Congress XIX, Nagoya, Japan.

Ricks, C.L. 1979, Flood history and sedimentation at the mouth of Redwood Creek, Humboldt County, California: Corvallis, Oregon State University, M.S. thesis, 179 p. 
Ricks, C.L. 1985, Flood history and sedimentation at the mouth of Redwood Creek, Humboldt County, California: Redwood National Park Technical Report 15, 156 p.

Ricks, C.L., 1995, Effects of channelization on sediment distribution and aquatic habitat at the mouth of Redwood Creek, northwestern California., in Nolan, K.M., Kelsey, H.M., and Marron, D.C., eds., Geomorphic processes and aquatic habitat, Redwood Creek basin, northwestern California: U.S. Geological Survey Professional Paper 1454, p. Q1-Q17.

Ritchie, J.C., and McHenry, R.J., 1990, Application of radioactive fallout Cesium-137 for measuring soil erosion and sediment accumulation rates and patterns; a review: Journal of Environmental Quality, v. 19, p. 215-233, https://doi. org/10.2134/jeq1990.00472425001900020006x.

Rizynk, R.Z., 1973, Interstitial diatoms from two tidal flats in Yaquina Estuary, Oregon, USA: Botanica Marina, v. XVI, p. 113-138, https://doi.org/10.1515/botm.1973.16.3.113.

Robbins, J.A., and Edgington, D.N, 1975, Determination of recent sedimentation rates in Lake Michigan using $\mathrm{Pb}-210$ ad Cs-137: Geochimica et Cosmochimica Acta, v. 39, p. 285-304, http://doi.org/10.1016/0016-7037(75)90198-2.

Roe, H.M., Doherty, C.T., Patterson, R.T., and Swindles, G.T., 2009, Contemporary distributions of saltmarsh diatoms in the Seymour-Belize Inlet Complex, British Columbia, Canada-Implications for studies of sea-level change: Marine Micropaleontology, v. 70, no. 3-4, p. 134-150, https://doi. org/10.1016/j.marmicro.2008.12.001.

Ross, S.L., Jones, L.M., Miller, K., Porter, K.A., Wein, A., Wilson, R.I., Bahng, B., Barberopoulou, A., Borrero, J.C., Brosnan, D.M., Bwarie, J.T., Geist, E.L., Johnson, L.A., Kirby, S.H., Knight, W.R., Long, K., Lynett, P., Mortensen, C.E., Nicolsky, D.J., Perry, S.C., Plumlee, G.S., Real, C.R., Ryan, K., Suleimani, E., Thio, H., Titov, V.V., Whitmore, P.M., and Wood, N.J., 2013, The SAFRR tsunami scenario-Improving resilience for California: U.S. Geological Survey Fact Sheet 2013-3081, 4 p., https://pubs.usgs.gov/fs/2013/3081/.

Russell, N., and Griggs, G., 2012, Adapting to sea-level rise-A guide to California's coastal communities: California Energy Commission Public Interest Environmental Research Program, 54 p., accessed December 18, 2017, at https:// seymourcenter.ucsc.edu/OOB/Adapting $\% 20$ to $\% 20$ Sea $\% 20$ Level\%20Rise.pdf.

Ryan, H.F., von Huene, R., Wells, R.E., Scholl, D.W., Kirby, S., and Draut, A.E., 2012, History of earthquakes and tsunamis along the eastern Aleutian-Alaska megathrust, with implications for tsunami hazards in the California Continental Borderland, in Dumolin, J.A., and Dusel-Bacon, C., eds., Studies by the U.S. Geological Survey in Alaska, 2011: U.S. Geological Survey Professional Paper 1795-A, 31 p., https://pubs.usgs.gov/pp/1795/a/pp1795a.pdf.
SAFRR Tsunami Modeling Working Group, 2013, Modeling for the SAFRR Tsunami Scenario - Generation, propagation, inundation, and currents in ports and harbors, chap. D of Ross, S.L., and Jones, L.M., eds., The SAFRR (Science Application for Risk Reduction) Tsunami Scenario: U.S. Geological Survey Open-File Report 2013-1170, 136 p., http://pubs.usgs.gov/ of $/ 2013 / 1170 / \mathrm{d} /$.

Sanchez-Cabeza, J.A., and Ruiz-Fernandez, A.C., 2012, ${ }^{210} \mathrm{~Pb}$ sediment radiochronology - An integrated formulation and classification of dating materials: Geochmimica et Cosmochemica Acta, v. 82, p. 183-200, https://doi. org/10.1016/j.gca.2010.12.024.

San Mateo County Harbor District, 2018, Pillar Point Harbor, accessed June 30, 2018, at https://www.smharbor.com/pillarpoint-harbor-650-726-4382.

Satake, K., Shimazaki, K., Tsuji, Y., and Ueda, K., 1996, Time and size of a giant earthquake in Cascadia inferred from Japanese tsunami records of January 1700: Nature, v. 379, no. 6562, p. 246-249.

Satake, K., Wang, K., and Atwater, B.F., 2003, Fault slip and seismic moment of the 1700 Cascadia earthquake inferred from Japanese tsunami descriptions: Journal of Geophysical Research, v. 108, no. B11, p. 17, https://doi. org/10.1029/2003JB002521.

Sawai, Y., 2001, Distribution of living and dead diatoms in tidal wetlands of northern Japan-Relations to taphonomy: Palaeogeogrpahy, Palaeoclimatology, Palaeoecology, v. 173, p. 125-141, https://doi.org/10.1016/S0031-0182(01)00313-3.

Sawai, Y., Horton, B.P., Kemp, A.C., Hawkes, A.D., Nagumo, T., and Nelson, A.R., 2016, Relationships between diatoms and tidal environments in Oregon and Washington, USA: Diatom Research, v. 31, no. 1, p. 17-38, https://doi.org/10.1080/02692 49X.2015.1126359.

Sawai, Y., Jankaew, K., Martin, M.E., Prendergast, A., Choowong, and M., Charoentitirat, T., 2009, Diatom assemblages in tsunami deposits associated with the 2004 Indian Ocean tsunami at Phra Thong Island, Thailand: Marine Micropaleontology, v. 73, p. 70-79, https://doi.org/10.1016/j. marmicro.2009.07.003.

Sawai, Y., Nagumo, T., Namegaya, Y., Cisternas, M.V., Lagos, M., and Shishikura, M., 2017, Diatom (Bacillariophyceae) assemblages in salt marshes of south-central Chile-Relations with tidal inundation time and salinity: Phycological Research, v. 65, no. 1, p. 29-37, https://doi.org/10.1111/pre.12156.

Schwartz, D.P., Lienkaemper, J.J., Hecker, S., Kelson, K.I., Fumal, T.E., Baldwin, J.N., Seitz, G.G., and Niemi, T.M., 2014, The earthquake cycle in the San Francisco Bay region, A.D. 1600 2012: Bulletin of the Seismological Society of America, v. 104, no. 3, p. 1299-1328, https://doi.org/10.1785/0120120322. 
Shanmugam, G., 2012, Process-sedimentological challenges in distinguishing paleo-tsunami deposits: Natural Hazards, v. 63 , no. 1, p. 5-30, https://doi.org/10.1007/s11069-0119766-z.

Shennan, I., Long, A.J., Rutherford, M.M., Green, F.M., Innes, J.B., Lloyd, J.M., Zong, Y., and Walker, K.J., 1996, Tidal marsh stratigraphy, sea-level change and large earthquakesPart I, A 5000 year record in Washington, U.S.A: Quaternary Science Reviews, v. 15, no. 10, p. 1023-1059, https://doi. org/10.1016/S0277-3791(96)00007-8.

Shennan, I., Long, A.J., Rutherford, M.M., Innes, J.B., Green, F.M., and Walker, K.J., 1998, Tidal marsh stratigraphy, sealevel change and large earthquakes - Part II, Submergence events during the last 3500 years at Netarts Bay, Oregon, USA: Quaternary Science Reviews, v. 17, no. 4, p. 365-393, https://doi.org/10.1016/S0277-3791(97)00055-3.

Shepard, F.P., Macdonald, G.A., and Cox, D.C., 1950, The tsunami of April 1, 1946: Bulletin of the Scripps Institution of Oceanography, v. 5, no. 6, p. 391-528, accessed December 18, 2017, at http://escholarship.org/uc/item/89040915.pdf.

Sherrod, B.L., 1999, Gradient analysis of diatom assemblages in a Puget Sound salt marsh — Can such assemblages be used for quantitative paleoecological reconstructions?: Palaeogeography, Palaeoclimatology, Palaeoecology, v. 149, no. 1, p. 213-226, http:/www.sciencedirect.com/science/ article/pii/S0031018298002028.

Simpson, G.D., and Knudsen, K.L., 2000, Paleoseismic investigation of the northern San Gregorio Fault at the Pillar Point marsh near Half Moon Bay, California: U.S. Geological Survey Bay Area Paleoseismic Experiment (BAPEX) Final Technical Report, 34 p.

Smucker, N.J., Edlund, M.B. and Vis, M.L., 2008, The distribution, morphology and ecology of a non-native species, Thalassiosira lacustris (Bacillariophyceae), from benthic stream habitats in North America: Nova Hedwigia, v. 87, p. 201-220, https://doi.org/10.1127/0029-5035/2008/00870201 .

Spiske, M., Piepenbreier, J., Benavente, C., and Bahlburg, H., 2013, Preservation potential of tsunami deposits on arid siliciclastic coasts: Earth-Science Reviews, v. 126, p. 58-73, https://doi.org/10.1016/j.earscirev.2013.07.009.

Spiske, M., Weiss, R.,B., Bahlburg, H., Roskosch, J., and Amijaya, H., 2010, The TsuSedMod inversion model applied to the deposits of the 2004 Sumatra and 2006 Java tsunami and implications for estimating flow parameters of palaeotsunami: Sedimentary Geology, v. 224, p. 29-37, https://doi. org/10.1016/j.sedgeo.2009.12.005.

Stuiver, M., Reimer, P.J., and Reimer, R.W., 2016, CALIB 7.1 [WWW program], accessed June 1, 2016, at http://calib.qub. ac.uk/calib/.
Switzer, A.D., and Jones, B.G., 2008, Large-scale washover sedimentation in a freshwater lagoon from the southeast Australian coast - Sea-level change, tsunami or exceptionally large storm?: The Holocene, v. 18, no. 5, p. 787-803, https://doi.org/10.1177/0959683608089214.

Szczuciński, W., 2012, The post-depositional changes of the onshore 2004 tsunami deposits on the Andaman Sea coast of Thailand: Natural Hazards, v. 60, no. 1, p. 115-133, https://doi.org/10.1007/s11069-011-9956-8.

Szczuciński, W., Kokociński, M., Rzeszewski, M., ChaguéGoff, C., Cachão, M., Goto, K., and Sugawara, D., 2012, Sediment sources and sedimentation processes of 2011 Tohoku-oki tsunami deposits on the Sendai Plain, Japan-Insights from diatoms, nannoliths and grain size distribution: Sedimentary Geology, v. 282, p. 40-56, https://doi.org/10.1016/j.sedgeo.2012.07.019.

Talbot, M.M.B., Bate, G.C., and Campbell, E.E., 1990, A review of the ecology of surf-zone diatoms, with special reference to Anaulus australis: Oceanography and Marine Biology Annual Reviews, v. 28, p. 155-175.

Tudor, W.J., 1964, Tsunami damage at Kodiak, Alaska and Crescent City, California from Alaskan Earthquake of 27 March 1964: Port Hueneme, Calif., U.S. Naval Civil Engineering Laboratory Technical Note No. N-622, 128 p.

Tynni, R., 1986, Observations of diatoms on the coast of Washington: Geological Survey of Finland Report No. 75, p. 5-25, accessed January 17, 2012, at http://tupa.gtk.fi/ julkaisu/tutkimusraportti/tr_075.pdf.

U.S. Coast and Geodetic Survey, 1916, Pacific Coast Harbor Chart 5895, St. George Reef and Crescent City, California: NOAA Historical Map and Chart Collection, scale 1:40,000, https://historicalcharts.noaa.gov.

U.S. Coast and Geodetic Survey, 1928, Chart T-4402, Point St. George, Crescent City and Viscinity, California, Thorson, A.C., (surveyor): NOAA historical surveys database, scale 1:10,000, accessed June 22, 2018, at https:// nosimagery.noaa.gov/images/shoreline_surveys/survey_ scans/T-4402.jpg.

U.S. Coast and Geodetic Survey, 1929, Chart T-4524, Pillar Point, Half Moon Bay to Point San Pedro, California, Bond, J.A., (surveyor): NOAA historical surveys database, scale 1:10,000, accessed December 18, 2017, at http:// nosimagery.noaa.gov/images/shoreline_surveys/survey_ scans/T-4524.jpg.

U.S. Coast and Geodetic Survey, 1947, Chart 5520, Half Moon Bay: NOAA historical surveys database, scale 1:20,000, accessed June 20, 2018, at https://historicalcharts. noaa.gov. 
U.S. Coast Survey, 1859, Chart T-741, Crescent City Harbor, California, Lawson, J.S., (surveyor): NOAA historical surveys database, scale 1:10,000, accessed December 18, 2017, at http://nosimagery.noaa.gov/images/shoreline_surveys/survey_ scans/T-741.jpg.

U.S. Coast Survey, 1861, Chart T-933, Coast of California in the viscinity of Half Moon Bay, Johnson, W.M., (surveyor): NOAA historical surveys database, scale 1:10,000, accessed December 18, 2017, at http://nosimagery.noaa.gov/images/shoreline surveys/survey_scans/T-993.jpg.

U.S. Coast Survey, 1863, Pacific Coast Harbor Chart 620, Half Moon Bay, California, Rodgers, A.F., (surveyor): NOAA photograph library database, scale 1:20,000, accessed December 18, 2017, at http://www.photolib.noaa.gov/bigs/ cgs05223.jpg.

U.S.C. Tsunami Research Group, 2016, 1946 Aleutian Tsunami: University of Southern California Tsunami Research Center, accessed August, 6, 2016, at http://cwis.usc.edu/dept/tsunamis/ alaska/1946/webpages/index.html.

U.S. Department of Commerce, 2016, Chart 18682, Half Moon Bay: National Oceanographic and Atmospheric Administration, Office of Coast Survey, scale 1:20,000, accessed June 20, 2018, https://www.charts.noaa.gov/OnLineViewer/18682.shtml.

Valentine, D.W., Keller, E.A., Carver, G., Li, W-H., Manhart, C., and Simms, A.R., 2012, Paleoseismicity of the southern end of the Cascadia subduction zone, northwestern California: Bulletin of the Geological Society of America, v. 102, no. 3, p. 1059-1078, https://doi.org/10.1785/0120110103.

Van de Vijver, B., and Beyens, L., 1997, The epiphytic diatom flora of mosses from Strømness Bay area, South Georgia: Polar Biology, v. 17, p. 492-501, https://doi.org/10.1007/ s003000050148.

von Huene, R., Miller, J.J., and Dartnell, P., 2016, A possible transoceanic tsunami directed toward the U.S. west coast from the Semidi segment, Alaska convergent margin: Geochemistry, Geophysics, Geosystems, v. 17, no. 3, p. 645-659, https://doi. org/10.1002/2015GC006147.

Waterman, T.T., 1920, Yurok Geography: University of California Publication in American Archaeology and Ethnology, v. 16, no. 5, p. 177-314, accessed December 18, 2017, at https://babel. hathitrust.org/cgi/pt?id=uc1.b4517529;view=1 up;seq=5.

Wells, E.L., 1949, Notes on the winter of 1861-1862 in the Pacific Northwest: Northwest Science, v. 21, p. 76-82.

Whiting, M.C., and Schrader, H., 1985, Late Miocene to Early Pliocene marine diatom and silicoflagellate floras from the Oregon coast and continental shelf: Micropaleontology, v. 31, no. 3, p. 249-270, http://www.jstor.org/stable/1485544.
Wilson, R.I., Admire, A.R., Borrero, J.C., Dengler, L.A., Legg, M.R., Lynett, P., McCrink, T.P., Miller, K.M., Ritchie, A., Sterling, K., and Whitmore, P.M., 2013, Observations and impacts from the 2010 Chilean and 2011 Japanese tsunamis in California (USA): Pure and Applied Geophysics, v. 170, no. 6-8, p. 1127-1147, https://doi.org/10.1007/s00024-0120527-z.

Wilson, R.I., Barberopoulou, A., Miller, K.M., Goltz, J.D., and Synolakis, C.E., 2008, New maximum tsunami inundation maps for use by local emergency planners in the State of California, USA [abs.]: Eos Transactions American Geophysical Union, v. 89, no. 53, abstract OS43D-1343.

Wilson, R.I., Barberopoulou, A., Miller, K.M., Goltz, J.D., and Synolakis, C.E., 2010, New maximum tsunami inundation maps for use by local emergency planners in the State of California, USA, in Lee, W.H.K., Kirby, S.H., and Diggles, M.F., compilers, 2010, Program and abstracts of the Second Tsunami Source Workshop; July 19-20, 2010: U.S. Geological Survey Open-File Report 2010-1152, 33 p., http://pubs.usgs.gov/of/2010/1152/.

Wilson, R., Hemphill-Haley, E., Jaffe, B., Richmond, B., Peters, R., Graehl, N., Kelsey, H., Leeper, R., Watt, S., McGann, M., Hoirup, D., Chague-Goff, C., Goff, J., Caldwell, D., and Loofbourrow, C., 2014, The search for geologic evidence of distant-source tsunamis using new field data in California, chap. C of Ross, S.L., and Jones, L.M., eds., The SAFRR (Science Application for Risk Reduction) tsunami scenario: U.S. Geological Survey Open-File Report 2013-1170, 214 p., http://doi.org/10.3133/ofr20131170c.

Witkowski, A., Lange-Bertalot, H., and Metzeltin, D., 2000, Diatom Flora of Marine Coasts I, in Lange-Bertalot, H. (ed.), Iconographia Diatomologica, v. 7: A.R.G. Gantner Verlag, $925 \mathrm{p}$.

Witter, R.C., Carver, G.A., Briggs, R.W., Gelfenbaum, G., Koehler, R.D., La Selle, S., Bender, A.M., Engelhart, S.E., Hemphill-Haley, E., and Hill, T.D., 2016, Unusually large tsunamis frequent a currently creeping part of the Aleutian megathrust: Geophysical Research Letters, v. 43, no. 1, p. 76-84, https://doi.org/10.1002/2015GL066083.

Witter, R.C., Hemphill-Haley, E., Hart, R., and Gay, L., 2009, Tracking prehistoric Cascadia tsunami deposits at Nestucca Bay, Oregon: U.S. Geological Survey National Earthquake Hazards Reduction Program Final Technical Report, 92 p., accessed December 18, 2017, at www.oregongeology.org/ tsuclearinghouse/resources/poster-Nestucca-v2.pdf.

Witter, R.C., Jaffe, B., Zhang, Y., and Priest, G., 2012, Reconstructing hydrodynamic flow parameters of the 1700 tsunami at Cannon Beach, Oregon, USA: Natural Hazards, v. 63, p. 223-240, https://doi.org/10.1007/s11069-011-9912-7. 
Witter, R.C., Zhang, Y., Wang, K., Priest, G.R., Goldfinger, C., Stimely, L.L., English, J.T., and Ferro, P.A., 2011, Simulating tsunami inundation at Bandon, Coos County, Oregon, using hypothetical Cascadia and Alaska earthquake scenarios: Oregon Department of Geology and Mineral Industries Special Report 43 [DVD].
Yamaguchi, D.K., Atwater, B.F., Bunker, D.E., Benson, B.E., and Reid, M.S., 1997, Tree-ring dating the 1700 Cascadia earthquake: Nature, v. 389, no. 6654, p. 922-923.

Zuber, G., Hufford, T., Blankenship, B., and Barlow, S., 1985, Oreq-w; Orick Then and Now: Historical Committee of the Orick Chamber of Commerce, $342 \mathrm{p}$. 


\section{Appendixes}




\section{Appendix 1. Locations and Descriptions of Cores and Surface Samples}

Table 1.1. Locations and elevations of cores, surface samples, and real-time kinematic data points collected at five northern California study sites.

[Geographic coordinates are provided in the Universal Transverse Mercator (UTM) Zone 10N coordinate system using the North American Datum of 1983 (NAD83). m, meter; NAVD88, North American Vertical Datum of 1988; MLLW, mean lower low water]

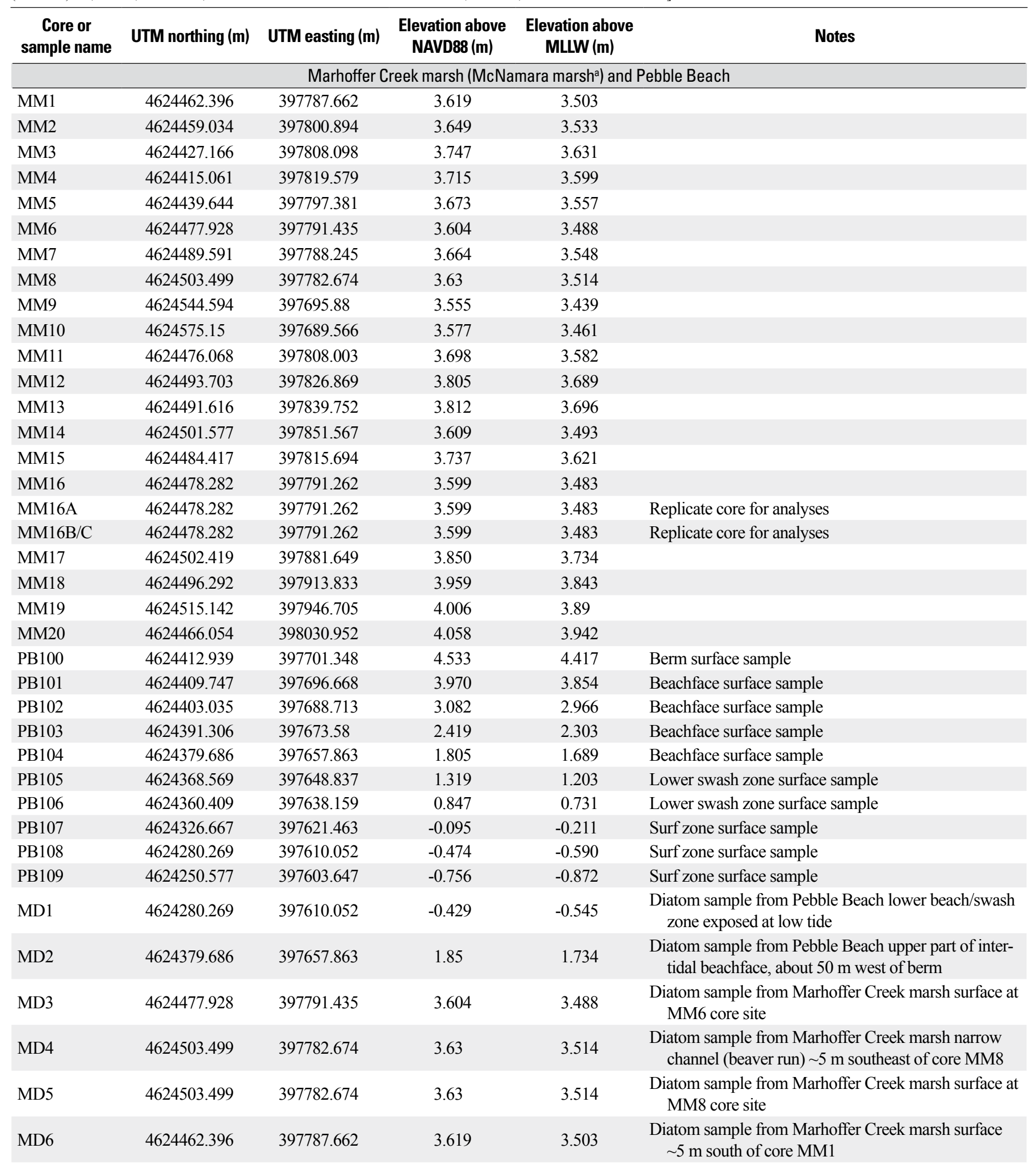


Table 1.1.-Continued

\begin{tabular}{|c|c|c|c|c|c|}
\hline $\begin{array}{c}\text { Core or } \\
\text { sample name }\end{array}$ & UTM northing (m) & UTM easting (m) & $\begin{array}{l}\text { Elevation above } \\
\text { NAVD88 (m) }\end{array}$ & $\begin{array}{l}\text { Elevation above } \\
\operatorname{MLLW}(\mathrm{m})\end{array}$ & Notes \\
\hline MD7 & 4624462.396 & 397787.662 & 3.619 & 3.503 & $\begin{array}{l}\text { Diatom sample from Marhoffer Creek marsh surface at } \\
\text { MM1 core site }\end{array}$ \\
\hline MD8 & 4624476.068 & 397808.003 & 3.698 & 3.582 & $\begin{array}{l}\text { Diatom sample from Marhoffer Creek marsh surface } \\
\text { between cores MM11 and MM15 }\end{array}$ \\
\hline MD9 & 4624491.616 & 397839.752 & 3.812 & 3.696 & $\begin{array}{l}\text { Diatom sample from Marhoffer Creek marsh surface at } \\
\text { MM13 core site }\end{array}$ \\
\hline \multicolumn{6}{|c|}{ Elk Creek marsh } \\
\hline EC1 & 4623371.891 & 401474.399 & 2.354 & 2.238 & Duplicate core \\
\hline EC2 & 4623343.515 & 401500.458 & 2.236 & 2.12 & \\
\hline EC3 & 4623425.957 & 401321.665 & 2.378 & 2.262 & \\
\hline EC7 & 4623470.239 & 401435.734 & 2.331 & 2.215 & \\
\hline EC8 & 4623461.654 & 401463.304 & 2.077 & 1.961 & \\
\hline EC9 & 4623448.92 & 401497.023 & 2.143 & 2.027 & \\
\hline $\mathrm{EC} 10$ & 4623433.849 & 401472.228 & 2.297 & 2.181 & \\
\hline EC11 & 4623410 & 401528 & & & \\
\hline $\mathrm{EC} 12$ & 4623474 & 401531 & & & \\
\hline \multicolumn{6}{|c|}{ Sand Mine marsh } \\
\hline SM1 & 4621663 & 403174 & & & \\
\hline SM2 & 4621826.112 & 403113.168 & 3.223 & 3.107 & Duplicate core \\
\hline SM3 & 4621814.848 & 403186.275 & 3.158 & 3.042 & \\
\hline SM8 & 4621642.286 & 403191.92 & 2.786 & 2.67 & \\
\hline SM9 & 4621645.16 & 403185.132 & 2.77 & 2.654 & \\
\hline SM9x & 4621645.16 & 403185.132 & 2.77 & 2.654 & \\
\hline SM10 & 4621650.711 & 403177.011 & 2.648 & 2.532 & Duplicate core \\
\hline SM11 & 4621652.963 & 403174.228 & 2.708 & 2.592 & \\
\hline SM11x & 4621652.963 & 403174.228 & 2.708 & 2.592 & \\
\hline SM12 & 4621648.792 & 403173.909 & 2.668 & 2.552 & \\
\hline \multicolumn{6}{|c|}{ O'rekw marsh } \\
\hline OM1 & 4570789.378 & 408679.589 & 2.723 & 2.607 & \\
\hline OM2 & 4570785.256 & 408681.784 & 2.626 & 2.51 & \\
\hline OM3 & 4570790.211 & 408684.145 & 2.731 & 2.615 & \\
\hline OB104 & 4570789.471 & 408678.411 & 2.578 & 2.462 & Beach profile \\
\hline OB105 & 4570789.629 & 408673.076 & 2.725 & 2.609 & Beach profile \\
\hline OB106 & 4570790.713 & 408668.382 & 2.79 & 2.674 & Beach profile \\
\hline OB107 & 4570794.119 & 408660.297 & 3.052 & 2.936 & Beach profile \\
\hline OB108 & 4570799.719 & 408649.371 & 3.99 & 3.874 & Beach profile \\
\hline OB109 & 4570805.226 & 408639.871 & 5.994 & 5.878 & Beach profile \\
\hline OB110 & 4570812.925 & 408620.03 & 6.972 & 6.856 & Beach profile \\
\hline OB111 & 4570815.125 & 408610.224 & 4.565 & 4.449 & Beach profile \\
\hline
\end{tabular}


Table 1.1.-Continued

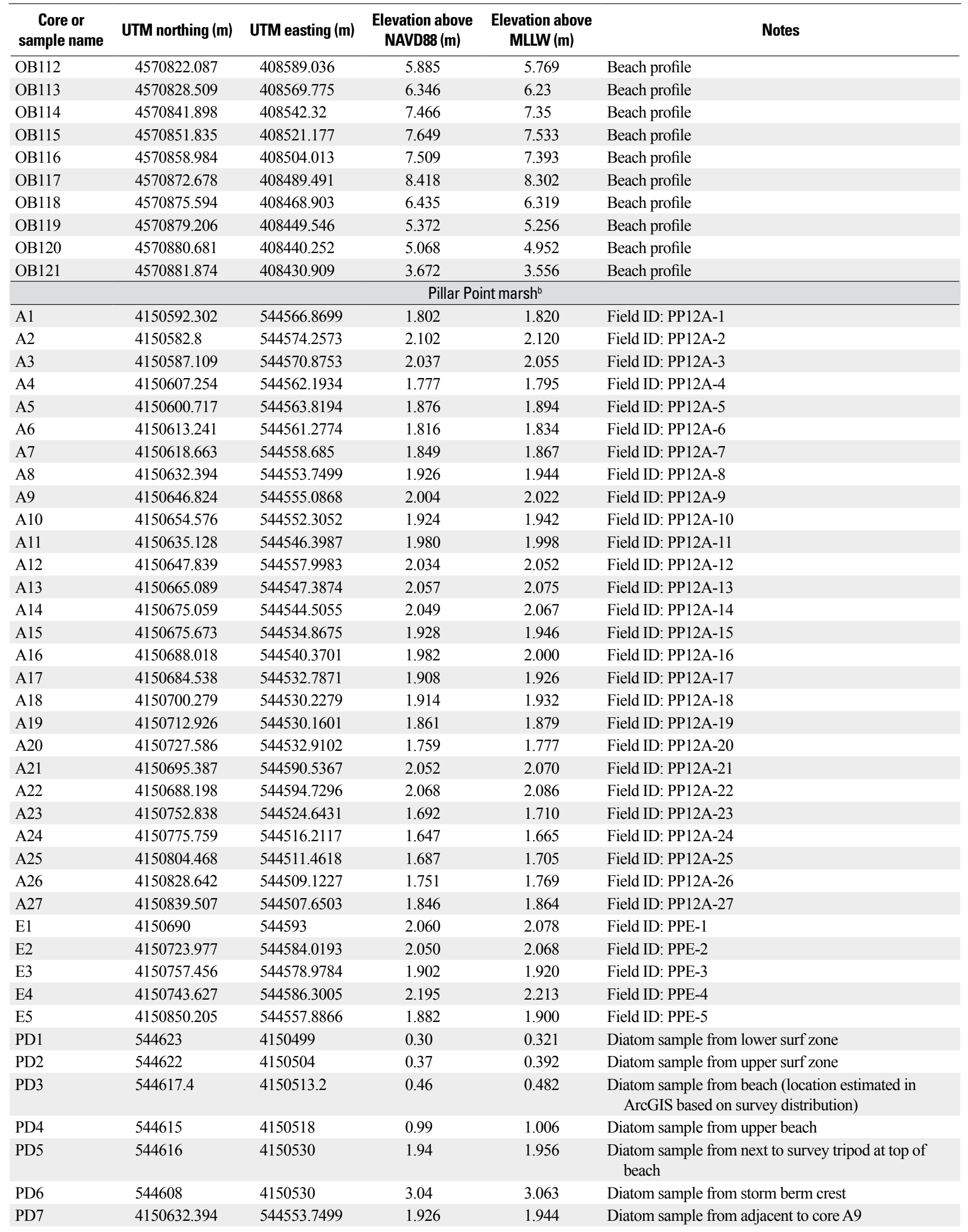


Table 1.1.-Continued

\begin{tabular}{lccccc}
\hline $\begin{array}{c}\text { Core or } \\
\text { sample name }\end{array}$ & UTM northing (m) & UTM easting (m) & $\begin{array}{c}\text { Elevation above } \\
\text { NAVD88 }(\mathbf{m})\end{array}$ & $\begin{array}{c}\text { Elevation above } \\
\mathbf{M L L W}(\mathbf{m})\end{array}$ & Notes \\
\hline PD8 & 4150646.824 & 544555.0868 & 2.004 & 2.022 & Diatom sample from adjacent to core A8 \\
PD9 & 4150665.089 & 544547.3874 & 2.057 & 2.075 & Diatom sample from adjacent to core A13 \\
PD10 & 4150675.673 & 544534.8675 & 1.928 & 1.946 & Diatom sample from adjacent to core A15 \\
PD11 & 4150712.926 & 544530.1601 & 1.861 & 1.879 & Diatom sample from adjacent to core A19 \\
PD12 & 4150775.759 & 544516.2117 & 1.647 & 1.665 & Diatom sample from adjacent to core A24 \\
PD13 & 4150839.507 & 544507.6503 & 1.846 & 1.864 & $\begin{array}{c}\text { Diatom sample from cattail marsh landward of core } \\
\text { A27 }\end{array}$ \\
\hline
\end{tabular}

${ }^{a}$ Marhoffer Creek marsh was informally called McNamara marsh by Wilson and others (2014).

${ }^{b}$ Real-time kinematic elevation data for Pillar Point marsh cores acquired by Steve Watt, U.S. Geological Survey. 


\section{Marhoffer Creek Marsh}

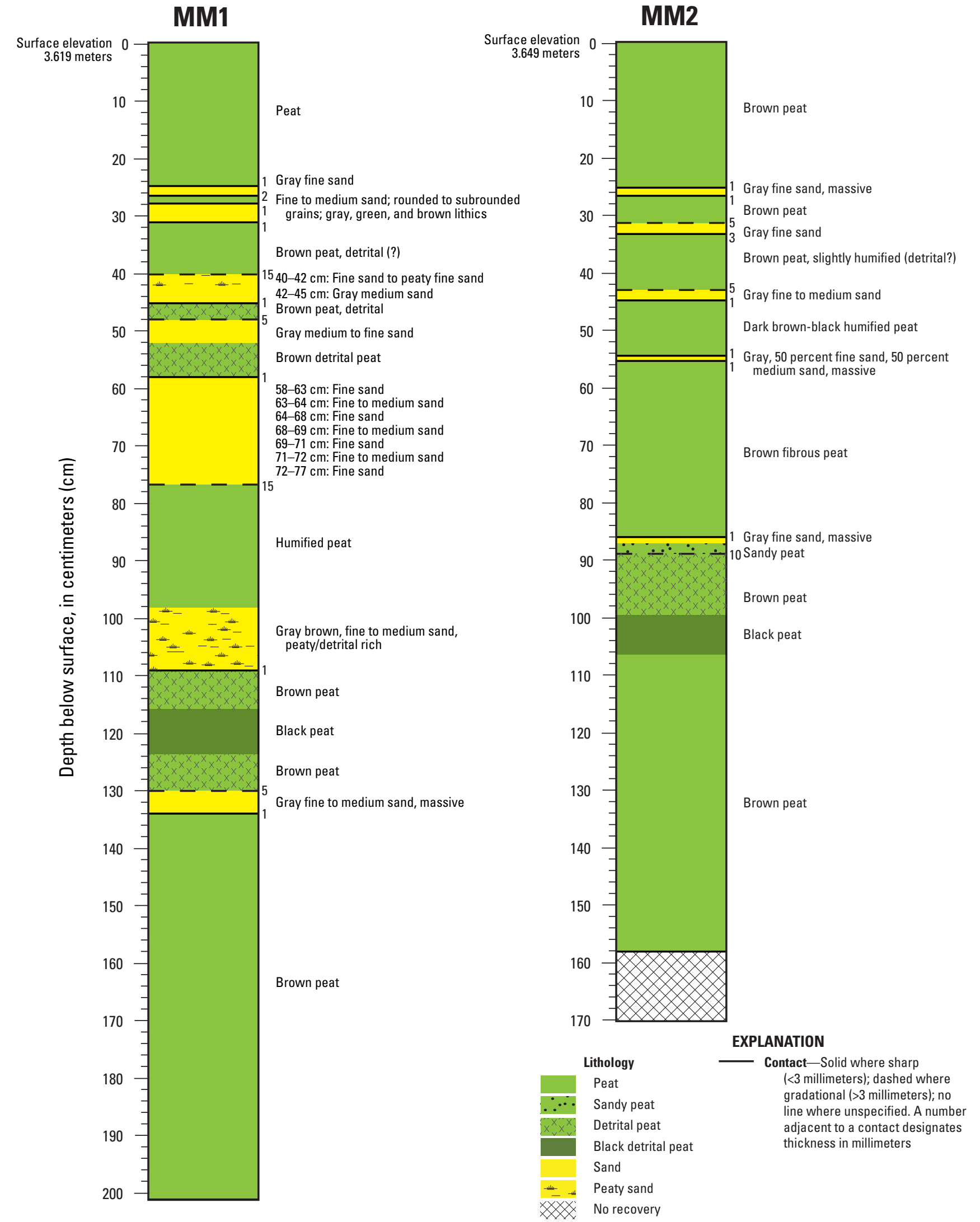

Figure 1.1. Lithologic description of cores MM1 and MM2 from Marhoffer Creek marsh. Elevations are relative to the North American Vertical Datum of 1988. 
MM3

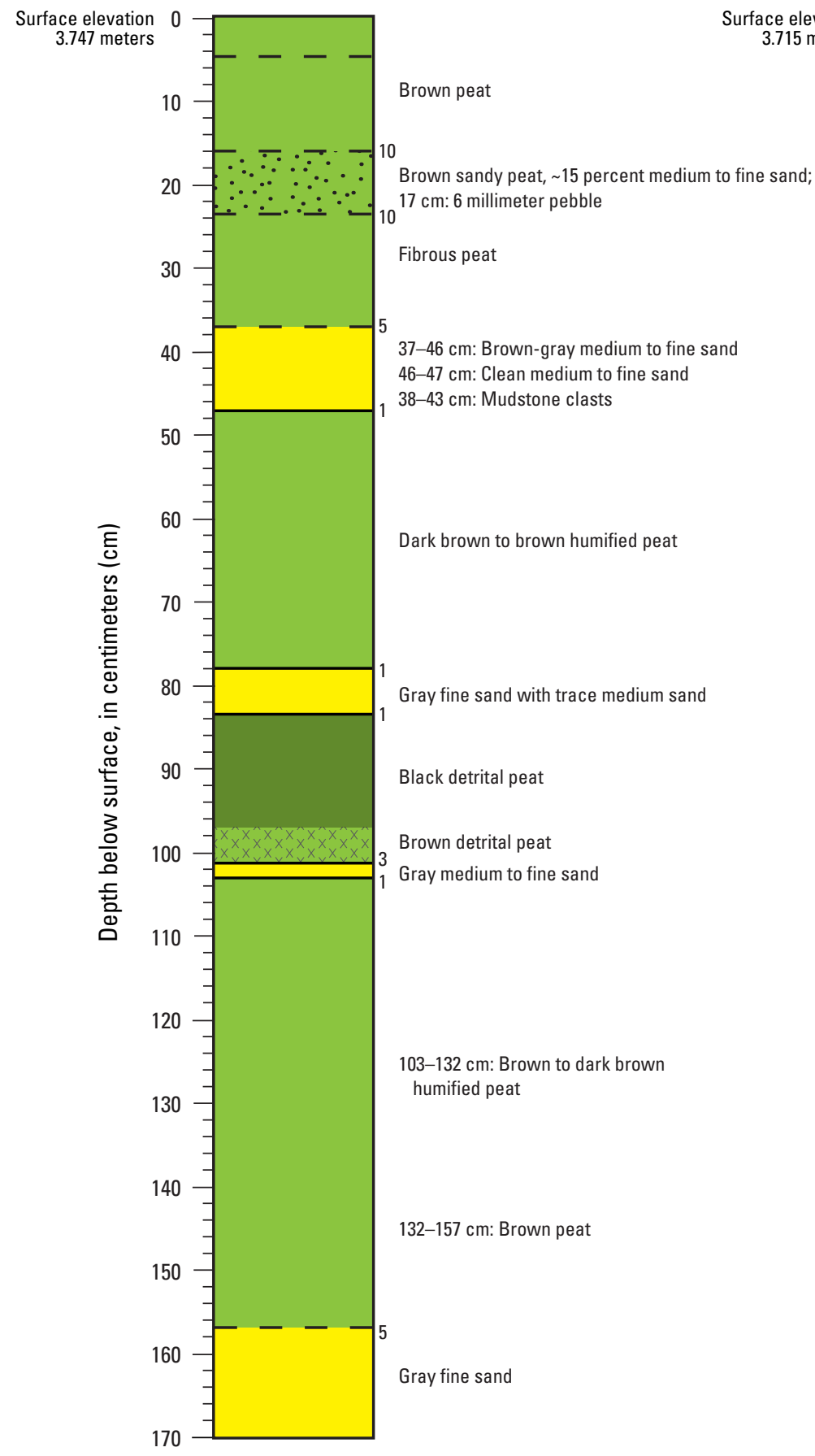

MM4
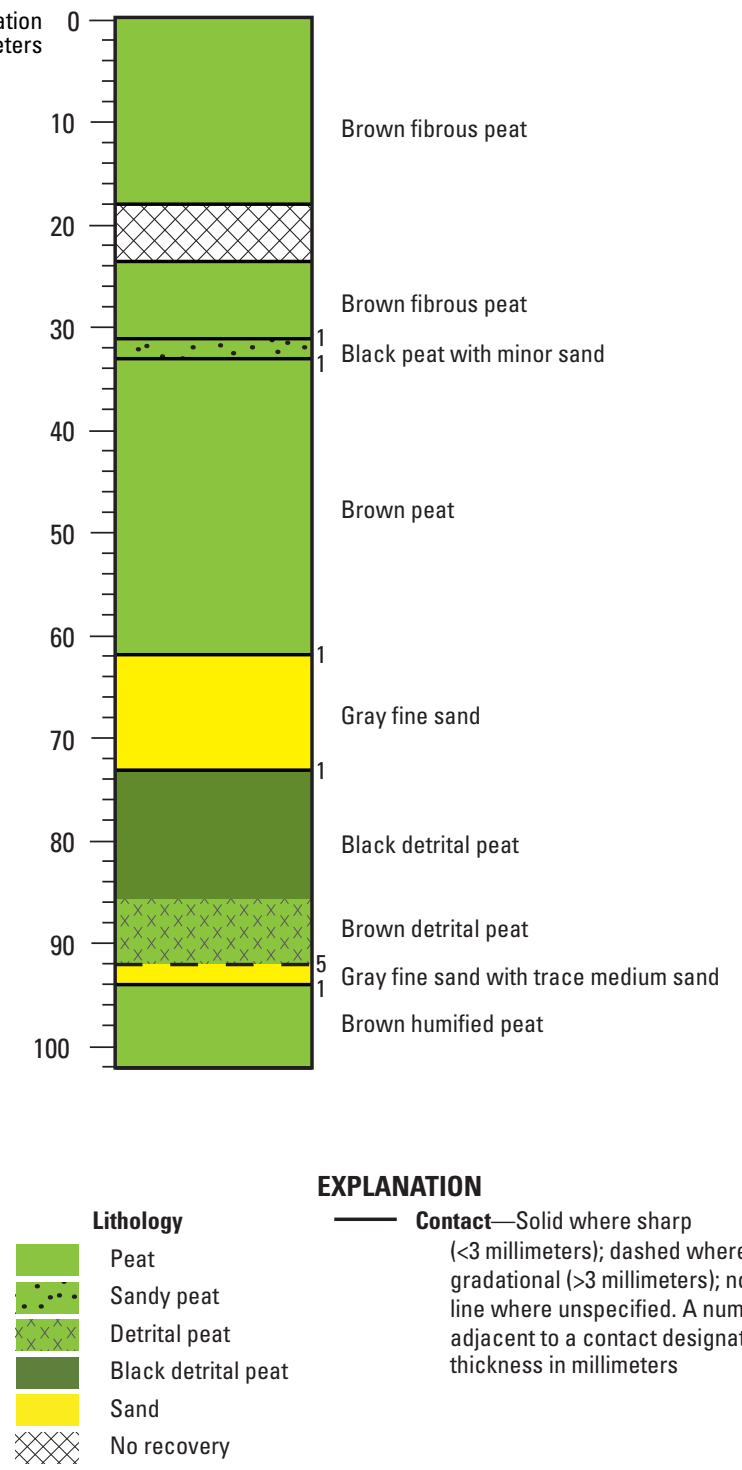

EXPLANATION

— Contact-Solid where sharp ( $<3$ millimeters); dashed where gradational ( $>3$ millimeters); no line where unspecified. A number adjacent to a contact designates thickness in millimeters

Figure 1.2. Lithologic description of cores MM3 and MM4 from Marhoffer Creek marsh. Elevations are relative to the North American Vertical Datum of 1988. 

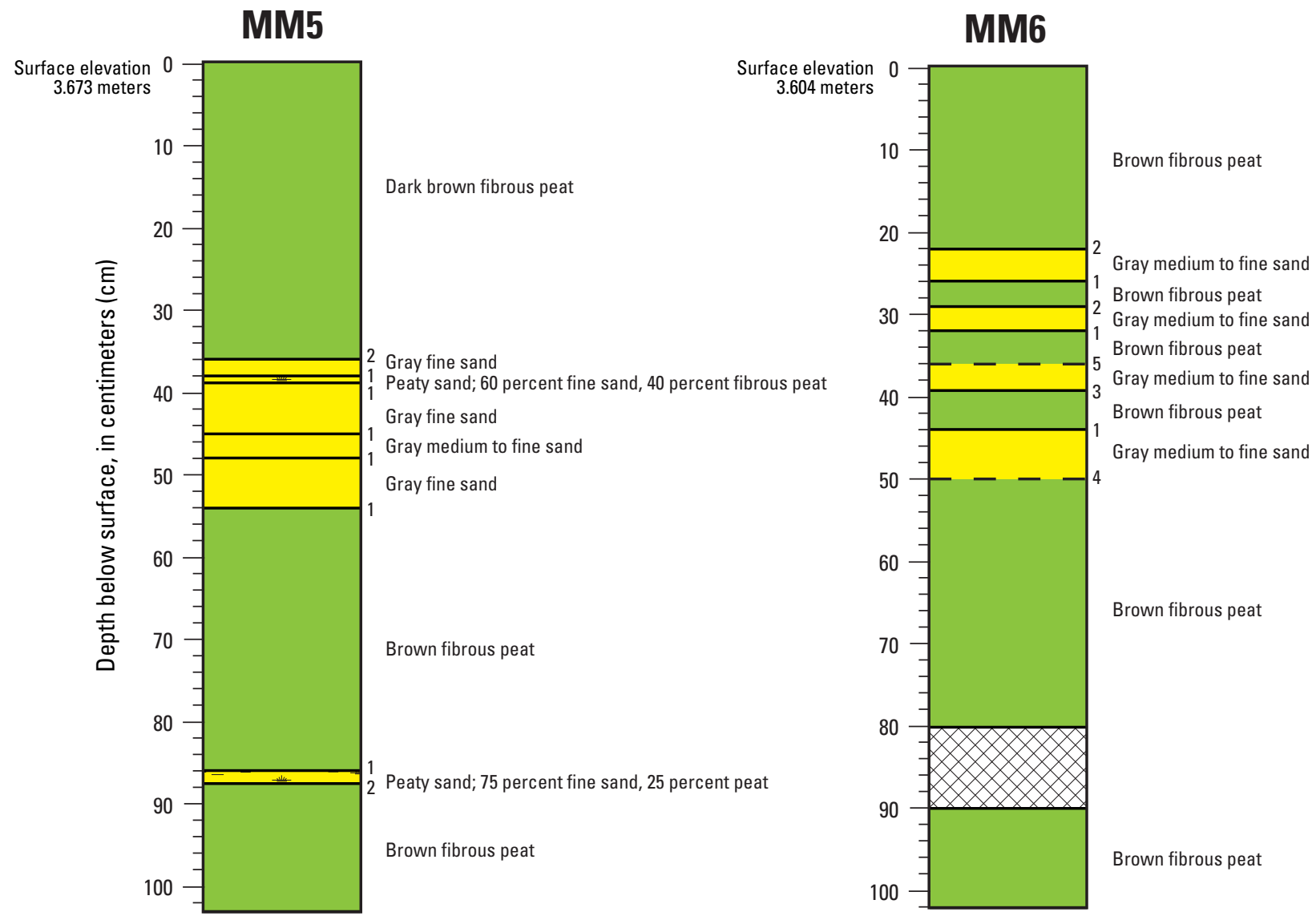

EXPLANATION

\begin{tabular}{|c|c|}
\hline \multicolumn{2}{|c|}{ Lithology } \\
\hline & Peat \\
\hline & Sand \\
\hline & Peaty sand \\
\hline$X X X$ & No recovery \\
\hline
\end{tabular}

Contact-Solid where sharp (<3 millimeters); dashed where gradational ( $>3$ millimeters). A number adjacent to a contact designates thickness in millimeters

Figure 1.3. Lithologic description of cores MM5 and MM6 from Marhoffer Creek marsh. Elevations are relative to the North American Vertical Datum of 1988. 


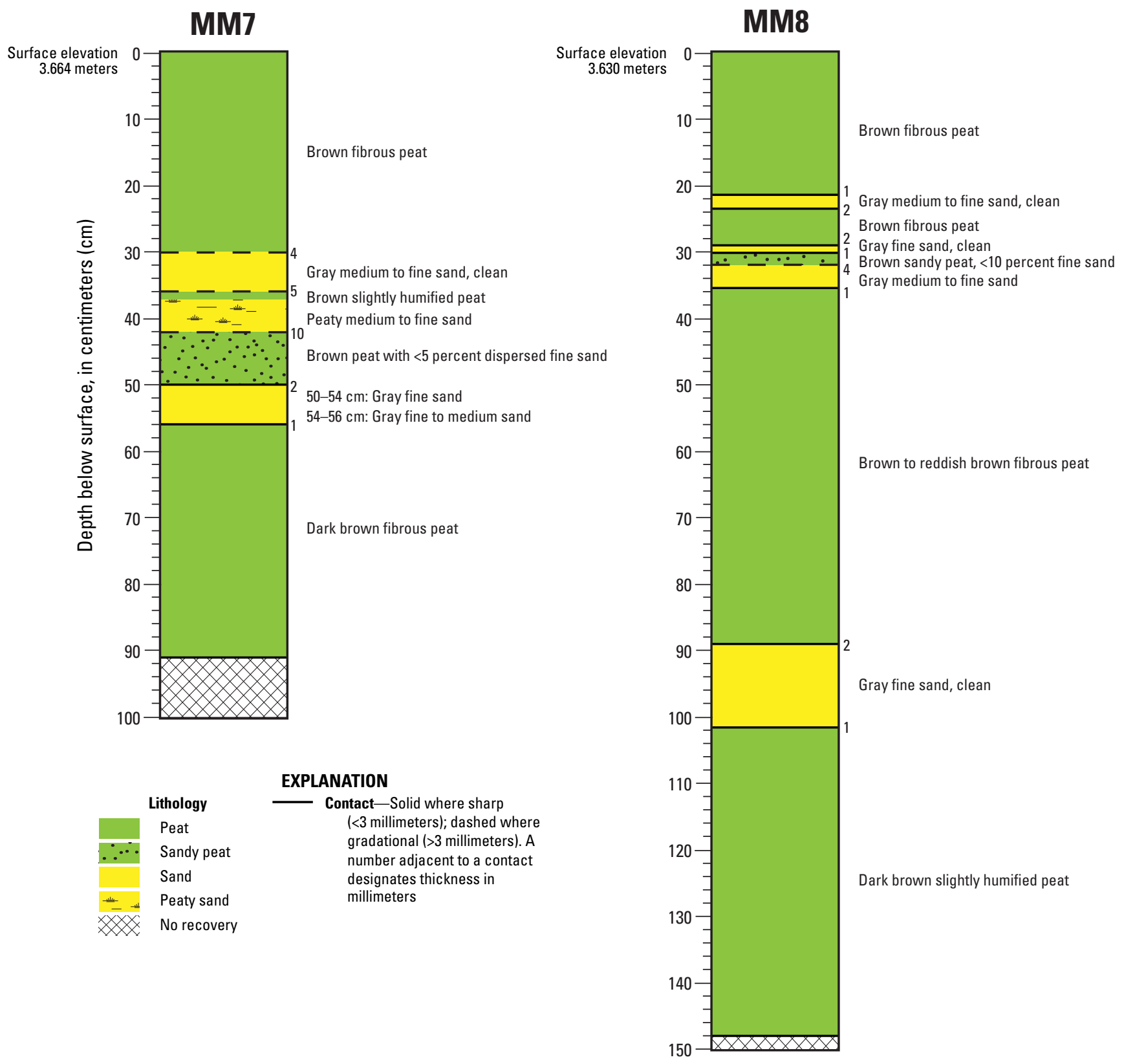

Figure 1.4. Lithologic description of cores MM7 and MM8 from Marhoffer Creek marsh. Elevations are relative to the North American Vertical Datum of 1988. 


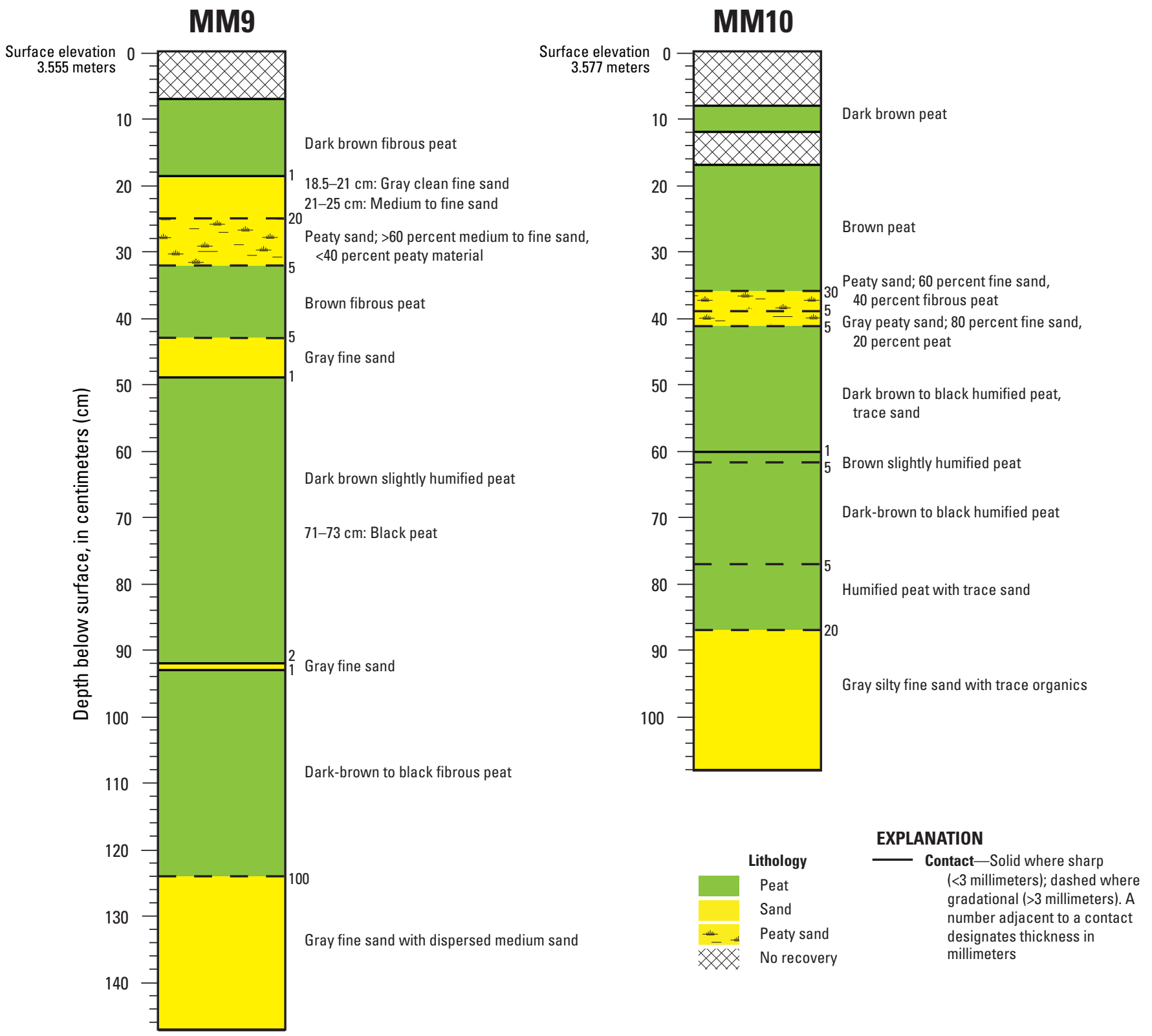

Figure 1.5. Lithologic description of cores MM9 and MM10 from Marhoffer Creek marsh. Elevations are relative to the North American Vertical Datum of 1988. 
MM11

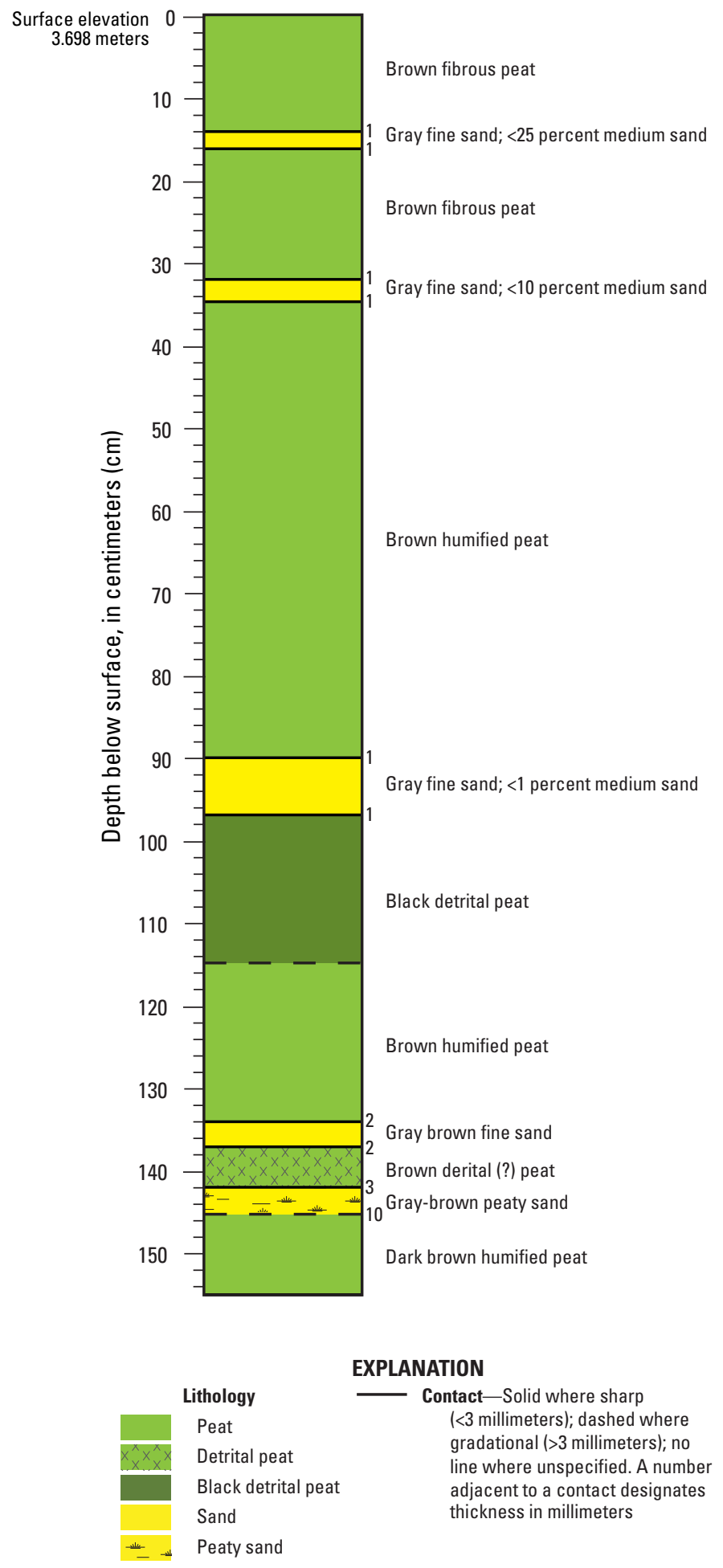

\section{MM12}

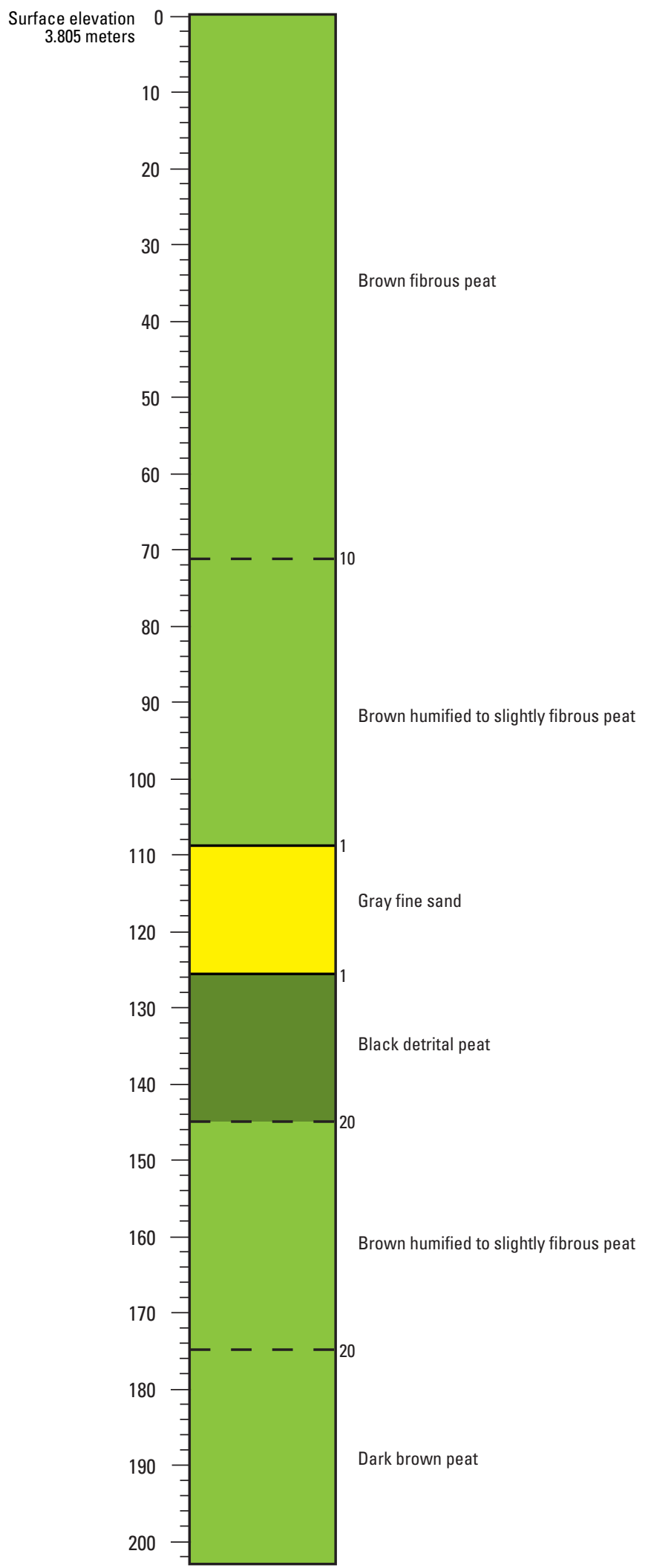

Figure 1.6. Lithologic description of cores MM11 and MM12 from Marhoffer Creek marsh. Elevations are relative to the North American Vertical Datum of 1988. 
MM13

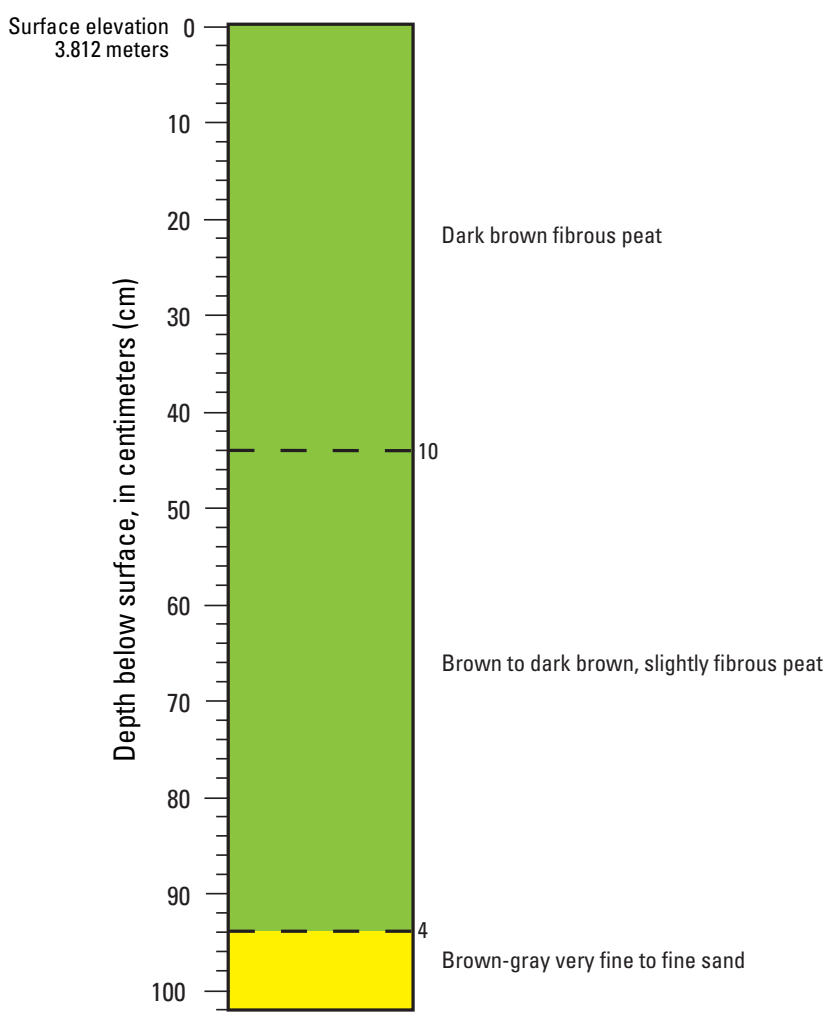

EXPLANATION

\begin{tabular}{cc} 
Lithology & \multicolumn{1}{c}{$\begin{array}{c}\text { Contact-Solid where sharp } \\
\text { Peat }\end{array}$} \\
Sand & gradational $(>3$ millimeters $)$. A \\
number adjacent to a contact & number \\
designates thickness in \\
millimeters
\end{tabular}

MM14

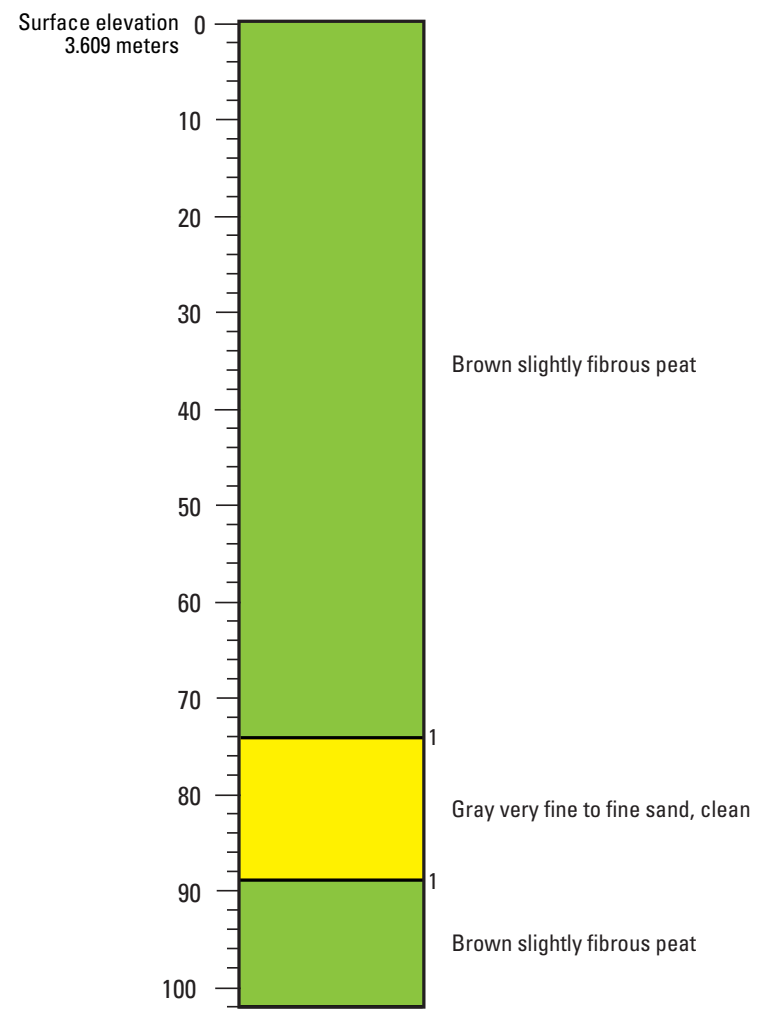

MM15

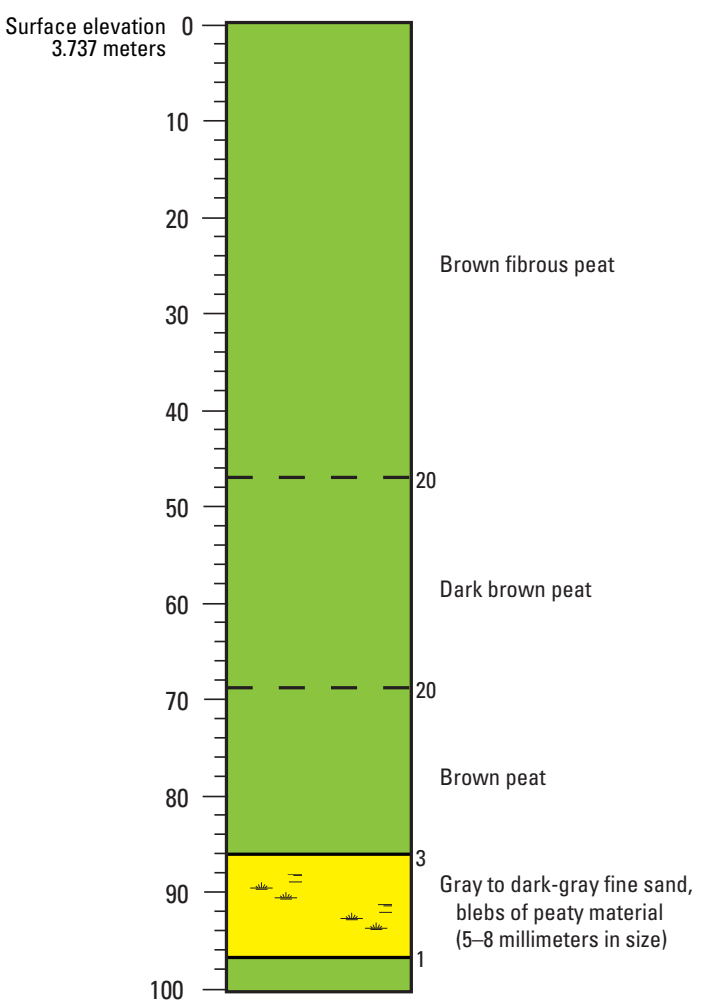

Figure 1.7. Lithologic description of cores MM13, MM14, and MM15 from Marhoffer Creek marsh. Elevations are relative to the North American Vertical Datum of 1988. 
MM16

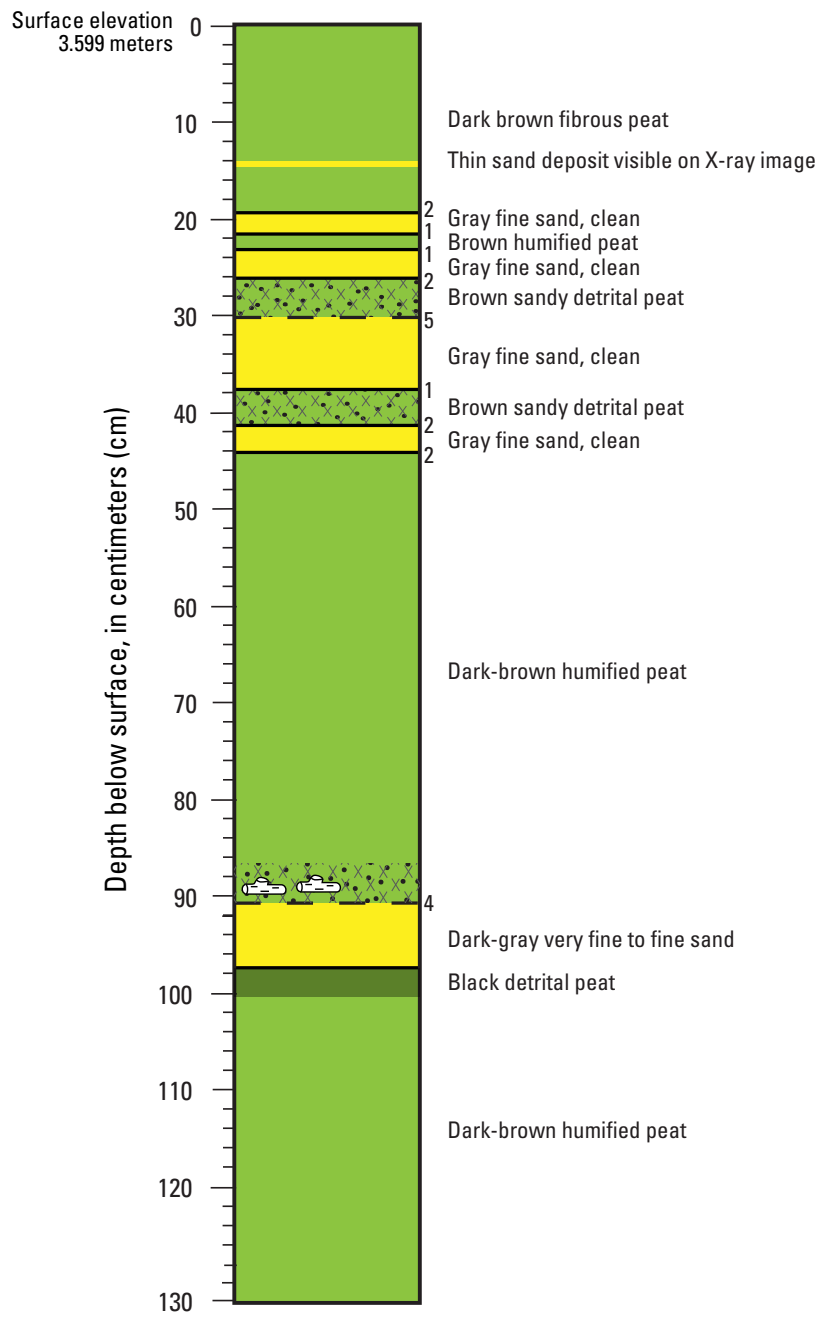

\section{EXPLANATION}

\begin{tabular}{|c|c|c|c|}
\hline & Lithology & & Contact—Solid where sharp \\
\hline & Peat & & (<3 millimeters); dashed where \\
\hline$\therefore$ & Sandy peat & & line where unspecified. A number \\
\hline$-x^{*} \cdot x^{8}$ & Sandy detrital peat & & adjacent to a contact designates \\
\hline & Black detrital peat & & thickness in millimeters \\
\hline & Sand & 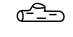 & Wood \\
\hline & Peaty sand & & \\
\hline
\end{tabular}

MM16A

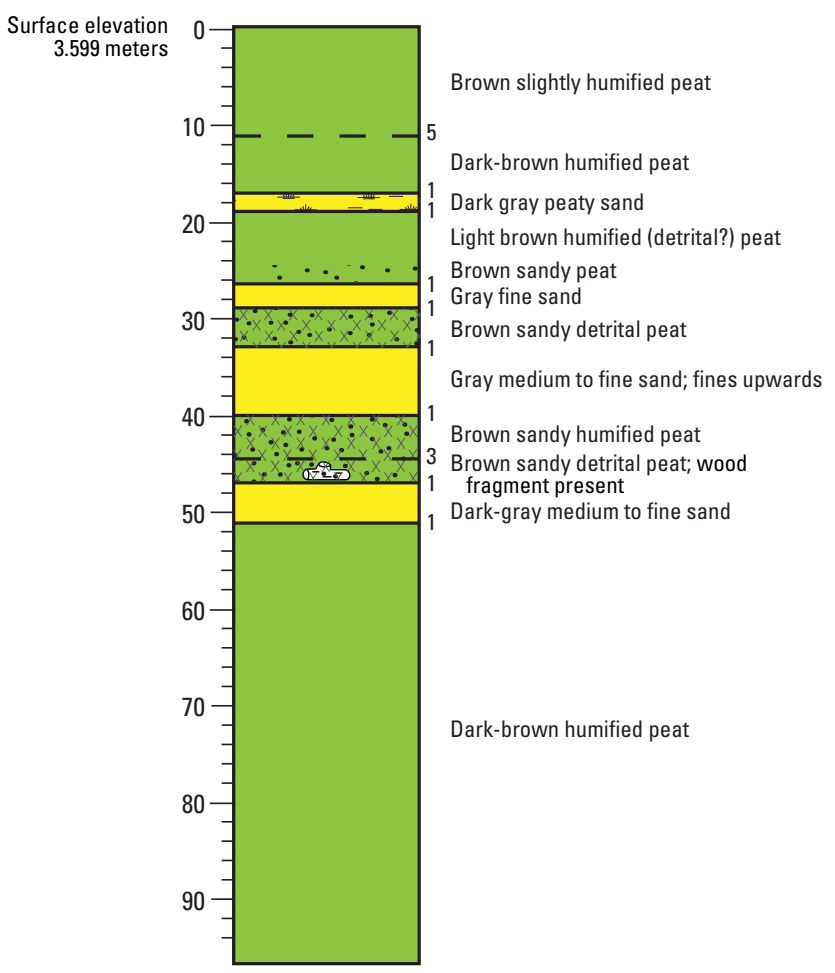

\section{MM16B}

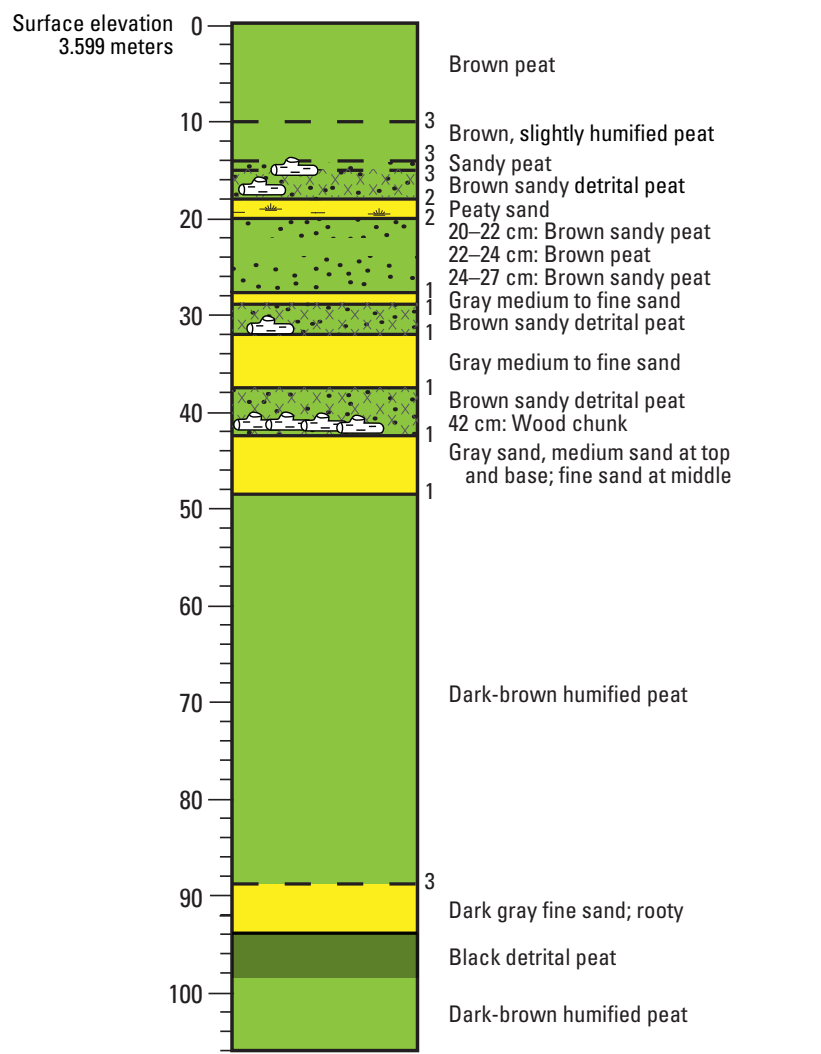

Figure 1.8. Lithologic description of cores MM16, MM16A, and MM16B from Marhoffer Creek marsh. Elevations are relative to the North American Vertical Datum of 1988. 
MM17

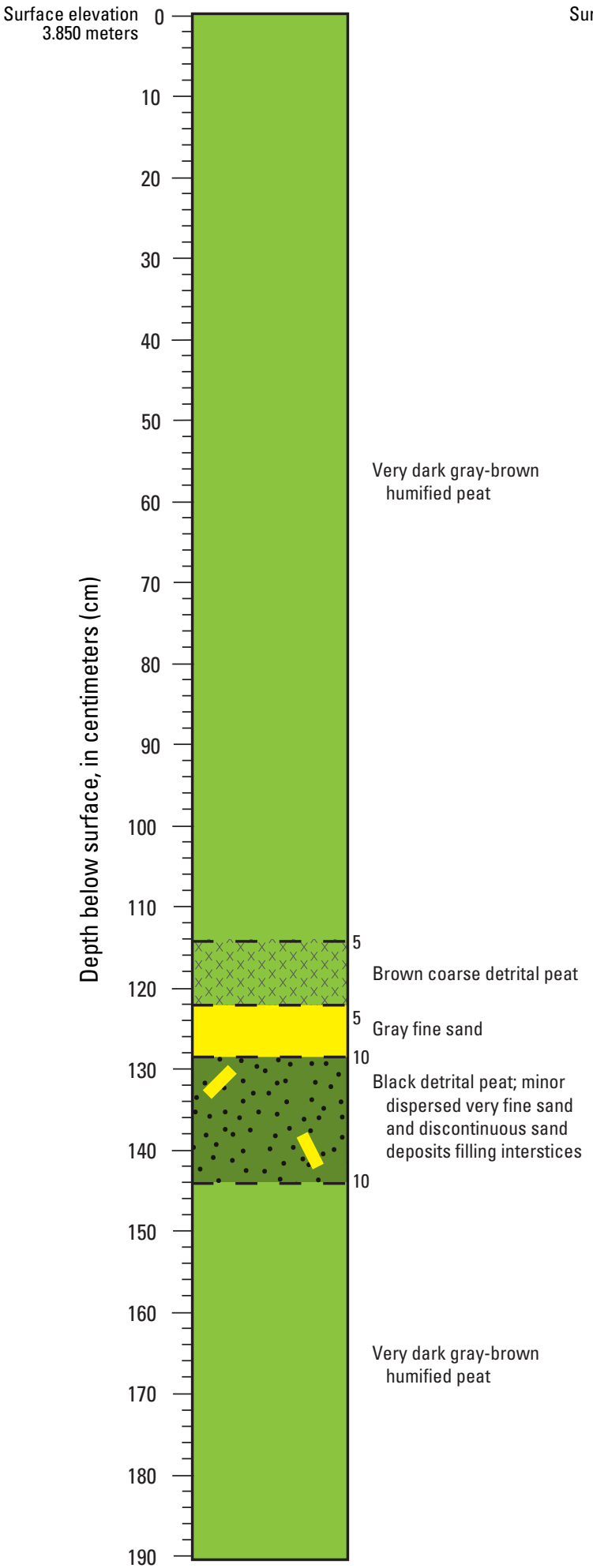

\section{MM18}

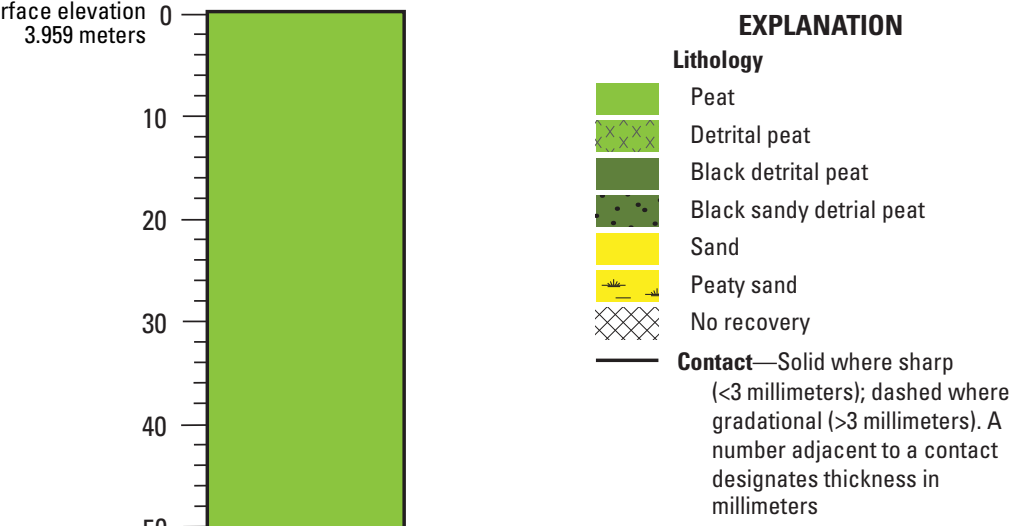

Very dark gray-brown humified peat

Gray fine sand with patches of black organic detritus

120

140

150

Very dark gray-brown humified peat

Figure 1.9. Lithologic description of cores MM17 and MM18 from Marhoffer Creek marsh. Elevations are relative to the North American Vertical Datum of 1988. 


\section{MM19}

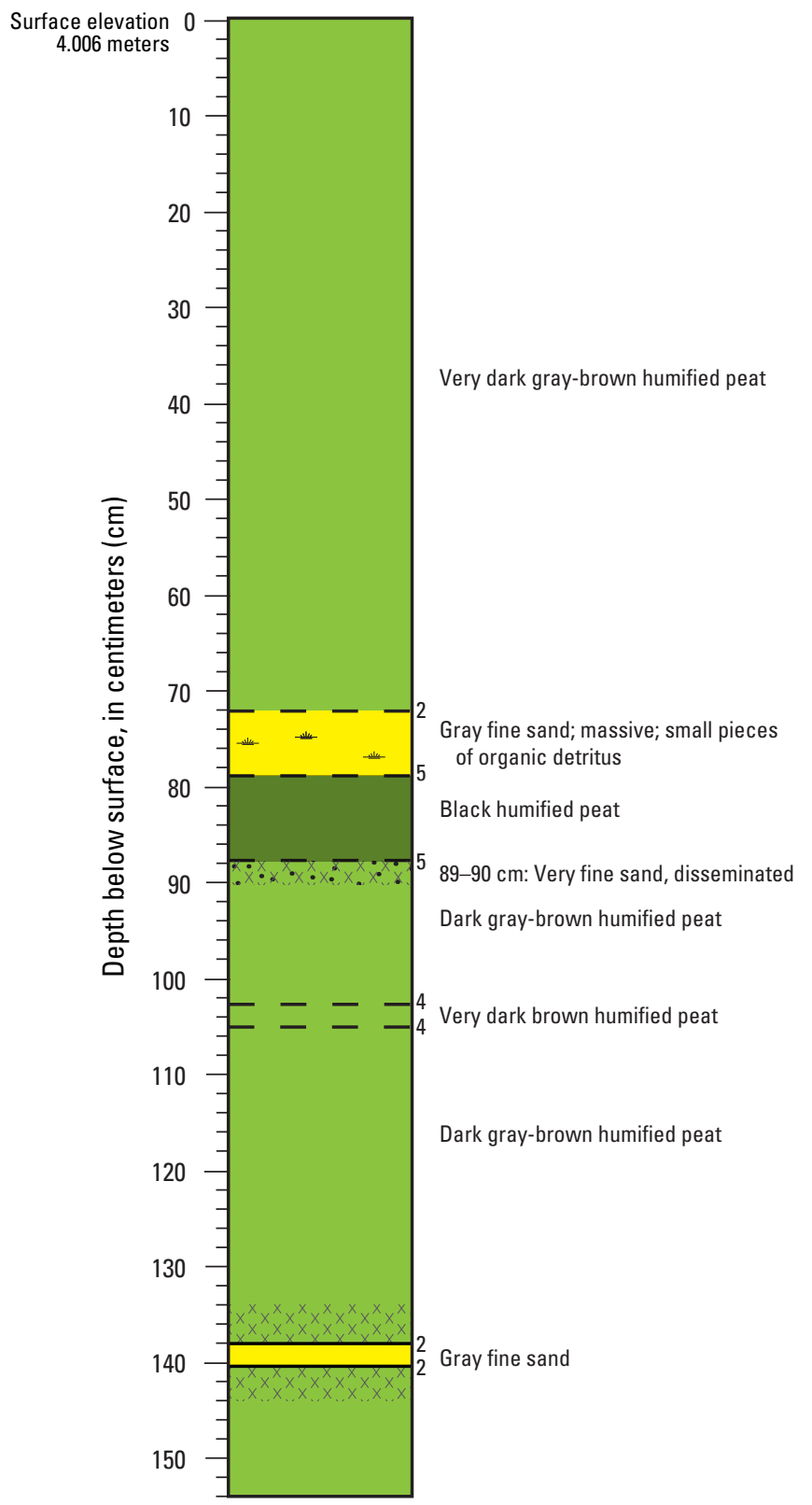

MM20

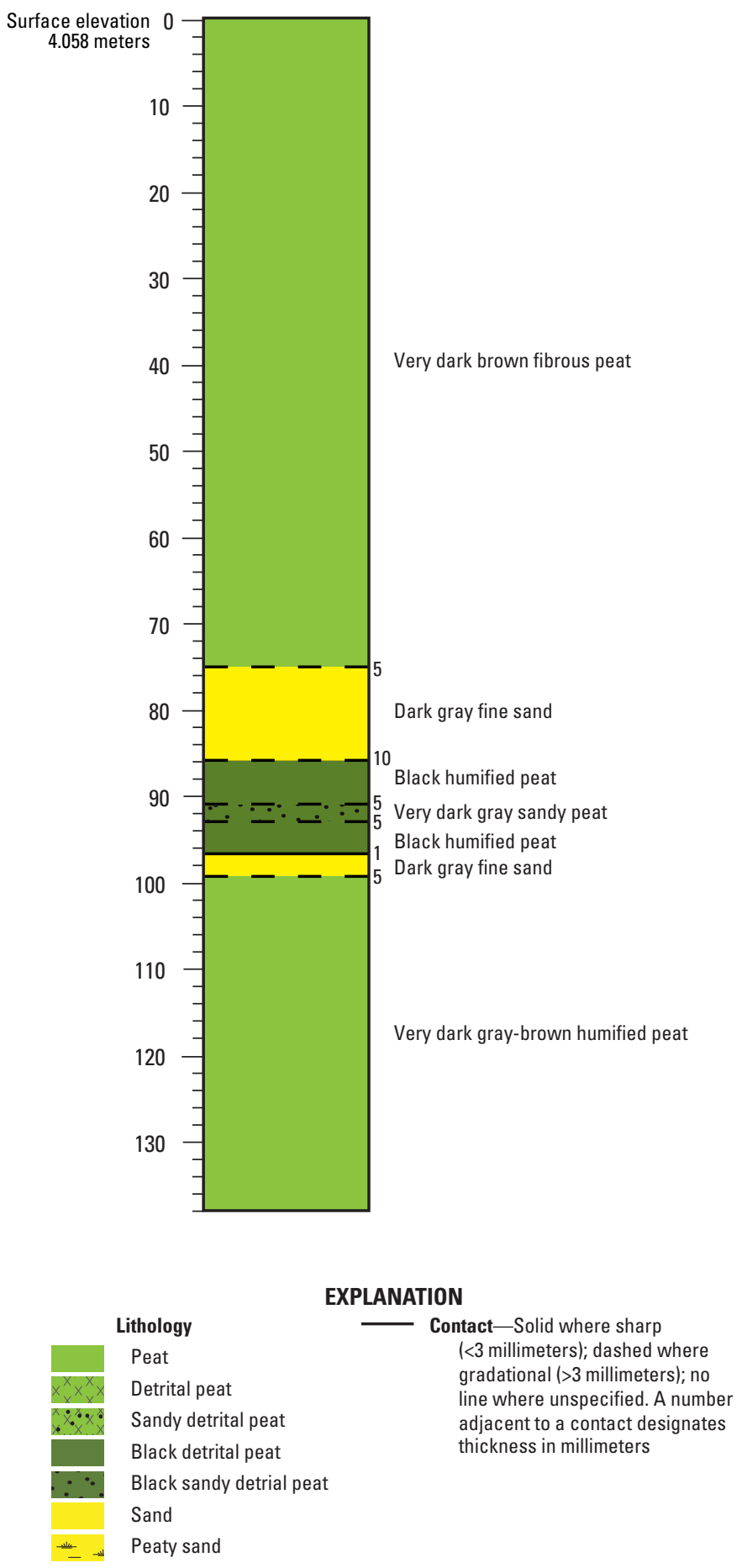

Figure 1.10. Lithologic description of cores MM19 and MM20 from Marhoffer Creek marsh. Elevations are relative to the North American Vertical Datum of 1988. 


\section{Elk Creek Wetland}

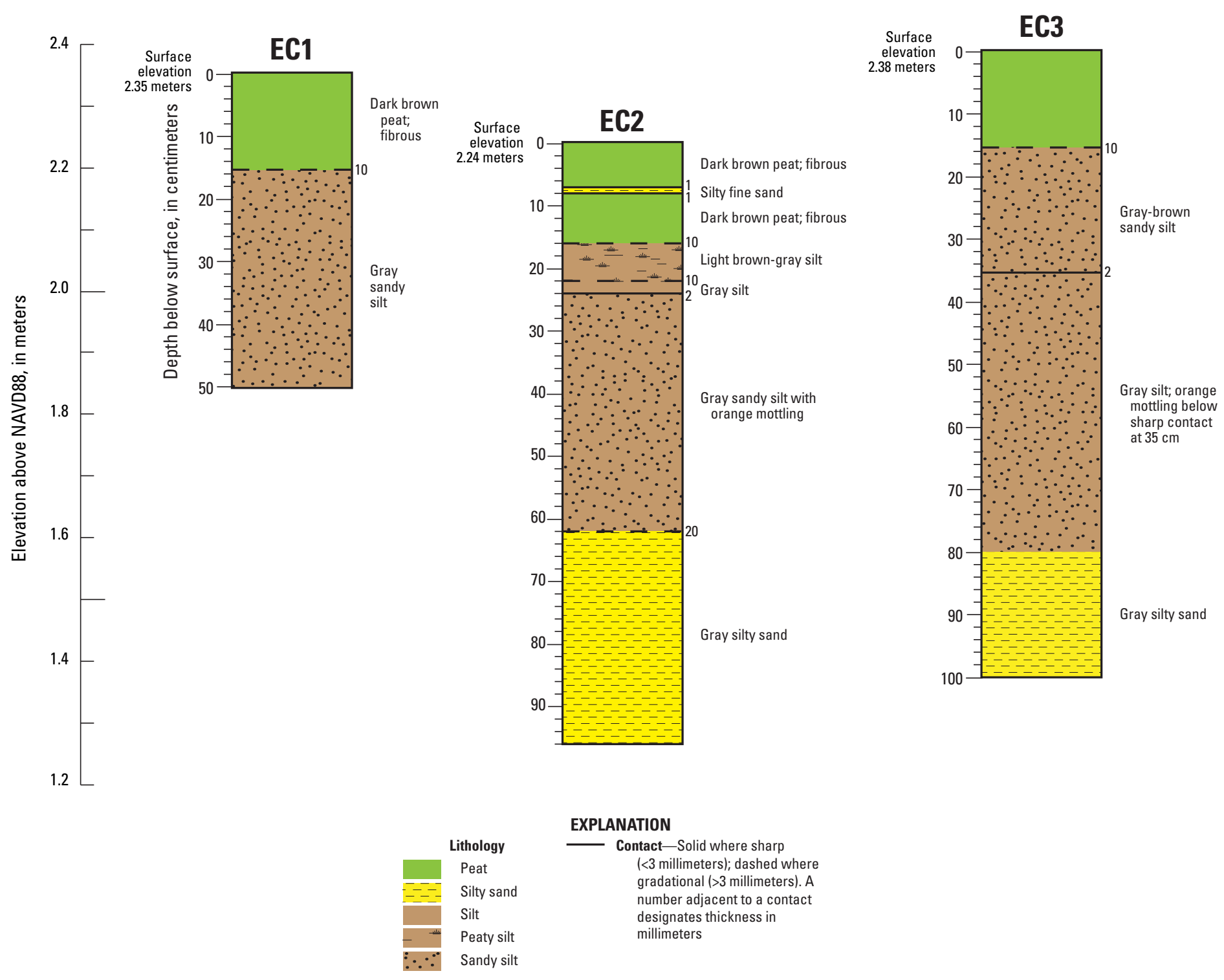

Figure 1.11. Lithologic description of cores EC1, EC2, and EC3 from Elk Creek Wetland. Elevations are relative to the North American Vertical Datum of 1988 (NAVD88). 


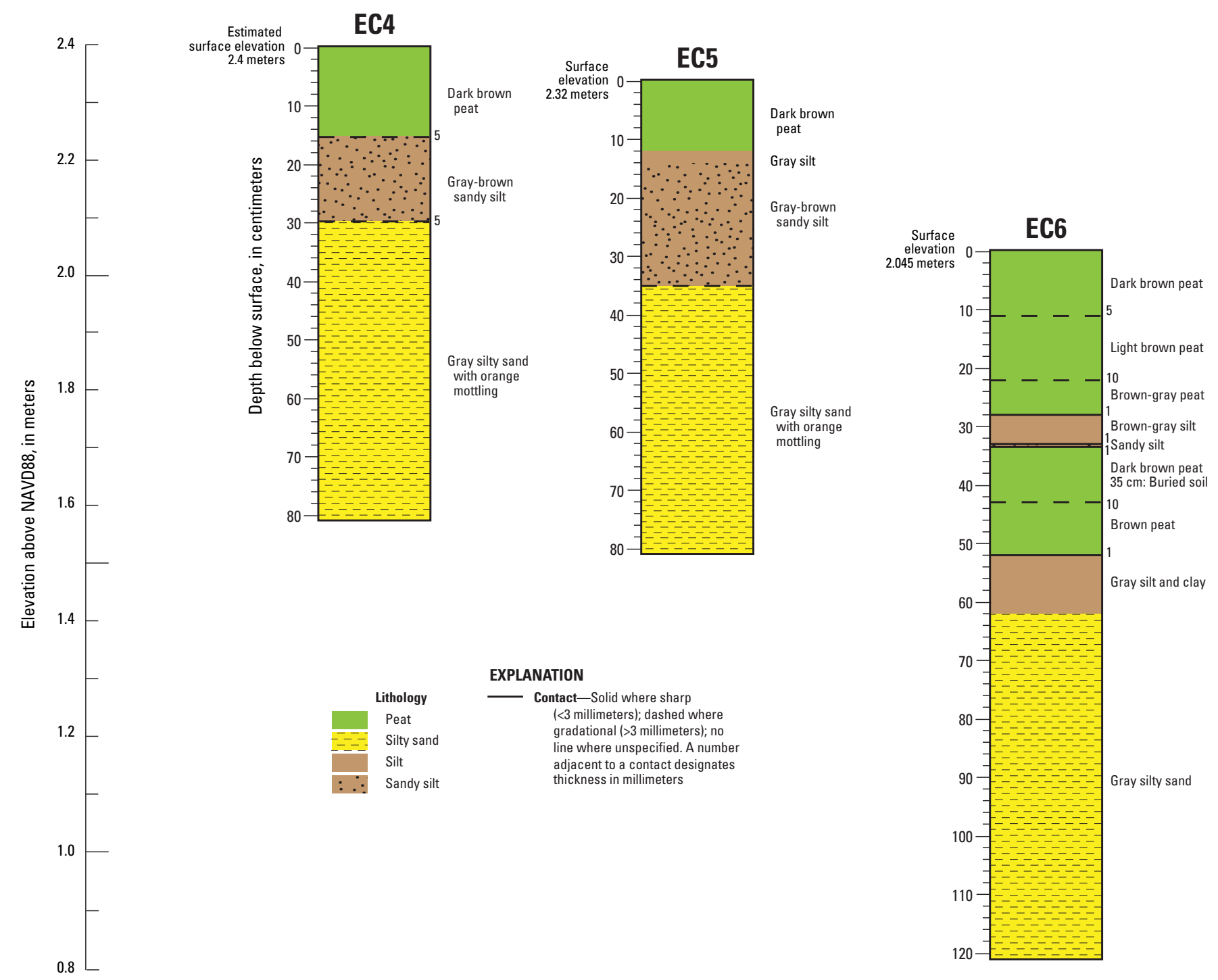

Figure 1.12. Lithologic description of cores EC4, EC5, and EC6 from Elk Creek Wetland. Elevations are relative to the North American Vertical Datum of 1988 (NAVD88). 


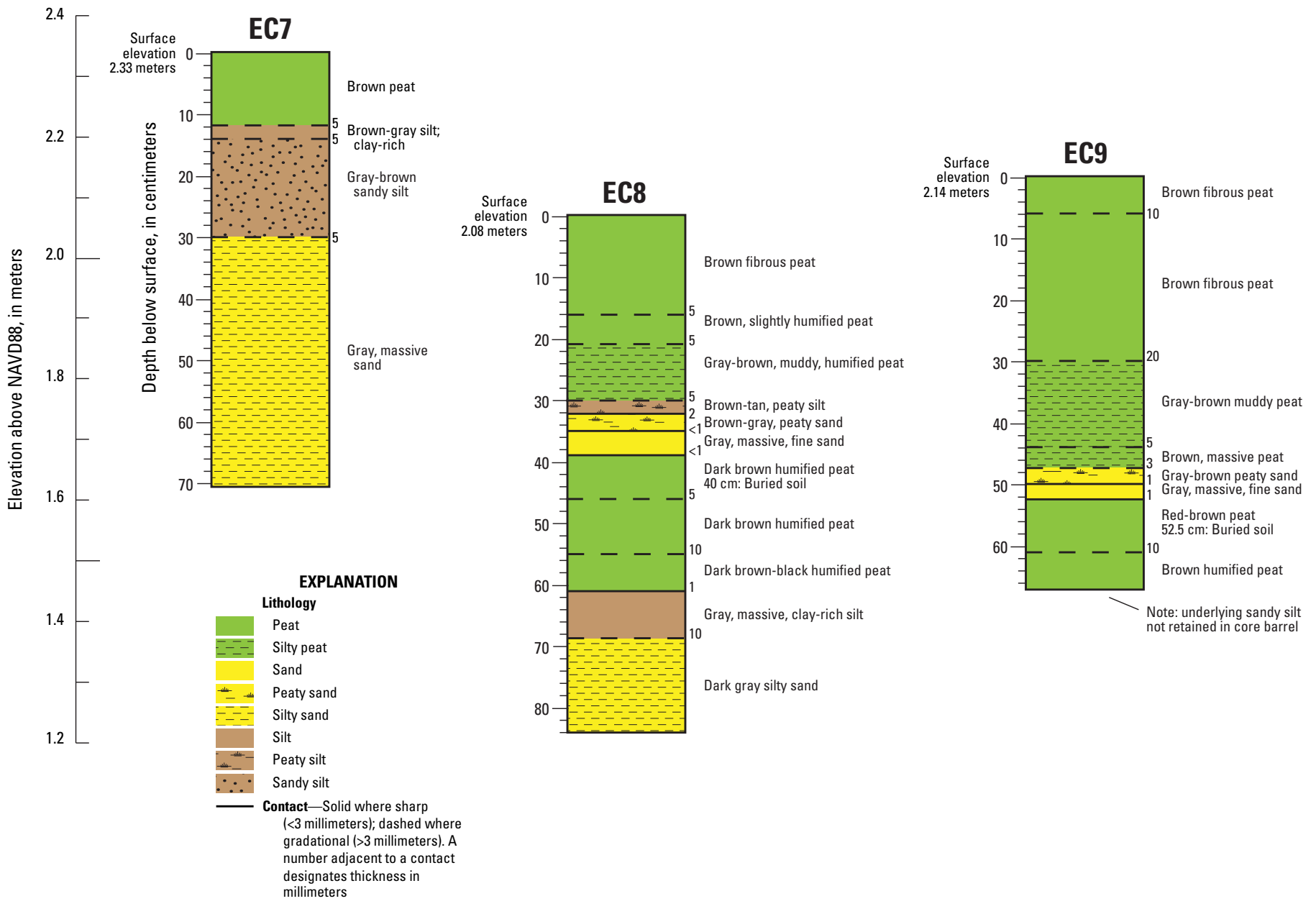

Figure 1.13. Lithologic description of cores EC7, EC8, and EC9 from Elk Creek Wetland. Elevations are relative to the North American Vertical Datum of 1988 (NAVD88). 


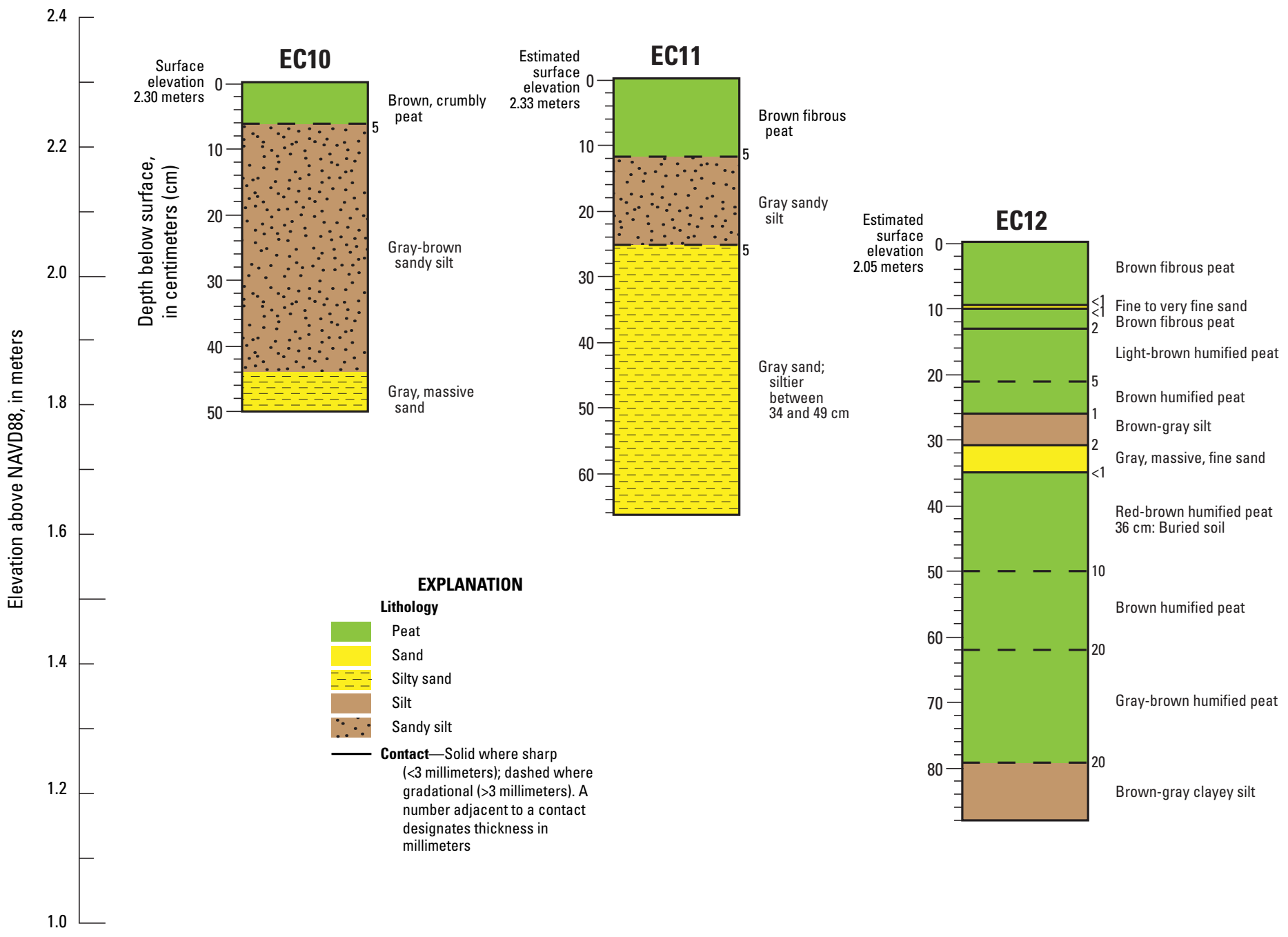

Figure 1.14. Lithologic description of cores EC10, EC11, and EC12 from Elk Creek Wetland. Elevations are relative to the North American Vertical Datum of 1988 (NAVD88). 


\section{Sand Mine Marsh}

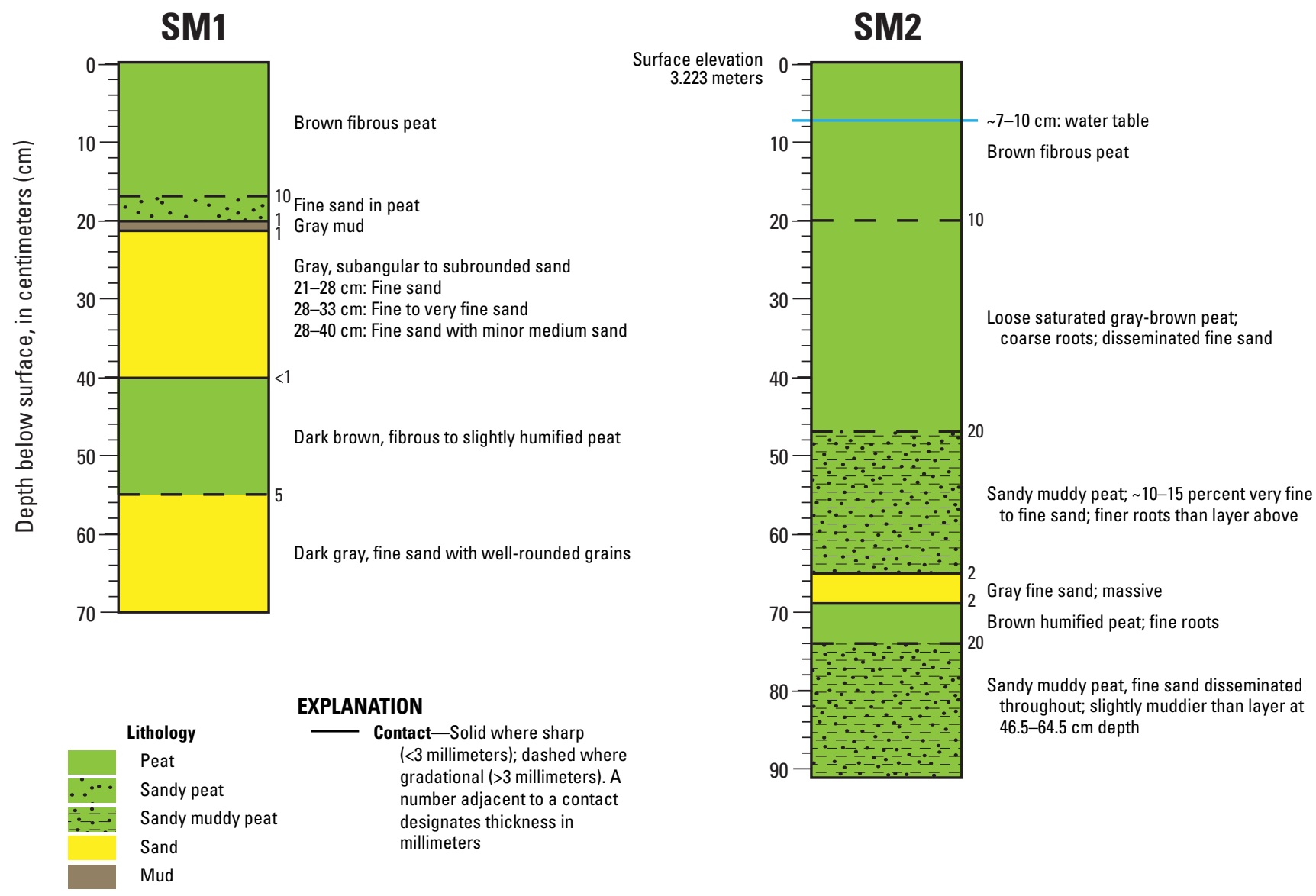

Figure 1.15. Lithologic description of cores SM1 and SM2 from Sand Mine marsh. For core SM2, the top 20 centimeters (cm) are described from the core pit and $20-91 \mathrm{~cm}$ depth are described from the $60-\mathrm{cm}$ core barrel. Elevations are relative to the North American Vertical Datum of 1988. 


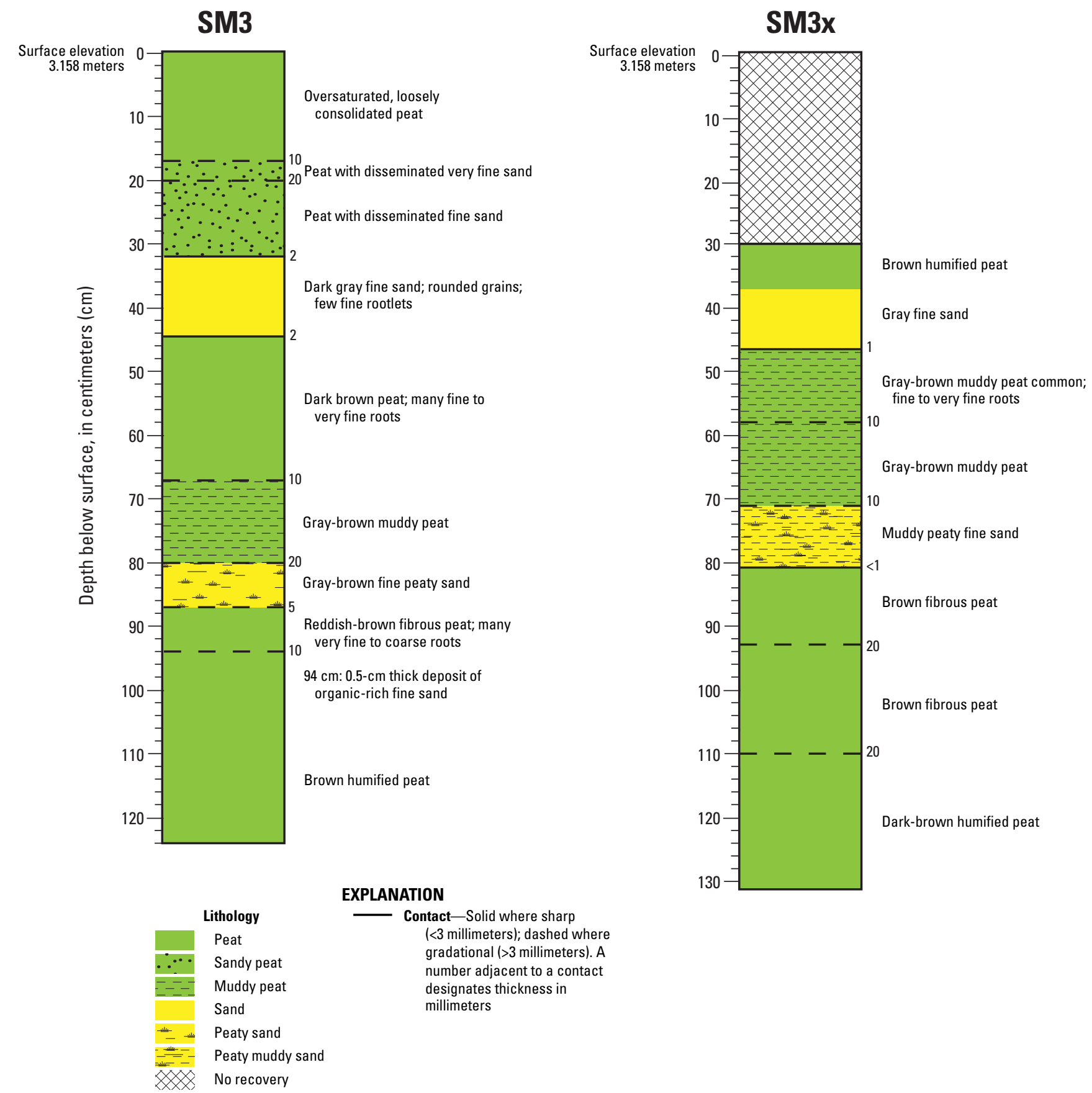

Figure 1.16. Lithologic description of cores SM3 and SM3x from Sand Mine marsh. Elevations are relative to the North American Vertical Datum of 1988. 

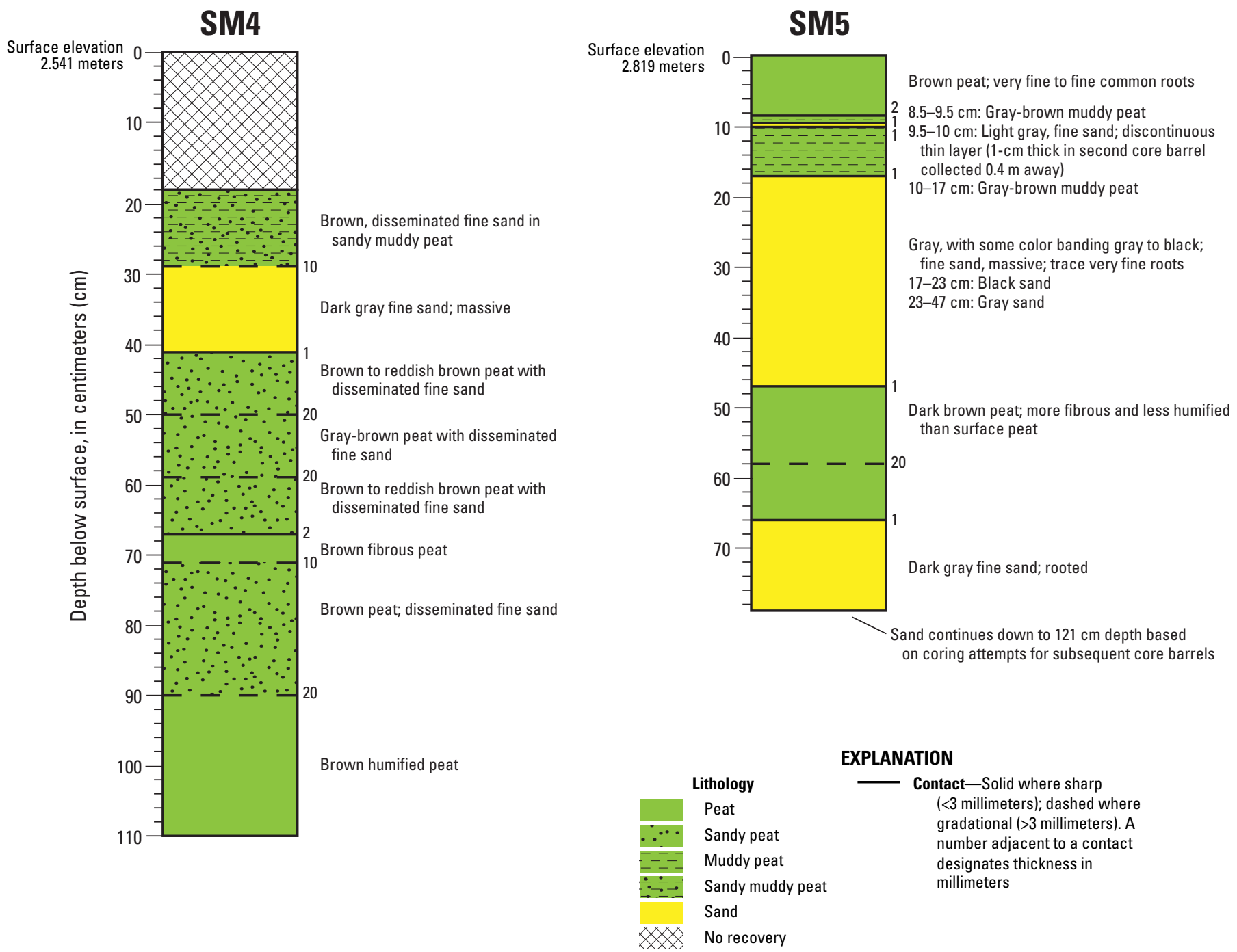

Figure 1.17. Lithologic description of cores SM4 and SM5 from Sand Mine marsh. Elevations are relative to the North American Vertical Datum of 1988. 


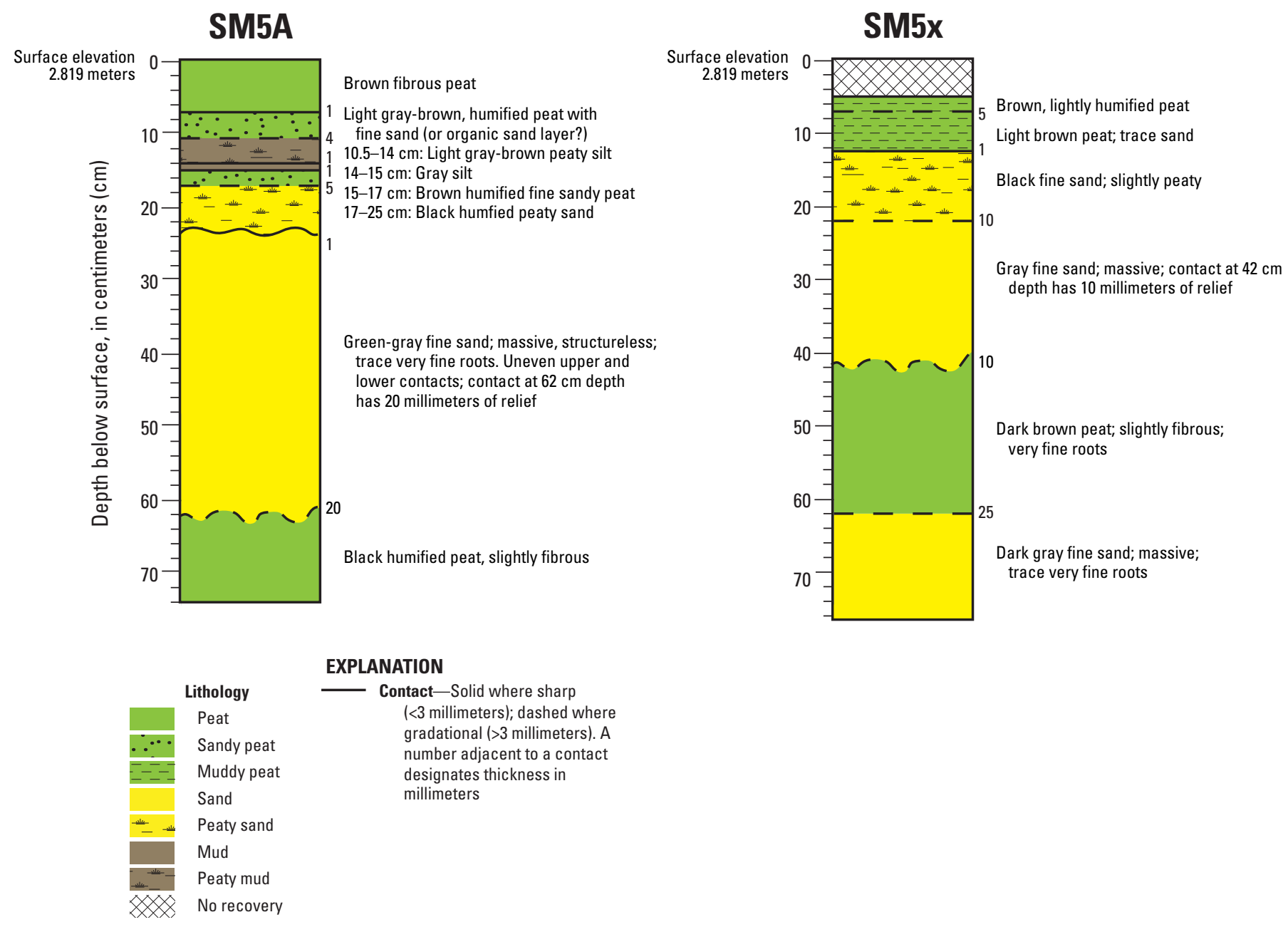

Figure 1.18. Lithologic description of cores SM5A and SM5x from Sand Mine marsh. Elevations are relative to the North American Vertical Datum of 1988. 
SM6

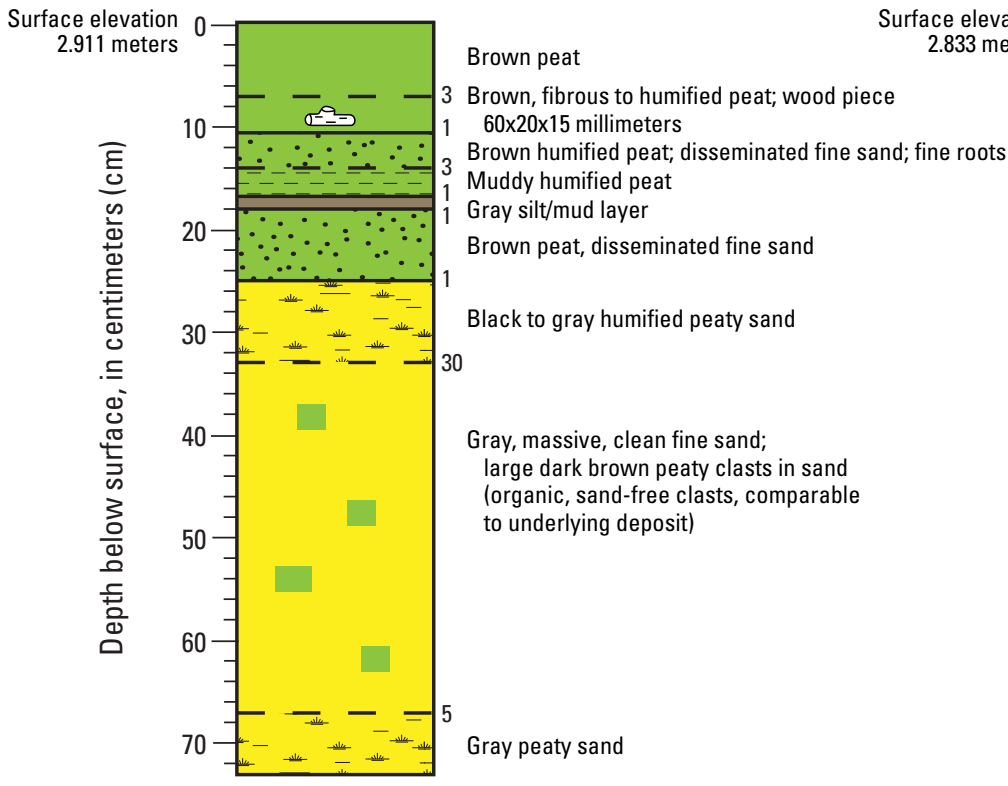

\section{SM7}

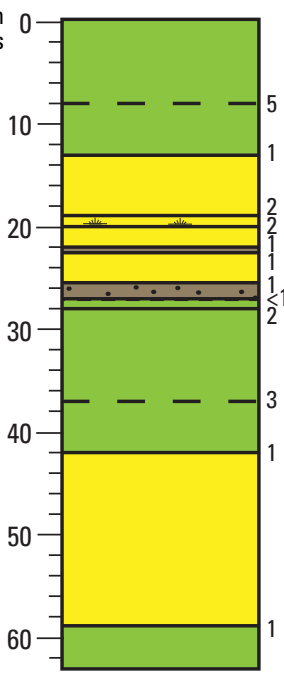

Brown peat; very fine to fine roots

Light-brown humified peat; fine roots

Gray fine sand; few roots

19-20 cm: Common very fine roots

20-22 cm: Gray, massive, few roots

22-22.5 cm: Light brown-gray, discontinuous

$<1$ mud layer (mud with fine sand)

$22.5-25.5 \mathrm{~cm}$ : Gray fine sand; few very fine roots

25.5-27 cm: Gray fine sandy mud

$27-28 \mathrm{~cm}$ : Brown muddy peat

28-37 cm: Brown, humified; common roots

$37-42 \mathrm{~cm}$ : Fibrous to humified; rooty

Gray fine sand; massive; fibrous roots

throughout

42-49 cm: Gray to light gray

49-59 cm: Dark gray

Dark brown, slightly fibrous peat

\section{EXPLANATION}

Lithology

Peat

Sandy peat

Muddy peat

Sand

Peaty sand

Mud

Sandy mud
- Contact-Solid where sharp

(<3 millimeters); dashed where gradational (>3 millimeters); no

line where unspecified. A number

adjacent to a contact designates thickness in millimeters
Wood

Figure 1.19. Lithologic description of cores SM6 and SM7 from Sand Mine marsh. Elevations are relative to the North American Vertical Datum of 1988. 
SM8

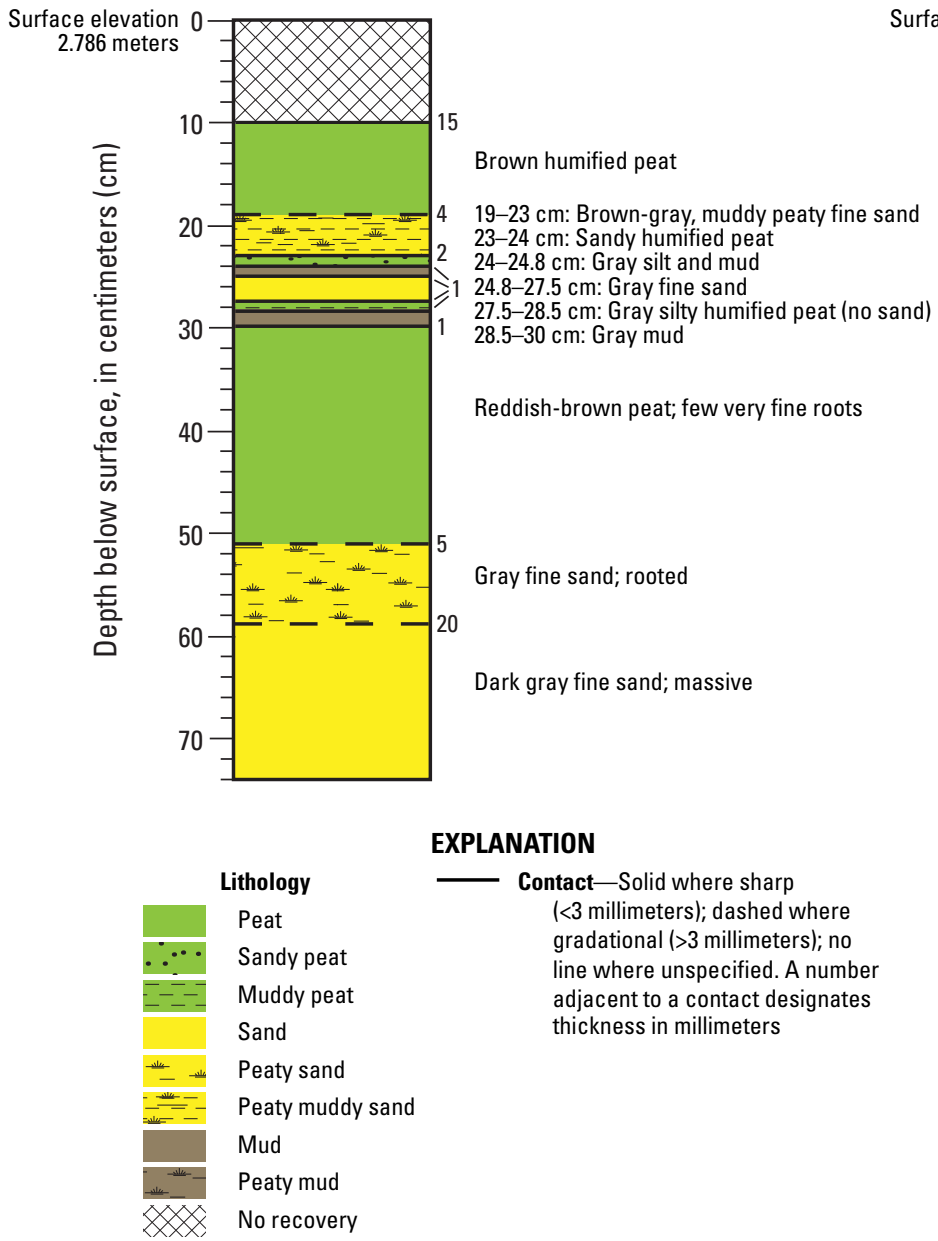

SM9

ace elevation 2.770 meters

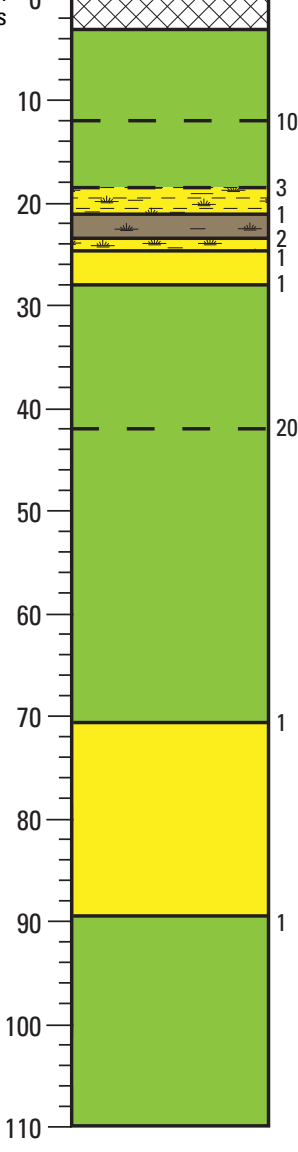

Brown peat

Brown to gray-brown peat

$18.5-21 \mathrm{~cm}$ : Gray, muddy peaty fine sand

$21-23.5 \mathrm{~cm}$ : Gray peaty mud

$23.5-24.5 \mathrm{~cm}$ : Brown-gray, peaty fine sand

$24.5-28 \mathrm{~cm}$ : Gray fine sand; massive

Brown, slightly fibrous peat

Brown peat; more humified than the layer at $28-42 \mathrm{~cm}$ depth

Dark gray fine sand; rooted

Brown humified peat

Figure 1.20. Lithologic description of cores SM8 and SM9 from Sand Mine marsh. Elevations are relative to the North American Vertical Datum of 1988. 
SM9x

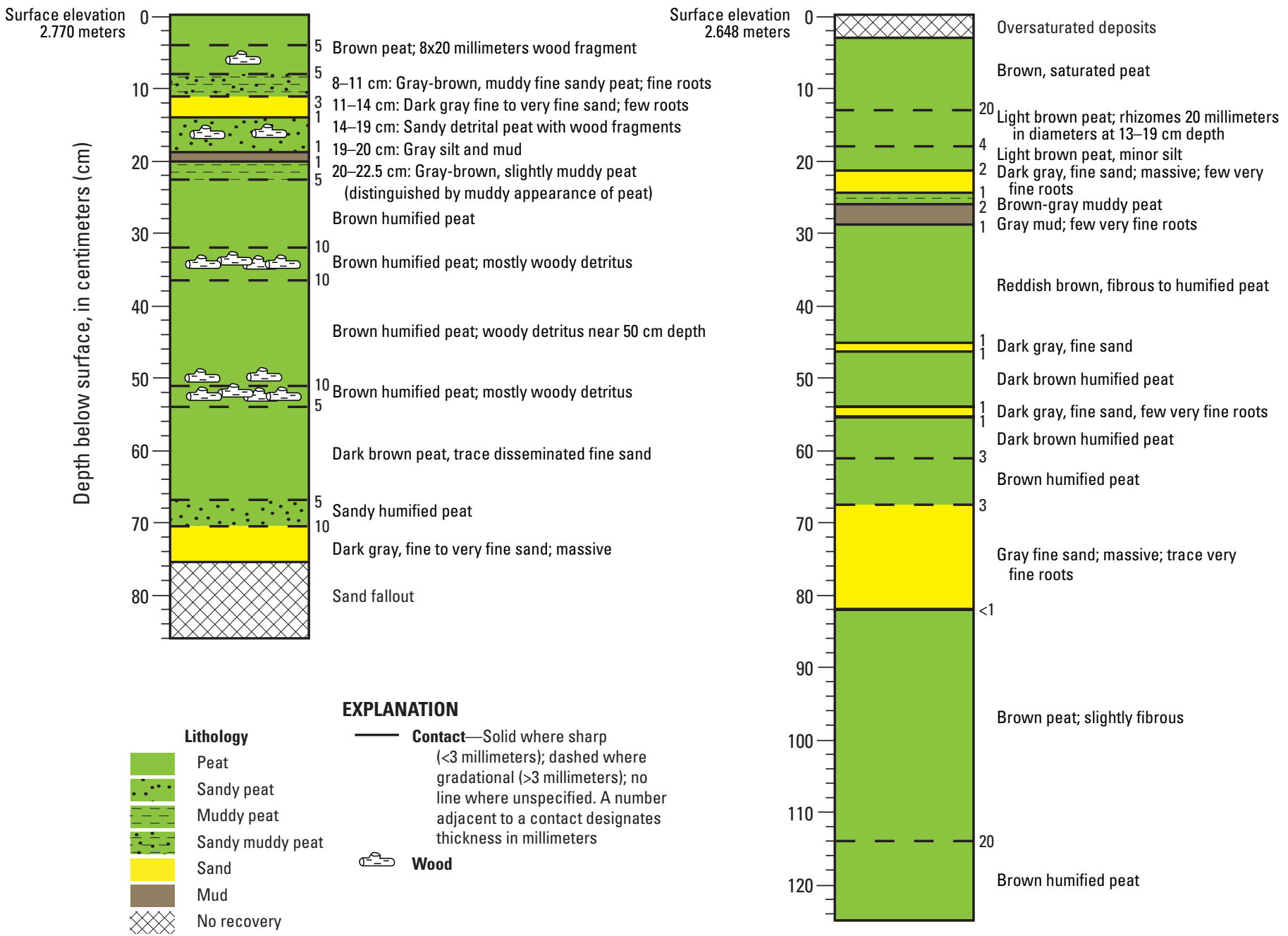

Figure 1.21. Lithologic description of cores SM9x and SM10 from Sand Mine marsh. Elevations are relative to the North American Vertical Datum of 1988. 


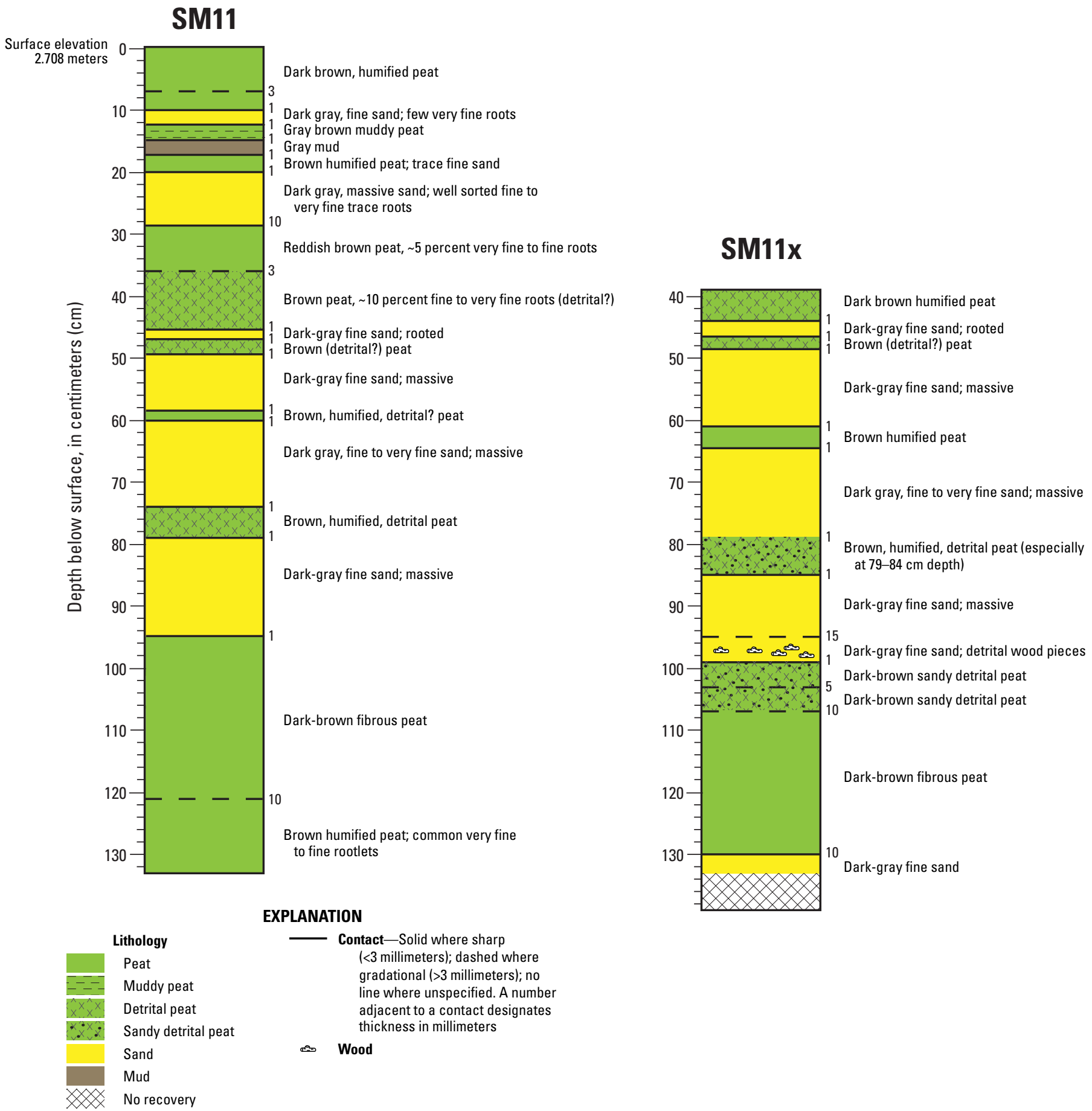

Figure 1.22. Lithologic description of cores SM11 and SM11x from Sand Mine marsh. The top of core SM11x (a replicate core collected for ${ }^{14} \mathrm{C}$ dating and diatom analyses) occurs at $39 \mathrm{~cm}$ depth. Elevations are relative to the North American Vertical Datum of 1988. 


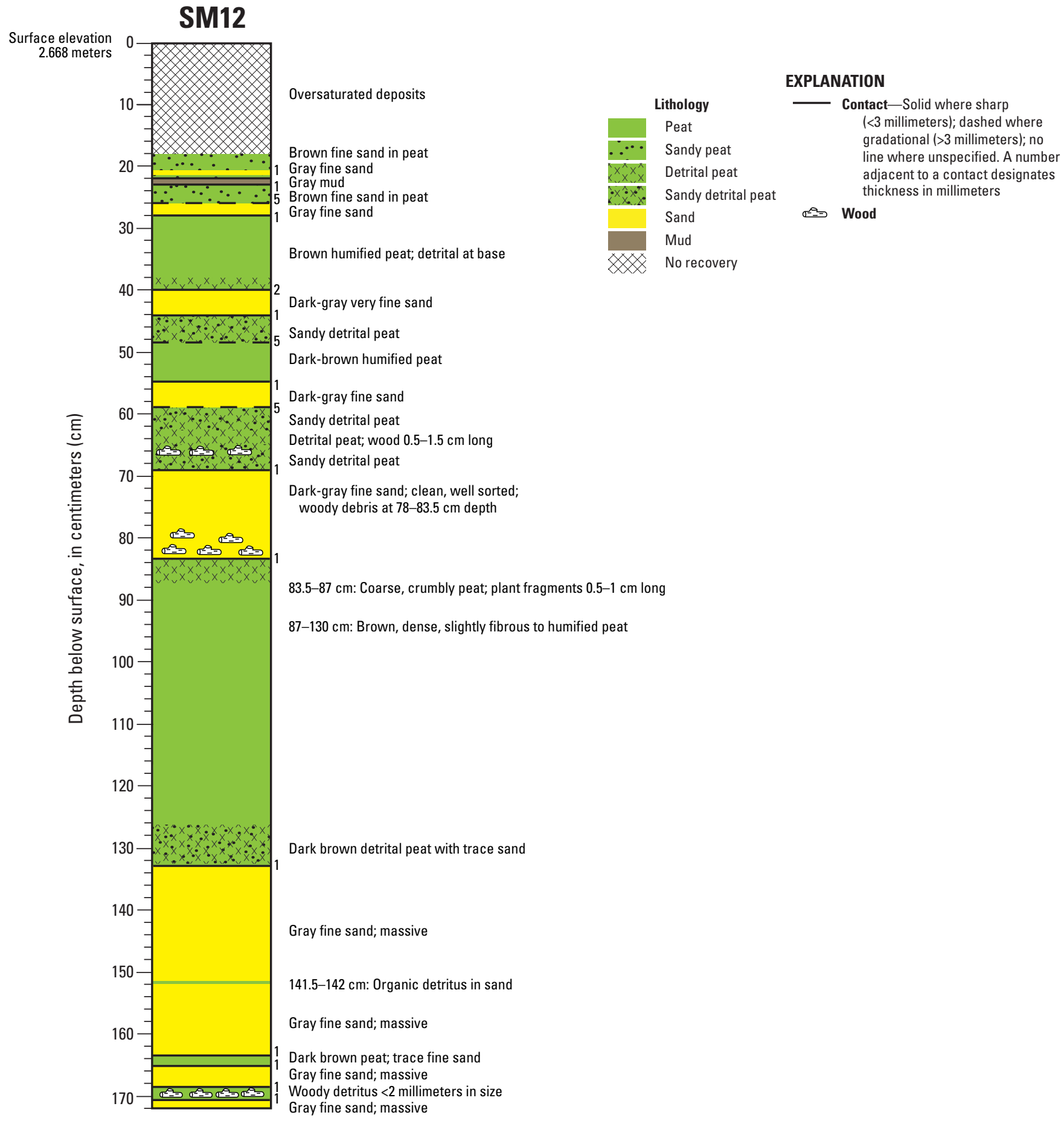

Figure 1.23. Lithologic description of core SM12 from Sand Mine marsh. Elevations are relative to the North American Vertical Datum of 1988. 


\section{O'rekw Marsh}

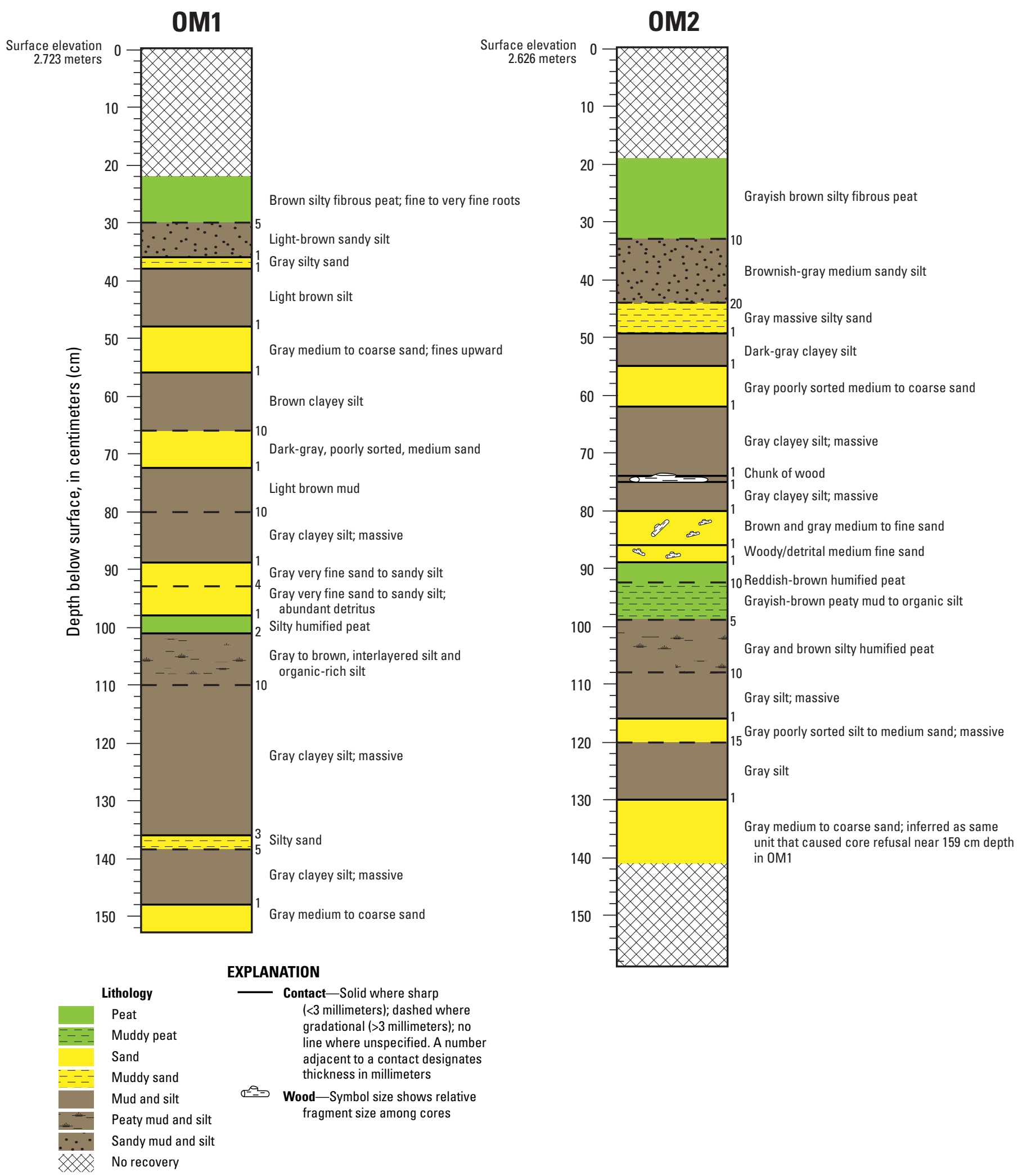

Figure 1.24. Lithologic description of cores $0 \mathrm{M} 1$ and $\mathrm{OM} 2$ from 0 'rekw marsh. Elevations are relative to the North American Vertical Datum of 1988. 


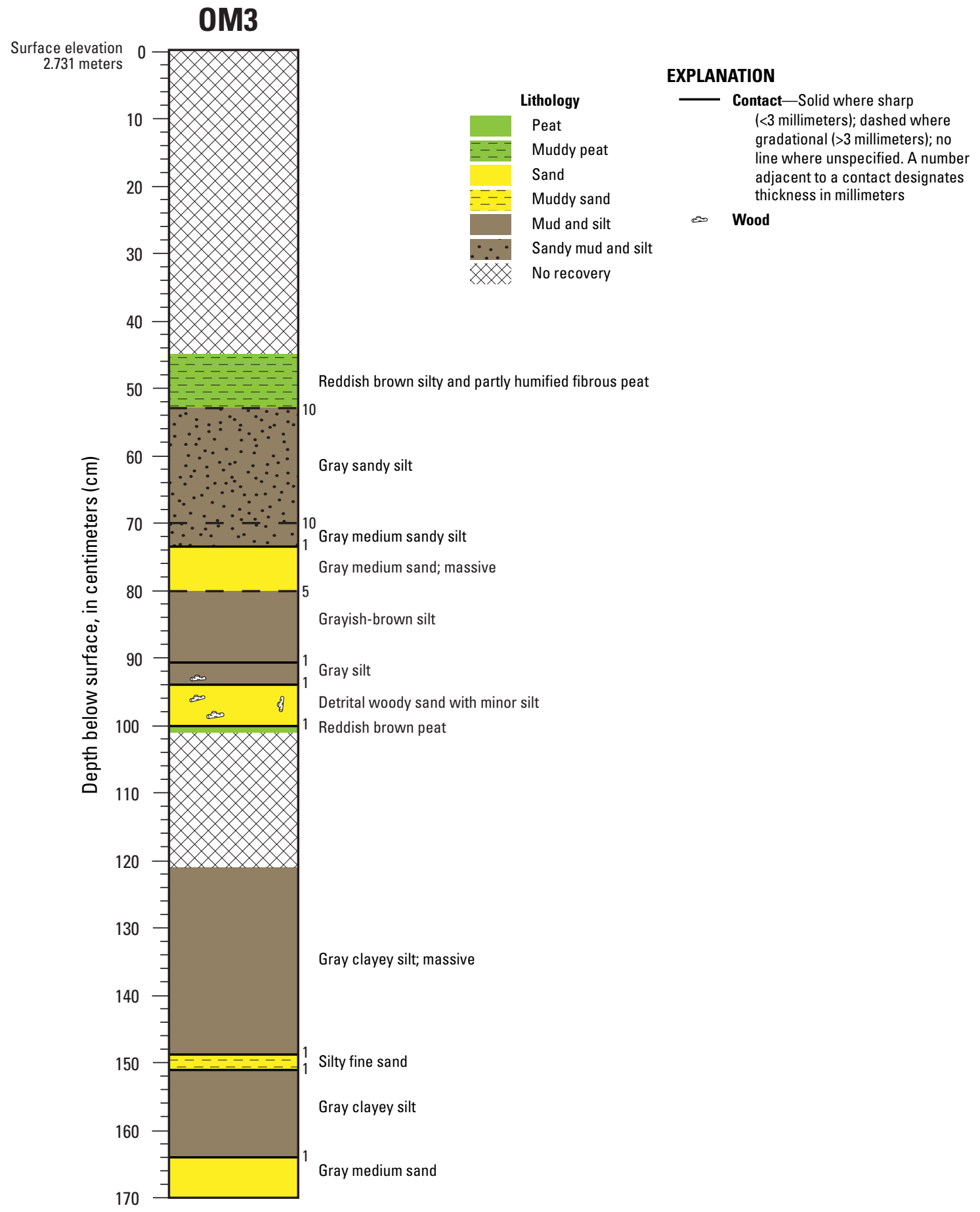

Figure 1.25. Lithologic description of cores $0 \mathrm{M} 3$ from O'rekw marsh. Elevations are relative to the North American Vertical Datum of 1988. 


\section{Pillar Point Marsh}

A1

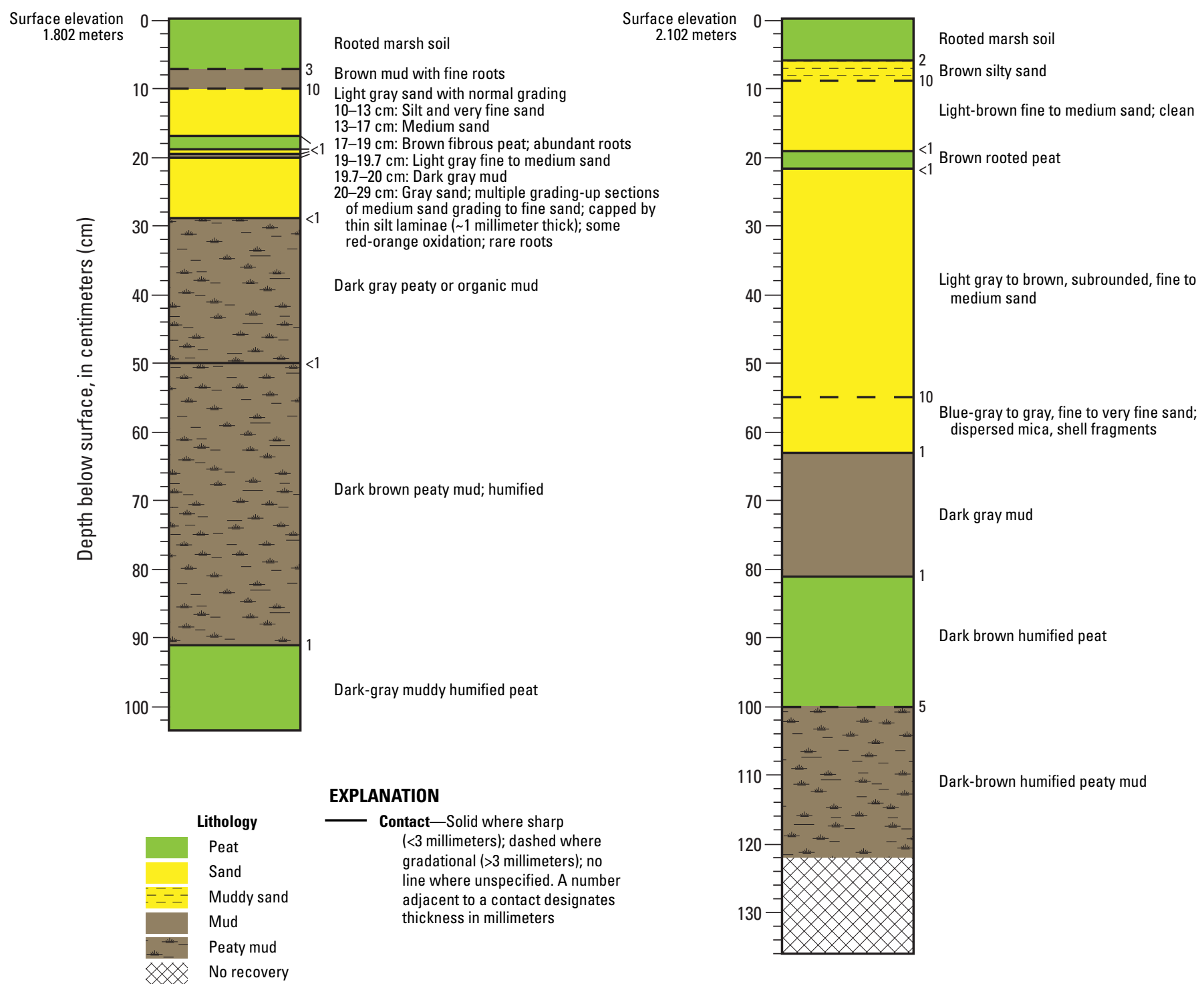

Figure 1.26. Lithologic description of cores $\mathrm{A} 1$ and $\mathrm{A} 2$ from Pillar Point marsh. Elevations are relative to the North American Vertical Datum of 1988. 
A3

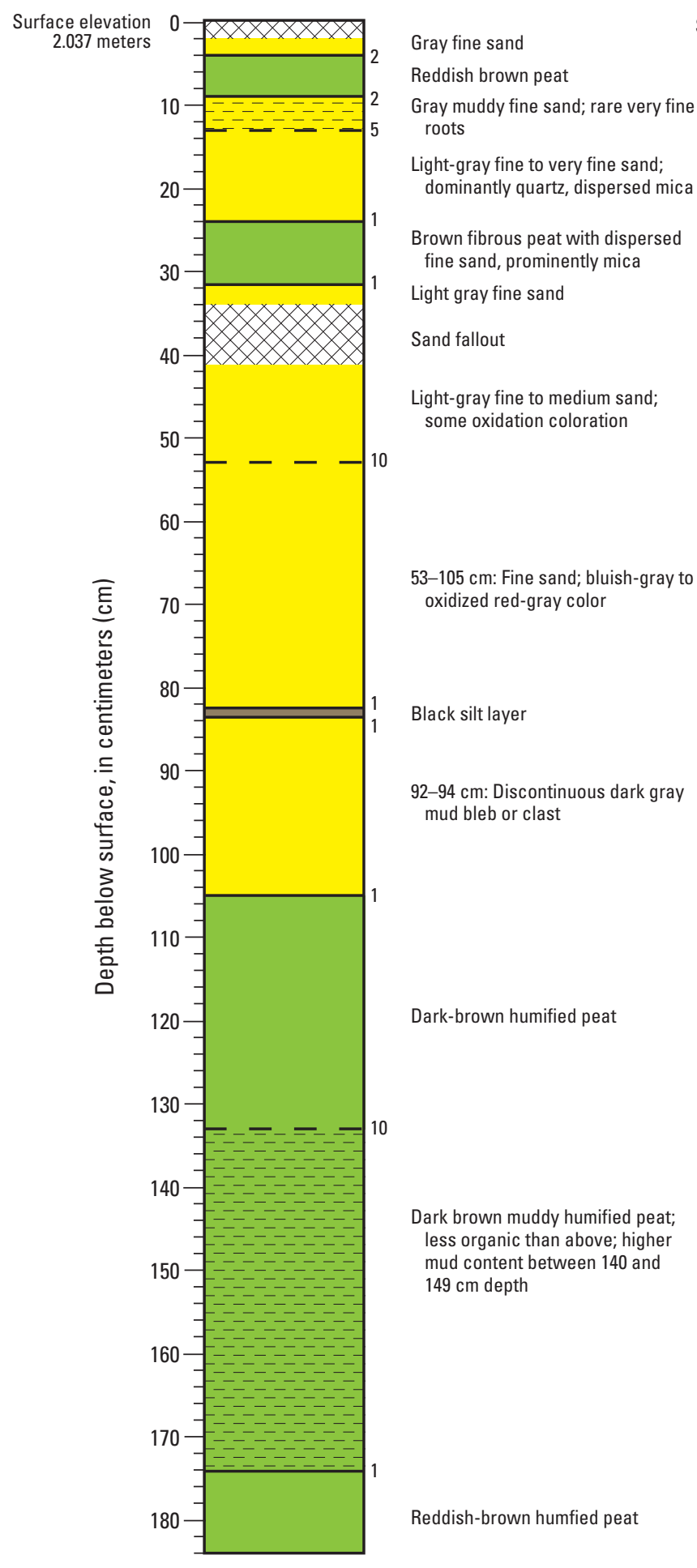

A4

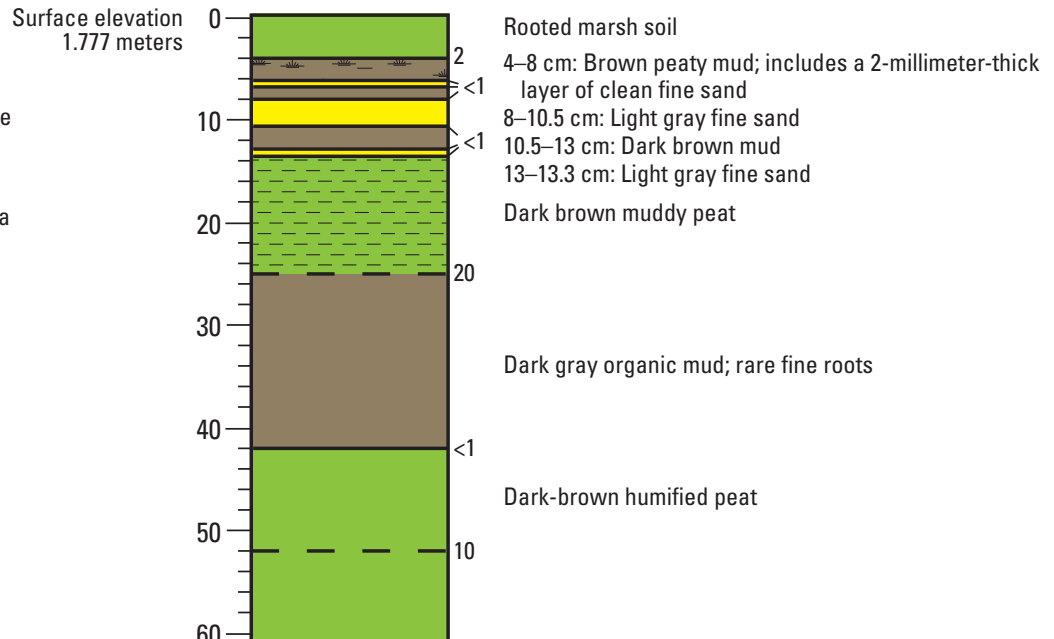

Reddish-brown peat; scattered very fine roots; organic fragment (10 millimeters in diameter) at $64 \mathrm{~cm}$ depth

\begin{tabular}{|l} 
EXPLANATION \\
Lithology \\
Peat \\
Muddy peat \\
Mud \\
Peaty mud \\
No recovery \\
Contact-Solid where sharp \\
(<3 millimeters); dashed where \\
gradational (>3 millimeters); no \\
line where unspecified. A number \\
adjacent to a contact designates \\
thickness in millimeters
\end{tabular}

Muddy humified peat with dispersed mica

Figure 1.27. Lithologic description of cores $\mathrm{A} 3$ and A4, Pillar Point marsh. Elevations are relative to the North American Vertical Datum of 1988. 


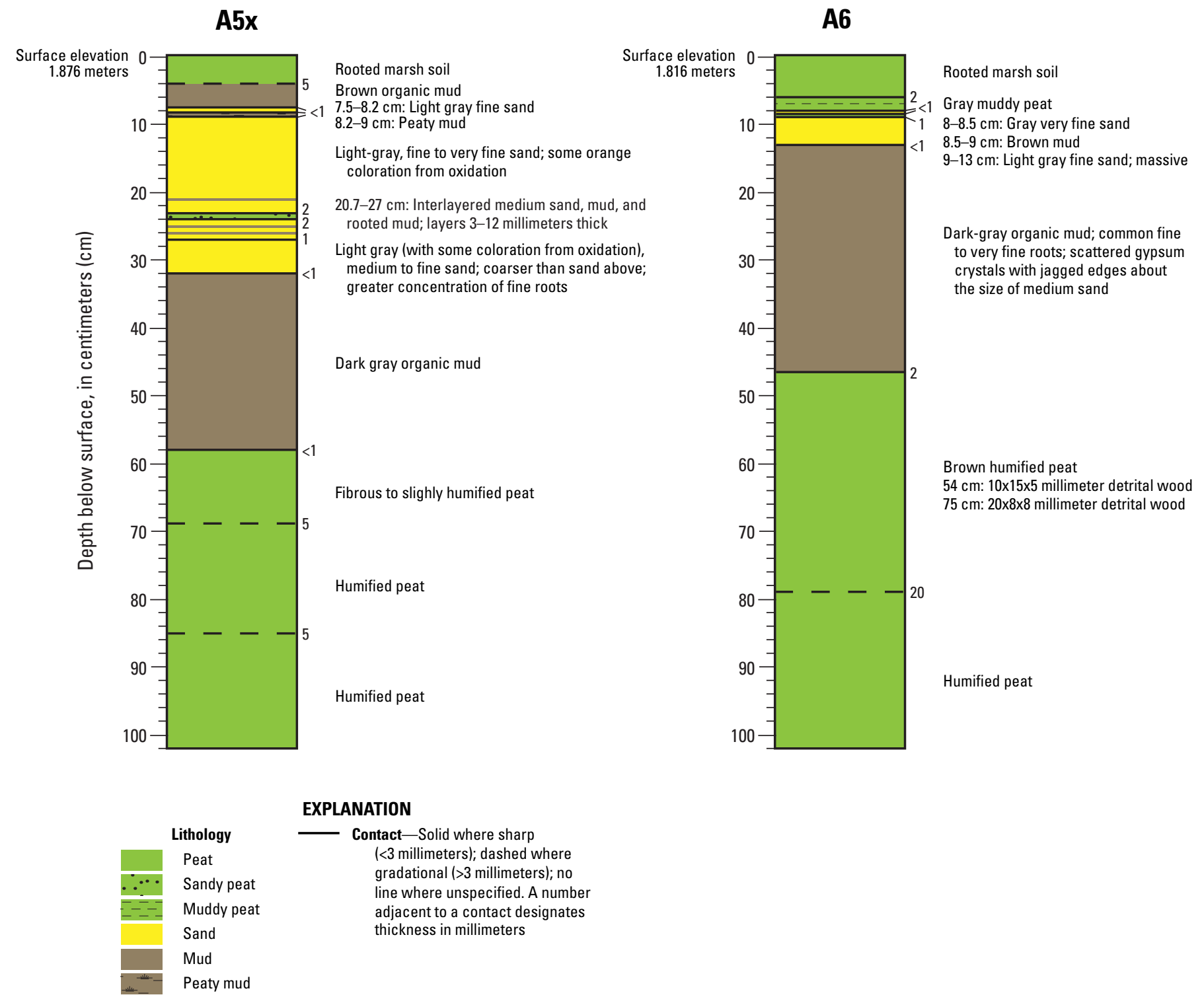

Figure 1.28. Lithologic description of cores $A 5$ and $A 6$ from Pillar Point marsh. Elevations are relative to the North American Vertical Datum of 1988. 
A6x

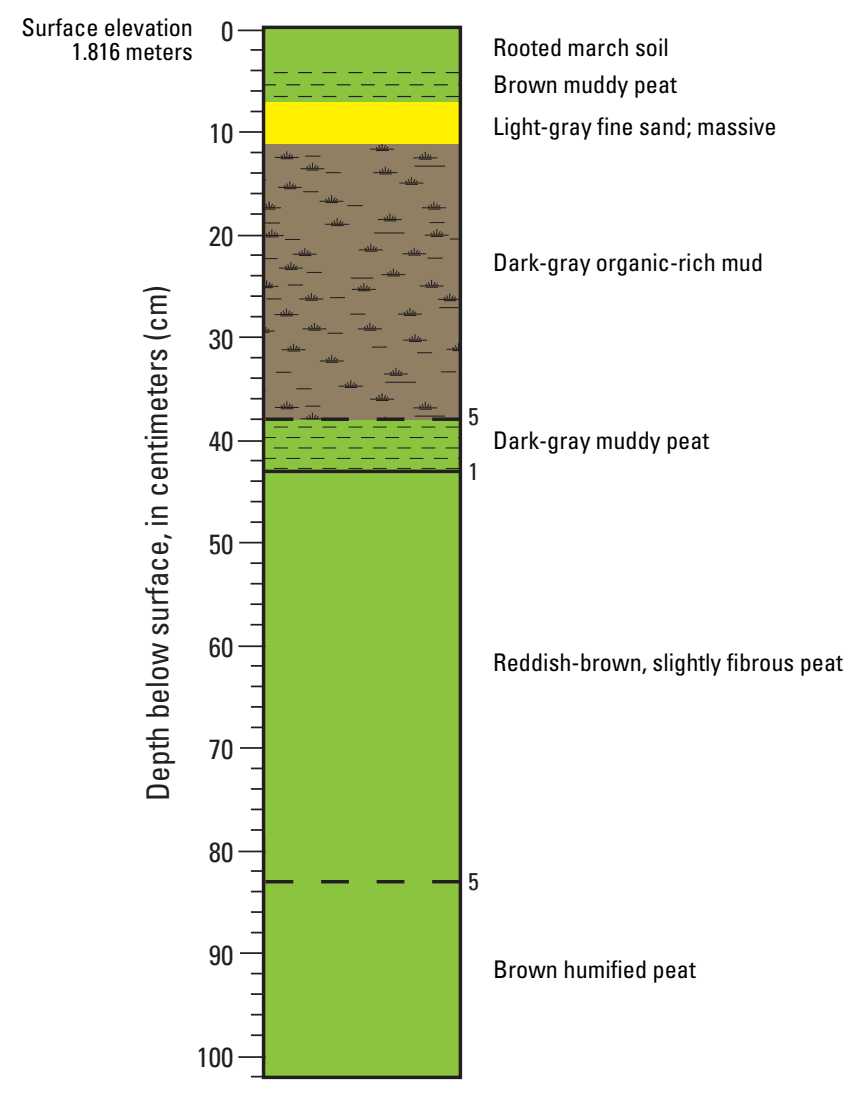

A7

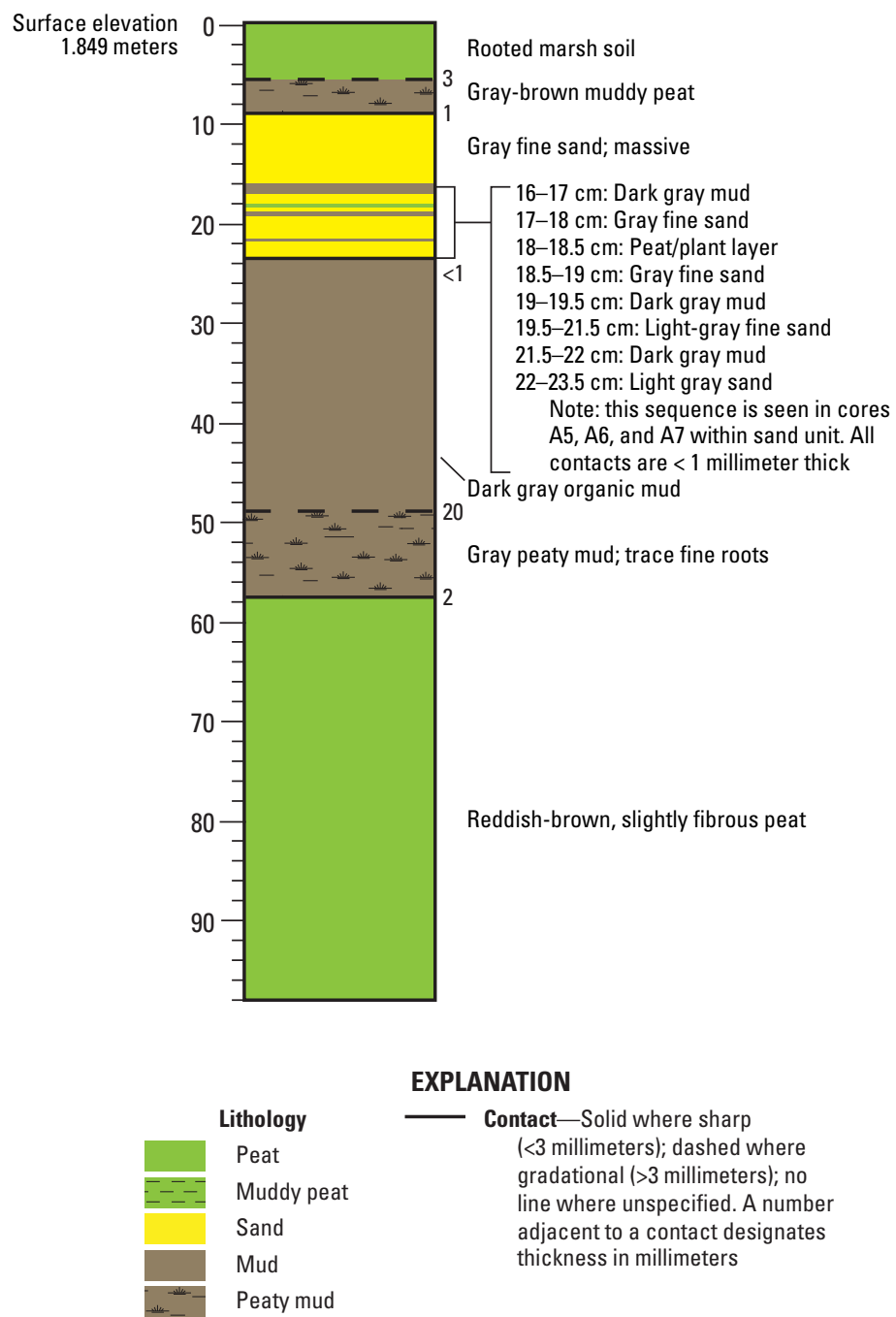

Figure 1.29. Lithologic description of cores A6x and A7 from Pillar Point marsh. Elevations are relative to the North American Vertical Datum of 1988. 


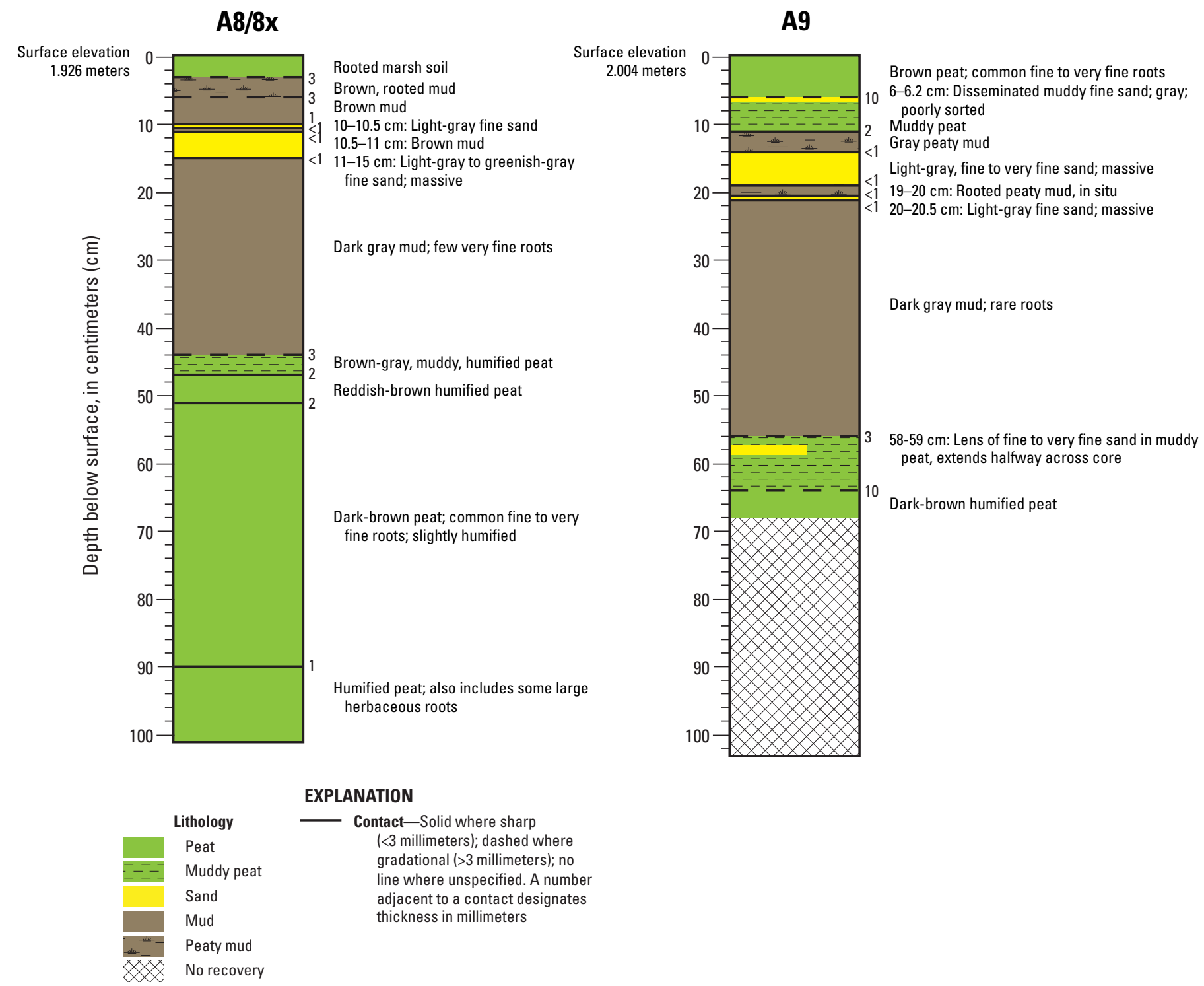

Figure 1.30. Lithologic description of cores A8 and A9 from Pillar Point marsh. Elevations are relative to the North American Vertical Datum of 1988. 
A10

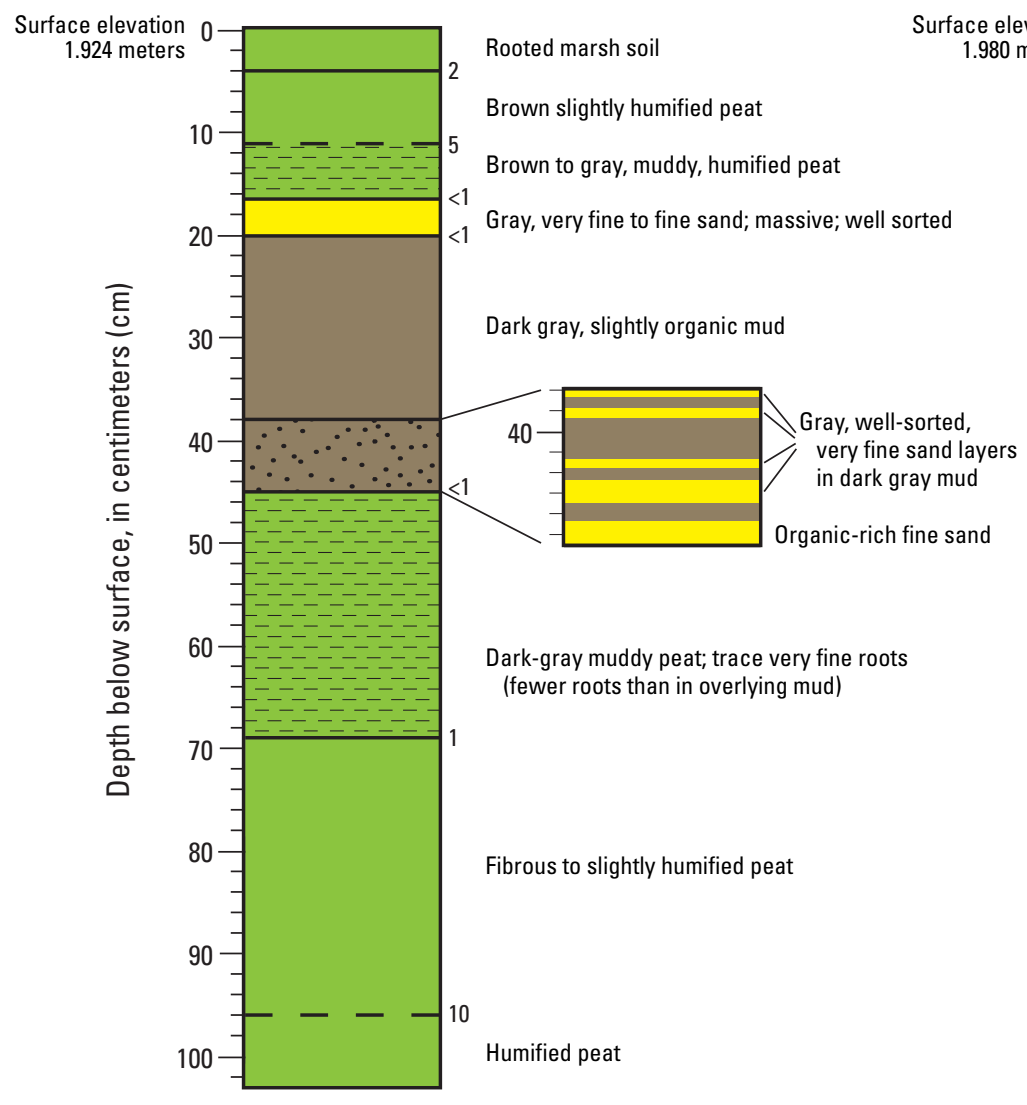

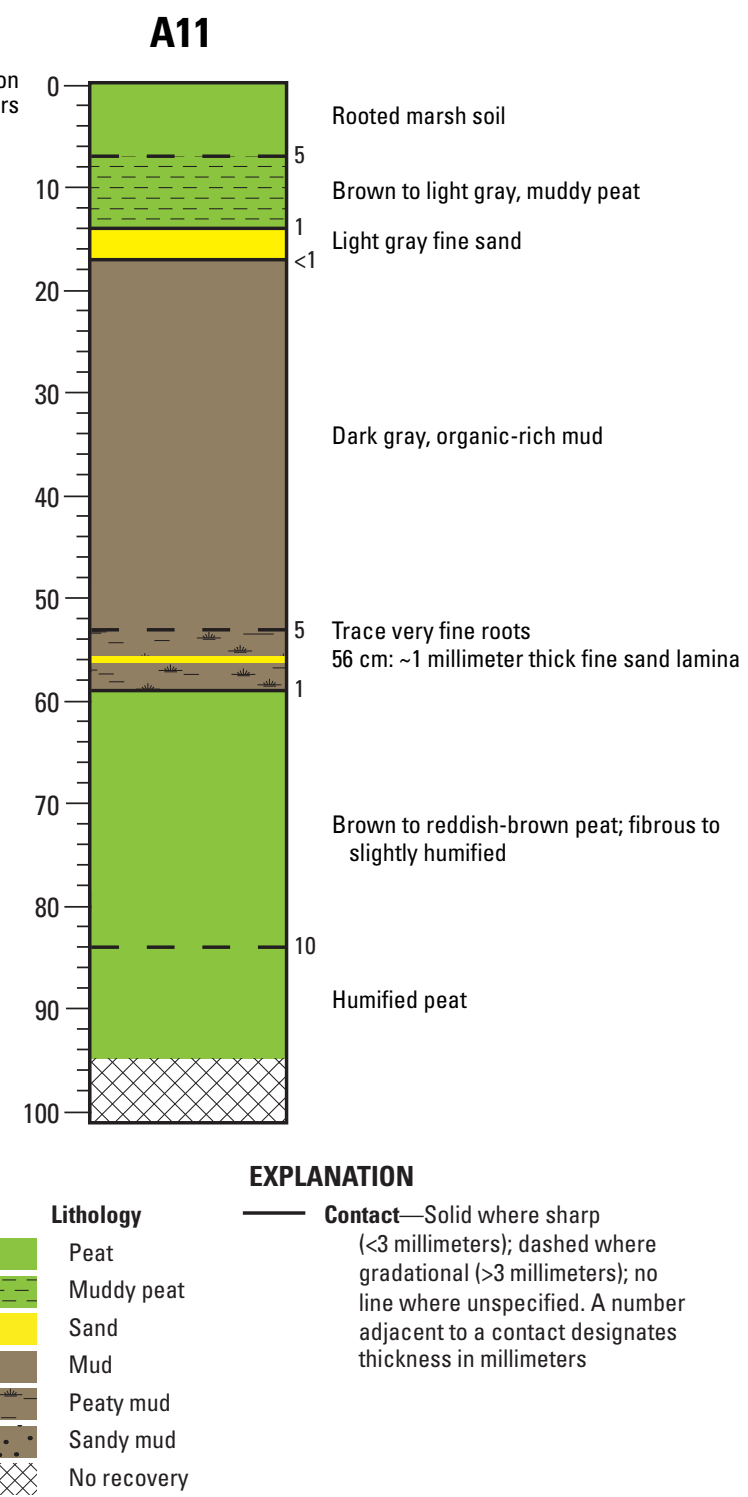

Figure 1.31. Lithologic description of cores $\mathrm{A} 10$ and $\mathrm{A} 11$ from Pillar Point marsh. Elevations are relative to the North American Vertical Datum of 1988. 


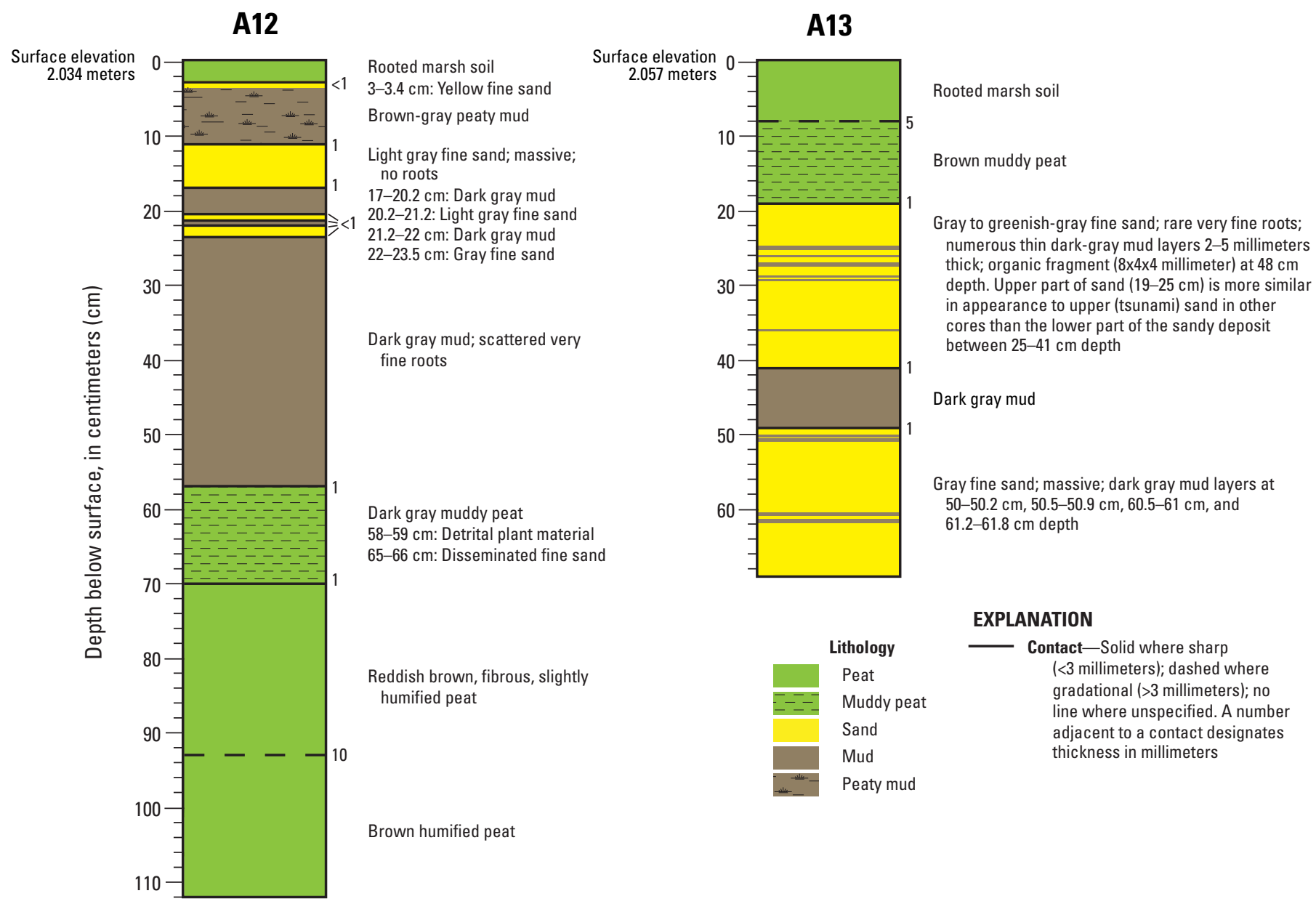

Figure 1.32. Lithologic description of cores $\mathrm{A} 12$ and $\mathrm{A} 13$ from Pillar Point marsh. Elevations are relative to the North American Vertical Datum of 1988. 
A14

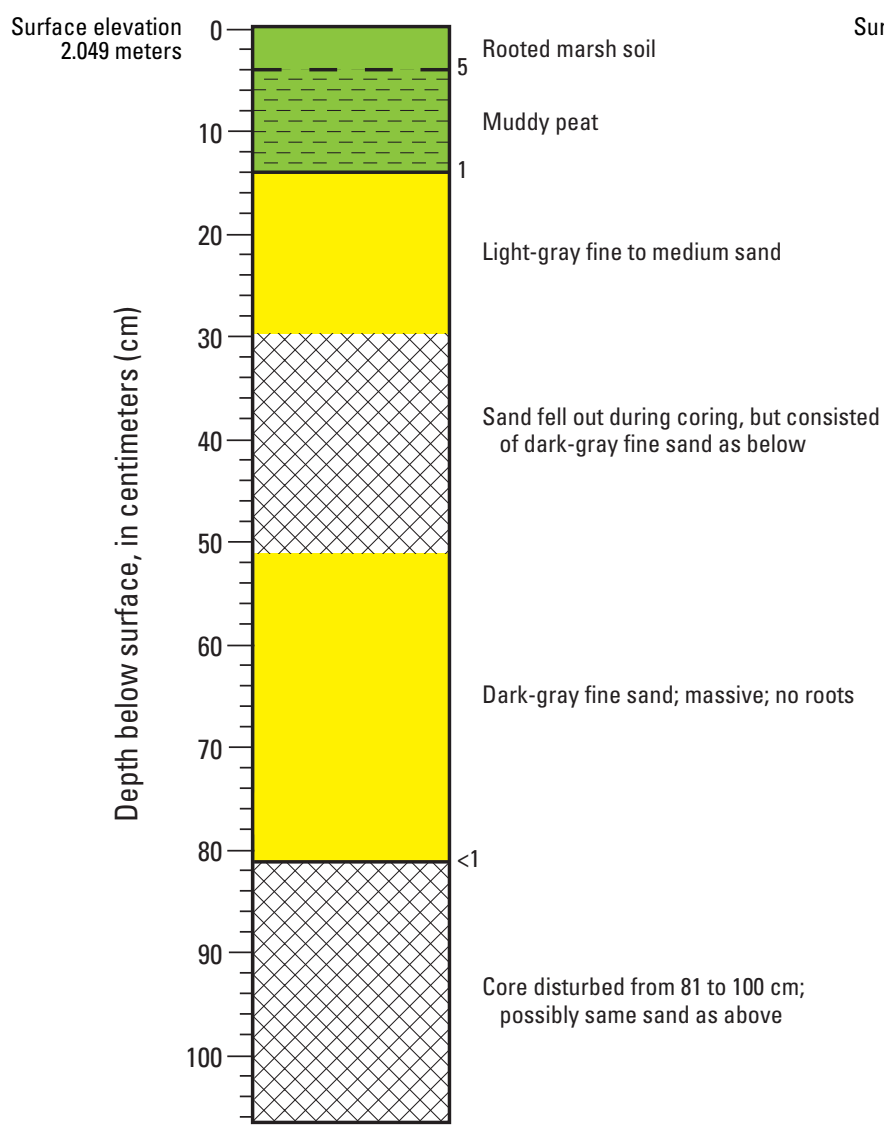

A15

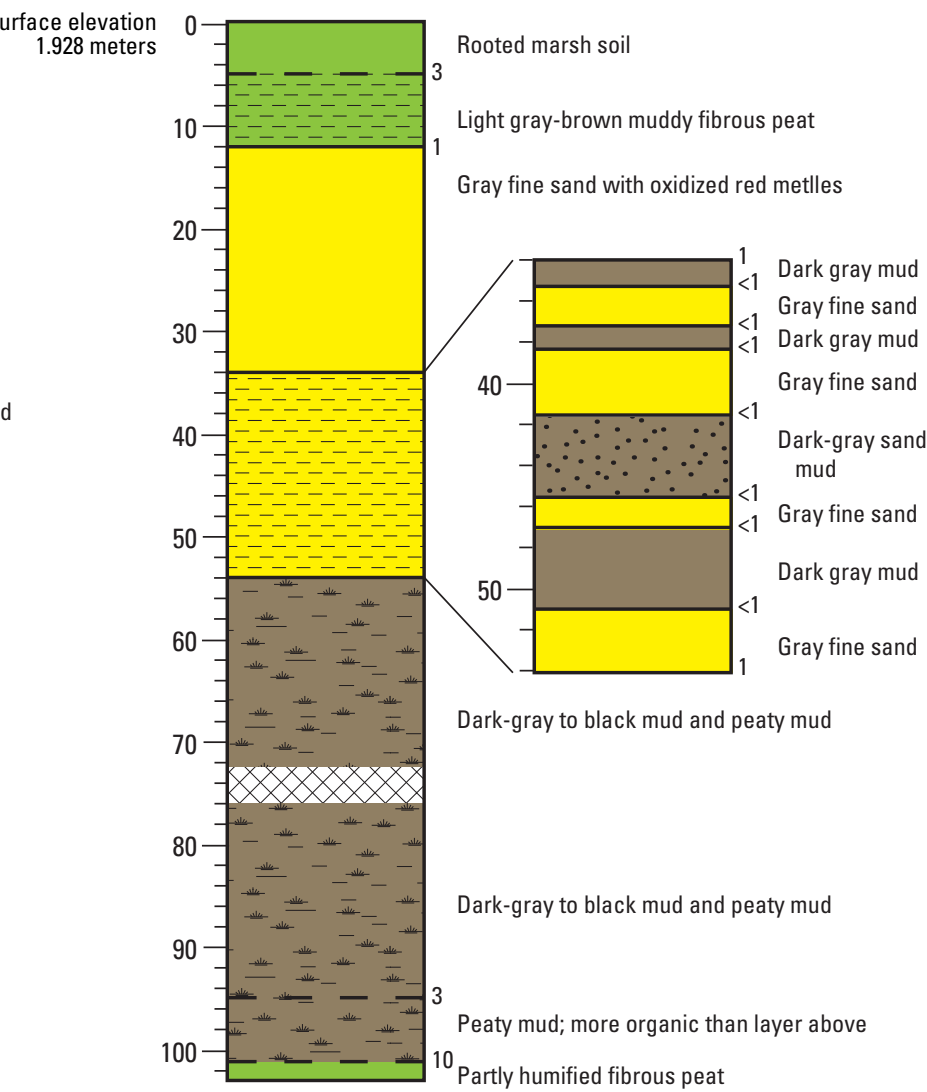

\section{EXPLANATION}

\begin{tabular}{|c|c|c|}
\hline & Lithology & \multirow{5}{*}{$\begin{array}{l}\text { Contact-Solid where sharp } \\
\text { (<3 millimeters); dashed where } \\
\text { gradational ( }>3 \text { millimeters); no } \\
\text { line where unspecified. A number } \\
\text { adjacent to a contact designates } \\
\text { thickness in millimeters }\end{array}$} \\
\hline & Peat & \\
\hline 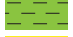 & Muddy peat & \\
\hline & Sand & \\
\hline--- & Muddy sand & \\
\hline & Mud & \\
\hline & Peaty mud & \\
\hline & Sandy mud & \\
\hline & No recovery & \\
\hline
\end{tabular}

Figure 1.33. Lithologic description of cores A14 and A15 from Pillar Point marsh. Elevations are relative to the North American Vertical Datum of 1988. 

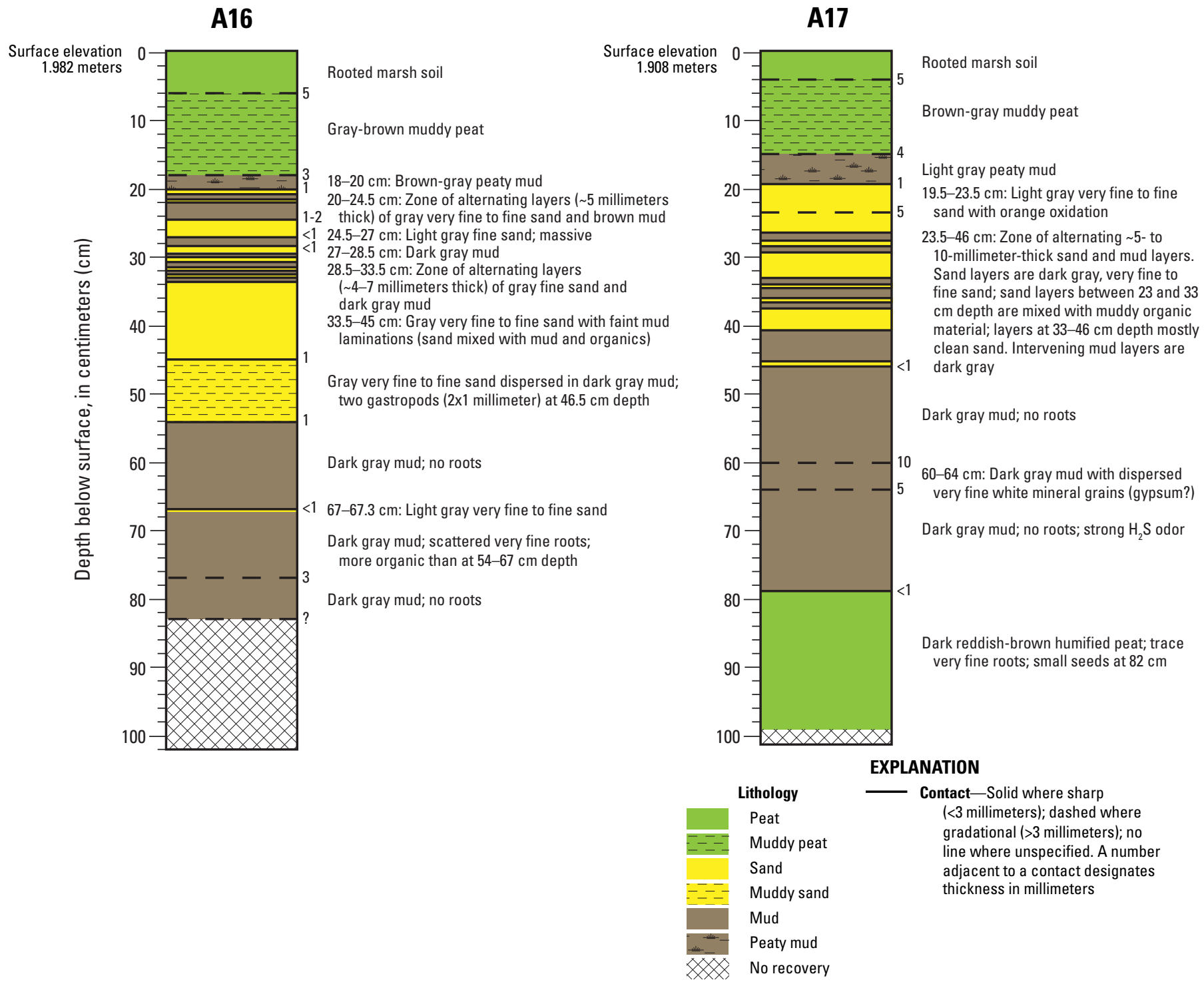

Figure 1.34. Lithologic description of cores A16 and A17 from Pillar Point marsh. Elevations are relative to the North American Vertical Datum of 1988. 
A18

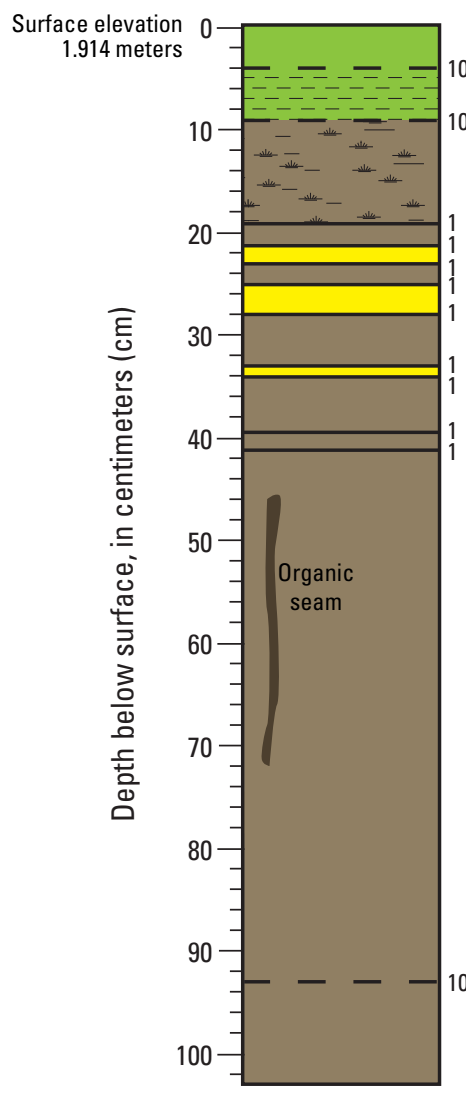

A19

Rooted marsh soil

Brown-gray peat; slightly muddy

Light brown-gray peaty mud

19-21 cm: Gray mud; organic; trace roots

21-23 cm: Light gray very fine to fine sand:

large wood fragment $(5 \times 2 \times 0.5 \mathrm{~cm})$ at $22 \mathrm{~cm}$ depth

23-25 cm: Gray mud; organic

$25-28 \mathrm{~cm}$ : Light gray fine sand; clean

28-33 cm: Gray mud; wood detritus at 30-32

$\mathrm{cm}$ depth (including one $5 \times 1 \times 1-\mathrm{cm}$ piece)

33-34 cm: Dark gray fine sand; clean

$34-39.5 \mathrm{~cm}$ : Dark gray mud

39.5-41 cm: Dark gray mud with discontinuous layers ("stringers") of fine sand

Dark gray organic mud

46-71 cm: Vertical seam of organic material, possibly decayed root; mostly reddish brown but with distinctive copper-colored tint

Dark brown-gray mud

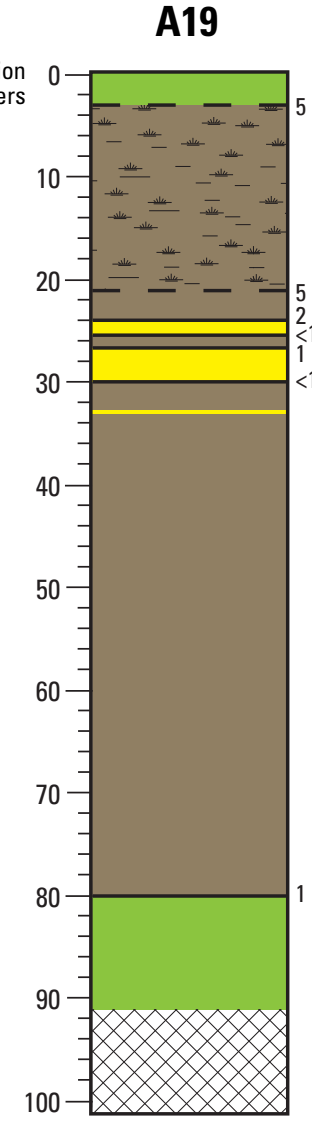

Rooted marsh soil

Light brown-gray peaty mud; very fine roots

common; rare medium roots

$14 \mathrm{~cm}$ : 2x3-cm white coated paper (gum wrapper?)

21-24 cm: Light gray to brown orange (oxidized) mud; no roots

24-25.5 cm: Gray very fine to fine sand; massive;

1 micaceous; clean

$25.5-26.5 \mathrm{~cm}$ : Dark gray mud

26.5-30 cm: Fine sand; consistent grain size but

with light and dark gray banding; some oxidation

$33 \mathrm{~cm}$ : Fine sand lamina in mud; 1 millimeter thick

30-80 cm: Dark gray mud with scattered pieces of dark brown organic fragments (similar brown to copper color in core A18)

$41 \mathrm{~cm}$ : Concentration of mica

77.5-80 cm: Color change to lighter brown gray

Dark reddish gray-brown; humified

$87-91 \mathrm{~cm}$ : Increase in organic material (very fine roots and small seeds)

\section{EXPLANATION}

$\begin{array}{ll} & \text { Lithology } \\ & \text { Peat } \\ & \text { Muddy peat } \\ & \text { Sand } \\ & \text { Mud } \\ & \text { Peaty mud } \\ & \text { No recovery }\end{array}$

Contact-Solid where sharp

( $<3$ millimeters); dashed where gradational (>3 millimeters); no line where unspecified. A numbe adjacent to a contact designates thickness in millimeters

Figure 1.35. Lithologic description of cores A18 and A19 from Pillar Point marsh. Elevations are relative to the North American Vertical Datum of 1988. 


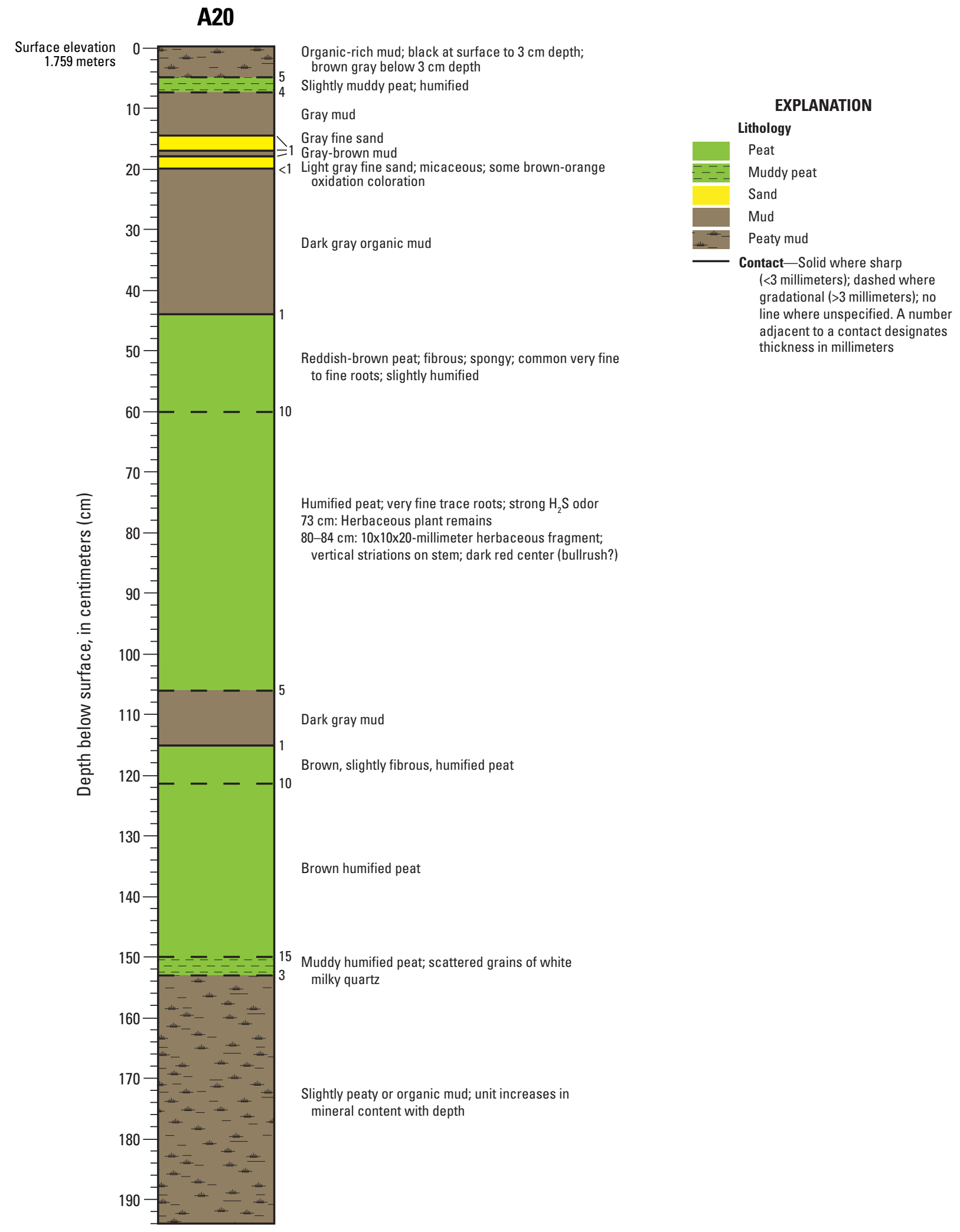

Figure 1.36. Lithologic description of core A20 from Pillar Point marsh. Elevations are relative to the North American Vertical Datum of 1988. 


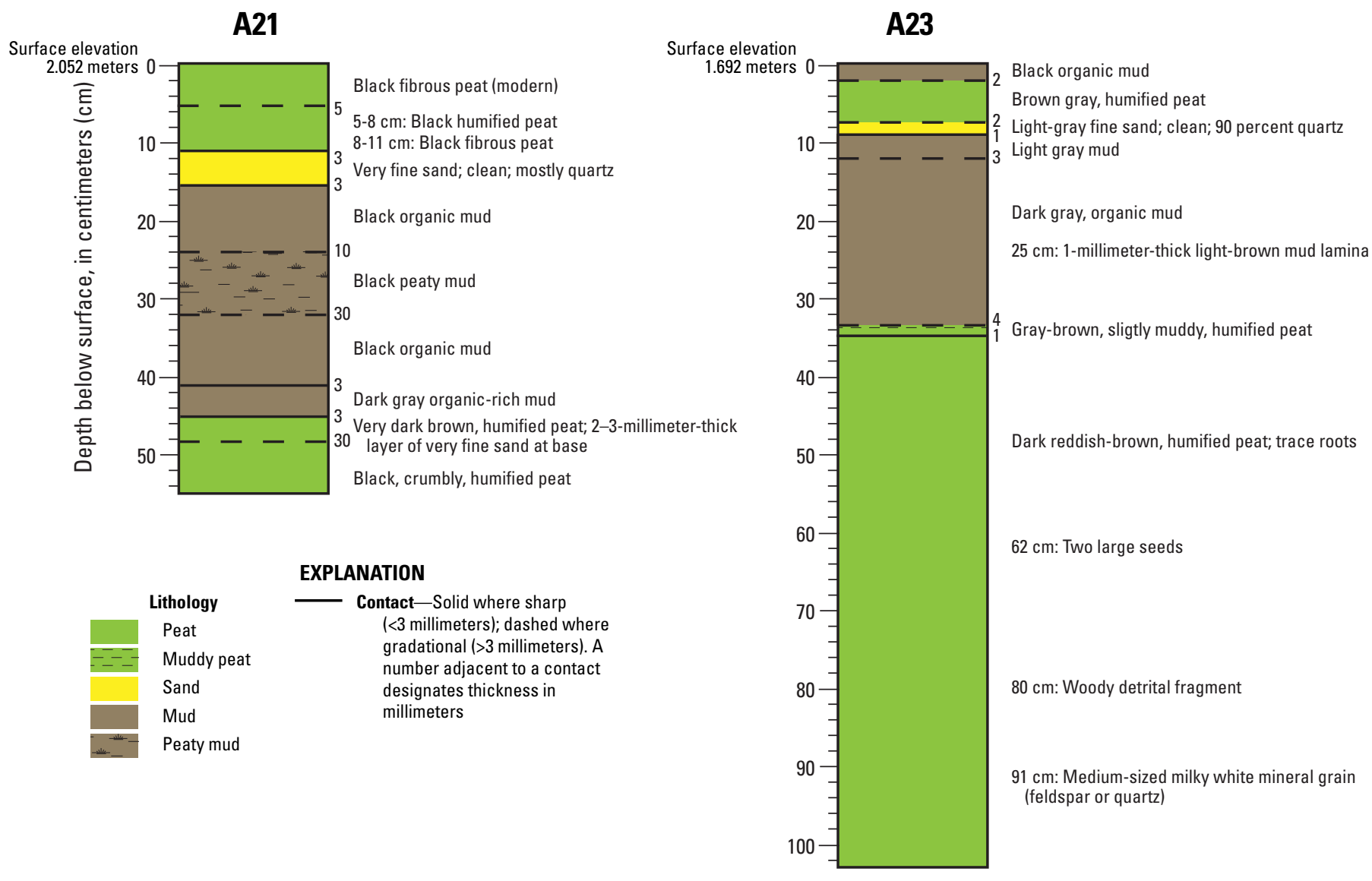

Figure 1.37. Lithologic description of cores A21 and A23 from Pillar Point marsh. Elevations are relative to the North American Vertical Datum of 1988. 


\section{A24}

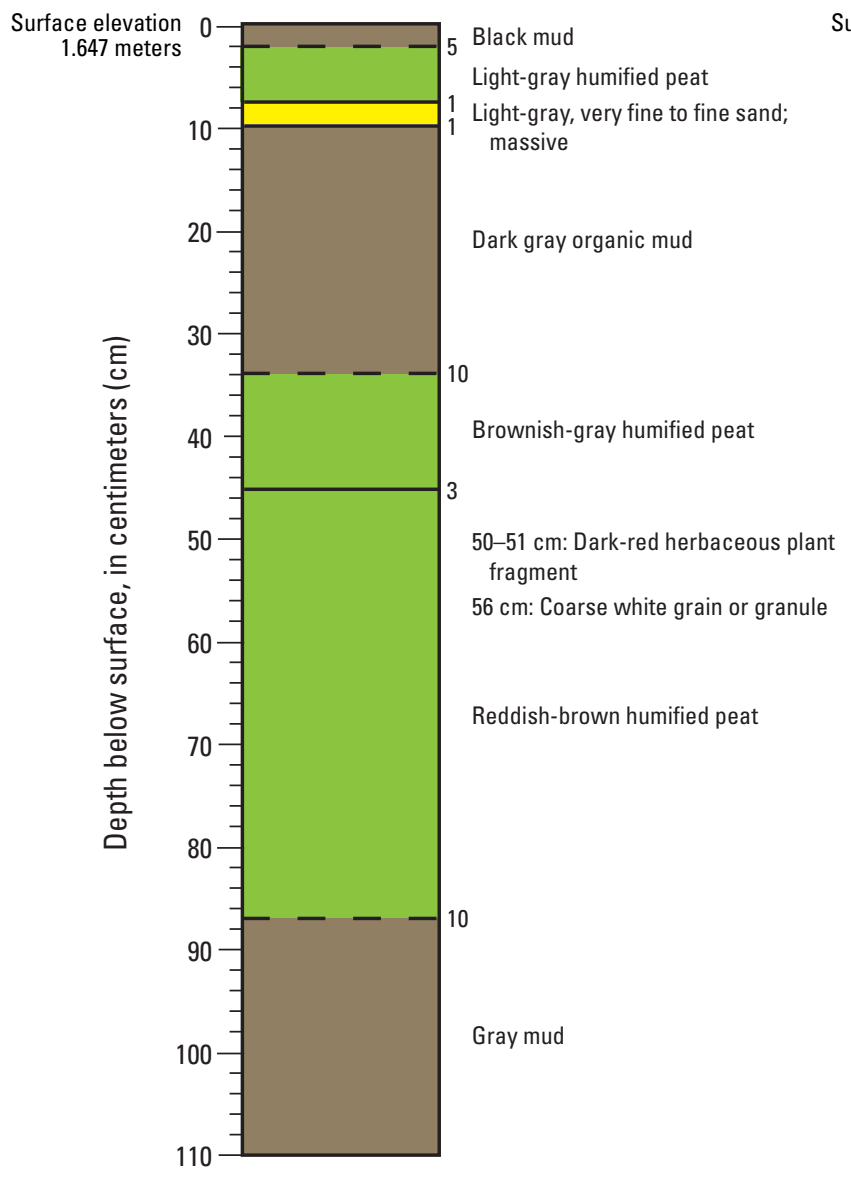

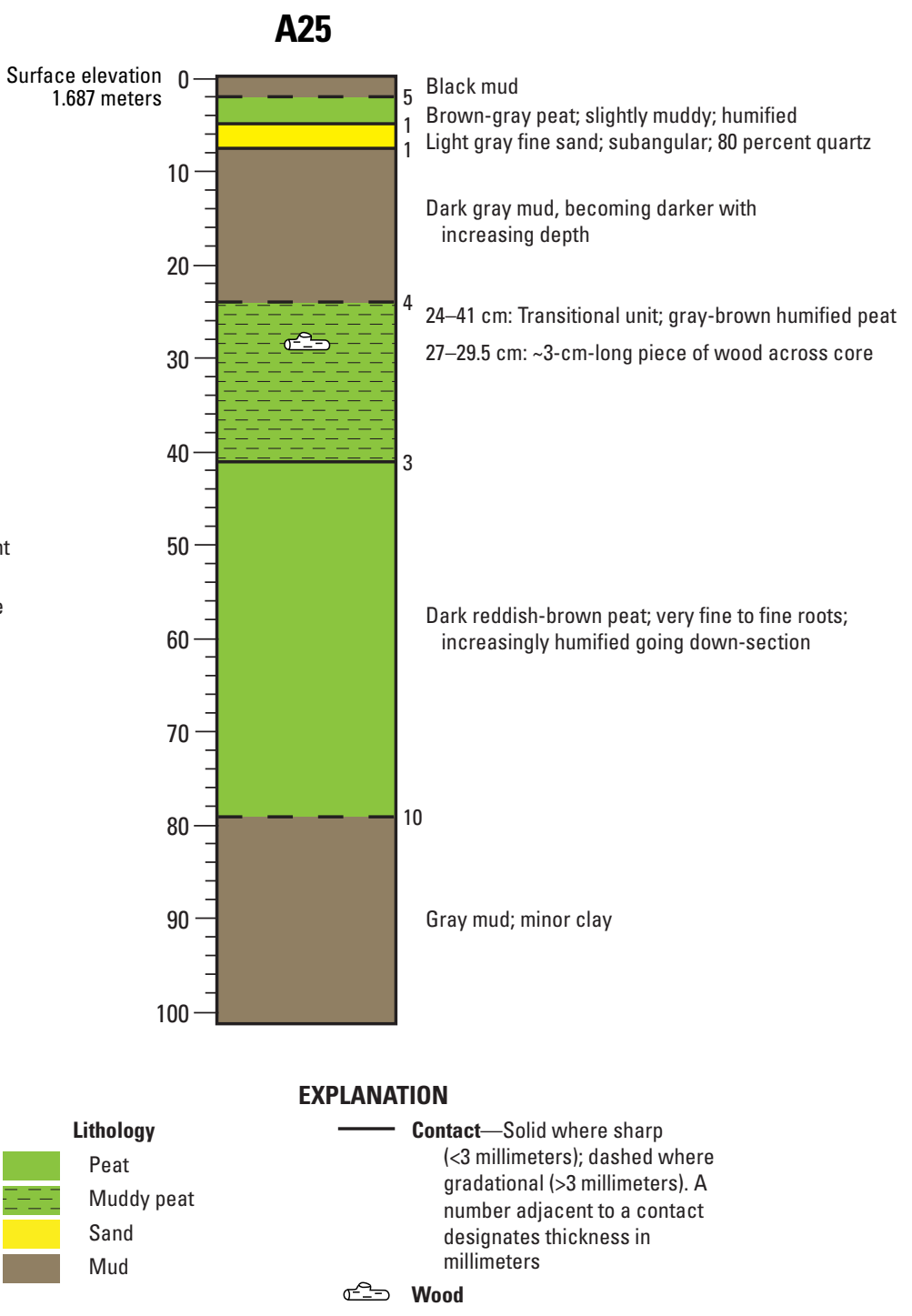

Figure 1.38. Lithologic description of cores A24 and A25 from Pillar Point marsh. Elevations are relative to the North American Vertical Datum of 1988. 
A26

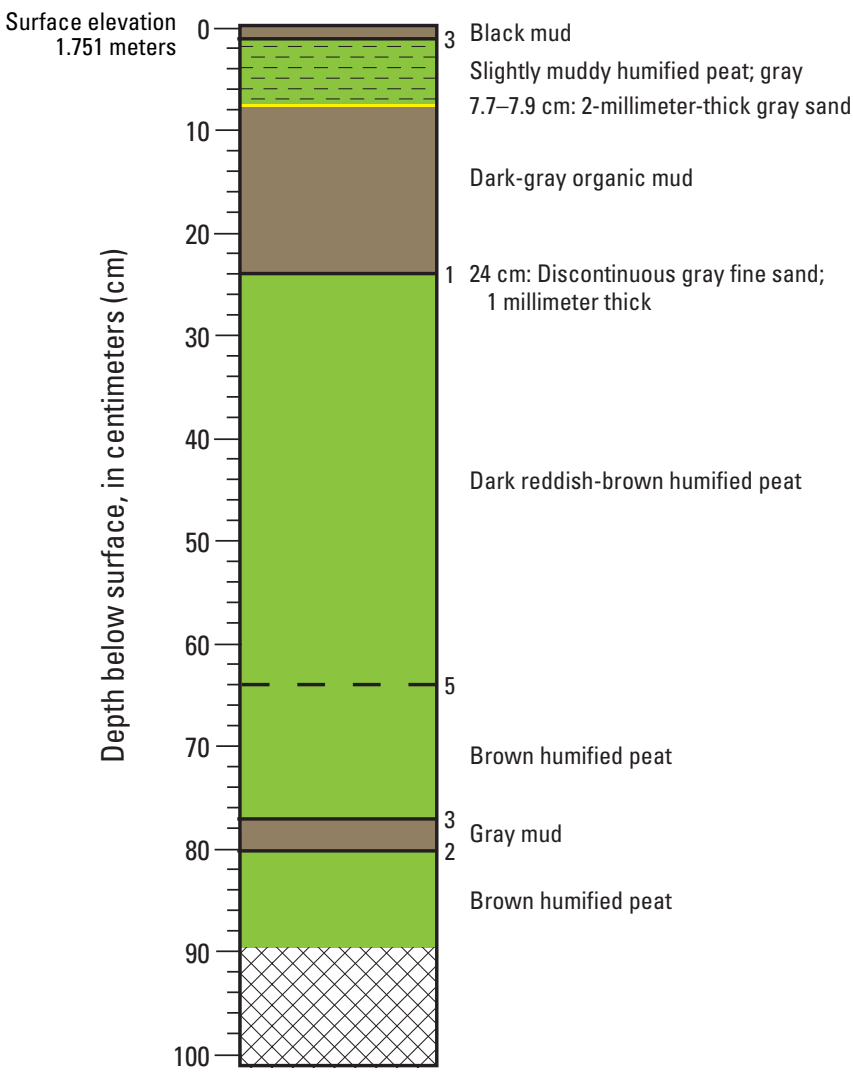

A27

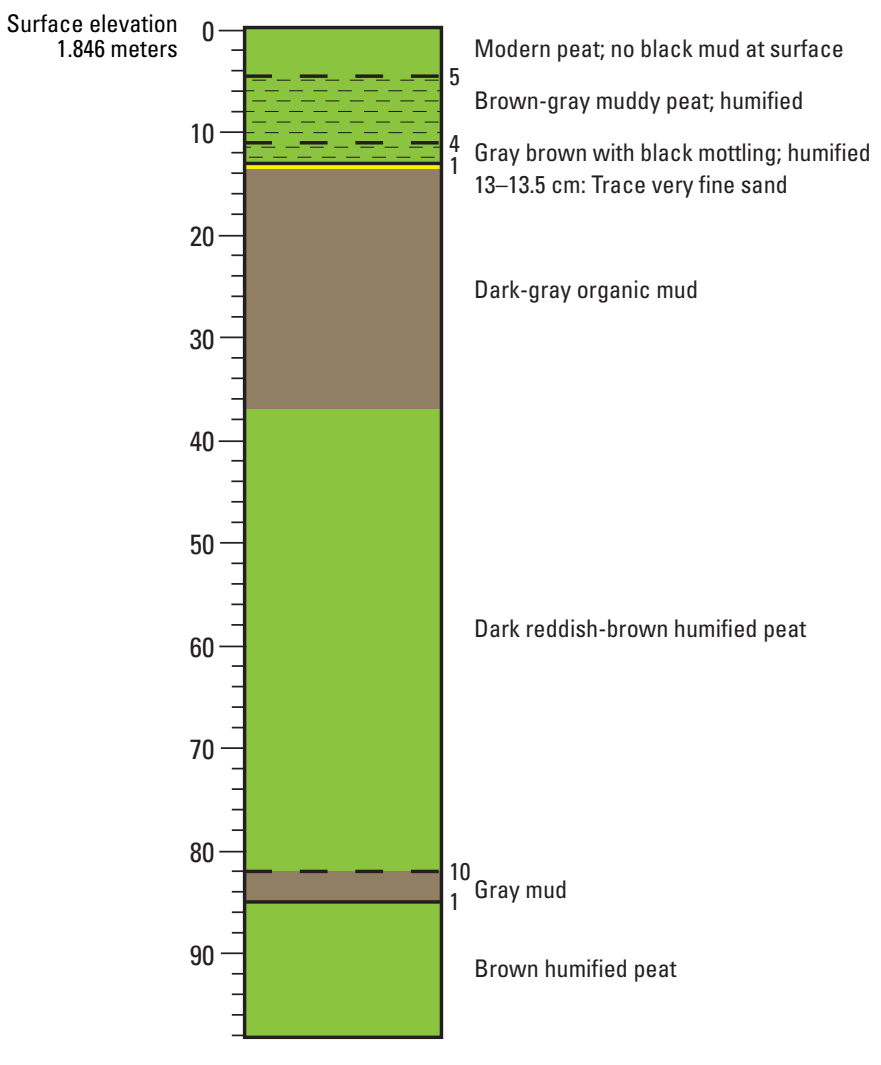

EXPLANATION

Lithology Contact-Solid where sharp (<3 millimeters); dashed where gradational ( $>3$ millimeters); no line where unspecified. A number adjacent to a contact designates thickness in millimeters

Figure 1.39. Lithologic description of cores A26 and A27 from Pillar Point marsh. Elevations are relative to the North American Vertical Datum of 1988. 


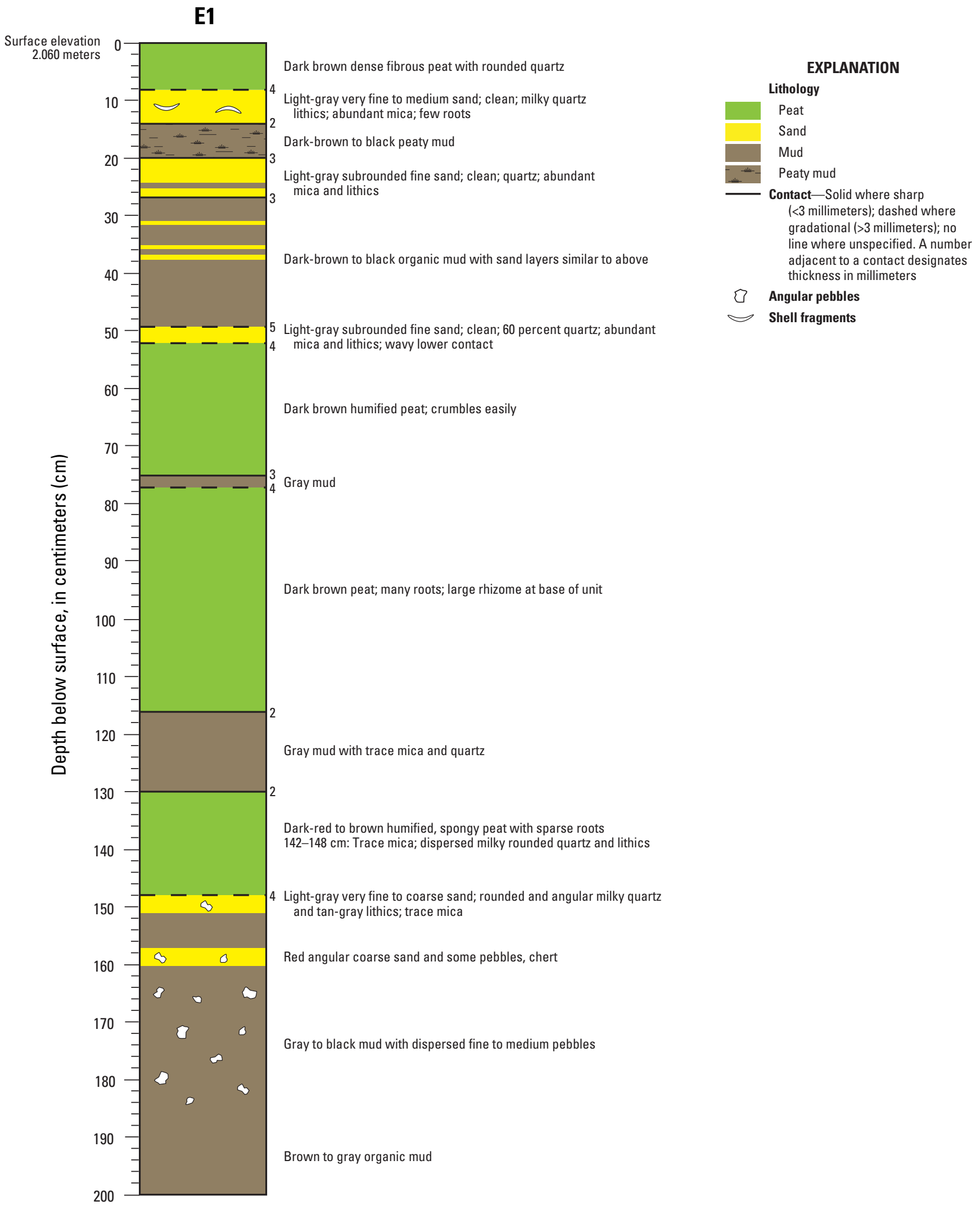

Figure 1.40. Lithologic description of core E1 from Pillar Point marsh. Elevations are relative to the North American Vertical Datum of 1988. 
E2

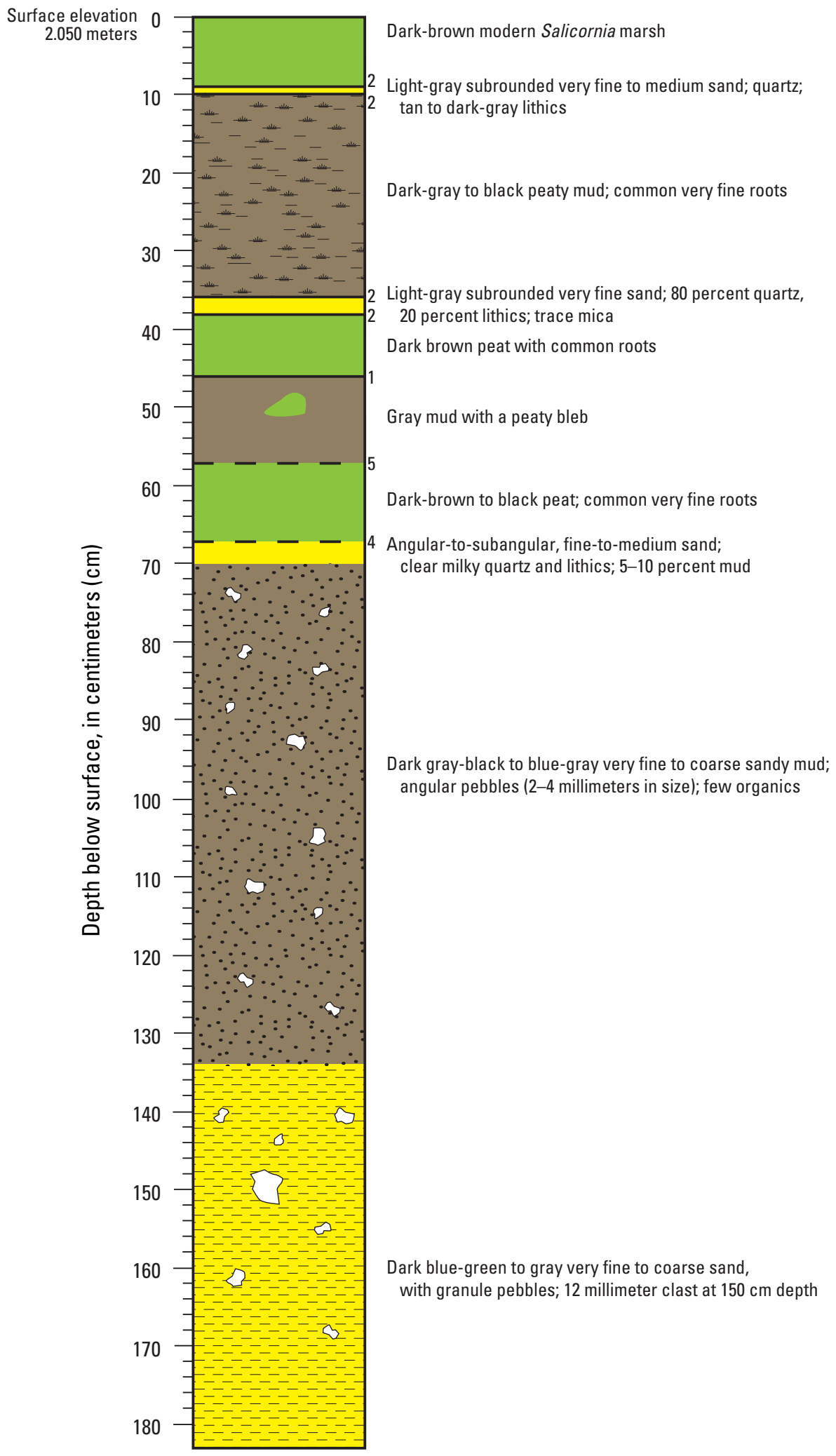

Figure 1.41. Lithologic description of core E2 from Pillar Point marsh. Elevations are relative to the North American Vertical Datum of 1988. 


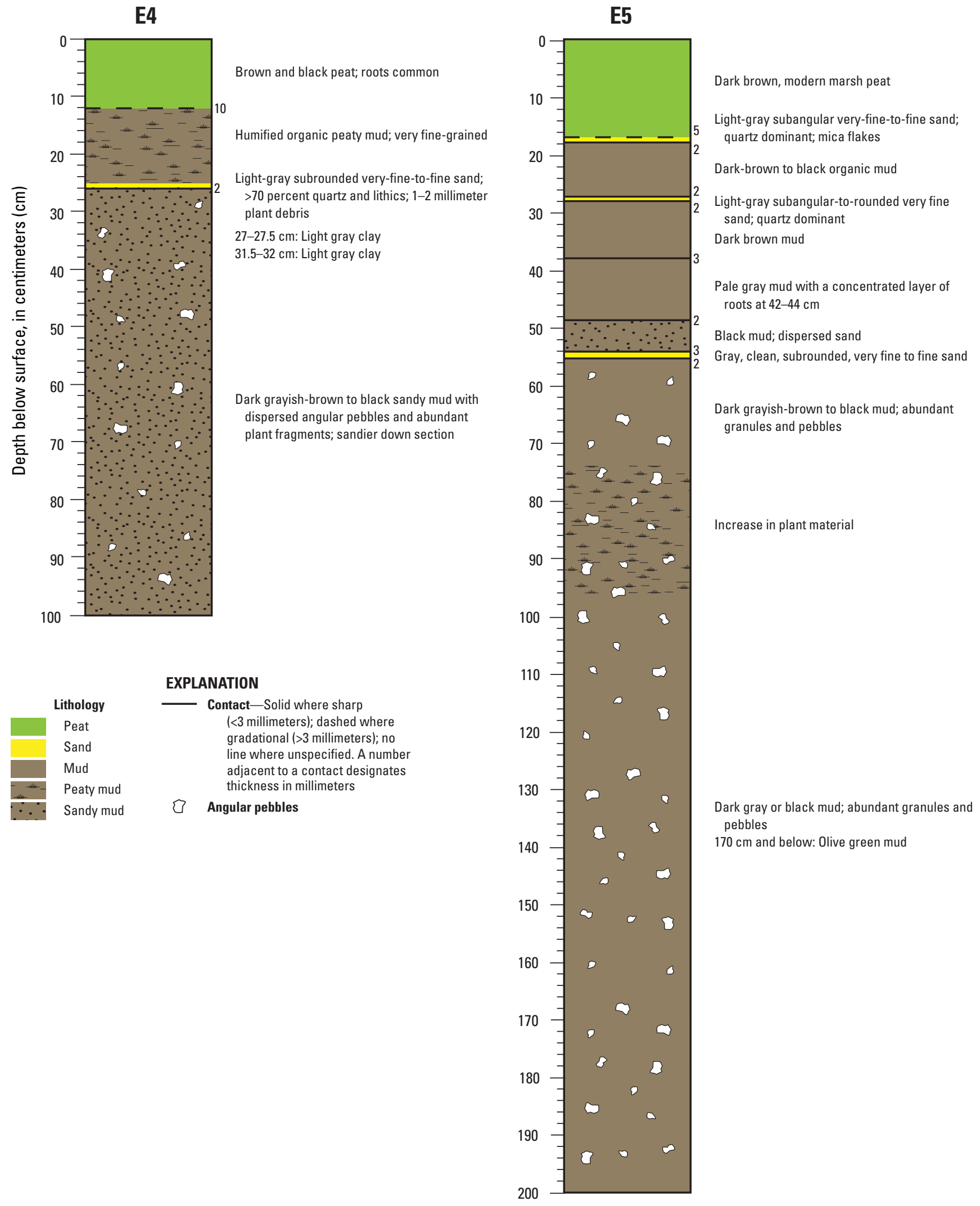

Figure 1.42. Lithologic description of cores E4 and E5 from Pillar Point marsh. Elevations are relative to the North American Vertical Datum of 1988. 


\section{Appendix 2. Radionuclide analysis results}

\section{Methods}

Activities of ${ }^{210} \mathrm{~Pb},{ }^{234} \mathrm{Th},{ }^{214} \mathrm{~Pb},{ }^{7} \mathrm{Be}$, and ${ }^{137} \mathrm{Cs}$ were measured by gamma ray spectroscopy in the U.S. Geological Survey Woods Hole Coastal and Marine Science Center gamma counting laboratory in Woods Hole, Massachusetts. Samples of known weight (tables 2.1-2.6) were analyzed on planar germanium detectors (Canberra Industries, Inc., model GS2020S). The radionuclides ${ }^{210} \mathrm{~Pb},{ }^{234} \mathrm{Th},{ }^{214} \mathrm{~Pb},{ }^{7} \mathrm{Be}$, and

${ }^{137} \mathrm{Cs}$ were measured using net counts of the $46.5,63.3,352$, 477.6, and 661.6 kiloelectron volt ( $\mathrm{keV})$ gamma-ray peaks, respectively. Net counts per second (cps) were converted to decays per minute per dry gram $(\mathrm{dpm} / \mathrm{g})$ for each sample. ${ }^{214} \mathrm{~Pb}$ activity at $352 \mathrm{keV}$ was subtracted from the total ${ }^{210} \mathrm{~Pb}$ activity to calculate the excess ${ }^{210} \mathrm{~Pb}$ activity (Joshi, 1987). Excess ${ }^{210} \mathrm{~Pb},{ }^{7} \mathrm{Be}$, and ${ }^{137} \mathrm{Cs}$ were decay-corrected to the date of core collection. The efficiency of the detectors over the energy range 46.5-661.6 keV was calibrated using U.S. Environmental Protection Agency (EPA) standard pitchblende ore in the same range of geometry as the samples. Calibration of the detectors specifically for ${ }^{137} \mathrm{Cs}$ was carried out with a certified standard solution from Isotope Products Laboratory. For cores MM16, MM16A, A21, and SM11, a correction for self-absorption on all of the radionuclides was made based on the geometry of the gamma-counted samples (Cutshall and others, 1983). For cores A8x and SM8, a correction for self-absorption on all of the radionuclides was made based on the geometry of the gamma-counted samples from adjacent cores A21 and SM11, respectively. Final results were reported per salt-corrected dry weight. Raw counting (cps) errors were calculated at 1 sigma using the following formula (Aptec Instruments, Ltd,, 1999).

$$
\text { Percent error }=\left(\frac{\sqrt{G+B}}{N}\right) \times 100
$$

where $G$ is gross counts, $B$ is background counts, and $N$ is net counts.

Reported activity ( $\mathrm{dpm} / \mathrm{g}$ ) errors include errors propagated from raw and background counts.

Raw detection limits were calculated as 1.645 sigma using the following formula (Aptec Instruments, Ltd., 1999):

Minimum Detectable Activity (MDA) $=\frac{\left(K^{2}+2 K \times \sqrt{2 B}\right)}{T}$

where $K$ is the MDA sigma value (=1.645), $B$ is background counts, and $T$ is live time. Reported detection limits for results less than the MDA were expressed as a function of sample weight (in grams) and were calculated as

$$
\frac{\text { MDA }}{\text { sample weight }}
$$

Accuracy was assessed by analyses of standard reference materials. Average agreement was within 9.7, 8.3, 6.0, and 7.7 percent of certified values for ${ }^{210} \mathrm{~Pb},{ }^{234} \mathrm{Th},{ }^{214} \mathrm{~Pb}$, and ${ }^{137} \mathrm{Cs}$, respectively.

The constant rate of supply (CRS) model (Appleby and Oldfield, 1978) was used with excess ${ }^{210} \mathrm{~Pb}$ activities in the cores to calculate dates of deposition. Activities of excess ${ }^{210} \mathrm{~Pb}$ in missing intervals were interpolated by averaging the surrounding results. Owing to a lack of samples in the upper portion of some cores, the concept of the CRS model was applied starting at the ${ }^{137} \mathrm{Cs}$ peak and extending downward in the core. The ${ }^{137} \mathrm{Cs}$ peaks are interpreted to correspond to the year 1963 in which there was a maximum in ${ }^{137} \mathrm{Cs}$ atmospheric fallout from nuclear weapons testing (Health and Safety Laboratory, 1972; Robbins and Edgington, 1975). Using the 22.3 year half-life for excess ${ }^{210} \mathrm{~Pb}$, the lambda value is equal to $\ln (2) / 22.3$. The CRS formula (adapted from de Souza and others, 2012) was in the following format to calculate the age of deposition $(t)$,

$$
t=\lambda^{-1} \times \ln \left(\frac{\sum \text { all }}{\sum \text { below }}\right)
$$

where $\lambda=\ln (2) /$ half-life, all is all activities in the integrated range of the core until background is reached, and below is activities below the interval or until background is reached.

Uncertainties pertaining to the ages of deposition were calculated for the CRS model ages in the following manner.

$$
\begin{gathered}
\delta \sum \text { all }=\sqrt{\sum \text { all }^{2}} \\
\delta \sum \text { below }=\sqrt{\sum \text { below }^{2}} \\
\delta\left(\frac{\sum \text { all }}{\sum \text { below }}\right)=\left(\frac{\sum \text { all }}{\sum \text { below }}\right) \times \sqrt{\left(\frac{\delta \sum \text { all }}{\sum \text { all }}\right)^{2}+\left(\frac{\delta \sum \text { below }}{\sum \text { below }}\right)^{2}} \\
\text { CRS age range }=\lambda^{-1} \times \ln \left(\left(\frac{\sum \text { all }}{\sum \text { below }}\right) \pm \delta\left(\frac{\sum \text { all }}{\sum \text { below }}\right)\right)
\end{gathered}
$$

The output age ranges from the CRS model are shown down to a depth for which a valid date and error was possible to determine, because errors exceeded 100 percent at greater depths. 
A gross calculation for deposition dates of sediment shallower than the $1963{ }^{137} \mathrm{Cs}$ peak was made using either the bulk linear rate of dry sediment accumulation (in centimeters per year $[\mathrm{cm} / \mathrm{yr}]$ ) or the bulk mass accumulation rate of dry sediment per area (in grams per square centimeter per year $\left[\mathrm{g} / \mathrm{cm}^{2} / \mathrm{yr}\right]$ ), and the ${ }^{137} \mathrm{Cs}$ peak's interval midpoint depth and corresponding assumed age (1963.5). Errors were not determined for these calculations and it was assumed that the rate of accumulation (either in $\mathrm{cm} / \mathrm{yr}$ or $\mathrm{g} / \mathrm{cm}^{2} / \mathrm{yr}$ ) did not change from the ${ }^{137} \mathrm{Cs}$ peak to the top of the core. It was assumed that neither ${ }^{210} \mathrm{~Pb}$ nor ${ }^{137} \mathrm{Cs}$ have been chemically mobile or physically mixed within the cores.

All cores were collected from salt marshes thought to have been impacted by tsunamis in the past. A tsunami is expected to interrupt gradual accretion by suddenly depositing large pulses of sand from barrier beach overwash and other sources. Major ocean storms might have a similar impact. Spikes in bulk wet density, sandy texture, and minimum values in percentage of porewater content may be indicators of these events. The excess ${ }^{210} \mathrm{~Pb}$ profiles were often complicated; attempts at generating dates of deposition were not straight forward and several different strategies were attempted. Ultimately the ${ }^{137} \mathrm{Cs}$ peak was used as the marker for 1963 and dates of deposition for shallower depths were calculated from it based on accumulated mass or depth. For depth intervals deeper than the ${ }^{137} \mathrm{Cs}$ peak, the excess ${ }^{210} \mathrm{~Pb}$ CRS model was used, often tied to the 1963 peak.

\section{Results and Interpretation}

\section{Cores A21 and A8x from Pillar Point Marsh}

Radionuclide activities and deposition dates in cores A21 and A8x are reported in tables 8 and 9 of the main text, respectively. The maximum ${ }^{137} \mathrm{Cs}$ activities were found at a depth of 8.5 centimeters $(\mathrm{cm})$ in both cores and are interpreted to correspond to the year 1963 . The ${ }^{137} \mathrm{Cs}$ peaks correspond to bulk linear sediment accumulation rates of 0.172 and $0.173 \mathrm{~cm} / \mathrm{yr}$ for cores A21 and A8x, respectively, or if expressed as bulk mass accumulation rate, are 0.045 and $0.043 \mathrm{~g} / \mathrm{cm}^{2} / \mathrm{yr}$.

Excess ${ }^{210} \mathrm{~Pb}$ activities, ${ }^{137} \mathrm{Cs}$ activities, and dates of deposition for core A21 and A8x are plotted in figures 89 (of the main text) and 2.1, respectively.

\section{Cores MM16 and MM16A from Marhoffer Creek Marsh}

Radionuclide activities and deposition dates in cores MM16 and MM16A are reported in tables 3 and 4 of the main text, respectively. The maximum ${ }^{137} \mathrm{Cs}$ activities were found at depths of 16.5 and $20 \mathrm{~cm}$ in cores MM16 and MM16A, respectively, and are interpreted to correspond to the year 1963. The ${ }^{137} \mathrm{Cs}$ peaks correspond to bulk linear sediment accumulation rates of 0.332 and $0.406 \mathrm{~cm} / \mathrm{yr}$ for cores MM16 and MM16A, respectively, or if expressed as bulk mass accumulation rate, are 0.036 and $0.053 \mathrm{~g} / \mathrm{cm}^{2} / \mathrm{yr}$.

Excess ${ }^{210} \mathrm{~Pb}$ activities, ${ }^{137} \mathrm{Cs}$ activities, and dates of deposition for cores MM16 and MM16A are plotted in figures 11 and 12 of the main text, respectively. The CRS model output for core MM16 agreed well with the $1963{ }^{137} \mathrm{Cs}$ peak.

\section{Cores SM8 and SM11 from Sand Mine Marsh}

Radionuclide activities and deposition dates in cores SM8 and SM11 are reported in tables 6 and 7 of the main text, respectively. Both cores exhibited twin ${ }^{137} \mathrm{Cs}$ peaks, with the deeper one being the maximum at depths of 22.5 and $12.5 \mathrm{~cm}$ in cores SM8 and SM11, respectively, and are interpreted to correspond to the year 1963. The overall shapes of the excess ${ }^{210} \mathrm{~Pb}$ and ${ }^{137} \mathrm{Cs}$ profiles in core SM8 are very similar to those in core SM11 except that the depth is greater by about $10 \mathrm{~cm}$. The ${ }^{137} \mathrm{Cs}$ peaks listed above correspond to bulk linear sediment accumulation rates of 0.457 and $0.254 \mathrm{~cm} / \mathrm{yr}$ for cores SM8 and SM11, respectively. The deeper of the two ${ }^{137} \mathrm{Cs}$ peaks is interpreted to be the 1963 marker and the shallower peak is interpreted as an artifact of redeposition of surface material from the nearshore and marsh by the tsunami whose deposit overlies the 1963 peak, which is evidenced by detrital peat and sand above.

Excess ${ }^{210} \mathrm{~Pb}$ activities, ${ }^{137} \mathrm{Cs}$ activities, and dates of deposition for cores SM8 and SM11 are plotted in figures 52 and 54 of the main text, respectively.

\section{References Cited}

Appleby, P.G., Oldfield, F., 1978, The calculation of lead-210 dates assuming a constant rate of supply of unsupported ${ }^{210} \mathrm{~Pb}$ to the sediment: Catena, v. 5, p. 1-8.

Aptec Instruments, Ltd., 1999, Aptec Multichannel Application, version 6.31, release 16 .

Cutshall, N.H., Larsen, I.L., and Olsen, C.R., 1983, Direct analysis of ${ }^{210} \mathrm{~Pb}$ in sediment samples - Self-absorption corrections: Nuclear Instruments and Methods in Physics Research, v. 206, nos. 1-2, p. 309-312, https://doi.org/10.1016/01675087(83)91273-5.

Health and Safety Laboratory, 1972, Fallout Program quarterly summary report appendix: U.S. Atomic Energy Commision HASL-258, A-40-41, A-93-94.

Joshi, S.R., 1987, Nondestructive determination of lead-210 and radium-226 in sediments by direct photon analysis: Journal of Radioanalytical and Nuclear Chemistry, v. 116, no. 1, p. 169-182, http://doi.org/10.1007/BF02037220.

Robbins, J.A., and Edgington, D.N, 1975, Determination of recent sedimentation rates in Lake Michigan using $\mathrm{Pb}-210$ and Cs-137: Geochimica et Cosmochimica Acta, v. 39, p. 285-304.

de Souza, V.L.B., Rodrigues, K.R.G., Pedroza, E.H., de Melo, R.T., de Lima, V.L., Hazin, C.A., de Almeida, M.G.O., and do Nascimento, R.K., 2012, Sedimentation rate and ${ }^{210} \mathrm{~Pb}$ sediment dating at Apipucos Reservoir, Recife, Brazil: Sustainability, v. 4, p. 2419-2429, http://doi.org/10.3390/ su4102419. 
${ }^{137} \mathrm{Cs}$ activity $(\mathrm{dpm} / \mathrm{g})$
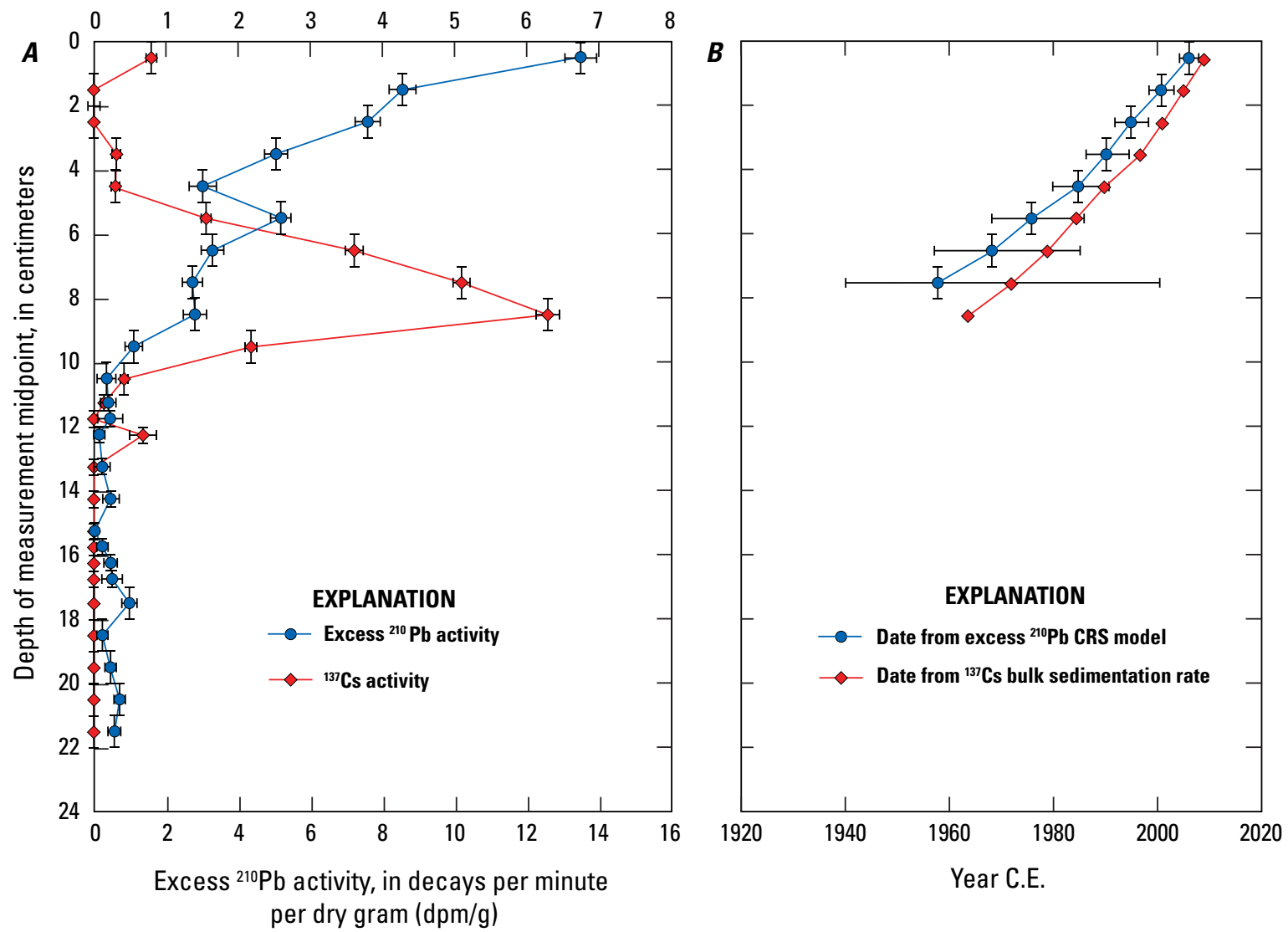

Figure 2.1. Radionuclide results for core SM8x from Sand Mine marsh. $A$, Graph of ${ }^{137} \mathrm{C}$ s and excess ${ }^{210} \mathrm{~Pb}$ radionuclide activities. $B$, Age estimates based on the bulk sedimentation rate (in grams per year) derived from ${ }^{137} \mathrm{Cs}$ (red) and the ${ }^{210} \mathrm{~Pb}$ constant rate of supply (CRS) model (blue). ${ }^{210} \mathrm{~Pb}$ CRS model dates are graphed as deep as 100 percent error. 


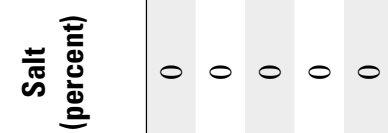

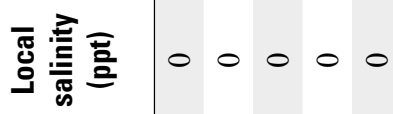

竞

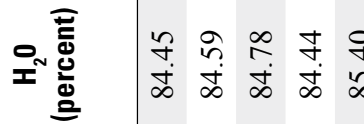

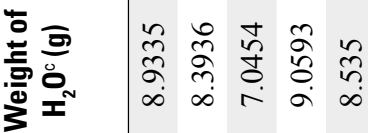

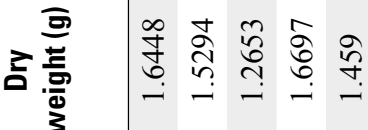

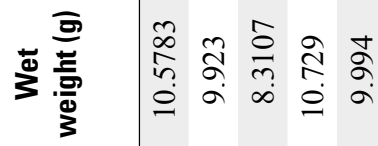

흥

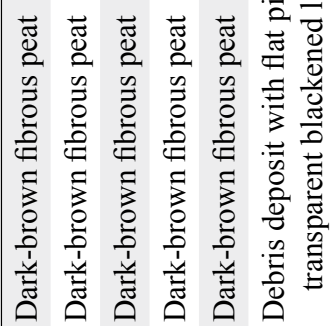

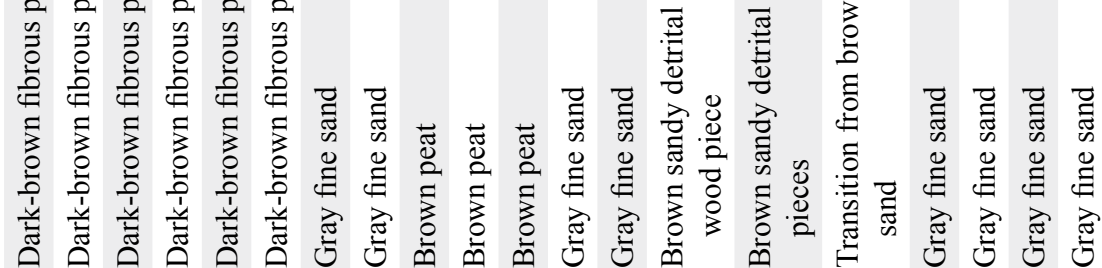

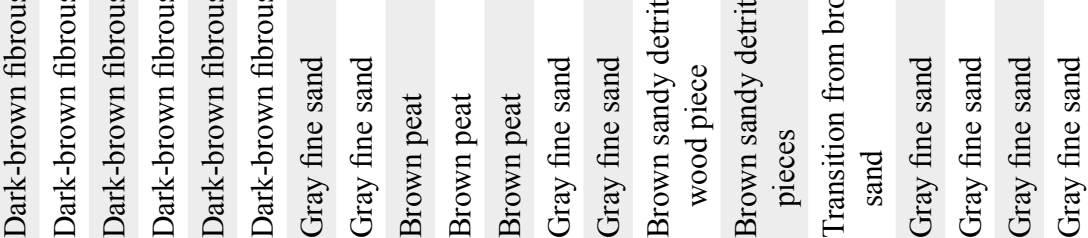

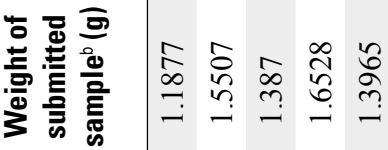

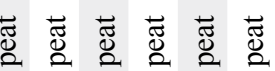

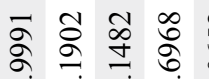

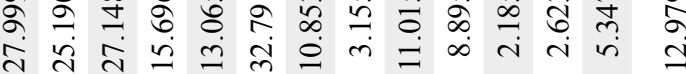

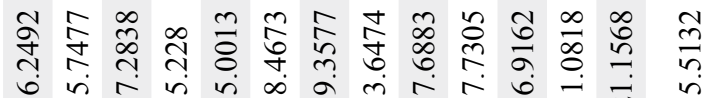

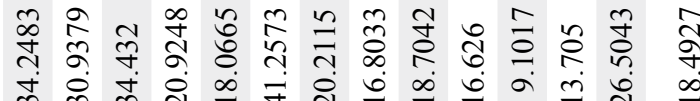

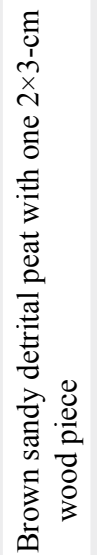

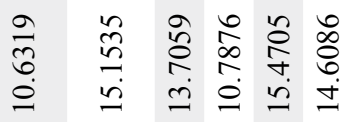

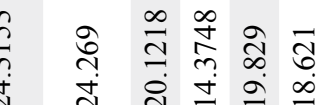

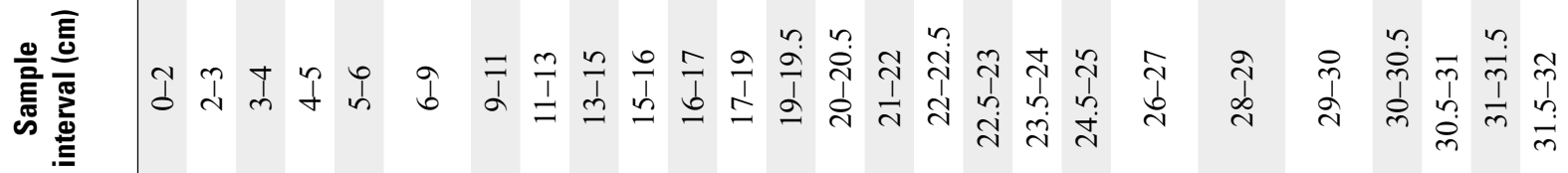




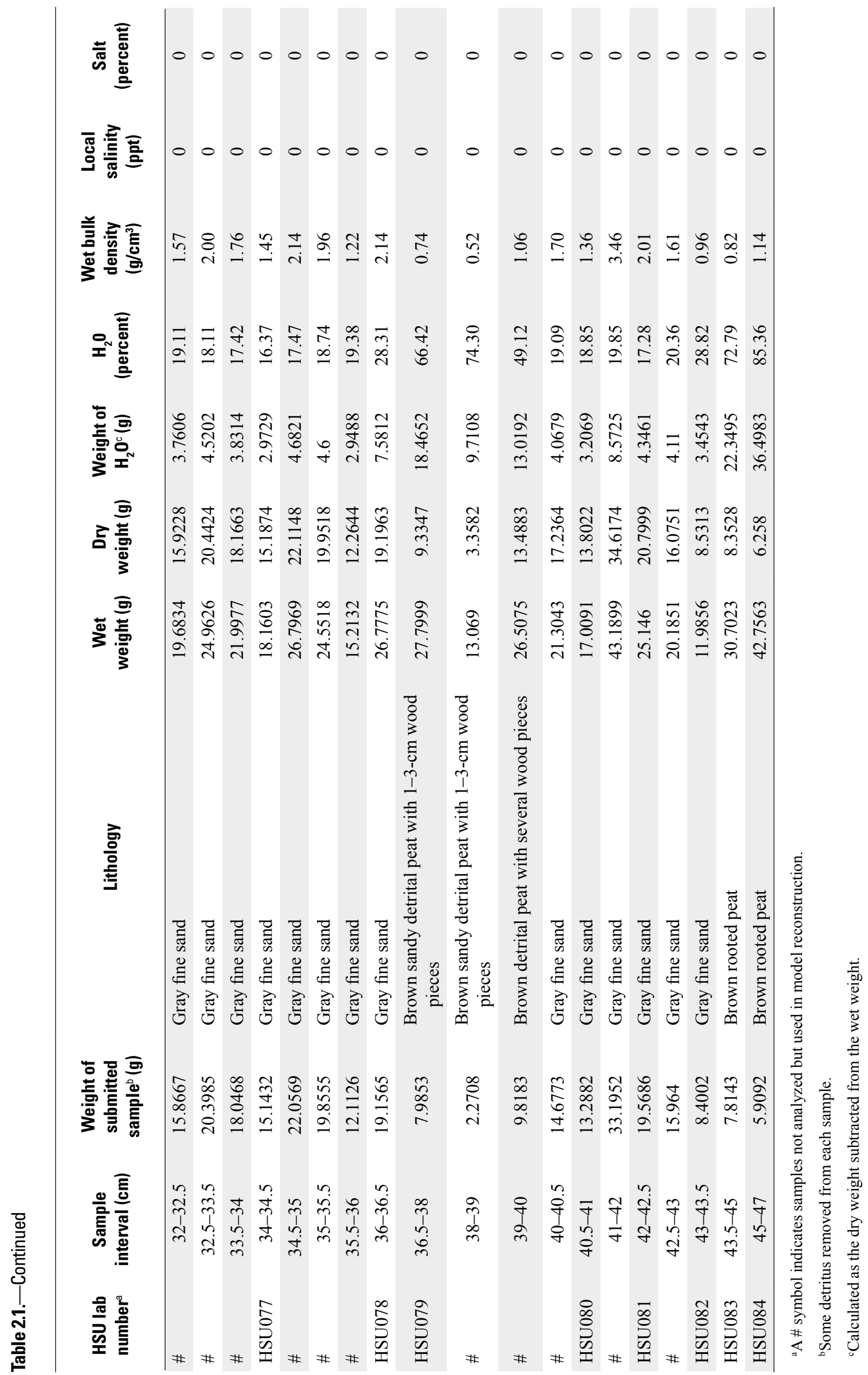




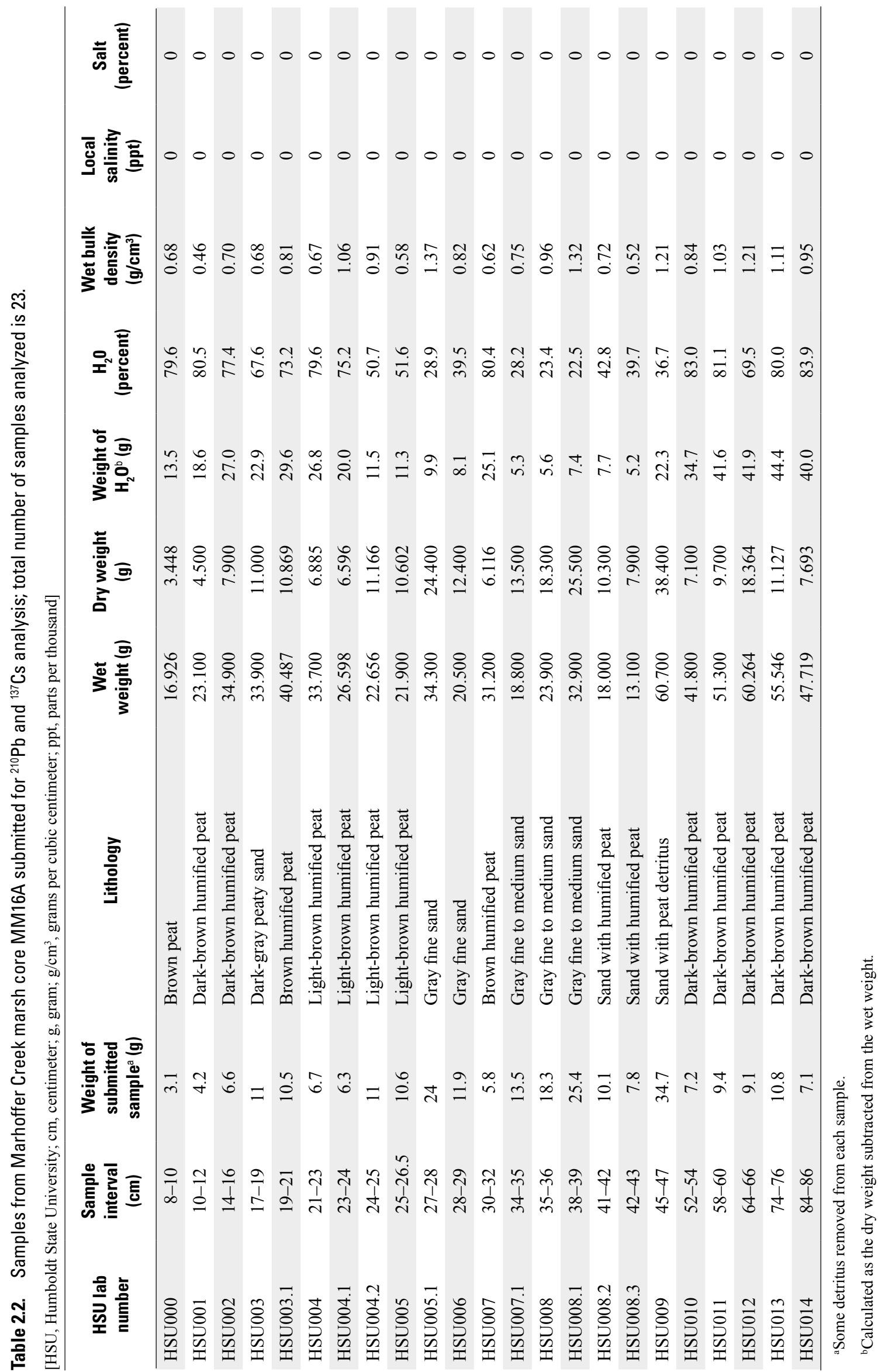




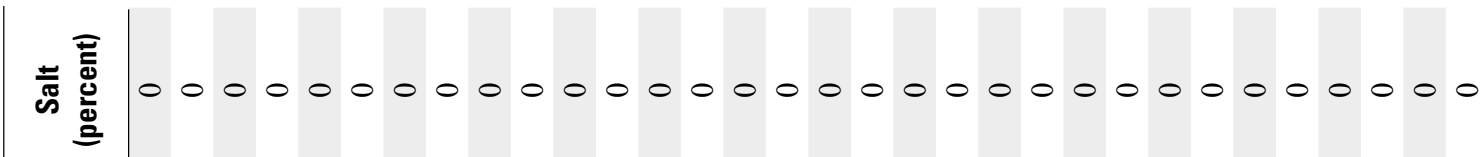

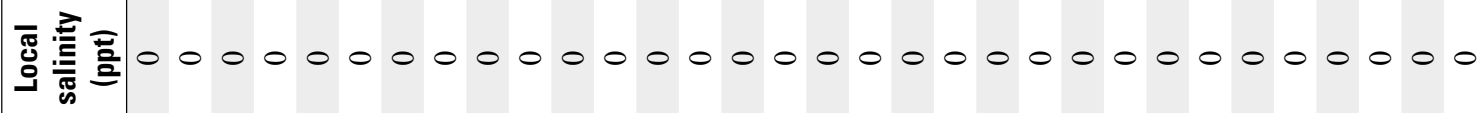

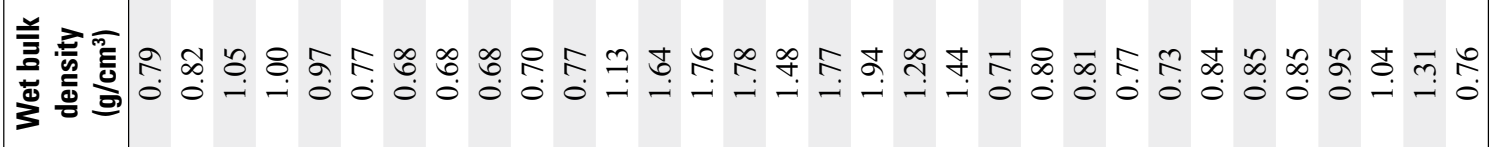

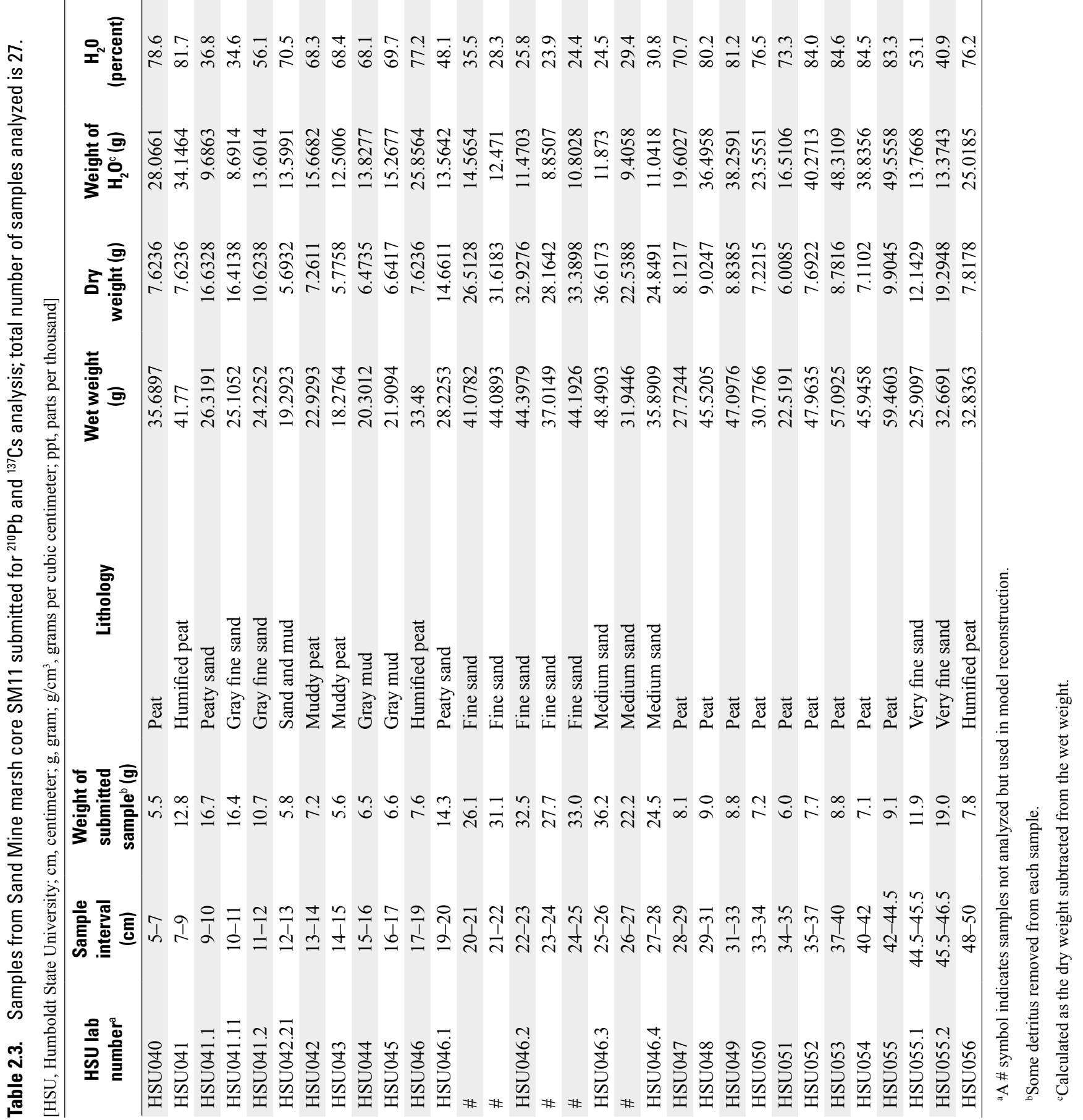




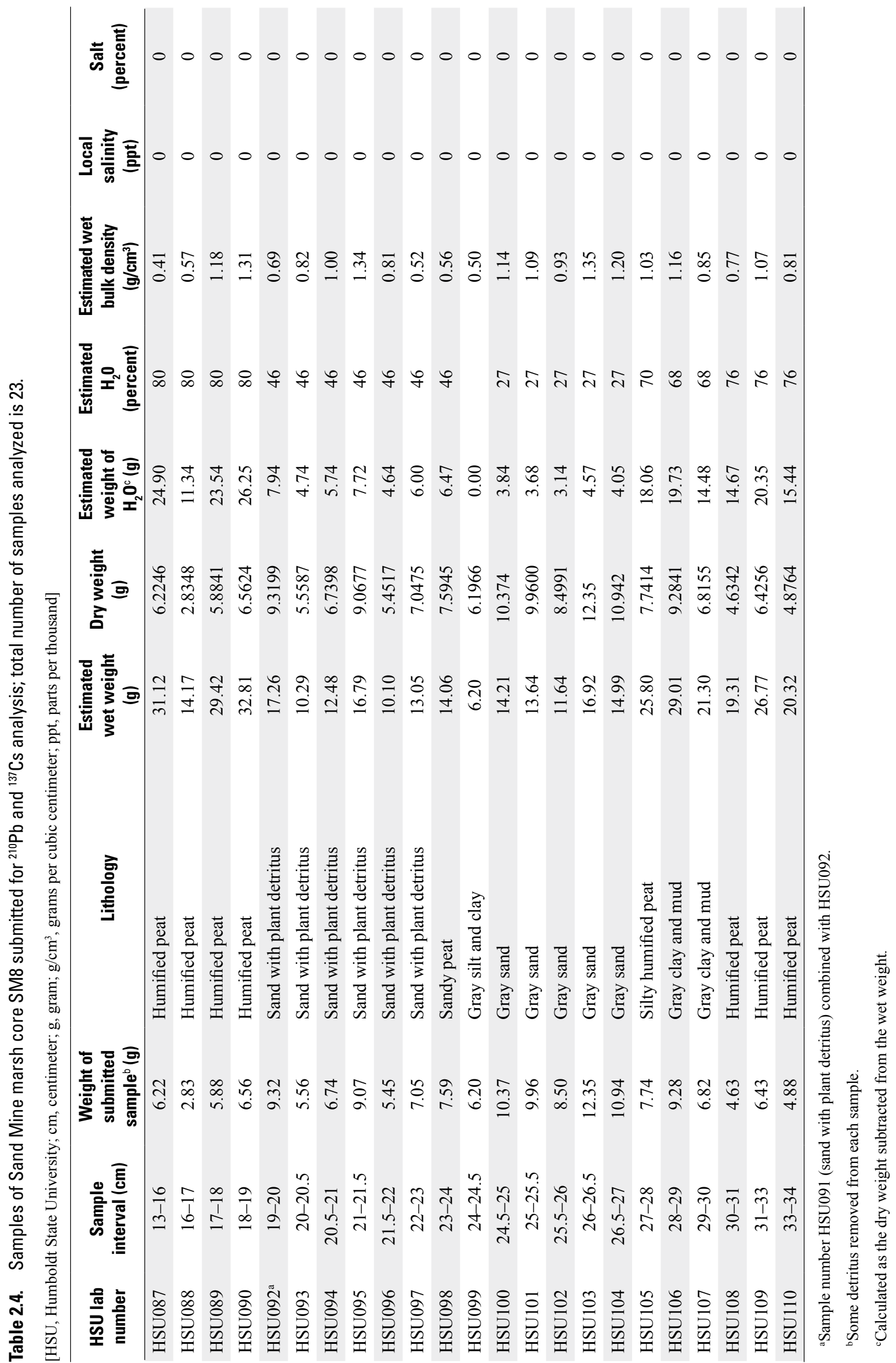




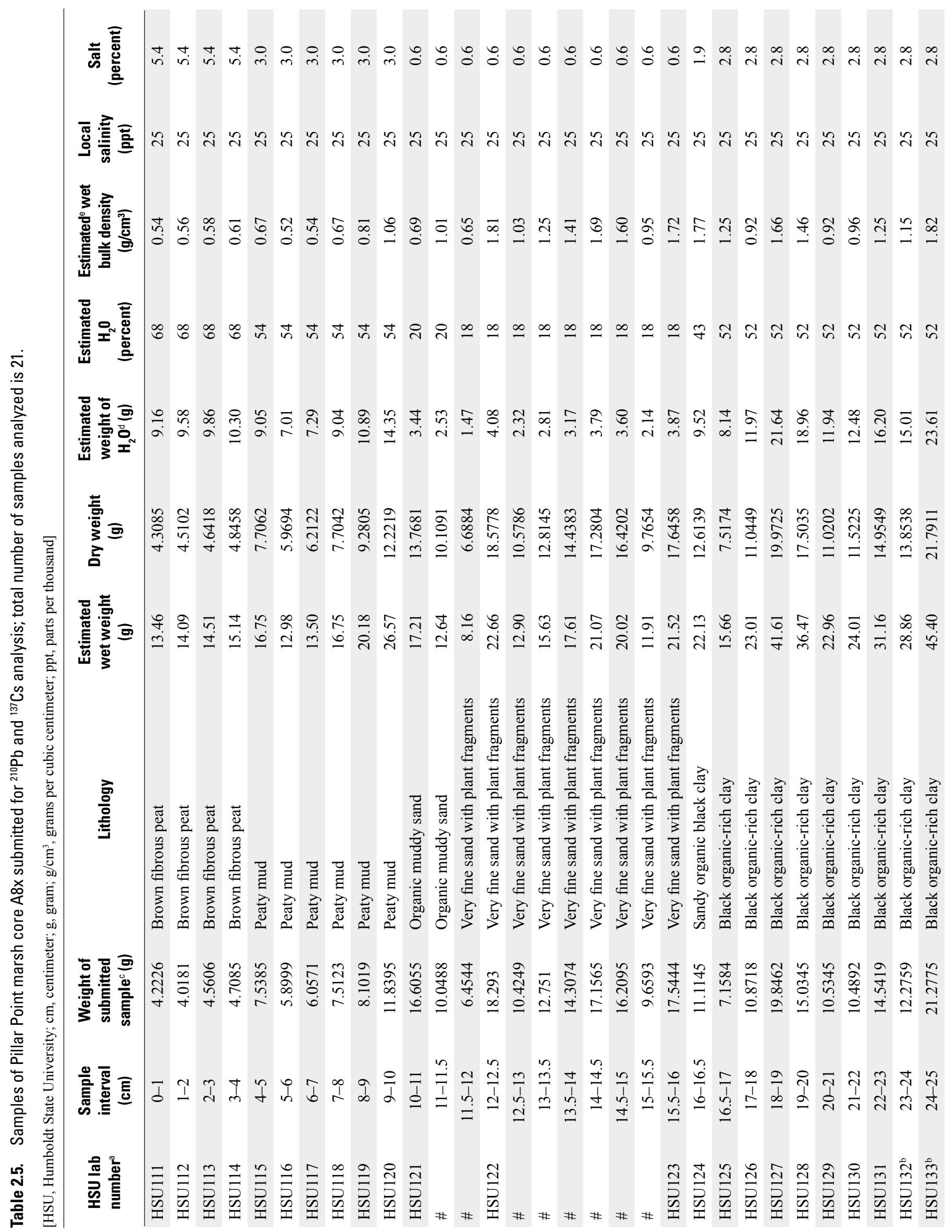




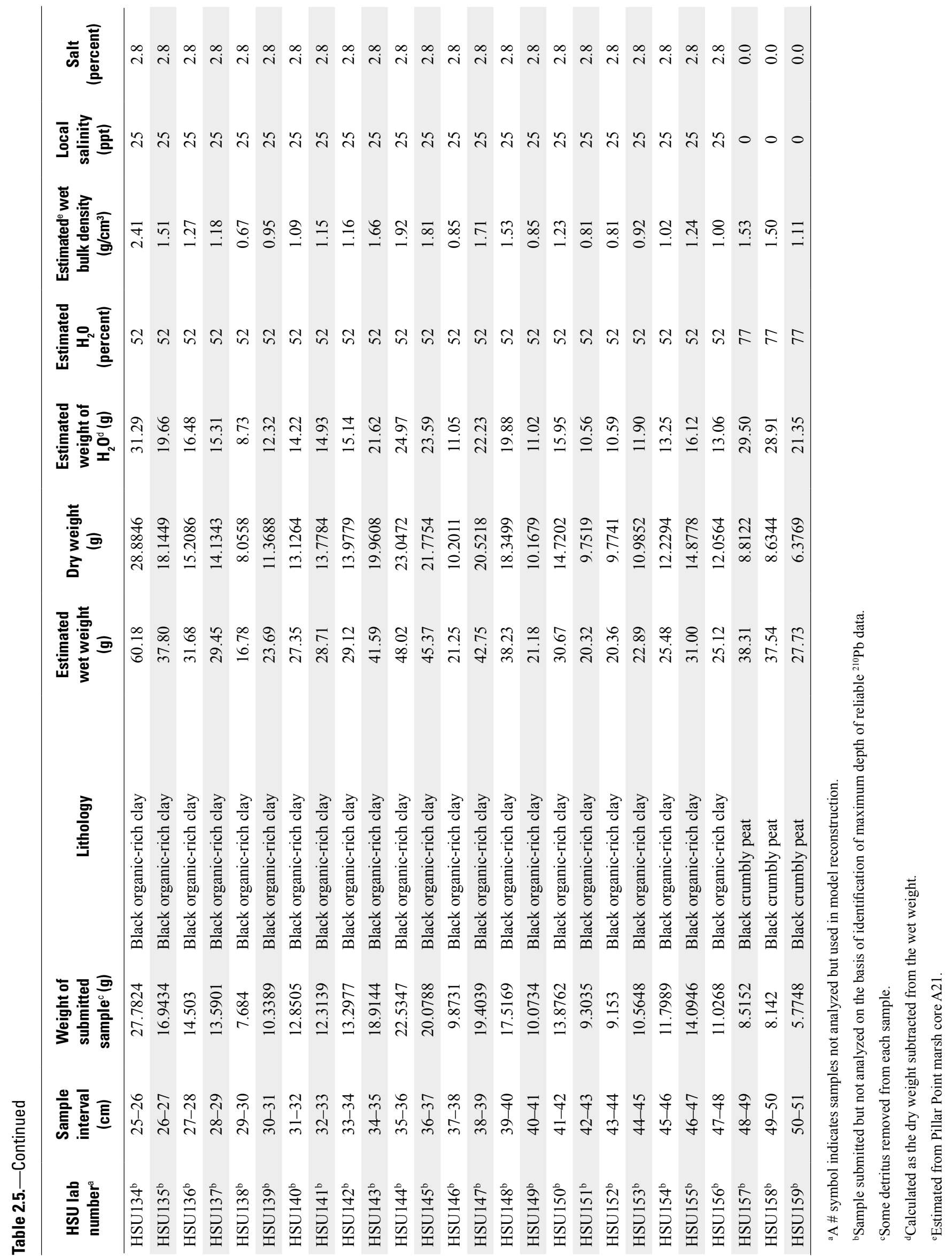




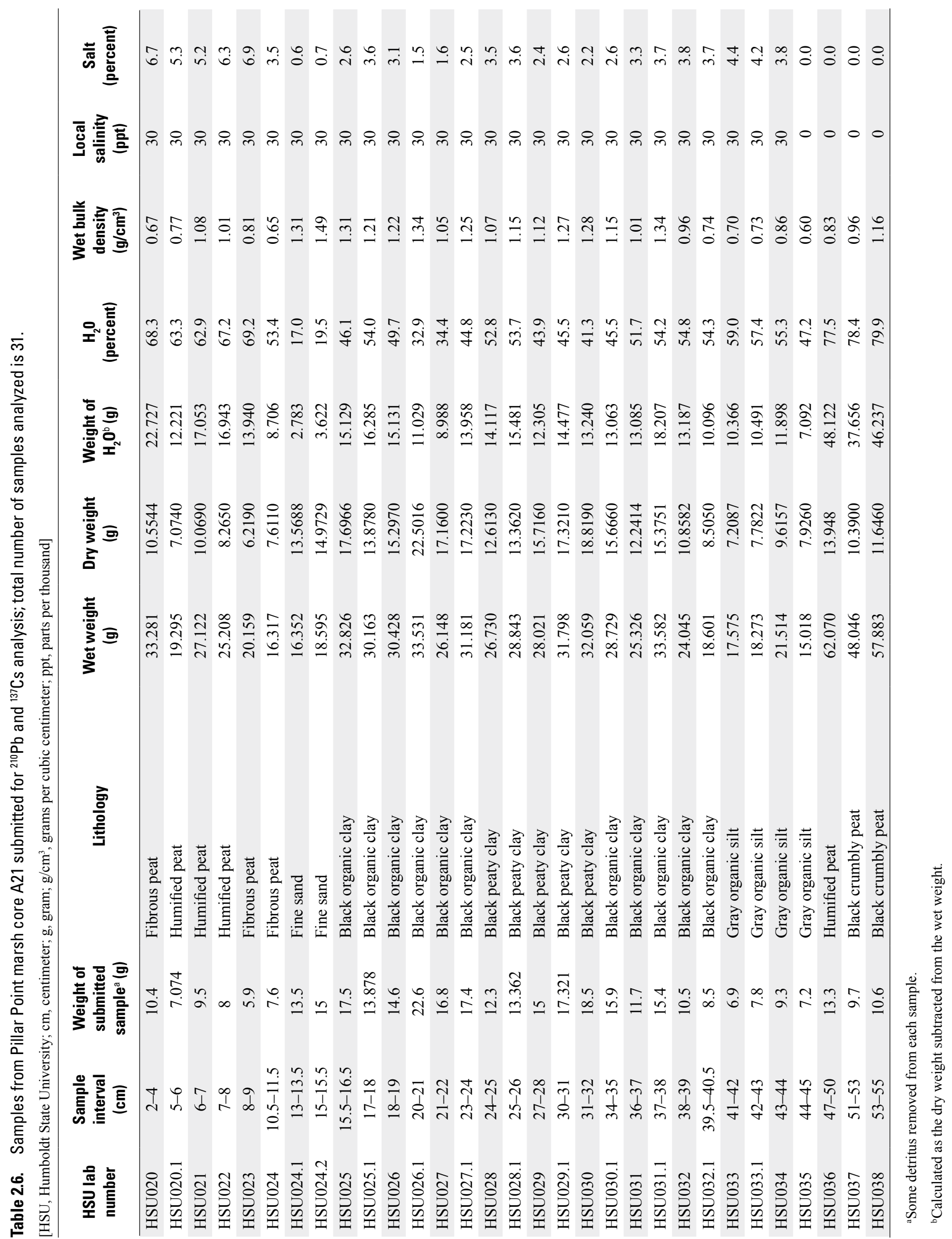




\section{Appendix 3. Particle-Size Analysis Results}

Tables 3.1-3.10 of appendix 3 are available as an Excel table and may be downloaded from https://doi.org/10.3133/sir20185111.

\section{Appendix 4. Diatom Analysis Results}

Tables 4.1-4.13 of appendix 4 are available as an Excel table and may be downloaded from https://doi.org/10.3133/sir20185111. Figures $4.1-4.8$ are providede here.

\section{Marhoffer Creek Marsh}

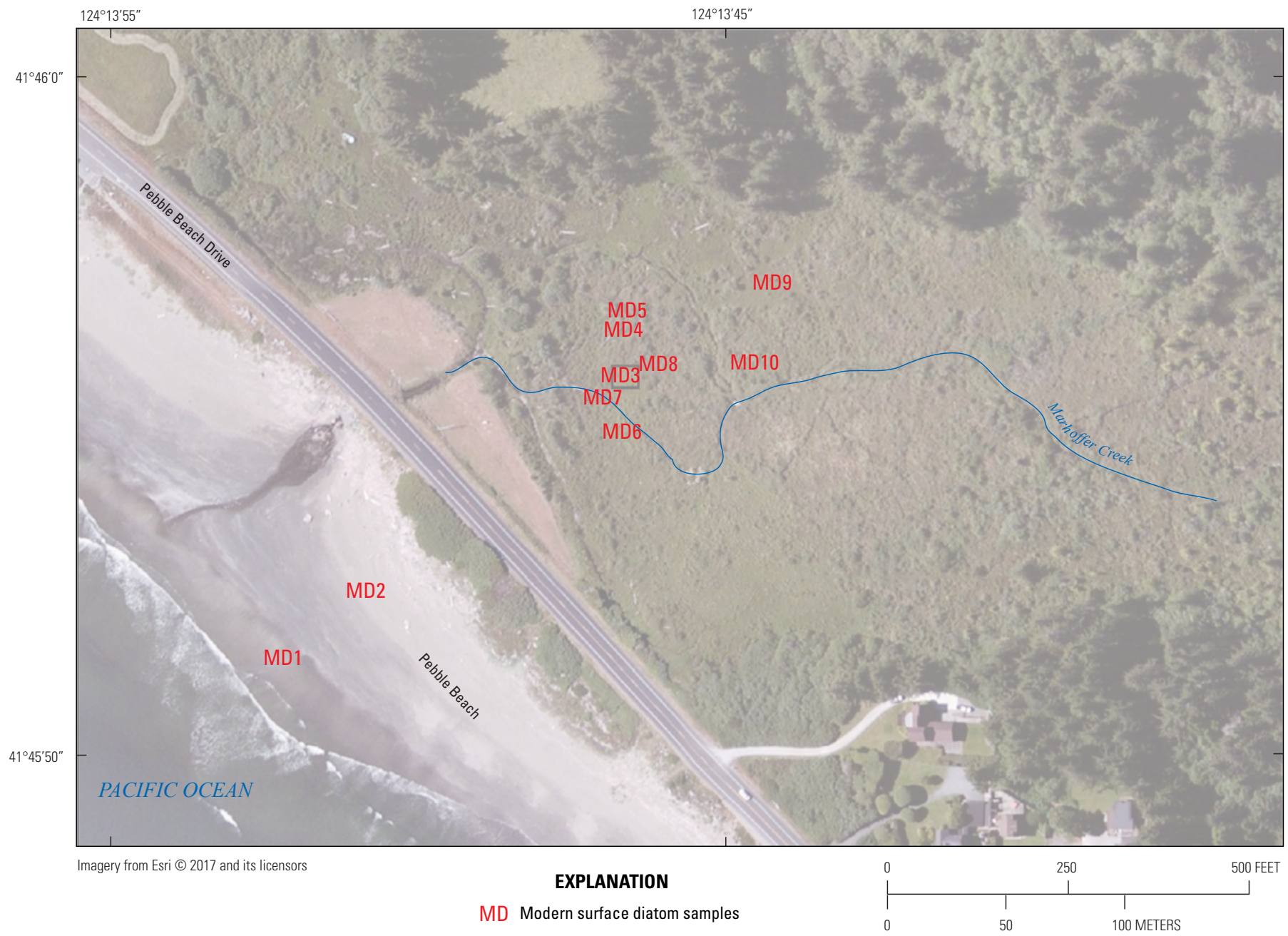

Figure 4.1. L Locations of modern diatom samples from Pebble Beach and Marhoffer Creek marsh in northern California. 

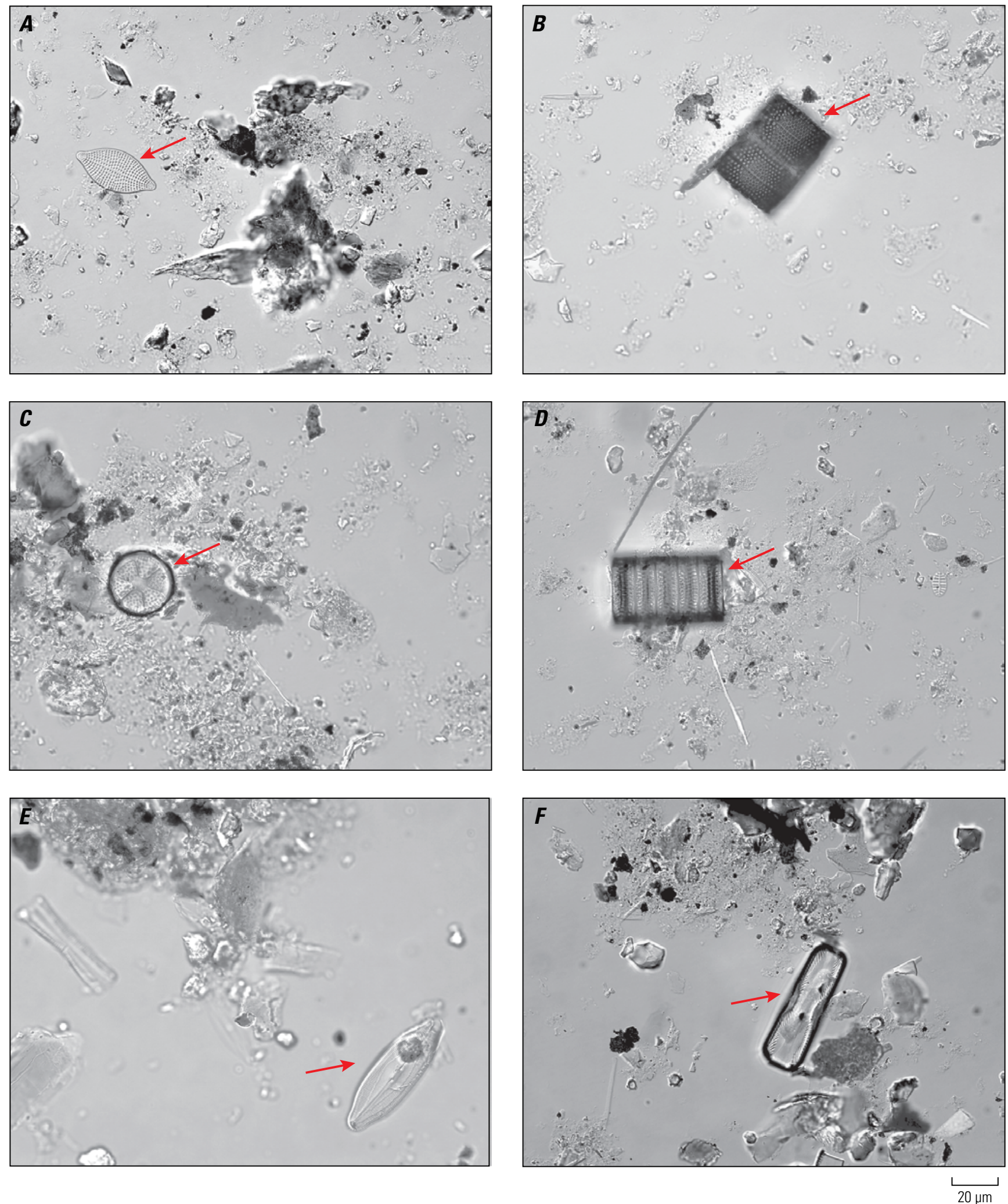

Figure 4.2. Photomicrographs of diatoms from surface samples MD1 and MD2 collected at Pebble Beach. Sample locations are shown in figure 4.1. Sample MD1 is surface sand collected from the lower beach or surf zone that is exposed at low tide. Diatoms in this sample are diverse but not abundant in comparison to the background sediment. Sample MD2 is surface sand collected from the upper intertidal beach, about 50 meters west of the beach berm. $A$, Arrow points to Rhaphoneis amphiceros. $B$, Arrow points to connected frustules of Endictya hendeyi. C, Arrow points to Actinoptychus senarius. D, Arrow points to connected frustules of Paralia sulcata. E, Arrow points to Caloneis brevis. F, Arrow points to Pinnularia cf. rectangulata. $\mu \mathrm{m}$, micrometers. 

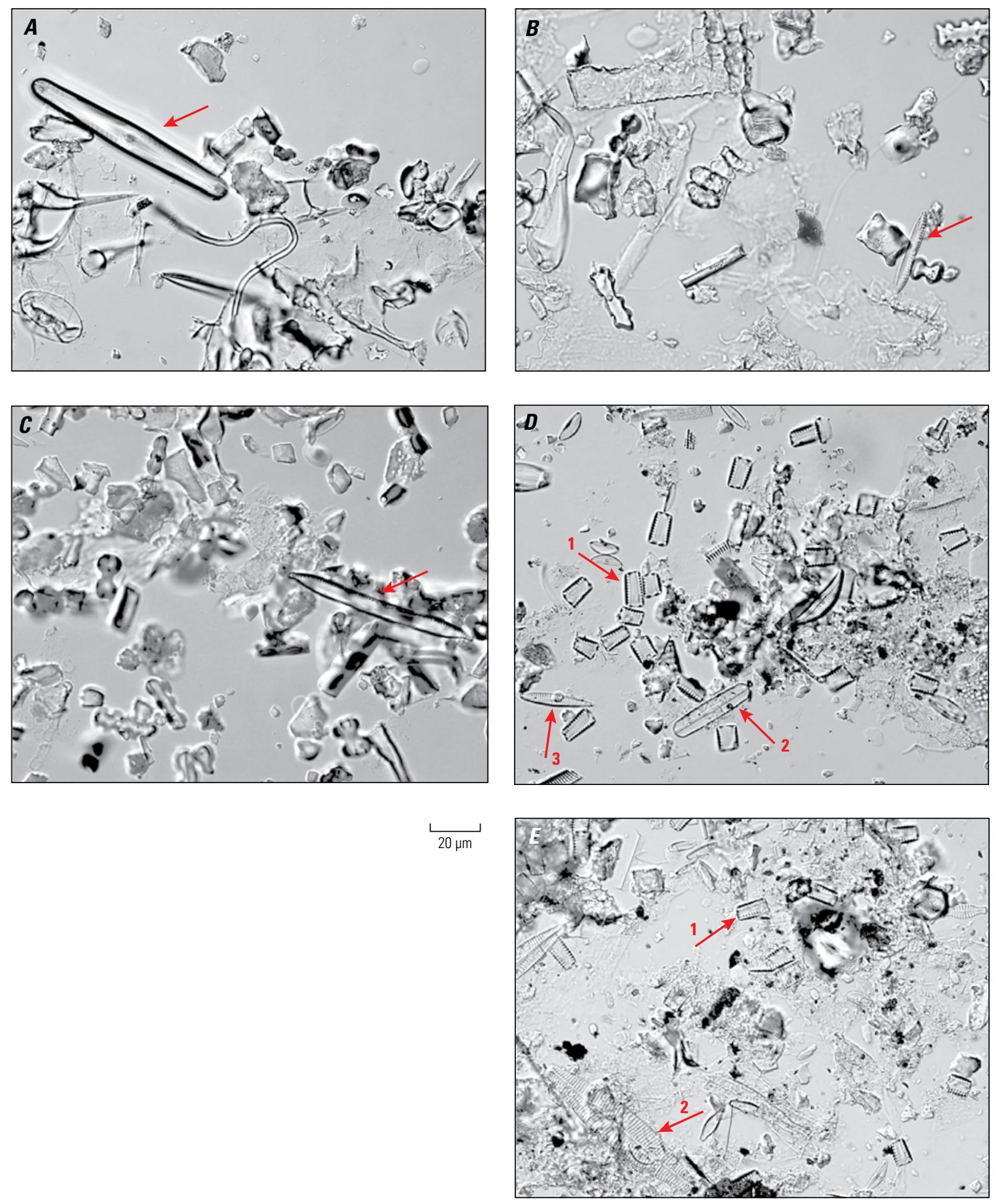

Figure 4.3. Photomicrographs of diatoms from surface samples MD3 and MD4 collected at Marhoffer Creek marsh. Sample locations are shown in figure 4.1. Sample MD3 is from the well-drained modern marsh surface, which is vegetated with grasses and clumps of sedges. The surface is fairly dry with low sunlight penetration. Diatoms in this sample are rare in comparison to background particles; phytoliths are common. Sample MD4 is sediment collected from a 50-centimeter-wide by 40-centimeter-deep channel that cuts through the marsh. This sample has a distinct diatom assemblage dominated by Martyana spp. as well as large pennate taxa (such as Navicula spp., medium-sized Pinnularia spp., and Sellaphora pupula). A, Arrow points to Pinnularia stomatophora. B, Arrow points to Nitzschia vitrea. C, Arrow points to Hantzschia amphioxys. D, Arrows point to (1) Martyana martyi (many valves present), (2) Sellaphora pupula, and (3) Gomphonema sp. E, Arrows point to (1) Martyana martyi and (2) Navicula sp. $\mu \mathrm{m}$, micrometers. 

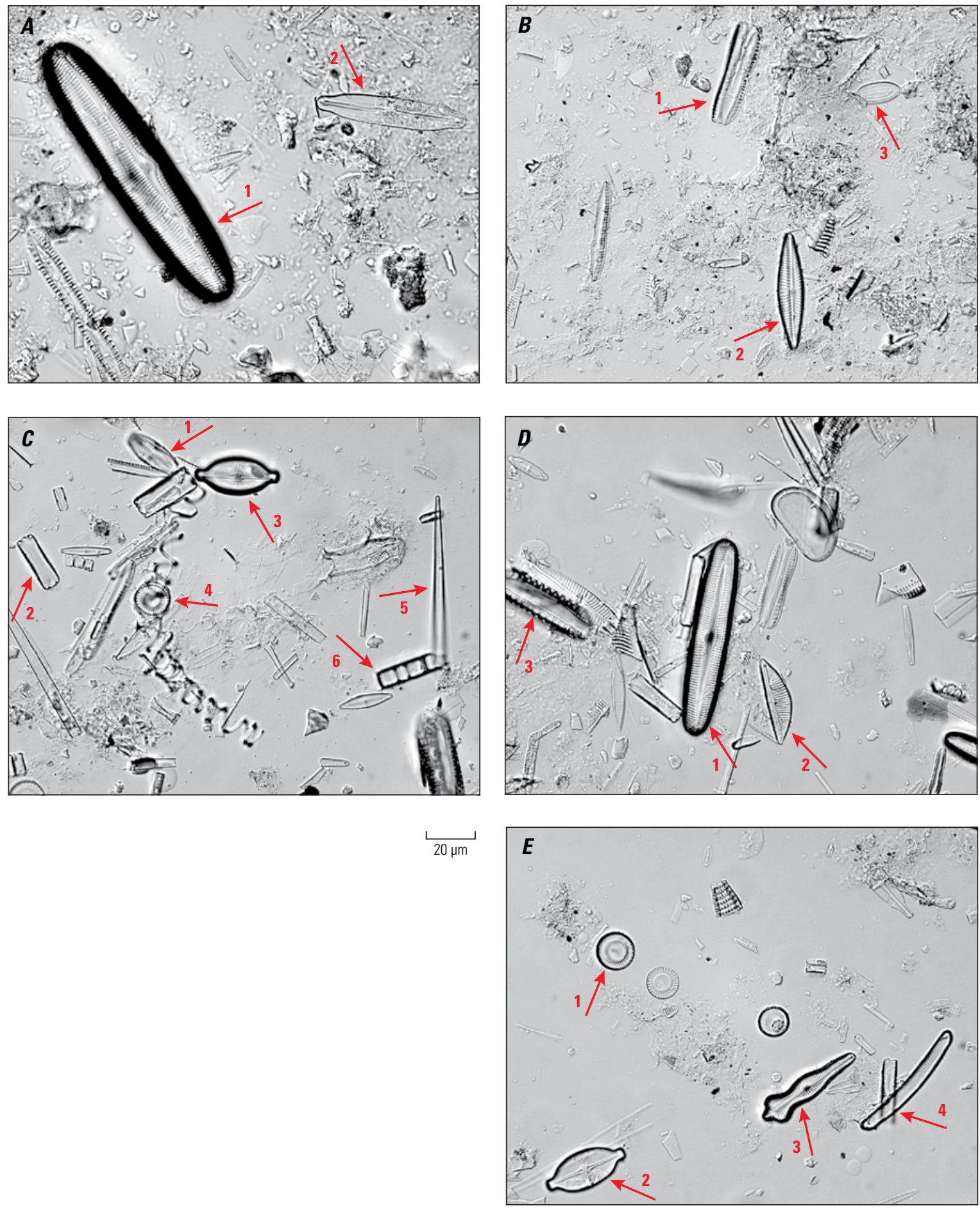

Figure 4.4. Photomicrographs of diatoms from surface samples MD5 and MD6 collected at Marhoffer Creek marsh. Sample locations are shown in figure 4.1. Sample MD5 is from the well-drained marsh surface that has low-standing Juncus; there is good sunlight penetration at the marsh surface. Sample MD6 is from the moist but well-drained marsh surface that has grasses and hummocky vegetation and good sunlight penetration. Diatoms from both samples MD5 and MD6 are abundant and diverse. A, Arrows point to (1) Pinnularia cf. dactylus and (2) Frustulia vulgaris. B, Arrows point to (1) Nitzschia vitrea, (2) Navicula sp., and (3) Tryblionella debilis. C, Arrows point to (1) Amphora libyca, (2) Eunotia minor, (3) Cosmioneis pusilla, (4) Cyclotella meneghiniana, (5) Synedra ulna, and (6) Aulacoseira ambigua. D, Arrows point to (1) Pinnularia viridis, (2) Encyonema sp., and (3) Epithemia adnata. E, Arrows point to (1) Cyclotella meneghiniana, (2) Cosmioneis pusilla, (3) Gomphonema acuminatum var. coronata, and (4) Eunotia glacialis. $\mu$ m, micrometers. 



Figure 4.5. Photomicrographs of diatoms from surface samples MD7 and MD8 collected at Marhoffer Creek marsh. Sample locations are shown in figure 4.1. Sample MD7 is from the wet marsh surface that has about 5 centimeters of standing water. Diatoms from this sample are abundant and diverse. Sample MD8 is from the densely vegetated marsh surface between cores MM11 and MM15. This sample has a diverse assemblage of large diatoms that are not abundant. $A$, Arrows point to (1) Aulacoseira italica and (2) Eunotia formica. B, Arrows point to (1) Navicula vaneii, (2) Sellaphora pupula, (3) Gomphonema truncatum, and (4) Aulacoseira ambigua. C, Arrows point to (1) Eunotia formica, (2) Amphora libyca, and (3) Diploneis sp. D, Arrows point to (1) Pinnularia sp. and (2) a pollen grain. E, Arrows point to (1) Gomphonema sp., (2) Pinnularia nodosa, (3) Navicula peregrina, (4) Diadesmis contenta, and (5) Eunotia incisa. F, Arrows point to (1) Pinnularia nodosa and (2) Staruroneis nobilis. $\mu \mathrm{m}$, micrometers. 

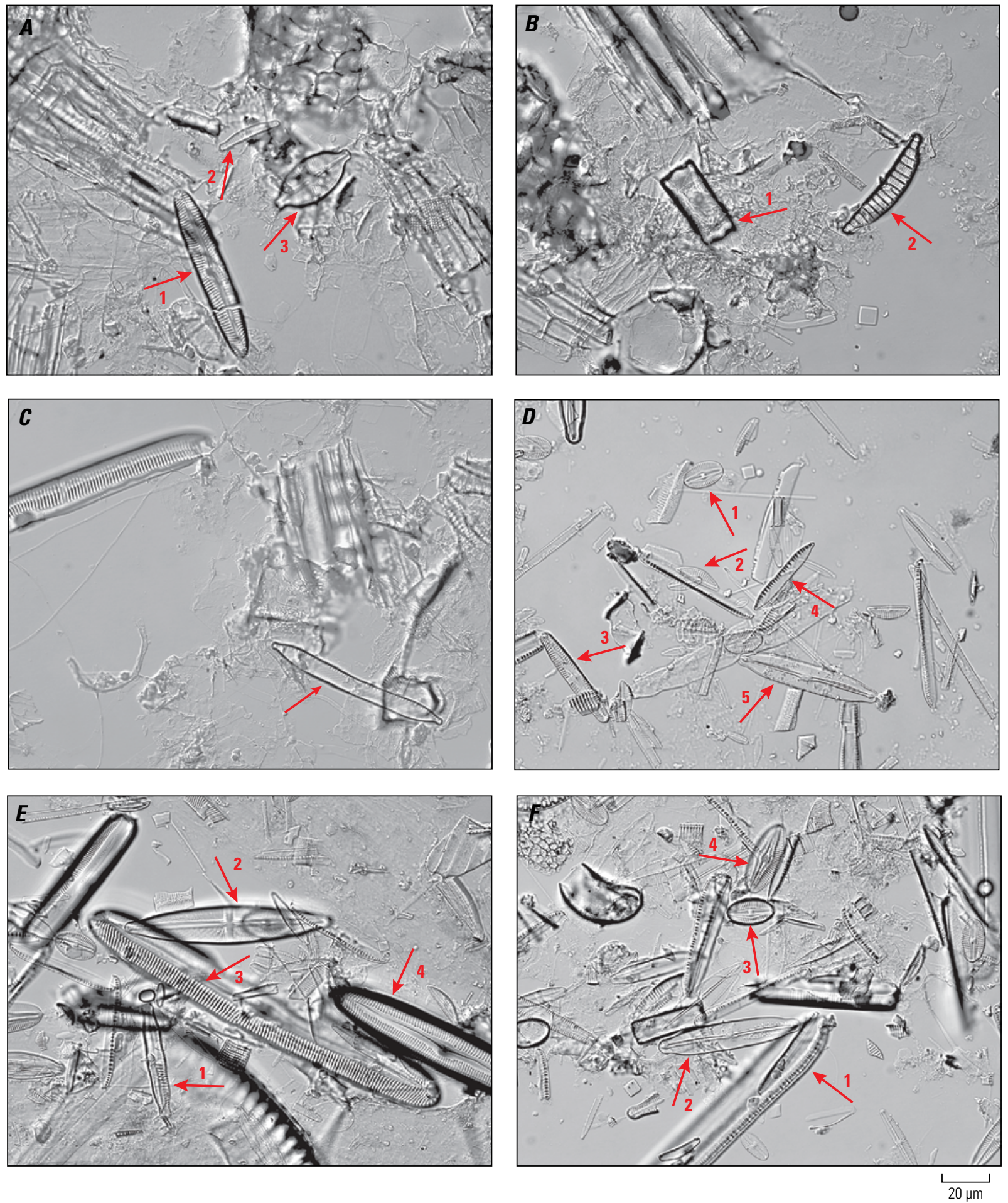

Figure 4.6. Photomicrographs of diatoms from surface samples MD9 and MD10 collected at Marhoffer Creek marsh. Sample locations are shown in figure 4.1. Sample MD9 is from the well-drained marsh that is densely vegetated with sedges and willows that are taller than 1 meter. The moist marsh surface receives low sunlight penetration. Sample MD10 is from the well-drained marsh surface that has low-standing (10-30 centimeters tall) sedges. Sunlight exposure is high at the marsh surface here.

Diatoms from this sample are abundant and diverse. A, Arrows point to (1) Pinnularia viridis, (2) Eunotia minor, and (3) Cosmioneis pusilla. B, Arrows point to (1) Cosmioneis pusilla and (2) Eunotia adnata. C, Arrow points to Hantzschia amphioxys. D, Arrows point to (1) Diploneis sp., (2) Encyonema sp., (3) Pinnularia divergens, (4) Nitzschia vitrea, and (5) Frustulia vulgaris. E, Arrows point to (1) Pinnularia nodosa, (2) Stauroneis nobilis, (3) Pinnularia major, and (4) Pinnularia viridis. F, Arrows point to (1) Nitzschia scalaris, (2) Frustulia vulgaris, (3) Diploneis elliptica, and (4) Diploneis finnica. $\mu \mathrm{m}$, micrometers. 


\section{Elk Creek Wetland}
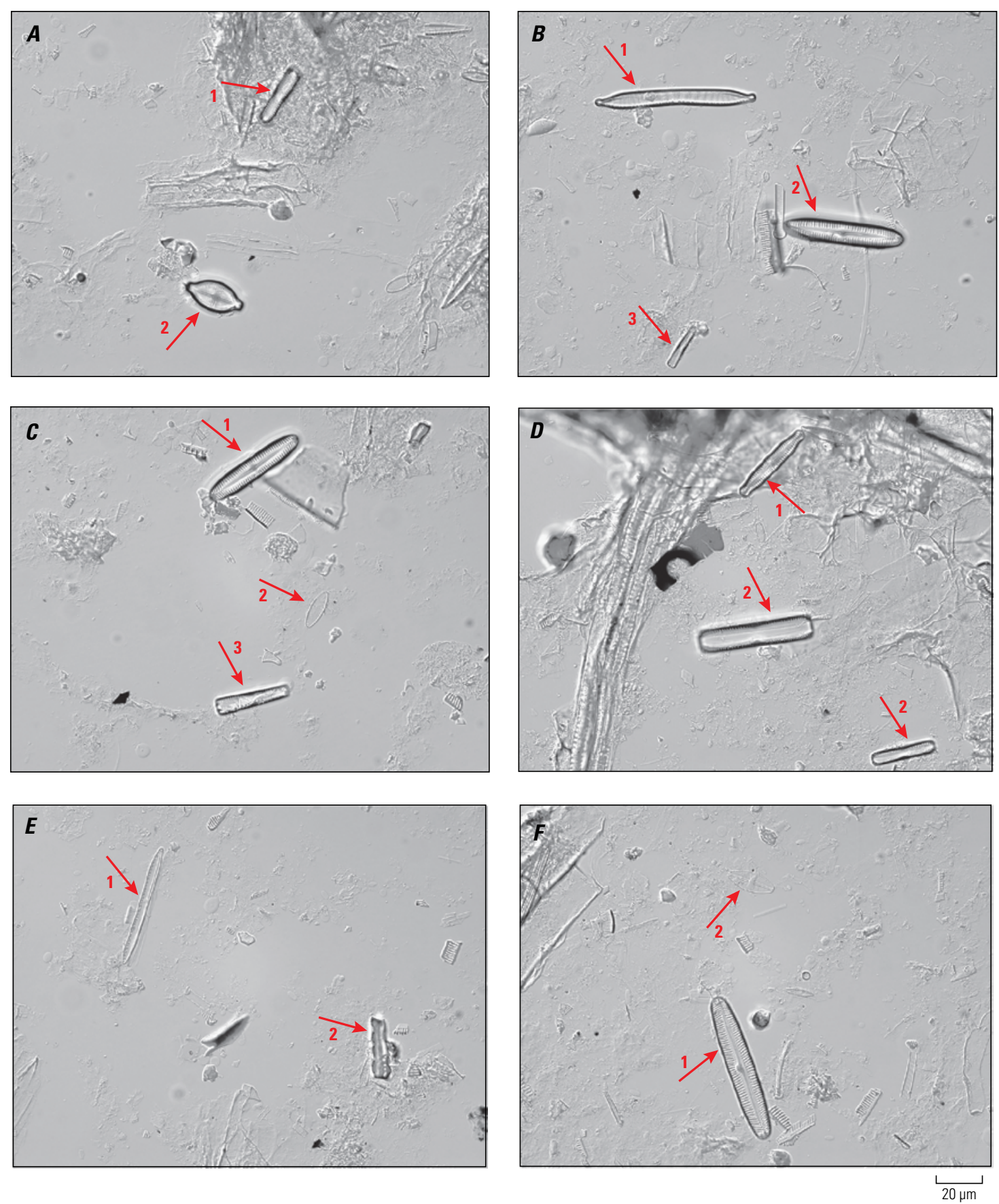

Figure 4.7. Photomicrographs of diatoms from 5 centimeters depth in core EC2 from Elk Creek wetland. This sample is representative of the modern meadow environment at the core site. A, Arrows point to (1) Pinnularia lagerstedii and (2) Cosmioneis pusilla. B, Arrows point to (1) Hantzschia amphioxys, (2) Pinnularia viridis, and (3) Gomphonema sp. C, Arrows point to (1) Pinnularia viridis, (2) Psammothidium (?) sp., and (3) Gomphonema sp. D, Arrows point to (1) Pinnularia divergens and (2) Pinnularia sp. E, Arrows point to (1) Nitzschia terrestris and (2) a phytolith. F, Arrows point to (1) Pinnularia viridis and (2) Cavinula lapidosa. $\mu \mathrm{m}$, micrometers. 

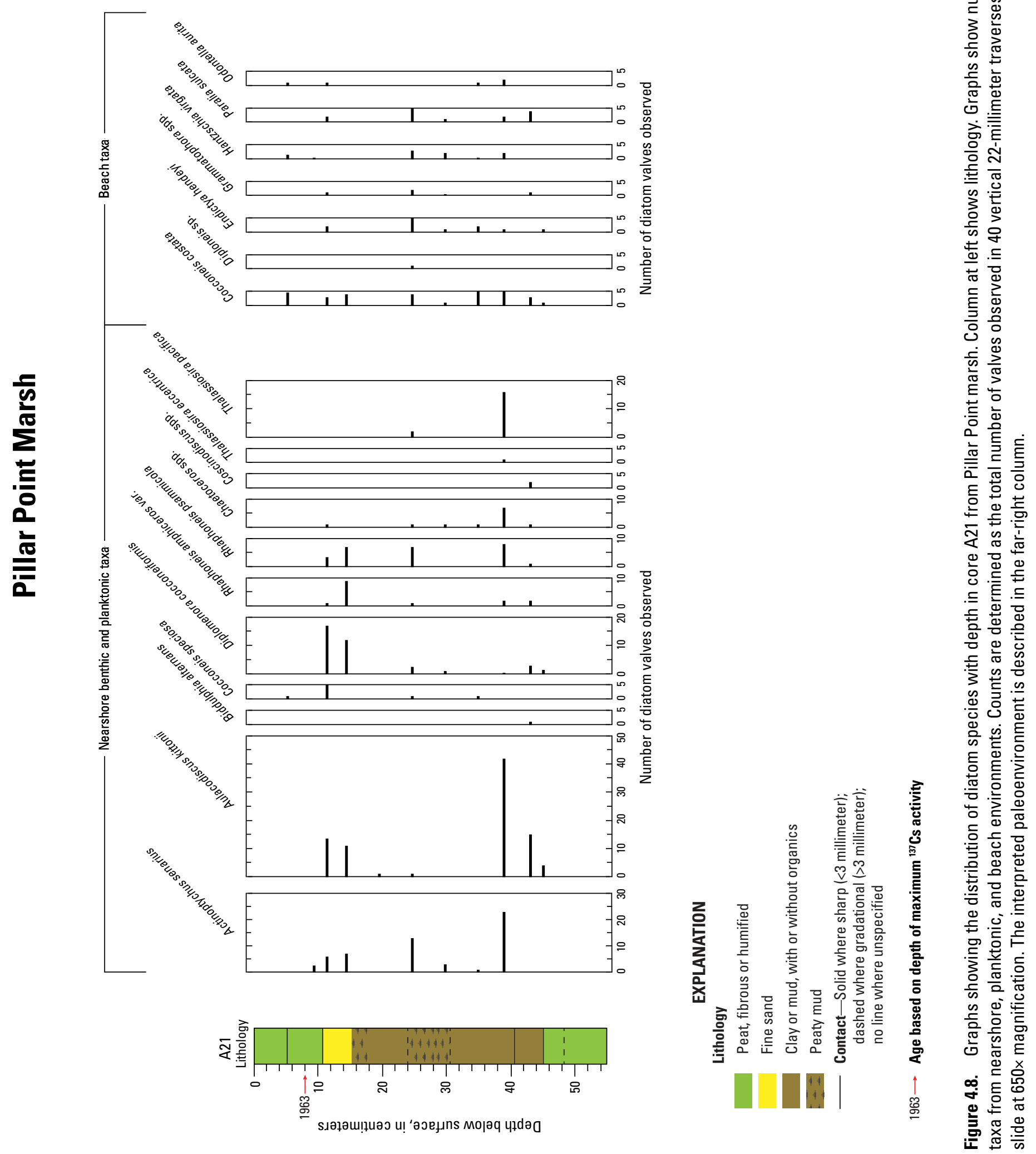

Menlo Park Publishing Service Center

Manuscript approved August 9, 2018

Edited by Monica Erdman

Layout and design by Cory Hurd 
